回回 UNIVERSIDADE DE BRASÍLIA - UNB

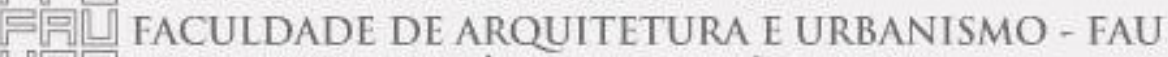

凹ñ PROGRAMA DE PÓS-GRADUAÇÃO - PPG

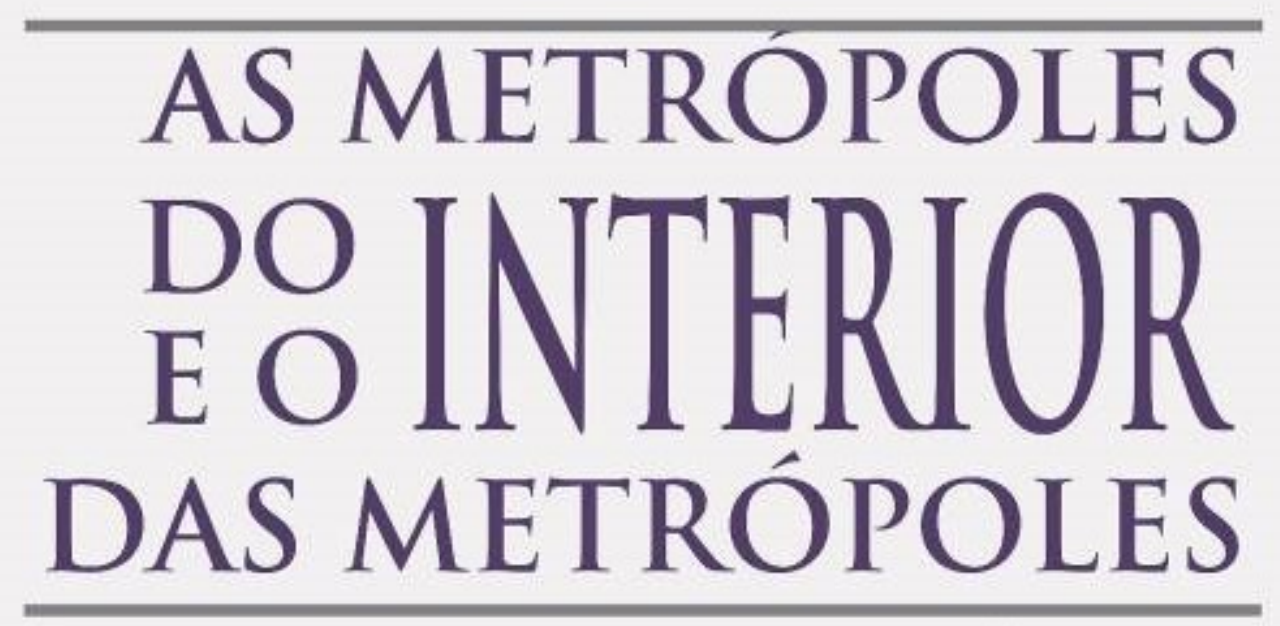

TESE DE DOUTORADO

ME. ANA PAUla Campos GuRgel DISCENTE DR. FREDERICO DE HOLANDA ORIENTADOR

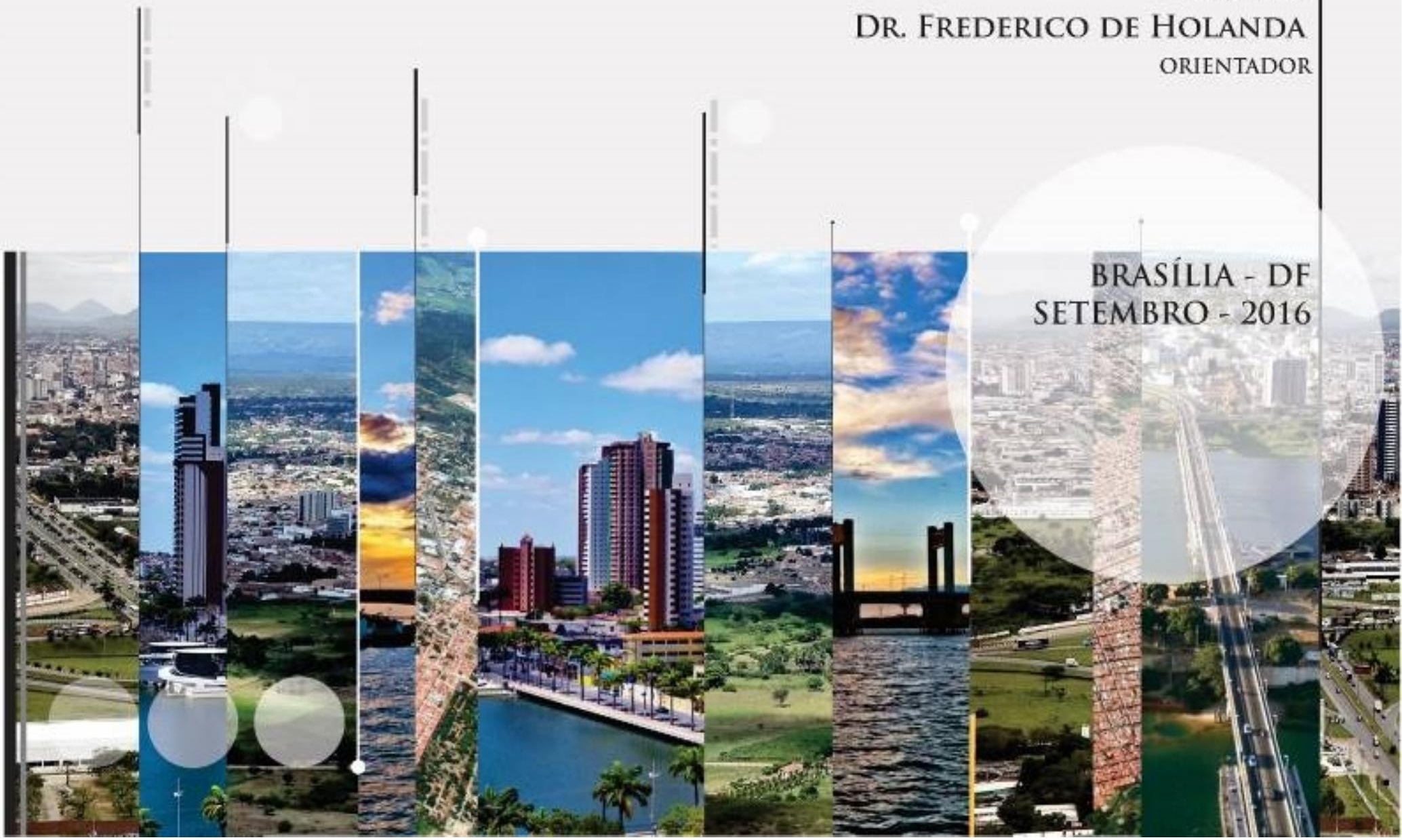


ANA PAULA CAMPOS GURGEL

\section{AS METRÓPOLES DO INTERIOR E O INTERIOR DAS METRÓPOLES}

Tese apresentada ao Programa de PósGraduação em Arquitetura e Urbanismo da Universidade de Brasília, na Área de Concentração Projeto e Planejamento, como requisito parcial para obtenção do título de Doutora em Arquitetura e Urbanismo.

Orientador: Dr. Frederico de Holanda

Brasília - DF 


\section{AS METRÓPOLES DO INTERIOR E O INTERIOR DAS METRÓPOLES}

Tese de doutoramento aprovada como requisito parcial para obtenção do grau de Doutor pelo Programa de Pesquisa e Pós-graduação da Faculdade de Arquitetura e Urbanismo da Universidade de Brasília.

\section{COMISSÃO EXAMINADORA:}

Prof. Dr. Frederico Rosa Borges de Holanda (Orientador)

Faculdade de Arquitetura e Urbanismo - UnB

Prof. Dr. Benny Schvasberg

Faculdade de Arquitetura e Urbanismo - UnB

Neio Lucio de Oliveira Campos

Departamento de Geografia - UnB

Valério Augusto Soares de Medeiros

Faculdade de Arquitetura e Urbanismo - UnB

Edja Bezerra Faria Trigueiro

Departamento de Arquitetura e Urbanismo - UFRN 
G979 Gurgel, Ana Paula Campos

As metrópoles do interior e o interior das metrópoles:/ Ana Paula Campos Gurgel. - Brasília, 2016. - 314 f. : il.

Tese (Doutorado em Arquitetura) - Universidade de Brasília, Faculdade de Arquitetura e Urbanismo, 2016. Orientação: Prof. Dr. Frederico de Holanda

1.Morfologia. 2. Sintaxe espacial. 3. Metropolização. 4. Cidades médias. 5. Nordeste. I. Título. 
Agradeço a todos aqueles que de alguma forma contribuíram na minha caminhada até aqui. Tal como numa árvore, pude contar tanto com o suporte das minhas raízes quanto dos troncos, galhos e folhas que me alçaram ao alto:

À minha família - minha raiz nordestina - pelo apoio incondicional sempre, mesmo que distante e que me deu o privilégio de ter como herança o estudo.

A todos os professores que acompanham a minha trajetória acadêmica, vocês foram e sempre serão meu robusto tronco tal qual um Oiti, árvore símbolo da minha memória nordestina:

Ao meu orientador, Prof. Dr. Frederico de Holanda, que me ensinou muitíssimo, por sua compreensão, apoio e estímulo prestado durante todo o trabalho. Obrigada compartilhar os conhecimentos na minha trajetória acadêmica.

À Edja Trigueiro, minha MUsA inspiradora, por me fazer ir mais longe.

Às diversas ramificações e galhos que expandiram meus caminhos:

Aos membros da minha banca de qualificação, Prof. Dr. Benny Schvasberg e Prof. Dr. Neio Campos, por seus comentários encorajadores e pertinentes.

Ao Programa de Pós-Graduação da Faculdade de Arquitetura e Urbanismo da Universidade de Brasília, pela oportunidade de realização do curso de doutorado. Obrigada a todos do corpo docente pela dedicação e aos funcionários pelos préstimos ao longo desses quase quatro anos.

Às minhas folhas, diversas interfaces com o mundo exterior que me deram alimento para a alma:

Ao amigo Felipe Musse, pelos abraços e ouvidos sempre disponíveis mesmo à distância.

Ao amigo Carlos Onofre, pela capa da qualificação e pelo abstract.

Aos amigos que fiz em Brasília que deram suporte e que levo comigo para sempre. Em especial à Ana Isabela Soares, Lisânia Rosa, Maria Claudia Candeias, Orlando Nunes e Suzete Bomfim, pelas revisões, discussões e apoio.

Aos meus alunos: por cada dúvida que me trouxe novas reflexões, por cada brilho no olhar ao descobrir um novo horizonte e pela instiga de aprender sempre. Especialmente àqueles que contribuíram diretamente com este trabalho: Amanda Brasil (UnB); Iasmim de Oliveira, Klairton Rodrigues, Lucas Lima, Pâmela Corrêa e Plácido Ferreira (meus bolsistas de IC da UNIPLAN).

Espero ter florescido como imaginado. O fruto está aqui. Muito obrigada! 
Sertão é isto: o senhor empurra para trás, mas de repente ele volta a rodear o senhor dos lados. Sertão é quando menos se espera. [...] Estive nessas vilas, velhas, altas cidades... Sertão é o sozinho. [...] O sertão é sem lugar. [...] O sertão é confusão em grande demasiado sossego. [...] Só que o sertão é grande ocultado demais.

ROSA, J.G. Grande sertão: Veredas. 19. ed. Rio de Janeiro: Nova Fronteira, 2001.

Vi a cidade passando, Rugindo, através de mim... Cada vida era uma batida dum imenso tamborim. Eu era o lugar, ela era a viagem Cada um era real, cada outro era miragem

Esse ruído são os séculos pingando... E as cidades crescendo e se cruzando Como círculos na água da lagoa. 
O objetivo deste trabalho é compreender de que modo as propriedades configuracionais, em termos de acessibilidade da malha viária em perspectiva comparada, dão suporte à constituição do que se denominou neste estudo de Regiões Metropolitanas no Interior do Nordeste (RMINE's). Na última década, a urbanização cresceu nas cidades médias (definidas pelo IBGE como aquelas que possuem entre 100.000 e 500.000 habitantes, embora, por vezes essa acepção populacional varie) e nas franjas perimetropolitanas, convertendo esses territórios em polos de atração de migrações internas e inter-regionais. Com isso, algumas dessas cidades de médio porte emergiram como subcentros metropolitanos de polarização do desenvolvimento regional, refletindo o dinamismo socioespacial do interior do País num amplo processo de estruturação urbana regional. Este estudo está vinculado ao embasamento teórico-metodológico da Sintaxe Espacial, estabelecendo relações entre a forma do espaço e suas práticas socioculturais. O universo da pesquisa abrange as RMINE's com mais de 500.000 habitantes (IBGE,2010) que apresentam indícios de conurbação física, a saber: (1) RM de Feira de Santana/BA; (2) RM do Cariri/CE; (3) RM do Sudoeste maranhense; (4) RM de Campina Grande/PB; (5) RAID de Petrolina/Juazeiro. Somam-se a estas, as metrópoles de Fortaleza, Recife e Salvador, além de outras cidades que não são legalmente RM's mas têm a mesma hierarquia na rede urbana que as cidades-núcleo das RMINE's destacadas. Portanto, este trabalho é focado em entender as bases socioespaciais que dão suporte à formação de RM's, abrangendo cidades de médio porte do Nordeste, visando assim, contribuir para a análise dessas áreas frente à estruturação urbana regional, dando foco na estrutura interna dessas metrópoles, buscando a caracterização de um tipo metropolitano regional. A hipótese verificada neste estudo é que existem propriedades morfológicas que dão suporte ao processo de metropolização do interior do Nordeste, caracterizado em estágio intermediário em relação às grandes metrópoles nacionais e que congregam equipamentos, serviços e empregos que atendem a uma escala regional e que, portanto, representam uma dominância socioeconômica e funcional destas cidades-sede sobre suas hinterlândias.

Palavras-chave: morfologia; sintaxe espacial; metropolização; cidades médias; nordeste. 
The target of this thesis is to perceive how the configurational properties, regarding highway systems's accessibility in comparative perspective, support the creation of what is called in the study in original language of Metropolitan Areas in the Northeast Up-Country (RMINE's). In the last decade, urbanization grew in medium-sized cities (defined by IBGE as those that carry between 100,000 to 500,000 denizens) and the metropolitan edges, converting these territories into attraction poles of internal and inter-regional migration. Thus, some of these medium-sized cities have emerged as metropolitan subcenters of regional development bias, reflecting the socio-spatial dynamics of the up-country in a broad process of regional urban structure. This study is linked to the theoretical and methodological basis of Space Syntax, establishing relationships between the shape of the space and its socio-cultural practices. The research covers RMINE's with more than 500,000 denizens (IBGE, 2010) which exhibit signs of physical conurbation, namely: (1) Feira de Santana's Metropolitan Area/BA; (2) Cariri's Metropolitan Area/CE; (3) Maranhão's Southwest Metropolitan Area; (4) Campinas Grande's Metropolitan Area/PB; (5) Petrolina's/Juazeiro's RAID. In addition to those, the metropolises of Fortaleza, Recife and Salvador, and other cities that are not legally MA's but have the same hierarchy in the urban network as the core city of RMINE's highlighted are included. This work is therefore focused on understanding the socio-spatial bases that support the formation of MA's, covering medium-sized cities in the Northeast up-country, thus aiming to contribute to the analysis of those areas across the regional urban structure, focusing on the internal structure of these cities, seeking the characterization of a metropolitan area type. The hypothesis found in this study is that there are morphological properties that support the process of metropolises of the Northeast, characterized at an intermediate stage in relation to major national cities and which bring together equipment, services and jobs that serve a regional scale and represent a socio-economic and functional dominance of those cities on their hinterlands.

Keywords: morphology; space syntax; metropolization; medium-sized cities; northeast upcountry. 


\section{LISTA DE FIGURAS}

Figura 1: Espacialização das 71 RM's brasileiras: a grande maioria localiza-se no Sudeste e no Sul. No Nordeste destaca-se a Paraíba (as cores são utilizadas apenas para esclarecer os limites entre as RM's).

Figura 2: Esquema conceitual - comparação entre os aportes de Soja (2000) e Ascher (2012). 18

Figura 3: Pôster de divulgação da Welwyn Garden City, cidade inspirada nas concepções de Howard e do condomínio residencial Monteverdi (localizado em Arcos/MG): ambos vendem a ideia de convívio com a natureza, importante fator que agrega valor aos empreendimentos imobiliários brasileiros...... 25

Figura 4: Big Brother urbano: à esquerda, orla da cidade de Madre de Deus, região metropolitana de Salvador que pretende se tornar a cidade mais vigiada do Brasil. À direita, um dos drones, robôs voadores equipados com câmeras, que se espalham pela cidade de São Paulo para observar lugares e pessoas

Figura 5: Tirinha que representa o enclausuramento das residências ao longo do tempo.... 29

Figura 6: À esquerda, vista de uma cidade montada no jogo SimCity, e à direita, um exemplo do "sonho americano de morar" em Celebration, comunidade desenvolvida pela Walt Disney próxima aos parques da empresa na Flórida, Estados Unidos da América - EUA.

Figura 7: Cidades que receberam o Programa Nacional de Capitais e Cidades de Porte Médio PNCCPM divididas por regiões.

Figura 8: Mapa com a distribuição de cidades com 100.001 a 500 mil habitantes na Região Nordeste.

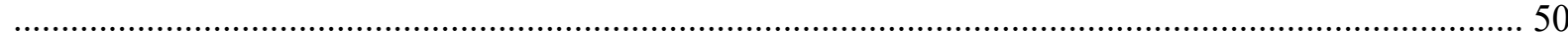

Figura 9: Mapa da distribuição espacial da Rede Urbana da Região Nordeste................................ 55

Figura 10: Rede urbana brasileira segundo o IBGE (2007). 59

Figura 11: Esquema de concepção da medida de integração proporcional, sob base cartográfica de Sobral/CE. 70

Figura 12: Representação em forma de grafo de um trecho de uma malha urbana onde os nós representam as vias e as arestas representam os cruzamentos. 74

Figura 13: Mapa axial de Integração Global do Crajubar/Ceará 75

Figura 14: Comparativo entre as representações axial e de segmentos (sob base cartográfica fictícia).

Figura 15: Exemplos de Conurbação Física. 82

Figura 16: À direita, vista de uma balsa atravessando o Rio Tocantins com, ao fundo, a Ponte da Liberdade. À esquerda, uma imagem de satélite da divisa interestadual MA-TO. 83

Figura 17: Espacialização das RM's e municípios em estudo.

Figura 18: Mapa de distribuição de renda (V005) por setor censitário da RM de Feira de Santana/BA.

Figura 19: Mapa de distribuição de renda (V005) por setor censitário da RM Cariri/CE. 99

Figura 20: Mapa de distribuição de renda (V005) por setor censitário da RM Sudoeste Maranhense/MA.

Figura 21: Mapa de distribuição de renda (V005) por setor censitário da RM Campina Grande/PB. 101

Figura 22: Mapa de distribuição de renda (V005) por setor censitário da RAID de Petrolina/Juazeiro. 
Figura 23: Mapa de distribuição de renda (V005) por setor censitário da RM Agreste/AL. 103

Figura 24: Mapa de distribuição de renda (V005) por setor censitário de Vitória da Conquista/BA. 104

Figura 25: Mapa de distribuição de renda (V005) por setor censitário de Sobral/CE. 105

Figura 26: Mapa de distribuição de renda (V005) por setor censitário de Mossoró/RN....... 106

Figura 27: Mapa de distribuição de renda (V005) por setor censitário de Caruaru/PE 107

Figura 28: Mapa de distribuição de renda (V005) por setor censitário da RM Salvador/BA. 108

Figura 29: Mapa de distribuição de renda (V005) por setor censitário da RM Fortaleza/CE. 109

Figura 30: Mapa de distribuição de renda (V005) por setor censitário da RM Recife/PE 110

Figura 31: Esquemas de distribuição de renda. 111

Figura 32: Av. Getúlio Vargas, que possui alto valor de integração em Feira de Santana/BA. 132

Figura 33: À esquerda, a Av. João Durval Carneiro e, à esquerda, a Av. Presidente Dutra. 132 Figura 34: Verticalização em Feira de Santana/BA, skyline a partir da Avenida Noide Cerqueira.... 133 Figura 35: Mapa axial da RM de Feira de Santana/BA calculado por Integração HH global (Rn).... 134 Figura 36: Vista geral de Feira de Santana/BA. Em primeiro plano, o Boulevard Shopping. 135

Figura 37: Bairro Calumbi, em imagem de satélite (à esquerda) e vista de uma de suas vielas (à direita), em Feira de Santana/BA. 136

Figura 38: Bairro Muchila, em imagem de satélite (à esquerda) e vista de uma de suas vielas (à direita), em Feira de Santana/BA.

Figura 39: Intensidade de Concentração de Condomínios Fechados em Feira de Santana (BA) - 1995 a 2010.

Figura 40: Mapa de segmentos da RM de Feira de Santana/BA calculado por Integração. 137

Figura 41: Vistas da Av. Maria Quitéria em Feira de Santana/BA. 138

Figura 42: Vista da Rua Senador Quintino (à esquerda) e vista aérea do Condomínio Alphaville Feira de Santana I, situado às margens da BR-116 (à direita), em Feira de Santana/BA 138

Figura 43: Mapa axial da RM de Feira de Santana/BA calculado por Escolha (choice). 139

Figura 44: Mapa de segmentos da RM de Feira de Santana/BA calculado por Escolha (choice). ..... 140

Figura 45: Tipos de empreendimentos "Minha casa, Minha Vida" em Feira de Santana/BA. 140

Figura 46: Núcleo de integração do Crajubar: à esquerda, uma vista geral do Triângulo e, à direita, maquete eletrônica de um projeto para a área. 142

Figura 47: Av. Padre Cícero (à esquerda), ligação entre Crato e Juazeiro do Norte, e a Av. Leão Sampaio (à direita). 142

Figura 48: Vista geral do bairro Triângulo, onde é possível observar o entroncamento viário e os equipamentos que atendem a uma demanda regional, como o Hospital à direita. 142

Figura 49: Mapa axial da RM do Cariri/CE calculado por Integração HH global (Rn). 143

Figura 50: Mapa de segmentos da RM do Cariri/CE calculado por integração. 144

Figura 51: Cenário do bairro Lagoa Seca, área nobre de Juazeiro do Norte/CE que muda com a verticalização de seus imóveis. 145

Figura 52: Exemplo dos novos loteamentos no Cariri: à esquerda, imagem de satélite do condomínio fechado "Cidade Kariris Residencial Club" e, à direita, uma imagem promocional do mesmo. 146 
Figura 53: Ligação entre o Crato e Barbalha, à direita, uma vista do distrito cratense Baixio das

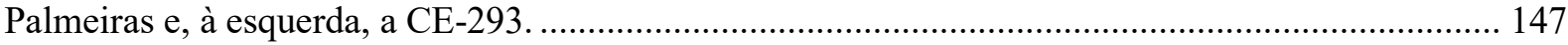

Figura 54: Mapa axial da RM do Cariri/CE calculado por Escolha (choice)................................ 147

Figura 55: Centro Tradicional do Crato que tem como principal eixo a R. Dr. João Pessoa............. 148

Figura 56: Vista geral da área central do Crato. Ao fundo, a Chapada do Araripe e, à direita, a Igreja da Sé (Praça da Sé) ............................................................................................... 148

Figura 57: Mapa de segmentos da RM do Cariri/CE calculado por Escolha (choice).

Figura 58: À esquerda, a BR-010 na altura do centro de Imperatriz e, à direita, uma vista da Av. Babaçulândia. 150

Figura 59: Imagem de satélite, apresentando os dois principais centros comerciais de Imperatriz. Em laranja, o Timbira Shopping Center; em verde, o Tocantins Shopping Center e, em vermelho, o Shopping Imperial. 151

Figura 60: À esquerda, o Tocantins Shopping Center e, à direita, o Shopping Imperial. 151

Figura 61: Mapa axial da RM do Sudoeste Maranhense/MA calculado por Integração HH global (Rn). 152

Figura 63: À esquerda, imagem de satélite das expansões residenciais no sul da cidade e, à direita, um folheto de propaganda do Loteamento "Cidade nova" em Davinópolis/MA. 153

Figura 64: Imagens de satélite das expansões residenciais ao noroeste da cidade: Parque Independência, à esquerda, e sua inserção "rural". À direita, uma vista das casas dispostas enfileiradas.

Figura 64: Mapa de segmentos da RM do Sudoeste Maranhense/MA calculado por Integração....... 154

Figura 65: Aeroporto de Imperatriz - Prefeito Renato Moreira. 155

Figura 66: Vista geral de Imperatriz. À esquerda, o Rio Tocantins e o discreto processo de verticalização desta área. 156

Figura 67: Mapa axial da RM do Sudoeste Maranhense/MA calculado por Escolha (choice) 157

Figura 68: Mapa de segmentos da RM do Sudoeste Maranhense/MA calculado por Escolha (choice). 158

Figura 69: À direita, uma imagem da Av. Marechal Floriano Peixoto. À esquerda, vista da verticalização do bairro da Prata e, em segundo plano, a verticalização do bairro da Bela Vista. ..... 159

Figura 70: Vistas do processo de verticalização de Campina Grande nos arredores de Açude Velho.

Figura 71: Mapa axial da RM de Campina Grande/PB calculado por Integração HH global (Rn).... 160

Figura 72: À direita, uma imagem da Av. Almirante Barroso e, à esquerda, vista da Av Juscelino Kubistchek. 161

Figura 73: Aspectos do Pedregal: à esquerda, sua ocupação densa em desenho irregular e, à direita, o protesto de uma moradora contra as péssimas condições de habitabilidade do bairro. 161

Figura 74: Mapa de segmentos da RM de Campina Grande/PB calculado por Integração. 162

Figura 75: Loteamento Alto da Serra. À esquerda, uma imagem de satélite que demonstra a diferenciação entre o tecido urbano novo e o existente. À direita, uma vista das residências construídas na tipologia de sobrados.

Figura 76: Residencial Dona Lindú. À esquerda, uma imagem que demostra a diferenciação entre o tecido novo (fechado) e o existente. À direita, uma vista das tipologia de "bloco H". 163

Figura 77: Mapa axial da RM de Campina Grande/PB calculado por Escolha (choice). 164 
Figura 78: Mapa de segmentos da RM de Campina Grande/PB calculado por Escolha (choice). ..... 165

Figura 79: À esquerda, uma imagem da Av. 7 de Setembro e, à direita, vista da Av. das Nações.... 166

Figura 80: À esquerda, uma vista do campus UNIVASF e, à direita, vista do River Shopping.

Figura 81: À esquerda, uma vista geral de Petrolina, destacando-se a expansão vertical ao longo da margem do Rio S. Francisco e, à direita, áreas carentes em infraestrutura (próximas ao aeroporto). 167

Figura 82: Mapa axial da RAID Petrolina-Juazeiro calculado por Integração HH global (Rn). ........ 168

Figura 83: Mapa de segmentos da RAID Petrolina-Juazeiro calculado por Integração.

Figura 84: À esquerda, uma vista ponte Presidente Dutra com, ao fundo a cidade de Juazeiro. À direita, a Av. Santos Dumont. 170

Figura 85: Vista da Igreja Sagrado Coração de Jesus, em Petrolina, e, ao fundo, o processo de verticalização da cidade ao longo da margem do Rio São Francisco. 170

Figura 86: Mapa axial da RAID Petrolina-Juazeiro calculado por Escolha (choice). 171

Figura 87: Mapa de segmentos da RAID Petrolina-Juazeiro calculado por Escolha (choice). 172

Figura 88: Comparativo entre os mapas por meio da Medida de Integração Proporcional. 173

Figura 89: À esquerda, a Av. Benjamim Freire de Amorim (bairro Brasiliana). À direita, a rua São Francisco (bairro Centro).

Figura 90: A esquerda vista geral de Arapiraca/Al, mostrado sua tímida verticalização, e a direita um

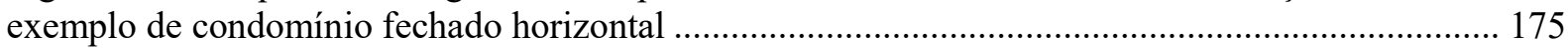

Figura 91: Mapa axial da RM do Agreste/AL calculado por Integração HH global (Rn). ................ 175

Figura 92: Vista do Arapiraca Garden Shopping, à esquerda, a fachada do empreendimento e, à direita, sua localização (em rosa) às margens da rodovia AL-115, área de expansão da cidade. ....... 177

Figura 93: Mapa de segmentos da RM do Agreste/AL calculado por Integração. 178

Figura 94: Mapa axial da RM do Agreste/AL calculado por Escolha (choice). 179

Figura 95: Mapa de segmentos da RM do Agreste/AL calculado por Escolha (choice). 180

Figura 96: Vistas dos empreendimentos habitacionais em Arapiraca/AL: Residencial Sierra, condomínio fechado de alto padrão a $3 \mathrm{~km}$ do Arapiraca Garden Shopping e $5 \mathrm{~km}$ do centro. 181

Figura 97: Vistas dos empreendimentos habitacionais em Arapiraca/AL: Residencial Brisa do Lago, conjunto habitacional de interesse social implantado na área periférica da cidade. 181

Figura 98: À esquerda, a BR-116, que atravessa Vitória da Conquista/BA e, à direita, uma vista da Av. Brumadinho. 182

Figura 99: À esquerda, uma imagem de satélite da zona sul de Vitória da Conquista/BA, destacado em vermelho o shopping e, em verde, o Condomínio Green Ville. À direita, Shopping Conquista Sul... 182

Figura 100: Mapa axial de Vitória da Conquista/BA calculado por Integração HH global (Rn). ...... 183

Figura 101: À esquerda, um exemplo de residência no condomínio Green Ville e, à direita, a vista de seu muro externo onde há outro padrão construtivo e de infraestruturas urbanas. . 184

Figura 102: Mapa de segmentos de Vitória da Conquista/BA calculado por Integração. 185

Figura 103: Mapa axial de Vitória da Conquista/BA calculado por Escolha (choice). 186

Figura 104: Mapa de segmentos de Vitória da Conquista/BA calculado por Escolha (choice). 187

Figura 105: À esquerda, uma visão geral da Grendene em Sobral/CE e, à direita, a Av. Dr José

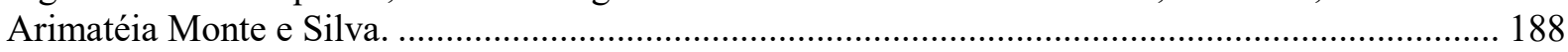

Figura 106: Mapa axial de Sobral/CE calculado por Integração HH global (Rn). 190 
Figura 107: Vistas da intervenção sobre Margem Esquerda do rio Acaraú. 191

Figura 108: Novos loteamentos em Sobral/CE.

Figura 109: Mapa de segmentos de Sobral/CE calculado por Integração.

Figura 110: North Shopping Sobral. À esquerda e em vermelho, sua localização na foto aérea e, à direita, a vista das duas torres que recebem escritórios e um hotel.

Figura 111: À esquerda, Av. Monsenhor Aloísio Pinto e, à direita, uma vista geral dos bairros Centro (em primeiro plano) e Dom Expedito.

Figura 112: Mapa geral do sistema de mobilidade integrado de Sobral/CE. 194

Figura 113: Vistas do VLT em Sobral/CE. 194

Figura 114: Mapa axial de Sobral/CE calculado por Escolha (choice)... 195

Figura 115: Mapa de segmentos de Sobral/CE calculado por Escolha (choice). 196

Figura 116: Mapa axial de Mossoró/RN calculado por Integração HH global (Rn). 197

Figura 117: À esquerda, a R. Frei Miguelinho e, à direita, a R. Duodécimo Rosado 198

Figura 118: À esquerda, o Partage Shopping Mossoró e, à direita, uma imagem de satélite, na qual destaco em azul o condomínio Alphaville, em vermelho, o shopping, em amarelo, a Estrada da Alagoinha e, em laranja, o Hotel Thermas. 198

Figura 119: Mapa de segmentos de Mossoró/RN calculado por Integração. 199

Figura 120: Mapa axial de Mossoró/RN calculado por Escolha (choice).......................................... 200

Figura 121: Processo de verticalização em Mossoró/RN..................................................................... 201

Figura 122: Mapa de segmentos de Mossoró/RN calculado por Escolha (choice)............................. 201

Figura 123: À esquerda, a BR-104. À direita, a R. Leão Dourado. 202

Figura 124: Feira de Caruaru, à esquerda, quando era locada no centro da cidade (1992) e, à direita, nos dias atuais ocupando seu novo espaço. 203

Figura 125: Caruaru Shopping, à esquerda, na imagem de satélite (em vermelho) e, à direita, em uma vista aérea. 203

Figura 126: Mapa axial de Caruaru/PE calculado por Integração HH global (Rn). 204

Figura 127: Processo de verticalização de Caruaru/PE. 205

Figura 128: À esquerda, imagem de satélite do condomínio fechado Quintas da Colina e, à direita, exemplo de uma residência neste empreendimento, cujo valor venal é de $\mathrm{R} \$ 650.000,00 \ldots \ldots \ldots \ldots \ldots . . . . . . .205$

Figura 129: Mapa de segmentos de Caruaru/PE calculado por Integração. 206

Figura 130: À esquerda, imagem de satélite do bairro Boa Vista e, à direita, exemplo do conjunto Jardim Ipojuca, que possui apartamentos com média de $50 \mathrm{~m}^{2}$. 206

Figura 131: Mapa axial de Caruaru/PE calculado por Escolha (choice) ............................................... 207

Figura 132: Vista panorâmica de Caruaru/PE a partir do Monte do Bom Jesus. ................................. 207

Figura 133: Mapa de segmentos de Caruaru/PE calculado por Escolha (choice)............................... 208

Figura 134: Comparativo entre os mapas por meio da Medida de Integração Proporcional.

Figura 135: À esquerda, vista da BR-324 e, à direita, uma vista da Av. Luís Viana (mais conhecida como Paralela) e sua ocupação lindeira marcada pela verticalização.

Figura 136: Duas vistas da Estrada do Coco (BA-099) - à esquerda, na altura do município de Lauro de Freitas e, à direita, na Praia de Arembepe (localizada no município de Camaçari). Abaixo um mapa esquemático da via. 
Figura 137: Mapa axial de Salvador/BA calculado por Integração HH global (Rn) e Escolha.......... 213

Figura 138: Mapa axial da RM de Salvador/BA calculado por Integração HH global (Rn). ............. 214

Figura 139: Mapa axial da RM de Salvador/BA calculado por Escolha (choice)............................... 215

Figura 140: Vista da Baía de Todos os Santos, demonstrando o denso processo de verticalização de Salvador/BA.

Figura 141: Vista da Praia de Guarajuba, Camaçari - à esquerda, imagem de satélite onde destacam-se os condomínios fechados entre a Estrada do Coco e o Oceano Atlântico e, à direita, exemplo de uma residência de luxo nestes condomínios.

Figura 142: Vistas do Centro Histórico de Salvador/BA: à esquerda, o Pelourinho e, à direita, uma moradora da Ladeira da Preguiça, que passou por demolições em decorrência das fortes chuvas de 2015.

Figura 143: Vista do Centro Histórico de Salvador/BA. Em primeiro plano, o Terreiro de Jesus e, ao fundo, as expansões verticais.

Figura 144: Duas vistas da via mais integrada da RM de Salvador, a BA-526, na área em que se localiza o Aeroporto, e o Salvador Norte Shopping (à direita).

Figura 145: Eixos de expansão de Fortaleza À esquerda, a Av. Bezerra de Menezes e, à direita, vista aérea da BR-116.

Figura 146: Mapa axial de Fortaleza/CE calculado por Integração HH global (Rn) e Escolha.......... 220

Figura 147: Mapa axial da RM de Fortaleza/CE calculado por Integração HH global (Rn).

Figura 148: Esquema de expansão da cidade de Fortaleza/CE desenvolvido por Capasso (2007) baseado no esquema de Hoyt.

Figura 149: Vista do bairro Aldeota: à esquerda, a Praça Portugal, espaço simbólico do bairro, e, à direita, uma imagem do Shopping Aldeota localizado na mesma praça.

Figura 150: Mapa axial da RM de Fortaleza/CE calculado por Escolha (choice).

Figura 151: Tipologias habitacionais no bairro Passaré, em Fortaleza/CE.

Figura 152: Loteamento Porto das Dunas, exemplo de condomínio residencial de alto padrão, relacionado com a atividade turística.

Figura 153: Eixos de expansão do núcleo de integração da RM de Recife/PE. À direita, a PE-015, em Olinda, e, à esquerda, a PE-008.

Figura 154: Panorama do bairro de Santo Antônio, em Recife/PE.

Figura 155: Mapa axial da aglomeração Olinda-Recife-Jaboatão dos Guararapes/PE calculado por Integração HH global (Rn).

Figura 156: Processo de verticalização em Recife/PE. À esquerda, o grande adensamento e, à direita, esse processo na Praia de Boa Viagem, Zona Sul da cidade.

Figura 157: Mapa axial da RM de Recife/PE calculado por Integração HH global (Rn).

Figura 158: Shoppings em Recife. No alto, à esquerda, o Shopping Center Recife, visto em foto de satélite (em rosa) e seu entorno, à direita. Embaixo, à esquerda, o Shopping Guararapes, visto em foto de satélite (em amarelo) e, seu entorno, à direita.

Figura 159: Mapa axial da RM de Recife/PE calculado por Escolha (choice).

Figura 160: Preservação e transformações patrimoniais em Olinda/PE. À esquerda, uma vista do colorido casario próximo aos "quatro cantos" e, à direta, uma vista das transformações dos edifícios. 
Figura 162: Comparativo entre os mapas por meio da Medida de Integração Proporcional.

Figura 163: Mapa de Densidade Populacional (em habitantes por hectare) por setor censitário da RM Feira de Santana/BA.

Figura 164: Mapa de Densidade Populacional (em habitantes por hectare) por setor censitário da RM do Cariri/CE.

Figura 165: Mapa de Densidade Populacional (em habitantes por hectare) por setor censitário da RM do Sudoeste maranhense/MA.

Figura 166: Mapa de Densidade Populacional (em habitantes por hectare) por setor censitário da RM Campina Grande/PB. 242

Figura 167: Mapa de Densidade Populacional (em habitantes por hectare) por setor censitário da RAID Petrolina/PE e Juazeiro/BA.

Figura 168: Mapa de Densidade Populacional (em habitantes por hectare) por setor censitário da RM do Agreste/AL.

Figura 169: Mapa de Densidade Populacional (em habitantes por hectare) por setor censitário de Vitória da Conquista/BA.

Figura 170: Mapa de Densidade Populacional (em habitantes por hectare) por setor censitário de Sobral/CE. 248

Figura 171: Mapa de Densidade Populacional (em habitantes por hectare) por setor censitário de Mossoró/RN.

Figura 172: Mapa de Densidade Populacional (em habitantes por hectare) por setor censitário de Caruaru/PE.

Figura 173: Mapa de Densidade Populacional (em habitantes por hectare) por setor censitário da RM Salvador/BA.

Figura 174: Mapa de Densidade Populacional (em habitantes por hectare) por setor censitário da RM Fortaleza/CE.

Figura 175: Mapa de Densidade Populacional (em habitantes por hectare) por setor censitário da RM de Recife/PE. 256

Figura 176: Esquema conceitual do tipo metropolitano do interior do Nordeste. 267 


\section{LISTA DE QUADROS}

Quadro 1: Critérios de inclusão de municípios a RM's (anos 1970) 44

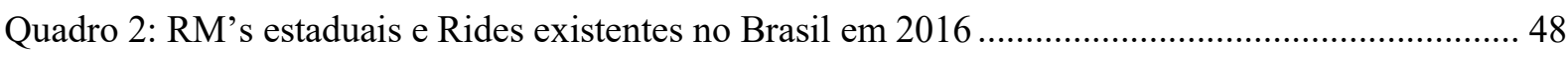

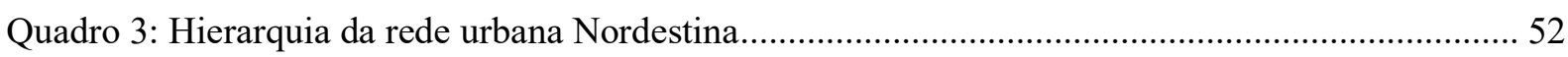

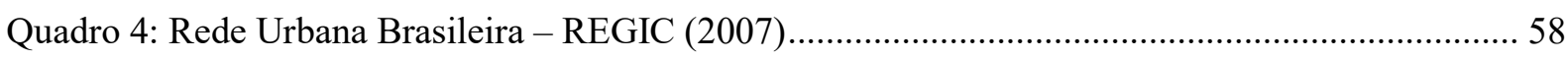

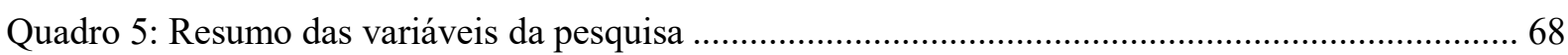

Quadro 6: Outras cidades/aglomerações de interesse ........................................................................... 80

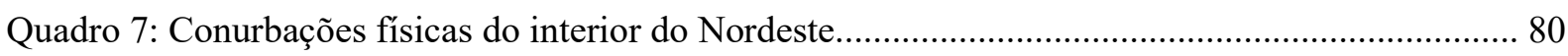

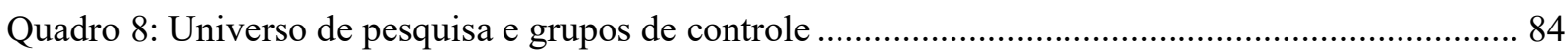

Quadro 9: Comparativo entre centralidades, usos e distribuição de densidades e rendas.................... 257

Quadro 10: Comparativo entre as tipologias de expansão residencial ............................................ 261 


\section{LISTA DE TABELAS}

Tabela 1: Demonstrativo das RM's do Nordeste do Brasil. 79

Tabela 2: PIB total das RM's, do município sede e per capita 89

Tabela 3: Pessoas de 10 anos ou mais de idade, por classes de rendimento nominal mensal, nas RMINE's selecionadas

Tabela 4: Pessoas de 10 anos ou mais de idade, por classes de rendimento nominal mensal, no Grupo de controle 01 - 2010

Tabela 5: Pessoas de 10 anos ou mais de idade, por classes de rendimento nominal mensal, no Grupo de controle $02-2010$.

Tabela 6: Pessoas de 10 anos ou mais de idade, por classes de rendimento nominal mensal, no Grupo de controle 02 (RM de Recife/PE)- 2010

Tabela 7: Pessoas de 10 anos ou mais de idade, por nível de instrução nas RMINE's selecionadas 2010 .

Tabela 8: Pessoas de 10 anos ou mais de idade, por nível de instrução no Grupo de Controle 01 - 2010 113

Tabela 9: Pessoas de 10 anos ou mais de idade, por nível de instrução no Grupo de Controle 02 - 2010

Tabela 10: Pessoas de 10 anos ou mais de idade, ocupadas na semana de referência, por grandes grupos de ocupação no trabalho principal, para as RMINE's selecionadas- 2010. 118

Tabela 11: Pessoas de 10 anos ou mais de idade, ocupadas na semana de referência, por grandes grupos de ocupação no trabalho principal, para o grupo de controle 01-2010......

Tabela 12: Pessoas de 10 anos ou mais de idade, ocupadas na semana de referência, por grandes grupos de ocupação no trabalho principal, para o grupo de controle 02 - RM de Salvador - 2010 .. 120

Tabela 13: Pessoas de 10 anos ou mais de idade, ocupadas na semana de referência, por grandes grupos de ocupação no trabalho principal, para o grupo de controle 02 - RM de Fortaleza - 2010 ... 121

Tabela 14: Pessoas de 10 anos ou mais de idade, ocupadas na semana de referência, por grandes grupos de ocupação no trabalho principal, para o grupo de controle 02 - RM de Recife - 2010 ....... 122

Tabela 15: Pessoas ocupadas na semana de referência, que trabalhavam fora do domicílio e retornavam para seu domicílio diariamente, por tempo habitual de deslocamento para o trabalho 2010.

Tabela 16: Pessoas ocupadas na semana de referência, que trabalhavam fora do domicílio e retornavam para seu domicílio diariamente, por tempo habitual de deslocamento para o trabalho 2010.

Tabela 17: Pessoas ocupadas na semana de referência, que trabalhavam fora do domicílio e retornavam para seu domicílio diariamente, por tempo habitual de deslocamento para o trabalho 2010.

Tabela 18: Medida de integração proporcional das RMINE'S

Tabela 19: Medida de integração proporcional do Grupo de controle 01

Tabela 20: Medida de integração proporcional do Grupo de controle 02

Tabela 21: Distribuição da população e densidade nos municípios constituintes da RM de Feira de Santana/BA 
Tabela 22: Distribuição da população e densidade nos municípios constituintes da RM do Cariri/CE 236

Tabela 23: Distribuição da população e densidade nos municípios constituintes da RM do Sudoeste maranhense/MA 238

Tabela 24: Distribuição da população e densidade nos municípios constituintes da RM de Campina Grande/PB 240

Tabela 25: Distribuição da população e densidade nos municípios constituintes da RAID Petrolina/PE e Juazeiro/BA

Tabela 26: Distribuição da população e densidade nos municípios constituintes da RM do Agreste/AL 244

Tabela 27: Distribuição da população e densidade nos municípios do Grupo de Controle 01 246

Tabela 28: Distribuição da população e densidade nos municípios constituintes da RM de

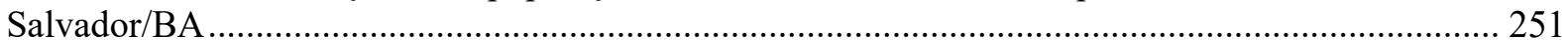

Tabela 29: Distribuição da população e densidade nos municípios constituintes da RM de Fortaleza/CE. 253

Tabela 30: Distribuição da população e densidade nos municípios constituintes da RM do Recife/PE 255 


\section{LISTA DE GRÁFICOS}

Gráfico 1: número de RM’s criadas por região por década 46

Gráfico 2: Comparativo entre os PIB per capita (2013) 90

Gráfico 3: Pessoas de 10 anos ou mais de idade, por classes de rendimento nominal mensal nas RM's e cidades selecionadas 96

Gráfico 4: Distribuição dos níveis de instrução nas RMINE's selecionadas - 2010 113

Gráfico 5: Distribuição dos níveis de instrução no Grupo de Controle 01 - 2010 114

Gráfico 6: Distribuição dos níveis de instrução no Grupo de Controle 02 - 2010. 116

Gráfico 7: Distribuição do tempo habitual de deslocamento para o trabalho nas RMINE's selecionadas $-2010$

Gráfico 8: Distribuição do tempo habitual de deslocamento para o trabalho no Grupo de Controle 01 2010.

Gráfico 9: Distribuição do tempo habitual de deslocamento para o trabalho no Grupo de Controle 02 2010. 128

Gráfico 10: Comparativo entre as densidades populacionais $\left(\mathrm{hab} / \mathrm{km}^{2}\right)$ nas cidades-sede e RM's .... 259

Gráfico 11: Comparação das integrações HH máxima, média e mínima para os totais, cercanias e miolos das RM's e cidades em estudo 


\section{LISTA DE ABREVIATURAS E SIGLAS}

\begin{tabular}{ll} 
AC & Acre \\
ACP & Áreas de Concentração de População \\
AL & Alagoas \\
AM & Amazonas \\
AP & Amapá \\
AU & Aglomerações Urbanas \\
Av. & Avenida \\
BA & Bahia \\
BNH & Banco Nacional de Habitação \\
BR & Rodovias Federais \\
CAB & Centro Administrativo da Bahia \\
CAD & Computer Aided Design \\
CCS & Centro de Comércio e Serviços \\
CE & Ceará \\
CF & Constituição Federal \\
CHESF & Companhia Hidrelétrica do São Francisco \\
CNN & Cable News Network \\
COD & Classificação de Ocupações para Pesquisas Domiciliares \\
DAC & Desenho Assistido por Computador \\
DF & Distrito Federal \\
DIMPU & Dimensões Morfológicas do Processo de Urbanização \\
Dr. & Doutor \\
EUA & Estados Unidos da América \\
GAM & Grupo de Áreas Metropolitanas \\
GIS & Geographic Information Systems \\
GO & Goiás \\
GPS & Global Positioning System \\
GTDN & Grupo de Trabalho para o Desenvolvimento do Nordeste \\
HH & Hillier e Hanson \\
IBGE & Instituto Brasileiro de Geografia e Estatística \\
INFRAERO & Empresa Brasileira de Infraestrutura Aeroportuária \\
IPEA & Instituto de Pesquisa Econômica Aplicada \\
IPHAN & Instituto do Patrimônio Histórico e Artístico Nacional \\
IPPUR & Instituto de Pesquisa e Planejamento Urbano e Regional \\
JK & Juscelino Kubitschek \\
Km & Quilômetros \\
Km2 & Quilômetros quadrados \\
MA & Maranhão \\
MG & Minas Gerais \\
MS & Mato Grosso do Sul \\
MT & Mato Grosso \\
NESUR & Núcleo de Economia Social, Urbana e Regional \\
ONU & Organização das Nações Unidas \\
OSM & OpenStreetMap \\
PA & Pará \\
& \\
\hline &
\end{tabular}




\begin{tabular}{|c|c|}
\hline PAC & Programa de Aceleração do Crescimento \\
\hline PB & Paraíba \\
\hline РСРМ & Programa para Cidades de Porte Médio \\
\hline PE & Pernambuco \\
\hline PEA & População Economicamente Ativa \\
\hline PI & Piauí \\
\hline PIB & Produto Interno Bruto \\
\hline PL & Projeto de Lei \\
\hline PMCMV & Programa Minha Casa, Minha Vida \\
\hline PNCCPM & Programa nacional de Capitais e Cidades de Porte Médio \\
\hline PND & Plano Nacional de Desenvolvimento \\
\hline PNPRU & Política Nacional de Planejamento Regional Urbano \\
\hline PR & Paraná \\
\hline PSDB & Partido da Social Democracia Brasileira \\
\hline PT & Partido dos Trabalhadores \\
\hline R. & Rua \\
\hline RAID & Região Administrativa Integrada de Desenvolvimento \\
\hline RECIME & Rede de Pesquisadores sobre Cidades Médias \\
\hline REDBCM & Rede Brasileira de Estudos sobre Cidades Médias \\
\hline REGIC & Regiões de Influência das Cidades \\
\hline RIDe & Região Integrada de Desenvolvimento \\
\hline RJ & Rio de Janeiro \\
\hline $\mathbf{R M}$ & Região Metropolitana \\
\hline RMINE & Regiões Metropolitanas no Interior do Nordeste \\
\hline $\mathbf{R N}$ & Rio Grande do Norte \\
\hline RO & Rondônia \\
\hline $\mathbf{R R}$ & Roraima \\
\hline RS & Rio Grande do Sul \\
\hline SC & Santa Cantarina \\
\hline SE & Sergipe \\
\hline SE & Sintaxe Espacial \\
\hline SIG & Sistemas de Informação Geográfica \\
\hline SP & São Paulo \\
\hline SUDAM & Superintendência do Desenvolvimento da Amazônia \\
\hline SUDECO & Superintendência do Desenvolvimento do Centro-Oeste \\
\hline SUDENE & Superintendência do Desenvolvimento do Nordeste \\
\hline TO & Tocantins \\
\hline UERN & Universidade Estadual do Rio Grande Norte \\
\hline $\mathbf{U F}$ & Unidades da Federação \\
\hline UFAL & Universidade Federal de Alagoas \\
\hline UFCa & Universidade Federal do Cariri \\
\hline UFERSA & Universidade Federal Rural do Semiárido \\
\hline UFPB & Universidade Federal da Paraíba \\
\hline UFPE & Universidade Federal do Pernambuco \\
\hline UFRJ & Universidade Federal do Rio de Janeiro \\
\hline UFRN & Universidade Federal do Rio Grande do Norte \\
\hline UnB & Universidade de Brasília \\
\hline UNESCO & United Nations Educational, Scientific and Cultural Organization \\
\hline UNICAMP & Universidade Estadual de Campinas \\
\hline UNIVASF & Universidade Federal do Vale do São Francisco \\
\hline
\end{tabular}


2.1 O PLANEJAMENTO URBANO E O TEMA METROPOLITANO NO BRASIL ATÉ OS ANOS 1970: O NORDESTE, A SUDENE E SUAS AÇÕES

2.2 Os Planos NACIONAIS DE DESENVOLVIMENTO, METRÓPOLES E CIDADES MÉDIAS

2.3 As RM A PARTIR DA CONSTITUIÇÃO FEDERAL DE 1988 E O ESTATUTO DAS METRÓPOLES: AVANÇOS E LIMITES

3.2 MÉTODO: AS CATEGORIAS ANALÍTICAS E SUAS RELAÇÕES 67

3.3 TÉCNICAS

\section{AS PESSOAS E A CIDADE: ANÁLISE DAS VARIÁVEIS DE ORDEM} SOCIOECONÔMICA

\section{A CIDADE E AS PESSOAS: ANÁLISE DAS VARIÁVEIS DE ORDEM}


5.1.1 RMINE'S SELECIONADAS 132

5.1.2 GRUPO DE CONTROLE 01

174

5.1.3 GRUPO DE CONTROLE 02

210

5.2 ANÁLISE DAS VARIÁVEIS DO SISTEMA DE ENCONTROS E ESQUIVANÇAS: DENSIDADE POPULACIONAL

5.2.1 RMINE'S SELECIONADAS

5.2.2 GRUPO DE CONTROLE 01 


\section{INTRODUÇÃO}




\section{INTRODUCCÃO}

Somos "seres urbanos". Há milênios a civilização humana entendeu a necessidade (e as vantagens) de se organizar em um espaço não-rural. Segundo relatório da Organização das Nações Unidas - ONU - de 2014, 54\% da população mundial vive em áreas urbanas e deve atingir 66\% em 2050. Esses números trazem consigo imensos desafios: habitação, infraestrutura, saúde, educação etc. Esta pesquisa tem a motivação inicial de compreender tal crescimento urbano - em especial o caso brasileiro - e colaborar com a gerência e melhoria do maior artefato que a sociedade criou: a cidade.

Muito se fala das grandes metrópoles ou megacidades ${ }^{1}$, mas apenas um a cada oito habitantes estão nesses centros, enquanto cerca de 1,9 bilhões de habitantes residem em aglomerações com até 500 mil habitantes (ONU, 2014). E estas são as cidades que apresentam maior taxa de crescimento. No Brasil os dados não são discrepantes: nos últimos anos, as cidades médias foram aquelas que apresentaram maior crescimento anual do Produto Interno Bruto - PIB - e crescimento mais elevado da população (MOTTA \& MATA, 2009).

Traça-se um breve parêntesis acerca da definição de cidades médias. Não há definição cristalizada e aceita nas diversas áreas de estudo; entretanto, o critério mais adotado é o tamanho demográfico: significando, em geral, as populações entre 100 e 500 mil habitantes. O IPEA definiu na década de 1970 as aglomerações urbanas com população entre 50 e 250 mil habitantes como cidades médias, o que demonstra como essa classificação demográfica mudou ao longo dos anos. Classificações congruentes trazem maior detalhamento, separando duas categorias: (1) cidades médias-pequenas, com população de 50 a 100 mil habitantes; (2) cidades médias-grandes, aquelas que possuem de 300 a 500 mil habitantes (LOPES JÚNIOR, 2007). Tais divisões por critérios demográficos são resquícios de uma tradição quantitativa da geografia de modo que:

[...] por um lado, uma das contextualizações para a definição das cidades médias é a temporal e, por outro lado, as cidades médias se apresentam médias quando permeadas pelos contextos e conteúdos do processo de urbanização. Nestes, portanto, devem ser apreendidas e desveladas de forma que sejam pensadas interpenetradas ao

\footnotetext{
${ }^{1}$ O mesmo relatório da ONU indica que em 1990 havia dez "megacidades" com 10 milhões de habitantes ou mais cada, contabilizando 153 milhões de pessoas, cerca de 7\% da população urbana global à época. Em 2014, haviam 28 megacidades no mundo comportando 453 milhões de pessoas, cerca de $12 \%$ da população mundial. 
movimento dos processos sociais, econômicos e espaciais contemporâneos. As cidades médias, nesta direção, não se constituem inertes enquanto médias e definidas por atributos fixados temporalmente, não sendo apreendidas de forma dissociada ao processo de reprodução da sociedade e do capital, de forma dissociada da realidade social em incessante e inconstante movimento (OLIVEIRA JÚNIOR, 2008, p. 11).

Esse critério demográfico também pode ser criticado tendo em vista a heterogeneidade da rede urbana brasileira: seria ingênuo supor que duas cidades de 50 mil habitantes, uma no Norte e outra em São Paulo, possuem as mesmas capacidades de polarização, como discutidas por Souza (2003, p. 30-31): "uma cidade média em uma região pobre [...] tenderá a não apresentar comércio e serviços tão diversificados e sofisticados quanto uma cidade de mesmo porte em uma região mais próspera, com uma presença bem mais expressiva de estratos de renda médios". Nos últimos anos, novos estudos ${ }^{2}$ foram realizados acerca da temática, decorrentes do crescimento do número de cidades médias e do incremento populacional expresso nelas e, sobretudo, devido à posição que as estas passaram a ocupar na rede urbana brasileira. Ou seja, o termo "médio" faz referência à posição que essas cidades exercem na rede urbana: uma mediação entre os grandes centros urbanos e as pequenas aglomerações populacionais do interior. Em outras palavras, sua função de intermediação na hierarquia urbana permite-lhes constituir centros de desenvolvimento regional por meio da desconcentração das grandes metrópoles. Para Amorim Filho (1984, p. 9) as cidades médias devem apresentar os seguintes atributos:

- interações constantes e duradouras tanto com seu espaço regional, quanto com aglomerações urbanas de hierarquia superior;

- tamanho demográfico e funcional suficientes para que possam oferecer um leque bastante largo de bens e serviços ao espaço microrregional a elas ligado;

- capacidade de receber e fixar os migrantes de cidades menores ou da zona rural, através do oferecimento de oportunidades de trabalho, funcionando, assim, como pontos de interrupção do movimento migratório na direção das grandes cidades, já saturadas;

- condições necessárias ao estabelecimento de relações de dinamização com o espaço rural microrregional que as envolve;

- diferenciação do espaço intraurbano, com um centro funcional já bem individualizado e uma periferia dinâmica, evoluindo segundo um modelo bem parecido com o das grandes cidades, isto é, através da multiplicação de novos núcleos habitacionais periféricos;

- aparecimento, embora evidentemente em menor escala, de certos problemas semelhantes aos das grandes cidades, como por exemplo, a pobreza das populações de certos setores urbanos.

\footnotetext{
${ }^{2}$ Em sua maioria vinculada ao RECIME - Rede de Pesquisadores sobre Cidades Médias.
} 
O fenômeno metropolitano é recorrente na narrativa urbana. Sua etimologia remete à Grécia Antiga, empregada para uma cidade progenitora de outras em uma relação de dependência. Portanto, a metrópole exercia um domínio sobre um determinado território por meio da oferta de bens e serviços distintos para uma região. Este é o cerne para compreender o fenômeno da metropolização, entendido como uma interdependência funcional entre a cidade-núcleo e outros municípios, e exemplificado por um mercado de trabalho com mais oportunidades e uma maior oferta de equipamentos urbanos e serviços. De acordo com o exposto em Teixeira (2005), as RM's são compostas por um conjunto de municípios cujas áreas urbanas unem-se com certa continuidade, caracterizadas ainda por alta densidade demográfica e que compartilham familiaridades socioeconômicas que devem ser coordenadas por uma ação governamental conjuntamente planejada.

A temática das Regiões Metropolitanas é recorrente dentro dos estudos de Planejamento Urbano e Regional no Brasil e no mundo, pois em seu crescimento as metrópoles permeiam-se por diversos problemas de ordem urbanística que suscitam inúmeros debates. Destaca-se a rede de pesquisadores do "Observatório das Metrópoles" que desenvolve estudos sobre 15 aglomerações urbanas brasileiras ${ }^{3}$ a partir de diferentes pontos de vista teórico-conceituais. Embora não esteja entre os objetivos deste trabalho discutir as bases teóricas e socioeconômicas do desenvolvimento urbano brasileiro, será considerado que o processo de formação das regiões metropolitanas brasileiras está intimamente ligado àquele de industrialização que estimulou o fluxo migratório expressivo, acarretando o inchamento populacional dessas áreas (SANTOS, 1993; GROSTEIN, 2001; LENCIONI, 2003).

Como consequência dos estrangulamentos externos gerados pelas duas Guerras Mundiais e pela Crise de 1929, nascem os planos de desenvolvimento nacional, com ênfase na industrialização e na construção de infraestrutura, intensificando-se na década de 1950 sob a égide do presidente Juscelino Kubitschek. Sua ambiciosa política modernizadora foi representada pela construção da nova capital, Brasília, mas que:

Em razão da priorização desse projeto, o governo de Kubitschek (1956-1961) sofreu diversas críticas e incomodava ao presidente um possível desvio de foco, ou a possibilidade de a construção da nova

\footnotetext{
${ }^{3}$ O Observatório das Metrópoles é uma rede virtual de pesquisadores que debruça suas análises sobre as metrópoles do Rio de Janeiro (onde está sua coordenação geral, o IPPUR/UFRJ - Instituto de Pesquisa e Planejamento Urbano e Regional da Universidade Federal do Rio de Janeiro), São Paulo, Baixada Santista, Porto Alegre, Belo Horizonte, Curitiba, Goiânia, Recife, Salvador, Natal, Fortaleza, Belém, Santos, Vitória, Brasília e a aglomeração urbana de Maringá. Para mais informações ver a página do grupo: $<$ http://www.observatoriodasmetropoles.net/>. Destacamos a participação do grupo de pesquisas DIMPU/UnB Dimensões Morfológicas do Processo de Urbanização da Universidade de Brasília, ao qual vincula-se esse trabalho.
} 
capital vir a ser interrompida. Sobre Brasília, era denunciado o fato de sua construção absorver um montante importante de recursos, que costumava (ou poderia) ser destinado a políticas sociais, as quais deveriam agir, sobretudo, na região mais carente de investimentos do Brasil: o Nordeste. (CABRAL, 2011, p. 19, grifo nosso).

A realidade nordestina compunha um panorama aterrador e ainda não completamente superado nos dias atuais: uma estrutura agrária marcada pelas secas e pelo latifúndio improdutivo, elevadas taxas de crescimento demográfico, deficiências de infraestrutura básica (saneamento, distribuição de energia elétrica e transportes, por exemplo) e um quadro social onde predominava o analfabetismo, a mortalidade infantil, as endemias e a carência alimentar. A literatura regionalista representava esse cenário desde 1920, como em o Grande Sertão: Veredas, de Guimarães Rosa.

A situação agravou-se na década de 1950 com estiagens rigorosas. A estiagem de 1952, por exemplo, inspirou a canção Vozes da Seca, de autoria de Luiz Gonzaga e Zé Dantas, cujos versos dirigem-se aos políticos em forma de protesto. Na visão dos autores, o Nordeste não precisava de mais "esmolas", mas sim de ações definitivas que não ferissem a dignidade do povo nordestino, acentuando a responsabilidade política dos governantes: "nosso distino [sic], mercê [sic] tem na vossa mão" (GONZAGA; DANTAS, s/d, s/p). A criação do Banco do Nordeste do Brasil naquele mesmo ano, a partir da Lei Federal nº.1649, se insere, portanto, na luta contra o subdesenvolvimento da região ${ }^{4}$.

Em 1958, mais uma grande seca afligiu a região. Os governadores eleitos àquele momento assumiam um discurso desenvolvimentista ao mesmo tempo em que formavam um coro a respeito do desamparo da região pelo governo federal (CABRAL, 2011). Preocupado com essa pressão - que poderia vir a atrapalhar a construção de Brasília, além de seu plano de ser reeleito - JK deu início ao projeto de lei que originaria a Superintendência do Desenvolvimento do Nordeste - SUDENE, criada em 1959. Um dos objetivos da SUDENE era o incremento industrial que permitisse a criação de novos empregos, promovendo a manutenção da mão de obra na Região ao invés da migração intensa para o Sudeste e o Sul do país. Entretanto, seus resultados apresentavam uma dissociação entre plano e ação, discurso versus prática $^{5,}$ que se agravaram no período do Regime Militar.

\footnotetext{
${ }^{4}$ O Nordeste entrou nos anos 1950 com uma população de 17.974 mil habitantes, o que representava 34,58\% da população brasileira à época. Em termos econômicos, o PIB gerado na Região representava 16,4\% da renda gerada no país e a renda per capita do nordestino alcançava apenas 48,0\% do que ganhava o brasileiro. (VIANNA, s/d.).

${ }^{5}$ Separação esta que permeia toda a história do planejamento urbano brasileiro tal como explora Villaça (1999). 
Nas últimas décadas, tem-se vivenciado estes processos de metropolização nas áreas urbanizadas de médio porte. Novos $\operatorname{estudos}^{6}$ foram realizados acerca dessa temática, decorrentes do crescimento do número de cidades médias e do incremento populacional expresso nelas e, sobretudo, devido à posição que estas passaram a ocupar na rede urbana brasileira. Entende-se, portanto, o termo "médio" como referência à posição que essas cidades exercem na rede urbana: uma mediação entre os grandes centros urbanos e as pequenas aglomerações populacionais do interior. A crescente importância das cidades de porte mediano no cenário econômico e na rede urbana brasileira tem destaque desde a década de 1970, cujo fortalecimento é evidenciado pelo processo de desconcentração da produção e da população no território nacional. Entretanto, o estudo das cidades médias do Nordeste enquanto centros secundários da rede urbana é um campo ainda pouco explorado nos estudos urbanos.

A partir da Constituição Federal de 1988, transferiu-se aos Estados a competência de instituir regiões metropolitanas, definidas como "aglomerações urbanas e microrregiões, constituídas por agrupamentos de municípios limítrofes, para integrar a organização, o planejamento e a execução de funções públicas de interesse comum” (art. $25 \S 3^{\circ}$ - BRASIL, 1988, s/p). A passagem dessa competência para instituir regiões metropolitanas não teve efeitos imediatos significativos, entretanto:

Numa perspectiva mais ampla, no entanto, a gestão metropolitana ganhou complexidade adicional, entre outros fatores, em virtude de efeitos perversos decorrentes da grande autonomia municipal após a constituição de 1988: a competição fiscal, o neolocalismo e as dificuldades adicionais de coordenação interinstitucional. (GARSON et al., 2009, s/p).

Alguns autores (COSTA, 2013; FIRKOWSKI, 2012) observam que após a Constituição de 1988 criou-se uma distinção entre as metrópoles e as RM's. Concebe-se as primeiras como o resultado de um processo socioespacial que conforma "um espaço que é percebido como comum por uma população que compartilha (não de forma homogênea e não sem conflitos) de seus recursos, infraestrutura, serviços e possibilidades" (COSTA, 2013, p. 324), e as segundas, como fruto de "uma instituição de ordem jurídico-institucional, baseada em motivações múltiplas - nem sempre explícitas - que sugere a intenção de tratar, intervir ou gerir esta nova territorialidade, a qual pode ou não, integral ou parcialmente, corresponder a um espaço metropolitano" (COSTA, 2013, p. 324). Embora discutir os entrelaces entre esses

\footnotetext{
${ }^{6}$ Em sua maioria vinculada a Rede Brasileira de Estudos sobre Cidades Médias- REDBCM.
} 
dois conceitos seja um dos objetivos desta tese, essa dualidade é visível quando se calcula a existência de cerca de 70 RM's no Brasil - quase trinta delas somente no Nordeste $^{7}$ (ver Figura 1e Tabela 1) - enquanto os espaços metropolitanos, de acordo com a metodologia e os critérios utilizados para identificá-los e caracterizá-los, provavelmente não passem de vinte. Resultaram regiões metropolitanas que são regiões, mas que não são necessariamente metropolitanas (FIRKOWSKI, 2012). Criticando esse divórcio, Costa (2013, p. 324) realça que:

[...] a adoção do instrumento da regionalização não tem relação direta com o processo socioespacial de conformação dos espaços metropolitanos. Mas mais que isto, a fragilidade e baixa efetividade dos arranjos e desenhos institucionais, quando existentes, põe em cheque o próprio sentido dessa institucionalização.

É nesse contexto que residem as discussões acerca do Estatuto das Metrópoles, no qual se organizam as novas diretrizes para a Política Nacional de Planejamento Regional Urbano - PNPRU. Após ser discutida por quase uma década no Congresso Nacional, em 12 de janeiro de 2015 foi promulgada a Lei no 13.089 a qual "estabelece diretrizes gerais para o planejamento, a gestão e a execução das funções públicas de interesse comum em regiões metropolitanas e em aglomerações urbanas ${ }^{8}$ instituídas pelos Estados" (BRASIL, 2015, s/p). Em consonância com o Estatuto da Cidade (Lei ${ }^{\circ} 10.257$, de 10 de julho de 2001), a lei aprovada versa sobre as questões de governança e gestão metropolitana por meio de instrumentos de desenvolvimento urbano integrado.

Entretanto, mesmo após a promulgação desta lei ainda nos deparamos com a inexistência de critérios claros para delimitação e/ou classificação das RM's e da real aplicação de uma política em âmbito nacional que verse sobre a questão, uma vez que o tema é permeado por motivações e interesses políticos estaduais. O caso nordestino exemplifica essa discrepância: observa-se a proliferação de RM's no interior da Paraíba (Figura 1), a maioria com população total inferior a 150 mil habitantes (citando apenas o critério demográfico).

\footnotetext{
${ }^{7}$ Serão apresentadas detalhadamente no capítulo 03, item 3.4 Definição referencial empírico (tabela 01).

${ }^{8}$ Definidas na lei como "unidade territorial urbana constituída pelo agrupamento de 2 (dois) ou mais Municípios limítrofes, caracterizada por complementaridade funcional e integração das dinâmicas geográficas, ambientais, políticas e socioeconômicas" (BRASIL, 2015, s/p). Enquanto por metrópole entende-se " espaço urbano com continuidade territorial que, em razão de sua população e relevância política e socioeconômica, tem influência nacional ou sobre uma região que configure, no mínimo, a área de influência de uma capital regional, conforme os critérios adotados pela Fundação Instituto Brasileiro de Geografia e Estatística - IBGE” (BRASIL, 2015, s/p). 
Portanto, questiona-se no presente estudo: (1) O que define uma metrópole em termos demográficos e socioespaciais? Estas definições são condizentes com a realidade brasileira? (2) A decisão de criar RMINE’s possui, nos casos a serem analisados, suporte no ambiente edificado, ou seja, há indícios morfológicos de metropolização nas aglomerações urbanas a serem estudadas? (3) Entre as RMINE's existem padrões morfológicos em comum, bem como entre elas e as demais cidades em situação semelhante na hierarquia urbana do Nordeste e também com as RM's do restante do país?

Figura 1: Espacialização das 71 RM's brasileiras: a grande maioria localiza-se no Sudeste e no Sul. No Nordeste destaca-se a Paraíba (as cores são utilizadas apenas para esclarecer os limites entre as RM's).

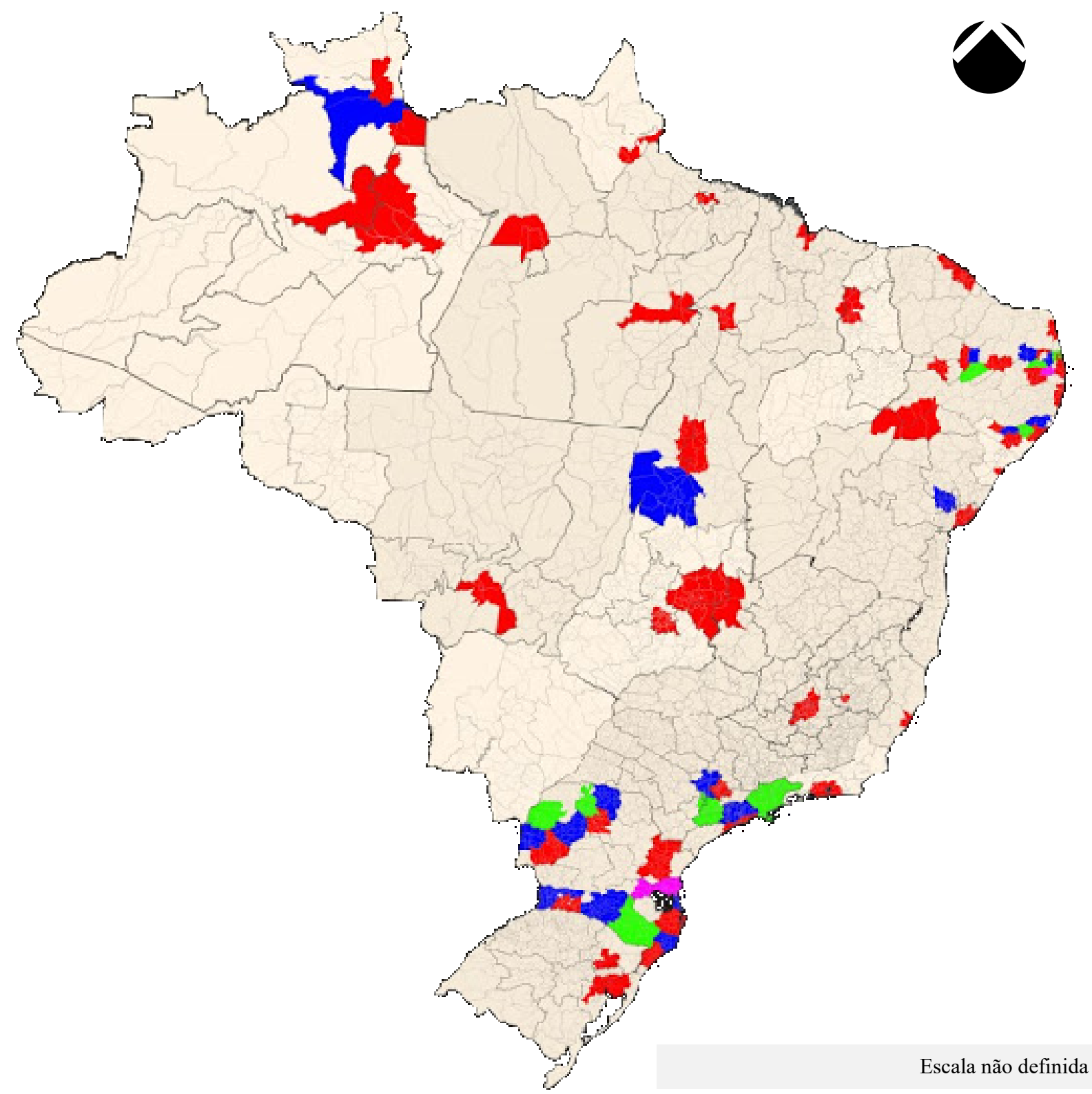

Fonte: Elaborado a partir das legislações estaduais (2016). Disponível em: $<$ http://tudolistasmais.blogspot.com.br/2015/06/mapa-das-regioes-metropolitanas-no.html>. Acesso em: 01 mar. 2016. 
A hipótese norteadora deste estudo é que existem propriedades morfológicas intrínsecas que dão suporte ao processo de metropolização verificado em algumas das RMINE's, embora nem sempre sejam estas características que norteiam a decisão de criar regiões metropolitanas no país. Além disso, devido ao viés político inerente à questão, acredita-se que algumas outras cidades nordestinas apresentem também padrões morfológicos de metropolização, mesmo que não sejam pertencentes a RM's. Esta hipótese subsidia uma segunda, na qual se acredita que há tipo metropolitano regional no interior do Nordeste, caracterizado por um processo de metropolização em estágio intermediário em relação às grandes metrópoles nacionais.

O objetivo geral deste trabalho é compreender de que modo as propriedades morfológicas, em termos de acessibilidade da malha viária em perspectiva comparada, dão suporte a constituição de Regiões Metropolitanas no interior do Nordeste. São explorados aqui os novos conteúdos do processo de urbanização contemporânea e suas interpenetrações com os aspectos socioeconômicos e culturais, tendo como objetivos específicos deste trabalho: (1) entender o fenômeno da urbanização e metropolização do interior do Nordeste sob o ponto de vista da relação entre estrutura espacial, acessibilidade, movimento e usos do solo, seus desdobramentos e justaposições em escalas sucessivas; (2) investigar o processo atual de conurbação física e reestruturação espacial das RMINE's selecionadas, nos termos definidos pela literatura específica; (3) mensurar propriedades morfológicas para estabelecer inter-relações entre processos de metropolização e reestruturação urbana, em face das visões apontadas na revisão bibliográfica e por meio da modelagem da estrutura viária dos conjuntos, mediante emprego de ferramentas analíticas da Sintaxe do Espaço; (4) correlacionar os resultados encontrados nos aglomerados urbanos buscando apontar possíveis padrões morfológicos em comum, assim como individuais; (5) comparar os dados obtidos nas etapas anteriores com outras metrópoles (Fortaleza, Salvador e Recife), elencando as diferenças morfológicas entre os aglomerados que são e os que não são definidos como metropolitanos; (6) contribuir para a definição do conceito de "região metropolitana", frente às novas realidades metropolitanas brasileiras a partir da descrição de um tipo metropolitano regional.

Portanto, este trabalho é focado em entender as bases socioespaciais que dão suporte a formação de RM's, abrangendo cidades de médio porte do Nordeste, visando assim, contribuir para a análise dessas áreas frente à estruturação urbana regional, dando foco na estrutura interna dessas metrópoles, buscando a caracterização de um tipo metropolitano 
regional. Enquanto arquiteta e urbanista, interessa-me prioritariamente o espaço ${ }^{9}$ - o protagonista da arquitetura (ZEVI, 1984 ${ }^{10}$ ) - na busca de relacionar os padrões morfológicos às características socioeconômicas, adiro ao aparato teórico-metodológico da Sintaxe Espacial - SE. Criada em meados dos anos 1970 em Londres, a SE tem como base o pensamento estruturalista a partir de filiação ao pensamento sistêmico e holístico (MEDEIROS, 2006).

Partindo da premissa de que cada sistema de relações espaciais tem em sua configuração uma lógica social inerente, o ponto central de análise é compreender que a significação se respalda no sistema de relações desempenhado pelos objetos, mas não se fundamenta apenas em visões subjetivas (embora estas não sejam completamente desconsideradas em algumas pesquisas, mas o que ressalto é a possibilidade de analisar o fenômeno sem a convocação dos sujeitos). Compreende-se a arquitetura como uma variável independente que impacta meio ambiente e pessoas, em diferentes dimensões (HOLANDA, 2013a). Nesta tese serão analisadas as metrópoles como lugares arquitetônicos essencialmente por meio de seus elementos-fim, isto é, seus espaços, com foco na relação entre eles e em busca de possíveis padrões socioespaciais em comum.

A segunda motivação deste trabalho é fruto da minha experiência acadêmica. Na ocasião do trabalho final de graduação em Arquitetura e Urbanismo na Universidade Federal do Rio Grande do Norte - UFRN - dediquei-me ao estudo da história urbana de Crato/CE, local em que nasci e onde assisti, ao longo da minha juventude, a dilapidação de seu patrimônio edificado. Ao cabo daquele estudo percebi que não era mais possível entender Crato como uma cidade isolada, pois existiam relações de ordem socioeconômica - e seus rebatimentos no espaço urbano - com as cidades vizinhas de Juazeiro do Norte e Barbalha. No mestrado busquei aprender padrões individuais e conjuntos de formação/transformação/especialização de centralidades dessas três cidades, entendidas em sua nova denominação: Região Metropolitana do Cariri. Daí surgiram novas inquietações: por que criar uma RM no interior do Ceará? E a principal: por que isso estava acontecendo também em outras localidades do Nordeste, região que sempre foi tida como uma das menos urbanizadas do País? Existem pontos em comum, especialmente de ordem morfológica, entre essas cidades? Em busca dessas e de outras respostas, dei início ao meu doutorado na Universidade de Brasília.

\footnotetext{
${ }^{9}$ As conceituações aprofundadas dos termos virão no capítulo "Referencial teórico-metodológico".

${ }^{10}$ A visão do espaço como foco central da arquitetura também está presente nos trabalhos de Coutinho (1970), Hillier (1996) e Holanda (2013).
} 
Esse trabalho propõe uma reflexão sobre os critérios para a definição de RM's em três vieses: (1) de ordem socioeconômica, por meio da integração socioeconômica entre os municípios; (2) de ordem morfológica, avaliando a acessibilidade topológica do seu sistema viário e a presença de equipamentos de abrangência regional, por exemplo; (3) do sistema de encontros e esquivanças, para além da contiguidade da mancha urbana entre os municípios, diz respeito à concentração e dispersão de pessoas de modo que "cada sistema social implica uma peculiar maneira de organizar grupos de pessoas no espaço e no tempo, maneira que estabelece quem está próximo ou distante de quem, fazendo o quê, onde e quando" (HOLANDA, 2007, p. 124). O primeiro critério é explorado em várias pesquisas, como aquelas desenvolvidas pelo IBGE, com destaque para a publicação Regiões de Influência das Cidades $2007^{11}$ (IBGE, 2008). A abordagem desta tese está no segundo e terceiro vieses (e em seu inter-relacionamento com os outros dois): como padrões socioespaciais perceptíveis a partir da organização da forma dos espaços - e seus relacionamentos - podem ser utilizados para definir as RM's especialmente frente às especificidades do caso nordestino.

A contribuição desta tese está na descrição de um tipo metropolitano regional em um recorte analítico que é pouco estudado no Brasil, por meio da discussão do processo de urbanização que se manifesta tanto na metropolização quanto na própria regionalização metropolitana em sua instituição via Regiões Metropolitanas. E, ante aos novos processos de metropolização do interior do País, espera-se contribuir com os estudos sobre a rede urbana brasileira e com uma nova conceituação de "metrópole", além daquelas expostas no Estatuto das Metrópoles, estimulando assim, o debate sobre o planejamento urbano brasileiro, especialmente para o caso nordestino.

A metropolização do interior do Nordeste e os consequentes processos de reestruturação do espaço urbano são campos de estudo relativamente novos no quadro da arquitetura e do urbanismo se compararmos ao extensivo estudo dos grandes centros. Embora existam esforços para estudar o fenômeno de constituição de RM's, que parece ocorrer de maneira semelhante na região Sul, no Nordeste, pouco se tem avançado nesse sentido, até mesmo em redes como o Observatório das Metrópoles. Mais raros ainda são os estudos que analisam tal problemática sob o viés morfológico, do ponto de vista das relações entre unidades espaciais componentes, como é feito aqui. Este trabalho visa explorar essa lacuna por meio da elaboração de um panorama urbano das RMINE's, numa perspectiva comparada, assim como busca contribuir para o entendimento da metropolização brasileira. Trabalhos

${ }^{11}$ Retomarei essa publicação nos capítulos 02 e 03 (para a definição do referencial empírico desse estudo). 
como este se fazem urgentes pela sua relevância para a análise da cidade enquanto construção social.

Este trabalho está organizado em três partes: (1) estado da arte, onde pretende-se apresentar os principais tópicos acerca da urbanização contemporânea, por meio da leitura de autores que tangenciam os temas da metropolização e cidades médias, dividiu-se esses temas em dois capítulos, um em âmbito geral e outro dando enfoque ao Brasil e ao Nordeste; (2) referencial teórico-metodológico, que versa acerca dos temas que dão o embasamento da $\mathrm{SE}$ enquanto teoria, método e ferramentas - tríade da pesquisa científica, tal como proposta por Holanda (2013) - e o referencial empírico, que tratará dos critérios de definição para o recorte espacial da pesquisa, utilizando principalmente dados censitários e publicações técnicas do IBGE e Instituto de Pesquisa Econômica Aplicada - IPEA; (3) estudos de caso, dividido em dois capítulos, onde será apresentada a etapa prática do trabalho, por meio da análise das RMINE's, das demais RM's e das cidades definidas como universo de estudo, correlacionando-as às características morfológicas obtidas a partir dos procedimentos da SE. Fecha-se esta tese com as considerações finais onde são discutidos os achados, limites e possíveis desdobramentos desta pesquisa, baseados no referencial teórico e nos estudos de caso analisados. 


\section{MeTRÓPOLES:}

PROCESSO

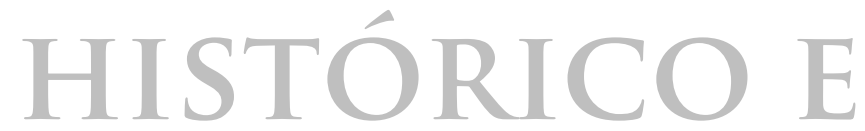

\section{ESTRUTURAÇÃO}

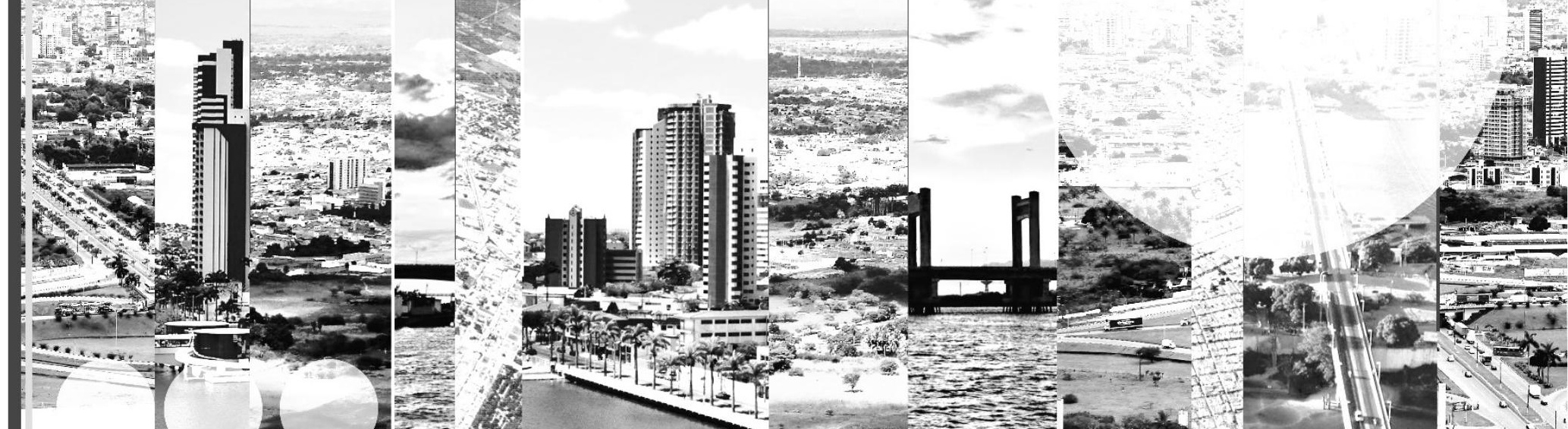




\section{METRÓPOLES: PROCESSO HISTÓRICO E ESTRUTURAÇÃO}

Este capítulo tem por finalidade apresentar uma leitura crítica da bibliografia que tangencia os assuntos que serão abordados nesta tese, a exemplo dos processos de formação/transformação urbana em escala metropolitana. Partindo de uma apreciação dos processos urbanos contemporâneos, o objetivo é avaliar como e em que medida esses conceitos podem ser visualizados na realidade urbana nordestina.

\subsection{Conceituações de metrópole}

A origem da palavra metrópole remonta à Grécia antiga, berço da civilização ocidental. Juntando-se o prefixo grego metra - que significa mãe, ventre - ao radical polis que remete diretamente a cidade, urbe - na origem epistemológica de metrópole fica clara a significação de cidade-mãe. No mundo grego quando as cidades-estados atingiam um certo patamar de estabilidade político-econômica e a população crescia, eram adicionadas novas estruturas urbanas: as neápoles ou as colônias, vinculadas político-administrativamente às cidades de origem (BENEVOLO, 2012). Portanto, observa-se uma relação de dependência ou de domínio exercido por uma determinada cidade ou núcleo matriz em relação às demais. $\mathrm{O}$ mesmo termo foi utilizado para distinguir as capitais provinciais romanas na parte oriental do Império (MIEG, 2010 apud QUEIROZ, 2013) e com o desenvolvimento do Cristianismo, o termo foi adotado com o significado:

[...] eclesiástico ao denominar uma província composta por várias dioceses lideradas por um bispo chamado metropolitano. Na linguagem eclesiástica, é considerada metropolitana, a sede episcopal e/ou do prelado superior a quem os bispos sufragâneos - bispos ordinários que lideram dioceses regionais devem obediência. (QUEIROZ, 2013, p. 28).

No sistema mercantilista de meados do século XV, com a expansão marítima em busca de novas terras produtoras e de mercados consumidores, as potências europeias como Portugal, Espanha e Inglaterra eram reconhecidas como metrópoles e os territórios sob seu domínio e exploração foram denominadas colônias. É clara a acepção ao sistema de submissão e controle que foi iniciado em menor escala no mundo clássico. 
As relações entre corte-província e campo-cidade se transformaram drasticamente com o desenvolvimento do capitalismo e os elos de dominação colonial foram parcialmente quebrados. Ainda assim, o emprego da palavra nos dias atuais emana o sentido de hegemonia exercida por um núcleo sobre outros mesmo frente às novas formas do processo de urbanização na etapa contemporânea da sociedade capitalista. A partir do século XIX, com o crescimento exacerbado das cidades após a Revolução Industrial se retoma o debate acerca dos processos de metropolização, tendo em vista as novas relações políticas e sociais que se constroem e que geram diversos problemas urbanísticos e ambientais. Surgiu uma nova ordem socioespacial urbana, cujos conteúdos e estruturas diferiam-se das cidades existentes até então devido os limites urbanos desenraizados “[...] a partir dos círculos sociais dominantes dentro dela e de sua forma - um desenraizamento do lugar (como um local de habitação) ligado à habitação [...] a cidade se afasta ao longo das ruas e eixos que se cruzam com a sua estrutura ${ }^{12 "}$ (CACCIARI, 1973, p. 199-200 apud CUNNINGHAM, 2005, p. 16).

Cunningham (2005), a partir da leitura dos principais teóricos da filosofia urbana do início do século XX, considera que esse conceito de "desenraizamento" da morfologia urbana e de sua determinação fenomenológica do 'lugar', resulta no que ele considera ser a “[...] construção familiar da metrópole como uma alegoria ou uma figura da modernidade capitalista, o lugar essencial da experiência moderna de Baudelaire, Benjamin e Debord ${ }^{13}$ ". (CUNNINGHAM, 2005, p. 16). Essa imagem simbólica de metrópole reaparece nos escritos de Karl Scheffler, o qual afirma "[...] que é absolutamente determinante para o conceito de metrópole moderna não é o número de seus habitantes, mas sim o espírito da metrópole [Grossstadt Geist]. ${ }^{14 ”, ~(1910 ~ a p u d ~ C U N N I N G H A M, ~ 2005, ~ p . ~ 16) . ~ E s s a ~ a c e p c ̧ a ̃ o ~ a o ~ t a m a n h o ~}$ populacional é, portanto, secundária, uma vez que predomina o conceito de uma nova ordem espacial imanente ao processo de metropolização que se desenvolve a partir do século XX. Desse modo:

\footnotetext{
${ }^{12}$ No original: "[...] from the social circles dominant within it, from its form - an uprooting from the place (as a place of dwelling) connected to dwelling. The city 'departs' along the streets and axes that intersect with its structure. " (Tradução Luciana Rocha. Disponível em: <http://www.e-publicacoes.uerj.br/ index.php/periferia/ article/viewFile/3461/2377>. Acesso em 10 de jun, de 2016).

${ }^{13}$ No original: "[...] the familiar construction of the metropolis as allegory or privileged figure of capitalist modernity, the essential 'site' of modern experience from Baudelaire to Benjamin to Debord." (Tradução Luciana Rocha. Disponível em: <http://www.e-publicacoes.uerj.br/index.php/periferia/article/viewFile/ 3461/2377>. Acesso em 10 de jun, de 2016).

${ }^{14}$ No original: "What is absolutely decisive for the concept of the modern metropolis is not the number of its inhabitants but rather the spirit of the metropolis [Grossstadt Geist]" (Tradução Luciana Rocha. Disponível em: $<$ http://www.e-publicacoes.uerj.br/index.php/periferia/article/viewFile/3461/2377>. Acesso em 10 de jun, de 2016).
} 
[...] o conceito de metrópole pode ser desenvolvido historicamente não como um simples sinônimo de cidade e da linhagem antiga que esta designa, mas, ao contrário, como a manifestação de uma lógica espacial e produtiva caracteristicamente moderna que se opõe e desestabiliza esse cenário. Como tal, o conceito só se molda conceitualmente ao final de um processo durante o qual as velhas formas urbanas explodem. ${ }^{15}$ (CUNNINGHAM, 2005, p.17).

Os processos de metropolização têm se asseverado nas últimas quatro décadas, destacando uma cidade principal de uma região como elemento estruturador de toda a rede urbana. Essa predominância se dá não apenas pela sua dimensão populacional e econômica, mas também pela execução de funções diversificadas, além de estabelecer relações econômicas com diferentes aglomerações/metrópoles. É a complexidade de suas funções que lhe assegura uma posição de comando sobre as demais aglomerações urbanas. (SANTOS, 1967). Nesse sentido, as metrópoles constituem:

[...] centros do poder econômico, social e político. Portanto, são unidades capazes de polarizar o território nas escalas nacional, regional e local. Entre essas características, ressalta-se a organização funcional dos espaços; a concentração/distribuição de população, produto e rendimentos; os fluxos de mercadorias, população e serviços; as condições de infraestrutura urbana; os processos de ocupação territorial; as articulações de poder; entre outras. $\mathrm{O}$ processo de metropolização passa por tais características e as transformações na natureza e na configuração espacial das cidades levam a níveis distintos de integração dos territórios a essa dinâmica. (RIBEIRO et al., 2012, p. 2).

Embora alguns teóricos discutam que a metrópole é uma forma do urbano em via de tornar-se historicamente superada frente à chamada sociedade em rede (CASTELLS, 1999), há um outro lado dos estudos urbanos no qual acredita-se que as metrópoles possuem hoje, como nunca antes visto, uma grande força enquanto centros de comandos e/ou nós, exatamente de tal rede (QUEIROZ, 2013; ASCHER, 2012). Desta maneira, nos itens subsequentes apresento uma revisão das formas e expressões sociais das metrópoles contemporâneas.

\footnotetext{
${ }^{15}$ No original: "[...] the concept of metropolis can be shown to develop historically, not as a simple synonym for the city, and for the ancient lineage it designates, but, on the contrary, as the manifestation of a distinctively modern spatial-productive logic which opposes and unsettles it. As such it only 'take[s] shape conceptually [at] the end of a process during which the old urban forms ... burst apart'. (Tradução Luciana Rocha. Disponível em: $<$ http://www.e-publicacoes.uerj.br/index.php/periferia/article/viewFile/3461/2377>. Acesso em 10 de jun, de 2016).
} 


\section{$1.2 \mathrm{O}$ fenômeno urbano contemporâneo}

Frente à complexidade de escalas morfológicas, vivências sociais e esferas políticas que surgem e exacerbam-se a partir dos anos 1960, há o desabrochar de diferentes abordagens teóricas que versam sobre o urbano. Desde então desenvolvem-se novos constructos ou atualizam-se técnicas do passado para entender as profundas transformações que passam as estruturas urbanas. Rejeitando a lógica simplista de oposição entre o modernismo e pósmodernismo, alguns debates pregam a interdisciplinaridade, dando destaque à dimensão espacial (sem excluir o social, a história ou demais vieses da questão). Dentro da linha lefebvreana, destaca-se o trabalho de Edward W. Soja com a publicação Postmetropolis ${ }^{16}$ (2000). A metrópole contemporânea, ou a pós-metrópole, é analisada a partir da história urbana, desde as antigas cidades com Ur ou Jericó, até sua culminância atual em Los Angeles, Nova Iorque, São Paulo e outras, resultantes dos processos de aglomeração e industrialização.

Soja (2000) aponta quatro revoluções urbanas: (1) o desenvolvimento da agricultura a cerca de dez milênios atrás e a criação das primeiras cidades; (2) o desenvolvimento do Crescente Fértil e a fundação da organização social dividida em classes e das cidades-estados; (3) a revolução industrial e a formação do capitalismo industrial e sua subsequente transformação das cidades; (4) a intensa reestruturação urbana dos últimos 30 anos (Figura 2). Não cabe nos objetivos desse trabalho traçar um completo panorama dos processos de formação/transformação urbana que abarque de Ur a São Paulo, mas adotar uma breve revisão das revoluções urbanas desde a Era Moderna é fundamental para elucidar a situação atual das metrópoles.

Entre o terceiro e quarto recorte propostos por Soja (2000), Ascher (2012) aponta três revoluções urbanas: (1) a alta modernidade: o fim da idade média e o mercantilismo; (2) a modernidade média: a revolução industrial; (3) a modernidade avançada ou radical que vivemos nos dias atuais. O desenvolvimento da modernidade ${ }^{17}$ deu-se sobre o tripé da individualização, racionalização e diferenciação social, parâmetros que vêm se cambiando e recombinando de modo que "a cada uma das duas primeiras fases da modernização

\footnotetext{
16 O livro, sem tradução para o português, completa a trilogia iniciada com Postmodern Geographies: The Reassertion of Space in Critical Social Theory, de 1989 - publicado em português em 1993 sob o título Geografias pós-modernas: a reafirmação do espaço na teoria social crítica - e seguida por Thirdspace: Journeys to Los Angeles and Other Real-and-Imagined Places, sem tradução para o português.

17 Também não será discutido a fundo o conceito de modernidade, mas nas palavras de Ascher "a modernidade não é um estado, mas um processo de transformação da sociedade" (ASCHER, 2012). A modernidade é antes de tudo a consciência da mutação constante e da efemeridade onde "tudo que é sólido desmancha no ar" (BERMAN, 1986).
} 
correspondeu uma mutação profunda da maneira de conceber, de produzir, de utilizar e de gerir os territórios em geral e as cidades em particular” (ASCHER, 2012, p. 30).

$\mathrm{Na}$ terceira revolução urbana moderna é possível vivenciar de maneira cada vez mais clara as profundas mutações que se comentou acima, mas Ascher (2012) sistematiza-as em cinco: (1) a metapolização, as estruturas urbanas assumem novas escalas e formas; (2) a transformação dos sistemas de mobilidade que redefine também a maneiras de deslocamentos dos bens, das pessoas e das informações; (3) a reposição social das cidades acentuada pela individualização do espaço-tempo; (4) redefinição das relações entre interesses individuais, coletivos e gerais; (5) novas relações com os riscos, com a crescente preocupação em termos de segurança física, econômica, ambiental etc. Esses pontos fazem referência ao que será tratado no tópico seguinte deste capítulo.

Figura 2: Esquema conceitual - comparação entre os aportes de Soja (2000) e Ascher (2012).
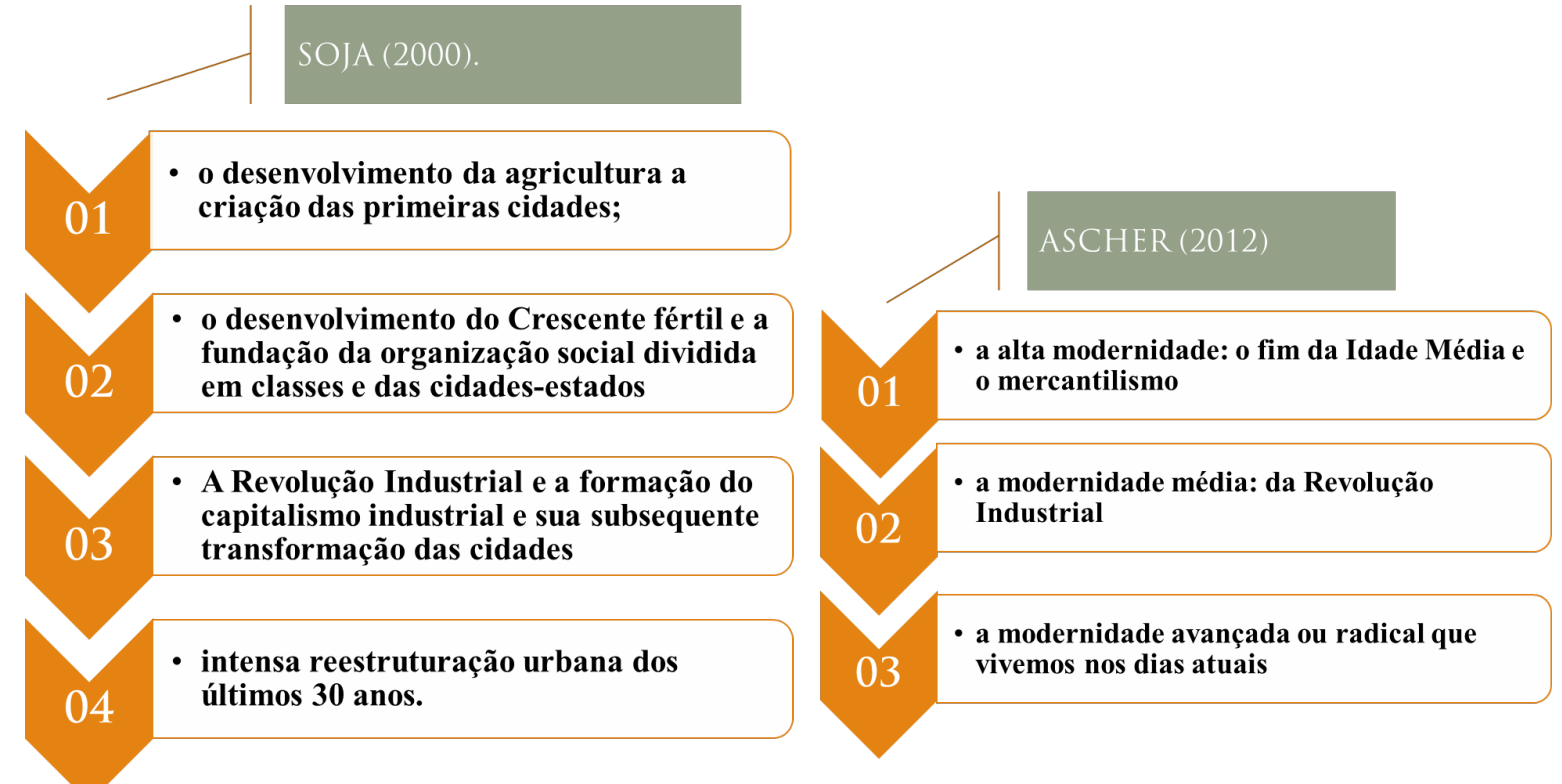

Fonte: elaboração própria (2016).

Porém vale destacar o primeiro ponto que faz referência direta ao escopo desse tópico. Ascher cunhou o termo "metápolis" (ou metápole, traduzindo para português) para designar as aglomerações urbanas contemporâneas em suas características: conurbadas, extensas, descontínuas, heterogêneas e multipolarizadas. O prefixo "meta" é advindo do grego e significa "depois", "além de", denotando o aparecimento de uma outra forma urbana, distinta da metrópole, mas não necessariamente melhor ou pior, de modo que uma metápole é definida como: 
[...] o conjunto de espaços cujo todo ou parte dos habitantes, das atividades econômicas ou dos territórios estão integrados no funcionamento quotidiano (ordinário) de uma metrópole. Uma metápole constitui geralmente uma só zona de emprego, de habitação e de atividades. Os espaços que compõem uma metápole são profundamente heterogêneos e necessariamente contíguos. Uma metápole compreende ao menos algumas centenas de milhares de habitantes. (ASCHER, 1995, p. 34). ${ }^{18}$

Em que pesem as especificidades nacionais e regionais, a metropolização representa a concentração de pessoas, e a decorrente diversidade de mercado, que é exigida e incentivada numa via de mão dupla pela globalização e pelo aprofundamento da divisão do trabalho (ASCHER, 2012). O processo de formação de metrópoles não é novo, mas fez parte de todas as fases da modernização e prossegue hoje sob novas formas:

O crescimento interno das aglomerações, por expansão para suas periferias imediatas e por densificação, dá amplamente lugar a um crescimento externo, ou seja, pela absorção na sua zona de funcionamento quotidiano, de cidades, de vilas e de aldeias cada vez mais distanciadas. Os limites e as diferenças físicas entre a cidade e o campo tornam-se cada vez mais tênues. [...] As formas metropolitanas, muito ligadas aos meios de transporte e de comunicação, são gravadas progressivamente sobre todo o território, tanto nas zonas que incluem cidades muito grandes como nas cidades médias. [...] as pequenas e médias cidades esforçam-se assim por se ligar a melhor possível às aglomerações muito grandes para se beneficiar o a máximo possível da sua urbanidade (do seu potencial). (ASCHER, 2012, p. 63, grifo nosso).

Os processos de crescimento e reestruturação urbana já foram abordados por muitos autores (CARLOS, 1994; SANTOS, 1997; VILLAÇA, 2001; SANTOS, 2002). No Brasil destaco o trabalho de Spósito (1998), que versa sobre os interesses fundiários e imobiliários, bem como a lógica locacional residencial que tende a se valer dos princípios urbanísticos monofuncionais e que é também fortemente calcada na legislação urbanística produzida por essas políticas. Por outro viés, o interesse comercial - juntamente com os agentes imobiliários - promove o "desenvolvimento de novas escalas de distribuição de bens e serviços, por meio da instalação de grandes equipamentos na periferia [...] em alguns nós rodoviários e, às vezes até mesmo nas áreas mais densamente ocupadas das cidades, redefinindo seus usos e conteúdos" (SPÓSITO, 1998, p. 30). Mas é importante destacar que isso só se torna possível com a disseminação do automóvel e com as melhorias do sistema de transporte coletivo, uma vez que esses equipamentos não atendem à escala do pedestre.

\footnotetext{
${ }^{18}$ Tradução de Vicente Naspolini (2009).
} 
Vislumbra-se uma tendência de crescimento urbano centrífugo - a rarefação do tecido urbano - que parece unir as lógicas locacionais residenciais e comerciais, como uma "solução frente ao nível de isolamento e monofuncionalidade" (SPÓSITO, 1998, p. 31). Para atender aos interesses fundiários e imobiliários, a lógica locacional residencial tende a se valer dos princípios urbanísticos monofuncionais, que é também fortemente calcada na legislação urbanística produzida por essas políticas. Esse fenômeno designa uma cidade-mosaico, ou cidade fragmentada, denominada de "colcha de retalhos" por Medeiros (2008), áreas que:

[...] parecem setores que mais se justapõem, do que se articulam. Produz-se uma paisagem urbana recortada, com forte desequilíbrio e sem estreitas ligações entre habitação, trabalho, comércios e serviços. Se não temos mais a continuidade da cidade compacta, se não temos mais uma cidade organizada, hierarquicamente, em círculos concêntricos em torno de um centro único, se temos que questionar a ideia de uma cidade que expressa unidade ou totalidade, devemos pensar as categorias de análise centro e periferia, não como dicotômicas, mas como espaços de interpenetração. (SPÓSITO, 1998, p. 31).

Temos nas cidades uma configuração espacial com diferentes estágios de consolidação da ocupação e cuja infraestrutura pode ser mais aproveitada ou mais ociosa. E, voltando à citação de Ascher (2012), tais padrões não são mais exclusivos dos grandes centros, as cidades médias (tais como aquelas estudadas neste trabalho) passam por processos similares com suas especificidades regionais e locais.

\subsection{Seis processos urbanos}

Extrapolando os conceitos apresentados anteriormente, Soja (2000) propõe novos processos urbanos: (1) a especialização flexibilizada das metrópoles industriais pós-fordistas; (2) cidade-região globalizada ou Cosmopolis; (3) a megacidade pós-urbana ou Exopolis; (4) a cidade fractal das desigualdades intensificadas e polarizada socialmente; (5) o arquipélago carcerário das cidades fortificadas; (6) as hiper-reais Simcities, onde a vida cotidiana ocorre como num jogo de computador (SOJA, 2000). A princípio algumas dessas ideias podem parecer delírios ou que extrapolem em muito a realidade brasileira de urbanização, mas alguns aportes são perceptíveis nos mais diversos rincões do nosso mundo globalizado.

No primeiro deles, o autor busca interpretar o papel da produção industrial e o impacto da reestruturação industrial na vida urbana contemporânea. Embora o termo "pós" seja usado na pós-modernidade para assinalar uma clara quebra entre dois momentos, o pós-fordismo 
não é completamente desvinculado do fordismo. A transição entre os dois modelos econômicos é baseada nos processos de flexibilização:

[...] dos processos de trabalho, novos mercados de trabalho, dos produtos e padrões. Caracteriza-se pelo surgimento de setores de produção inteiramente novos, novas maneiras de fornecimento de serviços financeiros, novos mercados e, sobretudo, taxas altamente intensificadas de inovação comercial, tecnológica e organizacional. A acumulação flexível envolve rápidas mudanças dos padrões de desenvolvimento desigual, tanto entre setores como entre regiões geográficas, criando, por exemplo, um vasto movimento no emprego do chamado "setor de serviços", bem como conjuntos industriais completamente novos em regiões até então subdesenvolvidas (tais como, a Terceira Itália, Flandes, vários vales e gargantas de silício, para não falar da vasta profusão de atividades dos países recém-industrializados). (HARVEY, 2012, p.140).

A acumulação flexível denominada por Harvey (2012) se articula diretamente com o segundo ponto destacado por Soja (2000): a globalização do espaço da cidade. É preciso ter em mente que a globalização não é um fenômeno novo, pois é intrínseco ao capitalismo desde o desenvolvimento do mercantilismo, mas que se exacerba nos últimos anos devido à reorganização dos mercados internacionais, como pela formação dos blocos econômicos (por exemplo a União Europeia ou o Mercosul) ou pela emergência de poderosas instituições que promovem integração financeira internacional (SOJA, 2000). Mesmo não aprofundando a discussão em nível político-econômico, diversos autores (SASSEN, 1998; CASTELLS, 1999) trabalham com a hipótese de uma cidade mundial em que se visualizam profundas estratificações sociais e espaciais.

Da confluência dos dois processos descritos acima, temos a reestruturação da forma urbana ou exopolis. Os impactos da globalização e da reestruturação da economia geraram incontáveis novos termos e conceitos para descrever a reconfiguração espacial das pósmetrópoles. O prefixo "exo" vem do grego ékso, exprime a noção de exterior ou externo ${ }^{19}$, e aqui na acepção de Soja (2000) sugere o crescimento para "fora" da cidade. Ao longo dos anos, os centros urbanos passaram por profundas transformações, sobretudo no que tange ao processo de expansão dos seus tecidos urbanos, em um crescimento exponencial e desordenado como descreve Lefebvre (2008) “o tecido urbano prolifera, estende-se, corrói os resíduos de vida agrária" (p.17). Vale ressaltar que o autor frisa que o termo "tecido urbano" não é empregado apenas no sentido restrito do espaço construído, mas no predomínio da cidade sobre o campo em suas diversas manifestações, retomando o que Cacciari (1973 apud

19 "exo", in Dicionário Priberam da Língua Portuguesa [em linha], 2008-2013, disponível em $<$ http://www.priberam.pt/DLPO/exo>, consultado em 02-02-2015. 
CUNNINGHAM, 2005) chamou de desenraizamento dos lugares. Sob o ponto de vista morfológico, esse espraiamento das manchas urbanas cria uma descontinuidade nas metrópoles o que é expressão do processo de fragmentação urbana, entendido como:

[...] quando já não temos mais a cidade como unidade espacial, como territorialidade contínua, como morfologia integrada, e, portanto, quando as relações entre a cidade e seu conteúdo não se expressam, de forma clara, através de formas espaciais que possam ser facilmente distinguidas daquelas que definem a morfologia rural. (SPÓSITO, 1999, p. 85).

A autora, ao delinear o fim da "cidade como unidade espacial" refere-se não apenas às questões de dimensão, mas aos processos perversos de desigualdade em acessar bens e serviços que se desenvolvem nas grandes aglomerações, especificamente no mundo subdesenvolvido. Em outras palavras, não é o tamanho da cidade (físico ou populacional) que impede que seus habitantes tenham acesso a infraestruturas e equipamentos de maneira igualitária, mas é a falta de uma estruturação "polinucleada, interna e externamente articulada por amplos sistemas de transportes e comunicação" (SPÓSITO, 1999, p.85). Espaços da cidade segregados, desarticulados uns dos outros pela ausência de um sistema de mobilidade são características desse processo de fragmentação. Diversos teóricos e urbanistas buscaram dar soluções a este problema por meio de um:

[...] retorno das formas mais compactas de urbanização, muitas vezes resgatando configurações "tradicionais" da cidade pré-industrial, sumarizadas em interpretações agrupadas sob a insígnia de cidade compacta. Esse termo não constitui um conceito em si; em vez disso, reúne um conjunto de diretrizes urbanísticas, que procuram:

(1) promover unidades territoriais autônomas em termos de oferta de equipamentos, serviços, empregos e moradia, como forma de diminuir a demanda por transporte e as distâncias a serem percorridas;

(2) fortalecer subcentros e criar novas centralidades para diminuir a convergência de deslocamentos para os centros das cidades;

(3) ocupar o solo de forma compacta (maiores densidades populacionais e construtivas) para diminuir as distâncias intramunicipais e viabilizar o transporte coletivo e os modos não motorizados;

(4) ocupar vazios urbanos para otimizar os deslocamentos via transporte público;

(5) limitar áreas de expansão urbana (PESCATORI, 2015, p. 46-47, grifo nosso)

Em que pesem os diversos debates acerca da oposição entre "cidade compacta" versus "cidade dispersa", a configuração densa não significa ausência de fragmentação espacial. Por exemplo, as cidades coloniais latino-americanas possuíam uma estrutura 
compacta organizada em torno de uma praça principal que congregava as principais funções sociais, porém conforme se distanciam desse centro “[...] reduzia-se o status socioeconômico dos ocupantes dos lotes, ou seja, o princípio de estruturação socioespacial revelava-se por gradientes decrescentes, do centro à periferia" (LACERDA, 2011, p. 24).

Retomando um conceito clássico da geografia apresentado por Corrêa (1997), entendemos que o espaço urbano é em sua definição fragmentado, mas ao mesmo tempo é articulado, assim como reflexo e condicionante social, além de campo simbólico e de lutas. Segundo o autor, a fragmentação se expressa na justaposição de diferentes formas de uso do solo urbano, o que pode ser observado na paisagem urbana por meio da:

[...] divisão da cidade em partes (fragmentos), que podem ser individualizadas, a partir da identificação dos diversos padrões de uso e ocupação do solo, bem como dos níveis de provimento das infraestruturas, mais particularmente das redes de mobilidade de matéria (pessoas e bens) e informação. Esses níveis, por sua vez, definem o grau de integração de cada uma das partes com as demais e, até mesmo, com as de outras cidades do país e do exterior. (CORRÊA, 1997, p. 22).

Essa ocupação fragmentada do território deixa extensos espaços menos adensados entre núcleos ocupados que são recorrentemente denominados de "vazios urbanos". Entretanto, Pescatori (2015) acredita que há um erro nessa interpretação pois esses espaços “constituem partes produtivas e intrínsecas à cidade e às suas dinâmicas" (Ibid., p. 46). Aliados a processos de especulação imobiliária que cria uma dilatação horizontal, nas áreas periféricas, quase que ilimitada do tecido urbano, em contraposição à concentração das oportunidades urbanas em áreas centrais, esse modelo de crescimento e expansão tem sido erroneamente identificado como falta de planejamento urbano e por isso as cidades são "caóticas" ou "desorganizadas". Olhando sob um outro ponto de vista, a cidade é produto da ação de diversos atores urbanos, cujas opções de planejamento e de políticas urbanas refletem em sua organização socioeconômica. Há uma sobreposição dos interesses capitalistas na organização geral das zonas luminosas ${ }^{20}$, adensadas ou centrais, enquanto as zonas opacas, periféricas ou vazias se inserem de forma subserviente a tais interesses (SANTOS, 2008). A sociedade capitalista construiu um modelo em que muitos perdem e pouquíssimos ganham, criando uma ordem urbanística excludente e predatória (CÂMARA, 2002).

\footnotetext{
${ }^{20}$ Santos define como zonas luminosas aqueles territórios que acumulam densidades técnicas e informacionais e, portanto, se tornam mais aptos a atrair atividades econômicas, capitais, tecnologia e organização, enquanto, os espaços onde estas características estão escassas são chamados de territórios opacos. Nas palavras do autor: "Do ponto de vista da composição quantitativa e qualitativa dos subespaços (aportes de ciência, da tecnologia e da informação), haveria áreas de densidade (zonas "luminosas"), áreas praticamente vazias (zonas "opacas") e uma infinidade de situações intermediárias"(SANTOS, 2008, p. 48).
} 
Entram em cena as discussões acerca da redefinição nas relações entre o centro e a periferia. No caso brasileiro é comum associar o termo "periferia" a certas porções do espaço urbano com a presença de favelas e loteamentos destinados às camadas de mais baixa renda, onde predomina a dificuldade de acesso a bens de consumo coletivo. Entretanto, neste trabalho, convencionou-se adotar o termo para "designar as áreas de expansão da cidade, incorporadas ou modificadas pelas formas mais recentes de redefinição das cidades e não, necessariamente, articuladas de forma contínua ao tecido urbano constituído" (SPÓSITO, 1998, p. 29).

Nessa dinâmica de redefinição de centro e periferia, observam-se três processos simultâneos e articulados: (1) a valorização fundiária e imobiliária das áreas no entorno da cidade, por meio de implantação de usos ou substituição dos usos anteriores por outros mais modernos e mais valorizados, muitas vezes numa revisão romantizada das ideias da cidadejardim proposta por Ebenezer Howard em 1898 (Figura 3); (2) construção de grandes equipamentos comerciais que "atendem, em parte, às exigências colocadas pelas novas localizações residenciais e, em parte, produzem novos fluxos no interior das cidades, em função das novas possibilidades e formas de consumo que resultam dessa nova localização" (SPÓSITO, 1998, p. 29); (3) transformações das políticas locacionais da indústria em decorrência da superação dos modelos de produção fordistas para formas de produção flexíveis, que se apresentam por meio da "diminuição da área destinada à produção e acentuase a apropriação ou produção de novas localizações em áreas urbanas ou não urbanas" (SPÓSITO, 1998, p. 30) conforme comentado no primeiro item de Soja (2000). Tais processos se manifestam na estrutura urbana por meio de diferentes formas de expansão e periferização do tecido urbano, a citar:

[...] a abertura de novos loteamentos urbanos, destinados a engendrar diferentes padrões ocupacionais; construção de grandes conjuntos habitacionais associados ou não a instalação de pequenos equipamentos para a realização de um consumo imediato; aparecimento de grandes equipamentos comerciais e de serviço (shopping centers e hipermercados) e, mesmo, de outros centros de atividades mais complexos, que incluem a presença de sede de empresas, serviços de hotelaria e espaços para a realização de eventos de toda natureza.. (SPÓSITO, 1998, p. 30).

Esses processos se articulam diretamente com a cidade-mosaico ou colcha de retalhos. E, embora seja necessário compreender que esses processos se manifestam em intensidades diferentes nas cidades brasileiras, não podemos negar a recorrência de análise desses 
processos nos estudos urbanos brasileiros (diversas teses, dissertações, artigos e a própria rede de pesquisadores do Observatório das Metrópoles).

Figura 3: Pôster de divulgação da Welwyn Garden City, cidade inspirada nas concepções de Howard e do condomínio residencial Monteverdi (localizado em Arcos/MG): ambos vendem a ideia de convívio com a natureza, importante fator que agrega valor aos empreendimentos imobiliários brasileiros.
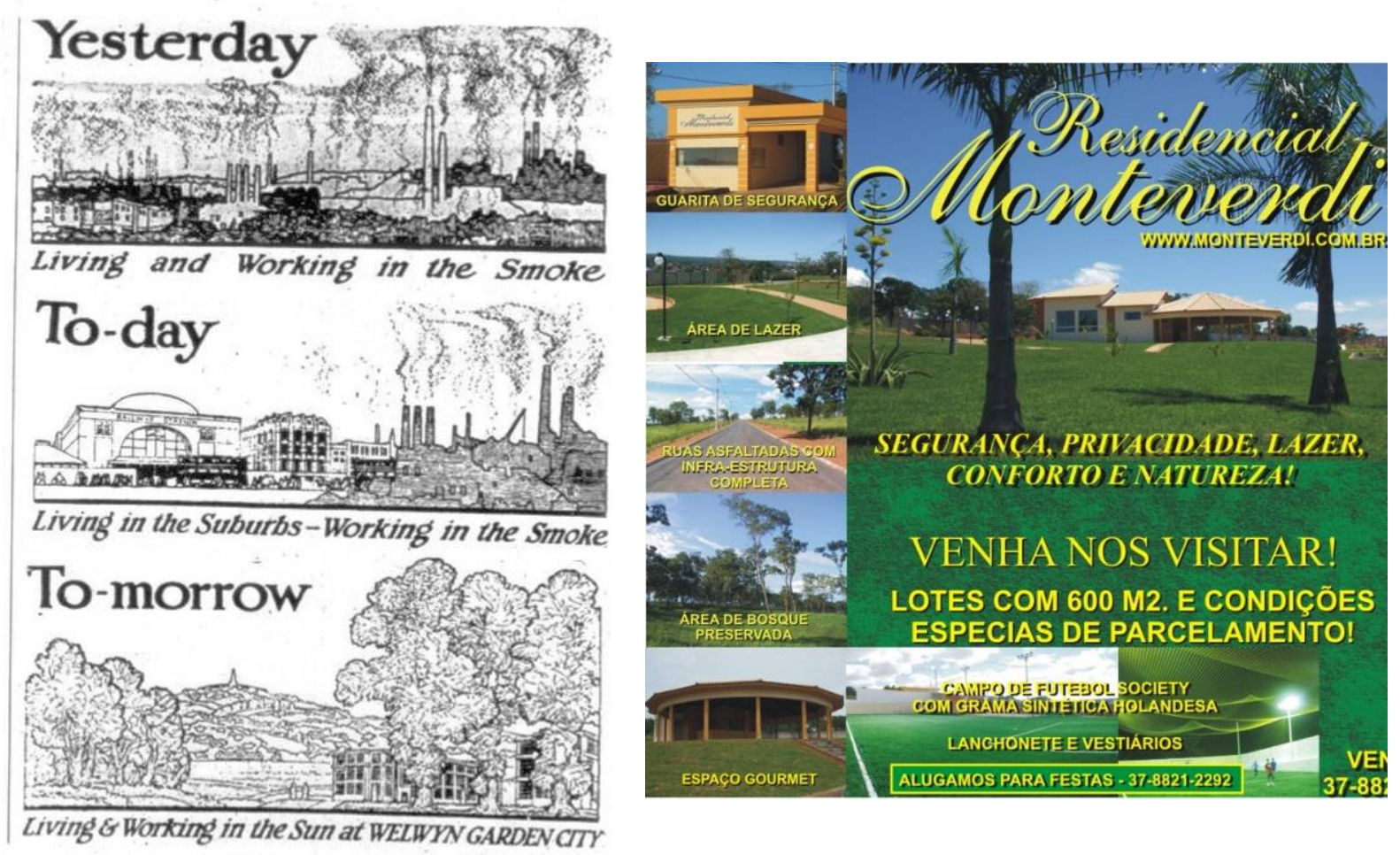

Fonte: Autoria desconhecida. Disponível em <http://ocw.mit.edu/ans7870/11/11.001j/f01/lectureimages/6/> e $<$ http://www.monteverdi.com.br/>. Acesso em 20 de jan. de 2015.

O quarto ponto é a cidade fractal. São analisadas as características sociais da pósmetrópoles: relações fluidas, fragmentadas, descentralizadas e reorganizadas em complexos padrões que formam o mosaico social das cidades (SOJA, 2000, p. 265). Diversos estudiosos afirmam que os novos processos de urbanização intensificam as desigualdades socioespaciais visto que estas disparidades são "expressão do processo de urbanização capitalista, um produto da reprodução ampliada do capital que se perpetua como condição de permanência da desigualdade social" (RODRIGUES, 2007, p. 74).

Dentre eles, destacamos novamente a visão marxista de David Harvey (1980) com seu "A Justiça Social e a Cidade", onde argumenta que no funcionamento normal do sistema urbano sob o capitalismo sempre há uma tendência de distribuição de renda em favor dos ricos. Embora seja possível interferir nesse processo por meio de um planejamento eficaz e da intervenção pública em habitação, na questão fundiária e nos mercados de trabalho, esse não 
parece ser a frente de ação pública dos últimos trinta anos uma vez que predominam governos neoliberais, de modo que Harvey (1980) argumenta que a verdadeira justiça social e territorial só pode ser obtida por meio do socialismo.

Complementarmente, na visão de Ascher (1995) frente à complexidade de grupos e práticas sociais abrem-se dois caminhos para as cidades contemporâneas: (1) o da civilidade, com a "capacidade de observar as 'conveniências', 'boas maneiras em uso num grupo social'"(ASCHER, 1995, p. 155, tradução de NASPOLINI, 2009) promovendo uma urbanidade intensa, repleta de trocas sociais (civilização "rica"); (2) o da negação do "outro", da diminuição da sociabilidade a microgrupos que apenas coexistem na base de relações utilitárias mínimas (civilização "minimal”), o que levaria a uma metápole "na qual uma individualização empurrada a seu limite extremo distende as relações sociais, mina as instituições políticas, ou mesmo gera a reconstituição de pequenas comunidades fechadas" (ASCHER, 1995, p. 156, tradução de NASPOLINI, 2009).

A opção entre esses dois percursos estaria sujeita àquilo que Ascher (1995) chamou de “citadinité". Diferentemente da cidadania (em francês citoyenneté), a "citadinidade" pode ser definida como a "consciência do pertencimento a uma coletividade urbana e o exercício dos direitos e deveres relacionados" (NASPOLINI, 2009, p. 90). Porém, em nossa sociedade contemporânea ambos os conceitos são dificilmente aplicados e predomina o individualismo e o comunitarismo, que parecem nos conduzir ao segundo caminho. Segundo Bauman (2001), a modernidade é marcada por uma expansiva autonomia do homem em relação à vida social que passa a ter como cerne o individualismo. Um exemplo é a "síndrome NIMBY" (sigla em inglês para not in my backyard, ou seja, não no meu jardim) que é verificada, por exemplo, quando uma determinada comunidade é contrária à implementação de equipamentos coletivos próximos a suas casas, pois mesmo sendo de grande utilidade à população em geral, essa atração do "outro" em suas cercanias parece ser para eles mais danosa do que as vantagens que tais serviços podem trazer.

Portanto, alguns espaços urbanos promovem e exacerbam as desigualdades sociais, pois neles não há lugar para subjetividades frente aos interesses de mercado que visam à promoção do consumo. A ideia de estar "sozinho no meio da multidão" se faz clara nesses espaços. Bauman (2001) denomina esses locais de "lugares fágicos", numa acepção direta ao ato de "devorar" corpos e espíritos estranhos de modo a fazê-los, pelo metabolismo, idênticos aos corpos que os ingerem, portanto não distinguíveis deles" (BAUMAN, 2001, p.118). São espaços onde as subjetividades individuais e componentes culturais devem invariavelmente 
amoldar-se ao todo, muitas vezes sob a alegação de torná-los mais protegidos. Entretanto, prevalecem os interesses do mercado e a "pasteurização" coíbe movimentos contestatórios. Um exemplo são os "templos de consumo": os shoppings centers, que como o próprio autor descreve, não são programados para a interação social, mas para o consumo. Ali as pessoas (enquanto consumidores) se veem diante de uma outra "realidade". Tal como seu edifício não permite a entrada de luz solar, parece a realidade propriamente dita (entendida como contestações, acasos e possibilidades diversas de convívio genuíno) também não pode penetrar no shopping.

Esses quatro discursos juntos (pós-fordismo, globalização, reestruturação urbana e polarização social) definem um novo regime de urbanização, enquanto o quinto e sexto pontos exploram as mudanças institucionais, comportamentais e ideológicas que estão reorganizadas para conformar o modo de regularização socioespacial das pós-metrópoles (SOJA, 2000, p. 299). Observa-se o agravamento das segregações socioespaciais. O inchamento populacional dos arranjos metropolitanos:

[...] traduzem-se na multiplicação das zonas de habitação precárias, bidonvilles e taudis ${ }^{21}$, tão bem inscritos nas paisagens urbanas. Sem dúvida este gênero de habitação ocorre, mas eles alojam somente uma fração cada vez mais reduzida das populações desprovidas cada vez mais numerosas. Ao contrário, vastos espaços fora da cidade se transformam em "zonas de urbanização irregular": loteamentos precários e ilegais permitem apropriarse de pequenas parcelas nas quais as famílias pobres autoconstroem sua pequena casa, freqüentemente [sic] desprovida de equipamentos básicos e de todo elemento de conforto. Muitas nuanças poderiam ser indicadas para descrever o mecanismo global da periurbanização mas, de toda maneira, ela reforça a oposição entre os espaços dos ricos e aqueles dos pobres, entre a cidade legal e a cidade ilegal... Esta segregação socioespacial favorece o aumento da violência urbana. (ROCHEFORT, 2002, s/p.).

Ora, se os novos processos de urbanização aumentam disparidades sociais e econômicas bem como a heterogeneidade cultural, favorecendo a multiplicação dos pontos de tensão e de confronto com base em diferenças de raça, etnia, sexo, renda, orientação sexual, idade, e outros atributos sociais e espaciais, o que tem impedido as pós-metrópoles de explodir com mais frequência e mais violentamente do que tem ocorrido ao longo da última década é o exacerbado controle social e espacial trazido à tona pelo desenvolvimento de novos meios e tecnologias de vigilância, policiamento, privatização e desenho do ambiente construído e a geografia política do espaço da cidade (SOJA, 2000, p. 299). Segundo Muñoz

\footnotetext{
${ }^{21}$ Do Francês, podendo ser traduzido literalmente por favelas e barracos, ou de maneira geral, como um conjunto de habitações em ruim estado de salubridade construído à margem das grandes aglomerações urbanas.
} 
(2008), principalmente antes dos atentados de 11 de setembro, as áreas vigiadas eram circunscritas às zonas militares, industriais ou outras em que se desenvolvessem funções que necessitassem de vigilância. Entretanto, na última década proliferam as "paisagens da segurança" (Figura 4): entradas restritas e protegidas, circuitos de câmeras etc., de modo que “[...] a segurança urbana não deixa de ser um objeto de consumo, mas, neste sentido, se tornaria um elemento com capacidade para diferenciar status econômico e social ou definir estilos de vida distintos"22 (MUÑOZ, 2008, p.78, tradução nossa).

Os quesitos de segurança definem um novo estilo de morar, o lock living (MUÑOZ, 2008), ou seja, em que cada vez mais nos protegemos em nossas residências por meio de diversos aparelhos de segurança que nos enclausuram em uma tipologia introspectiva (Figura 5). Essa busca incessante por proteção e segurança vai de encontro às ideias de Jacobs (2000) que defendia que "o principal atributo de um distrito urbano próspero é que as pessoas se sintam seguras e protegidas na rua em meio a tantos desconhecidos” (p. 30).

Figura 4: Big Brother urbano: à esquerda, orla da cidade de Madre de Deus, região metropolitana de Salvador que pretende se tornar a cidade mais vigiada do Brasil. À direita, um dos drones, robôs voadores equipados com câmeras, que se espalham pela cidade de São Paulo para observar lugares e pessoas.

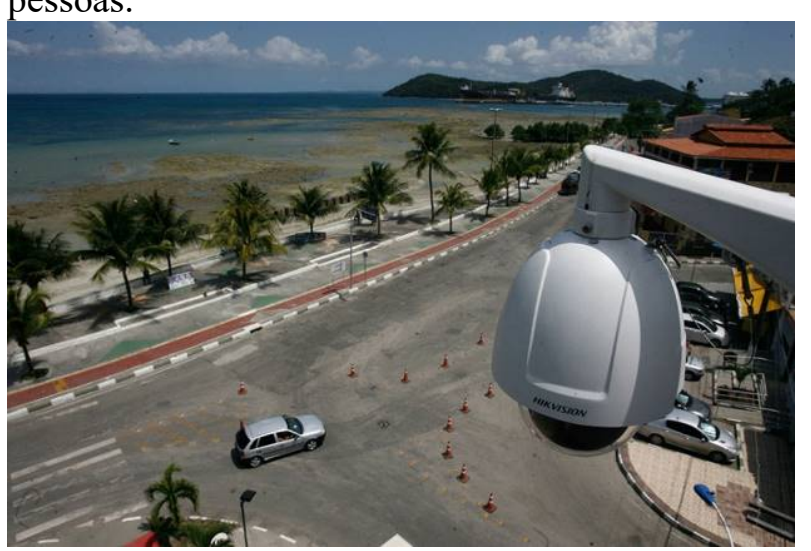

Fonte: Fotos de autor desconhecido (s/d).

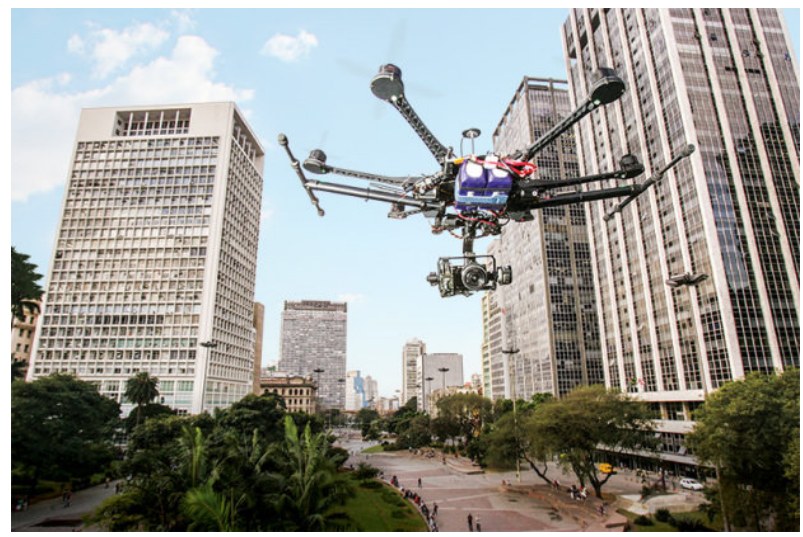

$<$ http://vejasp.abril.com.br>. Acesos em 20 jan. 2015.

A segurança faz parte dos processos de produção das pós-metrópoles. Essas paisagens se multiplicam no nosso dia a dia: moramos em condomínios fechados ou pelo menos procuramos um prédio com vigilância 24 horas; ao fazermos compras é comum nos depararmos com o cartaz "sorria, você está sendo filmado" e as câmeras invadem também o espaço público (Figura 4 e Figura 5). Por exemplo, em 2001, São Paulo já possuía cerca de

\footnotetext{
${ }^{22}$ No original: "[...] la seguridad urbana no deja de ser un objeto de consumo más y, en esse sentido, habría devenido un elemento con capacidad para diferenciar status económicos y sociales o bien definir estilos de vida distintos".
} 
125.000 câmeras que monitoram as atividades dos pedestres em prédios, parques, lojas e calçadas (KENSKI, 2001). Trago para o debate também as ideias do sociólogo polonês Bauman (2001), que descreve que alguns espaços urbanos embora sejam públicos, não são "civis", isto é, perderam sua qualidade de gerar encontros não-programados entre estranhos. Em sua conceituação de "lugares êmicos", define os espaços programados para proteger os agentes internos a eles, do contato com estranhos e mantê-los à distância, de modo que:

As variantes extremas da estratégia 'êmica' são hoje, como sempre, o encarceramento, a deportação e o assassinato. As formas elevadas, 'refinadas' (modernizadas) da estratégia 'êmica' são a separação espacial, os guetos urbanos, o acesso seletivo a espaços e o impedimento seletivo a seu uso. (BAUMAN, 2001, p.118).

Figura 5: Tirinha que representa o enclausuramento das residências ao longo do tempo.
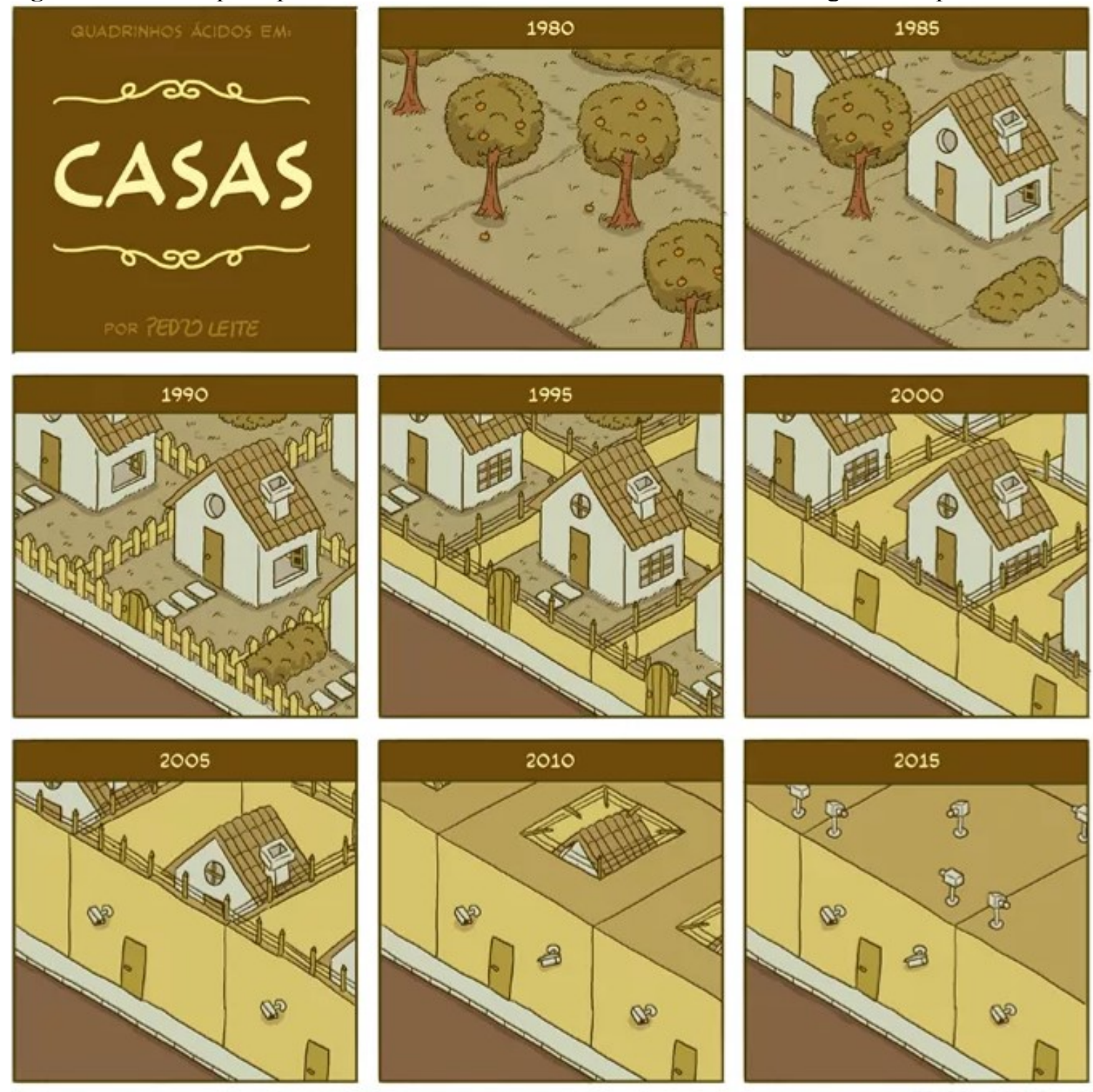

www.quadrinhosacidos.com,br

Fonte: Ilustração de Pedro Leite. Disponível em <http://www.quadrinhosacidos.com.br/>. 
O espaço urbano precisa ser remodelado de acordo com as políticas de segurança, pois é recorrente nos discursos que a cidade tradicional é "desorganizada" - em seus traçados orgânicos e interstícios urbanos - o que dificulta o controle dos espaços. De novo, observo o contraponto com Jacobs: "sob a aparente desordem da cidade tradicional, existe, nos lugares em que ela funciona a contento, uma ordem surpreendente que garante a manutenção da segurança e a liberdade. É uma ordem complexa" (JACOBS, 2000, p. 52). A cidade contemporânea, por outro lado, perde graus de complexidade e diversidade espacial e social ${ }^{23}$ (MUÑOZ, 2008, p.81).

Por fim, o último ponto é definido por Soja (2000) como as hiper-reais Simcities ${ }^{24}$, onde a vida cotidiana é jogada como num computador (Figura 6). Embora o termo pareça à primeira vista fantasioso, o foco principal da discussão é sobre a reestruturação do imaginário urbano, ou seja "[...] nossos mapeamentos mentais ou cognitivos da realidade urbana e as redes interpretativas por meio das quais nós pensamos, experimentamos, avaliamos e decidimos agir nos lugares, espaços e comunidades em que vivemos ${ }^{25 "}$ (SOJA, 2000, p. 324, tradução nossa). Entretanto, antes de nos aprofundarmos em como essa (re)fabricação ideológica do imaginário urbano afeta a vida cotidiana nas postmetropolis, é importante traçarmos uma conceituação de imagem como correspondente à:

[...] informação solidamente relacionada com um significado que se constrói numa síntese de contornos claros que a faz única e intransferível. A imagem tem um e apenas um significado, corresponde a um dado solidamente codificado no modo de ser daquela sintaxe. É um código urbano e impõe uma leitura e fruição que estão claramente inscritos na cidade como espaço construído. Ao contrário, o imaginário corresponde à necessidade do homem de produzir conhecimento pela multiplicação do significado, atribuir significados a significados; suas produções não são únicas, não se acumulam e passam a significar mais por um processo associativo onde um significado dá origem a um segundo ou terceiro e, assim, sucessivamente. Pelo imaginário, a imagem urbana - locais, monumentos, emblemas, espaços públicos ou privados - passam a significar mais pela incorporação de significados extras e autônomos em relação à imagem básica que lhes deu origem. (FERRARA, 2008, p. 194, grifo nosso).

\footnotetext{
${ }^{23}$ Essa "adaptação" da cidade às condicionantes de segurança e controle social não são novas. Lembremos que uma das justificativas da remodelação de Haussmman em Paris era a segurança, por isso a destruição de bairros perigosos que eram foco de revoltas e a abertura de grandes avenidas para controle visual e facilitar o transporte das forças policiais. Da mesma maneira, poderíamos analisar a reforma de Pereira Passos no Rio de Janeiro no início do século XX.

${ }^{24} \mathrm{O}$ autor faz referência direta ao jogo simulação para computadores lançado em 1989, no qual o objetivo é construir e gerenciar uma cidade.

${ }^{25}$ No original: "The urban imaginary, as it is used here, refers to our mental or cognitive mappings of urban reality and the interpretive grids through which we think about, experience, evaluate, and decide to act in the places, spaces, and communities in which we live".
} 
Para Lynch (2011), a imagem do lugar é formada por três componentes: identidade, estrutura e significação. A primeira é intrinsecamente ligada ao objeto, pois é por meio dela que a imagem se manifesta como entidade individualizada. Outras duas categorias dizem respeito às relações entre observador com as partes do objeto (estrutura) e à maneira com que o sujeito vê e atribui significados às partes formadoras do objeto (significação). Este é um processo por meio do qual o espaço já percebido e conhecido se manifesta para o indivíduo. A imagem formada é vinculada tanto ao sujeito quanto aos atributos físicos da realidade estudada. Ou seja, ela depende não só da maneira como se percebeu aquele lugar, como também das informações contidas na memória, não somente do ponto de vista do lugar em si, como também do ponto de vista conceitual ${ }^{26}$.

Contrastando com o mundo real, a mudança do imaginário urbano diz respeito à ideia de hiper-realidade, onde a diferenciação entre o verdadeiro e o falso, o real e o imaginário, é turva. Nas simcities, a imagem da cidade gira em torno a simulacros criados pela mídia e acessados por meio do ciberespaço: tecnologia, eletrônica e conexões à Internet criam um espaço único onde podemos estar em todos os lugares ao mesmo tempo (SOJA, 2000, p. 336).

Figura 6: À esquerda, vista de uma cidade montada no jogo SimCity, e à direita, um exemplo do "sonho americano de morar" em Celebration, comunidade desenvolvida pela Walt Disney próxima aos parques da empresa na Flórida, Estados Unidos da América - EUA.

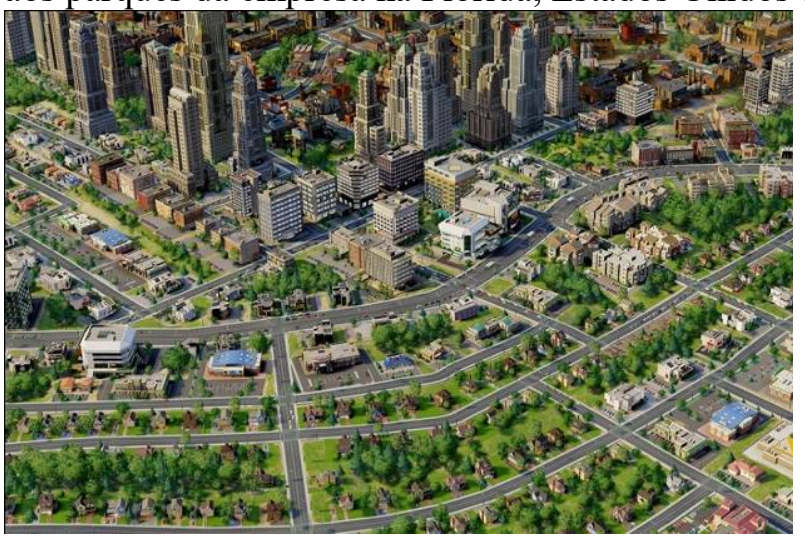

Fonte: Fotos de autor desconhecido (s/d). $<$ http://fineartamerica.com>. Acesso em 25 jan. 2015.

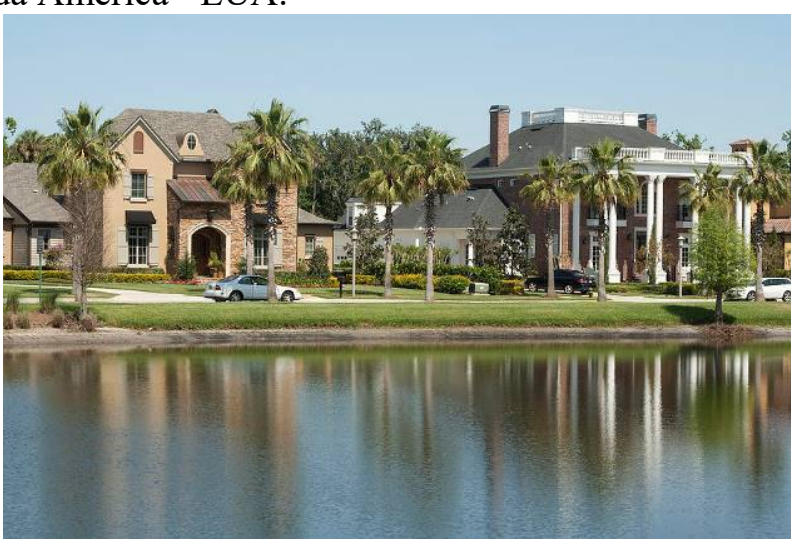

Disponível em <http://worldgamer1.com> e

O imaginário urbano de qualquer cidade é muito influenciado por simulacros por meio da mídia, publicidade e planejamento urbano. De acordo com Hollywood, o sonho americano é vivido em um cenário suburbano com uma grande casa, garagem para dois carros, um

\footnotetext{
${ }^{26}$ A partir dos anos 1960, diversos pesquisadores têm utilizado os princípios e as metodologias da imagem da cidade como suporte para a valorização do espaço urbano. A análise topoceptiva busca avaliar as características dos lugares que influenciam na noção de localização dos indivíduos, em termos de orientação e identificação. Para aprofundamento sobre o tema sugere-se a leitura de Kohlsdorf (1996).
} 
pequeno jardim e quintal grande, dois filhos e um caro e grande automóvel para caber tudo dentro. Esse sonho é oneroso e fora de alcance para a maioria das famílias. Esses tipos de simulacros, por sua vez, afetam socioespacialmente as áreas urbanas de uma forma que é inevitável e incapaz de ser recusado.

As televisões, celulares, computadores, internet são ferramentas políticas poderosas porque a sua função é a de não fabricar ou transportar bens físicos, mas influenciar as crenças e percepções humanas. A ilusória democracia oferecida pelos meios de comunicação são apenas manobras de distração do verdadeiro poder por trás dos bastidores das novas tecnologias, a substituição da democracia por um estado mercantil global que exerce o seu controle por meio da manipulação do desejo, auxiliada pelos meios de comunicação mais do que pelos meios ortodoxos de vigilância e controle.

As cidades são recompostas como variações de um parque temático, em culturas simuladas, estilos de vida e preferências dos consumidores. Numa Simcity os moradores escolhem o seu local de residência, não só com base em padrões convencionais de localização, mas também para pagar por um lugar simbólico que simula um tema específico ou um pacote de paisagens e imagens. A "colcha de retalhos" (MEDEIROS, 2008) de comunidades monofuncionais que resulta daí é muito mais refinada quando se refere à sua territorialidade porque além das antigas segregações por raça ou classe, incluem muitas outras novas (SOJA, 200, p. 341)

As reflexões urbanas contemporâneas caminham no sentido de explorar as relações sociais que transcendem o espaço físico, especialmente sob efeito de uma economia global. Pesquisadores como Ascher (2012) propõem pensar as escalas urbanas além dos prefixos mega ou metro, introduzindo o conceito de metápolis: a transversalidade subjugando os limites físicos, complexidade ao invés da densidade dos assentamentos, falta de consenso entre os sistemas de governança que tal como o processo de globalização:

[...] induz a um duplo processo de homogeneização e de diferenciação: homogeneização porque os mesmos actores [sic] económicos ou o mesmo tipo de actores [sic] económicos estão presentes com as mesmas lógicas em todos os países e em todas as cidades; diferenciação, porque a concorrência interurbana se alarga e se anima, acentuando a importância das diferenças. (ASCHER, 2012, p.63-64).

As cidades, na busca de se inserir na cultura globalizada, são ao mesmo tempo massificadas enquanto procuram apresentar atrativos que as difiram das demais concorrentes. Exemplo disso é Dubai, que ao mesmo tempo em se que coloca nos padrões ocidentais de 
mercado (com edifícios de volumetria contemporânea ou construção de condomínios fechados), explora suas particularidades culturais cenograficamente como atrativo turístico (os interiores daqueles edifícios ostentam profusa decoração árabe ou as novas áreas residenciais em formato de palmeira, lua crescente etc.).

As desigualdades em face dos efeitos urbanos da globalização são visíveis na oposição entre o mundo desenvolvido - que dispõe das mais importantes cidades globais que controlam as trocas internacionais - e o mundo em desenvolvimento que sucumbe ao peso desta nova forma de dominação (ROCHEFORT, 2002). Porém, há também as diferenciações regionais que operam no interior dos territórios nacionais. Ou seja, os processos descritos se inserem na realidade brasileira, entretanto é preciso entender como e em que medida eles se dão em nossa rede urbana.

\subsection{Conclusões parciais}

Ante o exposto, destaco a inegável relação de dominância exercida por algumas cidades frente à sua rede de influência. Esta acepção, presente desde a origem da palavra metrópole, supera as tradicionais delimitações populacionais ou de tamanho da mancha urbana - o que é condizente com o tipo metropolitano que pretendo caracterizar neste estudo. A partir desse entendimento, ganham destaque outras dimensões que representam a polarização metropolitana, por exemplo, social, política, econômica e por que não incluir também os aspectos morfológicos, numa perspectiva em que não é somente o tamanho físico ou populacional que facilita os acessos às infraestruturas da cidade e que produz as desigualdades socioespaciais.

A metropolização contemporânea é um fenômeno complexo que produz novas paisagens. Novas formas de morar e consumir, novos arranjos das forças produtivas e meios de produção rebatidos arquitetonicamente na construção dos edifícios e espaços urbanos, nas redes de circulação e transportes, entre outros, assinalam a materialidade espacial da metropolização. O câmbio diário dos meios de comunicação adiciona novos paradigmas imateriais a esse processo, por meio de plataformas que permitem o intercâmbio de informação em escala global e as maneiras pelas quais nos relacionamos com o outro.

Vivenciamos um novo estágio histórico da produção do espaço, não apenas como uma nova maneira de urbanização, mas a "metamorfose do processo de urbanização" (LENCIONI, 2006). Do ponto de vista político, a metropolização pode ser vista com a “[...] 
hierarquização do espaço a partir da dominação de centros que exerce sua função administrativa, jurídica, parcelares cujo conjunto escapa ao indivíduo" (CARLOS, 1994, p. 191). A metropolização vai além da concentração demográfica, diz respeito a multiplicação das aglomerações urbanas por meio da dilatação dos conteúdos metropolitanos que reproduzem as contradições do espaço.

No próximo capítulo introduzo como - e em que graus- esses processos podem ser visualizados na rede urbana do Nordeste brasileiro, ante os paradigmas socioespaciais construídos historicamente. A globalização já se embrenhou nos mais diversos confins do planeta. Incluo aí o Nordeste e suas reconhecidas problemáticas de desenvolvimento (pobreza, desigualdades sociais, baixa escolarização, recursos naturais limitados, dentre outros) que parecem se exacerbar frente às novas formas de (re)produção do capital, agrícola e urbano, impostas pelo mercado global. Portanto, este trabalho foca-se em compreender os novos arranjos territoriais que se organizam no Nordeste brasileiro a partir das recentes transformações do processo de urbanização globalizado. 


\section{METRÓPOLES}

NO BRASIL

E NO

NORDESTE 
Neste capítulo apresento uma breve revisão do tema metropolitano no Brasil, com especial destaque ao caso da região Nordeste e as especificidades da sua rede urbana. São abordadas as origens e organizações das instituições e das legislações que incidiram sobre a questão urbana no Brasil desde os anos 1970 (década que são reguladas as primeiras RM's do país).

\subsection{O planejamento urbano e o tema metropolitano no Brasil até os anos 1970: o Nordeste, a SUDENE e suas ações}

Ao longo da história do Brasil, o processo de formação e consolidação de cidades teve importante papel "no processo de ocupação do território, servindo como sítios de suporte ao povoamento, centros de controle político e de armazenamento da produção agroextrativa, núcleos de conexão com os circuitos mercantis, pólos [sic] de crescimento industrial e nós das redes financeiras" (IPEA, IBGE, UNICAMP, 2001, p. 85). Resumidamente, o processo de urbanização do Brasil pode ser sistematizado em três etapas de formação territorial: (1) escravista, predominante na costa Atlântica durante o Período Colonial (de 1500-34 até 180822) ao do Império Nacional (1808-22 até 1870-89); (2) agromercantil, entre 1870-89 e 193045 com o campo constituindo-se como principal fonte de riqueza e a cidade, seu locus de comercialização; (3) urbano-industrial, consolidada a partir da década de 1930 e que caracteriza-se pelo processo de industrialização (IPEA, IBGE, UNICAMP, 2001, p. 85).

A industrialização pode, por sua vez, ser dividida em três fases: a) industrialização restringida (1930-45 a 1956-60), ainda em dependência da importação de bens de produção do mercado mundial; b) fase da industrialização pesada (1956-60 a 1975-79), período em vigor do Plano de Metas até o II Plano Nacional de Desenvolvimento, que foram responsáveis por significativo aceleramento no ritmo de desenvolvimento do mercado doméstico, que se expressa em novas relações cidade/campo, iniciando o processo de constituição da rede urbana; c) fase de internacionalização financeira (1975-79 a 1991-95), “caracterizada por crise e esgotamento fiscal e financeiro do Estado nacional, cuja capacidade de comandar o processo de industrialização foi seriamente comprometida pelo endividamento interno e externo" 
(IPEA, IBGE, UNICAMP, 2001, p. 86), o que acarretou a redução do ritmo de crescimento das grandes metrópoles e pela emergência de outros núcleos dinâmicos além do eixo Rio São Paulo (por exemplo Fortaleza, Manaus, Brasília-Goiânia, dentre outros).

Principalmente nas cidades da região Sudeste, onde os processos de industrialização foram preponderantes, intensificaram-se os movimentos de êxodo rural e o seu crescimento acelerado. Esse inchaço das cidades impõe uma ordem urbanística excludente e predatória: espaços das classes mais pobres são segregados, carentes de infraestrutura básica e ambientalmente degradados. Em que pesem as críticas sobre a profundidade da abordagem, a sistemática trazida por Villaça (1999) acerca da história do planejamento urbano no Brasil aponta que predominavam ações de embelezamento urbano até meados dos anos 1930, quando há uma mudança:

Começa a se gestar um período no qual surge um novo discurso que, a partir
daquele momento, será pronunciado por lideranças políticas e sociais e
usado não mais para justificar obras que eram executadas, mas para tentar
justificar a falta de solução para os chamados "problemas urbanos" [...] já se
insinua o "caos urbano", o "crescimento descontrolado" e a necessidade de
"planejamento". (VILLAÇA, 1999, p. 206).

É, portanto, para mitigar tais “problemas urbanos" - como cita Villaça anteriormente que as classes dominantes investem em planos como o Plano de Avenidas Prestes Maia para São Paulo (1930) e Plano Agache para o Rio de Janeiro (elaborado no final da década de 1920). Estes projetos eram constituídos por obras (principalmente na sua estrutura viária) que atendiam às partes da cidade que interessavam às classes dominantes, como a remodelação do centro. Do ponto de vista legal, na Constituição de 1937 são encontradas as primeiras referências legais sobre o agrupamento de municípios no Brasil com a finalidade de administração de serviços públicos comuns (UFPE, 2007). Embora não caiba nos objetivos deste trabalho discutir as bases teóricas e socioeconômicas do desenvolvimento urbano brasileiro, pode-se abordar sucintamente que a formação das regiões metropolitanas brasileiras está intimamente ligada ao processo de industrialização. O processo de industrialização substitutivo de importações é consequência dos estrangulamentos externos gerados pelas duas Guerras Mundiais e pela Crise de 1929, que também enfatizaram a importância dos planos de desenvolvimento nacionais, com ênfase na industrialização e na construção da infraestrutura, intensificando-se na década de 1950 sob a égide de Juscelino Kubitschek. Em âmbito regional, deu-se a criação do Banco do Nordeste (1952) e da Superintendência do Desenvolvimento do Nordeste - SUDENE (1959). As consequências 
destas decisões políticas são sentidas na estrutura de nossas cidades até hoje, tal como explicita Monte-Mór:

Em países subdesenvolvidos, de industrialização fordista periférica e incompleta, como o Brasil, os espaços 'incompletamente organizados' (Santos, 1978) e as periferias urbanas precárias proliferaram com áreas de sub-habitação e ausência de serviços urbanos e sociais básicos. Essa suburbanização precária que se iniciou nas grandes cidades, como Rio de Janeiro e São Paulo, com a industrialização substitutiva de importações, produziu periferias pobres parcialmente integradas à dinâmica urbana. A expansão do modelo fordista a partir dos anos sessenta, contrariamente à expectativa de maior inclusão social, resultou no agravamento das condições de exclusão urbana. (MONTE-MÓR, s/p, 2006).

Essa dinâmica centro-periferia é não apenas recorrente na escala intraurbana, mas reflete também na rede urbana brasileira: cidades que respondem a uma escala global de articulação e que concentram os investimentos públicos e privados (até mesmo do capital internacional) enquanto outras são completamente dependentes economicamente, carentes até das infraestruturas mais básicas que temos a dificuldade de classificá-las como "cidades". Essas disparidades acentuam-se ao fazermos um comparativo inter-regional. Houveram tentativas de interferir nessas heterogeneidades, dentre as quais interessa ao recorte espacial desse estudo destacar a SUDENE.

Tendo em vista as desigualdades inter-regionais anteriormente descritas, foi criada a Superintendência do Desenvolvimento do Nordeste - SUDENE pela Lei n 3692 de 15 de dezembro de 1959 e com sede em Recife tendo à frente o economista Celso Furtado ${ }^{27}$. A realidade nordestina compunha um quadro aterrador: uma estrutura agrária marcada pelas secas e pelo latifúndio improdutivo, as elevadas taxas de crescimento demográfico, as deficiências de infraestrutura básica (saneamento, distribuição de energia elétrica e transportes, por exemplo) e um quadro social onde predominavam o analfabetismo, a mortalidade infantil, as endemias e a carência alimentar. Soma-se um contexto de estagnação econômica:

[...] reportada à dominância da economia açucareira. Impunha-se desentrelaçar a economia regional da produção açucareira e promover a industrialização do Nordeste. Essa foi a idealização política maior dos intelectuais e dos industriais à época, para fazer frente aos entraves econômicos, à miséria do povo e ao crescimento populacional (PONTUAL, $\mathrm{s} / \mathrm{p}, 2001)$.

27 O economista inicia sua atuação como o interventor do Grupo de Trabalho para o Desenvolvimento do Nordeste - GTDN em 1958, cujos resultados dos estudos resultaram num plano de política econômica para aquela região, o que posteriormente levou à criação da SUDENE. (CARDOZO, 2011). 
Em que pesem as atuações de incentivo à produção agrícola em áreas irrigadas e a colonização do Maranhão ${ }^{28}$, as ações da SUDENE desenvolvidas no período da ditadura militar desviam-se dos objetivos iniciais. Soma-se aos seus objetivos o incremento industrial, com ambição de que a indústria permitisse a criação de novos empregos, promovendo a manutenção da mão de obra na região ao invés da migração intensa para o Sudeste e o Sul do País, entretanto:

O planejamento regional também teve que se ajustar aos novos tempos. No caso do Nordeste [...] a SUDENE teve que abandonar a proposta industrializante, mas reformista, do GTDN para promover a industrialização situada [...] ao invés de uma indústria colada à base de recursos regionais e voltada para atender prioritariamente o mercado nordestino [...] a indústria incentivada pela SUDENE compra sobretudo ao Sudeste a maior parte dos insumos que transforma e vende para lá a grande parte do que produz. (ARAÚJO, p. 89-90, 1993).

Além da política industrial voltada para as elites do Sudeste, prevaleceram os interesses das oligarquias agrárias de matriz colonial, cujo conservadorismo tinha em vista a manutenção de benefícios advindos das políticas de combate à seca. A SUDENE não tem força para lutar contra o sistema e dentre as críticas à atuação da instituição, podemos destacar que:

Enquanto as agências de planejamento do desenvolvimento regional (SUDENE, SUDAM, SUDECO) se debruçavam sobre planos nunca concretizados e distribuíam incentivos fiscais entre grupos dominantes locais e nacionais, o território ia sendo tecido pelas decisões tomadas em grandes agências setoriais. Não eram os planejadores regionais que planejavam a região, mas os planejadores e tomadores de decisão em cada um dos macrosetores de infra-estrutura [sic]: no setor elétrico, a Eletrobrás e suas coligadas (CHESF, Eletronorte, Furnas, Eletrosul, Light), bem como algumas grandes empresas estaduais (Eletropaulo, Copel); no setor mínerometalúrgico, a Companhia Vale do Rio Doce, as grandes companhias siderúrgicas estatais; no setor petroquímico, a Petrobrás. Já nos anos 50, Brasília e a rodovia Belém-Brasília, assim como mais tarde a Transamazônica e outras intervenções viárias, redesenhavam o território regional, trazendo à vida novas regiões e novas regionalizações. (VAINER, $\mathrm{s} / \mathrm{p}, 2007)$.

Essa dissociação entre plano e ação, discurso versus prática, permeia toda a história do planejamento urbano brasileiro tal como explora Villaça (1999). Isso se agrava no período do regime militar, quando a "fantasia é desfeita" segundo o próprio Furtado (1989) boa parte dos

${ }^{28}$ O Estado do Maranhão, por meio de lei estadual de 1961, colocou as terras compreendidas entre os rios Pindaré e Turiaçu, ao longo da atual BR-316, à disposição da SUDENE para o projeto de Colonização do Maranhão. 
planos esbarrava em dificuldades técnico-administrativas ou no interesse político de colocá-lo em prática. É nesse contexto que se explora os Planos Nacionais de Desenvolvimento.

\subsection{Os Planos Nacionais de Desenvolvimento, metrópoles e cidades médias}

O regime militar estabelecido em abril de 1964 encontrou um momento de estagnação econômica e de aceleração inflacionária justificando preocupações, sobretudo, em estabilizar a economia. Dentre os vários planos, projetos e ações empreendidos no período, têm destaque nos recortes dessa revisão o I e II Plano Nacional de Desenvolvimento - PND. O processo de substituição de importações comentado anteriormente, exacerba-se a partir do modelo econômico em curso no país pós-1964, sendo implementado por meio de políticas públicas que tinham como alvo a independência do país em relação ao mercado externo (MARICATO, 1997).

O I PND foi instituído pela Lei 5.727, promulgada em 4 de novembro de 1971. Seu principal objetivo era preparar a infraestrutura, com ênfase em setores como transportes e telecomunicações, necessária para o desenvolvimento do Brasil nas décadas seguintes. Segundo Campos (1974), o plano oficializou ambiciosamente o conceito de "modelo brasileiro", definindo-o como:

[...] modo brasileiro de organizar o Estado e moldar as instituições para, no espaço de uma geração, transformar o Brasil em nação desenvolvida [...] deveria por um lado, criar uma economia moderna, competitiva e dinâmica, e por outro lado, realizar democracia econômica, social, racial e política [...] Entre seus pontos essenciais estava a influência crescente do governo, mediante expansão dos investimentos e uso da capacidade regulatória, que era considerada como uma incorporação dos modernos instrumentos de evolução das economias desenvolvidas. (CAMPOS, 1974, p. 69).

Foi no âmbito do I PND que foram elaborados os planos e/ou empreendidas as obras para grandes projetos na área de infraestrutura, como a ponte Rio-Niterói, a rodovia Transamazônica, a hidrelétrica de Três Marias, a barragem de Itaipu, entre outras. Entretanto, num contexto mundial de crise $^{29}$, foi elaborado uma nova estratégia político-econômica durante o governo do general Ernesto Geisel (1974-79): o II Plano Nacional de Desenvolvimento.

\footnotetext{
${ }^{29}$ Especialmente a Crise do Petróleo de 1973, quando a Organização dos Países Exportadores de Petróleo OPEP aumentou o preço do produto como retaliação aos países pró-Israel na Guerra do Yom Kipur. 
Dentro do recorte temático desta tese, temos no contexto urbano brasileiro a aceleração dos processos de urbanização e transformação para uma sociedade predominantemente urbana. Entretanto, a rede urbana era extremamente desequilibrada: metropolização prematura onde os problemas urbanos assumiam grandes dimensões, a proliferação de grandes aglomerados urbanos a emergência das cidades médias e a pulverização de pequenas cidades, numa distribuição espacial concentrada no litoral (SERRA, 1991).

Figura 7: Cidades que receberam o Programa Nacional de Capitais e Cidades de Porte Médio PNCCPM divididas por regiões.

\begin{tabular}{|c|c|c|}
\hline Regiōes & Municipios & OTNs \\
\hline Norte & 13 & 862618 \\
\hline Nordeste & 44 & 32029294 \\
\hline Centro-Oeste & 16 & 7835280 \\
\hline Sudeste & 86 & 42916422 \\
\hline Sul & 35 & 9279415 \\
\hline Totais & 194 & 92923029 \\
\hline
\end{tabular}

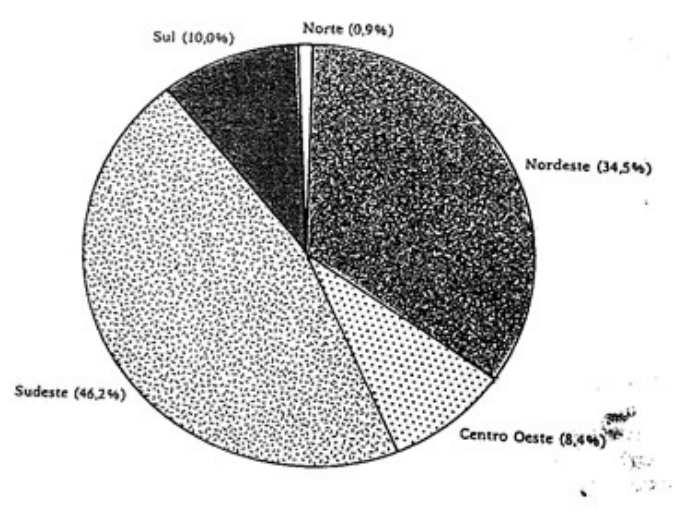

Fonte: SERRA, 1991, p. 93 (editado pela autora, 2015).

O II PND é o marco da iniciativa governamental de incentivo ao desenvolvimento de polos secundários e centros periféricos de médio porte em todas as regiões do país. Tem destaque o Programa para Cidades de Porte Médio - PCPM, elaborado no período de 1976-77, numa iniciativa federal que se inseria nas diretrizes de política territorial do II PND. Essa mudança de foco adivinha do "pressuposto de que a rede urbana é o instrumento articulador e o núcleo dinâmico do processo de ocupação territorial" (FRANCISCONI; SOUZA, 1976, p. 4). Tendo em mente essas especificidades, o PCPM em sua primeira etapa, beneficiou cerca de 70 cidades com população inferior a 500.000 habitantes. O objetivo era propiciar novos polos de desenvolvimento por meio da desconcentração da população e das atividades econômicas, criando novos empregos e reduzindo as desigualdades de renda. Essa nova compreensão das cidades médias reflete sua:

[...] escala funcional urbana indispensável para apoiar a desconcentração e a interiorização, razão pela qual mostrou-se que deveriam ser escolhidos centros específicos para cumprir a função de 
desconcentração e outros a função de dinamização. Tais centros desempenhariam papel de relevo na política de ordenamento territorial, contribuindo para: propiciar a criação de novos pontos de desenvolvimento do território nacional, estimular a desconcentração de atividades econômicas e de população, criar novas oportunidades de emprego e reduzir as disparidades inter-regionais e interpessoais de renda. (STEINBERGER; BRUNA, 2001, p.45, grifo nosso).

As cidades eram selecionadas segundo critérios espaciais (por exemplo: relevância regional; localização em relação aos eixos principais; distância de outras aglomerações ou centros; posição estratégica) e intraurbanos (por exemplo: demografia; desempenho ou dinamismo econômico; estrutura da população economicamente ativa; pobreza urbana). A Figura 7 mostra a distribuição regional das cidades contempladas pelo programa, onde o Nordeste corresponde ao segundo lugar.

Cabe ressaltar a singularidade das ações para cada região. No Sudeste, as ações visavam a descentralização das atividades produtivas das regiões metropolitanas de São Paulo e do Rio de Janeiro para centros periféricos de médio porte, por meio da desconcentração intrarregional com atuação preferencial sobre os núcleos urbanos com mais de 50 mil habitantes (tal como na região Sul). No Nordeste a preferência era o desenvolvimento das atividades produtivas, a dotação/melhoria de infraestrutura e dos equipamentos sociais nas capitais dos estados e nos polos secundários regionais, além da dinamização dos núcleos urbanos regionais que exercessem ou viessem a exercer funções de polarização do desenvolvimento regional. Por fim, no Norte e Centro-Oeste previa-se apoiar a dinamização das funções urbanas de capitais. Entretanto, as diversas avaliações pelas quais passou o programa ao longo da sua atuação (1976-86), mostram que:

Analisando o ambiente político-institucional da época, ganham proeminência três contradições que dificultaram a implantação das políticas urbanas nacionais: a sua pouca relação com as políticas econômica, setoriais e regional; a fragilidade institucional dos órgãos que a comandaram; e a excessiva centralização de poder nas mãos da União. Tais aspectos se configuram como contraditórios porque, afinal, as políticas urbanas faziam parte das políticas nacionais e para ser implantadas requeriam uma certa descentralização. Além disso, embora parte eles explicam o reduzido volume de recursos investidos no Programa de Cidades de Porte Médio. (STEINBERGER; BRUNA, 2001, p. 65).

Embora houvesse tal preocupação em despolarizar os grandes centros urbanos do Sudeste, pouco se concretizou destes incentivos nas cidades médias. Entretanto, as transferências de capitais públicos e privados para o Nordeste colaboraram para o avanço e 
expansão da base produtiva regional, originando uma reversão da polarização da economia brasileira no Sudeste. Nesse período as regiões periféricas obtiveram crescimento médio superior às regiões mais desenvolvidas. Na década de 1970, Bahia, Pernambuco e Ceará concentravam 63\% dos incentivos liberados pela SUDENE e participavam em média com $71 \%$ do PIB do Nordeste, derivada do decréscimo da economia nacional (IPEA, 2001).

Em consequência do rompimento com o modelo desenvolvimentista após os anos 1980, o Nordeste sofre com os rebatimentos da crise fiscal e financeira do Brasil, conexa à crise externa, devido a sua dependência dos investimentos do setor público. A rede urbana brasileira permanece extremamente heterogênea: poucas regiões metropolitanas com grande contingente populacional, um pequeno número de cidades medianas e uma pulverização de cidades pequenas de subsistência rural.

Do ponto de vista da definição dos arranjos metropolitanos, a Constituição Federal de 1967 colocou sob a responsabilidade do Governo Federal a criação e a delimitação das RM's do país, como explicitado no Artigo 157, § 10: “A União, mediante lei complementar, poderá estabelecer regiões metropolitanas, constituídas por Municípios que, independentemente de sua vinculação administrativa, integrem a mesma comunidade socioeconômica, visando à realização de serviços de interesse comum (BRASIL, 1967). Nota-se que as RM's poderiam ser compostas por municípios de diferentes UF's, como o caso do Rio de Janeiro, cuja área metropolitana englobava o então estado da Guanabara e o do Rio de Janeiro (BRANCO; PEREIRA; NADALIN, 2013).

A fim de identificar e delimitar as áreas metropolitanas que seriam criadas pela legislação federal, o IBGE criou em 1968 o Grupo de Áreas Metropolitanas - GAM. O documento que marca a proposta oficial do GAM foi o artigo de Galvão et al. (1969 apud BRANCO; PEREIRA; NADALIN, 2013). Com base nos critérios propostos nesse documento, foram definidas e delimitadas as nove primeiras RM's brasileiras, instituídas pelas Leis Complementares números 14/1973 e 20/1974: Belém, Fortaleza, Recife, Salvador, Belo Horizonte, Rio de Janeiro, São Paulo, Curitiba e Porto Alegre. Nesses documentos, metrópole era entendida como:

[...] uma grande cidade com relações em nível nacional, funções urbanas diversificadas e especializadas. A cidade central da RM deveria ter grande volume populacional, acima de 400 mil habitantes e densidade demográfica igual ou superior a 500 habitantes $/ \mathrm{km}^{2}$ no seu distrito-sede. [...] este corte populacional foi estabelecido a partir de um estudo do departamento de geografia - tudo indica que teria sido a pesquisa das regiões funcionais urbanas, realizada pelo IBGE 
em 1967 - que somente teria encontrado equipamento urbano e maior grau de diversificação em cidades acima do porte populacional de 400 mil habitantes, classificando-as como metrópoles nacionais e regionais. (BRANCO; PEREIRA; NADALIN, 2013, p.120).

Na metodologia de Galvão et al. (1969 apud BRANCO; PEREIRA; NADALIN, 2013), a incorporação de outros municípios à RM dependia da condição deste atender a pelo menos um dos critérios: (1) Densidade demográfica; (2) Crescimento populacional; (3) Estrutura econômica; (4) Integração por deslocamentos pendulares. Estes critérios estão detalhados no Quadro 1.

\section{Quadro 1: Critérios de inclusão de municípios a RM's (anos 1970)}

\begin{tabular}{|c|c|c|c|}
\hline $\begin{array}{l}\text { (1) DENSIDADE } \\
\text { DEMOGRÁFICA }\end{array}$ & $\begin{array}{l}\text { (2) CRESCIMENTO } \\
\text { POPULACIONAL }\end{array}$ & $\begin{array}{l}\text { (3) ESTRUTURA } \\
\text { ECONÔMICA }\end{array}$ & $\begin{array}{l}\text { (4) INTEGRAÇÃO } \\
\text { POR } \\
\text { DESLOCAMENTOS } \\
\text { PENDULARES. }\end{array}$ \\
\hline $\begin{array}{l}\text { Este nível de densidade } \\
\text { foi escolhido por estar } \\
\text { usualmente associado, } \\
\text { segundo os autores, a } \\
\text { uma predominância da } \\
\text { população urbana sobre a } \\
\text { rural naquela época. }\end{array}$ & $\begin{array}{l}\text { O município precisaria } \\
\text { ter apresentado } \\
\text { crescimento } \\
\text { populacional de no } \\
\text { mínimo } 45 \% \text { entre } 1950 \\
\text { e } 1960 \text {. } \\
\text { Este fenômeno de } \\
\text { crescimento era } \\
\text { marcadamente presente } \\
\text { naquele período de } \\
\text { desenvolvimento do país. }\end{array}$ & $\begin{array}{l}\text { O município deveria } \\
\text { apresentar uma das } \\
\text { seguintes características: } \\
\text { volume da produção } \\
\text { industrial pelo menos } \\
\text { três vezes maior que o } \\
\text { da produção agrícola, } \\
\text { ou pelo menos } \mathbf{1 0 \%} \text { de } \\
\text { população } \\
\text { potencialmente ativa } \\
\text { empregada em } \\
\text { atividades industriais. }\end{array}$ & $\begin{array}{l}\text { Um município "A" } \\
\text { poderia ser incorporado à } \\
\text { RM caso o volume total } \\
\text { de seus residentes que se } \\
\text { deslocam diariamente } \\
\text { para trabalhar em outros } \\
\text { municípios da região } \\
\text { somados aos moradores } \\
\text { da região que se } \\
\text { deslocam para trabalhar } \\
\text { em "A" correspondam a } \\
\text { pelo menos } 10 \% \text { da } \\
\text { população total residente } \\
\text { em "A". }\end{array}$ \\
\hline
\end{tabular}

Fonte: Elaboração própria (2016) com base em Galvão et al. 1969 apud BRANCO; PEREIRA; NADALIN, 2013.

Os critérios correspondem ao momento que vivia o país à época: acelerado ritmo de urbanização, com importante componente de fluxos migratórios do campo para as cidades além de altas taxas de fecundidade (BRANCO; PEREIRA; NADALIN, 2013). Embora alguns desses critérios estejam defasados em relação a atual realidade urbana brasileira, ainda se faz necessário debater sobre uma metodologia ou critérios para a delimitação de áreas metropolitanas no Brasil que considerem as transformações ocorridas na dinâmica urbanoregional das últimas décadas, especialmente após as mudanças impostas pela Constituição Federal de 1988. 


\subsection{As RM a partir da Constituição Federal de 1988 e o Estatuto das metrópoles: avanços e limites}

A partir da Constituição Federal de 1988 passou-se aos estados a competência de versar sobre a organização regional como especificado no $\S 3^{\circ}$ de seu artigo 25 , localizado no Título III, da Organização do Estado, Capítulo III, dos Estados Federados: “os Estados poderão, mediante lei complementar, instituir regiões metropolitanas, aglomerações urbanas e microrregiões, constituídas por agrupamentos de municípios limítrofes, para integrar a organização, o planejamento e a execução de funções públicas de interesse comum" (BRASIL, 1988, s/p). Por um lado, a decisão possibilitou novos arranjos regionais aglomerações urbanas e microrregiões, além de regiões metropolitanas -, e veio a dar resposta as críticas sob a centralização excessiva que predominava no estatuto anterior, a Carta de 1967 e em sua Emenda de 1969, na qual:

Verifica-se, na leitura destes textos, que o legislador do autoritarismo tratou de circunscrever o fato metropolitano, do ponto de vista da autoridade, à União, único poder autorizado a instituir unidades regionais da espécie e, do ponto de vista do alcance da ação metropolitana, apenas à realização de serviços de interesse comum, deixando de lado outras categorias que poderiam conotar esta ação. (HOTZ, 2000, s/p.).

Entretanto, a inexistência de critérios de delimitação e/ou classificação de RM's e de uma política em âmbito nacional que versasse sobre a questão metropolitana resultou na implementação de regiões metropolitanas que são regiões, mas que não são necessariamente metropolitanas (FIRKOWSKI, 2012) visto que refletem motivações e interesses estaduais. Até o Censo Demográfico de 2010, estavam institucionalizadas 36 RM's e três RIDe's ${ }^{30}$ (Quadro 2). Por exemplo, em Santa Catarina, dos 293 municípios do estado, apenas sete não pertencem a uma das onze RM's oficiais do estado. Ademais, os critérios utilizados para justificar a inclusão ou exclusão de municípios nos perímetros metropolitanos são obscuros, visto que as definições estabelecidas pelos estados não especificam a metodologia utilizada para a delimitação destas áreas ${ }^{31}$ (BRANCO; PEREIRA; NADALIN, 2013).

\footnotetext{
${ }^{30}$ Segundo Branco, Pereira e Nadalin (2013, p.117): “diferentemente das Constituições anteriores, a de 1988 não abriu a possibilidade da existência de RMs englobando municípios de diferentes Unidades da Federação (UFs). Assim, foi criada para estes casos uma nova unidade territorial, as regiões integradas de desenvolvimento (Rides), que são criadas por decreto e legislação complementar em nível federal. A Ride do Distrito Federal foi criada em 1998, e as de Teresina, Petrolina e Juazeiro, em 2001."

${ }^{31}$ Segundo Branco, Pereira e Nadalin (2013, p.118): "São exceções as legislações estaduais que criaram as RMs de Maceió, Vale do rio Cuiabá, Fortaleza, Cariri e Sudoeste Maranhense. Nestas regiões, a inclusão de novos municípios no conjunto metropolitano está prevista caso o município a ser incluído apresente: evidência ou 


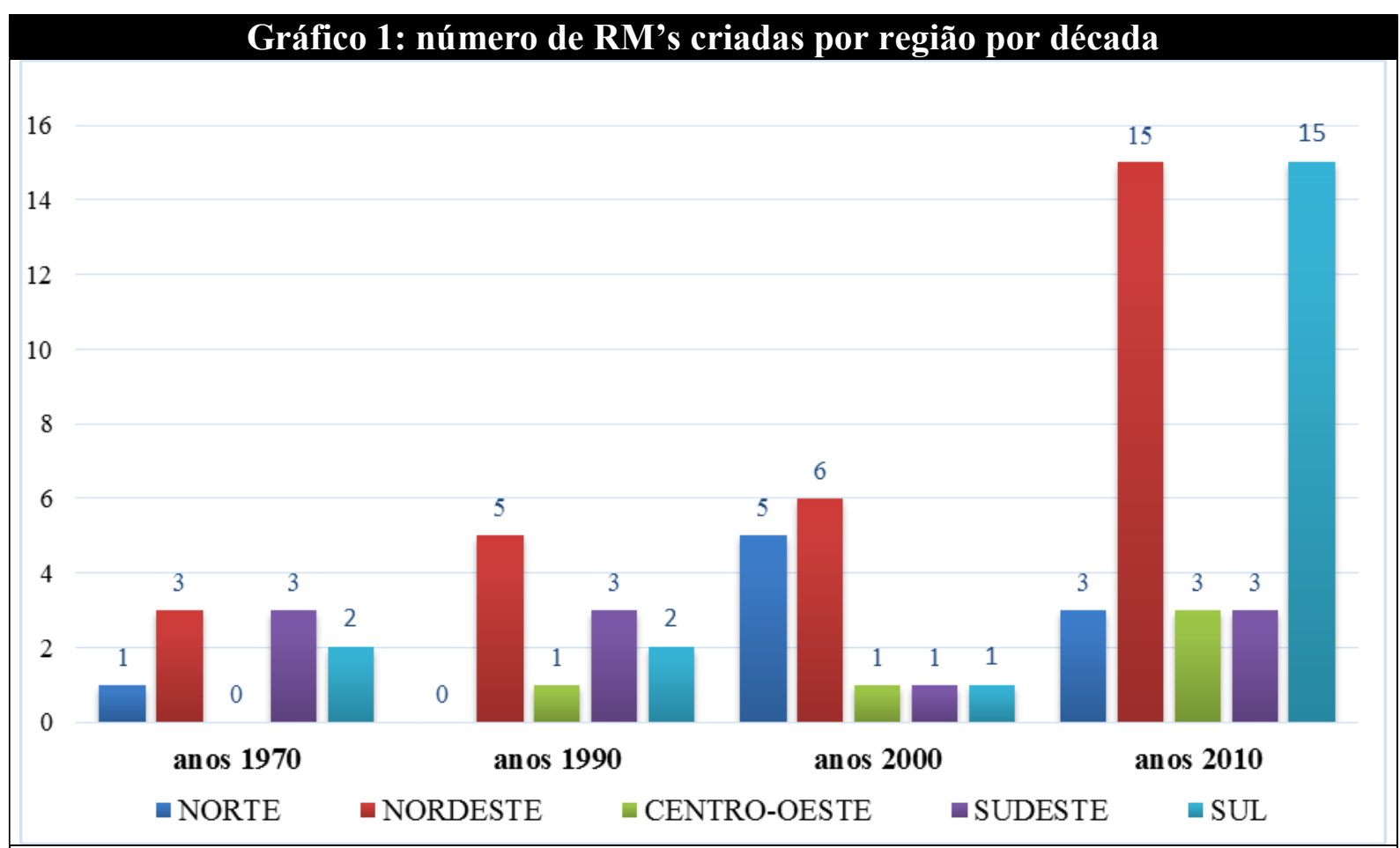

Fonte: Elaboração própria (2016) com base em Brasil (1973; 1974); Censo Demográfico de 2010 (IBGE, 2010); Branco; Pereira; Nadalin (2013) e legislações estaduais.

A falta de definição sobre os critérios para criação de regiões metropolitanas traz diversos prejuízos à gestão e planejamento urbano brasileiros bem como dificulta análises técnico-científicas de ordem comparativa entre as RM's do país. Retomando a reflexão sobre quais seriam os critérios básicos para a definição de RM's, apontam-se dois vieses: (1) de ordem funcional, ou seja, integração socioeconômica entre os municípios e presença de equipamentos de abrangência regional; (2) de ordem morfológica, destacando-se a contiguidade da mancha urbana. Esta discussão permanece aberta, mas:

[...] permite uma prevalência da discussão técnica sobre a política, na medida em que a criação de uma região metropolitana não depende exclusivamente da vontade e do interesse de grupos ou de políticos. [...] principais diferenças entre a institucionalidade e a espacialidade metropolitana. Enquanto a primeira se reveste, por vezes, de caráter político, da frágil compreensão do fenômeno metropolitano e da ausência de uma política regional consistente que faz da região metropolitana a única instância regional prevista na legislação, a segunda se caracteriza por sua dimensão de processo socioespacial, ou seja, um processo que está para além da vontade dos atores políticos e de seus interesses, mas que surge de uma dinâmica construída historicamente e por meio da inter-relação de distintos atores sociais, inclusive, mas não exclusivamente, os de natureza política. (FIRKOWSKI, 2012, p.35). estabelecem, contudo, como medir estes critérios ou quais patamares mínimos deveriam ser atingidos." 
Num contexto atual, as cidades médias assumem posição de destaque na rede urbana convertendo esses territórios em polos de atração de migrações internas e inter-regionais. Entretanto, a emergência desses novos conjuntos espaciais como centros de polarização do desenvolvimento não encontra respaldo nas políticas urbano-territoriais do país tal como antes. É nesse contexto que residem as discussões acerca do Estatuto da Metrópole, Lei $\mathrm{n}^{\mathrm{o}}$ 13.089, de 12 de janeiro de 2015. No texto que tramitou cerca de dez anos no Congresso Nacional - com uma série de solavancos, emendas, um substitutivo, alguns vetos, até a versão final publicada (MOURA; HOSHINO, 2015) $)^{32}$ - regulamenta-se a criação das unidades territoriais urbanas, sejam elas de natureza metropolitana ou não, e sua institucionalização como RM's ou Aglomerações Urbanas - AU's, visando implantar um processo permanente de planejamento regional em articulação com as escalas municipais, estaduais e federais.

O estatuto reafirma o poder estadual na instituição das RM's, bem como de RIDE's que envolvem municípios pertencentes a mais de uma unidade federativa, criados por meio de leis complementares estaduais que contenham no mínimo: (1) os municípios integrantes; (2) a justificativa da criação, do ponto de vista funcional ou de administração pública, estando os critérios técnicos adotados para esta definição explícitos no processo de elaboração da lei; (3) a organização dos sistemas de gestão administrativa e financeira; (4) "os meios de controle social da organização, do planejamento e da execução de funções públicas de interesse comum" (BRASIL, 2015, s/p.).

No documento, a metrópole não se define apenas por propriedades demográficas ou "pela existência de interesses comuns ou por interesses políticos, como ocorre atualmente" (RIBEIRO, et al, 2015), mas além desses critérios, como um espaço que "[...] tem influência nacional ou sobre uma região que configure, no mínimo, a área de influência de uma capital regional, conforme os critérios adotados pela Fundação Instituto Brasileiro de Geografia e

32 "Em 05/05/2004, o deputado Walter Feldman (PSDB/SP) submeteu à Câmara dos Deputados projeto de lei (PL 3.460/2004) com o fito de, nas palavras da própria ementa, instituir diretrizes para a Política Nacional de Planejamento Regional Urbano, criar o Sistema Nacional de Planejamento e Informações Regionais Urbanas e dar outras providências. Ainda nesse ano, o projeto foi analisado pelas comissões de Desenvolvimento Urbano, de Finanças e Tributação, de Constituição e Justiça e de Cidadania, da Câmara dos Deputados, porém, em 31/07/2007, sem emendas, foi arquivado pela primeira vez. [...]. Em março de 2008 é formatada Comissão Especial composta, além das já citadas, pelas comissões do Meio Ambiente e Desenvolvimento Sustentável, e de Desenvolvimento Econômico, Indústria e Comércio, na qual o debate tampouco avançou. A proposta é abandonada pela segunda vez, em janeiro de 2011. Dois meses mais tarde, o PL volta à pauta e o deputado Zezéu Ribeiro (PT-BA) é designado como seu relator. Nesta etapa, surgem 48 proposições de emendas. [...] A seu turno, no Senado Federal, o trâmite foi muito mais célere. Remetido pela Câmara dos Deputados em 17/03/2014, já na data de 19/12/2014 é encaminhado pela Casa para a sanção presidencial, que ocorreu no último dia 12 de janeiro. Nessas idas e vindas, vale destacar o notável empenho com que o deputado Zezéu Ribeiro, conduziu o processo, em diversos momentos. Sua equipe esteve engajada para aproximar o conteúdo técnico das propostas às exigências constitucionais, buscando clareza e coerência legislativas, sem abrir mão da perspectiva de participação democrática. " (MOURA; HOSHINO, 2015). 
Estatística - IBGE” (inciso V, art. $2^{\circ}$ - BRASIL, 2015, s/p.). Esta exigência contida no documento Regiões de Influência das Cidades - REGIC (IBGE, 2008), poderia, segundo Moura e Hoshino "ser mais restritiva, porém está adequada à grande diversidade da rede urbana brasileira na qual, em determinadas regiões de menor densidade de ocupação, centros regionais detêm efetivamente a condição de metrópoles" (2015, p. 5).

\begin{tabular}{|c|c|c|c|c|}
\hline $\begin{array}{l}\text { DÉCADA DE } \\
\text { CRIAÇÃO }\end{array}$ & \multicolumn{3}{|c|}{ RM's (ANO DE CRIAÇÃO) } & TOTAL \\
\hline 1970 & $\begin{array}{l}\text { Belém/PA (1973) } \\
\text { Curitiba/PR (1973) } \\
\text { Porto Alegre/RS (1973) }\end{array}$ & $\begin{array}{l}\text { Belo Horizonte/MG (1973) } \\
\text { Fortaleza/CE (1973) } \\
\text { Recife/PE (1973) }\end{array}$ & $\begin{array}{l}\text { Salvador/BA (1973) } \\
\text { São Paulo/SP (1973) } \\
\text { Rio de Janeiro/RJ (1974) }\end{array}$ & 09 \\
\hline 1980 & & - & & - \\
\hline 1990 & $\begin{array}{l}\text { Aracaju/SE (1995) } \\
\text { Baixada Santista/SP (1996) } \\
\text { Londrina/PR (1998) } \\
\text { Maringá/PR (1998) }\end{array}$ & $\begin{array}{l}\text { Grande Vitória/ES (1995) } \\
\text { Natal/RN (1997) } \\
\text { Maceió/AL (1998) } \\
\text { Ride do DF e entorno/MG-GO (1998) }\end{array}$ & $\begin{array}{l}\text { Ride Teresina/PI-MA (1995) } \\
\text { Grande São Luís/MA (1998) } \\
\text { Vale do Aço/MG (1998) }\end{array}$ & 11 \\
\hline 2000 & $\begin{array}{l}\text { Campinas/SP (2000) } \\
\text { Macapá/AP (2003) } \\
\text { Manaus/AM (2007) } \\
\text { Central/RR (2007) } \\
\text { Campina Grande/PB } \\
(2009)\end{array}$ & $\begin{array}{l}\text { Ride Petrolina/PE Juazeiro/BA (2001) } \\
\text { Sudoeste Maranhense/MA (2005) } \\
\text { Chapecó/SC (2007) } \\
\text { Boa Vista/RR (2007) } \\
\text { Vale do rio Cuiabá/MT (2009) }\end{array}$ & $\begin{array}{l}\text { João Pessoa/PB (2003) } \\
\text { Sul/RR (2007) } \\
\text { Agreste/AL (2009) } \\
\text { Cariri/CE (2009) }\end{array}$ & 14 \\
\hline 2010 & $\begin{array}{l}\text { Goiânia/GO (2010) } \\
\text { Carbonífera/SC (2010) } \\
\text { Lages/SC (2010) } \\
\text { Guarabira/PB (2011) } \\
\text { Feira de Santana/BA } \\
(2011) \\
\text { Cajazeiras/PB (2012) } \\
\text { Esperança/PB (2012) } \\
\text { Itabaiana/PB (2013) } \\
\text { Sousa/PB (2013) } \\
\text { Marabá/PA (2013) } \\
\text { Palmas/TO (2013) } \\
\text { Sorocaba/SP (2014) } \\
\text { Porto Velho/RO (2015) } \\
\end{array}$ & $\begin{array}{l}\text { Norte-Nordeste/SC }{ }^{27}(2010) \\
\text { Florianópolis/SC }(2010) \\
\text { Vale do Rio Itajaí/ SC }{ }^{27}(2010) \\
\text { Zona da Mata/AL }(2011) \\
\text { Cascavel/PR (2012) } \\
\text { Umuarama/PR (2012) } \\
\text { Barra de Santa Rosa/PB (2012) } \\
\text { Vale do Paraíba/SP (2012) } \\
\text { Palmeira dos Î́ndios/AL (2012) } \\
\text { Vale do Mamanguape/PB (2013) } \\
\text { Serra Gaúcha/RS (2013) } \\
\text { Gurupi/TO (2014) } \\
\text { Campo Mourão/PR (2015) }\end{array}$ & $\begin{array}{l}\text { Foz do Rio Itajaí/SC }{ }^{33}(2010) \\
\text { Tubarão/SC } 27(2010) \\
\text { Patos/PB (2011) } \\
\text { Vale do Paraíba/AL (2011) } \\
\text { Santarém/PA (2012) } \\
\text { Extremo Oeste/SC (2012) } \\
\text { Contestado/SC (2012) } \\
\text { Vale do Piancó/PB (2012) } \\
\text { Araruna/PB (2013) } \\
\text { Toledo/PR (2013) } \\
\text { Médio Sertão/AL (2013) } \\
\text { Apucarana/PR (2015) } \\
\text { Ribeirão Preto/SP (2016) }\end{array}$ & 39 \\
\hline \multicolumn{4}{|c|}{ TOTAL DE RM'S EXISTENTES (ATÉ JULHO DE 2016) } & 73 \\
\hline $\begin{array}{c}\text { EM } \\
\text { PROJETO }\end{array}$ & $\begin{array}{l}\text { Rio Branco /AC } \\
\text { Vitória da Conquista/BA } \\
\text { Sobral/CE } \\
\text { Campo Grande/MS } \\
\text { Governador Valadares /MG } \\
\text { Vale Alto Paraopeba/MG } \\
\text { Vale do Rio Grande/MG } \\
\text { Monteiro/PB } \\
\text { Pombal/PB } \\
\text { Cornélio Procópio/PR } \\
\text { Francisco Beltrão/PR } \\
\text { Picos/PI } \\
\text { Mossoró/RN } \\
\text { Pelotas/RS } \\
\text { Alto Vale do Itajaí/SC } \\
\text { Araçatuba/SP } \\
\text { Piracicaba/SP } \\
\text { Presidente Prudente/SP } \\
\text { Jundiaí/SP } \\
\text { São José do Rio Preto/SP }\end{array}$ & $\begin{array}{l}\text { Jequié/BA } \\
\text { Sul da Bahia/BA } \\
\text { Inhamuns/CE } \\
\text { Pouso Alegre/MG } \\
\text { Uberlândia/MG } \\
\text { Montes Claros/MG } \\
\text { Carajás/PA } \\
\text { São Bento/PB } \\
\text { Solânea/PB } \\
\text { Campos Gerais do Paraná/PR } \\
\text { Paranavaí/PR } \\
\text { Pato Branco/PR } \\
\text { Ponta Grossa/PR } \\
\text { Guarapuava/PR } \\
\text { Vale do Taquari/RS } \\
\text { Zona Sul/RS } \\
\text { Rio do Sul/SC } \\
\text { Bauru/SP } \\
\text { Franca/SP } \\
\text { Ride Cariri-Araripe }(\mathrm{CE} / \mathrm{PE} / \mathrm{PB} / \mathrm{PI})^{34}\end{array}$ & $\begin{array}{l}\text { Paulo Afonso/BA } \\
\text { Vale do Jaguaribe/CE } \\
\text { Anápolis /GO } \\
\text { Curvelo/MG } \\
\text { Juiz de Fora/MG } \\
\text { Triângulo Mineiro/MG } \\
\text { Catolé do Rocha/PB } \\
\text { Sumé/PB } \\
\text { Santa Luzia/PB } \\
\text { Cianorte/PR } \\
\text { Foz do Iguaçu/PR } \\
\text { União da Vitória/PR } \\
\text { Caruaru/PE } \\
\text { Alto Uruguai/RS } \\
\text { Passo Fundo/RS } \\
\text { ABC/SP } \\
\text { Barretos/SP } \\
\text { Itapetininga/SP } \\
\text { Araguaína/TO }\end{array}$ & 59 \\
\hline
\end{tabular}

Fonte: BRASIL (1973; 1974); Censo Demográfico de 2010 (IBGE, 2010); BRANCO; PEREIRA; NADALIN (2013) e legislações estaduais.

${ }^{33}$ Criada pela lei complementar estadual $n^{\circ} 221$ de 2002 foi extinta pela lei complementar estadual $n^{\circ} 381$ de 2007 e reinstituída pela lei complementar estadual $n^{\circ} 495$ de 2010.

34 A Região Integrada de Desenvolvimento do Cariri-Araripe foi proposta no PLS 122/2009, de autoria do senador Inácio Arruda (PCdoB-CE) e aprovada no Senado em agosto de 2013. A Ride seria composta por mais de 70 municípios do Ceará, Pernambuco, Paraíba e Piauí, abrangendo inclusive a RM do Cariri/CE. 
Entretanto, a nova lei ainda não é capaz de oferecer critérios objetivos para a criação de RM's ou dar clareza aos mecanismos de pactuação das diversas escalas de gestão metropolitana, bem como às fontes de financiamento e facilitação da participação da sociedade. É inequívoca a necessidade da inserção da dimensão regional no planejamento urbano. Contudo, visando aprofundar o debate sobre a questão, as pesquisadoras Moura e Firkowski (2008) e Carvalho (2012) pontuam diversos pontos dúbios no documento, dos quais se destacam: (1) a restrição da dimensão urbano-regional às funções pública, enquanto é preciso compreendê-la num sentido amplo da sociedade contemporânea que transcende os limites territoriais; (2) a carência de critérios técnicos e de referência nacional - estruturais, funcionais, socioeconômicos, hierárquicos e, porque não dizer, morfológicos - para a classificação e caracterização das unidades regionais urbanas, além da possibilidade de inserção de outras tipologias e casos específicos que porventura sejam identificados; (3) entender os planos regionais como a somatória e compatibilização dos Planos Diretores e demais políticas municipais, ao passo que é necessário pensar em um planejamento específico que, embora articule as diversas escalas, preveja mecanismos que superem os limites municipais; (4) a responsabilidade de autoria desses e outros planos específicos a partir da ampliação das competências do Ministério das Cidades, enquanto observa-se a necessidade de maior participação da instancia estadual. Dentre essas e outras considerações, as autoras criticam que o documento pode tornar-se apenas uma versão complementar ao Estatuto da Cidade $^{35}$ ou:

[...] constituir-se num instrumento isolado sem associar as unidades, planos e sistemas propostos a políticas e planos de outros ministérios (particularmente a Política Nacional de Desenvolvimento Regional e a política Nacional de Ordenamento Territorial, formuladas pelo Ministério da Integração), esgotando sua atuação ao âmbito do Ministério das Cidades. (MOURA; FIKOWSKI, 2008, s/p).

A inegável importância da Lei reside na tentativa de conceituar e classificar as unidades urbanas coibindo a proliferação de Regiões Metropolitanas, tirando (ou pelo menos reduzindo) essa delimitação das mãos dos interesses políticos estaduais, mesmo que não considere a heterogeneidade de configurações espaciais (a exemplo das cidades médias que se destacam neste trabalho) que existem nos processos de metropolização no Brasil. A lei retoma o debate acerca das ações sobre o urbano e a Política Nacional de Desenvolvimento Regional. Como resumem Moura e Hoshino, "o fato de a nova lei disciplinar a institucionalização e a governança de unidades territoriais urbanas nos estados, penalizando autoridades de diferentes

35 Lei 10.257, de 10 de julho de 2001, que regulamenta os artigos 182 e 183 da Constituição Federal, estabelecendo as diretrizes gerais da política urbana. 
escalões pelo descumprimento de seus dispositivos, significa, em si mesmo, um avanço" (2015, p. 12).

Figura 8: Mapa com a distribuição de cidades com 100.001 a 500 mil habitantes na Região Nordeste.

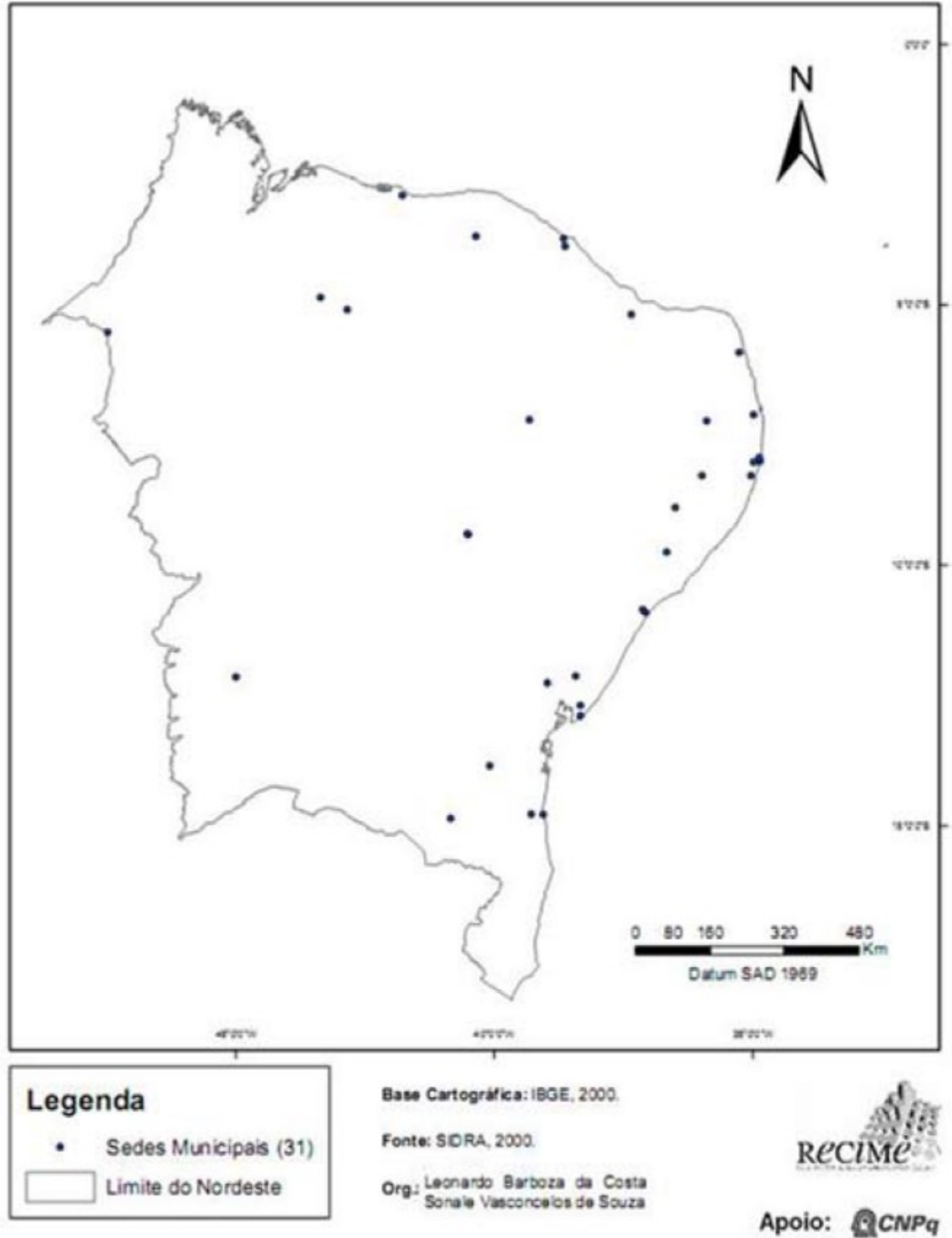

Fonte: MAIA, 2010, p.32. 
Embora não caiba nos objetivos deste estudo averiguar a fundo os motivos por trás do componente político da constituição das RM's, é impossível negar que na última década a urbanização cresceu nas cidades médias (Figura 8) e nas franjas peri-metropolitanas, convertendo esses territórios em polos de atração de migrações internas e inter-regionais. A emergência desses novos conjuntos espaciais como centros de polarização do desenvolvimento regional reflete o dinamismo socioespacial do interior do país.

Complementarmente, as transformações no sistema econômico brasileiro decorrentes da implantação do modelo neoliberal que preconiza a redefinição do papel do Estado e abertura econômica, aliadas aos novos estágios do desenvolvimento tecnológico trouxeram mudanças profundas na sociedade e, consequentemente, nas cidades e em sua hierarquização (SOARES, 1998). Assim, as cidades médias assumem novos papéis, vislumbradas no expressivo crescimento populacional, enquanto nas grandes metrópoles as taxas têm paralisado ou decaído. Alguns autores (ARMSTRONG \& McGEE, 1968; SANTOS, 1989 e 1993) afirmam que estaríamos presenciando um processo de involução metropolitana, enquanto outros destacam a disseminação do processo de metropolização para outros contextos urbanos. É na última acepção que se insere a presente tese.

\subsection{A Rede Urbana nordestina}

Segundo Corrêa (2001), a rede urbana pode ser entendida como um sistema de cidades articuladas funcionalmente em "complexos e mutáveis processos engendrados por diversos agentes sociais" (p. 424) e que, portanto, reflete as bases sociais que lhe dão suporte e lhe confere um dinamismo espaço-temporal. De modo que:

A rede urbana de um país reflete em grande medida o nível de integração dos sistemas produtivo, financeiro e sociocultural em seu território. Esta rede, por sua vez, também influencia a forma como aqueles sistemas se organizam territorialmente por meio do papel das cidades enquanto polos organizadores de processos econômicos e sociais, lócus de tomada de decisão. (EGLER, et al; 2010, p. 20).

Há uma tradição consolidada na análise da rede urbana brasileira exemplificada por meio de diversos estudos que se tornaram frequentes na Geografia a partir dos anos 1970, especialmente por meio das pesquisas desenvolvidas pelo IBGE. Dentre eles, destaco inicialmente o documento Configuração Atual e Tendências da Rede Urbana, realizado conjuntamente pelo IPEA, IBGE e Núcleo de Economia Social, Urbana e Regional da Universidade de Campinas - NESUR/UNICAMP (2001a, 2001b), o qual apresenta uma 
configuração da organização das cidades brasileiras segundo critérios de sua posição socioeconômica (por exemplo PIB e dados do REGIC - IBGE/1993), demográficos (por exemplo taxas de crescimento da população, densidade demográfica) e funcionais (por exemplo nível de oferta de serviços urbanos). Dentro dessa perspectiva a hierarquia urbana foi organizada em cinco níveis. Para o Nordeste, o Quadro 3 sistematiza os achados.

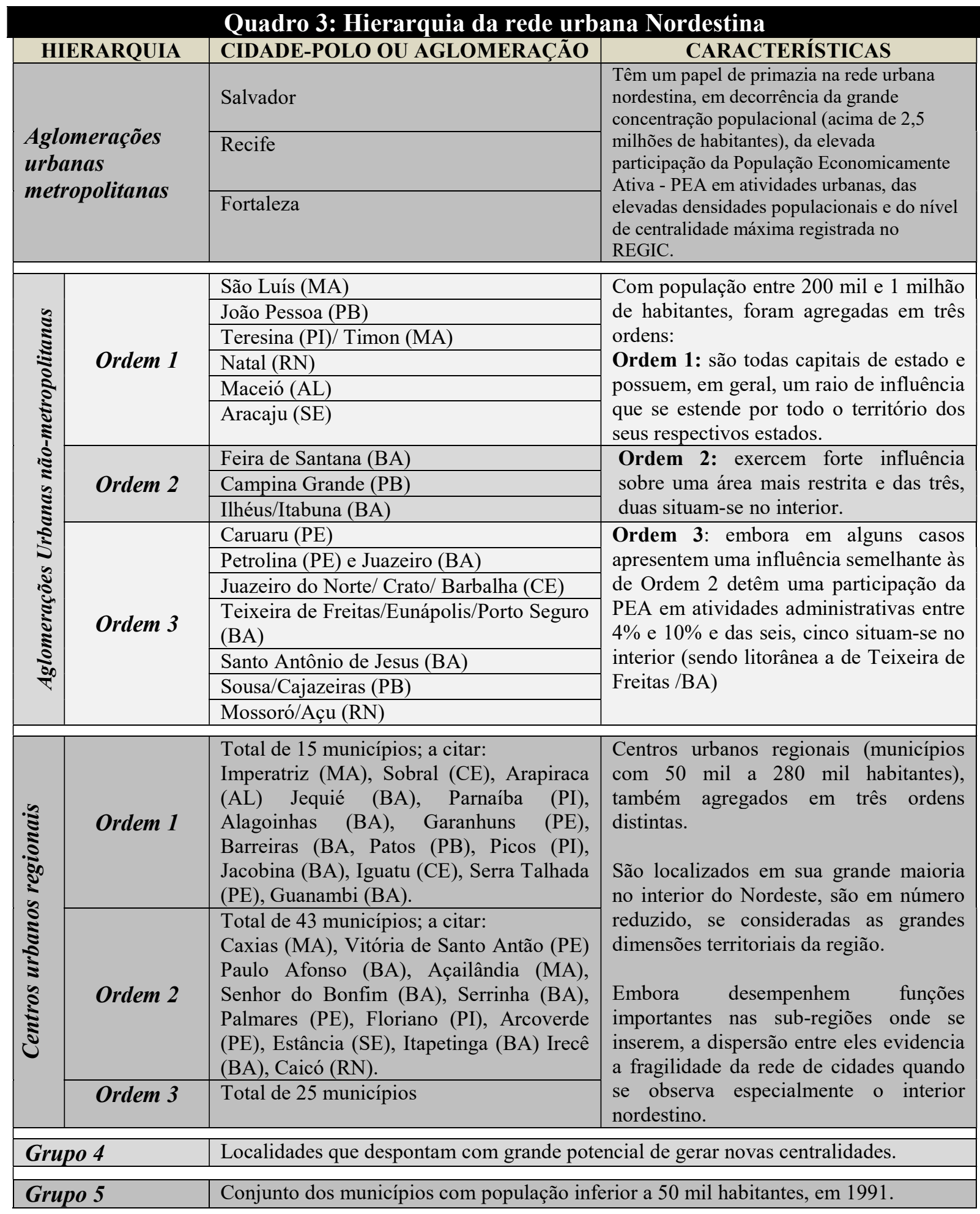

Fonte: IPEA, IBGE, UNICAMP, 2001. 
A divisão das aglomerações urbanas é feita em metropolitanas ou não. $\mathrm{O}$ documento explicita uma definição de metrópole que tem por característica o “ [...] pressuposto uma escala máxima de centralidade e de diferenciação económica [sic], especialmente do setor de serviços" (IPEA, IBGE, UNICAMP, 2001a, p. 48), além de demais critérios aplicados às demais aglomerações urbanas "a centralidade; a existência de processos de conurbação e/ou de intensa inter-relação; e integração de atividades e funções, [...]densidade, PEA ocupada em atividades urbanas, tamanho populacional e grau de urbanização" (IPEA, IBGE, UNICAMP, 2001a, p. 48). É esse teor técnico-científico que difere tal estudo das decisões políticas de constituição de RM's. Para o Nordeste, o estudo identifica como arranjos metropolitanos as RM's de Fortaleza, Recife e Salvador (Quadro 3).

Sobre o processo de metropolização dos anos 1990, os autores destacam que em decorrência da redução do crescimento econômico, as migrações rumo às principais metrópoles diminuíram no período e favoreceram os deslocamentos de retorno, de modo que o "conjunto da rede urbana brasileira passou a ter papel mais significativo do que as grandes metrópoles, servindo de amortecedor desses movimentos, fato que reforçou a característica relativamente desconcentrada do sistema urbano brasileiro" (IPEA, IBGE, UNICAMP, 2001a, p. 42). No Nordeste, a rede urbana tinha como foco os sistemas urbano-regionais das aglomerações urbanas metropolitanas (Salvador, Recife - configuração mais densa e consolidada, Fortaleza - mais altas taxas de crescimento urbano) e do meio-Norte (São Luís e Teresina), que naquele momento apresentavam em andamento seus processos de transição para uma economia urbano-industrial, com elevadas taxas de incremento da população urbana, enquanto um expressivo contingente de população ainda residia em núcleos rurais de pequenas dimensões (Figura 9). A dinâmica da rede urbana apresentava algumas especificidades:

- às disparidades entre os diversos grupos de centros urbanos, traduzidas pela perda de população dos municípios e de dinamismo económico[sic] de um número elevado de centros urbanos regionais; e

- à má organização espacial reforçada pelo processo de interiorização da urbanização rumo, apenas, a determinados subespaços regionais e pelo processo de litoralização, que vem ocorrendo por meio do crescimento das aglomerações urbanas. Essa litoralização tende a adquirir ainda mais vigor com as novas territorialidades decorrentes do impulso ao setor de turismo, o que já vem ocorrendo especialmente em anos recentes. (IPEA, IBGE, UNICAMP, 2001a, p. 309, grifo nosso).

Essas características da estrutura urbana são decorrentes das marcas do passado. No processo histórico de formação dessa rede urbana, é possível identificar alguns processos que 
Mueller (1996 apud IPEA, IBGE, UNICAMP, 2001a) chama de sistemas sub-regionais, que para o autor são quatro: (1) agroexportador; (2) do semiárido; (3) das zonas de expansão recente de fronteiras agrícolas; (4) dos complexos e polos industriais. O primeiro sistema subregional corresponde a faixa litorânea, que se inicia no norte do estado do Rio Grande do Norte e se estende até o sul da Bahia, concentrando as aglomerações urbanas que remontam ao período colonial que, em geral, não são capazes de oferecer emprego e serviços à população (pois excluem-se desse sistema as aglomerações urbanas metropolitanas e centros regionais). No segundo sistema, a recorrência de médias e pequenas propriedades "gerou um arcabouço urbano mais integrado à dinâmica económica [sic] e à vida das populações, diferentemente das áreas de monocultura canavieira e daquelas com predominância da pecuária sertaneja” (IPEA, IBGE, UNICAMP, 2001a, p. 284). Por isso, encontramos nesse sistema o maior número de aglomerações urbanas não-metropolitanas, ou seja, compõe-se de centros urbanos regionais, com áreas de influência definidas (por exemplo Campina Grande/PB, Arapiraca/AL e Feira de Santana/BA). A aplicação das técnicas de agricultura irrigada possibilitou:

[...] a ocorrência de áreas mais amplas, suscetíveis de aproveitamento agrícola, na margem pernambucana do rio São Francisco, explica por que a ocupação e o povoamento já tinham assumido ali maior expressividade [...] as mudanças profundas ocorridas na forma de uso dos recursos da área e da sua estrutura económica tornaram-na uma área de elevada densidade demográfica, contrastando com as extensões imensas de espaços sertanejos de baixíssimo povoamento. (IPEA, IBGE, UNICAMP, 2001a, p. 285).

No terceiro sistema, sub-regional de fronteiras agrícolas, destaca-se que o plantio de soja gerou alterações na economia dos cerrados baianos, nascendo uma nova rede urbana superposta à antiga e capitaneada pelo município de Barreiras, bem como cerrados maranhenses, com destaque para a área de influência da cidade de Imperatriz, sob a égide da concentração fundiária e da emergência do agronegócio. De maneira mais discreta, desponta nos cerrados piauienses, com destaque ao arroz, a introdução de novos métodos agrícolas é mais vagarosa, como resultado das precárias condições de infraestrutura (IPEA, IBGE, UNICAMP, 2001a, p. 286).

Por fim, o quarto sistema, sub-regional dos complexos e polos industriais, tem como base os grandes núcleos urbanos da região, com ênfase nas aglomerações urbanas metropolitanas e não-metropolitanas. Os parques industriais se voltam principalmente para o atendimento de demandas nacionais de bens intermediários. 
Figura 9: Mapa da distribuição espacial da Rede Urbana da Região Nordeste.

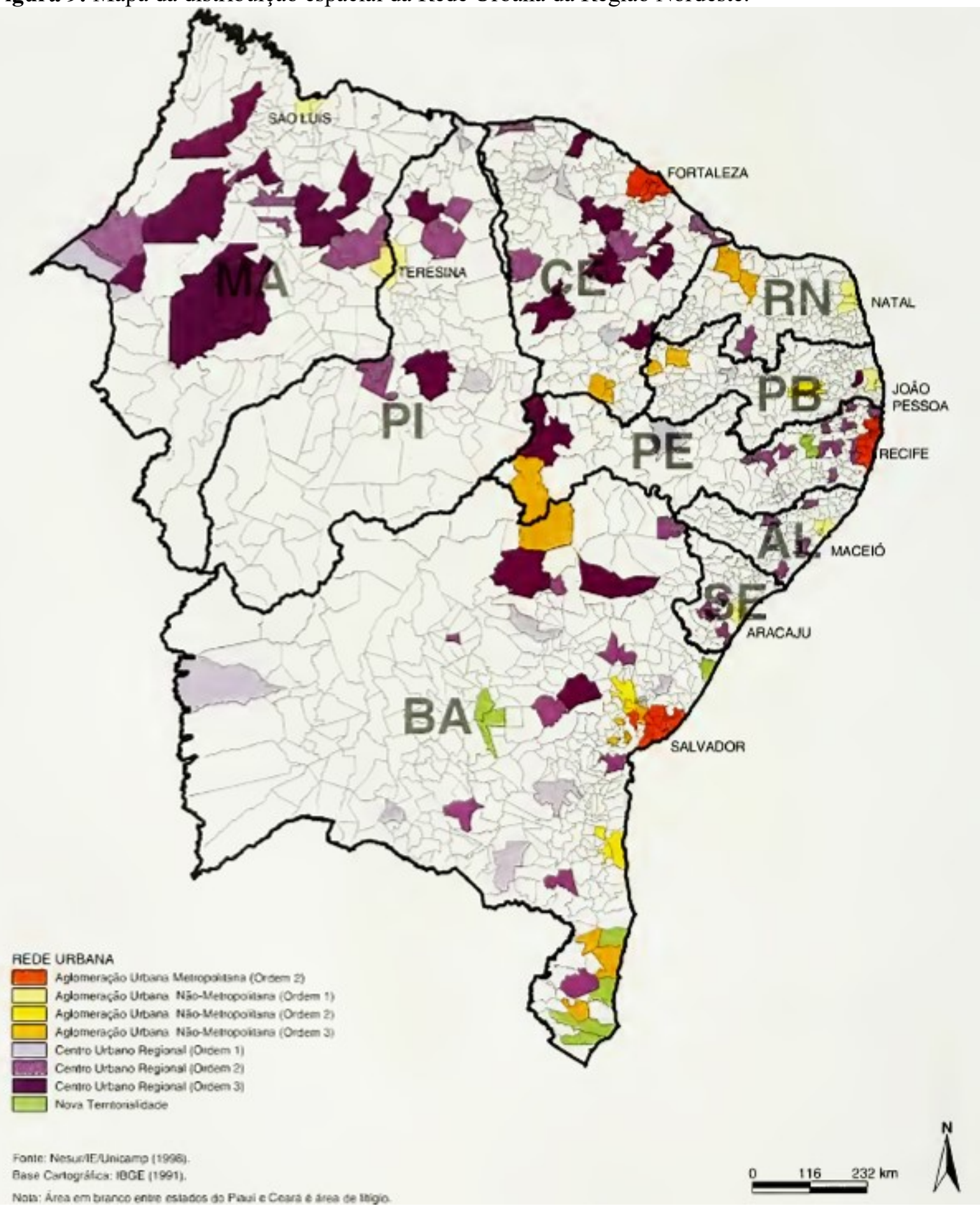

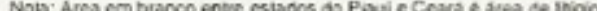

Fonte: IPEA, IBGE, UNICAMP, 2001b, p. 106.

As disparidades urbano-regionais entre o Nordeste e o restante do país (especialmente o Sudeste) eram ainda gritantes. Os estados nordestinos possuíam péssimos indicadores sociais de renda, alfabetização e acesso aos serviços urbanos, que se apresentavam como os mais críticos de toda a rede urbana nacional. A desigualdade regional é decorrência da dinâmica assimétrica capitalista, que se concentra em alguns espaços, 
enquanto condenam outros à estagnação e ao desperdício de fatores produtivos. Somado a isso, as heterogeneidades de acesso a serviços públicos de qualidade, há um ciclo que reforça as iniquidades e reduz as perspectivas de desenvolvimento dos territórios com frágil base econômica (BARRETO, 2010).

Numa visão mais recente, o Regiões de Influência das Cidades - REGIC 2007 (IBGE, 2008) é um documento que, sendo a quarta versão desta linha de pesquisa ${ }^{36}$, também apresenta contribuição importante com os estudos da rede urbana brasileira. Em sua metodologia estabelece-se primeiramente uma classificação dos centros - privilegiando a função de gestão do território - e, a seguir, delimitam-se suas áreas de atuação (IBGE, 2008, p. 130). Nessa hierarquização são utilizados diversos dados para definir a centralidade: "diferentes equipamentos e serviços - atividades de comércio e serviços, atividade financeira, ensino superior, serviços de saúde, Internet, redes de televisão aberta, e transporte aéreo" (IBGE, 2008, p. 130). Após realizados tais quantitativos, os pesquisadores descrevem áreas de influências, elucidando a articulação das redes no território por meio da averiguação das ligações entre cidades.

Há mudança de metodologia desse estudo para o anterior: enquanto o estudo Configuração Atual e Tendências da Rede Urbana (IPEA, IBGE, UNICAMP, 2001a) é medido na dimensão mesorregional, a REGIC "utiliza o município como referência metodológica e analítica, além de ter incluído, na sua última edição, as áreas de concentração de população (ACPs ${ }^{37}$ ) enquanto unidades básicas de análise" (EGLER, et al; 2010, p. 28). Portando os resultados diferem: o primeiro estudo define 98 centros sub-regionais e a REGIC traz uma amostra maior e mais detalhada de núcleos sub-regionais (e locais), com 239 centros, em decorrência da unidade de referência municipal. A nomenclatura atribuída a cada uma das hierarquias urbanas também difere nos dois estudos (Quadro 4). Algumas cidades do Nordeste também apresentam posições hierárquicas diferentes nos dois estudos, o que sugere também a aceleração das dinâmicas socioespaciais no interior do Nordeste, a citar, no caso baiano:

\footnotetext{
${ }^{36}$ Publicados em 1972, 1987, e 2000.

37 "As ACPs são criadas a partir da aglomeração de diferentes áreas conurbadas (com mais de 350 mil habitantes) de municípios que atendem a pelo menos dois de três critérios: alta densidade demográfica (850 habitantes por $\mathrm{km}^{2}$ ), predominância de atividades produtivas tipicamente urbanas (mínimo de 81,5\%) e grande integração ao conjunto (fluxo de movimento pendular em direção a um dos núcleos da área - fluxos superiores a 100 pessoas). Município, microrregiões e mesorregiões são as unidades referenciais de qualquer estudo, tendo em vista sua definição oficial do IBGE, para efeito de qualquer parâmetro a ser utilizado em análises regionais." (EGLER, et al; 2010, p. 28).
} 
[...] a classificação de Eunápolis e Teixeira de Freitas que, desde a década de 1990, destacavam-se ao lado de Vitória da Conquista, Feira de Santana, Juazeiro, Barreiras, Jequié, Itabuna e Santo Antônio de Jesus como cidades comerciais de porte interestadual [...] tais cidades desempenhavam funções semelhantes e estavam em níveis hierárquicos equivalentes, o que não se verificou nos estudos de âmbito nacional. Na publicação coordenada por Ipea, IBGE e UNICAMP, entendeu-se que tais centros tinham posições mais elevadas que Vitória da Conquista, Juazeiro, Barreiras e Jequié. Entretanto, segundo o REGIC 2007, algumas destas cidades estavam na condição de capitais regionais, e Teixeira de Freitas e Eunápolis na de centros subregionais. (DIAS; ARAÚJO, 2010, p. 181).

A distribuição desses níveis hierárquicos no território é repleta de disparidades: no Centro-sul predomina uma rede urbana estruturada - com um significativo número de metrópoles, capitais regionais e centros sub-regionais, com grande articulação entre si - e no Nordeste - apesar de sua ocupação consolidada e, em muitas áreas, densa - onde há ausência de alguns níveis hierárquicos intermediários (IBGE, 2008, p. 13).

Especificamente para o caso nordestino, a rede urbana dessa região é fortemente comandada pelas capitais dos estados que dominam tradicionalmente a oferta de equipamentos e serviços, e existem poucos centros de nível intermediário, “ainda que deva ser notado que estes, apesar de poucos, são tradicionais, e exercem forte polarização em suas áreas, a exemplo de Campina Grande, Petrolina-Juazeiro, Juazeiro do Norte-Crato-Barbalha e Mossoró" (IBGE, 2008, p. 13). Essa organização cria uma polarização entre capital-interior, que, em termos espaciais, pode ser sistematizada nas diferenças entre o litoral - ocupações antigas, mais populosas e com melhor acesso aos bens e serviços - e o interior, marcado pela estrutura agrícola de baixas densidades do semiárido.

Estes estudos, embora sejam referências importantes no planejamento urbano, principalmente pelo seu caráter de abrangência nacional, apresentam algumas limitações metodológicas, especialmente porque os centros urbanos são tratados como pontos, desconsiderando sua estruturação interna, como explicam Egler (et al; 2010, p. 29):

[...] usam-se modelos estáticos e parciais; em geral, as abordagens da interação de cidades desconsideram a dinâmica intraurbana, ou seja, as trocas entre as cidades são tratadas como massas de serviços e bens, sem se considerarem os diferentes níveis de diversificação econômica em cada cidade. Além disso, os bens e serviços, assim como os fatores e insumos, produzidos nas diferentes cidades ao longo de todo o território nacional, são assumidos como homogêneos, não se considerando características de oferta e de demanda. (EGLER, et al; 2010, p. 29). 


\section{Quadro 4: Rede Urbana Brasileira - REGIC (2007)}

Grande

metrópole nacional

SÃO PAULO
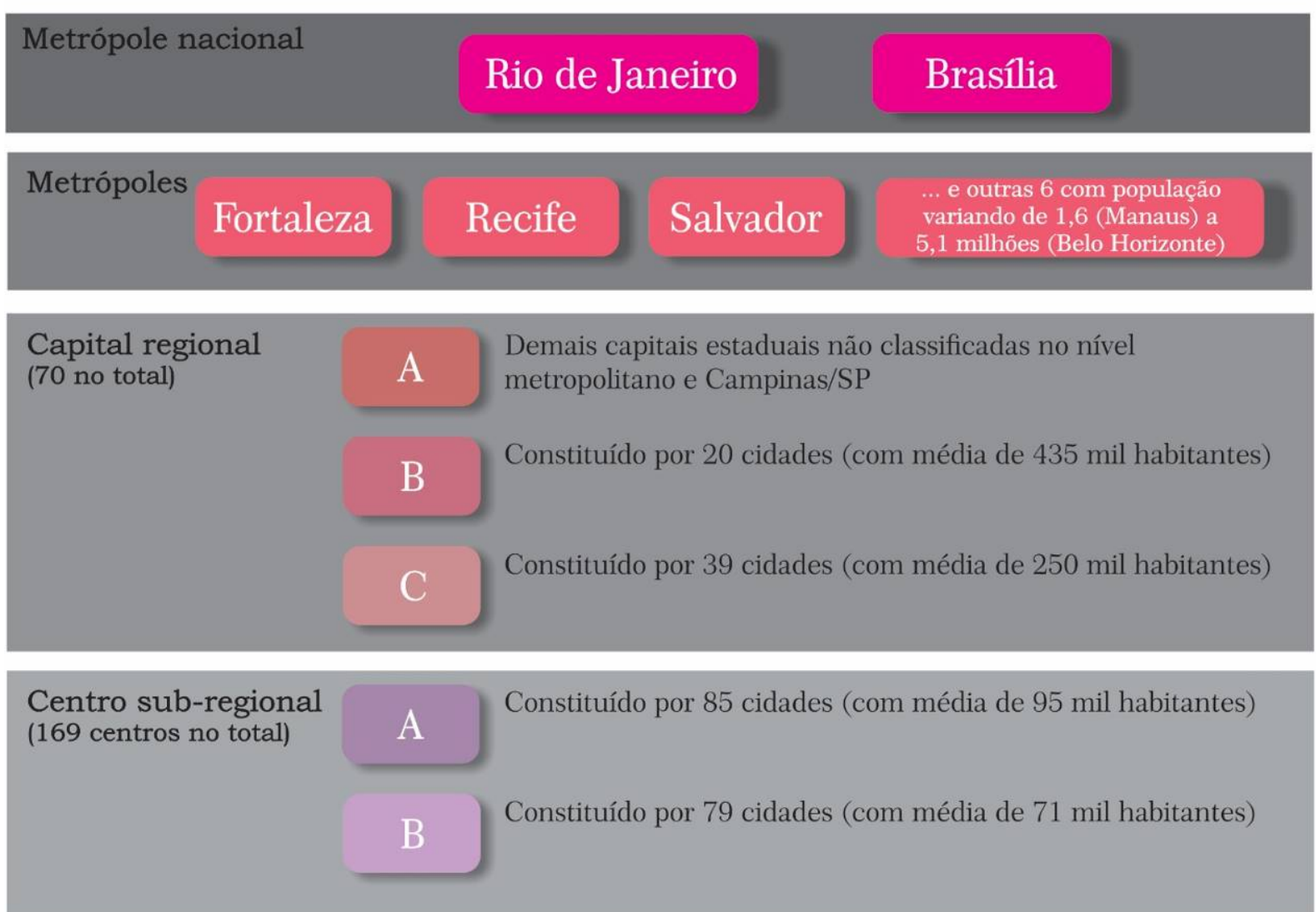

\section{Centro de zona}

( 556 centros no total)

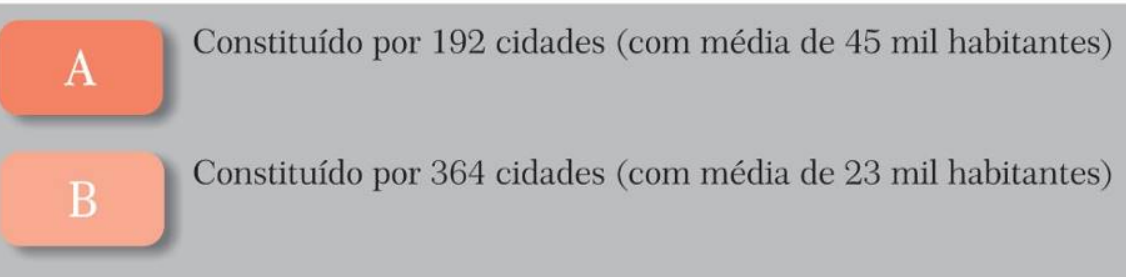

Centro local

As demais 4473 cidades cuja centralidade e atuação não extrapolam os limites do seu município, servindo apenas aos seus habitantes, têm população dominantemente inferior a 10 mil habitantes

Fonte: Elaboração própria (2016) com base em IBGE (2008).

Por fim, o desenvolvimento urbano nordestino está diretamente atrelado a uma organização social fundamentada ao longo dos anos na monocultura e no latifúndio, acarretando numa estrutura urbana regional resumida em duas dinâmicas: a litorânea e a do interior, de modo que os índices de atividades econômicas e de concentração demográfica diminuem gradativamente da costa para o interno. Do ponto de vista histórico, ambas dinâmicas são decorrência da estratégia agroexportadora da política econômica local que se 
agravou a partir dos anos 1970 com os investimentos industrias no litoral, em especial nas três metrópoles regionais: Recife, Salvador e Fortaleza.

A desconcentração de alguns desses investimentos do Sudeste foi em parte benéfica para a região (por exemplo a maior participação no PIB nacional), porém contribuiu para intensificar as desigualdades regionais internas do Nordeste, bem como aumentar as tensões intraurbanas das metrópoles (exemplificadas pelas lutas por moradia e acesso às infraestruturas e serviços urbanos pela população periférica). Autores como Fulgêncio \& Santos (2015) apontam que é necessário discutir e implementar um desenvolvimento menos concentrado, que se foque nas potencialidades locais e que traga novas possibilidades de empregabilidade baseadas na qualificação profissional.

Figura 10: Rede urbana brasileira segundo o IBGE (2007).

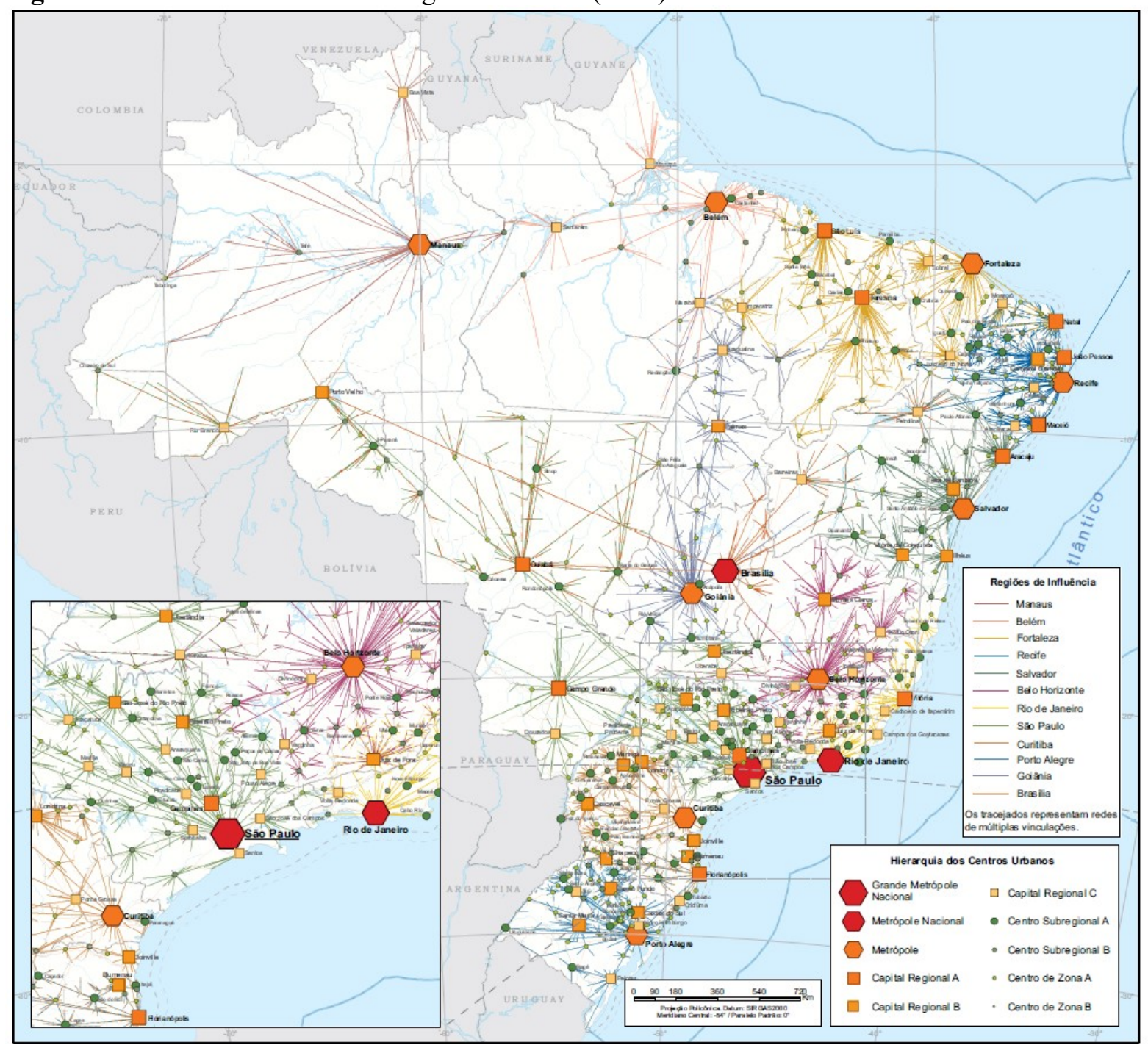

Fonte: REGIC 2007 (IBGE, 2008, p. 12). 


\subsection{Conclusões parciais}

O estudo do desenvolvimento das metrópoles brasileiras neste capítulo, com especial enfoque no caso Nordeste, aponta que a classificação e gestão política das metrópoles brasileiras teve ao longo dos anos diversas intervenções em âmbito nacional e regional. Embora justificassem em aliviar as disparidades socioeconômicas intraregionais existentes, por meio de ações de descentralização de atividades econômicas e de população, pouco conseguiram pôr em prática ou aquilo que foi feito atendia quase que exclusivamente aos interesses das oligarquias. Portanto, persiste a perpetuação histórica dos problemas regionais e intraurbanos, principalmente na dessemelhante dinâmica litoral e interior. Desta forma, vários autores ressaltam a importância do aprofundamento no estudo das heterogeneidades com intuito de abrandar a desigualdade na hierarquia da rede urbana brasileira.

A importância desses estudos deveria ser extensiva aos marcos legais que incidem sobre a delimitação dos arranjos metropolitanos no país. Definir a cidade-sede das RM's parece-me bastante "simples", dada a sua capacidade de polarização e destaque na rede urbana como comentado no capítulo anterior. Claro que há critérios técnicos que contabilizam esse poder de domínio de algumas cidades em relação a outras, a exemplo dos utilizados no REGIC (IBGE, 2008), que não são nada simplórios. Porém, parece-me que a definição das áreas de abrangência metropolitanas, ou seja, os demais municípios constituintes das RM's, são decididos por critérios, por vezes, alheios às questões técnicas (os quais, me atrevo a supor, são essencialmente políticos). Nem sempre foi assim: na definição das RM's dos anos 1970 havia critérios que, mesmo que questionáveis (e não necessariamente condizentes com o estágio atual da rede urbana brasileira e, portanto, não obrigatoriamente devam ser replicados hoje), traziam um viés técnico-cientifico a esta discussão. Perdemos a oportunidade de reaver isso com o Estatuto das Metrópoles, uma vez que a lei toma de empréstimo os critérios do REGIC, embora ela represente um importante passo para disciplinar a institucionalização e a governança de unidades territoriais urbanas (MOURA; HOSHINO, 2015).

Neste contexto ainda, ressalto que as cidades de médio porte assumem importante papel na constituição das regiões metropolitanas. É importante destacar o seu potencial no desenvolvimento socioeconômico local uma vez que estas cidades ofertam uma variedade serviços numa demanda regional, correspondem aos melhores indicadores sociais da região em que se inserem e têm os requisitos para a criação e desenvolvimento de polos tecnológicos. Ou seja, são alternativas à demasiada centralização industrial das regiões metropolitanas de grande porte, fatores que normalmente geram um aumento demográfico. 
Sua importância na rede urbana é visualizada como crescente entre os estudos do IPEA, IBGE, UNICAMP (2001) e do IBGE (2008), quando várias cidades mudaram de nível hierárquico. Seus processos de expansão urbana (algumas das quais com evidências de conurbação física ${ }^{38}$ ), a transformação e modernização dos espaços intraurbanos são indícios que justificam a constituição das Regiões Metropolitanas no interior do Nordeste - RMINE. Entretanto, seu entorno compõe-se de municípios de pequeno porte, com capacidade financeira e de suporte social desigual, ou seja, são cidades que permanecem dependentes dos serviços e infraestrutura oferecidos pela cidade-polo. A contribuição desta tese é focar-se nesses casos, buscando compreender seus papéis nas redes urbanas locais e regionais.

\footnotetext{
${ }^{38} \mathrm{O}$ conceito de conurbação é entendido como a fusão de duas ou mais áreas urbanas em uma única, envolvendo integração física e funcional. Ou seja, uma conurbação exige não somente a continuidade das malhas viárias, mas também uma relação de interdependência das cidades, que pode ser econômica, social e de serviços públicos urbanos, redes de infraestrutura e outros (FERRARI, 2004). Neste trabalho, frente a suas especificidades morfológicas, será explorada com maior afinco a dimensão da conurbação física.Por exemplo, Petrolina e Juazeiro da Bahia ou o Crajubar, nome dado à conurbação das cidades de Crato, Juazeiro do Norte e Barbalha no sul do Ceará. Retomarei esse ponto no Capítulo 3, a seguir.
} 


\section{3}

\section{REFERENCIAL TEÓRICO- METODOLOGICO}




\section{REFERENCIAL TEÓRICO-METODOLÓGICO}

Este capítulo tem por finalidade apresentar o referencial teórico-metodológico, que versa acerca dos temas que dão o embasamento da Sintaxe Espacial enquanto tríade da pesquisa científica (HOLANDA, 2013): teoria, método e ferramentas. Representa uma hierarquia que tem como fio condutor desde o entendimento dos questionamentos amplos que perpassam vários axiomas, aprofundados nas descrições e relações entre os itens de conhecimento específicos que tangem ao escopo dessa tese, até os procedimentos operacionais que permitem o teste das hipóteses. Apresenta-se aqui também o recorte empírico - aglomerações e cidades a serem analisadas como estudo de caso.

\subsection{Teoria}

Nos discursos que buscam uma definição de arquitetura, diversas palavras-chave são recorrentes: arte, beleza, forma, função, técnica, construção etc. Há, entretanto, um elemento que tangencia (e contém) todas essas acepções: o espaço. Esta é a essência da arquitetura. A adoção deste posicionamento é presente no campo da Estética, ao apontar o volume como essência da escultura e colocar a necessidade de uma funcionalidade, de um espaço interior (COUTINHO, 1970), que a distingue da arquitetura. Por possuir uma destinação prática que interfere diretamente no trabalho de criação, a arquitetura deve ser avaliada pelo seu "objetivo não-estético" (SUASSUNA, 2011, p. 300).

Dialoga com essa ideia, "o fato de o espaço, o vazio, ser o protagonista da arquitetura é, no fundo, natural, porque a arquitetura não é apenas arte nem só imagem da vida histórica ou da vida vivida por nós e pelos outros; é também, e sobretudo, o ambiente, a cena onde vivemos a nossa vida" (ZEVI, 2009, p. 28, grifo nosso). Entretanto, colocar o espaço no papel de ator principal não significa ignorar aquelas palavras-chave citadas anteriormente, mas compreender que elas são os aspectos, dimensões ou faces pelas quais a arquitetura impacta o meio ambiente natural e as pessoas (HOLANDA, 2013a). São, portanto, os resultados da arquitetura.

O que se pretende com esse posicionamento teórico é libertar o entendimento da arquitetura tão somente a partir da leitura de rótulos que dependem de grupos e da sociedade 
como um todo e que podem mudar com o tempo. Ou seja, são significados sobrepostos a arquitetura, uma semântica ${ }^{39}$, mas não são os elementos essenciais da arquitetura. De modo geral, “[...] as teorias [em arquitetura] têm sido extremamente normativas e pouco relacionais" (HILLIER; HANSON, 1997, p. 1-3); propõe-se que no lugar de postular uma fórmula e tentar a qualquer custo encaixá-la em edifícios e cidades, se estude o fenômeno em si para descobrir as suas relações intrínsecas (MEDEIROS, 2013). Em outras palavras, o que se busca é a sintaxe $\mathrm{e}^{40}$, ou seja, aquilo que é contido na própria configuração da arquitetura, que se mantém independente de tempo, lugar, sujeitos etc.

Mas se na linguística o elemento base da sintaxe e da semântica são as palavras, no campo da arquitetura os elementos da linguagem arquitetônica são os cheios ou "componentes-meio" e os vazios ou "componentes-fim" (e suas relações). A teoria e a história da arquitetura têm se detido prevalentemente nos "componentes-meio": a volumetria, a composição das fachadas, texturas, cores, materiais etc.; todavia, estes pertencem especificamente à linguagem da escultura. Os elementos por excelência da linguagem arquitetônica são os "componentes-fim": os espaços - cômodos no edifício; as ruas, avenidas, praças e parques na cidade; lugares abertos na paisagem natural etc. (HOLANDA, 2013a).

Essas ideias surgem num contexto de revisão dos paradigmas modernistas, quando na década de 1970 na University College London, Hillier, Hanson e seus colaboradores formularam a Social Logic of Space (HILLIER; HANSON,1984). A teoria, doravante referida como Sintaxe Espacial - SE, estuda a relação entre o espaço e práticas socioculturais mediante a representação e quantificação da configuração espacial, entendida como um sistema de permeabilidades e barreiras (áreas acessíveis ou não ao nosso movimento) e de opacidades e transparências (aquilo que é ou não facultado à nossa visão). A metodologia contribui para a compreensão de aspectos importantes do sistema urbano na medida em que permite avaliar o potencial da estrutura espacial quanto à geração de movimento, visibilidade, acessibilidade e outros fatores que se associam a essas propriedades.

Portanto, a SE pode ser entendida como uma teoria sobre a configuração do espaço (cheios, vazios e suas relações) que propõe um conjunto de técnicas para a análise da configuração espacial de qualquer tipo, especialmente quando a configuração importa para fins humanos, como nos edifícios e nas cidades. Entende-se que os padrões espaciais

\footnotetext{
${ }^{39}$ Ramo da linguística que estuda o significado das palavras.

${ }^{40}$ Parte da linguística que se dedica ao estudo das regras e dos princípios que regem a organização dos constituintes das frases.
} 
carregam em si informação e conteúdo social e que diferentes tipos de reprodução social requerem diferentes tipos de estrutura espacial. Considerando as discussões - cada vez mais recorrentes - sobre uma crescente "morte do espaço físico", no estágio histórico atual continuam a prevalecer as relações sociais que ocorrem no espaço, assim como não faz sentido falar de relações espaciais desvinculadas da sociedade.

O ambiente construído é, portanto, estruturado para viabilizar relações sociais que podem ser pensadas em termos de encontros e esquivanças e representadas para revelar padrões distintos de copresença ${ }^{41}$ os quais se associam a diferentes propriedades espaciais. Basicamente, a ideia é representar essas relações sociais em função dos usos/ações das pessoas no espaço público: "a vida é a arte do encontro, embora haja tanto desencontro pela vida", já dizia Vinicius de Moraes. Numa perspectiva histórica:

Cada sistema social implica uma peculiar maneira de organizar grupos de pessoas no espaço e no tempo, maneira que estabelece quem está próximo ou distante de quem, fazendo o quê, onde e quando. Sociedades variam, na história, em combinações diversas: as muito densas, que comprimem no espaço e no tempo toda classe de gente e práticas sociais diversas (todos estão próximos praticamente o tempo todo); as muito rarefeitas, que localizam diferentes tipos de pessoas e suas práticas em lugares especializados por categoria, lugares separados por grandes distâncias ou fortes barreiras físicas, pessoas cuja interação através do espaço é descontínua no tempo; combinações das duas coisas - e.g. concentrar separadamente - como é típico das sociedades contemporâneas com seus enclaves fortificados, campi universitários, centros cívico-administrativos, shopping centers, edge cities. (HOLANDA, 2007, s/p).

A SE está interessada na compreensão das razões morfológicas por trás da presença ou ausência de indivíduos e grupos (classes sociais, gênero, gerações etc.) e de como estes se movem nos espaços. Esta informação é importante para a concepção e o planejamento dos lugares, pois "com esse conhecimento em mãos, podemos projetar melhores lugares (já que não podemos projetar melhores pessoas)" (HOLANDA, 2013b). Ao pensar na maneira com a qual as pessoas se movem no espaço, mesmo que tomando decisões subjetivas, é possível fazer emergir um padrão objetivo de concentração ou dispersão delas no espaço (HOLANDA, 2013b). A SE investiga em que medida esse padrão é fruto direto da configuração, o que Hillier (1996) denominou movimento natural, ou natural movement, definido como o movimento resultante da configuração espacial por si só ou do modo como a estrutura viária se articula. Em outras palavras, o movimento de uma rua é mais influenciado pela posição

${ }^{41}$ Define-se copresença como a "presença de pessoas nos espaços públicos em movimento ou paradas que pressuponha a presença de outros indivíduos, mesmo que não engajados em atividade compartilhada" (BRAGA, 2003, p.23). 
desta em relação ao sistema urbano como um todo do que por seus atributos locais. Cabe ressaltar que:

O chamado movimento natural não é um fenômeno invariável, comum a todas as culturas e regiões do mundo: ele assume características próprias de acordo com o escopo cultural que o gerou, efeito que é da forma de articulação e disposição da malha viária. Entretanto, algumas feições são argumentadas como constantes, a exemplo da tendência à concentração de certas atividades em locais precisos. O que seria invariável é a lógica que conecta a configuração espacial com a geração de movimento. (MEDEIROS, 2006, p. 507).

Tais usos - especialmente o comercial e de serviços - apropriam-se dessas localizações e, além de valerem-se do poder de movimento gerado pela própria malha viária, atuam como pontos de atração ou magnetos, que multiplicam o movimento local. $\mathrm{O}$ entendimento desses aspectos é fundamental para a compreensão dos padrões de centralidades, uma vez que "a razão dessa fidelidade entre a análise espacial e a realidade funcional deve-se à poderosa influência que o movimento natural - a tendência que apresenta a estrutura da malha para constituir-se na principal influência sobre padrões de movimento tem sobre a evolução do formato urbano e sua distribuição em termos de uso do solo

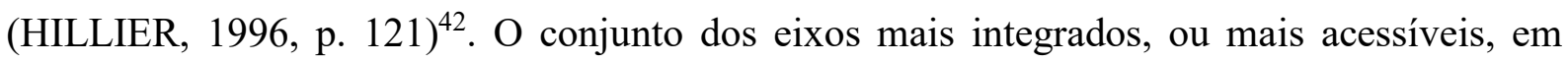
relação à estrutura do leiaute urbano como um todo recebe o nome de "núcleo de integração". Entretanto, essa definição pode variar de acordo com as especificidades da pesquisa, como explica Medeiros (2006, p. 507):

Há grande diversidade na definição do núcleo de integração, diferentes autores estabelecem diferentes parâmetros a depender do propósito da pesquisa. KARIMI (1997, p. 06.9) define, para as cidades históricas inglesas, o núcleo de integração como sendo o conjunto de linhas que está a um ou dois passos da linha mais integrada. HOLANDA (2002, p. 104), esclarece que os pesquisadores usualmente recorrem a $25 \%$ das linhas para assentamentos pequenos e $10 \%$ para sistemas maiores (acima de 100 eixos), havendo casos onde se uniformiza o percentual indistintamente em $10 \%$. HILLIER (2001, p. 02.8) prefere apontar como núcleo de integração o conjunto de linhas vermelhas, laranjas e amarelas, apegando-se ao padrão cromático e não a uma quantidade específica de eixos. (MEDEIROS, 2006, p. 507).

Neste trabalho é adotada a definição cromática de "núcleo de integração", defendida por Hillier. À parte essas conceituações, a relevância do exame dessa porção do espaço reside

\footnotetext{
${ }^{42}$ No original: "The reason that a spatial analysis can give such a true-to-life functional picture is due to the powerful influence that natural movement - the tendency of the structure of the grid itself to be the main influence on the pattern of movement - has on the evolution of the urban pattern and its distribution of land uses" (Tradução de Edja Trigueiro).
} 
nas suas propriedades de movimento natural, ou seja, em sua capacidade de atrair usos e atividades que já foram identificados como potencializadores na dinâmica de formação/transformações de centralidade. Aponta-se que:

Núcleos de integração em cidades são, em geral, áreas dotadas de alto grau de acessibilidade, do mesmo modo como são, em geral, ou pelo menos deveriam ser, os espaços de uso mais coletivo em edificações. [...] Numa organização espacial qualquer, os espaços dotados de maior grau de acessibilidade tendem a abrigar atividades dotadas de maior grau de coletivização ou publicização. Ao contrário, espaços dotados de menos acessibilidade tendem a abrigar atividades que requerem um maior grau de privacidade ou segregação. (AGUIAR, 2003, p. 89, grifo nosso).

Por outro lado, áreas menos integradas são menos disponíveis ao movimento natural, ou seja, têm menos potencial de gerar contatos interpessoais. Portanto, por meio de procedimentos específicos, busca-se antever as respostas que o meio construído dará à sociedade, uma vez que as relações sociais acontecem no espaço e esse responde ou afeta essas relações (MEDEIROS, 2013). A SE, enquanto metodologia de análise, permite que aspectos da configuração sejam matematicamente mensurados e claramente visualizados, permitindo também correlacionar outras variáveis; e, enquanto técnica, permite representar os espaços em linhas axiais, convexos ou isovistas. Tratarei do método e das técnicas a seguir, incluindo outras categorias de análise para além da SE.

\subsection{Método: as categorias analíticas e suas relações}

Retomando o que foi comentado na definição do problema desta tese, podemos explorar os arranjos metropolitanos sob três vieses: (1) de ordem socioeconômica; (2) de ordem configuracional, (3) do sistema de encontros e esquivanças, enquanto a sociedade é vista como artefato (HOLANDA, 2002). As variáveis analíticas que serão abordadas seguem, portanto, a mesma organização, embora algumas delas tangenciem as três categorias e haja possibilidade de conexões entre elas. O Quadro 5 resume as variáveis a serem trabalhadas na pesquisa, sistematizando as fontes a serem utilizadas e as possíveis correlações a serem traçadas.

Utilizando os dados do recenseamento (IBGE, 2010), será avaliada a distribuição de renda por setor censitário, mais especificamente, a renda média mensal equivalente à soma do rendimento mensal dos responsáveis pelos domicílios particulares permanentes. Para Villaça (2001), a segregação espacial das elites em determinadas áreas da cidade é uma das 
características mais marcantes das metrópoles brasileiras. Porém, estudos precedentes (HOLANDA, 2013; MEDEIROS, 2006; CARMO JÚNIOR, 2014, dentre outros) demostram que nem sempre essa dicotomia entre ricos e pobres é tão clara, ou ainda, que as classes mais baixas nem sempre se localizam em áreas periféricas da mancha urbana.

\begin{tabular}{|l|l|l|l|}
\hline \multicolumn{1}{|c}{ Grupo } & \multicolumn{1}{|c|}{ Vuadroável } & \multicolumn{1}{c|}{ Fonte a ser utilizada } & \multicolumn{1}{c|}{ Correlações } \\
\hline \multirow{4}{*}{$\begin{array}{l}\text { (1) de ordem } \\
\text { socioeconômica }\end{array}$} & Distribuição de renda & Censo do IBGE (2010) & Todas as categorias \\
\cline { 2 - 4 } & Nível de instrução & Censo do IBGE (2010) & $\begin{array}{l}\text { Demais categorias de ordem } \\
\text { socioeconômicas }\end{array}$ \\
\cline { 2 - 4 } & $\begin{array}{l}\text { Grupos de ocupação no } \\
\text { trabalho principal }\end{array}$ & Censo do IBGE (2010) & $\begin{array}{l}\text { Demais categorias de ordem } \\
\text { socioeconômicas }\end{array}$ \\
\cline { 2 - 4 } & $\begin{array}{l}\text { Tempo de deslocamento entre } \\
\text { a residência e o trabalho }\end{array}$ & Censo do IBGE (2010) & $\begin{array}{l}\text { Demais categorias de ordem } \\
\text { socioeconômicas e dispersão }\end{array}$ \\
\hline \hline \multirow{3}{*}{$\begin{array}{l}\text { (2) de ordem } \\
\text { configuracional }\end{array}$} & Centralidade morfológica & $\begin{array}{l}\text { Mapas axiais/segmentos } \\
\text { calculados por Integração e } \\
\text { Escolha }\end{array}$ & $\begin{array}{l}\text { Uso do solo/gabaritos } \\
\text { Densidade populacional }\end{array}$ \\
\cline { 2 - 4 } & $\begin{array}{l}\text { Medida de Integração } \\
\text { Proporcional }\end{array}$ & $\begin{array}{l}\text { Mapas axiais calculados por } \\
\text { Integração }\end{array}$ & $\begin{array}{l}\text { Comparativo entre os casos } \\
\text { selecionados }\end{array}$ \\
\hline \hline \multirow{2}{*}{$\begin{array}{l}\text { (3) do sistema de } \\
\text { encontros e } \\
\text { esquivanças }\end{array}$} & Densidade populacional & Censo do IBGE (2010) & $\begin{array}{l}\text { Todas de ordem } \\
\text { configuracional e dispersão }\end{array}$ \\
\hline
\end{tabular}

Fonte: Elaboração própria, 2016.

As variáveis que complementam o viés socioeconômico do trabalho são o nível de instrução (até fundamental incompleto, fundamental completo a médio incompleto; médio completo a superior incompleto, superior completo), grupos de ocupação no trabalho principal (Diretores e gerentes; Profissionais das ciências e intelectuais; Técnicos e profissionais de nível médio; Trabalhadores de apoio administrativo; Trabalhadores dos serviços, vendedores dos comércios e mercados, dentre outros) e tempo de deslocamento entre a residência e o trabalho (até 05 minutos, de 06 minutos até meia hora, mais de meia hora até uma hora, mais de uma hora até duas horas, mais de duas horas). Estas variáveis estão presentes em estudos sobre os arranjos domiciliares de outras metrópoles, a exemplo de Brasília (VASCONCELOS et al, 2015).

No segundo viés temos as variáveis de ordem configuracional, ou seja, aquelas que se relacionam à forma e ao espaço. A centralidade "refere-se a uma porção do espaço urbano na qual há concentração de atividades diversas, em sua maioria de usos que se privilegiam e necessitam dos fatores locacionais e de movimento dos centros, atrelado a um maior grau de apropriação coletiva" (GURGEL, 2012, p. 29). A centralidade morfológica pode ser correlacionada com o valor de integração da SE, o qual traduz a acessibilidade ou potencial de 
movimento de uma via (ou segmentos de via) em relação às demais que compõem o sistema viário. O conjunto das linhas mais integradas recebe o nome de Núcleos de Integração que:

[...] em cidades são, em geral, áreas dotadas de alto grau de acessibilidade, do mesmo modo como são, em geral, ou pelo menos deveriam ser, os espaços de uso mais coletivo em edificações [...]. Numa organização espacial qualquer, os espaços dotados de maior grau de acessibilidade tendem a abrigar atividades dotadas de maior grau de coletivização ou publicização. Ao contrário, espaços dotados de menos acessibilidade tendem a abrigar atividades que requerem um maior grau de privacidade ou segregação. (AGUIAR, 2003, p. 89).

Segundo Peponis (1992, p. 81), "a distribuição desse núcleo é uma das estruturas subjacentes pelas quais podemos caracterizar sistemas urbanos". O núcleo de integração é, portanto, a porção do sistema mais integrado, cuja tendência é ter mais movimento o que, por sua vez, atrairá novas construções e usos que se valham desses fluxos, em um efeito multiplicador, gerando áreas dinâmicas e com vitalidade urbana (HILLIER, 1996). Em contraponto, “[...] áreas menos integradas ou mais segregadas espacialmente geram bolsões de isolamento que quebram a continuidade da experiência urbana, gerando descontinuidade na malha viária por tratar-se de locais menos disponíveis ao movimento natural" (CARMO JÚNIOR, 2014, p. 23). Vemos aqui a inter-relação entre esta variável e o uso do solo. Além da integração, constatou-se em estudos anteriores (GURGEL, 2012) que a medida de choice (ou escolha de rota) - métrica e topológica - também contribui para a leitura de centralidades com maior refinamento. Ela é referente à frequência com que cada linha é usada nos caminhos topológicos mínimos de todas as linhas para todas as linhas do sistema:

Uma medida similar que leva em conta as relações entre cada espaço e todo o sistema é a 'escolha global', que indexa quantas vezes cada linha é usada em caminhos topologicamente mais curtos a partir de todas as linhas para todas as outras linhas do sistema. Assim, também indexa quantas vezes cada linha é visitada em simulações de viagens aleatórias por meio dos caminhos topologicamente mais curtos no sistema. (HILLIER et al., 1993, p. 35, tradução nossa) $)^{43}$.

Áreas urbanas com altos valores de integração e escolha topológica tendem a concentrar fluxos e fixos que configuram a centralidade em vários graus (centro principais ou subcentros) e especializações (tradicionais, de negócios ou comércio varejista, por exemplo). Segundo Deák (2001), o uso do solo, entendido como o conjunto das atividades

\footnotetext{
${ }^{43}$ No original: "A similar mesure taking into account the relations between each space and the whole system is 'global choice', which indexes how often each line is used on topologically shortest paths from all lines to all other lines in the system. It thus also indexes how often each line is visited on random jorney simulations through topologically shortest paths in the system."
} 
desenvolvidas por uma sociedade, pode ser visto como o rebatimento social no espaço urbano. Admite-se assim uma variedade de usos tão grande quanto as atividades da própria sociedade. A pergunta a ser respondida é "o lugar satisfaz as exigências práticas da vida cotidiana em termos de tipo e quantidade de espaços para as atividades, e seu inter-relacionamento?" (HOLANDA, 2013b). A análise de uso do solo pode ter graus de detalhamento que variam de acordo com a escala de apreciação.

Outra análise que se correlaciona com a centralidade urbana é o gabarito, que se refere à contagem do número de pavimentos das edificações. Esta variável é capaz de dar indícios do processo de verticalização e, do consequente, aumento da densidade da fração urbana em estudo. A multiplicação do solo urbano "[...] não deve ser considerada como uma consequência natural da urbanização, mas uma das possíveis opções traçadas e definidas pelos diferentes atores sociais e interesses econômicos que envolvem a estruturação interna das diferentes cidades" (RAMIREZ, 1988, p. 98). Este processo altera a paisagem urbana e cria novas espacialidades e urbanidades, por meio da criação de novos modos de viver e utilizar a cidade (e segregações inerentes). A verticalização é um dos aspectos recorrentes dos espaços metropolitanos e se relaciona diretamente com uso do solo e com densidade demográfica. As fontes utilizadas serão visitas in loco, imagens, fotos de satélite e do Google Street View, bem como estudos que versem sobre o tema nas aglomerações urbanas em análise.

Figura 11: Esquema de concepção da medida de integração proporcional, sob base cartográfica de Sobral/CE.

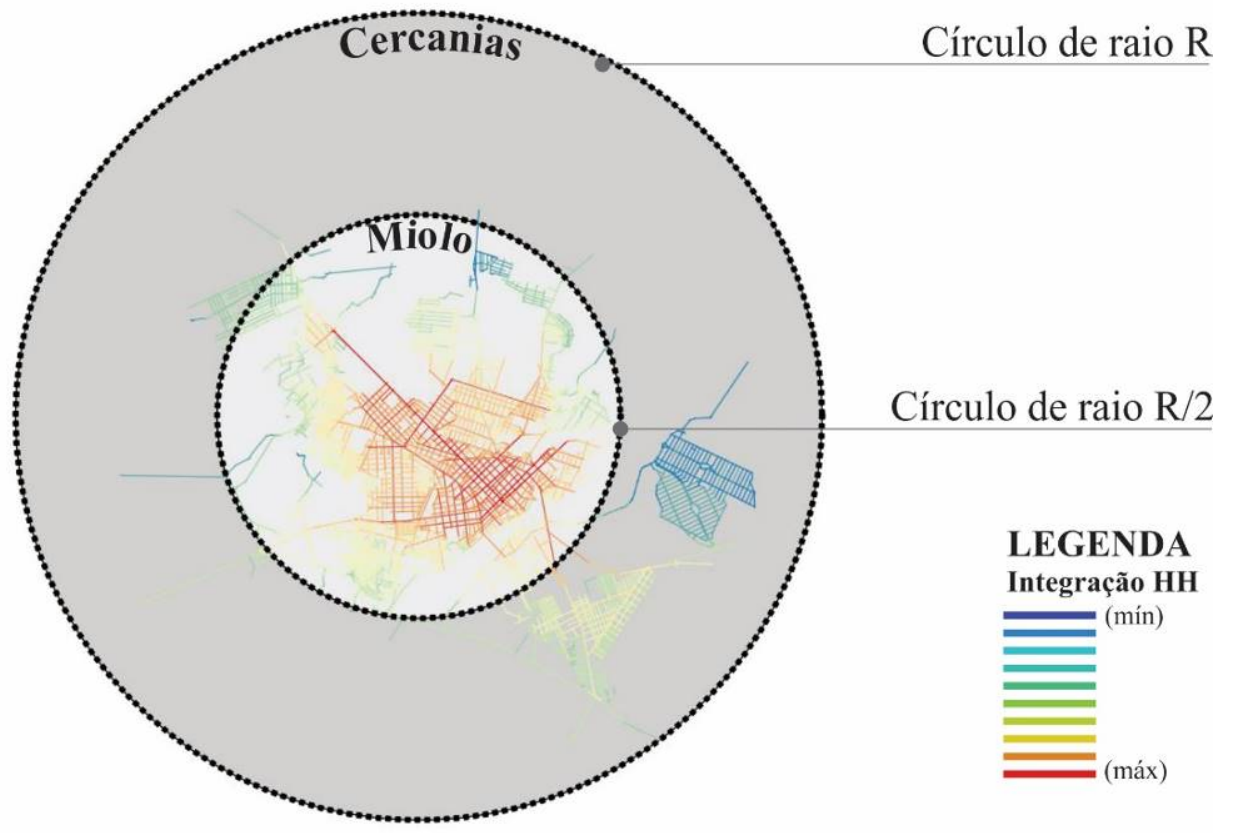

Fonte: Elaboração própria(2016). 
Para facilitar a comparação entre as RM's e as cidades em estudo, será utilizada a medida de integração proporcional, um mecanismo de cálculo criado neste trabalho para identificar as integrações médias dos sistemas em duas porções distintas: miolo e cercanias ${ }^{44}$ (Figura 11). Tomando como centro o ponto médio da linha mais integrada (HOLANDA, 2010), traçou-se um círculo de raio $\mathrm{R}$ que abarca todo o conjunto de linhas axiais. Uma segunda circunferência é traçada, porém com metade do raio anterior $(\mathrm{R} / 2)$, ou seja, como uma proporção de $50 \%$ de área do anterior a qual se denominou de miolo. Através de técnicas de geoprocessamento, são selecionadas as linhas contidas e que estão inseridas em cada uma das porções e são calculados os valores mínimos, máximos e as médias das integrações.

Neste trabalho será utilizada, por fim, a densidade residencial bruta, ou seja, a relação entre a população residente e a área bruta que ela ocupa por setor censitário, sem descontar nesse cálculo outras áreas (vias, equipamentos, comércios e espaços abertos), de acordo com os dados do censo do IBGE de 201045. A densidade é um conceito intrinsicamente relacionado à configuração urbana e muitos debates já foram, e continuam sendo, levantados acerca das densidades urbanas ideais em relação a "otimização" da infraestrutura. Não entrarei nessa disputa, o enfoque aqui é identificar se estas densidades estão de acordo com Teixeira (2005), quando ele explica que uma região metropolitana é caracterizada por alta densidade demográfica e por compartilhar familiaridades socioeconômicas com "funções urbanas altamente diversificadas, especializadas e integradas" (ALVES, 1988, p. 21 apud TEIXEIRA, 2005, p. 75), o que por sua vez se correlaciona com as duas variáveis expostas anteriormente. Focando, portanto, nessa escala regional, seria interessante avaliar também as densidades flutuantes, ou seja, aquelas decorrentes da concentração de trabalhos e serviços em determinados setores da cidade durante um determinado período de tempo. Infelizmente, não há dados disponíveis para que se avalie essa população de modo que os resultados sejam espacializados. Portanto, retomarei os dados vistos no grupo de variáveis 01 (especificamente o "Tempo de deslocamento entre a residência e o trabalho") para buscar avaliar os deslocamentos pendulares entre as cidades.

\footnotetext{
${ }^{44}$ Os nomes foram assim definidos para não haver ambiguidade com os temos núcleo de integração ou com dicotomia entre centro e periferia.

${ }^{45}$ Os dados estão disponíveis no sítio eletrônico do IBGE, em formato shapefile (compatível com programas de SIG) e em planilha eletrônica (compatíveis com programas de edição de planilhas, por exemplo, o Excel). Estas especificidades serão exploradas no item a seguir "técnicas".
} 


\subsection{Técnicas}

Este trabalho mescla duas técnicas: as da SE e aquelas de Sistemas de Informação Geográfica - SIG. A SE enquanto técnica de decomposição analítica propõe várias estratégias de representação do espaço urbano. Dentre essas, destacam-se três procedimentos, cada qual relacionado com a maneira como as pessoas se utilizam desse espaço: (1) a representação linear, uma abstração derivada da observação de que as pessoas se movem em linhas; (2) as pessoas agrupam-se em espaços convexos, o que corresponde ao estudo dos espaços convexos, (3) as isovistas, que se referem ao domínio visual a partir de qualquer ponto determinado.

Neste trabalho a técnica da axialidade é a que mais interessa porque é a que melhor se aplica a grandes sistemas e estruturas, como as RM's. Além disso, sua escolha se ampara na questão cognitiva das estratégias que os seres humanos utilizam ao percorrer os trajetos, pois “[...] percebemos o espaço urbano como montagens de elementos geométricos interrelacionados, e não como padrões complexos de distâncias métricas" (MEDEIROS, et al., 2011, p. 45). Esta abstração axial é interessante pois " [...] apresentam as duas propriedadeschaves de serem tanto muito simples quanto globais ${ }^{46 "}$ (HILLIER, 2001, p. 02.26).

O primeiro passo da técnica é a seleção da base cartográfica. Muitas das aglomerações estudadas têm bases desatualizadas. Por isso optou-se por elaborar as bases por meio de imagens de satélite, datadas do final de 2013 até meados de 2015, com as quais se constrói um mosaico de imagens de cada uma das cidades com base nos dados disponíveis no Google Earth Pro. Esta imagem é georrefenciada e levada para programas de Desenho Assistido por Computador - DAC (ou no mais usual, do inglês Computer Aided Design - CAD). Outra opção para a feição dos mapas axiais foi por meio da plataforma OpenStreetMap ${ }^{47}$, que possui interface com o software de geoprocessamento Quantum GIS, possibilitando a exportação em formato *.dxf (que dá interface com os programas de CAD e outros). No programa de desenho em CAD os eixos são desenhados segundo algumas regras, como sistematiza Paim (2015):

46 No original: "Lines have the two key properties of being both very simple and very global." (Tradução de Valério Medeiros).

${ }^{47}$ OpenStreetMap é um projeto para criar um mapa livre editável do mundo. Os mapas são criados usando dados de dispositivos portáteis de global positioning system - GPS, fotografias aéreas, de outras fontes livres ou simplesmente a partir do conhecimento local. O projeto foi iniciado porque a maioria dos mapas têm restrições legais ou técnicas para sua utilização, restringindo seu uso de forma criativa, produtiva ou outras formas alternativas. Ambas as imagens fundidas e o conjunto de dados vetoriais do OSM estão disponíveis para download. Disponível em <http://docs.qgis.org/1.8/pt_BR/ docs/ user_manual/osm/ openstreetmap.html>. Acesso em 20 jun. 2016. 
a) nas vias que possuem canteiro central, os leitos carroçáveis são desenhados separadamente, ou seja, por linhas duplas;

b) todos os eixos são representados por segmentos de retas, mesmo as linhas curvas;

c) quando houver cruzamentos de vias (como túneis, viadutos e outros) que não se conectam na realidade e, em menos de 300 metros, houver uma ou mais conexões, as linhas cruzadas são mantidas, porque existe uma conexão real nas imediações de modo a simplificar a representação do sistema sem distorcer em excesso os resultados globais;

d) quando não houver em menos de 300 metros essas conexões, são feitas adaptações no sistema de modo a manter as conexões existentes e não desfazer o cruzamento daquelas que na realidade não estão conectadas, ou seja, estão apenas sobrepostas;

e) os calçadões que possuem importância na malha viária são desenhados, enquanto que os largos, as praças e os calçadões de orla de praia (paralelos a vias) não são representados, pois funcionam mais como espaços convexos, de maneira a pouco acrescentar às ruas já existentes características em termos de movimentação;

f) todo o sistema viário contido dentro do perímetro urbano é representado;

g) as vias particulares urbanas ou rurais são desconsideradas quando não possuem edificações adjacentes e quando fora do perímetro urbano, porém são mantidas todas as ruas em conjuntos habitacionais, loteamentos e condomínios fechados e abertos. (PAIM, 2015, p. 59).

Assumo que há críticas ao modo pelo qual os sistemas foram desenhados, especialmente no ponto "a" visto que as ligações por meio de canteiros são na maioria das cidades "sazonais", ou seja, mudam de lugar e função com bastante frequência. Entretanto, uma parcela dos mapas utilizados neste trabalho foram gentilmente cedidos ${ }^{48}$ por Paim (2015) e julguei condizente valer-me das mesmas regras impostas por ele, e também porque por meio de testes desenvolvidos em trabalhos anteriores (MEDEIROS, 2006), não parece haver mudanças significativas nos valores de integração, a não ser na razão de milésimos, quando há a simplificação dos desenhos.

Isso posto, o sistema desenhado é levado para programas computacionais (Dephmap ou Mindwalk) que calculam paramentos grafo-numéricos que expressam diversas

\footnotetext{
48 As bases axiais de Salvador e Recife-Olinda-Jaboatão foram gentilmente cedidas por Valério Medeiros, provenientes da sua tese (MEDEIROS, 2006); o mapa de Fortaleza foi gentilmente cedido por Lucy Donegam, mas foram desenhadas as suas RM's a partir da Base Cartográfica do OpenStreetMap (2016) e imagens de satélite do Google Earth (2016) pelos alunos Iasmin Rodrigues, Klairton Rodrigues, Plácido Ferreira, Lucas Lima e Pâmela Corrêa (bolsitas de Iniciação Científica do Centro Universitário Planalto do Distrito Federal UNIPLAN, sob minha orientação). O mapa de Feira de Santana/BA e Sobral/CE foi desenhado por Amanda Brasil (aluna de graduação da FAU-UnB) a partir da Base Cartográfica do OpenStreetMap (2016) e imagens de satélite do Google Earth (2016). O mapa da RM do Cariri/CE foi atualizado por mim a partir de base elaborada na minha dissertação de mestrado (GURGEL, 2012) e o mapa da RM de Campina Grande/PB foi desenhado e revisado por mim a partir da Base Cartográfica do OpenStreetMap (2016) e imagens de satélite do Google Earth (2016).
} 
propriedades espaciais. Utilizando-se da "teoria dos grafos ${ }^{49}$ ”, a malha viária é representa por meio de um grafo onde as ruas correspondem aos nós e os cruzamentos são representados pelas arestas (Figura 12). Dessa forma é possível então criar uma hierarquia viária calculando as medidas topológicas (JALES, 2014).

Figura 12: Representação em forma de grafo de um trecho de uma malha urbana onde os nós representam as vias e as arestas representam os cruzamentos.

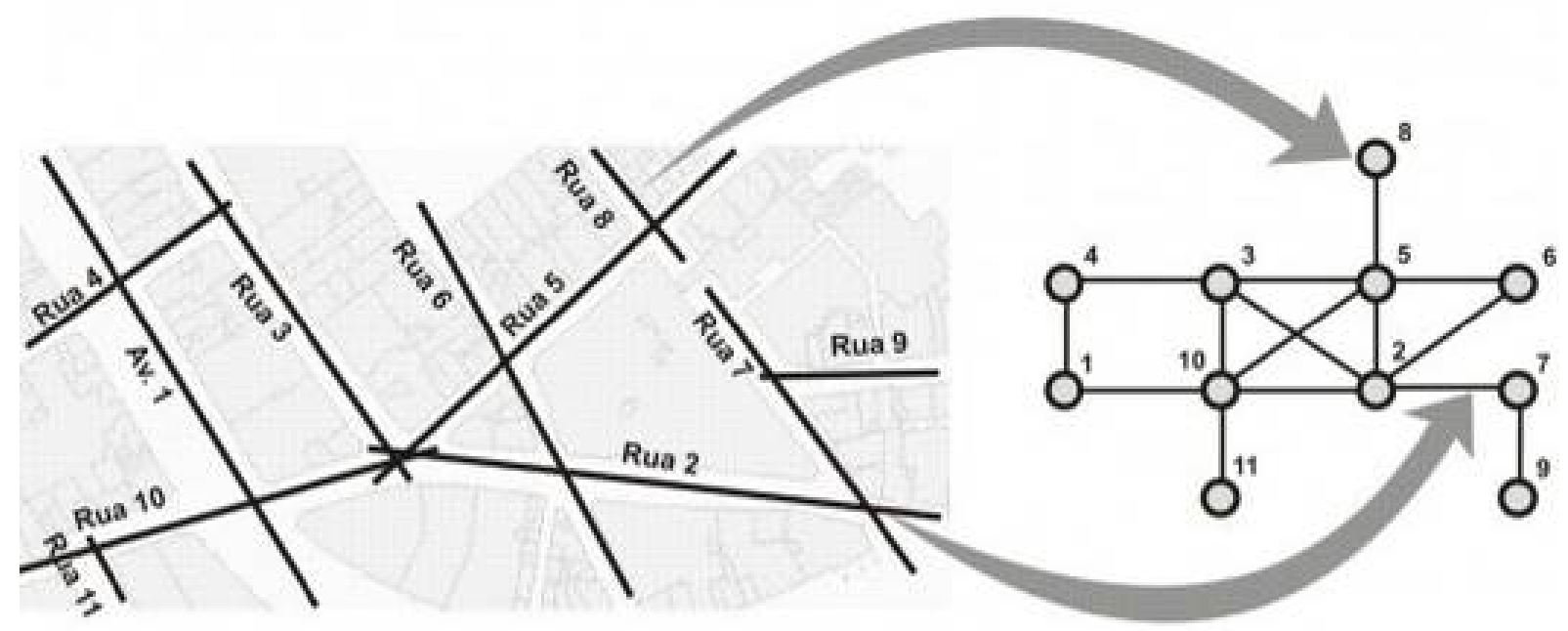

Fonte: Elaboração Antonio Wagner Jales (s/d). Disponível em: <http://www.vitruvius.com.br/revistas/read/ arquitextos/15.171/5289>. Acesso em 12 mai. 2016.

Dentre estas medidas, destaco o valor de integração que traduz a acessibilidade ou potencial de movimento de uma via (ou segmentos de via) em relação às demais que compõem o sistema viário. Esses valores de integração são calculados levando em consideração todos os caminhos possíveis, potencializando sua ligação com os demais, como se alguém percorresse todas as vias da cidade tomando como ponto de partida uma delas por vez e a partir daí os trajetos fossem medidos e hierarquizados ressaltando quais as vias mais e menos utilizadas (HILLER \& HANSON, 1984). O mapa axial pode ser calculado para várias medidas como integração e choice, exemplificado na Figura 13, na qual os valores cromáticos representam a integração das vias: tons quentes para as mais integradas e tons frios para as mais segregadas, de modo que:

Eixos mais integrados são aqueles mais permeáveis e acessíveis no espaço urbano, de onde mais facilmente se alcançam os demais. Implicam, em média, os caminhos topologicamente mais curtos para serem atingidos a partir de qualquer eixo do sistema. Eixos mais integrados tendem a assumir

49 A teoria dos grafos estuda objetos combinatórios — os grafos — que são um bom modelo para muitos problemas em vários ramos da matemática e que foi apropriada por Hillier e Hanson (1984) para descrever propriedades morfológicas da forma arquitetônica e urbana por meio da sua representação como um conjunto de elementos quantificáveis (OLIVEIRA et al, 2015). 
uma posição de controle, uma vez que podem se conectar a um maior número de eixos e hierarquicamente apresentam um potencial de integração superior. (MEDEIROS, 2006; p. 510).

Figura 13: Mapa axial de Integração Global do Crajubar/Ceará.

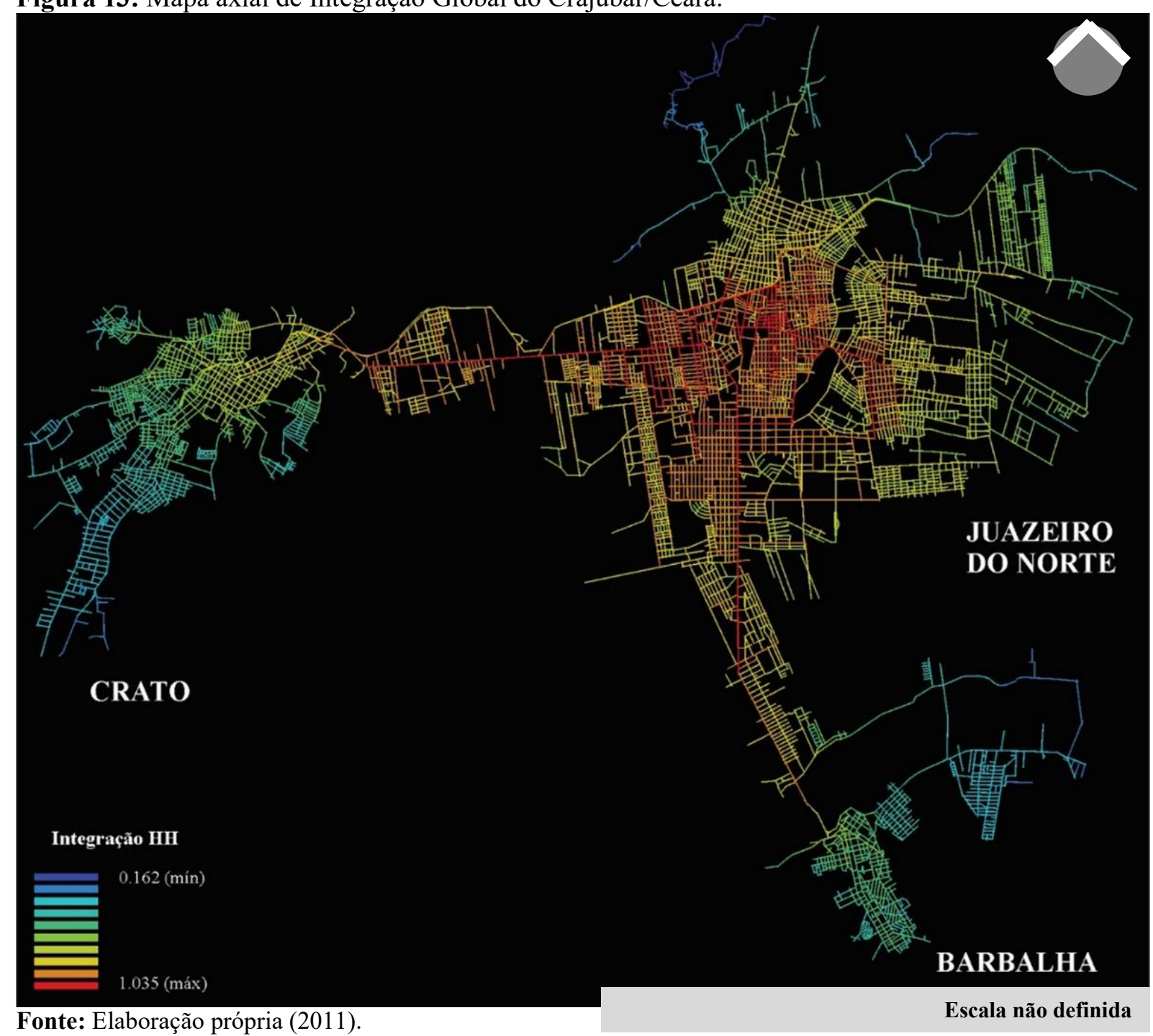

Complementarmente à análise axial, julgou-se válido comparar esses cálculos com outros procedimentos de modelagem, especificamente os segmentos. Pode-se definir um mapa de segmentos como aquele decorrente da transformação das linhas axiais em segmentos de eixos, tomando como ponto de separação os cruzamentos (links ou nós) - Figura 14. Isto permite que a análise da acessibilidade espacial seja mais detalhada, o que é extremamente válido para linhas muito longas, que podem ter diferentes graus de acessibilidade ao longo do percurso (CASTRO, 2016). As análises em escala local se tornam também mais eficientes, principalmente na escala do pedestre, pois: 
[...] quando os segmentos são examinados globalmente com a quantidade média de mudanças de direção que são feitas para chegar a qualquer outra linha dentro do sistema (a análise angular do grafo de segmentos) o ambiente urbano assume resultados muito similares à análise de integração, porém numa escala mais refinada. (TURNER, 2004, p. 26). ${ }^{50}$

Segundo Turner (2004), a análise dos segmentos examina o caminho mais curto entre um nó e uma série de outros nós do sistema, podendo ser calculada das seguintes maneiras: (1) angular - o caminho mais curto é o que minimiza o ângulo entre você e seu destino; (2) topológica - o caminho mais curto é aquele que usa o menor número de inflexões de percurso (note que é essa análise é também de caráter topológico, como a axial, mas com uma fina resolução); (3) segmento - o caminho mais curto é aquele que usa o menor número de trechos, ruas para atingir seu destino; (4) métrica ${ }^{51}$ - o caminho mais curto é aquele que é o mais curto fisicamente (TURNER, 2008).

Figura 14: Comparativo entre as representações axial e de segmentos (sob base cartográfica fictícia).

\section{REPRESENTAÇ̃̃O AXIAL}

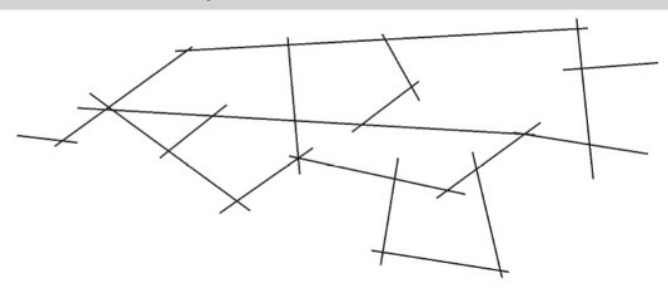

REPRESENTACุÃO DE SEGMENTOS

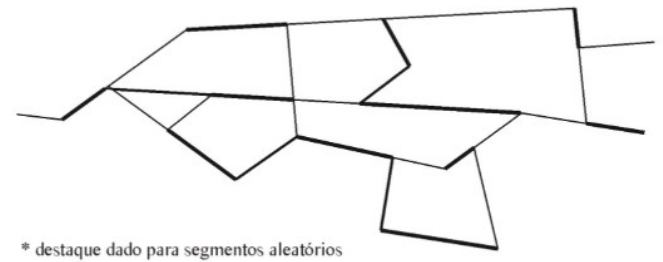

Fonte: GURGEL, 2012, p. 24 (editado).

A possibilidade de empregar diferentes tipos de raios (topológicos, angulares e métricos) contribui para avaliar as propriedades intrínsecas do espaço em distintas escalas. Hillier (2001) afirma que a cidade apresenta duas características em sua estrutura morfológica: na escala local, destacam-se as propriedades métricas, advindas de fenômenos como a intensificação das malhas viárias ortogonais, para reduzir o tempo médio de deslocamentos às áreas centrais, e a redução do fluxo de pessoas a polos geradores de movimento com distância métrica; e a escala global, apresenta propriedades topogeométricas, pois é necessário se valer ao mesmo tempo da geometria como da conectividade de redes urbanas em grandes escalas para capturar medidas que se aproximem dos padrões de

\footnotetext{
${ }^{50}$ No original: "[...] however, when the segments are examined globally according to the average amount of turning it takes to get to any other line within the system (an angular analysis of the segment graph) urban environments take on results much like integration analysis, but on a finer scale" (Tradução da autora).

${ }^{51}$ É importante entendermos que todas as análises da Sintaxe do Espaço são igualmente calculadas sob o viés topológico, ou seja, embora adotemos a denominação dada por Turner (2008), aquela análise dita "métrica" é igualmente topológica, porém circunscrita a determinado raio métrico.
} 
movimento na rede urbana, além da facilidade de se deslocar pelos caminhos mais retilíneos pelo espaço urbano (CASTRO, 2016).

Para facilitar a correlação entre as variáveis de pesquisa, os dados espacializáveis serão organizados e catalogados, ajuntando-se a estes as informações referentes à SE, utilizando-se de ferramentas de geoprocessamento, no chamado Sistema de Informação Geográfica - SIG (do inglês Geographic Information Systems - GIS). Estes aplicativos computacionais trabalham por abordagem quantitativa baseada em shape analysis, ou seja, uma "[...] unidade de referência espacial de forma urbana - o polígono morfológico de cidade ou polígono de cidade - corresponde a um tipo de objecto [sic] vectorial com graus de complexidade variável, sendo utilizado para representar entidades espaciais que ocupam uma superfície" (SILVA, 2011, p. 218).

Segundo Cruz e Campos (2015), a análise espacial em SIG’s baseia-se na ideia de conexão entre dados espaciais (shapes) e de atributos alfanuméricos (variáveis, por exemplo), traduzindo-se numa série de funções relacionadas com a seleção, pesquisa e modelagem de dados. Para Aronoff (1989 apud CRUZ; CAMPOS, 2015), existem quatro grandes categorias de funções a serem consideradas na análise espacial em SIG: (1) de acesso ou pesquisa, classificação e medição; (2) de superposição de mapas (overlay); (3) de análise de vizinhança; (4) de análise de conectividade.

A utilização de SIG's é cada vez mais presente na análise e planejamento urbano devido à sua facilidade de manipulação e visualização de imagens (mapas), as quais possibilitam a interação de vários fenômenos para explicar uma determinada situação no espaço. As pesquisas realizadas pelo IBGE já são disponibilizadas ${ }^{52}$ em formato compatível com as ferramentas de SIG e os mapas confeccionados para a SE também são intercambiáveis com estas plataformas, facilitando a elaboração de correlações entre as variáveis de pesquisa.

\subsection{Definição do Referencial Empírico}

Desde a Constituição Federal de 1988, cada governo estadual tem alterado ou instituído novas RM's. Em geral essas decisões são tomadas sem explicitar os critérios utilizados para justificar a delimitação dos municípios nestas regiões, comprometendo as análises comparativas entre elas. A primeira RMINE foi criada no Maranhão em 2005, sendo

52 Os arquivos com os setores censitários de 2010 em formato shapefile estão disponíveis no link: $<\mathrm{ftp} / /$ geoftp.ibge.gov.br/organizacao_do_territorio/malhas_territoriais/malhas_de_setores_censitarios_divisoes _intramunicipais/censo_2010/>. 
posteriormente instituídas outras a partir de 2009 (Tabela 1). Caso curioso é o do estado da Paraíba que criou onze RMINE's, as quais, com exceção da RM de Campina Grande, organizam-se em torno de cidades de pequeno porte sem indícios de crescimento demográfico, muito menos de metropolização - levantando novamente o problema da ausência de critérios nacionais de definições de RM's. Soma-se a esse mote a Região Administrativa Integrada de Desenvolvimento do Polo Petrolina e Juazeiro - RAID-PJ -, criada em 2001, que será tratada nesse estudo como uma região metropolitana apesar de abranger dois estados brasileiros. Dada a proliferação de RM's, especialmente na Paraíba e nas Alagoas, cabe adotar alguns critérios para a limitação desta pesquisa visto que a máxima “são regiões, mas não são metropolitanas" (FIRKOWSKI, 2012) é claramente visível no caso nordestino. Para tanto foi preciso elaborar parâmetros para a seleção do universo dessa pesquisa: (1) população; (2) posição na rede urbana; (3) indícios de conurbação física.

O primeiro critério de seleção é o mais tradicional. No Brasil, há relativo consenso na definição de cidades de porte médio como as que possuem entre 50.000 e 500.000 habitantes, ainda que esse intervalo esteja sujeito a alterações, cada vez que os resultados dos censos demográficos são divulgados (SPOSITO, 2010). Há no Nordeste 29 cidades médias, que congregavam em 2010 uma população de 5,9 milhões de habitantes (IBGE, 2012). Entretanto, só o agrupamento de pessoas não é suficientemente claro como argumento para a definição de uma "cidade média", já que nos interessa especialmente entender o seu papel em sua rede urbana. Como visto, a REGIC 2007 (IBGE, 2008) estabelece uma hierarquia dos centros urbanos brasileiros. Neste estudo tenho interesse nas capitais regionais nível B e C. Embora nem sempre se encaixem no critério populacional anterior, elas representam uma centralidade mediana na rede urbana e têm "[...] capacidade de polarizar um número grande de municípios no atendimento a bens e serviços de alta complexidade [...] concentram atividades de gestão pública e privada e articulam, na escala regional, órgãos e empresas privadas” (IBGE, 2013, $\mathrm{s} / \mathrm{p})$.

A Tabela 1 apresenta todas as RM's do Nordeste já instituídas por lei e em vigência atualmente. Destaco, em laranja, aquelas que se enquadram nos dois primeiros critérios apresentados. Entretanto, nessa primeira sistematização deixo de fora as cidades apresentadas no Quadro 6 que, embora não constituam RM’s (ainda, pois a maioria dessas cidades já é alvo de projetos de lei de criação de RM's), são destacadas no REGIC (IBGE, 2008) e que se destacavam em outros estudos sobre a rede urbana nordestina. A cidade de Mossoró/RN, por exemplo, possui 288.162 habitantes (IBGE/2015), a segunda maior população do estado. 
Conhecida como a "Capital do Oeste", a cidade exerce um importante papel na rede urbana da região entre o Rio Grande do Norte e o Ceará.

\begin{tabular}{|c|c|c|c|c|c|c|}
\hline Estado & Denominação da RM & $\begin{array}{c}\text { População } \\
2014\end{array}$ & $\begin{array}{c}\mathrm{N}^{\circ} \text { de } \\
\text { cidades }\end{array}$ & $\begin{array}{l}\text { Ano de } \\
\text { criação }\end{array}$ & Cidade polo & $\begin{array}{c}\text { Regiões de } \\
\text { Influência - IBGE } \\
(\mathbf{2 0 0 8 )}\end{array}$ \\
\hline \multirow{6}{*}{ Alagoas } & RM Maceió & 1.306 .251 & 14 & 1998 & Maceió & Capital regional A \\
\hline & RM Agreste & 508073 & 15 & 2009 & Arapiraca & Capital regional C \\
\hline & RM Zona da Mata & 303.236 & 15 & 2011 & União dos Palmares & Centro de Zona A \\
\hline & RM Vale do Paraíba & 210.751 & 13 & 2011 & Atalaia & Centro Local \\
\hline & RM Médio Sertão & 150.638 & 9 & 2013 & Santana do Ipanema & Centro sub-regional B \\
\hline & RM Palmeira dos Índios & 158.812 & 9 & 2012 & Palmeira dos Índios & Centro de Zona A \\
\hline \multirow{2}{*}{ Bahia } & RM Salvador & 3.919 .864 & 13 & 1973 & Salvador & Metrópole \\
\hline & RM Feira de Santana & 739615 & 6 & 2011 & Feira de Santana & Capital regional B \\
\hline \multirow{2}{*}{ Ceará } & RM Fortaleza & 3.818 .380 & 15 & 1973 & Fortaleza & Metrópole \\
\hline & RM Cariri & 590.209 & 9 & 2009 & Juazeiro do Norte & Capital Regional C \\
\hline \multirow{2}{*}{ Maranhão } & RM São Luís & 1.496 .100 & 6 & 2003 & São Luís & Capital Regional A \\
\hline & RM Sudoeste Maranhense & 351.653 & 8 & 2005 & Imperatriz & Capital Regional C \\
\hline \multirow{12}{*}{ Paraíba } & RM João Pessoa & 1.238 .914 & 12 & 2003 & João Pessoa & Capital regional A \\
\hline & RM Campina Grande & 630.777 & 19 & 2009 & Campina Grande & Capital regional B \\
\hline & RM Patos & 233768 & 24 & 2011 & Patos & Centro sub-regional A \\
\hline & RM Guarabira & 188.060 & 17 & 2011 & Guarabira & Centro sub-regional A \\
\hline & RM Cajazeiras & 174671 & 15 & 2012 & Cajazeiras & Centro sub-regional A \\
\hline & RM Vale do Piancó & 148739 & 18 & 2012 & Piancó & Centro de Zona B \\
\hline & RM Esperança & 139576 & 9 & 2012 & Esperança & Centro Local \\
\hline & RM Itabaiana & 135487 & 12 & 2013 & Itabaiana & Centro de Zona A \\
\hline & RM Vale do Mamanguape & 119049 & 9 & 2013 & Mamanguape & Centro de Zona A \\
\hline & RM Sousa & 116.093 & 9 & 2013 & Sousa & Centro sub-regional A \\
\hline & RM Barra de Santa Rosa & 80397 & 8 & 2012 & Barra de Sta. Rosa & Centro Local \\
\hline & RM de Araruna & 66925 & 6 & 2013 & Araruna & Centro de Zona B \\
\hline Pernambuco & RM Recife & 3.887 .261 & 16 & 1973 & Recife & Metrópole \\
\hline R. G. do Norte & RM Natal & 1.473 .877 & 10 & 1997 & Natal & Capital regional A \\
\hline Sergipe & RM Aracaju & 912.647 & 4 & 1995 & Aracaju & Capital regional A \\
\hline BA/PE & RAID - Petrolina-Juazeiro & 752433 & 8 & 2001 & Petrolina & Capital regional C \\
\hline PI/MA & RIDe da Grande Teresina & 1.189 .260 & 14 & 2002 & Teresina & Capital Regional A \\
\hline
\end{tabular}

Fonte: Elaboração própria (2016) a partir das legislações estaduais, dados censitários da estimativa IBGE/2014 e IBGE (2008). Obs.: em laranja destacam-se as RM's de interesse nesta pesquisa.

Por fim, o terceiro critério diz respeito à conurbação, entendida como a fusão de duas ou mais áreas urbanas em uma única, envolvendo integração física e funcional. Ou seja, uma conurbação exige não somente a continuidade das malhas viárias, mas também uma relação de interdependência das cidades, que pode ser econômica, social e de serviços públicos urbanos, redes de infraestrutura e outros (FERRARI, 2004). Observando o Quadro 7, verifica- 
se que a maioria dessas aglomerações urbanas se estrutura em torno de uma cidade-polo de médio porte que oferta uma variedade de serviços numa demanda regional e que corresponde aos melhores indicadores socioeconômicos do seu entorno. Por vezes elas têm os requisitos para a criação e desenvolvimento de polos tecnológicos e também despontam como alternativa à demasiada centralização industrial das regiões metropolitanas de grande porte, fatores que normalmente geram um aumento demográfico. Entretanto, seu entorno é composto por municípios de pequeno porte, com capacidade financeira e de suporte social desiguais, ou seja, são cidades que permanecem dependentes dos serviços e infraestrutura oferecidos pela cidade-polo.

\begin{tabular}{|c|c|c|c|c|}
\hline Estado & Cidade & $\begin{array}{l}\text { População } \\
\text { est. } 2015\end{array}$ & $\begin{array}{l}\text { Regiões de Influência } \\
\text { - IBGE (2008) }\end{array}$ & $\begin{array}{c}\text { Projeto para } \\
\text { criação de RM's? }\end{array}$ \\
\hline \multirow{3}{*}{ Bahia } & Vitória da Conquista/BA & 343.230 & Capital Regional B & Sim \\
\hline & $\begin{array}{l}\text { Ilhéus/BA } \\
\text { Itabuna/BA }\end{array}$ & $\begin{array}{l}180.213 \\
219.680\end{array}$ & Capital Regional B & Sim \\
\hline & Barreiras /BA & 153.918 & Capital Regional C & Não \\
\hline Ceará & Sobral/CE & 201.756 & Capital regional $\mathrm{C}$ & Sim \\
\hline Pernambuco & Caruaru/PE & 347.088 & Capital regional $\mathrm{C}$ & Sim \\
\hline R. G do Norte & Mossoró/RN & 288.162 & Capital regional C & Sim \\
\hline
\end{tabular}

Fonte: Elaboração própria (2016) a partir dos dados censitários da estimativa IBGE/2015 e IBGE (2008).

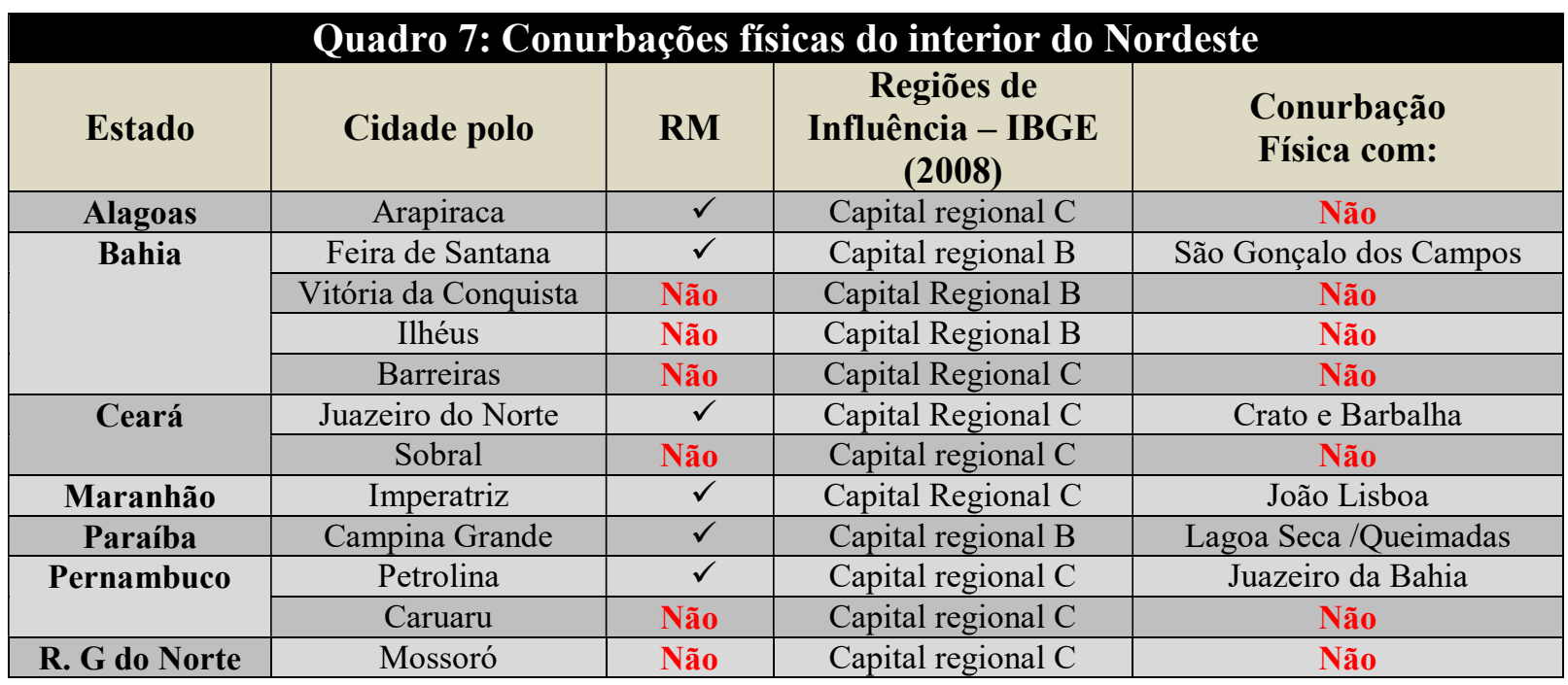

Fonte: Elaboração própria (2016) a partir de dados do IBGE (2008) e imagens de satélite do Google Earth (2015).

Portanto, a maioria delas não pode ser considerada como uma conurbação, tanto do ponto de vista socioeconômico - pois prevalece uma relação de dependência e não de interdependência - quanto espacial - pois não há a junção física das malhas urbanas. Como visto no Quadro 7, os critérios impostos reduziram drasticamente o número de aglomerações (são 20 RMINE's no total, segundo Tabela 1), a serem analisadas para somente cinco: (1) RM 
de Feira de Santana/BA; (2) RM do Cariri/CE; (3) RM do Sudoeste maranhense; (4) RM de Campina Grande/PB; (5) RAID de Petrolina/Juazeiro (Figura 15). Entre as aglomerações selecionadas só o caso cearense e a RAID têm processos de conurbação em aparente estágio consolidado. Petrolina e Juazeiro, apesar da barreira física do Rio São Francisco, são ligadas por uma ponte, de modo que a fronteira político-administrativa interestadual não é um empecilho para que as cidades desenvolvam suas relações comerciais e se complementem nas funções urbanas (ARAÚJO \& SILVA, 201). O Crajubar, como é conhecida aglomeração das cidades de Crato-Juazeiro do Norte-Barbalha desde meados dos anos 1960, congrega hoje o maior adensamento populacional do interior do estado e compartilham uma mesma ambiência climática e cultural que as diferencia dos sertões nordestinos à sua volta (GURGEL, 2012). O seu processo de conurbação, acentuado a partir dos incentivos industriais dos anos 1990, é uma das justificativas que subsidiou a criação da RM, conforme descrito na Lei Complementar $n^{\circ} 78,26$ de junho de 2009:

\footnotetext{
A Região Metropolitana do Cariri, unidade organizacional geoeconômica, social e cultural, tem sua ampliação condicionada ao atendimento dos requisitos básicos, verificados entre o âmbito metropolitano e sua área de influência, que são as seguintes:

I - Evidência ou tendência de conurbação;

II - Necessidade de organização, planejamento e execução de funções públicas de interesse comum;

III - Existência de relação de integração de natureza socioeconômica ou de serviços (CEARÁ, 2009, s/p.).
}

A Figura 15 apresenta as imagens de satélite das áreas conurbadas ou em processo de conurbação, como é o caso de Campina Grande/PB e Feira de Santana/BA, cujo espraiamento das manchas urbanas já ultrapassam os limites dos municípios. Na cidade paraibana, os avanços do tecido urbano nas fronteiras já são evidentes com o espraiamento no sentido nortesul sobre os territórios dos municípios de Lagoa Seca e Queimadas. A conurbação de Feira de Santana com São Gonçalo dos Campos se dá ao longo da BA-502, mas é possível encontrar processo semelhante a leste, com o município de Conceição do Jacuípe, onde há ocupação ao longo da BR-324 e BR-101, com a construção de grandes condomínios, em sua maioria de luxo. Há também o caso de Imperatriz/MA, onde verifica-se um adensamento junto aos limites com município tocantinense de São Miguel do Tocantins (não integrante da RM), embora haja a barreira imposta pelo Rio Tocantins vencida apenas pela Ponte da Liberdade (rodovia TO-126) e por balsas que fazem a travessia (Figura 16). 
Figura 15: Exemplos de Conurbação Física.
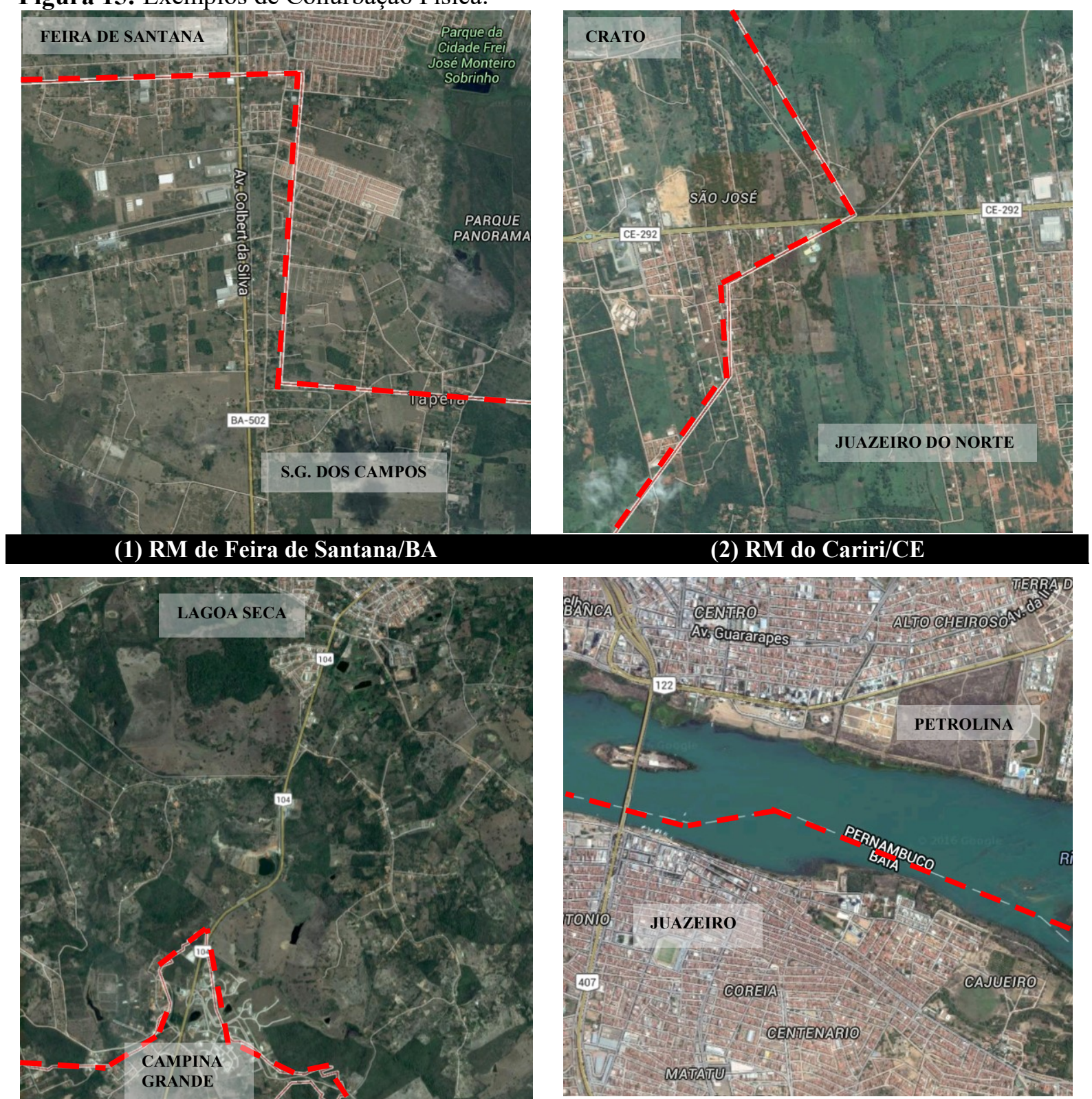

(3)RM de Campina Grande/PB

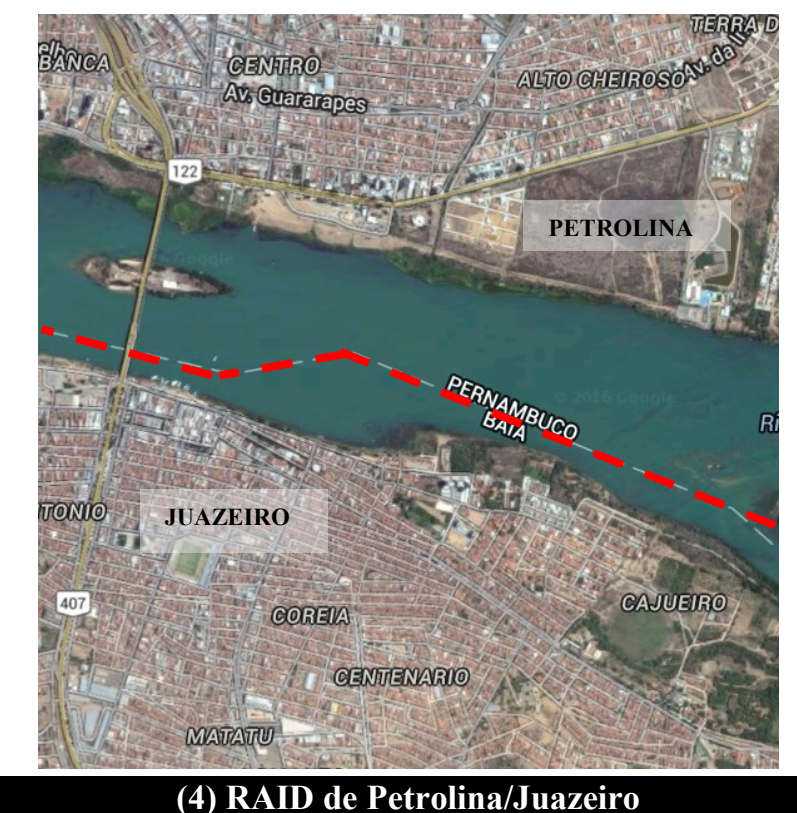

$-{ }_{-}-2$ Limites Municipais

Fonte: Edição própria (2016) a partir de imagens de satélite de 2015 disponíveis em: $<$ https://www.google.com.br/maps/>, acesso em 15 de jul. 2016.

Entretanto, as demais RMINE's (com mais de 500 mil habitantes) e cidades classificadas como capitais regionais no REGIC não serão completamente desconsideradas neste estudo. Verifica-se que na criação de RM's, principalmente por interesses políticos estaduais e mesmo com a promulgação do Estatuto da Metrópole (Lei n ${ }^{0} 13.089$, de 12 de janeiro de 2015), ainda não há meios claros - especialmente de cunho morfológico - para a definição e gestão dessas aglomerações urbanas. 
Figura 16: À direita, vista de uma balsa atravessando o Rio Tocantins com, ao fundo, a Ponte da Liberdade. À esquerda, uma imagem de satélite da divisa interestadual MA-TO.

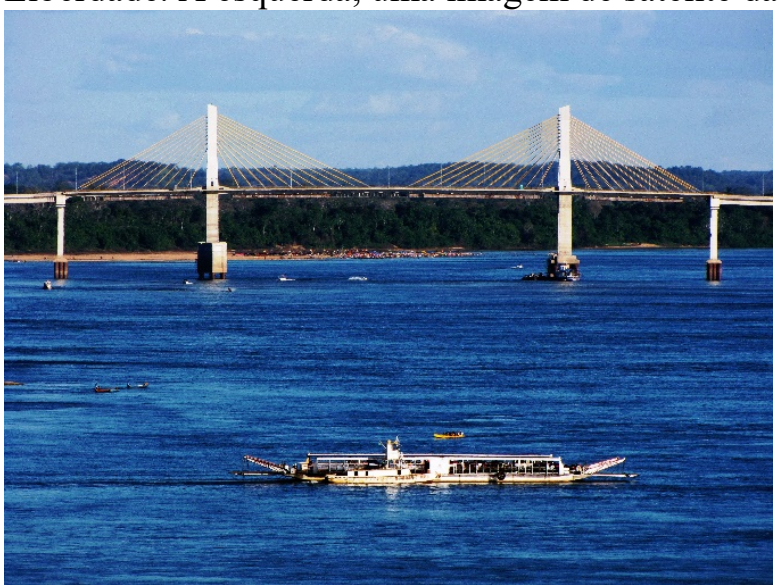

Fonte: foto de Iran Peixoto (2009). Disponível em: $<$ http://www.panoramio.com/photo/26000758>. Acesso em 17 de ago. 2016.

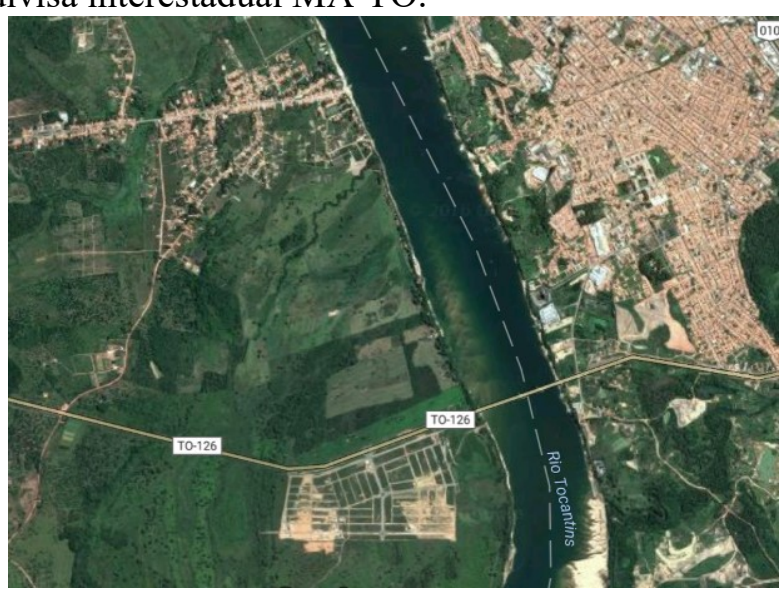

Fonte: Foto de satélite do Google Earth (2016). Acesso em 17 de ago. 2016.

Portanto, além das cinco RMINE's selecionadas, as demais cidades descritas no Quadro 07 serão o primeiro grupo de controle ${ }^{53}$ - a exceção dos municípios baianos de Ilhéus e Itabuna, pois possuem menos de 200.000 habitantes cada. Dentre as aglomerações selecionadas neste grupo apenas Arapiraca/AL tem a instituição de uma RM, embora haja projetos de lei para a criação de RM em todas as demais cidades, elaborados a partir de 2011 conforme descrito no Quadro 8. O segundo grupo de controle é formado pelas metrópoles Fortaleza, Salvador e Recife (apresentadas no Quadro 08), buscando clarificar as diferenças entre aglomerados que são e os que não são metropolitanos, por definição. A espacialização do universo de pesquisa está na Figura 17, mas optei por não incluir os municípios constituintes das RM's que ainda não foram institucionalizadas (Vitória da Conquista/BA, Sobral/CE, Mossoró/RN e Caruaru/PE), mantendo apenas os limites municipais individuais.

\footnotetext{
${ }^{53}$ Faço aqui uma referência à linguagem da metodologia de trabalho da pesquisa científica. Num experimento controlado quando dois experimentos idênticos são conduzidos, apenas em um deles o fator testado é aplicado, enquanto no outro - o grupo de controle - o fator testado não é aplicado.
} 


\begin{tabular}{|c|c|c|}
\hline GRUPO & DENOMINAÇÃO & MUNICÍPIOS CONSTITUINTES \\
\hline \multirow{5}{*}{$\begin{array}{l}\text { RMINE's } \\
\text { para a } \\
\text { análise }\end{array}$} & $\begin{array}{l}\text { (1) } \mathrm{RM} \text { de Feira } \\
\text { de Santana/BA }\end{array}$ & $\begin{array}{l}\text { Amélia Rodrigues, Conceição da Feira, Conceição do Jacuípe, Feira de } \\
\text { Santana, São Gonçalo dos Campos e Tanquinho }\end{array}$ \\
\hline & $\begin{array}{l}\text { (2) } \mathrm{RM} \mathrm{do} \\
\text { Cariri/CE }\end{array}$ & $\begin{array}{l}\text { Barbalha, Caririaçu, Crato, Farias Brito, Jardim, Juazeiro do Norte, Missão } \\
\text { Velha, Nova Olinda e Santana do Cariri }\end{array}$ \\
\hline & $\begin{array}{l}\text { (3) RM do } \\
\text { Sudoeste } \\
\text { maranhense }\end{array}$ & $\begin{array}{l}\text { Imperatriz, João Lisboa, Senador La Rocque, Buritirana, Davinópolis, } \\
\text { Governador Edison Lobão, Montes Altos e Ribamar Fiquene }\end{array}$ \\
\hline & $\begin{array}{l}\text { (4) RM Campina } \\
\text { Grande/PB }\end{array}$ & $\begin{array}{l}\text { Alcantil, Aroeiras, Barra de Santana, Boa Vista, Boqueirão, Campina } \\
\text { Grande, Caturité, Fagundes, Gado Bravo, Itatuba, Lagoa Seca, } \\
\text { Massaranduba, Matinhas, Natuba, Puxinanã, Queimadas, Santa Cecília, } \\
\text { Serra Redonda, Umbuzeiro }\end{array}$ \\
\hline & $\begin{array}{l}\text { (5) RAID de } \\
\text { Petrolina/Juazeiro }\end{array}$ & $\begin{array}{l}\text { Pernambuco: Petrolina, Lagoa Grande, Orocó e Santa Maria da Boa Vista; } \\
\text { Bahia: Juazeiro, Casa Nova, Curaçá e Sobradinho }\end{array}$ \\
\hline \multirow{5}{*}{$\begin{array}{l}\text { Grupo de } \\
\text { controle 01: } \\
\text { outras } \\
\text { aglomerações } \\
\text { e cidades }\end{array}$} & RM Agreste/AL & $\begin{array}{l}\text { Arapiraca, Campo Grande, Coité do Noia, Craíbas, Feira Grande, Girau do } \\
\text { Ponciano, Junqueiro, Lagoa da Canoa, Limoeiro de Anadia, Olho d'Água } \\
\text { Grande, São Sebastião, Taquarana, Traipu, São Brás e Jaramataia }\end{array}$ \\
\hline & $\begin{array}{l}\text { Vitória da } \\
\text { Conquista/BA }\end{array}$ & $\begin{array}{l}\text { "Região Metropolitana do Sudoeste da Bahia" (Projeto de Lei } \\
\text { Complementar no 101/2011) Vitória da Conquista, Anagé, Barra do Choça, } \\
\text { Belo Campo, Boa Nova, Bom Jesus da Serra, Caatiba, Caetanos, Cândido } \\
\text { Sales, Caraíbas, Cravolândia, Encruzilhada, Firmino Alves, Ibicuí, Iguaí, } \\
\text { Irajuba,Itambé, Itapetinga, Itaquara, Itarantim, Itiruçu, Itororó, Jaguaquara, } \\
\text { Jequié, Lafayette Coutinho, Lagedo do Tabocal, Macarani, } \\
\text { Maiquinique,Manoel Vitorino, Maracás, Mirante, Nova Canaã, Planaltino, } \\
\text { Planalto, Poções, Potiraguá, Ribeirão do Largo, Santa Inês e Tremedal }\end{array}$ \\
\hline & Sobral/CE & $\begin{array}{l}\text { "Região Metropolitana de Sobral" (Projeto de Lei no 318/2011) Sobral, } \\
\text { Massapê, Senador Sá, Uruoca, Santana do Acaraú, Forquilha, Coreaú, } \\
\text { Moraújo, Groairas, Reriutaba, Varjota, Cariré, Pacujá, Graça, Frecheirinha, } \\
\text { Miraíma, Meruoca e Alcântaras }\end{array}$ \\
\hline & Mossoró/RN & $\begin{array}{l}\text { "Região Metropolitana de Mossoró” (Projeto de Lei Complementar 2014) } \\
\text { Mossoró, Tibau, Areia Branca, Grossos, Porto do Mangue, Carnaubais, } \\
\text { Ipanguaçu, Assu, Itajá, Governador Dix-Sept Rosado, Caraúbas, Patu, } \\
\text { Umarizal, Campo Grande, Triunfo Potiguar, Janduís, Apodi, Baraúna, } \\
\text { Severiano Melo, Upanema, Serra do Mel, Rodolfo Fernandes, Olho } \\
\text { D’Água do Borges, Viçosa, Felipe Guerra e Riacho da Cruz }\end{array}$ \\
\hline & Caruaru/PE & $\begin{array}{l}\text { "Região Metropolitana do Agreste Central” (Projeto de Lei Complementar } \\
\left.n^{\circ} 568 / 2011\right)^{54} \text { : Agrestina, Altinho, Bezerros, Brejo da Madre de Deus, Frei } \\
\text { Miguelinho, Riacho das Almas, São Caetano e Toritama }\end{array}$ \\
\hline \multirow{3}{*}{$\begin{array}{l}\text { Grupo de } \\
\text { controle 02: } \\
\text { Metrópoles } \\
\text { do Nordeste }\end{array}$} & $\begin{array}{l}\text { RM de } \\
\text { Salvador/BA }\end{array}$ & $\begin{array}{l}\text { Salvador, Camaçari, Candeias, Itaparica, Lauro de Freitas, São Francisco } \\
\text { do Conde, Simões Filho, Vera Cruz (1973); Madre de Deus, Dias d'Ávila } \\
\text { (1990); Mata de São João, São Sebastião do Passé (2007); Pojuca (2008) }\end{array}$ \\
\hline & $\begin{array}{l}\text { RM de } \\
\text { Fortaleza/CE }\end{array}$ & $\begin{array}{l}\text { Fortaleza, Caucaia, Maranguape, Pacatuba e Aquiraz (quando criada em } \\
\text { 1973); Maracanaú (1983); Eusébio (1987); Itaitinga, Guaiuba (1992); } \\
\text { Chorozinho, Pacajus, Horizonte, São Gonçalo do Amarante (1999); } \\
\text { Pindoretama, Cascavel (2009); Paracuru, Paraipaba, Trairi, São Luís do } \\
\text { Curu (2014) }\end{array}$ \\
\hline & RM de Recife/PE & $\begin{array}{l}\text { Recife, Cabo de Santo Agostinho, Igarassu, Itamaracá, Jaboatão dos } \\
\text { Guararapes, Moreno, Olinda, Paulista, São Lourenço da Mata (1973); } \\
\text { Abreu e Lima, Camaragibe, Ipojuca, Ilha de Itamaracá, Itapissuma (1994) }\end{array}$ \\
\hline
\end{tabular}

Fonte: Elaboração própria (2016) a partir das legislações estaduais.

${ }^{54}$ Sua proposta foi negada pela Agência Estadual de Planejamento e Pesquisas (Condepe/Fidem), órgão técnico de planejamento, entre outros motivos, porque as sedes dos municípios do entorno de Caruaru não estão fisicamente ligadas à "capital do Agreste". 
Figura 17: Espacialização das RM's e municípios em estudo.
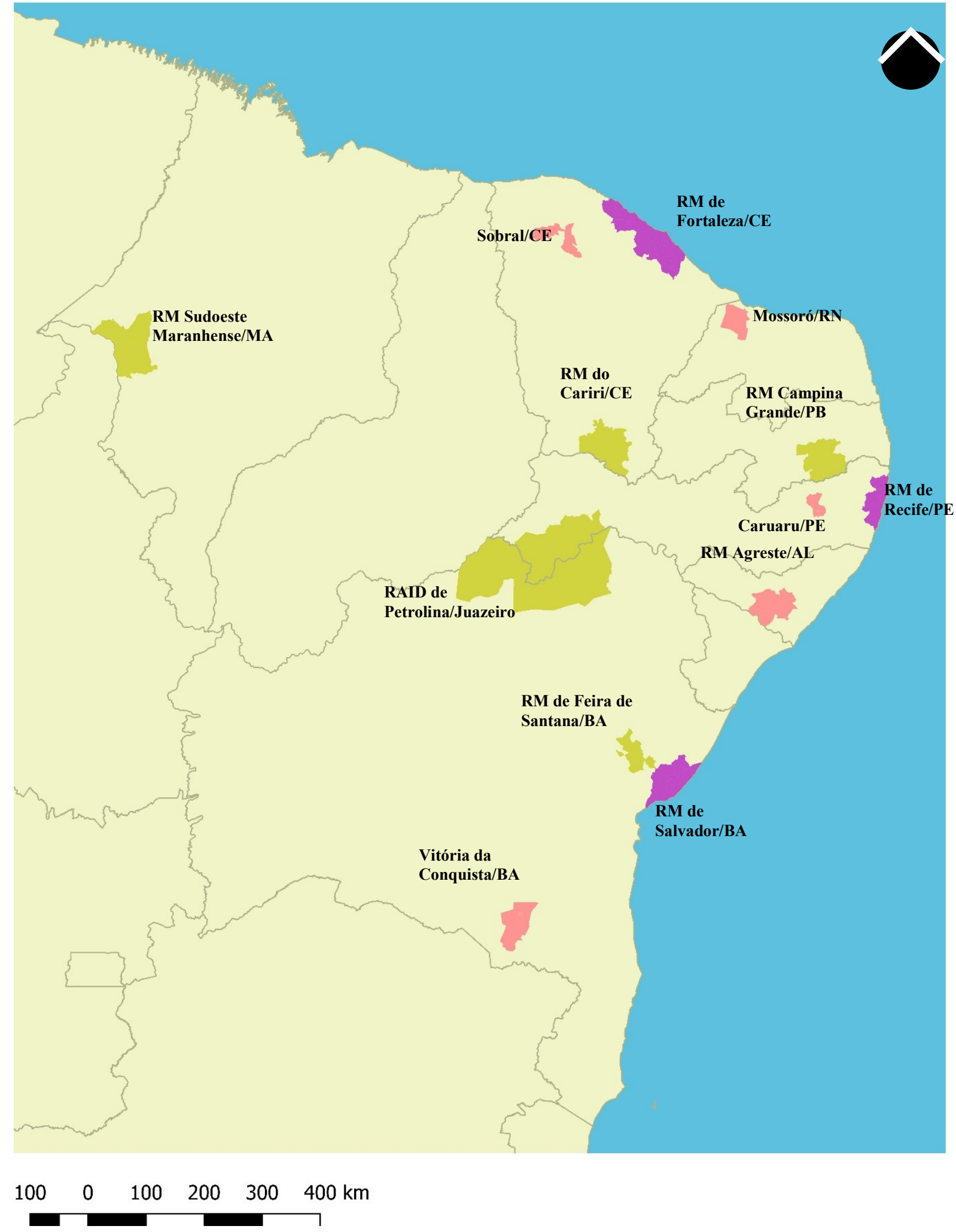

LEGENDA

RMINE's para a análise

Grupo de controle 01: Outras aglomerações
Grupo de controle 02:

Metrópoles do Nordeste

Fonte: Elaboração própria (2016) sob bases cartográficas do IBGE (2014). 


\subsection{Conclusões parciais}

Como visto no capítulo anterior e como demonstrado por meio dos dados apresentados neste capítulo, a definição das RM's se apoia em frágeis critérios. Estes podem ser descritos sobre dois pontos de vista: político-administrativo e configuracional. Primeiramente, prevalecem os interesses de fortalecimento eleitoral locais, que na leitura de Maricato tem como base "a tradição municipalista de raízes coloniais, recuperada pela Constituição de 1988, reafirmada pelas políticas paroquiais e clientelistas exercidas pelos executivos e legislativos, reforça esse localismo" (2011, p.12). Portanto, embora instituídas legalmente, há pouca cooperação intermunicipal, exemplificada pela falta de um pacto regional ou porque não há capacidades administrativas para viabilizar tal cooperação.

No segundo viés, refém das decisões políticas, a maioria desses arranjos não parece obedecer a quaisquer regras técnicas para a seleção dos municípios integrantes. Não há sequer o tradicional critério populacional, a exemplo da Paraíba, onde, com exceção da capital João Pessoa e Campina Grande, as demais RM's possuem menos de 250 mil habitantes, mesmo somadas as populações de mais de dez ou vinte municípios. A ausência de pessoas só não parece ser mais grave que a falta de processos de urbanização em escala metropolitana, visto que predominam características rurais. Mas não pretendo ser generalista. As 29 RM's nordestinas são extremamente heterogenias entre si e mais flagrante são as disparidades quando avaliamos na escala regional, o que significa dizer que é possível identificar dentre elas diversos estágios ou tipos metropolitanos.

Fica clara, portanto, a necessidade de haver uma discussão acerca destes critérios, e de que eles sejam gerais, mas, ao mesmo tempo, abarquem as características individuais. A SE permite avaliar, através de seu conjunto de métodos e técnicas que se apoiam em um consubstancial lastro teórico, a variável que permeia todos os casos: o espaço. Tomando de empréstimo alguns termos da Biologia, genótipo e fenótipo podem ser utilizados para sintetizar aspetos da organização espacial. O genótipo refere-se àquelas características intrínsecas e comuns de certos tipos de assentamentos humanos que não são observáveis e, portanto, são consideradas abstratas, ou seja, são constantes espaciais ou regras morfológicas de natureza topológica, construídas em função das circunstâncias sociais do momento. $\mathrm{O}$ fenótipo refere-se, por sua vez, àquelas feições particulares e observáveis que distinguem um assentamento de outro, ou seja, corresponde ao artefato urbano ou arquitetônico em que determinado genótipo foi aplicado. (BAFNA, 2012; MEDEIROS, 2013, GUARDA, 2015). 
Neste trabalho foco nessas questões morfológicas para identificar os genomas metropolitanos sob dois vieses: (1) entendendo como características genotípicas das RM's os processos socioespaciais descritos no capítulo 01, dentre as quais destaco: a expansão dos tecidos urbanos em processos de segregação social programada ou voluntária (cf. LEFEBVRE, 1991), calcada em diversos parâmetros de segurança e controle dos usos urbanos e que (re)produz a cidade fractal ou colcha-de-retalhos (SOJA, 2000; MEDEIROS, 2003), é preciso compreender dentro deste aparato as características fenotípicas das RMINE's; (2) definido este tipo metropolitano regional, é possível sistematizar suas distinções fenotípicas caso a caso, de acordo com os grupos de análise aqui propostos. São estes os pontos que serão alvo de análise nos próximos capítulos dessa tese.

Claro que há limitações na SE, pois enquanto teoria socioespacial, ela não é capaz de abarcar todas as relações possíveis (NETTO, 2013). Ademais, a construção do mapa axial é uma tarefa interpretativa do pesquisador, que decide intencionalmente como e sob que recorte temporal irá representar seu objeto de pesquisa. Portanto, há necessidade de parâmetros claros que devem guiar a elaboração da modelagem, passíveis de serem replicados por diferentes pessoas e facilitando a comparação entre sistemas diferentes. Cabe ressaltar aqui a dificuldade que é a obtenção das bases cartográficas oficiais e atualizadas, embora muito se tenha avançado a partir da possibilidade de utilização das imagens de satélite e outras ferramentas de georreferenciamento. Mais que uma "matematização do óbvio", bordão replicado pela crítica, a SE vem se consolidando como uma robusta ferramenta analítica, capaz ao mesmo tempo de revelar e de antecipar o surgimento de determinados processos, por sua propriedade de enfocar o artefato tanto como determinação quanto como determinante de práticas socioculturais (GURGEL \& TRIGUEIRO, 2011). 


\section{AS PESSOAS \\ E A CIDADE: \\ ANÁLISE DAS \\ VARIÁVEIS DE ORDEM \\ SOCIOECONÔMICA}




\section{AS PESSOAS E A CIDADE: ANÁlise dAS VARIÁVEIS DE ORDEM SOCIOECONÔMICA}

Neste capítulo serão apresentadas e avaliadas as variáveis de ordem socioeconômica: (1) distribuição de renda, (2) nível de instrução, (3) grupos de ocupação no trabalho principal, (4) tempo de deslocamento entre a residência e o trabalho. Serão utilizados os dados do IBGE colhidos no recenseamento (2010) organizados em tabelas, gráficos e quando possível em sua distribuição espacial.

\subsection{Distribuição de renda}

Para essa variável avaliei três níveis: (1) numa escala municipal ou regional, o Produto Interno Bruto - PIB total e per capita por RM's ou municípios; (2) também na escala municipal, as classes de rendimento nominal mensal, em salário mínimo, de acordo com as áreas de ponderação do censo 2010; (3) na escala dos setores censitários, o valor do rendimento nominal médio mensal das pessoas responsáveis por domicílios particulares permanentes espacializado no território municipal ou metropolitano.

\begin{tabular}{|c|c|c|c|c|c|}
\hline $\begin{array}{l}\mathbf{G} \\
\mathbf{R} \\
\mathbf{U} \\
\mathbf{P} \\
\mathbf{O}\end{array}$ & Aglomerações/cidades & $\begin{array}{l}\text { População } \\
\text { Estimativas } \\
\text { IBGE/2014 }\end{array}$ & $\begin{array}{c}\text { PIB } 2013 \\
\text { (Total da } R M \text { ) - } \\
\text { em mil reais }\end{array}$ & $\begin{array}{c}\text { PIB } 2013 \\
\text { (Município } \\
\text { sede) - em mil } \\
\text { reais }\end{array}$ & $\begin{array}{c}\text { PIB per capita } \\
2013\end{array}$ \\
\hline \multirow{5}{*}{ 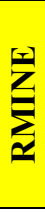 } & RM de Feira de Santana/BA & 786.086 & $\mathrm{R} \$ 13.059 .765$ & $\mathrm{R} \$ 10.840 .566$ & $\mathrm{R} \$ 16.613,66$ \\
\hline & RM do Cariri/CE & 590.209 & $\mathrm{R} \$ 5.743 .833$ & $\mathrm{R} \$ 3.221 .109$ & $\mathrm{R} \$ 9.731,86$ \\
\hline & RM Sudoeste Maranhense/MA & 419.536 & $\mathrm{R} \$ 5.739 .719$ & R\$ 5.039.597 & $\mathrm{R} \$ 13.681,11$ \\
\hline & RM Campina Grande/PB & 630.777 & $\mathrm{R} \$ 8.203 .666$ & $\mathrm{R} \$ 6.538 .929$ & $\mathrm{R} \$ 13.005,65$ \\
\hline & RAID de Petrolina/Juazeiro & 752.433 & $\mathrm{R} \$ 9.247 .104$ & $\mathrm{R} \$ 4.905 .327$ & $\mathrm{R} \$ 12.289,60$ \\
\hline \multirow{5}{*}{ ניత } & RM Agreste/AL & 508.073 & $\mathrm{R} \$ 4.687 .215$ & $\mathrm{R} \$ 2.955 .858$ & $\mathrm{R} \$ 9.225,48$ \\
\hline & Vitória da Conquista/BA & 343.230 & - & $\mathrm{R} \$ 4.935 .906$ & $\mathrm{R} \$ 14.380,75$ \\
\hline & Sobral/CE & 201.756 & - & $\mathrm{R} \$ 3.387 .605$ & $\mathrm{R} \$ 16.790,60$ \\
\hline & Mossoró/RN & 288.162 & - & $\mathrm{R} \$ 6.538 .346$ & $\mathrm{R} \$ 22.689,83$ \\
\hline & Caruaru/PE & 347.088 & - & $\mathrm{R} \$ 5.239 .833$ & $\mathrm{R} \$ 15.096,55$ \\
\hline \multirow{3}{*}{ త̂ } & RM Salvador & 3.953 .290 & $\mathrm{R} \$ 72.929 .817$ & $\mathrm{R} \$ 52.667 .933$ & $\mathrm{R} \$ 18.447,88$ \\
\hline & RM Fortaleza & 3.985 .297 & $\mathrm{R} \$ 60.578 .265$ & $\mathrm{R} \$ 49.745 .920$ & $\mathrm{R} \$ 15.200,44$ \\
\hline & RM Recife & 3.914 .317 & $\mathrm{R} \$ 89.802 .319$ & $\mathrm{R} \$ 46.445 .339$ & $\mathrm{R} \$ 22.942,01$ \\
\hline
\end{tabular}

Fonte: Elaboração própria (2016) a partir de dados coletados pelo IBGE (2013 e 2014), disponível em $<$ http://cidades.ibge.gov.br/.> 
A Tabela 2 apresenta os resultados para aquele primeiro nível de análise. As RM's das capitais do Nordeste (grupo de controle 02) apresentam os maiores valores no PIB total da tabela, o que é condizente com sua hierarquia urbana em escala nacional: são grandes polos populacionais e de geração de renda para o país, com suas redes de influência se estendendo aos demais estados nordestinos. Segundo o REGIC (IBGE, 2008, s/p.):

A rede de Fortaleza, a terceira maior em população do País (11,2\%), contava, em 2005, com apenas 4,5\% do PIB nacional. [...] A rede urbana de Recife é a quarta maior em população do País, com 10,3\% de sua população. Deste total, 19,5\% se concentram em Recife. Em 2005, a rede detinha 4,7\% do PIB nacional, sendo Recife responsável por $29,0 \%$ desta parcela, com um PIB per capita de R \$ 8,0 mil, e de R \$ 4,7 mil no restante da rede. [...] Salvador e sua rede urbana respondem por $8,8 \%$ da população do País e $4,9 \%$ do PIB nacional. Salvador concentra $22,4 \%$ da população e $44,0 \%$ do PIB da rede, com um PIB per capita de R\$ 12,6 mil, enquanto para os demais municípios componentes este valor é de R\$ 4,6 mil. (IBGE, 2008, $\mathrm{s} / \mathrm{p}$.).

Embora na Tabela 2 os dados apresentados estejam atualizados para a década de 2010, a realidade permanece a mesma: estas metrópoles continuam a concentrar grandes contingentes populacionais do Brasil, especialmente nos municípios sede (Fortaleza, Recife e Salvador), onde também se concentram a maior parte do PIB. Observa-se um entorno metropolitano relativamente pobre e não tão denso em população como o núcleo, o que pode demonstrar uma relação de dependência entre centro e periferias nesta escala metropolitana.

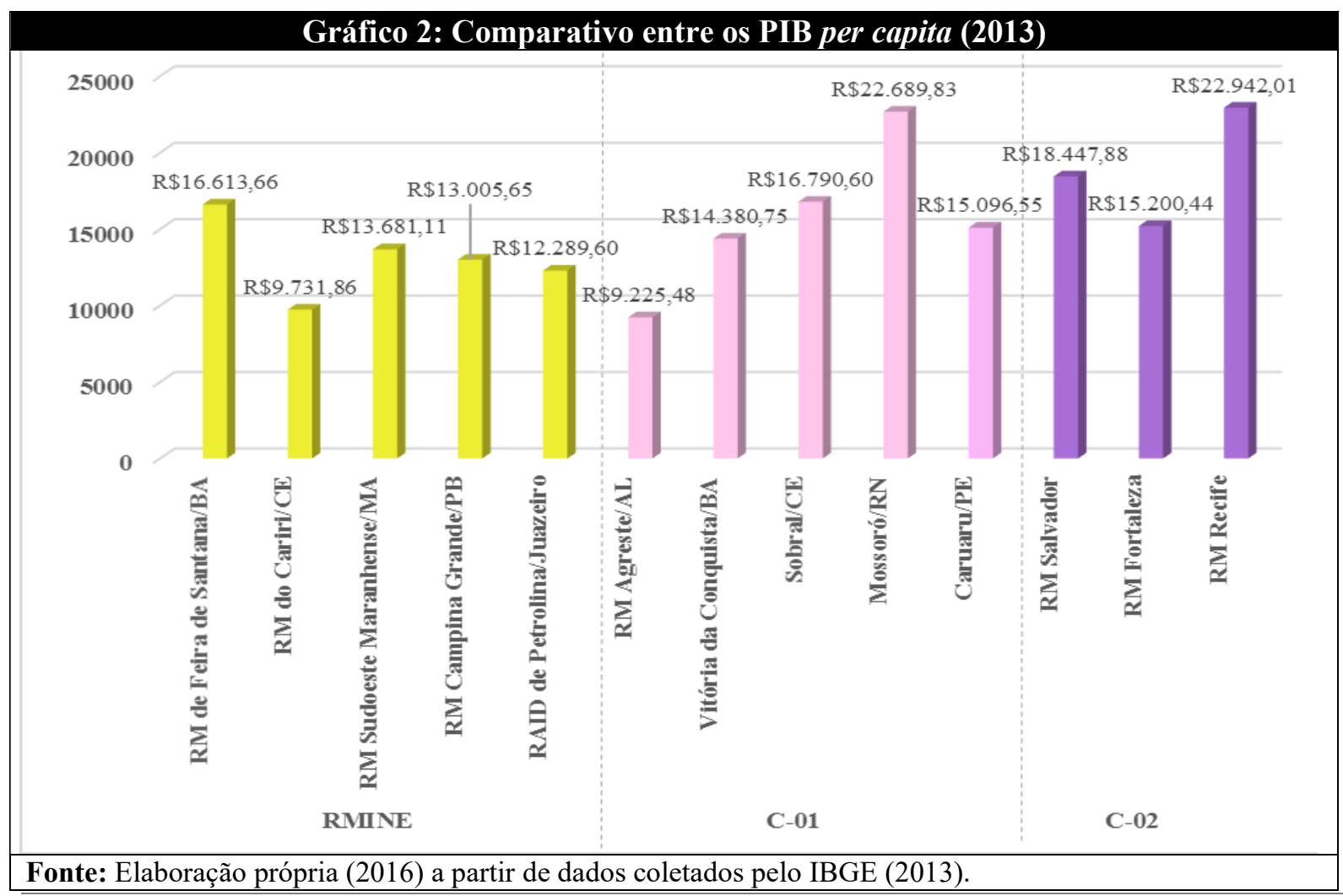


Quando comparamos então as metrópoles do Nordeste com as demais RMINE's e municípios em análise por meio do PIB per capita (já que há fortes variações entre os tamanhos populacionais), observamos que há uma relativa homogeneidade entre os resultados que variam entre nove mil e dezoito mil reais, à exceção da RM de Recife e Mossoró/RN. A cidade potiguar desponta devido ao seu dinâmico setor terciário (especificamente o comércio e prestação de serviços que polariza toda região oeste potiguar) e secundário, especificamente pela cidade ser a maior produtora de petróleo (em terra), além de ser responsável por $90 \%$ da produção salineira de todo o Brasil. Os menores PIB's per capita são das RMINE's do Cariri/CE e Agreste/AL. Embora o Cariri represente o terceiro maior polo calçadista do Brasil (atrás apenas de Franca/SP e Novo Hamburgo/RS), cerca de 80\% dos PIB's municipais advém do setor terciário (IBGE/2012). Em Arapiraca/AL, apesar de a cidade representar o segundo maior PIB do Estado, a pequena e média indústria (que processa a produção agrícola local, de base praticamente familiar) possui apenas $15 \%$ de representação no PIB municipal, enquanto o comércio e serviços representam cerca de 70\% (Fecomércio/AL, 2012).

Outra maneira de se avaliar a distribuição de renda foi por meio do rendimento nominal mensal dados em salários mínimos (que na época da pesquisa, 2010, equivaliam a $\mathrm{R} \$ 510,00)$. O IBGE apresenta estes dados por áreas de ponderação, ou seja, um agrupamento de setores censitários ${ }^{55}$ contíguos dentro de um único município que corresponde a um mínimo de 400 domicílios particulares ocupados na amostra (RIBEIRO \& TENORIO, 2015; CORTEZ, MONTENEGRO \& BRITO, 2012). São apresentadas as tabelas 3, 4, 5 e 6 organizadas de acordo com os grupos definidos no referencial empírico, vale ressaltar que nem todos os municípios constituintes das RM's foram localizados nas tabelas divulgadas pelo IBGE (2013), pois o estudo só apresentou as cidades com duas ou mais áreas de ponderação. A maior parcela da população nas cidades avaliadas recebia apenas um salário mínimo (que na época da pesquisa correspondia a $\mathrm{R} \$ 510,00$ ) ou não tinha rendimentos, categoria na qual foram incluídos aqueles que recebiam apenas benefícios, por exemplo do programa social Bolsa Família, embora essas porcentagens sejam menores nas cidades-sede das RM's, como pode ser visto no Gráfico 03, onde também estão os maiores salários. Novamente esse resultado pode ser interpretado como uma relação de interpendência - neste caso à oferta de empregos - entre os municípios do entorno e o núcleo sede da RM's, uma característica observada em todos os grupos analisados.

\footnotetext{
${ }^{55}$ Um setor censitário é definido como "a unidade territorial estabelecida para fins de controle cadastral, formado por área contínua, situada em um único quadro urbano ou rural, com dimensão e número de domicílios que permitam o levantamento por um recenseador. " (IBGE, 2010). Disponível em: <http:// censo2010. ibge.gov.br/ materiais/guia-do-censo/operacao-censitaria.html >. Acesso em 08 ago. 2016.
} 
Tabela 3: Pessoas de 10 anos ou mais de idade, por classes de rendimento nominal mensal, nas RMINE's selecionadas

\begin{tabular}{|c|c|c|c|c|c|c|c|c|c|c|c|c|c|c|c|c|c|}
\hline \multirow{3}{*}{$\begin{array}{l}\text { Unidades da } \\
\text { Federação, } \\
\text { municípios e } \\
\text { áreas de } \\
\text { ponderação }\end{array}$} & \multicolumn{17}{|c|}{ Pessoas de 10 anos ou mais de idade } \\
\hline & \multirow[b]{2}{*}{ Total } & \multicolumn{16}{|c|}{ Classes de rendimento nominal mensal (salário mínimo) ${ }^{(1)}$} \\
\hline & & Até 1 & $\%$ & $\begin{array}{c}\text { Mais } \\
\text { de } \\
1 \mathrm{a} 2\end{array}$ & $\%$ & $\begin{array}{c}\text { Mais } \\
\text { de } \\
2 \text { a } 3\end{array}$ & $\%$ & $\begin{array}{c}\text { Mais } \\
\text { de } \\
3 \text { a } 5\end{array}$ & $\%$ & $\begin{array}{c}\text { Mais de } \\
5 \text { a } 10\end{array}$ & $\%$ & $\begin{array}{c}\text { Mais de } \\
10 \text { a } 20\end{array}$ & $\%$ & $\begin{array}{l}\text { Mais } \\
\text { de } 20\end{array}$ & $\%$ & $\begin{array}{l}\text { Sem } \\
\text { rend. }^{(2)}\end{array}$ & $\%$ \\
\hline \multicolumn{18}{|c|}{ RM DE FEIRA DE SANTANA/BA } \\
\hline Feira de Santana & 471446 & 168230 & $35,68 \%$ & 85424 & $18,12 \%$ & 23626 & $5,01 \%$ & 21302 & $4,52 \%$ & 14170 & $3,01 \%$ & 4228 & $0,90 \%$ & 1810 & $0,38 \%$ & 152658 & $32,38 \%$ \\
\hline S. G. dos Campos & 27787 & 11895 & $42,81 \%$ & 4001 & $14,40 \%$ & 751 & $2,70 \%$ & 475 & $1,71 \%$ & 372 & $1,34 \%$ & 53 & $0,19 \%$ & 82 & $0,29 \%$ & 10157 & $36,55 \%$ \\
\hline \multicolumn{18}{|c|}{ RM DO CARIRI/CE } \\
\hline Barbalha & 45923 & 22365 & $48,70 \%$ & 5253 & $11,44 \%$ & 1266 & $2,76 \%$ & 916 & $1,99 \%$ & 661 & $1,44 \%$ & 283 & $0,62 \%$ & 28 & $0,06 \%$ & 15152 & $32,99 \%$ \\
\hline Crato & 101955 & 44316 & $43,47 \%$ & 12843 & $12,60 \%$ & 3305 & $3,24 \%$ & 3046 & $2,99 \%$ & 2540 & $2,49 \%$ & 808 & $0,79 \%$ & 259 & $0,25 \%$ & 34837 & $34,17 \%$ \\
\hline Juazeiro do Norte & 208158 & 93553 & $44,94 \%$ & 26818 & $12,88 \%$ & 6530 & $3,14 \%$ & 4846 & $2,33 \%$ & 3849 & $1,85 \%$ & 1213 & $0,58 \%$ & 648 & $0,31 \%$ & 70700 & $33,96 \%$ \\
\hline Missão Velha & 28051 & 15083 & $53,77 \%$ & 2421 & $8,63 \%$ & 355 & $1,27 \%$ & 404 & $1,44 \%$ & 196 & $0,70 \%$ & 76 & $0,27 \%$ & 74 & $0,26 \%$ & 9443 & $33,66 \%$ \\
\hline \multicolumn{18}{|c|}{ RM SUDOESTE MARANHENSE/MA } \\
\hline Imperatriz & 205148 & 76107 & $37,10 \%$ & 36038 & $17,57 \%$ & 9719 & $4,74 \%$ & 8521 & $4,15 \%$ & 6518 & $3,18 \%$ & 1907 & $0,93 \%$ & 1004 & $0,49 \%$ & 65333 & $31,85 \%$ \\
\hline \multicolumn{18}{|c|}{ RM DE CAMPINA GRANDE/PB } \\
\hline Campina Grande & 326980 & 115998 & $35,48 \%$ & 52800 & $16,15 \%$ & 14626 & $4,47 \%$ & 13686 & $4,19 \%$ & 10766 & $3,29 \%$ & 4592 & $1,40 \%$ & 1842 & $0,56 \%$ & 112671 & $34,46 \%$ \\
\hline \multicolumn{18}{|c|}{ RAID PETROLINA E JUAZEIRO } \\
\hline Petrolina/PE & 240136 & 83106 & $34,61 \%$ & 40486 & $16,86 \%$ & 10756 & $4,48 \%$ & 8303 & $3,46 \%$ & 6522 & $2,72 \%$ & 2237 & $0,93 \%$ & 1047 & $0,44 \%$ & 87679 & $36,51 \%$ \\
\hline S.M da B. V /PE & 30996 & 15027 & $48,48 \%$ & 3066 & $9,89 \%$ & 712 & $2,30 \%$ & 365 & $1,18 \%$ & 290 & $0,93 \%$ & 53 & $0,17 \%$ & 34 & $0,11 \%$ & 11449 & $36,94 \%$ \\
\hline Casa Nova/BA & 52425 & 23807 & $45,41 \%$ & 5589 & $10,66 \%$ & 1086 & $2,07 \%$ & 717 & $1,37 \%$ & 284 & $0,54 \%$ & 79 & $0,15 \%$ & 88 & $0,17 \%$ & 20776 & $39,63 \%$ \\
\hline Juazeiro/BA & 162160 & 61153 & $37,71 \%$ & 25417 & $15,67 \%$ & 6268 & $3,87 \%$ & 4879 & $3,01 \%$ & 3393 & $2,09 \%$ & 1036 & $0,64 \%$ & 578 & $0,36 \%$ & 59436 & $36,65 \%$ \\
\hline
\end{tabular}

(1) Salário mínimo utilizado: $\mathrm{R} \$ 510,00$. (2) Inclusive as pessoas que recebiam somente em benefícios.

Fonte: Elaboração própria (2016) a partir de tabela base do Censo Demográfico 2010 - Resultados Gerais da Amostra por áreas de ponderação (IBGE, 2013). 
Tabela 4: Pessoas de 10 anos ou mais de idade, por classes de rendimento nominal mensal, no Grupo de controle 01 - 2010

\begin{tabular}{|c|c|c|c|c|c|c|c|c|c|c|c|c|c|c|c|c|c|}
\hline \multirow{3}{*}{$\begin{array}{l}\text { Unidades da } \\
\text { Federação, } \\
\text { municípios e } \\
\text { áreas de } \\
\text { ponderação }\end{array}$} & \multicolumn{17}{|c|}{ Pessoas de 10 anos ou mais de idade } \\
\hline & \multirow[b]{2}{*}{ Total } & \multicolumn{16}{|c|}{ Classes de rendimento nominal mensal (salário mínimo) ${ }^{(1)}$} \\
\hline & & Até 1 & $\%$ & $\begin{array}{c}\text { Mais } \\
\text { de } \\
1 \text { a } 2\end{array}$ & $\%$ & $\begin{array}{c}\text { Mais de } \\
2 \text { a } 3\end{array}$ & $\%$ & $\begin{array}{c}\text { Mais de } \\
3 \text { a } 5\end{array}$ & $\%$ & $\begin{array}{c}\text { Mais de } \\
5 \text { a } 10\end{array}$ & $\%$ & $\begin{array}{c}\text { Mais } \\
\text { de } \\
10 \mathrm{a} \\
20\end{array}$ & $\%$ & $\begin{array}{l}\text { Mais } \\
\text { de } 20\end{array}$ & $\%$ & $\begin{array}{c}\text { Sem } \\
\text { rend. }\end{array}$ & $\%$ \\
\hline \multicolumn{18}{|c|}{ RM AGRESTE/AL } \\
\hline Arapiraca & 177219 & 74290 & $41,92 \%$ & 22959 & $12,95 \%$ & 5935 & $3,35 \%$ & 4842 & $2,73 \%$ & 3614 & $2,04 \%$ & 968 & $0,55 \%$ & 253 & $0,14 \%$ & 64357 & $36,32 \%$ \\
\hline G. do Ponciano & 29374 & 11543 & $39,29 \%$ & 2120 & $7,22 \%$ & 287 & \begin{tabular}{|l|}
$0,98 \%$ \\
\end{tabular} & 149 & $0,51 \%$ & 141 & $0,48 \%$ & 29 & $0,10 \%$ & - & & 15107 & $51,43 \%$ \\
\hline \multicolumn{18}{|c|}{ VITÓRIA DA CONQUISTA /BA } \\
\hline V. da Conquista & 257616 & 104174 & $40,44 \%$ & 39734 & $15,42 \%$ & 11769 & \begin{tabular}{|l|}
$4,57 \%$ \\
\end{tabular} & 10217 & \begin{tabular}{|l|}
$3,97 \%$ \\
\end{tabular} & 6506 & $2,53 \%$ & 2564 & $1,00 \%$ & 930 & \begin{tabular}{|l|}
$0,36 \%$ \\
\end{tabular} & 81722 & $31,72 \%$ \\
\hline \multicolumn{18}{|c|}{ SOBRAL/CE } \\
\hline Sobral & 158843 & 67533 & $42,52 \%$ & 18058 & $11,37 \%$ & 5004 & \begin{tabular}{|l|}
$3,15 \%$ \\
\end{tabular} & 4082 & \begin{tabular}{|l|}
$2,57 \%$ \\
\end{tabular} & 2800 & $1,76 \%$ & 994 & \begin{tabular}{|l|}
$0,63 \%$ \\
\end{tabular} & 497 & \begin{tabular}{|l|}
$0,31 \%$ \\
\end{tabular} & 59876 & $37,70 \%$ \\
\hline \multicolumn{18}{|c|}{ MOSSORÓ/RN } \\
\hline Mossoró & 220583 & 73100 & $33,14 \%$ & 41048 & $18,61 \%$ & 12467 & $5,65 \%$ & 9464 & $4,29 \%$ & 6585 & $2,99 \%$ & 2369 & $1,07 \%$ & 875 & $0,40 \%$ & 74676 & $33,85 \%$ \\
\hline \multicolumn{18}{|c|}{ CARUARU/PE } \\
\hline Caruaru & 265208 & 100299 & $37,82 \%$ & 50848 & $19,17 \%$ & 12738 & $4,80 \%$ & 9614 & $3,63 \%$ & 5898 & $2,22 \%$ & 2275 & $0,86 \%$ & 885 & $0,33 \%$ & 82650 & $31,16 \%$ \\
\hline
\end{tabular}

(1) Salário mínimo utilizado: R\$ 510,00. (2) Inclusive as pessoas que recebiam somente em benefícios.

Fonte: Elaboração própria (2016) a partir de tabela base do Censo Demográfico 2010 - Resultados Gerais da Amostra por áreas de ponderação (IBGE, 2013). 
Tabela 5: Pessoas de 10 anos ou mais de idade, por classes de rendimento nominal mensal, no Grupo de controle 02 - 2010

\begin{tabular}{|c|c|c|c|c|c|c|c|c|c|c|c|c|c|c|c|c|c|}
\hline \multirow{3}{*}{$\begin{array}{l}\text { Unidades da } \\
\text { Federação, } \\
\text { municípios e } \\
\text { áreas de } \\
\text { ponderação }\end{array}$} & \multicolumn{17}{|c|}{ Pessoas de 10 anos ou mais de idade } \\
\hline & \multirow[b]{2}{*}{ Total } & \multicolumn{16}{|c|}{ Classes de rendimento nominal mensal (salário mínimo) ${ }^{(1)}$} \\
\hline & & Até 1 & $\%$ & $\begin{array}{c}\text { Mais } \\
\text { de } \\
1 \text { a } 2\end{array}$ & $\%$ & $\begin{array}{c}\text { Mais de } \\
2 \text { a } 3\end{array}$ & $\%$ & $\begin{array}{c}\text { Mais de } \\
3 \text { a } 5\end{array}$ & $\%$ & $\begin{array}{c}\text { Mais de } \\
5 \text { a } 10\end{array}$ & $\%$ & $\begin{array}{c}\text { Mais } \\
\text { de } \\
10 \mathrm{a} \\
20\end{array}$ & $\%$ & $\begin{array}{l}\text { Mais } \\
\text { de } 20\end{array}$ & $\%$ & $\begin{array}{c}\text { Sem } \\
\text { rend. } .^{(2)}\end{array}$ & $\%$ \\
\hline \multicolumn{18}{|c|}{ RM DE SALVADOR/BA } \\
\hline Camaçari & 203005 & 62266 & $30,67 \%$ & 38293 & $18,86 \%$ & 13406 & $6,60 \%$ & 9264 & $4,56 \%$ & 5143 & $2,53 \%$ & 1371 & $0,68 \%$ & 678 & $0,33 \%$ & 72584 & $35,75 \%$ \\
\hline Candeias & 70360 & 21133 & $30,04 \%$ & 12077 & $17,16 \%$ & 4416 & $6,28 \%$ & 2715 & $3,86 \%$ & 1114 & $1,58 \%$ & 269 & $0,38 \%$ & 117 & $0,17 \%$ & 28519 & $40,53 \%$ \\
\hline Dias d'Ávila & 54370 & 15391 & $28,31 \%$ & 9348 & $17,19 \%$ & 3666 & $6,74 \%$ & 2301 & $4,23 \%$ & 1151 & $2,12 \%$ & 270 & $0,50 \%$ & 72 & $0,13 \%$ & 22171 & $40,78 \%$ \\
\hline Lauro de Freitas & 138732 & 38744 & $27,93 \%$ & 26642 & $19,20 \%$ & 7896 & $5,69 \%$ & 6377 & $4,60 \%$ & 7327 & $5,28 \%$ & 4486 & $3,23 \%$ & 1939 & $1,40 \%$ & 45321 & $32,67 \%$ \\
\hline M. de S. João & 33386 & 11099 & $33,24 \%$ & 5391 & $16,15 \%$ & 1386 & $4,15 \%$ & 878 & $2,63 \%$ & 581 & $1,74 \%$ & 71 & $0,21 \%$ & 39 & $0,12 \%$ & 13941 & $41,76 \%$ \\
\hline Salvador & 2331049 & 653067 & $28,02 \%$ & 431044 & $18,49 \%$ & 144405 & $6,19 \%$ & 133246 & $5,72 \%$ & 119258 & $5,12 \%$ & 54024 & $2,32 \%$ & 27728 & $1,19 \%$ & 768277 & $32,96 \%$ \\
\hline S. F. do Conde & 27712 & 8025 & $28,96 \%$ & 5187 & $18,72 \%$ & 1482 & $5,35 \%$ & 758 & $2,73 \%$ & 414 & $1,49 \%$ & 65 & $0,23 \%$ & 91 & $0,33 \%$ & 11690 & $42,18 \%$ \\
\hline Simões Filho & 97655 & 31202 & $31,95 \%$ & 16724 & $17,13 \%$ & 5252 & $5,38 \%$ & 3423 & $3,51 \%$ & 1480 & $1,52 \%$ & 360 & $0,37 \%$ & 138 & $0,14 \%$ & 39076 & $40,01 \%$ \\
\hline Vera Cruz & 31486 & 12847 & $40,80 \%$ & 4176 & $13,26 \%$ & 1235 & $3,92 \%$ & 740 & $2,35 \%$ & 529 & $1,68 \%$ & 112 & $0,36 \%$ & 60 & $0,19 \%$ & 11787 & $37,44 \%$ \\
\hline \multicolumn{18}{|c|}{ RM DE FORTALEZA/CE } \\
\hline Aquiraz & 61133 & 27317 & $44,68 \%$ & 6915 & $11,31 \%$ & 1610 & $2,63 \%$ & 1038 & $1,70 \%$ & 479 & $0,78 \%$ & 208 & $0,34 \%$ & 90 & $0,15 \%$ & 23476 & $38,40 \%$ \\
\hline Cascavel & 56077 & 27223 & $48,54 \%$ & 5995 & $10,69 \%$ & 1067 & $1,90 \%$ & 1014 & $1,81 \%$ & 360 & $0,64 \%$ & 153 & $0,27 \%$ & 29 & $0,05 \%$ & 20238 & $36,09 \%$ \\
\hline Caucaia & 271058 & 102346 & $37,76 \%$ & 42705 & $15,75 \%$ & 9947 & $3,67 \%$ & 6563 & $2,42 \%$ & 3750 & $1,38 \%$ & 786 & $0,29 \%$ & 251 & $0,09 \%$ & 104709 & $38,63 \%$ \\
\hline Eusébio & 38040 & 15336 & $40,32 \%$ & 5729 & $15,06 \%$ & 1047 & $2,75 \%$ & 786 & $2,07 \%$ & 860 & $2,26 \%$ & 491 & $1,29 \%$ & 310 & $0,81 \%$ & 13481 & $35,44 \%$ \\
\hline Fortaleza & 2106309 & 673079 & $31,96 \%$ & 378968 & $17,99 \%$ & 111255 & $5,28 \%$ & 101112 & $4,80 \%$ & 90426 & $4,29 \%$ & 40895 & $1,94 \%$ & 21527 & $1,02 \%$ & 689046 & $32,71 \%$ \\
\hline Horizonte & 45754 & 20338 & $44,45 \%$ & 6853 & $14,98 \%$ & 1123 & $2,45 \%$ & 561 & $1,23 \%$ & 426 & $0,93 \%$ & 67 & $0,15 \%$ & - & & 16387 & $35,82 \%$ \\
\hline Itaitinga & 29992 & 11147 & $37,17 \%$ & 3275 & $10,92 \%$ & 767 & $2,56 \%$ & 230 & $0,77 \%$ & 195 & $0,65 \%$ & 25 & $0,08 \%$ & 23 & $0,08 \%$ & 14329 & $47,78 \%$ \\
\hline Maracanaú & 176199 & 64126 & $36,39 \%$ & 32303 & $18,33 \%$ & 6886 & $3,91 \%$ & 3890 & $2,21 \%$ & 1642 & $0,93 \%$ & 224 & $0,13 \%$ & 113 & $0,06 \%$ & 7015 & $38,03 \%$ \\
\hline Maranguape & 94855 & 41487 & $43,74 \%$ & 11852 & $12,49 \%$ & 2005 & $2,11 \%$ & 1399 & $1,47 \%$ & 632 & $0,67 \%$ & 132 & $0,14 \%$ & 23 & $0,02 \%$ & 37325 & $39,35 \%$ \\
\hline Pacajus & 51595 & 24175 & $46,85 \%$ & 7324 & $14,20 \%$ & 1408 & $2,73 \%$ & 783 & $1,52 \%$ & 492 & $0,95 \%$ & 116 & $0,22 \%$ & 68 & $0,13 \%$ & 17229 & $33,39 \%$ \\
\hline Pacatuba & 59760 & 22434 & $37,54 \%$ & 10212 & $17,09 \%$ & 1835 & $3,07 \%$ & 959 & $1,60 \%$ & 555 & $0,93 \%$ & 128 & $0,21 \%$ & 32 & $0,05 \%$ & 23606 & $39,50 \%$ \\
\hline Paracuru & 26466 & 12572 & $47,50 \%$ & 2663 & $10,06 \%$ & 641 & $2,42 \%$ & 379 & $1,43 \%$ & 351 & $1,33 \%$ & 95 & $0,36 \%$ & 10 & $0,04 \%$ & 9756 & $36,86 \%$ \\
\hline S.G. do Amar. & 36737 & 15776 & $42,94 \%$ & 4622 & $12,58 \%$ & 951 & $2,59 \%$ & 589 & $1,60 \%$ & 235 & $0,64 \%$ & 65 & $0,18 \%$ & 50 & $0,14 \%$ & 14448 & $39,33 \%$ \\
\hline Trairi & 42152 & 19121 & $45,36 \%$ & 3156 & $7,49 \%$ & 698 & $1,66 \%$ & 405 & $0,96 \%$ & 179 & $0,42 \%$ & 66 & $0,16 \%$ & 10 & $0,02 \%$ & 18518 & $43,93 \%$ \\
\hline
\end{tabular}

(1) Salário mínimo utilizado: $R \$ 510,00$. (2) Inclusive as pessoas que recebiam somente em benefícios.

Fonte: Elaboração própria (2016) a partir de tabela base do Censo Demográfico 2010 - Resultados Gerais da Amostra por áreas de ponderação (IBGE, 2013). 
Tabela 6: Pessoas de 10 anos ou mais de idade, por classes de rendimento nominal mensal, no Grupo de controle 02 (RM de Recife/PE)- 2010

\begin{tabular}{|c|c|c|c|c|c|c|c|c|c|c|c|c|c|c|c|c|c|}
\hline \multirow{3}{*}{$\begin{array}{l}\text { Unidades da } \\
\text { Federação, } \\
\text { municípios e } \\
\text { áreas de } \\
\text { ponderação }\end{array}$} & \multicolumn{17}{|c|}{ Pessoas de 10 anos ou mais de idade } \\
\hline & \multicolumn{17}{|c|}{ Classes de rendimento nominal mensal (salário mínimo) ${ }^{(1)}$} \\
\hline & Total & Até 1 & $\%$ & $\begin{array}{l}\text { Mais } \\
\text { de } \\
1 \text { a } 2\end{array}$ & $\%$ & $\begin{array}{c}\text { Mais de } \\
2 \text { a } 3\end{array}$ & $\%$ & $\begin{array}{c}\text { Mais de } \\
3 \text { a } 5\end{array}$ & $\%$ & $\begin{array}{c}\text { Mais de } \\
5 \text { a } 10\end{array}$ & $\%$ & $\begin{array}{c}\text { Mais } \\
\text { de } \\
10 \mathrm{a} \\
20 \\
\end{array}$ & $\%$ & $\begin{array}{l}\text { Mais } \\
\text { de } 20\end{array}$ & $\%$ & $\begin{array}{l}\text { Sem } \\
\text { rend. }{ }^{(2)}\end{array}$ & $\%$ \\
\hline
\end{tabular}

\section{RM DE RECIFE/PE}

\begin{tabular}{|c|c|c|c|c|c|c|c|c|c|c|c|c|c|c|c|c|c|}
\hline \multicolumn{18}{|c|}{ RM DE RECIFE/PE } \\
\hline Abreu e Lima & 80277 & 28775 & $35,84 \%$ & 14195 & $17,68 \%$ & 3735 & $4,65 \%$ & 2291 & $2,85 \%$ & 1162 & $1,45 \%$ & 115 & $0,14 \%$ & 22 & $0,03 \%$ & 29982 & $37,35 \%$ \\
\hline C. de S. Agost. & 155710 & 50160 & $32,21 \%$ & 27730 & $17,81 \%$ & 7372 & $4,73 \%$ & 4684 & $3,01 \%$ & 2015 & $1,29 \%$ & 502 & $0,32 \%$ & 232 & $0,15 \%$ & 63016 & $40,47 \%$ \\
\hline Camaragibe & 123483 & 42421 & $34,35 \%$ & 22152 & $17,94 \%$ & 5210 & $4,22 \%$ & 3537 & $2,86 \%$ & 1886 & $1,53 \%$ & 600 & $0,49 \%$ & 199 & $0,16 \%$ & 47479 & $38,45 \%$ \\
\hline Igarassu & 85835 & 31062 & $36,19 \%$ & 14686 & $17,11 \%$ & 3594 & $4,19 \%$ & 2136 & $2,49 \%$ & 912 & $1,06 \%$ & 144 & $0,17 \%$ & 50 & $0,06 \%$ & 33250 & $38,74 \%$ \\
\hline Ipojuca & 65231 & 22016 & $33,75 \%$ & 10631 & $16,30 \%$ & 2489 & $3,82 \%$ & 1340 & $2,05 \%$ & 727 & $1,12 \%$ & 320 & $0,49 \%$ & 51 & $0,08 \%$ & 27658 & $42,40 \%$ \\
\hline Jab. dos Guar. & 547455 & 181349 & $33,13 \%$ & 95118 & $17,37 \%$ & 28009 & $5,12 \%$ & 20412 & $3,73 \%$ & 15126 & $2,76 \%$ & 6604 & $1,21 \%$ & 2535 & $0,46 \%$ & 198301 & $36,22 \%$ \\
\hline Moreno & 47884 & 19609 & $40,95 \%$ & 5856 & $12,23 \%$ & 1373 & $2,87 \%$ & 908 & $1,90 \%$ & 494 & $1,03 \%$ & 103 & $0,21 \%$ & 45 & $0,09 \%$ & 19496 & $40,71 \%$ \\
\hline Olinda & 325443 & 99035 & $30,43 \%$ & 58087 & $17,85 \%$ & 19305 & $5,93 \%$ & 16144 & $4,96 \%$ & 11645 & $3,58 \%$ & 3829 & $1,18 \%$ & 1436 & $0,44 \%$ & 115962 & $35,63 \%$ \\
\hline Paulista & 257939 & 79244 & $30,72 \%$ & 49837 & $19,32 \%$ & 15779 & $6,12 \%$ & 11777 & $4,57 \%$ & 6536 & $2,53 \%$ & 1390 & $0,54 \%$ & 345 & $0,13 \%$ & 93032 & $36,07 \%$ \\
\hline Recife & 1336198 & 389953 & $29,18 \%$ & 220664 & $16,51 \%$ & 74271 & $5,56 \%$ & 72372 & $5,42 \%$ & 74827 & $5,60 \%$ & 37461 & $2,80 \%$ & 24598 & $1,84 \%$ & 442052 & $33,08 \%$ \\
\hline S. L. da Mata & 86662 & 34421 & $39,72 \%$ & 12242 & $14,13 \%$ & 3078 & $3,55 \%$ & 1966 & $2,27 \%$ & 995 & $1,15 \%$ & 273 & $0,32 \%$ & 70 & $0,08 \%$ & 33617 & $38,79 \%$ \\
\hline
\end{tabular}

(1) Salário mínimo utilizado: $\mathrm{R} \$ 510,00$. (2) Inclusive as pessoas que recebiam somente em benefícios.

Fonte: Elaboração própria (2016) a partir de tabela base do Censo Demográfico 2010 - Resultados Gerais da Amostra por áreas de ponderação (IBGE, 2013). 
Gráfico 3: Pessoas de 10 anos ou mais de idade, por classes de rendimento nominal mensal nas RM's e cidades selecionadas -

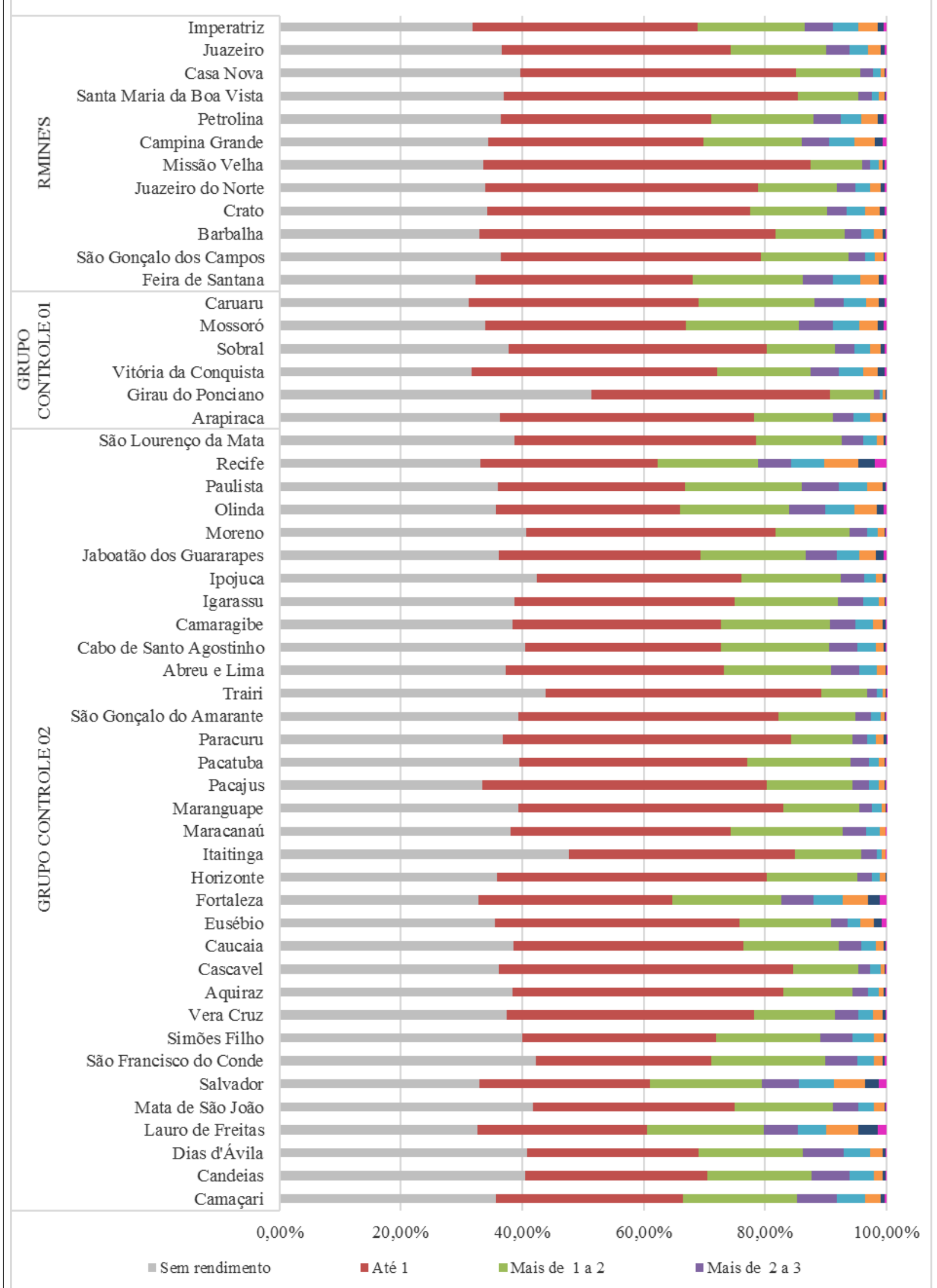

Fonte: Elaboração própria (2016) a partir de tabela base do Censo Demográfico 2010 - Resultados Gerais da Amostra por áreas de ponderação (IBGE, 2013). 
Por fim, num terceiro nível, para avaliar a distribuição de renda na escala municipal foram utilizados os dados do censo de 2010 do IBGE, especificamente o V005 - Valor do rendimento nominal médio mensal das pessoas responsáveis por domicílios particulares permanentes (com e sem rendimento), apresentado na tabela "características da População e dos Domicílios". Como os dados são desvinculados das bases cartográficas, foi necessário o uso de ferramentas de geoprocessamento que permitiram observar a distribuição dos dados por setores censitários, resultando uma série de mapas que são apresentados nas figuras 17 a 29.

Numa análise geral de todas as RM'S e municípios que compõem este estudo, a primeira observação é a já comentada concentração de renda nas cidades-sede das RM'S. No primeiro grupo destaco a exceção da RM do Cariri/CE (Figura 19) e da RAID PetrolinaJuazeiro (Figura 22). O Crajubar possui uma característica de conurbação que já ultrapassa a questão meramente espacial: as três cidades dividem, embora não de forma igualitária, as ofertas de emprego e geração de renda com destaque para os maiores rendimentos no Crato e no Juazeiro do Norte/CE. No segundo caso, embora haja a predominância de maiores rendas em Petrolina/PE, Juazeiro/BA também possui indicadores maiores do que os demais municípios integrantes da RAID. Percebemos um nível de "conurbação" diferente das demais RMINE's desse grupo, pois percebe-se que Feira de Santana;/BA e Campina Grande/PB concentram os valores de rendimento nominal em relação aos demais municípios de seu entorno. Ou seja, temos dois tipos de RMINE's: (1) aquelas em que existe uma relação forte de independência entre dois ou mais municípios e (2) aquelas em que a cidade-sede passa por um processo de crescimento que extravasa seus limites municipais.

Entretanto, não posso gerar um juízo de valor a partir dessa análise, pois nos grupos de controle parece haver uma relação muito mais forte do segundo caso, quando uma cidade polariza às demais a sua volta. No Grupo de Controle 02 , RM's das capitais, numa relação historicamente consolidada, as maiores concentrações de renda se distribuem ao longo do litoral dos municípios. Na RM de Fortaleza/CE (Figura 29) esse "espraiamento" ainda é bastante restrito aos municípios ao leste da capital: Eusébio e Aquiraz. $\mathrm{Na} \mathrm{RM}$ de Salvador/BA (Figura 28), o mesmo acontece em direção à costa norte, onde existem diversos condomínios habitacionais e turísticos de alto e médio padrão. Na RM de Recife/PE (Figura 30), além desta predominância litorânea há destaque ao eixo que liga a capital ao município de Camaragibe, que não possui fronteira marítima, mas conta com uma série de chácaras e residências de alto padrão. 
Figura 18: Mapa de distribuição de renda (V005) por setor censitário da RM de Feira de Santana/BA.

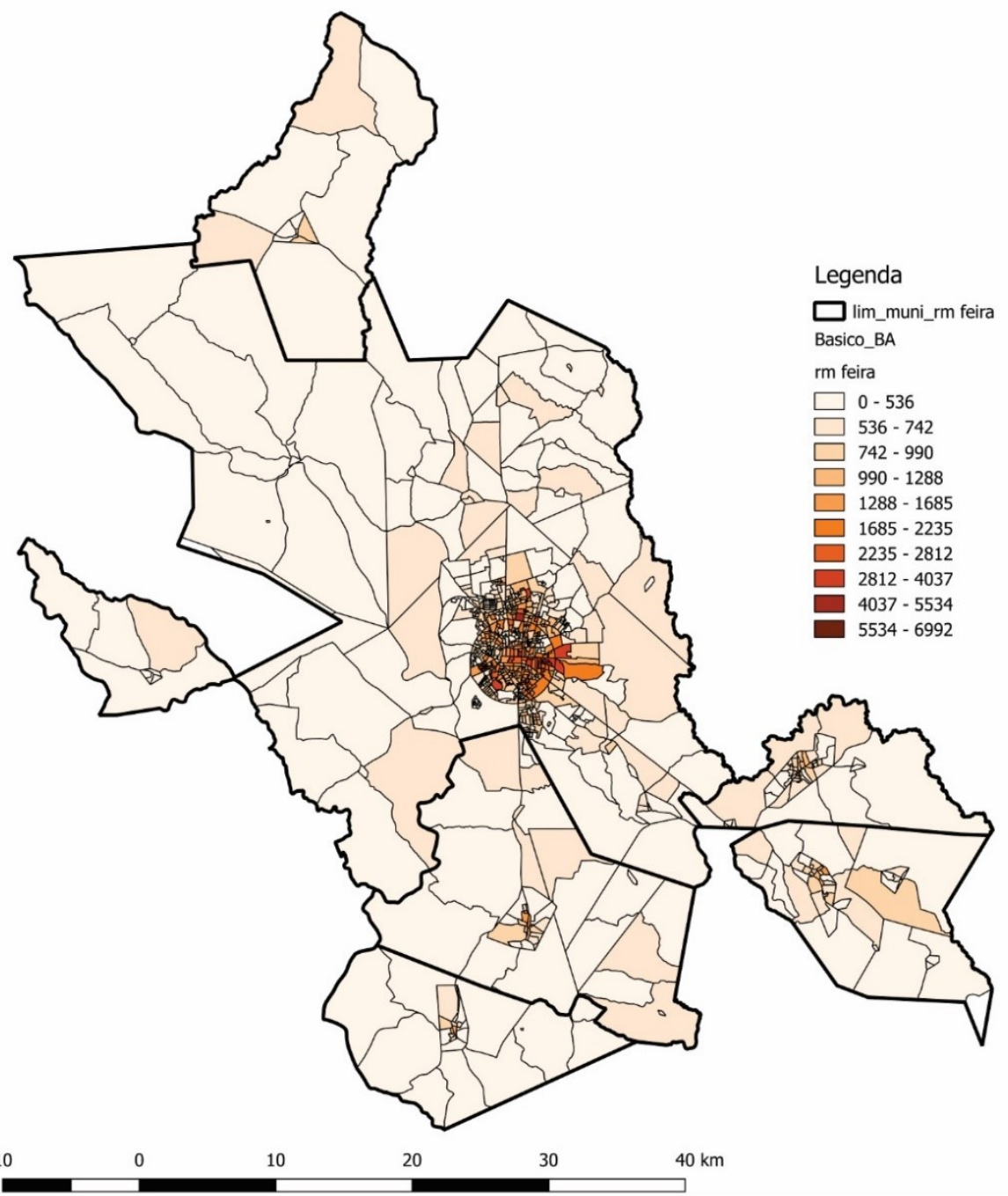

MAPA DE DISTRIBUIÇÃO DE RENDA POR SETOR CENSITÁRIO NA RM FEIRA DE SANTANA/BA

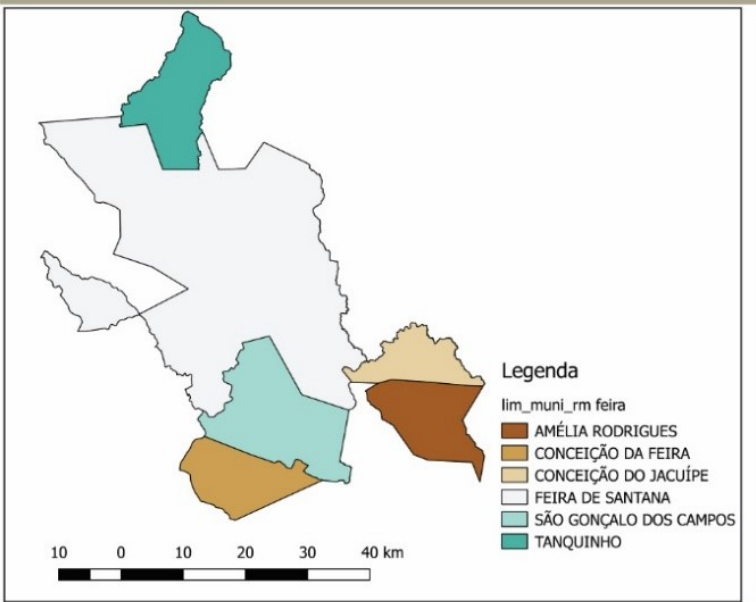

MAPA-CHAVE: MUNICÍPIOS CONSTITUINTES DA RM FEIRA DE SANTANA BA

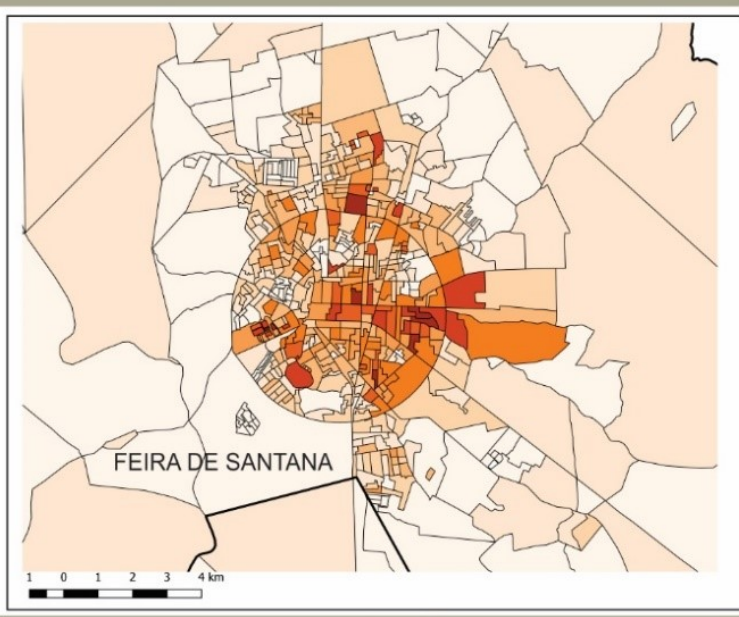

DETALHE DA DISTRIBUICÃO DE RENDA POR SETOR CENSITÁRIO NA RM FEIRA DE SANTANA/BA

Fonte: Elaboração própria (2016) a partir da Base Cartográfica do IBGE (2010) e dados do censo de 2010. 
Figura 19: Mapa de distribuição de renda (V005) por setor censitário da RM Cariri/CE.

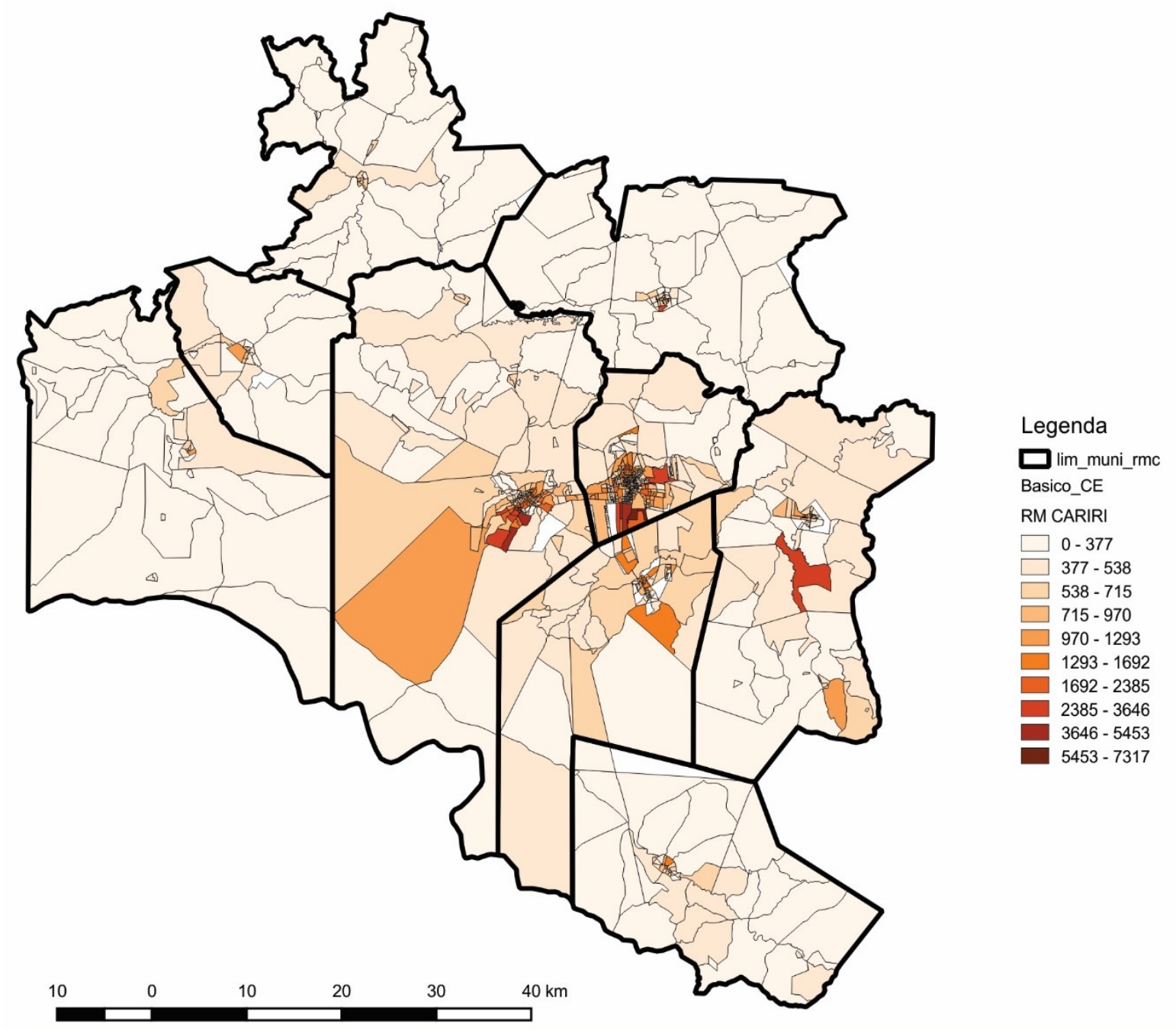

MAPA DE DISTRIBUIÇÃO DE RENDA POR SETOR CENSITÁRIO NA RM CARIRI/CE

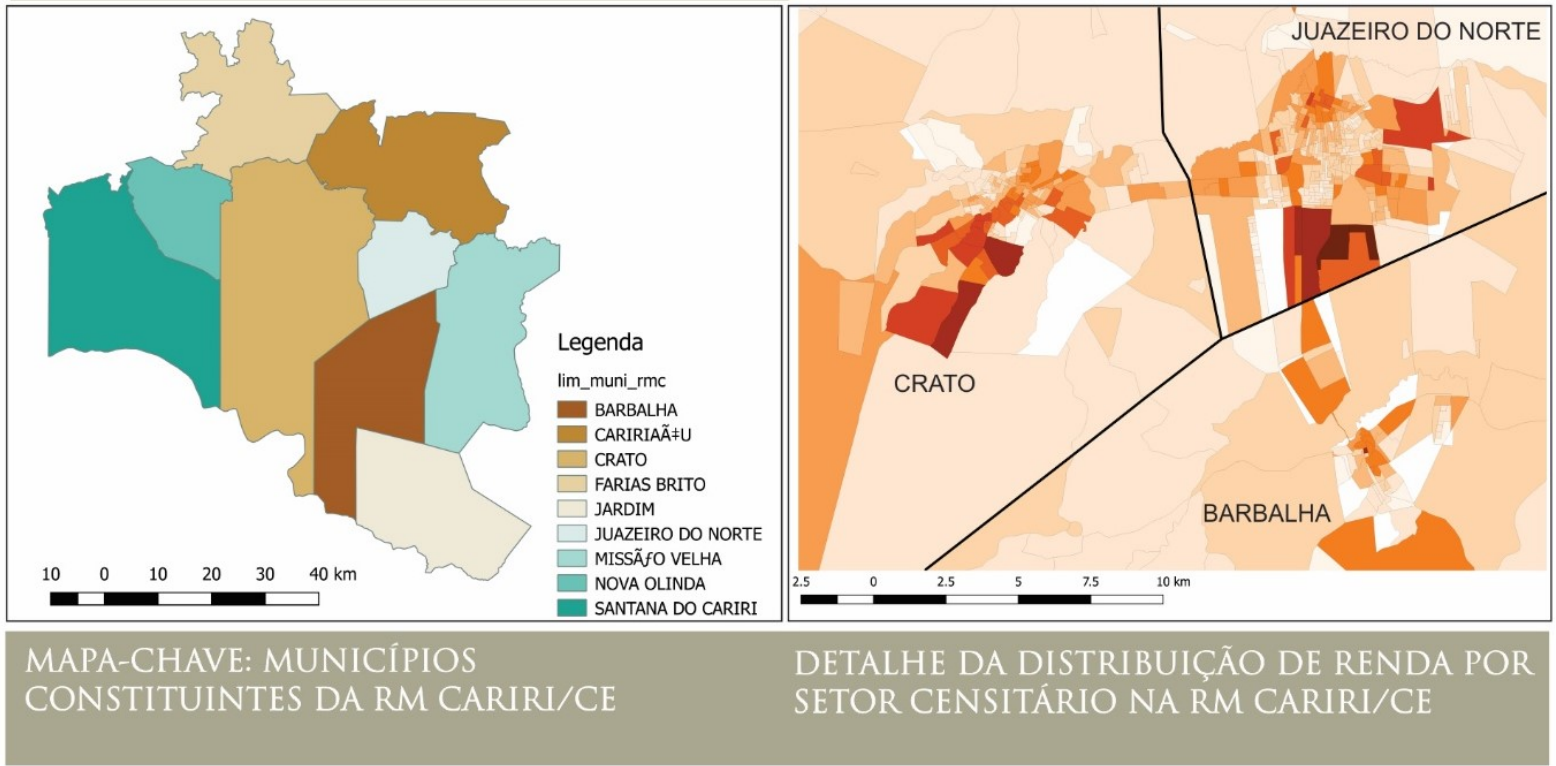

Fonte: Elaboração própria (2016) a partir da Base Cartográfica do IBGE (2010) e dados do censo de 2010. 
Figura 20: Mapa de distribuição de renda (V005) por setor censitário da RM Sudoeste Maranhense/MA.

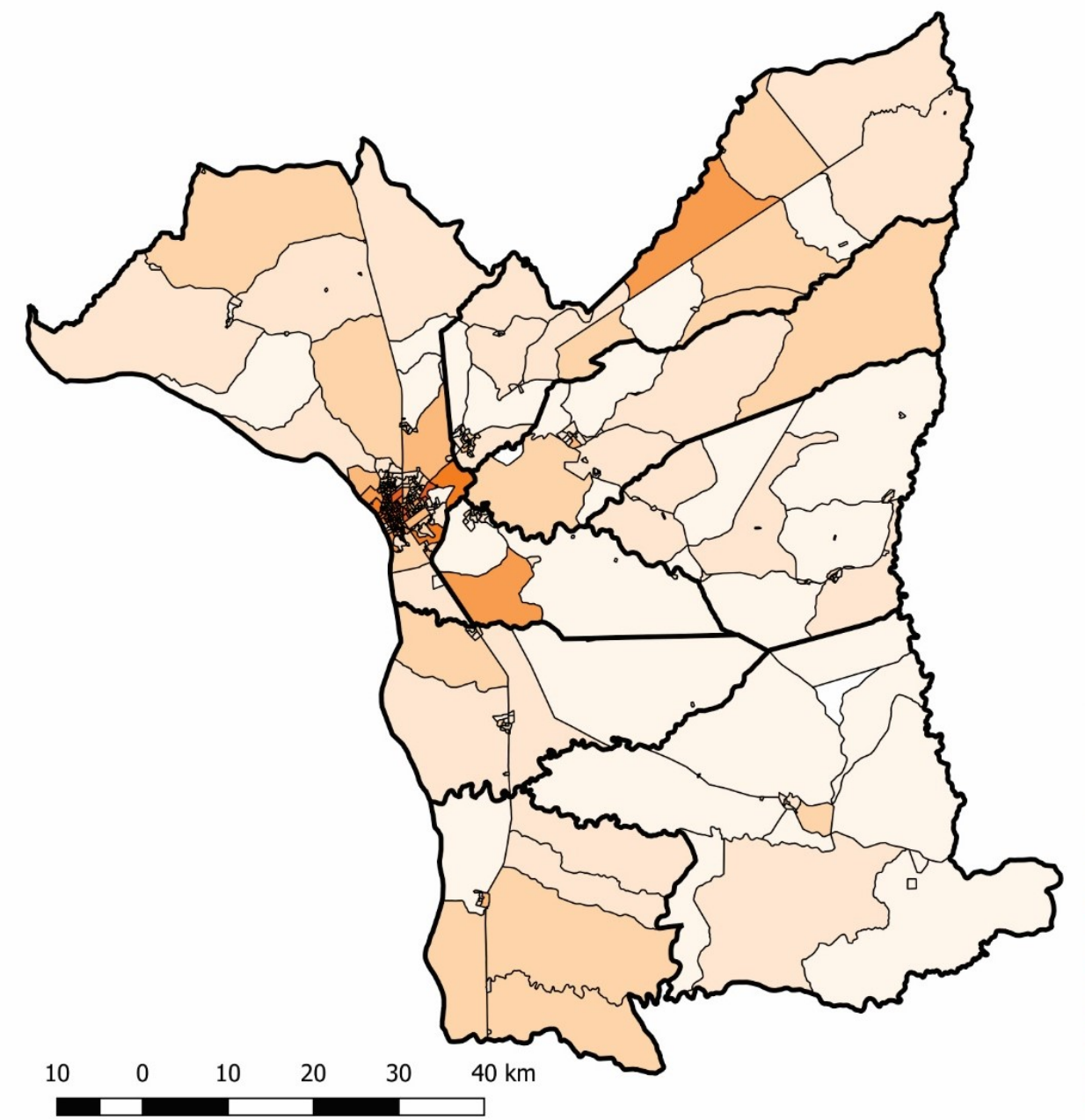

Legenda

Basico_MA

$\square$ lim_munip_rm imp RM IMPERATRIZ

$\square \quad 0-410$
$\square \quad 410-605$
$\square \quad 605-839$
$\square \quad 839-1118$
$\square \quad 1118-1414$
$\square 1414-1830$
$\square \quad 1830-2418$
$2418-3296$
$\square 3296-4751$
$\square 751-6498$

MAPA DE DISTRIBUIÇÃO DE RENDA POR SETOR CENSITÁRIO NA RM SUDOESTE MARANHENSE/MA

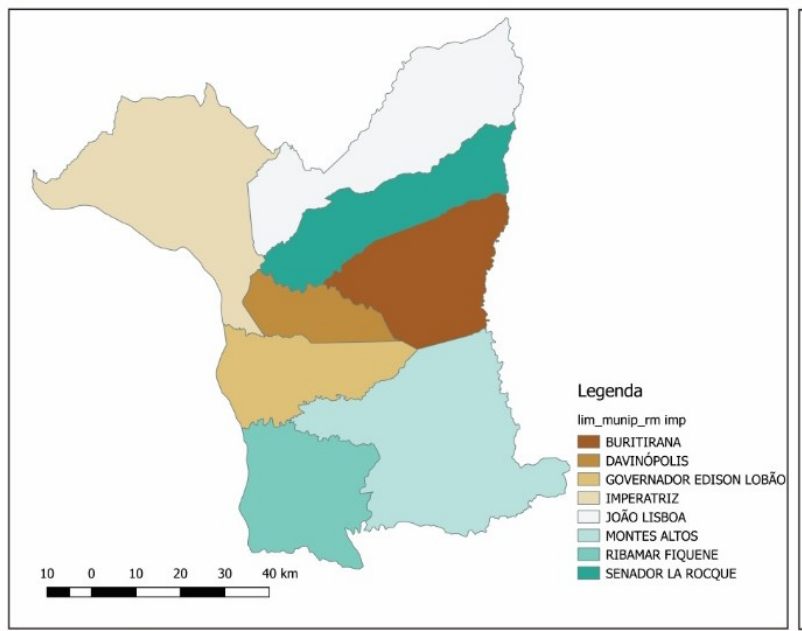

MAPA-CHAVE: MUNICÍPIOS

CONSTITUINTES DA RM SUDOESTE

MARANHENSE/MA

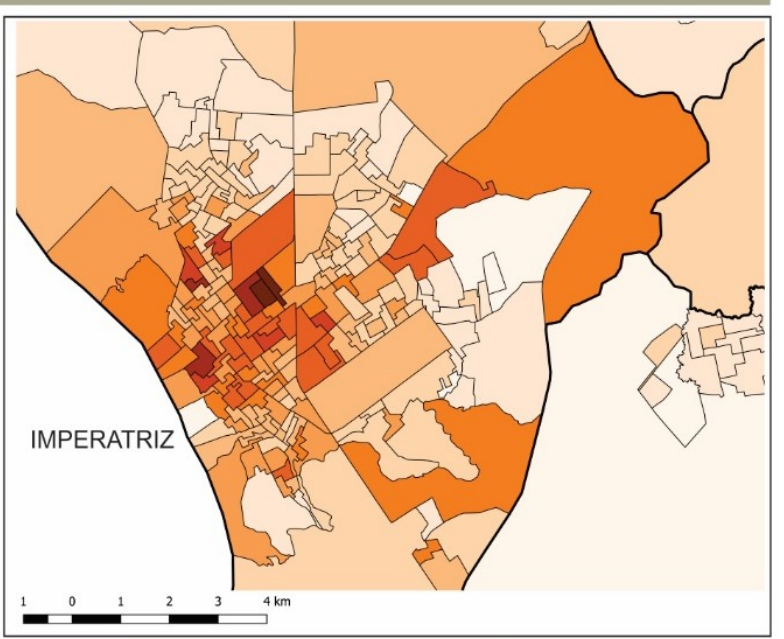

DETALHE DA DISTRIBUIÇÃO DE RENDA POR SETOR CENSITÁRIO NA RM SUDOESTE MARANHENSE/MA

Fonte: Elaboração própria (2016) a partir da Base Cartográfica do IBGE (2010) e dados do censo de 2010. 
Figura 21: Mapa de distribuição de renda (V005) por setor censitário da RM Campina Grande/PB.

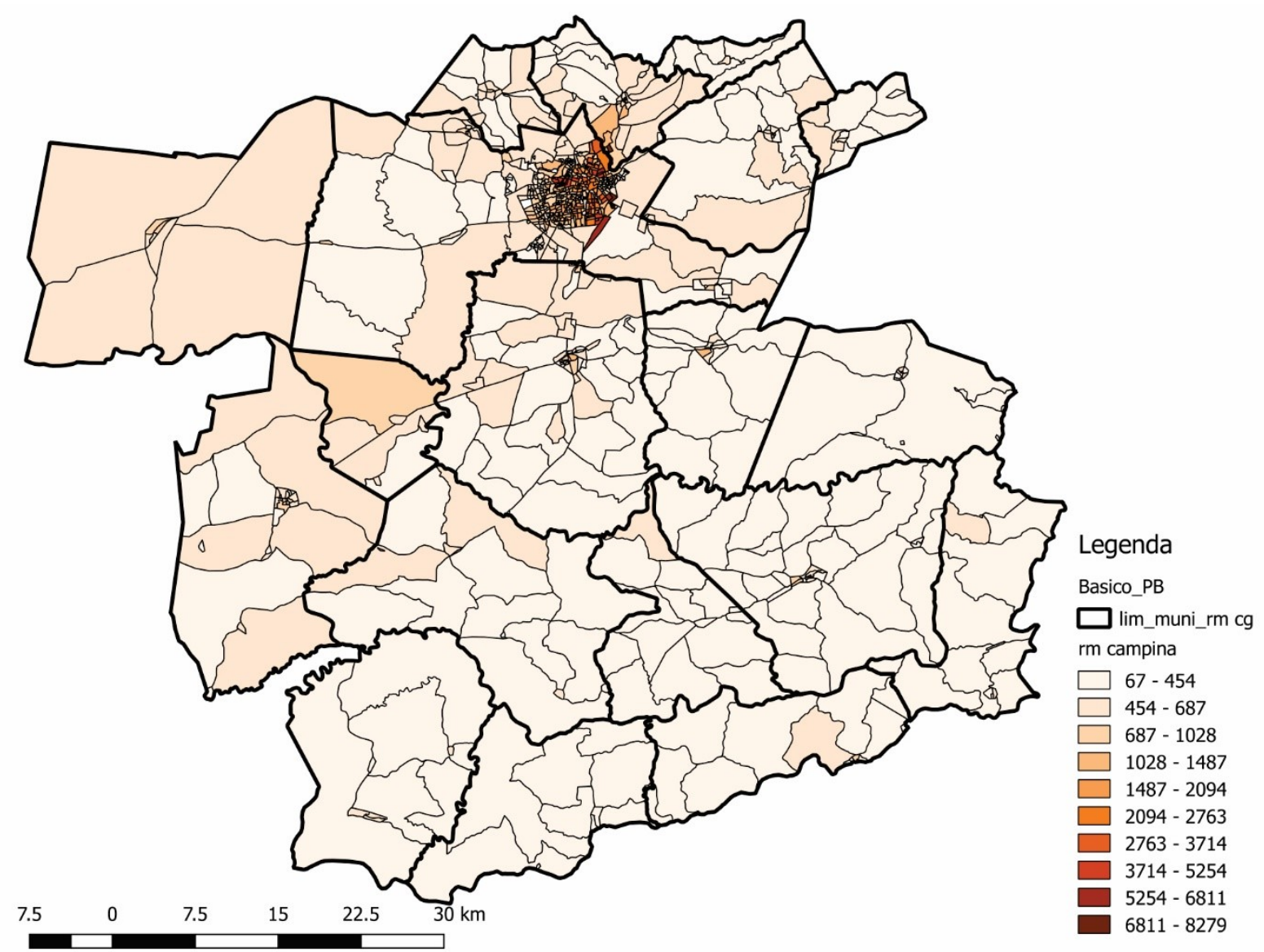

\section{MAPA DE DISTRIBUIÇÃO DE RENDA POR SETOR CENSITÁRIO NA RM CAMPINA GRANDE/PB}

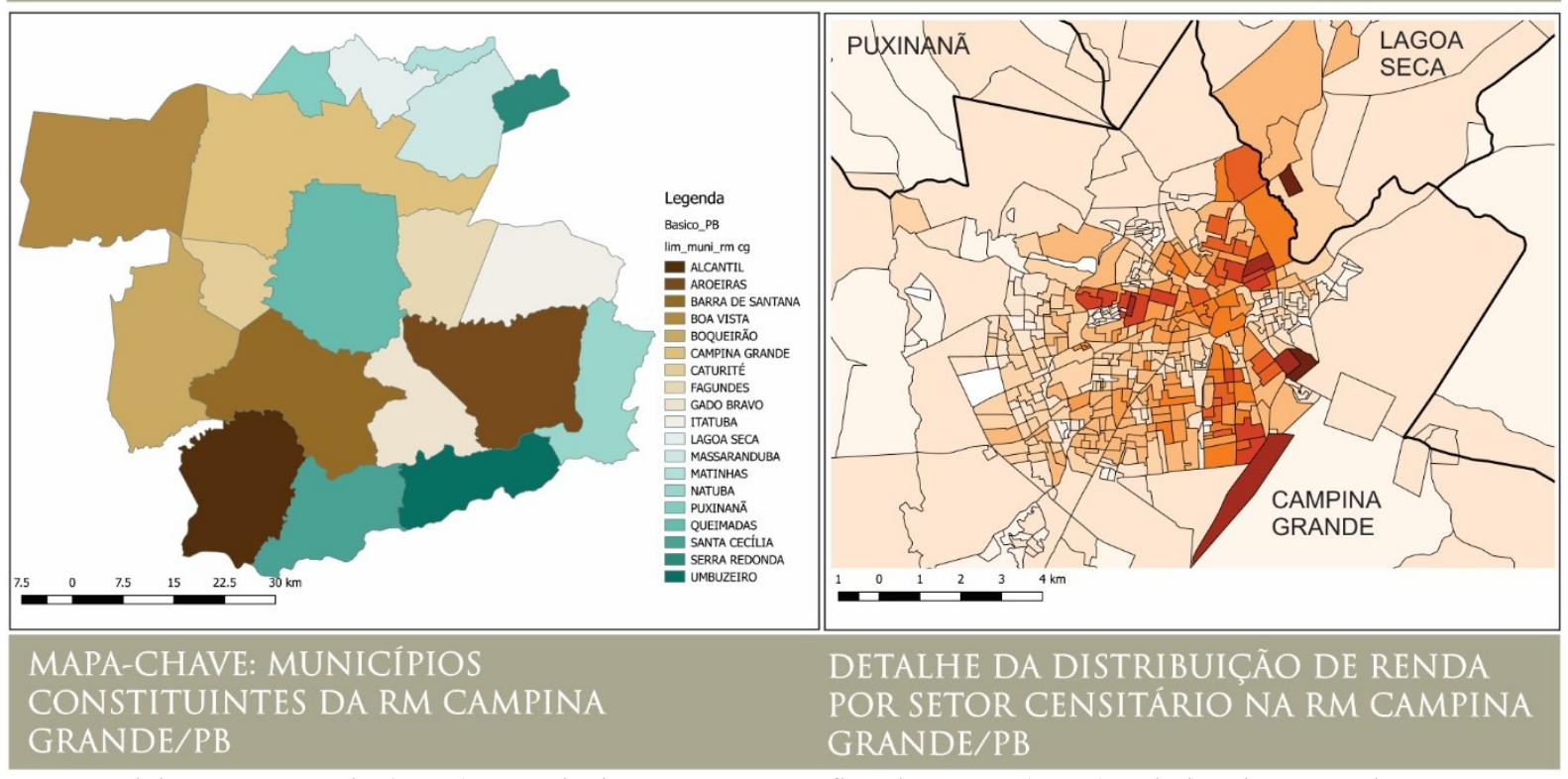

Fonte: Elaboração própria (2016) a partir da Base Cartográfica do IBGE (2010) e dados do censo de 2010. 
Figura 22: Mapa de distribuição de renda (V005) por setor censitário da RAID de Petrolina/Juazeiro.

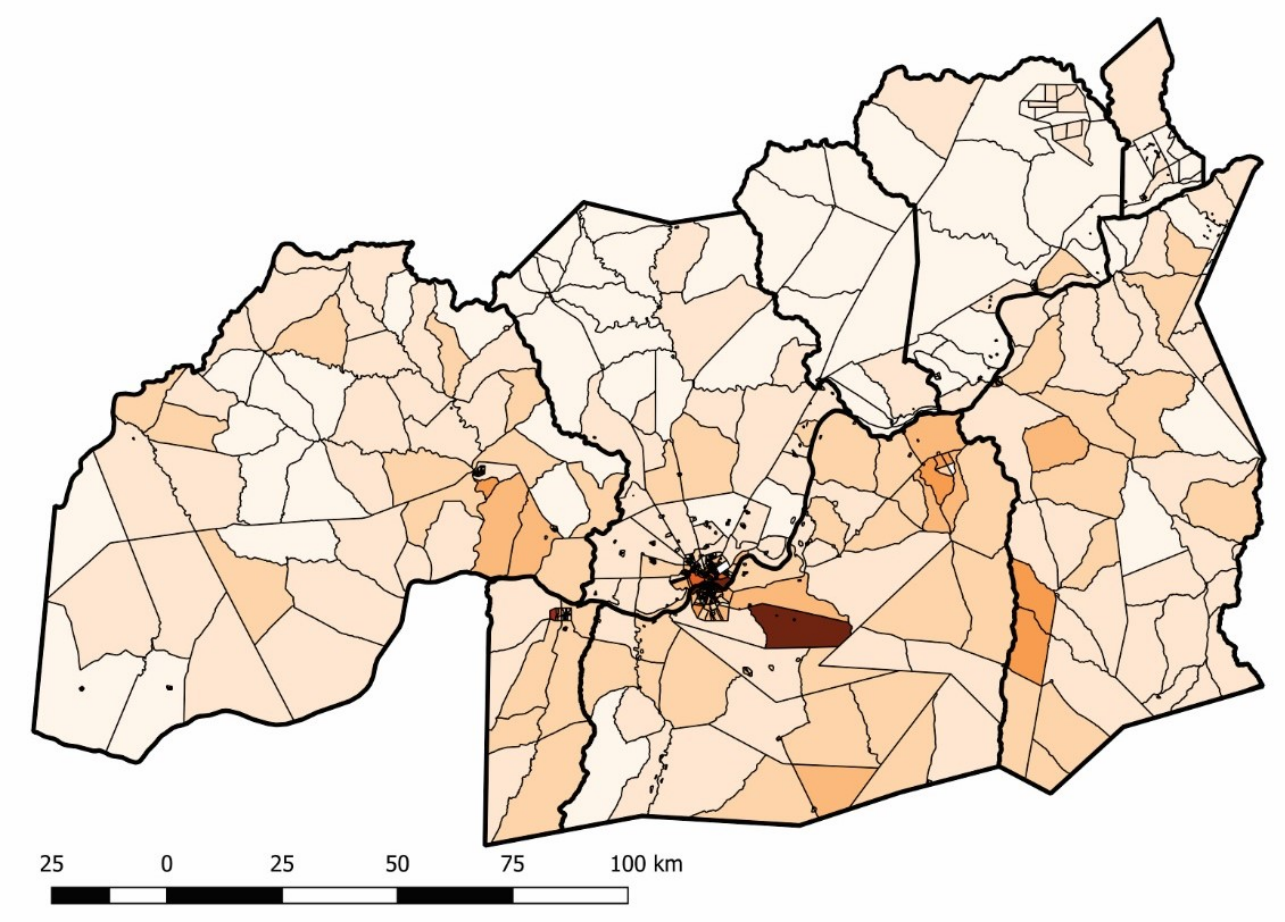

Legenda

Basico_PE

Basico_BA

$\square$ lim_mun_raid pe

$\square$ limites_mun_raid ba

RAID -PE novo

$\square$ - 393

$\square 393-594$

$\square 94-843$

$\square$ 843- 1144

$\square$ 1144- 1577

$\square 1577-2136$

$2136-3022$

$\square 3022-4144$

प $4144-5408$

$5408-6873$

RAID -BA c tabela

$\square 0$ - 269

$\square 269-399$

$\square 399-524$

$\square 24-691$

$691-932$

$\square 932-1254$

$\square 1254-1613$

$\square 1613-1986$

$1986-2932$

$2932-4879$

\section{MAPA DE DISTRIBUIČ̃̃ DE RENDA POR SETOR CENSITÁRIO NA RAID DE PETROLINA/JUAZEIRO}

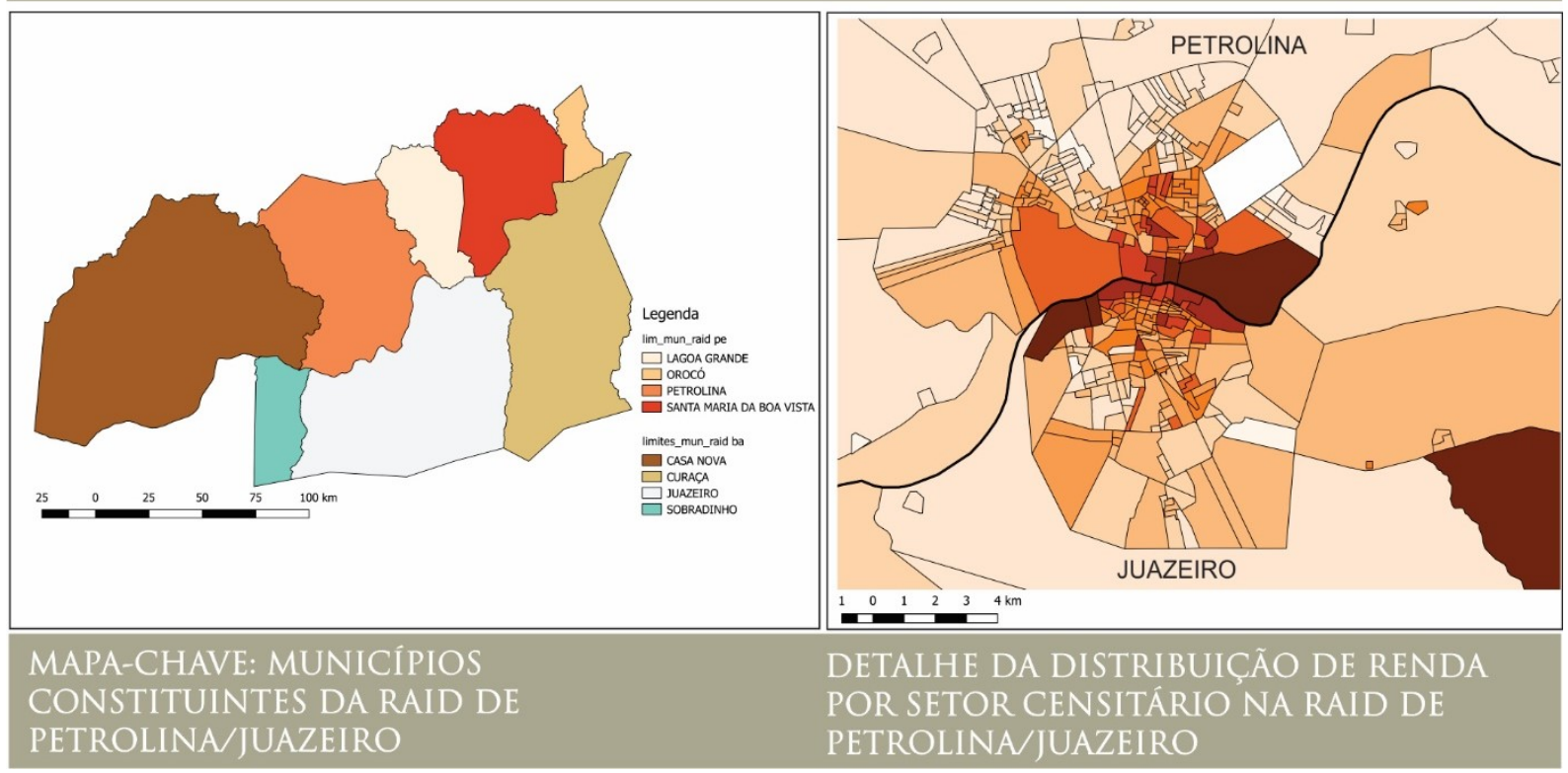

Fonte: Elaboração própria (2016) a partir da Base Cartográfica do IBGE (2010) e dados do censo de 2010. 
Figura 23: Mapa de distribuição de renda (V005) por setor censitário da RM Agreste/AL.

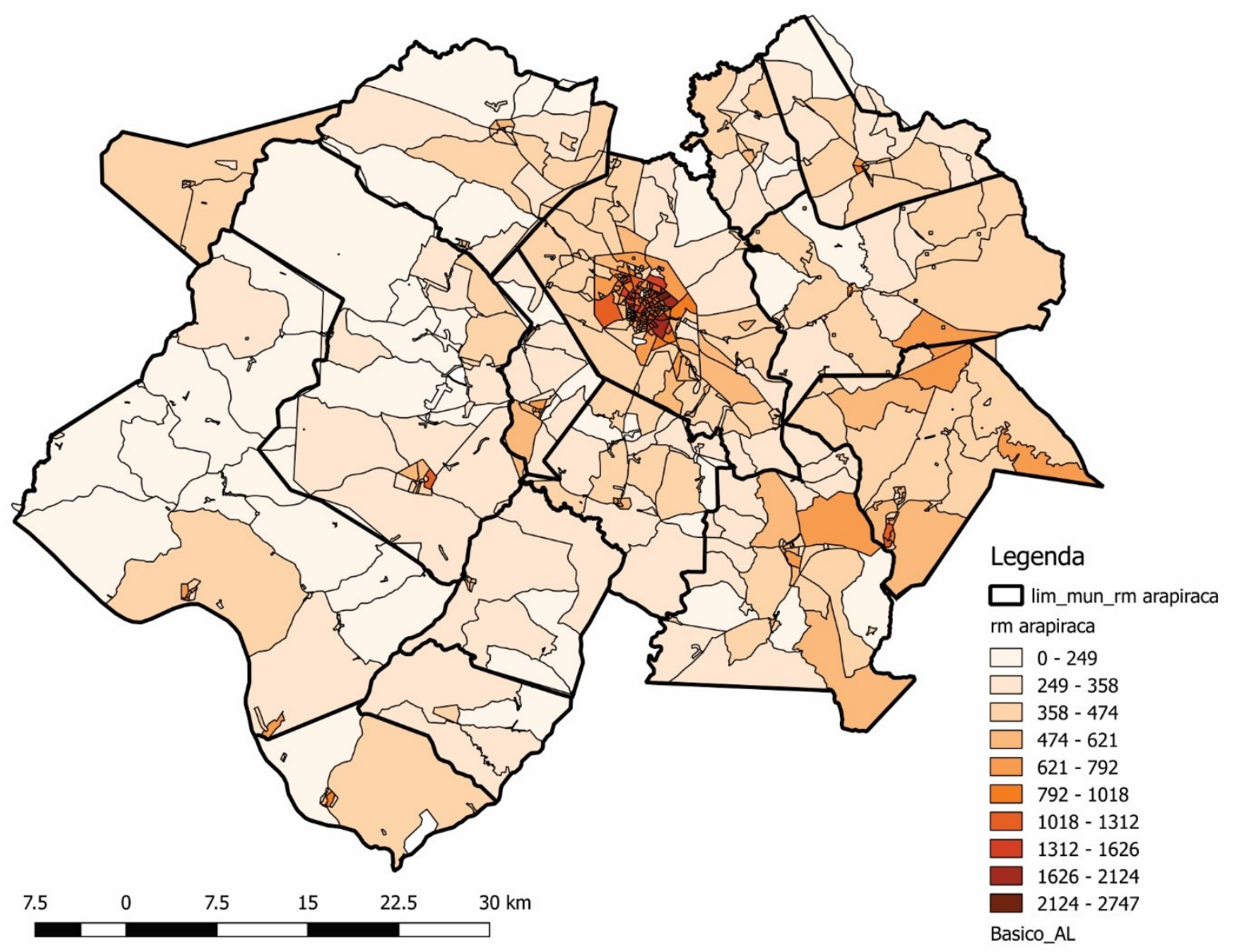

MAPA DE DISTRIBUIÇÃO DE RENDA POR SETOR CENSITÁRIO
NA RM AGRESTE/AL

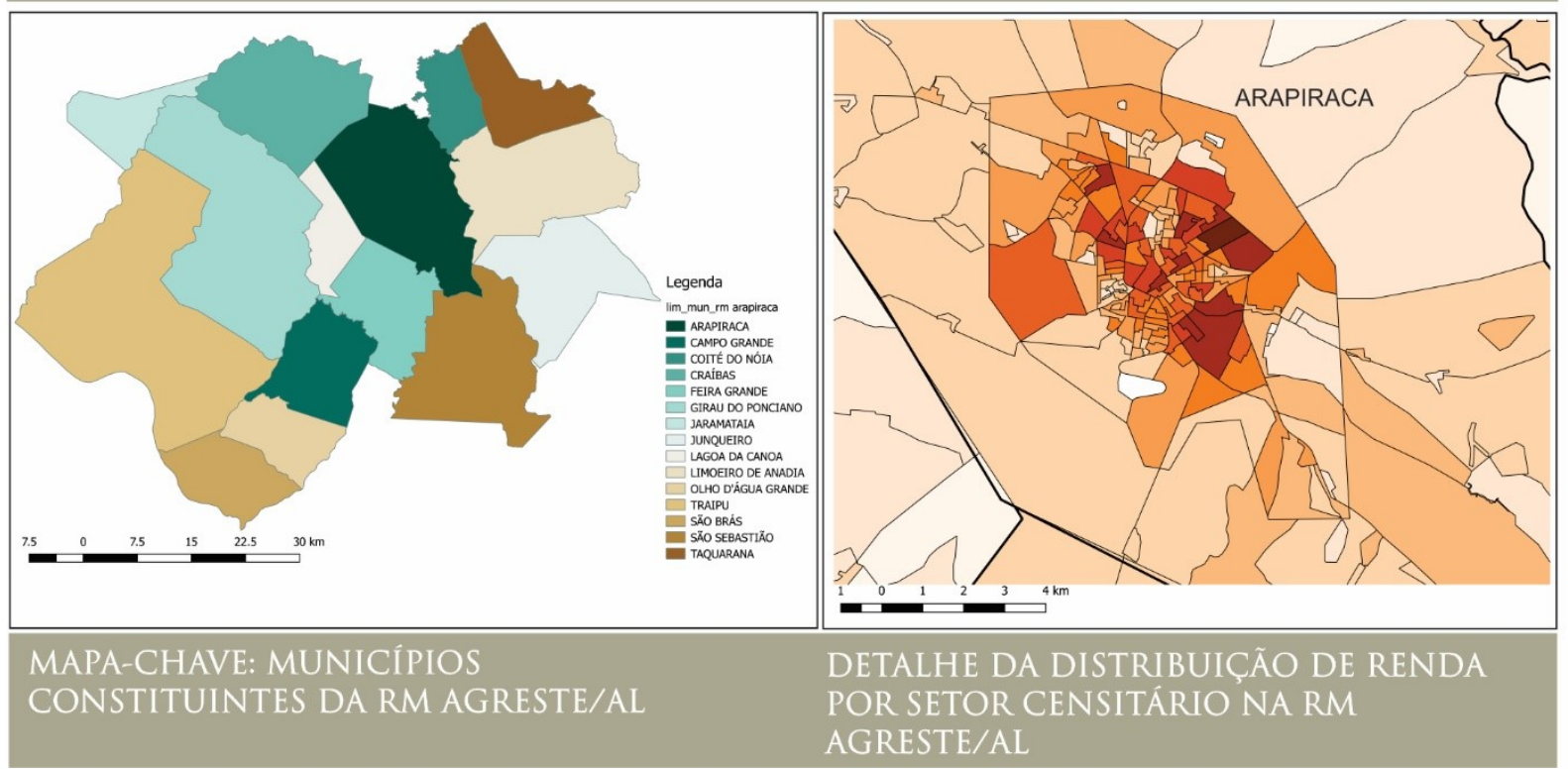

Fonte: Elaboração própria (2016) a partir da Base Cartográfica do IBGE (2010) e dados do censo de 2010. 
Figura 24: Mapa de distribuição de renda (V005) por setor censitário de Vitória da Conquista/BA.

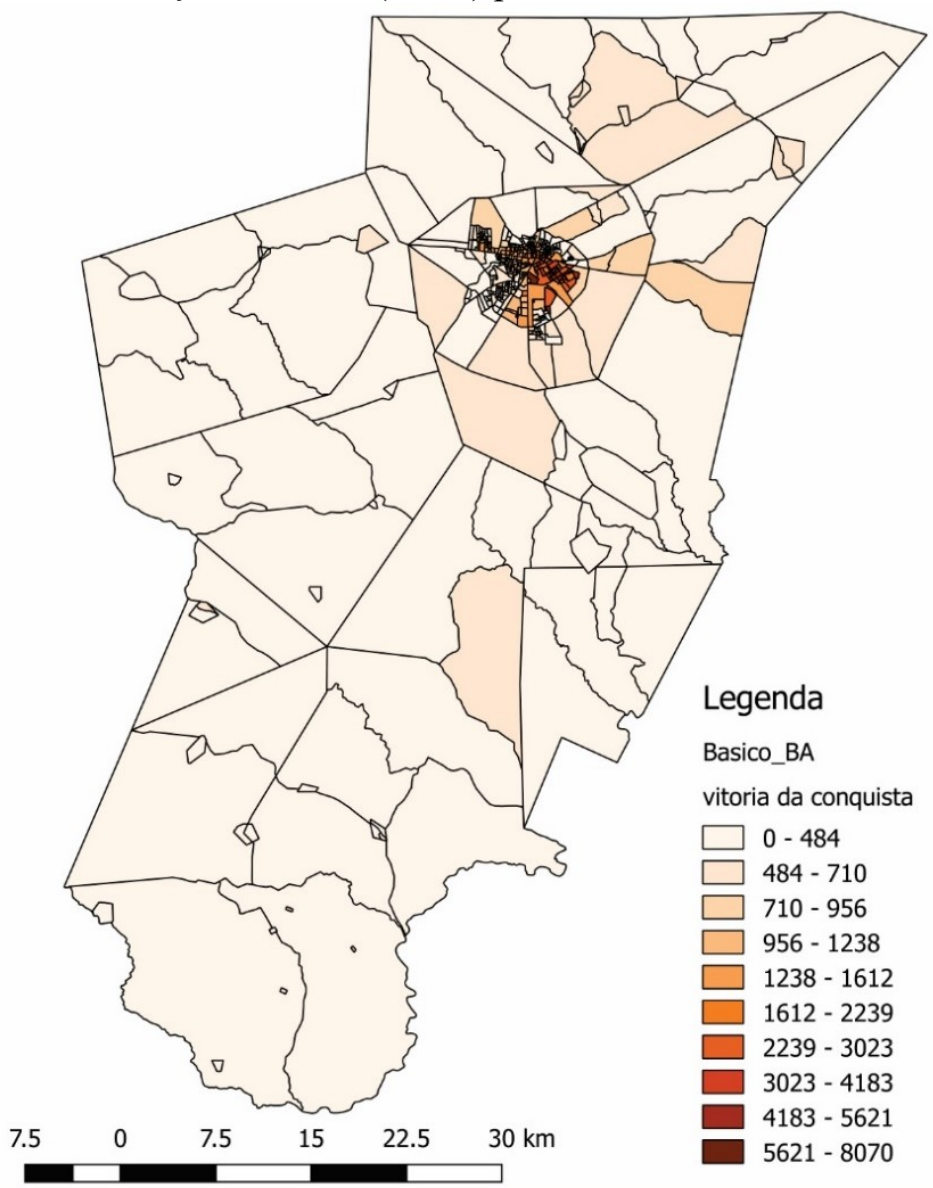

MAPA DE DISTRIBUIÇÃO DE RENDA POR SETOR CENSITÁRIO EM VITÓRIA DA CONQUISTA/BA

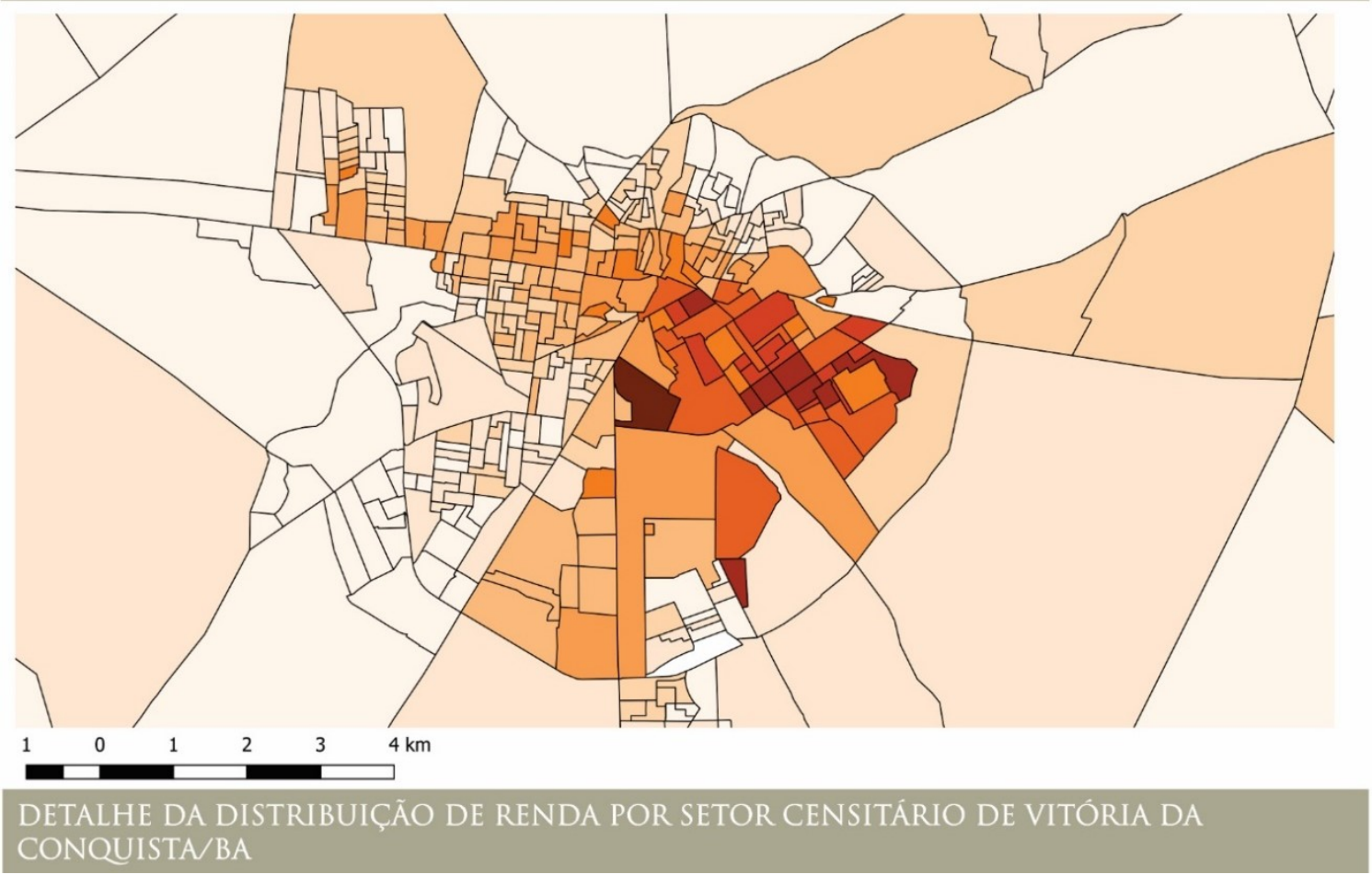

Fonte: Elaboração própria (2016) a partir da Base Cartográfica do IBGE (2010) e dados do censo de 2010. 
Figura 25: Mapa de distribuição de renda (V005) por setor censitário de Sobral/CE.

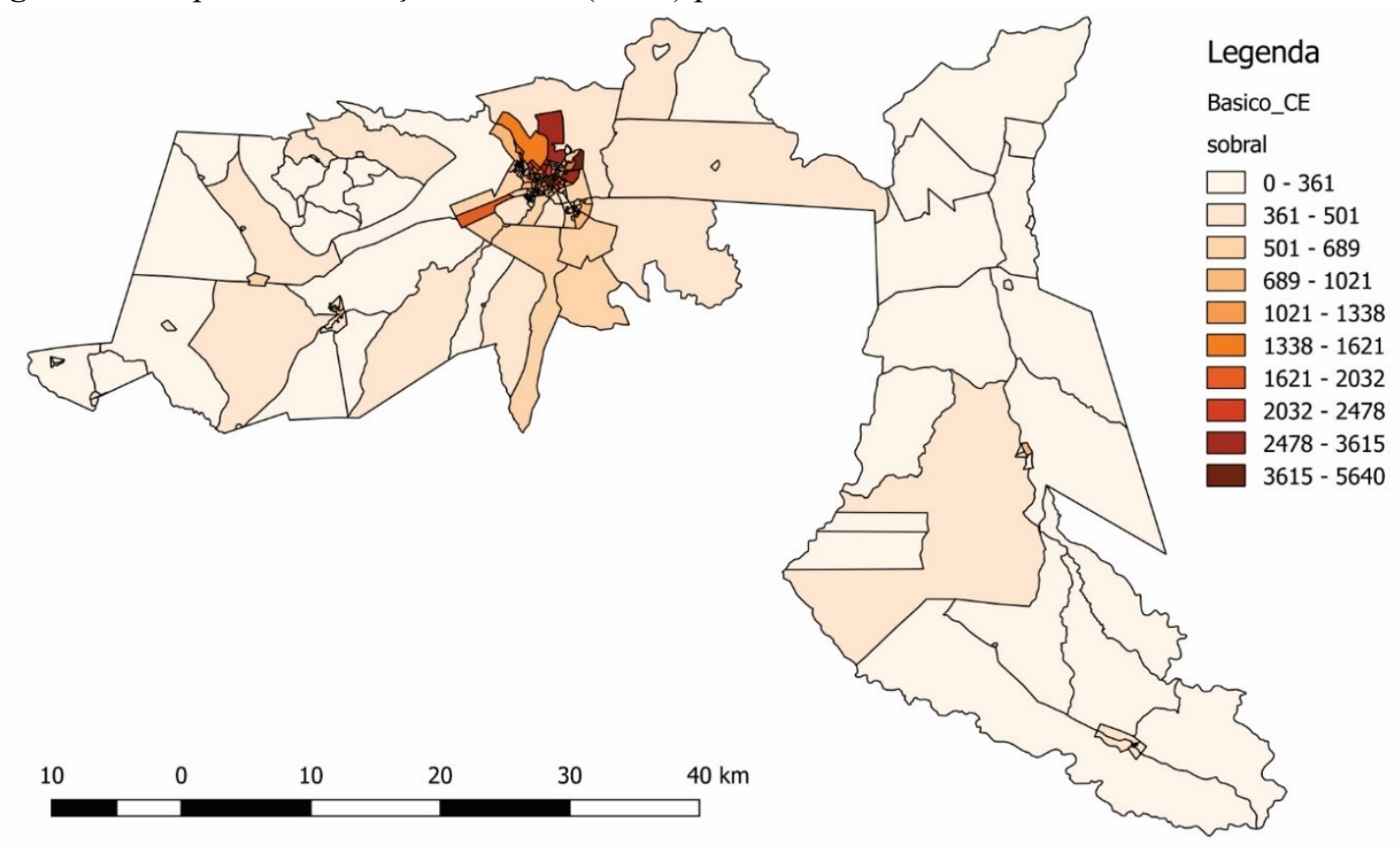

\section{MAPA DE DISTRIBUIÇÃO DE RENDA POR SETOR CENSITÁRIO} EM SOBRAL/CE

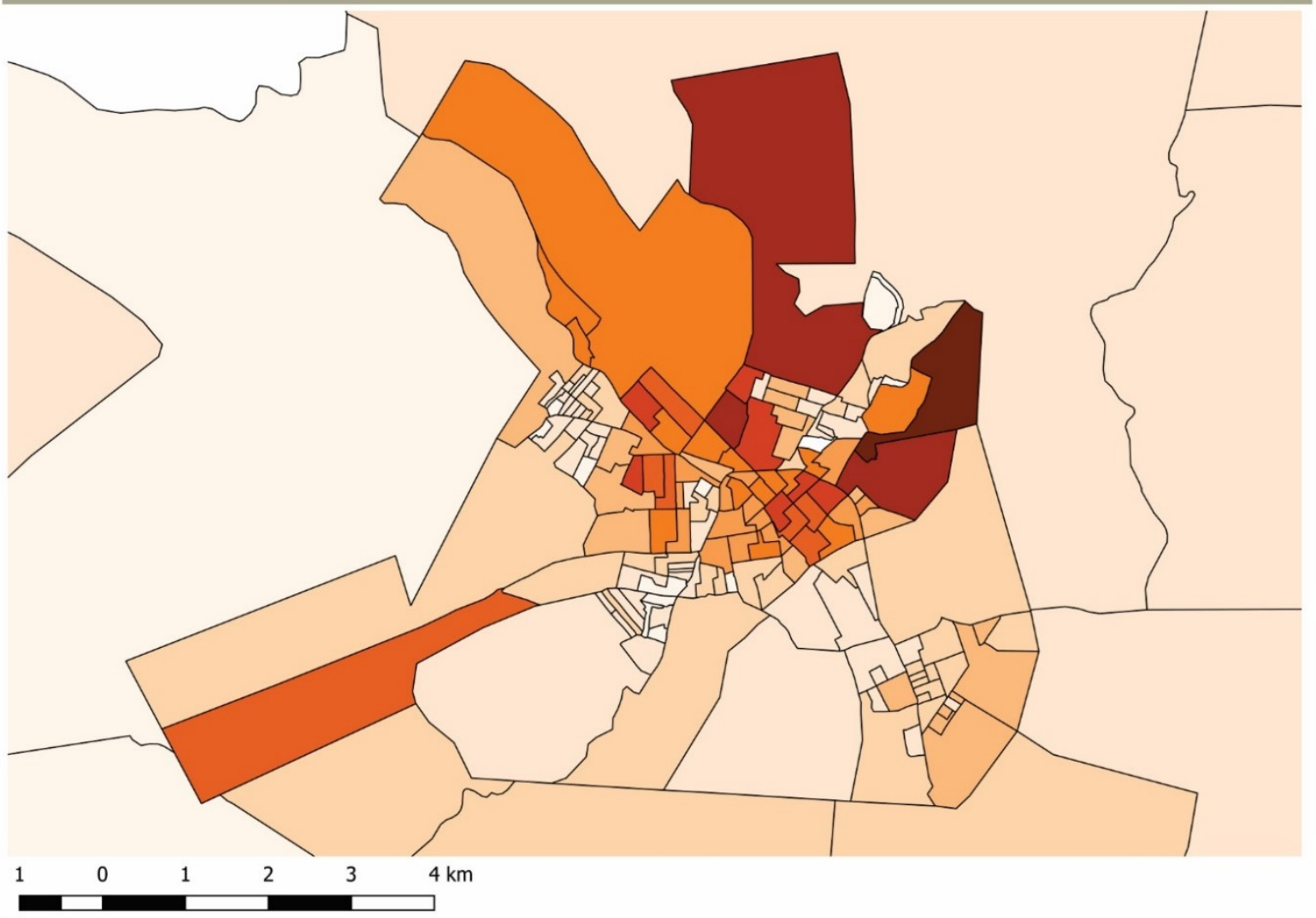

DETALHE DA DISTRIBUIÇÃO DE RENDA POR SETOR CENSITÁRIO DE SOBRAL/CE

Fonte: Elaboração própria (2016) a partir da Base Cartográfica do IBGE (2010) e dados do censo de 2010. 
Figura 26: Mapa de distribuição de renda (V005) por setor censitário de Mossoró/RN.

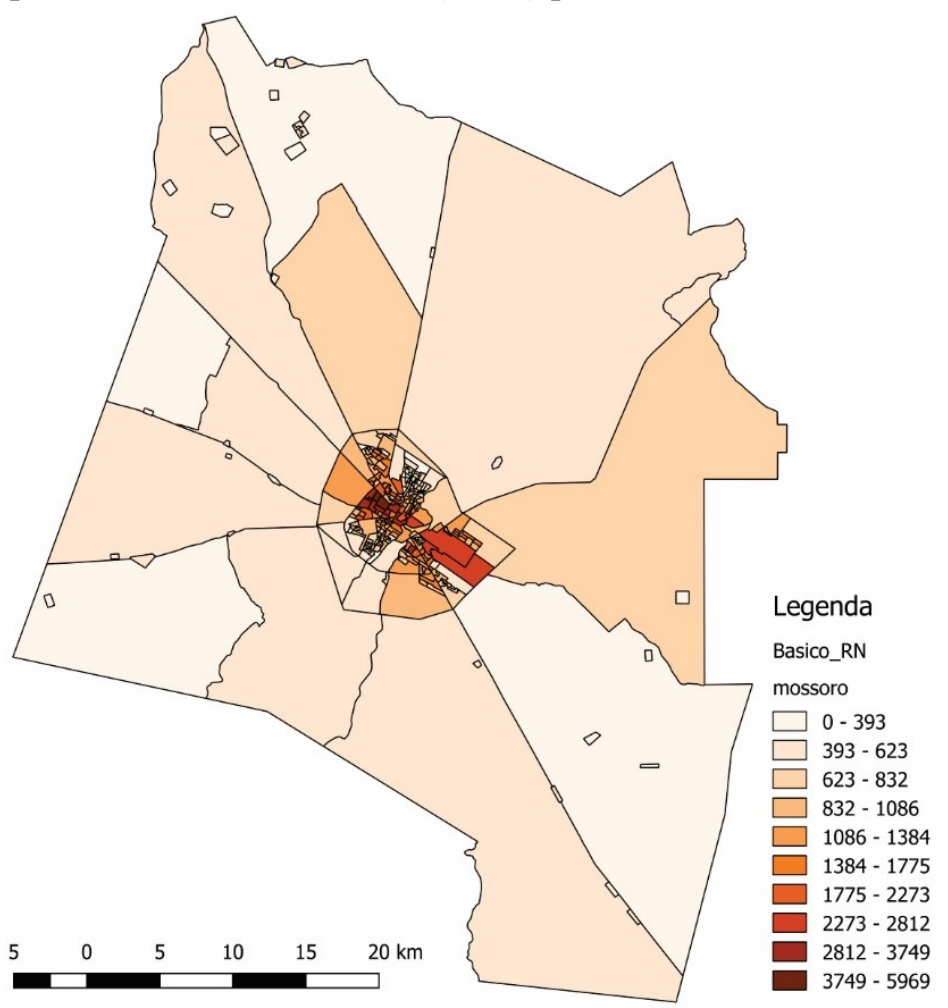

\section{MAPA DE DISTRIBUIÇÃO DE RENDA POR SETOR CENSITÁRIO} EM MOSSORÓ/RN

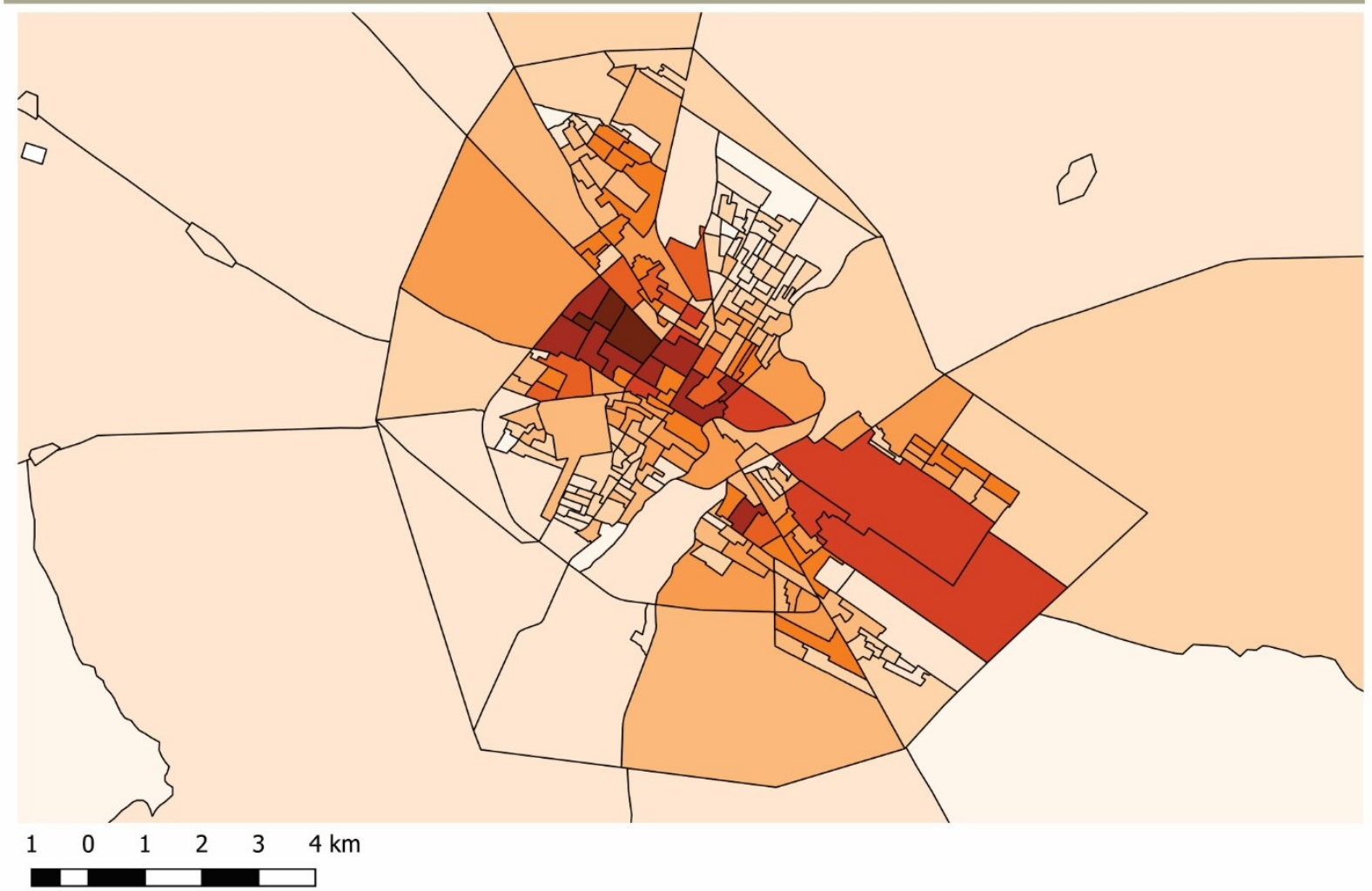

DETALHE DA DISTRIBUIÇÃO DE RENDA POR SETOR CENSITÁRIO DE MOSSORÓ/RN

Fonte: Elaboração própria (2016) a partir da Base Cartográfica do IBGE (2010) e dados do censo de 2010. 
Figura 27: Mapa de distribuição de renda (V005) por setor censitário de Caruaru/PE.
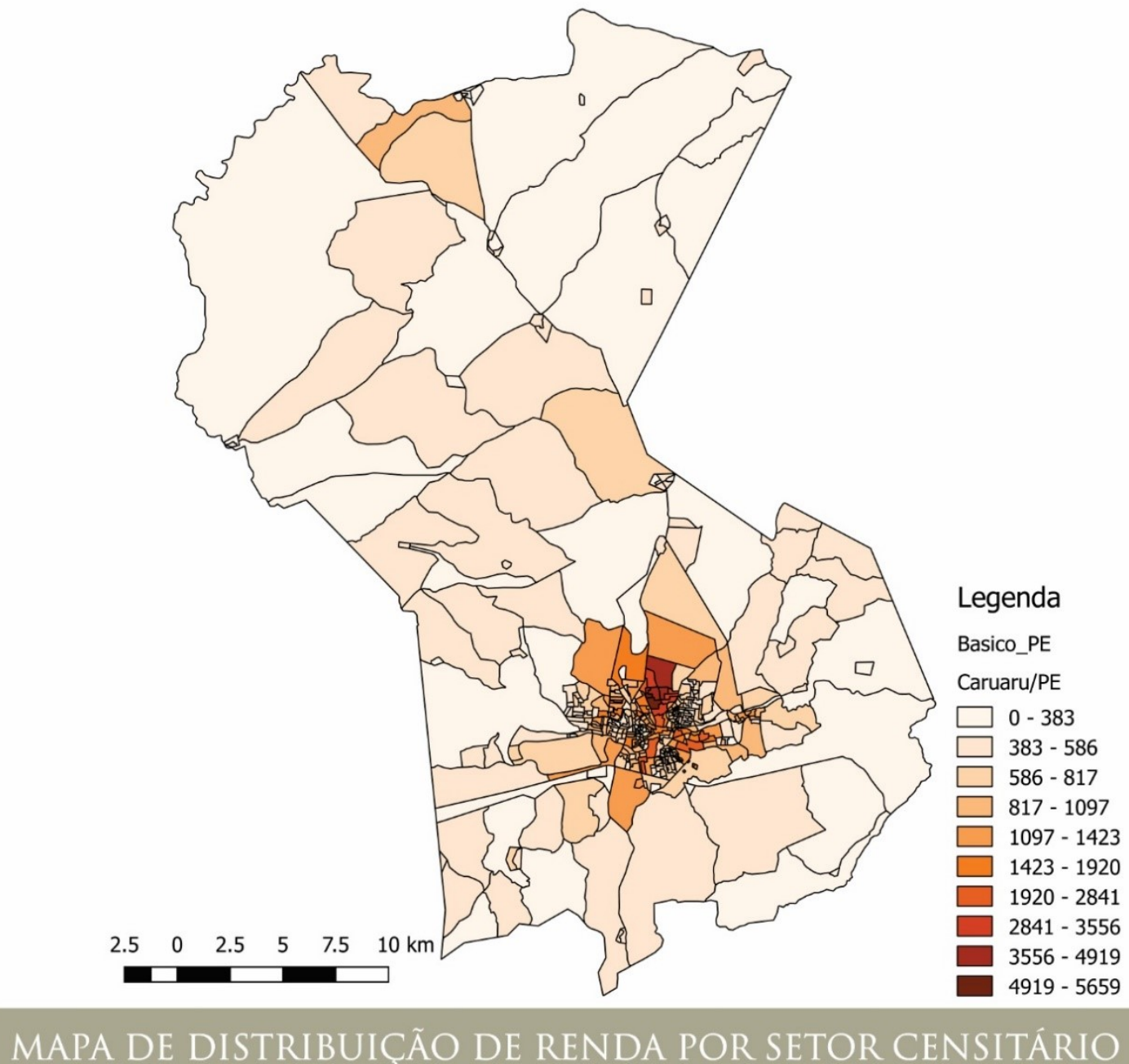
EM CARUARU/PE

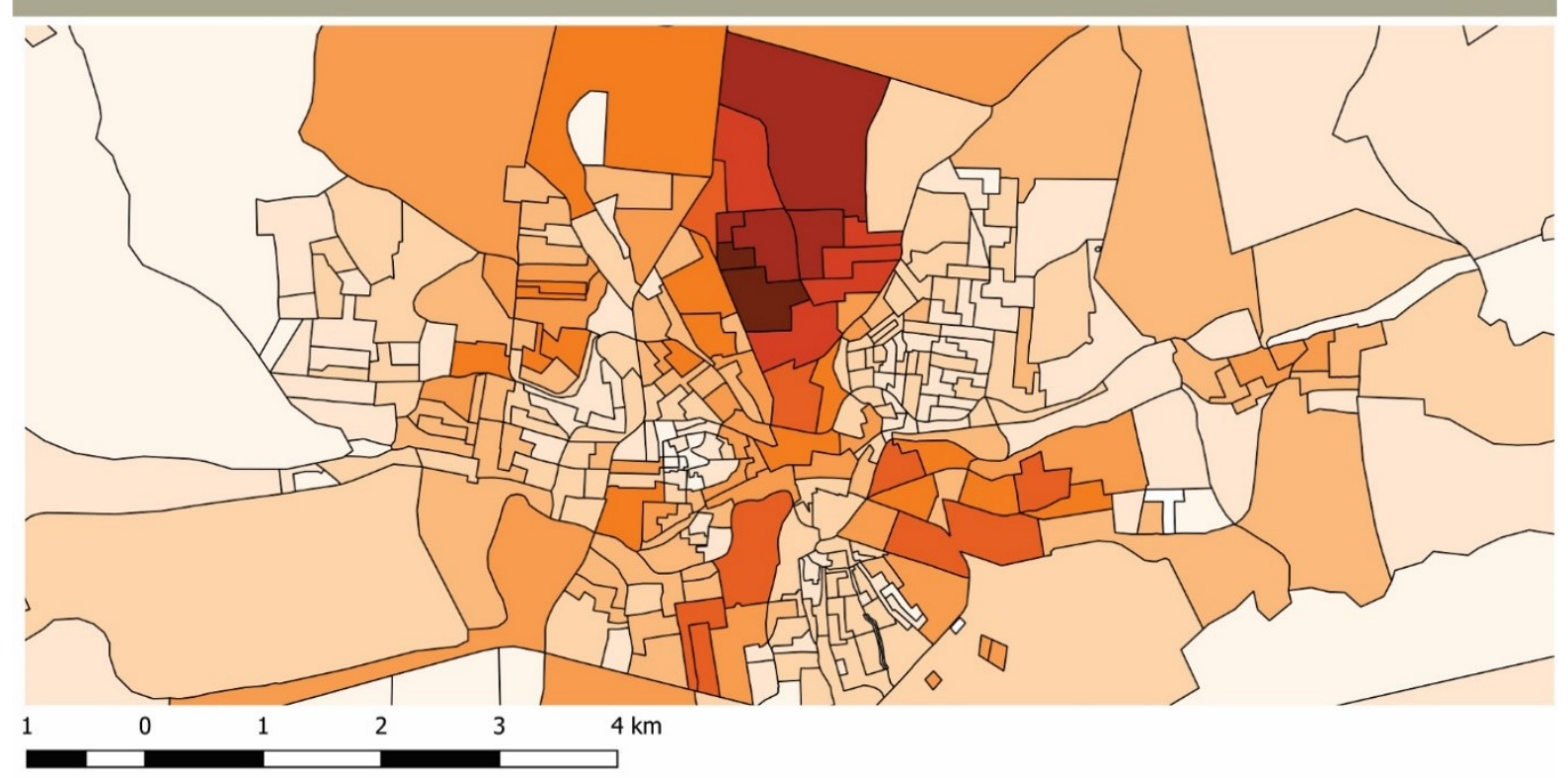

DETALHE DA DISTRIBUIÇÃO DE RENDA POR SETOR CENSITÁRIO DE CARUARU/PE

Fonte: Elaboração própria (2016) a partir da Base Cartográfica do IBGE (2010) e dados do censo de 2010. 
Figura 28: Mapa de distribuição de renda (V005) por setor censitário da RM Salvador/BA.

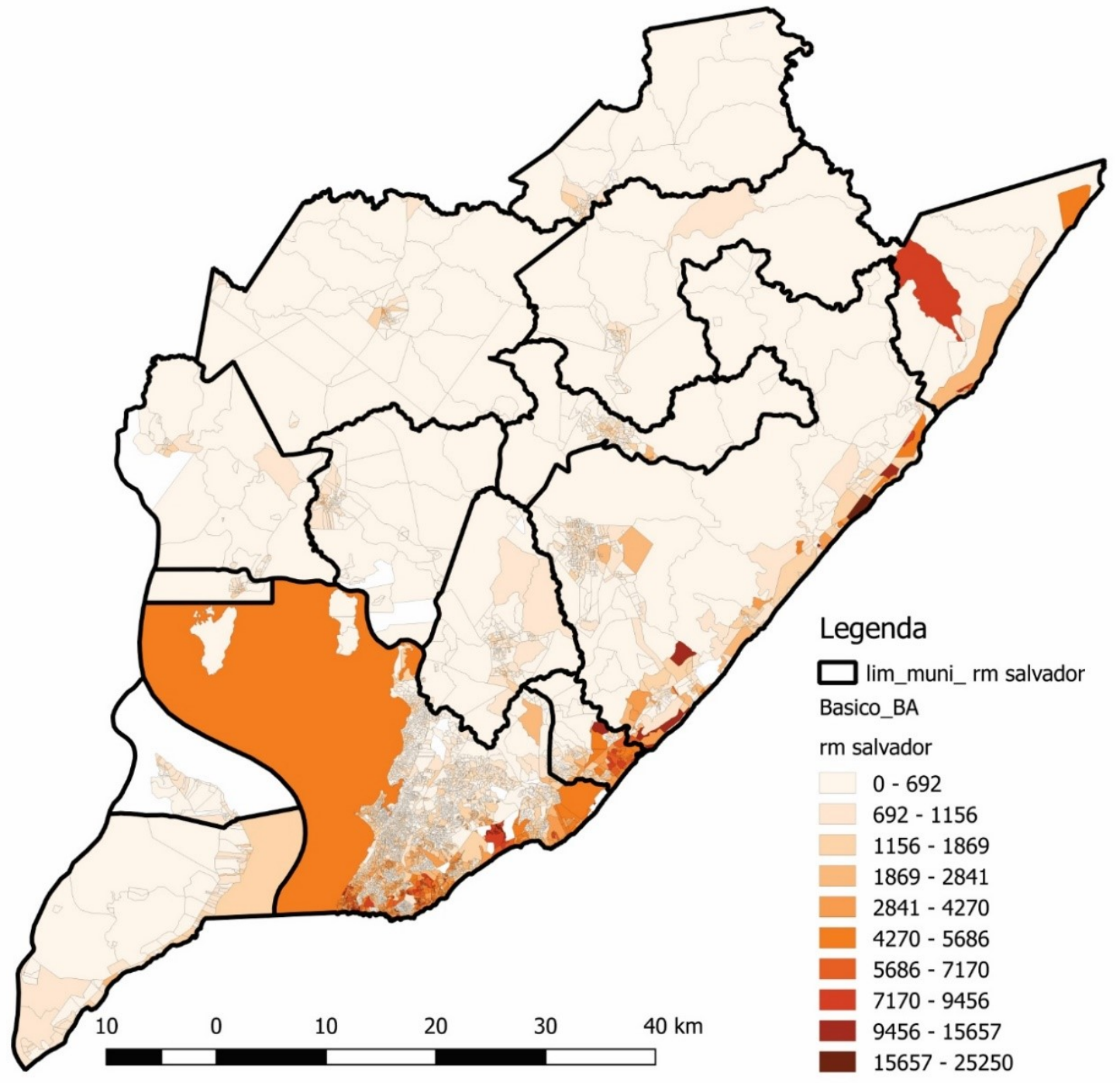

\section{MAPA DE DISTRIBUIÇÃO DE RENDA POR SETOR CENSITÁRIO NA RM SALVADOR/BA}

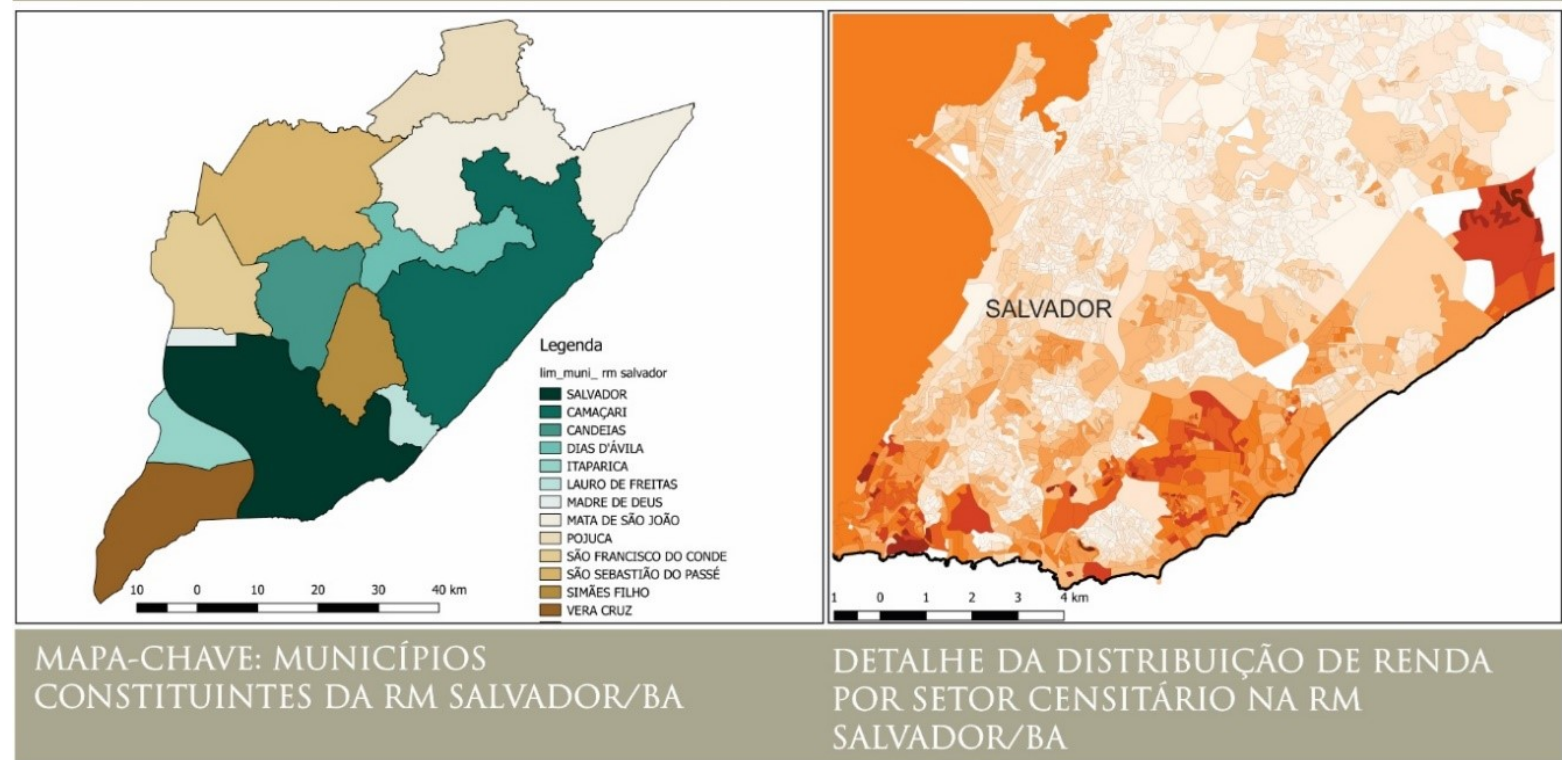

Fonte: Elaboração própria (2016) a partir da Base Cartográfica do IBGE (2010) e dados do censo de 2010. 
Figura 29: Mapa de distribuição de renda (V005) por setor censitário da RM Fortaleza/CE.

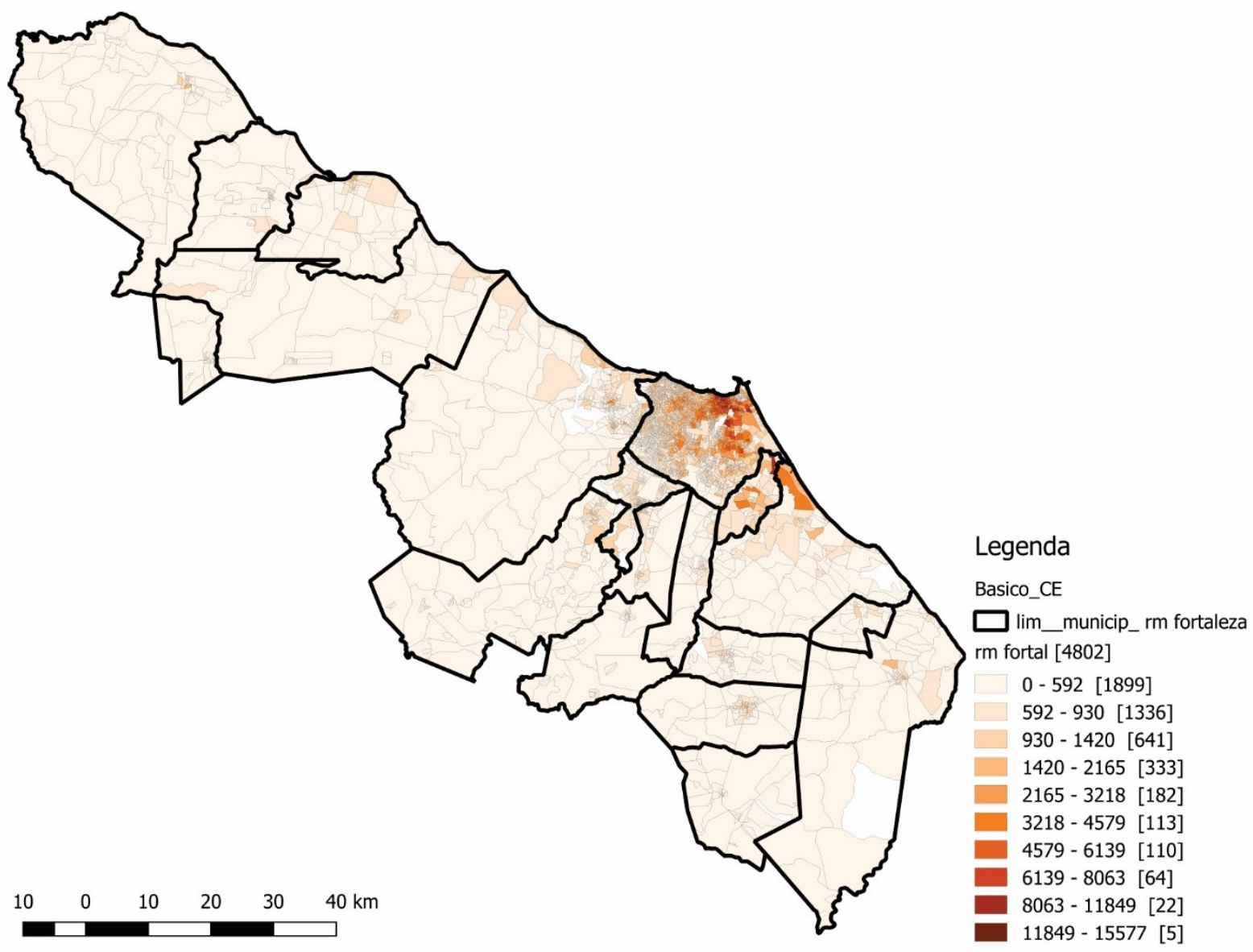

\section{MAPA DE DISTRIBUIÇÃO DE RENDA POR SETOR CENSITÁRIO NA RM FORTALEZA/CE}

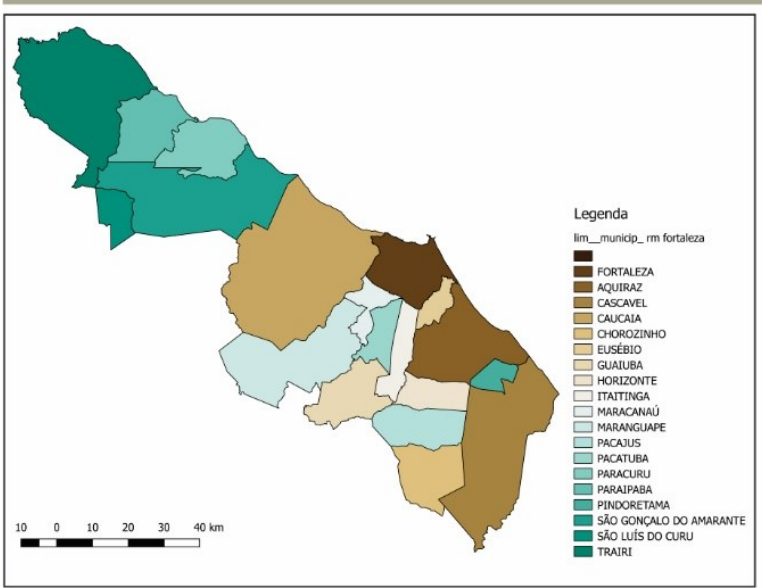

MAPA-CHAVE: MUNICIPIOS

CONSTITUINTES DA RM FORTALEZA/CE

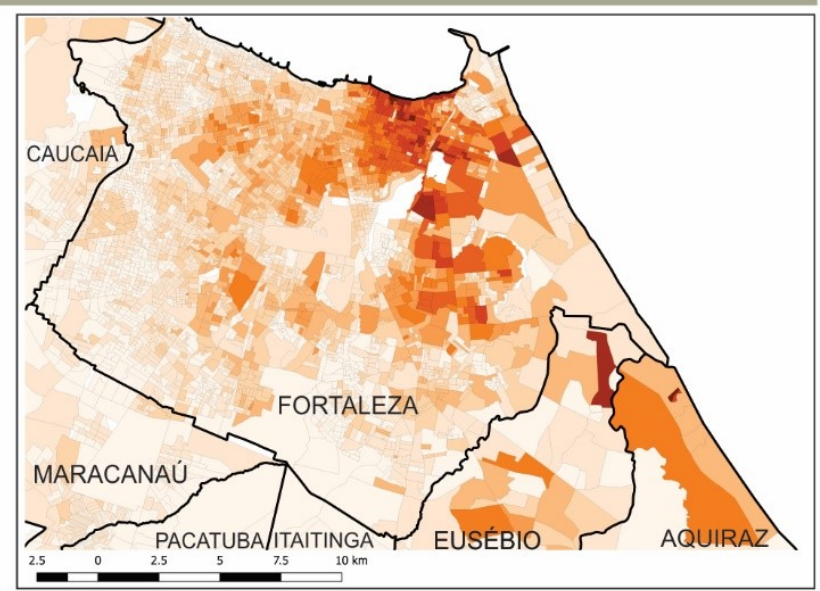

DETALHE DA DISTRIBUIÇÃO DE RENDA POR SETOR CENSITÁRIO NA RM FORTALEZA/CE

Fonte: Elaboração própria (2016) a partir da Base Cartográfica do IBGE (2010) e dados do censo de 2010. 
Figura 30: Mapa de distribuição de renda (V005) por setor censitário da RM Recife/PE.

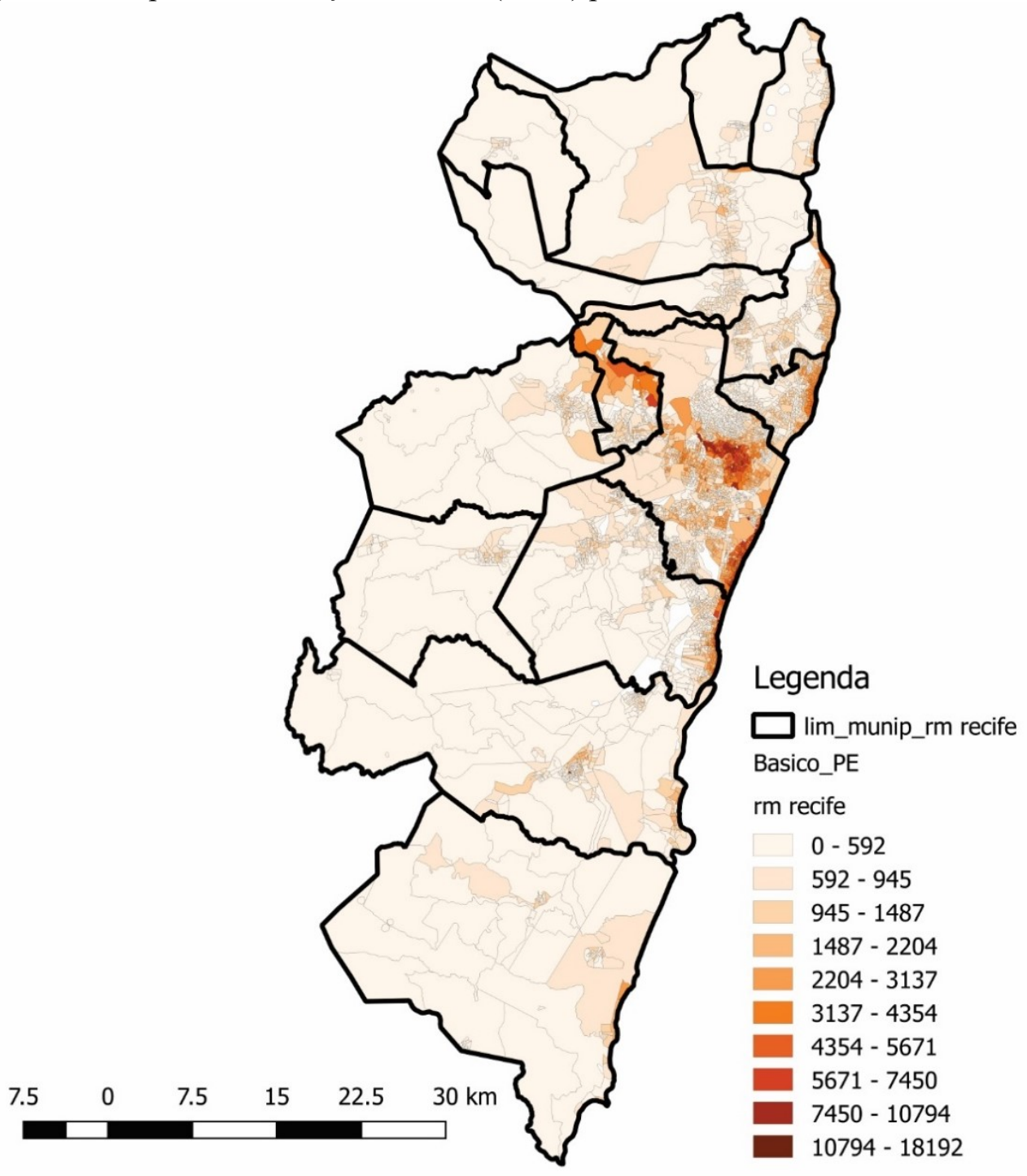

\section{MAPA DE DISTRIBUIÇÃO DE RENDA POR SETOR CENSITÁRIO} NA RM RECIFE/PE
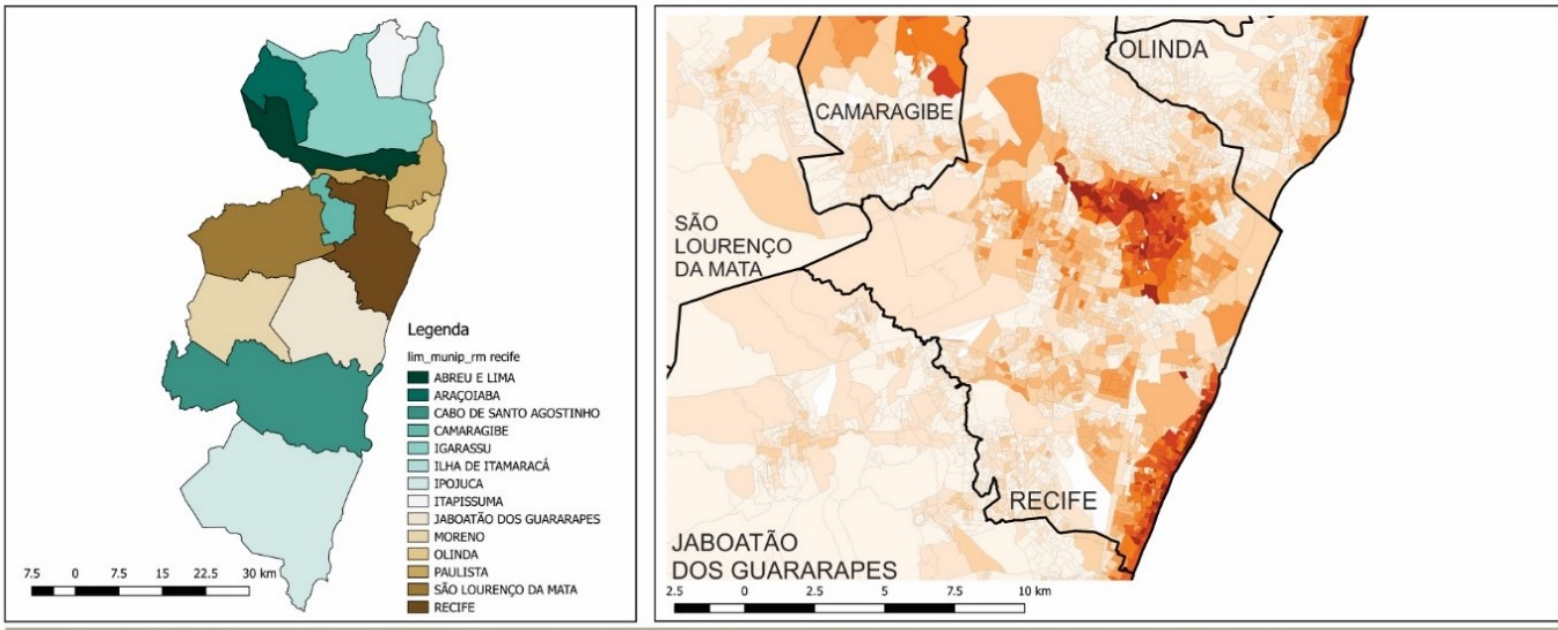

MAPA-CHAVE: MUNICÍPIOS

DETALHE DA DISTRIBUIÇÃO DE RENDA

CONSTITUINTES DA RM RECIFE/PE

POR SETOR CENSITÁRIO NA RM RECIFE/PE

Fonte: Elaboração própria (2016) a partir da Base Cartográfica do IBGE (2010) e dados do censo de 2010. 
A distribuição de renda nas cidades analisadas se dá de duas maneiras: de ângulo completo ou de ângulo reduzido, conforme esquematizado na Figura 31. O primeiro esquema é o que se encontra nas RM's e cidades interioranas dos dois primeiros grupos de estudo, onde as cidades-sede, ou núcleo urbano, concentram as maiores rendas, havendo um empobrecimento à medida em que nos afastamos desse centro. Alguns eixos de deslocamentos das elites parecem prevalecer, o que se correlaciona com a expansão dos tecidos urbanos e com as novas apropriações do capital imobiliário sobre o território. Nesse esquema, não parece haver uma forte influência de barreiras físicas naturais como rios, vales ou florestas.

Por outro lado, o segundo esquema acontece apenas no Grupo de Controle 02, nas RM's das capitais nordestinas que possuem a barreira física do oceano Atlântico (ao norte, no Ceará e, ao leste, na Bahia e Pernambuco), que condiciona a distribuição de altas rendas ao longo da costa litorânea, enquanto em direção ao interior (seta em linha tracejada) se concentram as mais baixas rendas. Há na RM de Recife, entretanto, um forte eixo de interiorização de faixas de alta e média renda em direção ao município de Camaragibe. Esta área é historicamente ocupada pelas elites desde os tempos da economia dos engenhos de açúcar que se valiam dos terrenos de Várzea ao longo do rio Camaragibe.

Figura 31: Esquemas de distribuição de renda.

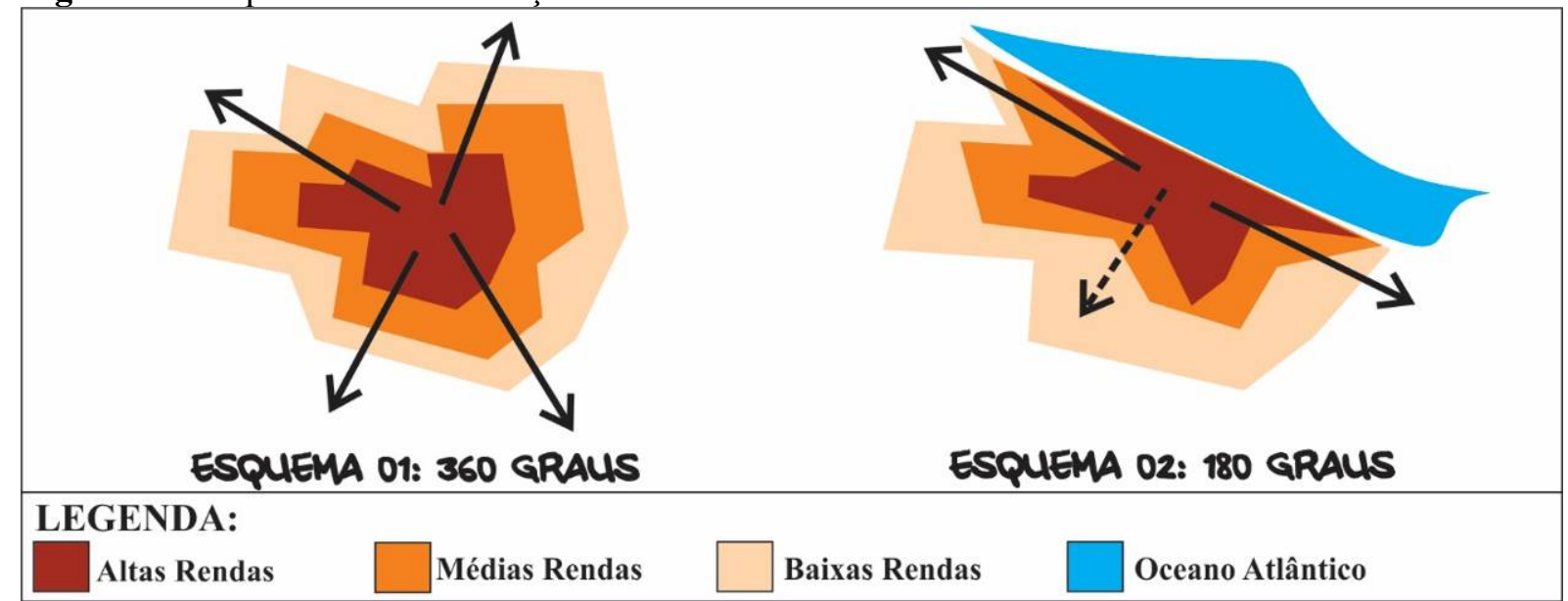

Fonte: Elaboração própria (2016).

\subsection{Nível de instrução}

Para avaliar este quesito foram utilizados os resultados do censo do IBGE 2010 por áreas de ponderação. Infelizmente, esses dados não permitem a espacialização pois as malhas cartográficas dessas unidades territoriais não foram disponibilizadas pelo órgão responsável. Porém, foram confeccionadas as tabelas 7, 8 e 9 (organizadas por grupos de análise e de 
controle), que se dividem nos seguintes níveis de instrução: sem instrução e fundamental incompleto, fundamental completo e médio incompleto, superior completo e não determinado.

Na Tabela 7 e no Gráfico 4, onde estão os dados das RMINE's observa-se que as cidades-núcleo apresentam percentuais maiores de pessoas com melhores níveis de instrução, com profissionais de nível superior representando entre $9 \%$ e $4 \%$, enquanto nas cidades ao seu entorno as médias são de $1 \%$ ou $2 \%$. Os dados se invertem na a categoria "sem instrução e fundamental incompleto", onde nas cidades periféricas das RM's os índices então entre $60 \%$ e $70 \%$ da população maior de 10 anos, contra os $48 \%$ a $54 \%$ das populações nos municípios polo como Campina Grande/PB ou Juazeiro/BA.

\begin{tabular}{|c|c|c|c|c|c|c|c|c|c|c|c|}
\hline \multirow{3}{*}{$\begin{array}{l}\text { Universo de estudo } \\
\text { por RM's e/ou } \\
\text { municípios }\end{array}$} & \multicolumn{11}{|c|}{ Pessoas de 10 anos ou mais de idade } \\
\hline & \multirow[b]{2}{*}{ Total } & \multicolumn{10}{|c|}{ Nível de instrução } \\
\hline & & $\begin{array}{c}\text { Sem } \\
\text { instrução e } \\
\text { fundamental } \\
\text { incompleto }\end{array}$ & $\%$ & $\begin{array}{l}\text { Fundamental } \\
\text { completo e } \\
\text { médio } \\
\text { incompleto }\end{array}$ & $\%$ & $\begin{array}{l}\text { Médio } \\
\text { completo e } \\
\text { superior } \\
\text { incompleto }\end{array}$ & $\%$ & $\begin{array}{l}\text { Superior } \\
\text { completo }\end{array}$ & $\%$ & $\begin{array}{l}\text { Não } \\
\text { det. }\end{array}$ & $\%$ \\
\hline \multicolumn{12}{|c|}{ RM FEIRA DE SANTANA/BA } \\
\hline Feira de Santana & 471446 & 229779 & $48,74 \%$ & 78084 & $16,56 \%$ & 137159 & $29,09 \%$ & 24458 & $5,19 \%$ & 1966 & $0,42 \%$ \\
\hline S. Gonçalo dos Campos & 27787 & 17502 & $62,99 \%$ & 4215 & $15,17 \%$ & 5482 & $19,73 \%$ & 410 & $1,48 \%$ & 177 & $0,64 \%$ \\
\hline \multicolumn{12}{|c|}{ RM DO CARIRI/CE } \\
\hline Barbalha & 45923 & 24685 & $53,75 \%$ & 7632 & $16,62 \%$ & 11244 & $24,49 \%$ & 2222 & $4,84 \%$ & 139 & $0,30 \%$ \\
\hline Crato & 101955 & 49786 & $48,83 \%$ & 17872 & $17,53 \%$ & 26394 & $25,89 \%$ & 7733 & $7,59 \%$ & 170 & $0,17 \%$ \\
\hline Juazeiro do Norte & 208158 & 109973 & $52,83 \%$ & 36491 & $17,53 \%$ & 50150 & $24,09 \%$ & 10823 & $5,20 \%$ & 720 & $0,35 \%$ \\
\hline Missão Velha & 28051 & 18421 & $65,67 \%$ & 4665 & $16,63 \%$ & 4114 & $14,67 \%$ & 809 & $2,88 \%$ & 42 & $0,15 \%$ \\
\hline \multicolumn{12}{|c|}{ RM DO SUDOESTE MARANHESE } \\
\hline Imperatriz & 205148 & 92526 & $45,10 \%$ & 40526 & $19,75 \%$ & 60293 & $29,39 \%$ & 11412 & $5,56 \%$ & 391 & $0,19 \%$ \\
\hline \multicolumn{12}{|c|}{ RM DE CAMPINA GRANDE/PB } \\
\hline Campina Grande & 326980 & 157389 & $48,13 \%$ & 53405 & $16,33 \%$ & 85431 & $26,13 \%$ & 29824 & $9,12 \%$ & 930 & $0,28 \%$ \\
\hline \multicolumn{12}{|c|}{ RAID PETROLINA E JUAZEIRO } \\
\hline Petrolina/PE & 240136 & 126536 & $52,69 \%$ & 38434 & $16,00 \%$ & 58675 & $24,43 \%$ & 15141 & $6,31 \%$ & 1351 & $0,56 \%$ \\
\hline $\mathrm{St}^{\mathrm{a}} \mathrm{M}^{\mathrm{a}}$ da Boa Vista/PE & 30996 & 21434 & $69,15 \%$ & 4307 & $13,90 \%$ & 4320 & $13,94 \%$ & 691 & $2,23 \%$ & 244 & $0,79 \%$ \\
\hline Casa Nova/BA & 52425 & 38763 & $73,94 \%$ & 5927 & $11,31 \%$ & 6681 & $12,74 \%$ & 944 & $1,80 \%$ & 109 & $0,21 \%$ \\
\hline Juazeiro/BA & 162160 & 88386 & $54,51 \%$ & 27542 & $16,98 \%$ & 37830 & $23,33 \%$ & 7493 & $4,62 \%$ & 909 & $0,56 \%$ \\
\hline
\end{tabular}

Fonte: Elaboração própria (2016) a partir de tabela base do Censo Demográfico 2010 - Resultados Gerais da Amostra por áreas de ponderação (IBGE, 2013).

Para o Grupo de Controle 02, a comparação entre núcleo e entorno é dificultada pela falta de dados (não há dados do IBGE por área de ponderação para todos os municípios, especificamente os menores). Entretanto, nos dados dos municípios apresentados na Tabela 8 e no Gráfico 5, repete-se, com uma ligeira queda, as médias apresentadas para as RMINE’S: pessoas com nível superior completo variam entre $7 \%$ e $4 \%$ da população maior de 10 anos e aqueles sem instrução ou com ensino fundamental incompleto estão entre $63 \%$ e $45 \%$, com Imperatriz/MA apresentando o melhor índice para os dois grupos. É interessante destacar que todas as cidades-núcleo das RMINE'S e as cidades do Grupo de Controle 01 são capitais 
regionais nível $\mathrm{B}$ ou $\mathrm{C}$, o que significa que são importantes polos educacionais, contando com um bom número de instituições de ensino superior, polarizando suas regiões de influência.

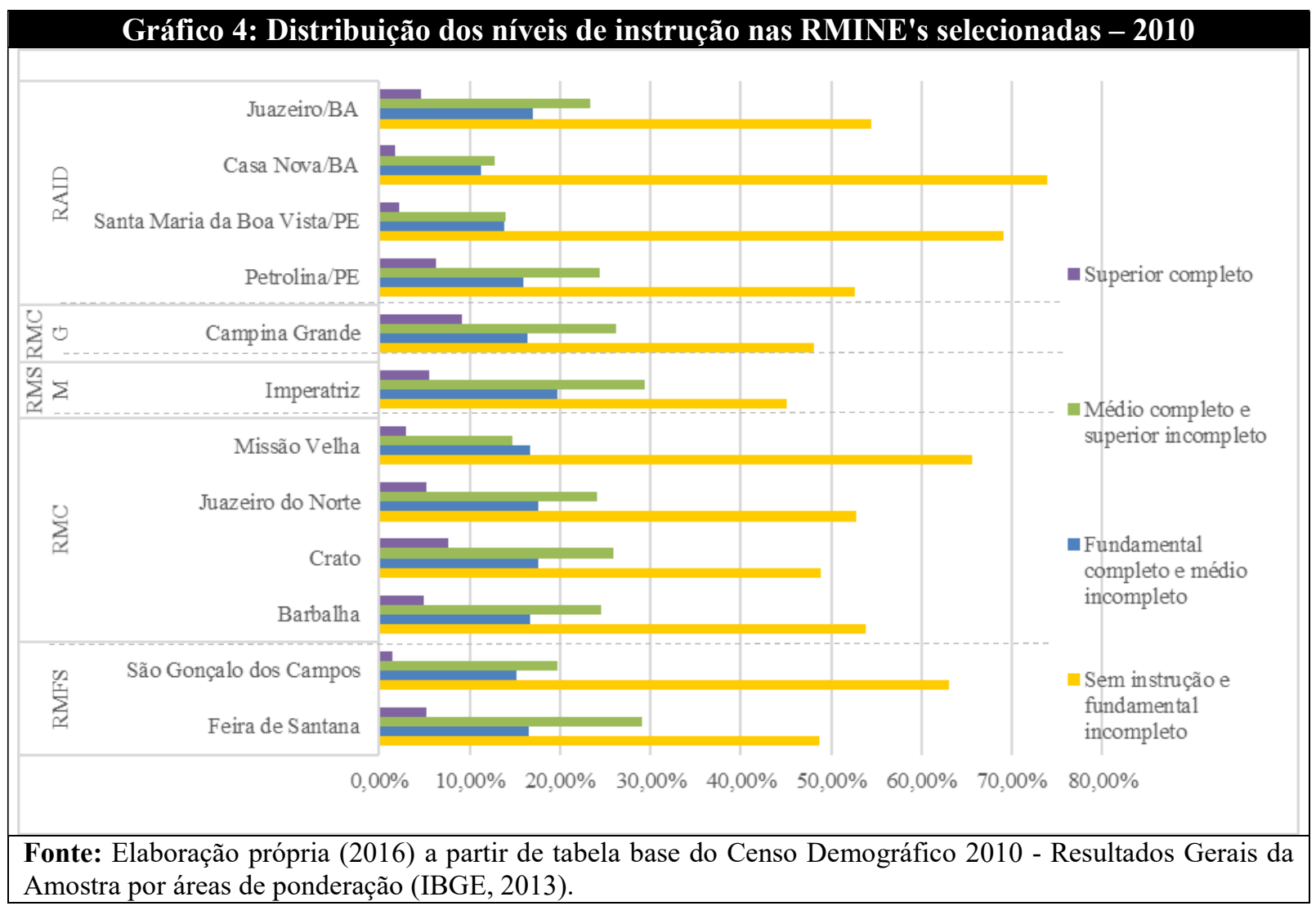

Tabela 8: Pessoas de 10 anos ou mais de idade, por nível de instrução no Grupo de Controle 01 2010

\begin{tabular}{|c|c|c|c|c|c|c|c|c|c|c|c|}
\hline \multirow{3}{*}{$\begin{array}{l}\text { Universo de estudo } \\
\text { por RM's e/ou } \\
\text { municípios }\end{array}$} & \multicolumn{11}{|c|}{ Pessoas de 10 anos ou mais de idade } \\
\hline & \multirow[b]{2}{*}{ Total } & \multicolumn{10}{|c|}{ Nível de instrução } \\
\hline & & $\begin{array}{l}\text { Sem } \\
\text { instrução e } \\
\text { fundamental } \\
\text { incompleto }\end{array}$ & $\%$ & $\begin{array}{l}\text { Fundamental } \\
\text { completo e } \\
\text { médio } \\
\text { incompleto }\end{array}$ & $\%$ & $\begin{array}{l}\text { Médio } \\
\text { completo e } \\
\text { superior } \\
\text { incompleto }\end{array}$ & $\%$ & $\begin{array}{l}\text { Superior } \\
\text { completo }\end{array}$ & $\%$ & $\begin{array}{l}\text { Não } \\
\text { det. }\end{array}$ & $\%$ \\
\hline \multicolumn{12}{|c|}{ RM DO AGRESTE/AL } \\
\hline Arapiraca & 177219 & 110423 & $62,31 \%$ & 29801 & $16,82 \%$ & 29257 & $16,51 \%$ & 7478 & $4,22 \%$ & 259 & $0,15 \%$ \\
\hline Girau do Ponciano & 29374 & 23150 & $78,81 \%$ & 3497 & $11,90 \%$ & 2405 & $8,19 \%$ & 259 & $0,88 \%$ & 63 & $0,21 \%$ \\
\hline \multicolumn{12}{|c|}{ VITÓRIA DA CONQUISTA/BA } \\
\hline V. da Conquista & 257616 & 143515 & $55,71 \%$ & 41761 & $16,21 \%$ & 56110 & $21,78 \%$ & 14771 & $5,73 \%$ & 1460 & $0,57 \%$ \\
\hline \multicolumn{12}{|c|}{ SOBRAL/CE } \\
\hline Sobral & 158843 & 80815 & $50,88 \%$ & 31212 & $19,65 \%$ & 37124 & $23,37 \%$ & 8803 & $5,54 \%$ & 889 & $0,56 \%$ \\
\hline \multicolumn{12}{|c|}{ MOSSORÓ /RN } \\
\hline Mossoró & 220583 & 106812 & $48,42 \%$ & 36903 & $16,73 \%$ & 60076 & $27,24 \%$ & 15685 & $7,11 \%$ & 1106 & $0,50 \%$ \\
\hline \multicolumn{12}{|c|}{ CARUARU/PE } \\
\hline Caruaru & 265208 & 152960 & $57,68 \%$ & 42018 & $15,84 \%$ & 54256 & $20,46 \%$ & 14550 & $5,49 \%$ & 1425 & $0,54 \%$ \\
\hline
\end{tabular}

Fonte: Elaboração própria (2016) a partir de tabela base do Censo Demográfico 2010 - Resultados Gerais da Amostra por áreas de ponderação (IBGE, 2013). 


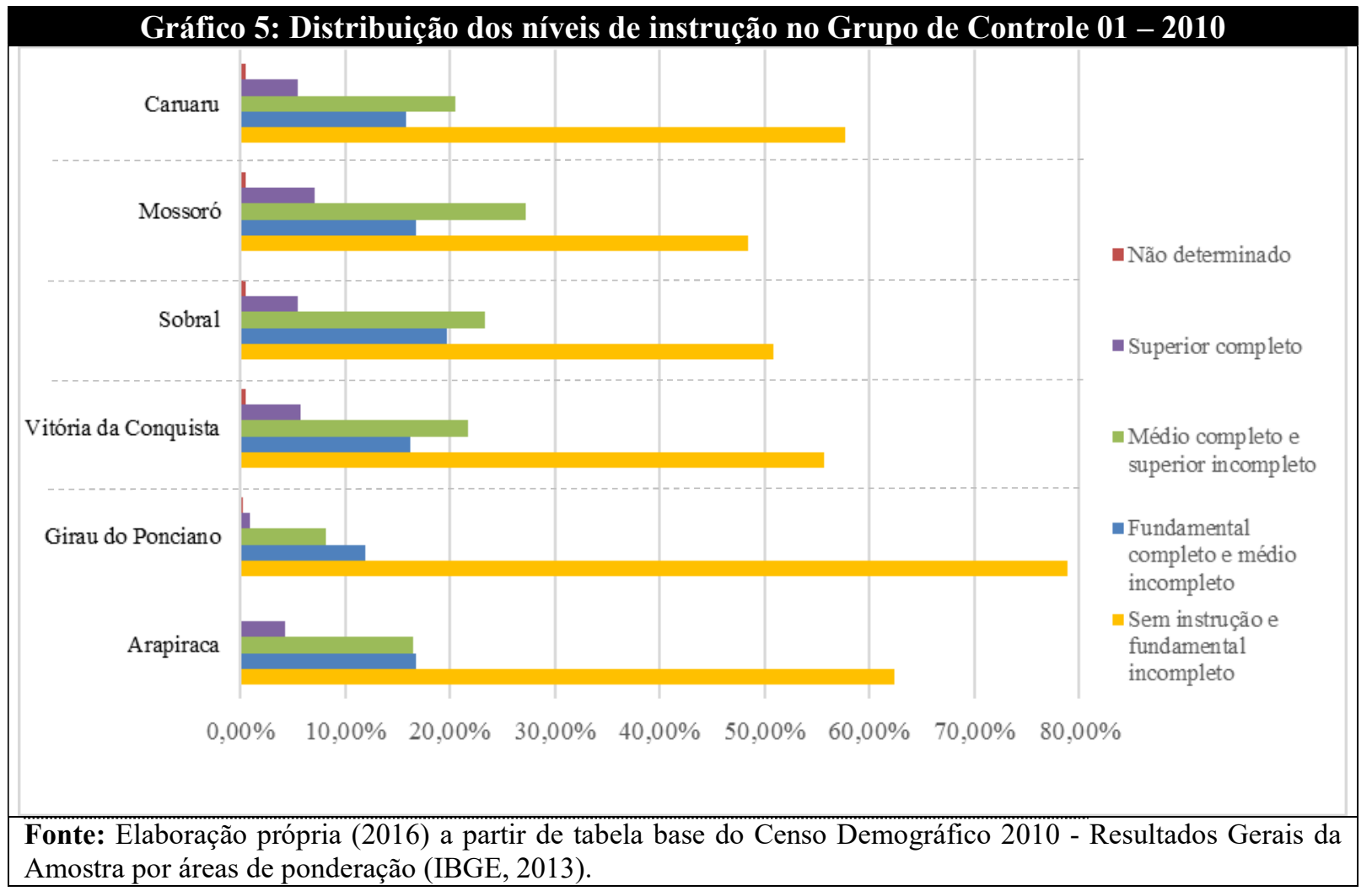

Por fim, no Grupo de Controle 02, podemos observar na Tabela 9 e no Gráfico 6 que os índices da população maior de 10 anos com ensino superior completo variam entre $9 \%$ e $14 \%$, estando Fortaleza com a menor e Recife com a maior porcentagem. Na RM de Salvador vale destacar que não é a capital que apresenta o maior índice, e sim, o município de Lauro de Freitas/BA, com cerca de $11 \%$ da população, fato provavelmente relacionado com o parque industrial situado ali, que conta com a única fábrica da Lenoxx Sound no Brasil, fabricante de aparelhos eletrônicos que gera cerca de 800 empregos diretos.

Quanto à categoria que representa os níveis de instrução mais baixos, as cidades-sede das RM'S possuem percentuais que variam entre $37 \%$ e $40 \%$ da população, enquanto algumas cidades do entorno chegam a apresentar taxas de $64 \%$ de habitantes dentro da faixa sem instrução ou apenas com o fundamental incompleto. Em que pesem outras questões demográficas, como uma parcela de população que é computada e ainda está em idade escolar visto que são apresentados os dados para a população maior de 10 anos, o Nordeste tem um problemático acesso a uma educação de qualidade e os dados vistos aqui ainda demonstram esta condição historicamente construída. 
Tabela 9: Pessoas de 10 anos ou mais de idade, por nível de instrução no Grupo de Controle 02 2010

\begin{tabular}{|c|c|c|c|c|c|c|c|c|c|c|c|}
\hline \multirow{3}{*}{$\begin{array}{l}\text { Universo de estudo } \\
\text { por RM's e/ou } \\
\text { municípios }\end{array}$} & \multicolumn{11}{|c|}{ Pessoas de 10 anos ou mais de idade } \\
\hline & \multirow[b]{2}{*}{ Total } & \multicolumn{10}{|c|}{ Nível de instrução } \\
\hline & & $\begin{array}{c}\text { Sem instrução } \\
\text { e fundamental } \\
\text { incompleto }\end{array}$ & $\%$ & $\begin{array}{c}\text { Fundamental } \\
\text { completo e } \\
\text { médio } \\
\text { incompleto }\end{array}$ & $\%$ & $\begin{array}{c}\text { Médio } \\
\text { completo e } \\
\text { superior } \\
\text { incompleto } \\
\end{array}$ & $\%$ & $\begin{array}{l}\text { Superior } \\
\text { completo }\end{array}$ & $\%$ & $\begin{array}{l}\text { Não } \\
\text { det. }\end{array}$ & $\%$ \\
\hline \multicolumn{12}{|c|}{ RM DE SALVADOR/BA } \\
\hline Camaçari & 203005 & 99087 & $48,81 \%$ & 35907 & $17,69 \%$ & 58719 & $28,93 \%$ & 7504 & $3,70 \%$ & 1789 & $0,88 \%$ \\
\hline Candeias & 70360 & 35169 & $49,98 \%$ & 11838 & $16,82 \%$ & 20462 & $29,08 \%$ & 1467 & $2,09 \%$ & 1424 & $2,02 \%$ \\
\hline Dias d'Ávila & 54370 & 28043 & $51,58 \%$ & 9762 & $17,96 \%$ & 14822 & $27,26 \%$ & 1402 & $2,58 \%$ & 341 & $0,63 \%$ \\
\hline Lauro de Freitas & 138732 & 56734 & $40,89 \%$ & 22706 & $16,37 \%$ & 43201 & $31,14 \%$ & 15455 & $11,14 \%$ & 637 & $0,46 \%$ \\
\hline Mata de São João & 33386 & 18443 & $55,24 \%$ & 5232 & $15,67 \%$ & 8907 & $26,68 \%$ & 628 & $1,88 \%$ & 177 & $0,53 \%$ \\
\hline Salvador & 2331049 & 867324 & $37,21 \%$ & 393781 & $16,89 \%$ & 795266 & $34,12 \%$ & 255606 & $10,97 \%$ & 19072 & $0,82 \%$ \\
\hline São F. do Conde & 27712 & 15629 & $56,40 \%$ & 4842 & $17,47 \%$ & 6240 & $22,52 \%$ & 729 & $2,63 \%$ & 273 & $0,98 \%$ \\
\hline Simões Filho & 97655 & 49419 & $50,61 \%$ & 16998 & $17,41 \%$ & 28101 & $28,78 \%$ & 2455 & $2,51 \%$ & 682 & $0,70 \%$ \\
\hline Vera Cruz & 31486 & 19184 & $60,93 \%$ & 5731 & $18,20 \%$ & 5507 & $17,49 \%$ & 878 & $2,79 \%$ & 187 & $0,59 \%$ \\
\hline \multicolumn{12}{|c|}{ RM DE FORTALEZA/CE } \\
\hline Aquiraz & 61133 & 38703 & $63,31 \%$ & 9932 & $16,25 \%$ & 10341 & $16,92 \%$ & 1744 & $2,85 \%$ & 413 & $0,68 \%$ \\
\hline Cascavel & 56077 & 34956 & $62,34 \%$ & 10476 & $18,68 \%$ & 9196 & $16,40 \%$ & 1255 & $2,24 \%$ & 194 & $0,35 \%$ \\
\hline Caucaia & 271058 & 143216 & $52,84 \%$ & 53468 & $19,73 \%$ & 64888 & $23,94 \%$ & 7951 & $2,93 \%$ & 1534 & $0,57 \%$ \\
\hline Eusébio & 38040 & 20312 & $53,40 \%$ & 6808 & $17,90 \%$ & 8857 & $23,28 \%$ & 1633 & $4,29 \%$ & 430 & $1,13 \%$ \\
\hline Fortaleza & 2106309 & 855536 & $40,62 \%$ & 394590 & $18,73 \%$ & 635690 & $30,18 \%$ & 206796 & $9,82 \%$ & 13697 & $0,65 \%$ \\
\hline Horizonte & 45754 & 24886 & $54,39 \%$ & 9383 & $20,51 \%$ & 10373 & $22,67 \%$ & 968 & $2,12 \%$ & 144 & $0,32 \%$ \\
\hline Itaitinga & 29992 & 18726 & $62,44 \%$ & 5674 & $18,92 \%$ & 5096 & $16,99 \%$ & 344 & $15 \%$ & 152 &, $51 \%$ \\
\hline Maracanaú & 176199 & 84053 & $47,70 \%$ & 35773 & $20,30 \%$ & 51711 & $29,35 \%$ & 3696 & $2,10 \%$ & 965 & $0,55 \%$ \\
\hline Maranguape & 94855 & 50007 & $52,72 \%$ & 19218 & $20,26 \%$ & 23088 & $24,34 \%$ & 2002 & $2,11 \%$ & 538 & $0,57 \%$ \\
\hline Pacajus & 51595 & 30023 & $58,19 \%$ & 9503 & $18,42 \%$ & 10374 & $20,11 \%$ & 1266 & $2,45 \%$ & 429 & $0,83 \%$ \\
\hline Pacatuba & 59760 & 29088 & $48,68 \%$ & 11129 & $18,62 \%$ & 16992 & $28,43 \%$ & 1185 & $1,98 \%$ & 1366 & $2,29 \%$ \\
\hline Paracuru & 26466 & 16263 & $61,45 \%$ & 4218 & $15,94 \%$ & 4922 & $18,60 \%$ & 945 & $3,57 \%$ & 119 & $0,45 \%$ \\
\hline São G. do Amarante & 36737 & 20481 & $55,75 \%$ & 6336 & $17,25 \%$ & 8464 & $23,04 \%$ & 1002 & $2,73 \%$ & 454 & $1,24 \%$ \\
\hline Trairi & 42152 & 27204 & $64,54 \%$ & 7352 & $17,44 \%$ & 6397 & $15,18 \%$ & 1025 & $2,43 \%$ & 174 & $0,41 \%$ \\
\hline \multicolumn{12}{|c|}{ RM DE RECIFE/PE } \\
\hline Abreu e Lima & 80277 & 41180 & $51,30 \%$ & 14596 & $18,18 \%$ & 22103 & $27,53 \%$ & 1988 & $2,48 \%$ & 409 & $0,51 \%$ \\
\hline C.de Santo Agostinho & 155710 & 83144 & $53,40 \%$ & 24757 & $15,90 \%$ & 42185 & $27,09 \%$ & 4156 & $2,67 \%$ & 1468 & $0,94 \%$ \\
\hline Camaragibe & 123483 & 62517 & $50,63 \%$ & 21319 & $17,26 \%$ & 34353 & $27,82 \%$ & 4729 & $3,83 \%$ & 564 & $0,46 \%$ \\
\hline Igarassu & 85835 & 47566 & $55,42 \%$ & 13498 & $15,73 \%$ & 22113 & $25,76 \%$ & 2218 & $2,58 \%$ & 440 & $0,51 \%$ \\
\hline Ipojuca & 65231 & 42316 & $64,87 \%$ & 9682 & $14,84 \%$ & 11354 & $17,41 \%$ & 1325 & $2,03 \%$ & 554 & $0,85 \%$ \\
\hline Jaboatão dos Guar. & 547455 & 260452 & $47,58 \%$ & 95882 & $17,51 \%$ & 154560 & $28,23 \%$ & 31357 & $5,73 \%$ & 5204 & $0,95 \%$ \\
\hline Moreno & 47884 & 28805 & $60,15 \%$ & 7800 & $16,29 \%$ & 9642 & $20,14 \%$ & 1330 & $2,78 \%$ & 307 & $0,64 \%$ \\
\hline Olinda & 325443 & 137303 & $42,19 \%$ & 56758 & $17,44 \%$ & 100359 & $30,84 \%$ & 28942 & $8,89 \%$ & 2081 & $0,64 \%$ \\
\hline Paulista & 257939 & 102213 & $39,63 \%$ & 49360 & $19,14 \%$ & 89953 & $34,87 \%$ & 15101 & $5,85 \%$ & 1311 & $0,51 \%$ \\
\hline Recife & 1336198 & 528739 & $39,57 \%$ & 220897 & $16,53 \%$ & 387467 & $29,00 \%$ & 191911 & $14,36 \%$ & 7183 & $0,54 \%$ \\
\hline São Lourenço da I & 86662 & 50728 & $58,54 \%$ & 13499 & $15,58 \%$ & 19567 & $22,58 \%$ & 2135 & $2,46 \%$ & 732 & $0,84 \%$ \\
\hline
\end{tabular}

Fonte: Elaboração própria (2016) a partir de tabela base do Censo Demográfico 2010 - Resultados Gerais da

Amostra por áreas de ponderação (IBGE, 2013). 


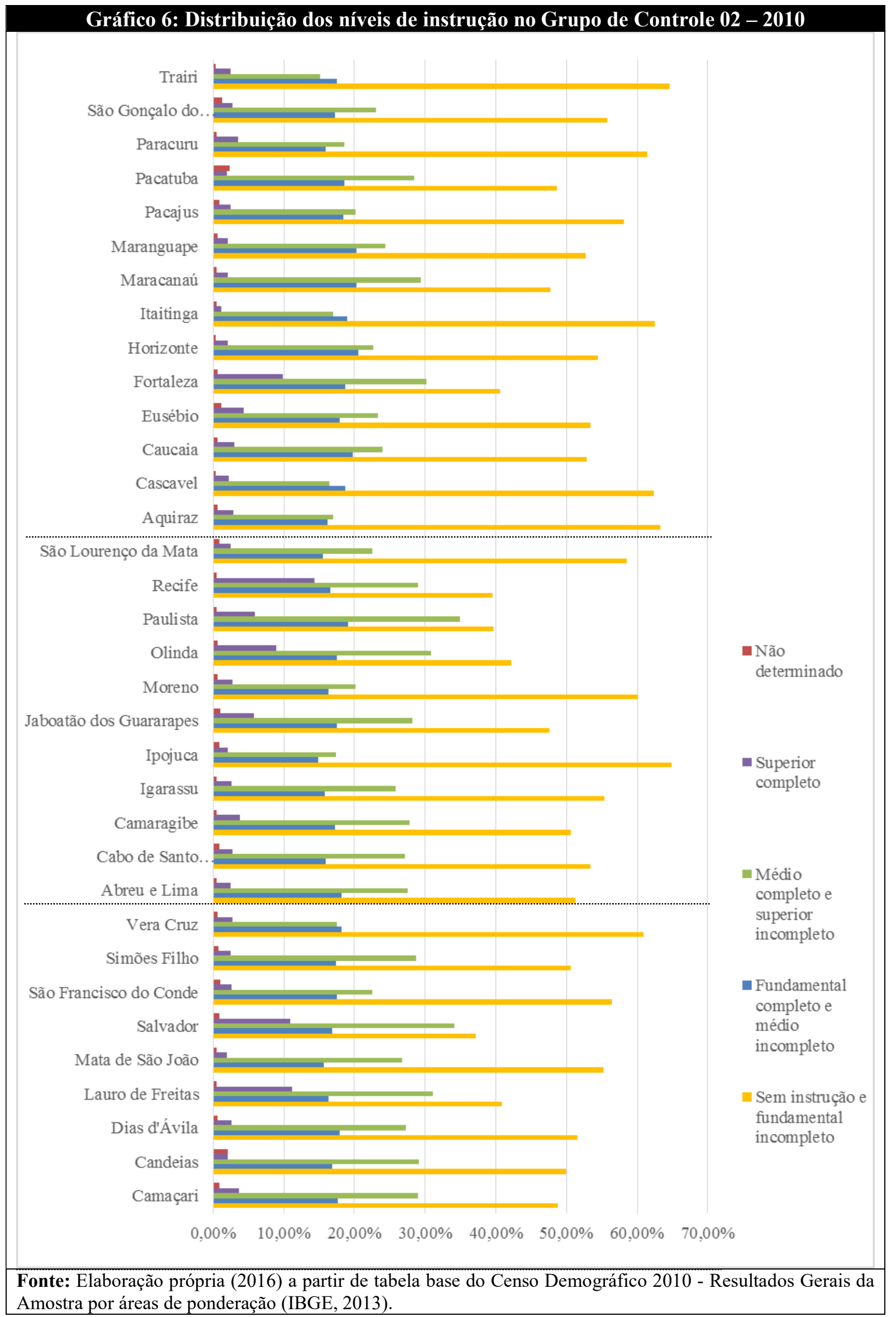




\subsection{Grupos de ocupação no trabalho principal}

Nesta variável são apresentadas onze categorias de ocupação trabalhista que variam de cargos de gerência e chefia até atividades elementares ou mal definidas (ver Anexo 01). Os dados foram colhidos no censo 2010, também por áreas de ponderação, e organizados de acordo com os grupos de cidades definidos no referencial empírico. Como são muitas categorias, analiso em detalhe algumas delas.

Primeiramente, os cargos de direção e gerência (coluna 01 nas tabelas), que representam cerca de 4\% dos empregos das RMINE'S, reduzem para cerca de 3\% no Grupo de Controle 01 e aumentam para cerca de 5\% no Grupo de Controle 02. Percentualmente os dados são muitos próximos, mas parecem revelar uma hierarquia na distribuição destes postos de trabalhos ao longo da rede urbana. A categoria 05 representa os trabalhadores do setor de serviços, vendedores dos comércios e mercados, ou seja, os empregados no setor terciário. Salvo as exceções comentadas quando apresentei os dados dos PIB's, este é um dos setores que mais contribui com as receitas municipais. Para todos os municípios-sede das RM's e cidades do Grupo de Controle 01, os percentuais se apresentam entre 18 e $22 \%$ da população maior de 10 anos atuando nessa área. A exceção é Juazeiro do Norte/CE, que possui 24,65\% dos seus moradores trabalhando com o comércio, especificamente relacionado com o turismo religioso associado às romarias e ao Padre Cícero, responsável pela atração de cerca de 2,5 milhões de fiéis por ano ao município. Uma categoria que permite a avaliação da relação entre o rural e o urbano é a número 6 (trabalhadores qualificados da agropecuária, florestais, da caça e da pesca). Nas RMINE'S selecionadas se destacam: (1) a conurbação PetrolinaJuazeiro, onde encontramos cerca de $12 \%$ da população exercendo tais atividades, índice condizente com o polo agrícola irrigação do Vale do Rio São Francisco, (2) Arapiraca onde cerca de $10 \%$ dos habitantes ocupados na categoria, condizendo com o fato da cidade ter sido grande produtora de fumo de corda e contar hoje com um Programa de Pós-Graduação em Agricultura e Ambiente vinculado a Universidade Federal de Alagoas - UFAL. Nas demais cidades-sede e municípios do Grupo de Controle 01, esta porcentagem não passa de $6 \%$. Este número reduz drasticamente no Grupo de Controle 02, onde apenas cerca de 0,43\% dos moradores de Salvador, Fortaleza e Recife são empregados nesse setor. Esses dados sugerem a hipótese de que baixos índices de trabalhadores do tipo 6 são verificados em áreas extremamente urbanizadas, onde é praticamente inexistente a agricultura em média ou larga escala, pois observando os mapas e fotos de satélite das capitais nordestinas percebe-se que seus tecidos urbanos ocupam cerca de $90 \%$ de seu território. 
Tabela 10: Pessoas de 10 anos ou mais de idade, ocupadas na semana de referência, por grandes grupos de ocupação no trabalho principal, para as RMINE's selecionadas- 2010

\begin{tabular}{|c|c|c|c|c|c|c|c|c|c|c|c|c|c|c|c|c|c|c|c|c|c|c|c|}
\hline \multirow{3}{*}{$\begin{array}{l}\text { Unidades da } \\
\text { Federação, } \\
\text { municípios e } \\
\text { áreas de } \\
\text { ponderaçãa }\end{array}$} & \multicolumn{23}{|c|}{ Pessoas de 10 anos ou mais de idade, ocupadas na semana de referência } \\
\hline & \multirow[b]{2}{*}{ Total } & \multicolumn{22}{|c|}{ Grandes grupos de ocupação no trabalho principal } \\
\hline & & 01 & $\%$ & 02 & $\%$ & 03 & $\%$ & 04. & $\%$ & 05 & $\%$ & 06 & $\%$ & 07 & $\%$ & 08 & $\%$ & 09 & $\%$ & 10 & $\%$ & 11 & $\%$ \\
\hline \multicolumn{24}{|c|}{ RM FEIRA DE SANTANA/BA } \\
\hline a de Santana & 261614 & 10842 & $4,14 \%$ & 21970 & $8,40 \%$ & 19380 & $7,41 \%$ & 18572 & $7,10 \%$ & 48162 & $18,41 \%$ & 13482 & $5,15 \%$ & 33741 & $12,90 \%$ & 21204 & $8,11 \%$ & 52464 & $20,05 \%$ & 1901 & $0,73 \%$ & 19895 & $7,60 \%$ \\
\hline G.dos Campos & 14174 & 394 & $2,78 \%$ & 576 & $4,06 \%$ & 474 & $3,34 \%$ & 411 & $2,90 \%$ & 1551 & $10,94 \%$ & 2251 & $15,88 \%$ & 1949 & $13,75 \%$ & 752 & $5,31 \%$ & 4839 & $34,14 \%$ & & & 978 & $6,90 \%$ \\
\hline \multicolumn{24}{|c|}{ RM DO CARIRI/CE } \\
\hline arbalha & 22137 & 595 & $2,69 \%$ & 1957 & $8,84 \%$ & 1383 & $6,25 \%$ & 1270 & $5,74 \%$ & 3708 & $16,75 \%$ & 3055 & $13,80 \%$ & 1983 & $8,96 \%$ & 1671 & $7,55 \%$ & 5683 & $25,67 \%$ & & & 831 & $3,75 \%$ \\
\hline rato & 50055 & 1802 & $3,60 \%$ & 5126 & $10,24 \%$ & 2276 & $4,55 \%$ & 2948 & $5,89 \%$ & 8554 & $17,09 \%$ & 5307 & $10,60 \%$ & 5274 & $10,54 \%$ & 3899 & $7,79 \%$ & 12498 & $24,97 \%$ & 72 & $0,14 \%$ & 2298 & $4,59 \%$ \\
\hline ua. do Norte & 102036 & 4089 & $4,01 \%$ & 8148 & $7,99 \%$ & 5135 & $5,03 \%$ & 5608 & $5,50 \%$ & 25154 & $24,65 \%$ & 3982 & $3,90 \%$ & 13543 & $13,27 \%$ & 9034 & $8,85 \%$ & 20882 & $20,47 \%$ & 424 & $0,42 \%$ & 6038 & $5,92 \%$ \\
\hline Missão Velha & 14196 & 293 & $2,06 \%$ & 711 & $5,01 \%$ & 621 & $4,37 \%$ & 454 & $3,20 \%$ & 1676 & $11,81 \%$ & 4597 & $32,38 \%$ & 755 & $5,32 \%$ & 575 & $4,05 \%$ & 4007 & $28,23 \%$ & & & 507 & $3,57 \%$ \\
\hline \multicolumn{24}{|c|}{ RM DO SUDOESTE MARANHESE } \\
\hline Imperatriz & 109622 & 5047 & $4,60 \%$ & 9503 & $8,67 \%$ & 7650 & $6,98 \%$ & 7753 & $7,07 \%$ & 24517 & $22,36 \%$ & 3793 & $3,46 \%$ & 14437 & $13,17 \%$ & 8505 & $7,76 \%$ & 18871 & $17,21 \%$ & 718 & $0,66 \%$ & 8827 & $8,05 \%$ \\
\hline \multicolumn{24}{|c|}{ RM DE CAMPINA GRANDE/PB } \\
\hline ampina Grande & 159942 & 6665 & $4,17 \%$ & 18022 & $11,27 \%$ & 10423 & $6,52 \%$ & 11036 & $6,90 \%$ & 36551 & $22,85 \%$ & 6519 & $4,08 \%$ & 19114 & $11,95 \%$ & 13785 & $8,62 \%$ & 27268 & $17,05 \%$ & 771 & $0,48 \%$ & 9788 & $6,12 \%$ \\
\hline \multicolumn{24}{|c|}{ RAID PETROLINA JUAZEIRO } \\
\hline etrolina/PE & 124213 & 4355 & $3,51 \%$ & 10912 & $8,79 \%$ & 6597 & $5,31 \%$ & 6588 & $5,30 \%$ & 20484 & $16,49 \%$ & 17164 & $13,82 \%$ & 12566 & $10,12 \%$ & 6987 & $5,63 \%$ & 28444 & $22,90 \%$ & 964 & $0,78 \%$ & 9151 & $7,37 \%$ \\
\hline S.Ma da B.Vista & 16879 & 227 & $1,35 \%$ & 1157 & $6,86 \%$ & 302 & 1,79\% & 287 & $1,70 \%$ & 1252 & $7,42 \%$ & 8582 & $50,85 \%$ & 618 & $3,66 \%$ & 564 & $3,34 \%$ & 3213 & $19,04 \%$ & 19 & $0,11 \%$ & 658 & $3,90 \%$ \\
\hline Casa Nova/BA & 25615 & 336 & $1,31 \%$ & 1098 & $4,29 \%$ & 526 & $2,05 \%$ & 461 & $1,80 \%$ & 2888 & $11,27 \%$ & 8435 & $32,93 \%$ & 1441 & $5,63 \%$ & 857 & $3,34 \%$ & 8595 & $33,56 \%$ & 17 & $0,07 \%$ & 962 & $3,76 \%$ \\
\hline Juazeiro/BA & 79661 & 2334 & $2,93 \%$ & 6019 & $7,56 \%$ & 4605 & $5,78 \%$ & 3969 & $4,98 \%$ & 15209 & $19,09 \%$ & 8583 & $10,77 \%$ & 7320 & $9,19 \%$ & 4456 & $5,59 \%$ & 21337 & $26,79 \%$ & 684 & $0,86 \%$ & 5145 & $6,46 \%$ \\
\hline
\end{tabular}

\section{LEGENDA}

01 Diretores e gerentes 02 Profissionais das ciências e intelectuais

05 Trabalhadores dos serviços, vendedores 06 Trabalhadores qualificados da dos comércios e mercados

09 Ocupações elementares agropecuária, florestais, da caça e da pesca

10 Membros das forças armadas, policiais bombeiros militares

Fonte: Elaboração própria (2016) a partir de tabela base do Censo Demográfico 2010 - Resultados Gerais da Amostra por áreas de ponderação (IBGE, 2013).
04 Trabalhadores de apoio administrativo

07 Trabalhadores qualificados, operários

08 Operadores de instalações e máquinas e outros oficios (08 Operadores
11 Ocupações mal definidas

AS METRÓPOIES DO INTERIORE O INTERIOR DAS METRÓPOIES: UMA PERSPECTIVA COMPARADA DA CONFIGURAÇÃO ESPACIAL DAS REGIÕES METROPOLITANAS DO INTERIOR DO NORDESTE. 
Tabela 11: Pessoas de 10 anos ou mais de idade, ocupadas na semana de referência, por grandes grupos de ocupação no trabalho principal, para 0 grupo de controle 01- 2010

Pessoas de 10 anos ou mais de idade, ocupadas na semana de referência

\begin{tabular}{l|l|l} 
Unidades da \\
Federação,
\end{tabular}

Federação,

áreas de

ponderação

Total

\begin{tabular}{|l|l|l|l|l|l|l|}
\hline 01 & $\%$ & 02 & $\%$ & 03 & $\%$ & 04. \\
\hline
\end{tabular}

( )

\begin{tabular}{|c|c|c|c|c|c|c|c|c|c|c|c|c|c|c|c|c|c|c|c|c|c|c|c|}
\hline \multicolumn{24}{|c|}{ RM DO AGRESTE/AL } \\
\hline Arapiraca & 85140 & 3743 & $4,40 \%$ & 7060 & $8,29 \%$ & 4376 & $5,14 \%$ & 5078 & $5,96 \%$ & 15827 & $18,59 \%$ & 9216 & $10,82 \%$ & 9806 & $11,52 \%$ & 5407 & $6,35 \%$ & 21014 & $24,68 \%$ & 294 & $0,34 \%$ & 3319 & $3,90 \%$ \\
\hline G. do Ponciano & 14259 & 81 & $0,57 \%$ & 756 & $5,30 \%$ & 216 & $1,51 \%$ & 105 & $0,74 \%$ & 687 & $4,81 \%$ & 5620 & $39,41 \%$ & 546 & $3,83 \%$ & 245 & $1,72 \%$ & 5693 & $39,93 \%$ & 26 & $0,19 \%$ & 285 & $2,00 \%$ \\
\hline \multicolumn{24}{|c|}{ VITÓRIA DA CONQUISTA/BA } \\
\hline V. da Conquis. & 138570 & 4492 & $3,24 \%$ & 12601 & $9,09 \%$ & 8371 & $6,04 \%$ & 9716 & $7,01 \%$ & 27724 & $20,01 \%$ & 11868 & $8,56 \%$ & 17561 & $12,67 \%$ & 10654 & $7,69 \%$ & 26473 & $19,10 \%$ & 498 & $0,36 \%$ & 8612 & $6,22 \%$ \\
\hline \multicolumn{24}{|c|}{ SOBRAL/CE } \\
\hline Sobral & 77723 & 1705 & $2,19 \%$ & 6655 & $8,56 \%$ & 3482 & $4,48 \%$ & 4894 & $6,30 \%$ & 14037 & $18,06 \%$ & 5129 & $6,60 \%$ & 6854 & $8,82 \%$ & 5865 & $7,55 \%$ & 21724 & $27,95 \%$ & 124 & $0,16 \%$ & 7253 & $9,33 \%$ \\
\hline \multicolumn{24}{|c|}{ MOSSORÓ/RN } \\
\hline Mossoró & 108849 & 3891 & $3,57 \%$ & 10501 & $9,65 \%$ & 8878 & $8,16 \%$ & 7365 & $6,77 \%$ & 20894 & $19,20 \%$ & 4392 & $4,03 \%$ & 13282 & $12,20 \%$ & 9588 & $8,81 \%$ & 19298 & $17,73 \%$ & 328 & $0,30 \%$ & 10433 & $9,59 \%$ \\
\hline \multicolumn{24}{|c|}{ CARUARU/PE } \\
\hline aruaru & 146265 & 5260 & $3,60 \%$ & 10334 & $7,07 \%$ & 7567 & $5,17 \%$ & 8166 & $5,58 \%$ & 26696 & $18,25 \%$ & 6910 & $4,72 \%$ & 342 & $9,12 \%$ & 149 & $19,93 \%$ & 936 & $5,00 \%$ & 426 & $0,29 \%$ & 16478 & \\
\hline
\end{tabular}

01 Diretores e gerentes

05 Trabalhadores dos serviços, vendedores

dos comércios e mercados

09 Ocupações elementares

06 Trabalhadores qualificados da

agropecuária, florestais, da caça e da pesca

10 Membros das forças armadas, policiais

bombeiros militares

Fonte: Elaboração própria (2016) a partir de tabela base do Censo Demográfico 2010 - Resultados Gerais da Amostra por áreas de ponderação (IBGE, 2013).
03 Técnicos e profissionais de nível médio

07 Trabalhadores qualificados, operários e

artes̃os

outros ofícios

4 Trabalhadores de apoio administrativo

08 Operadores de instalações e máquinas e

montadores

11 Ocupações mal definidas 
Tabela 12: Pessoas de 10 anos ou mais de idade, ocupadas na semana de referência, por grandes grupos de ocupação no trabalho principal, para 0 grupo de controle 02 - RM de Salvador - 2010

Pessoas de 10 anos ou mais de idade, ocupadas na semana de referência

\begin{tabular}{|c|c|c|c|c|c|c|c|c|c|c|c|c|c|c|c|c|c|c|c|c|c|c|c|}
\hline \multirow{3}{*}{$\begin{array}{l}\text { Unidades da } \\
\text { Federação, } \\
\text { municípios e } \\
\text { áreas de } \\
\text { ponderação }\end{array}$} & \multicolumn{23}{|c|}{ Pessoas de 10 anos ou mais de idade, ocupadas na semana de referência } \\
\hline & \multirow[b]{2}{*}{ Total } & \multicolumn{22}{|c|}{ Grandes grupos de ocupação no trabalho principal } \\
\hline & & 01 & $\%$ & 02 & $\%$ & 03 & $\%$ & 04. & $\%$ & 05 & $\%$ & 06 & $\%$ & 07 & $\%$ & 08 & $\%$ & 09 & $\%$ & 10 & $\%$ & 11 & $\%$ \\
\hline \multicolumn{24}{|c|}{ RM DE SALVADOR/BA } \\
\hline Camaçari & 106130 & 2740 & $2,58 \%$ & 5199 & $4,90 \%$ & 6069 & $5,72 \%$ & 6186 & $5,83 \%$ & 21150 & $19,93 \%$ & 2640 & $2,49 \%$ & 16152 & $15,22 \%$ & 8563 & $8,07 \%$ & 22104 & $20,83 \%$ & 87 & $0,08 \%$ & 15240 & $14,36 \%$ \\
\hline Candeias & 32506 & 540 & $1,66 \%$ & 2015 & $6,20 \%$ & 1502 & $4,62 \%$ & 1808 & $5,56 \%$ & 5838 & $17,96 \%$ & 926 & $2,85 \%$ & 6148 & $18,91 \%$ & 2375 & $7,31 \%$ & 5434 & $16,72 \%$ & - & & 5921 & $18,22 \%$ \\
\hline Dias d'Ávila & 24467 & 707 & $2,89 \%$ & 1143 & $4,67 \%$ & 1314 & $5,37 \%$ & 1408 & $5,76 \%$ & 4345 & $17,76 \%$ & 598 & $2,44 \%$ & 4560 & $18,64 \%$ & 2700 & $11,04 \%$ & 4713 & $19,26 \%$ & 9 & $0,04 \%$ & 2969 & $12,13 \%$ \\
\hline L. de Freitas & 78137 & 4390 & $5,62 \%$ & 8776 & $11,23 \%$ & 5389 & $6,90 \%$ & 5030 & $6,44 \%$ & 14817 & $18,96 \%$ & 304 & $0,39 \%$ & 8480 & $10,85 \%$ & 4627 & $5,92 \%$ & 16205 & $20,74 \%$ & 239 & $0,31 \%$ & 9881 & $12,65 \%$ \\
\hline M. de S.João & 15128 & 364 & $2,41 \%$ & 874 & $5,78 \%$ & 635 & $4,20 \%$ & 692 & $4,58 \%$ & 3552 & $23,48 \%$ & 650 & $4,30 \%$ & 2143 & $14,16 \%$ & 961 & $6,35 \%$ & 3460 & $22,87 \%$ & 48 & $0,32 \%$ & 1749 & $11,56 \%$ \\
\hline Salvador & 1252949 & 61982 & $4,95 \%$ & 160066 & $12,78 \%$ & 125839 & $10,04 \%$ & 120414 & $9,61 \%$ & 260293 & $20,77 \%$ & 5841 & $0,47 \%$ & 123285 & $9,84 \%$ & 75167 & $6,00 \%$ & 200624 & $16,01 \%$ & 8337 & $0,67 \%$ & 111101 & $8,87 \%$ \\
\hline S. F. do Conde & 11805 & 298 & $2,53 \%$ & 740 & $6,27 \%$ & 599 & $5,08 \%$ & 1136 & $9,62 \%$ & 1937 & $16,41 \%$ & 968 & $8,20 \%$ & 1695 & $14,36 \%$ & 532 & $4,51 \%$ & 2740 & $23,21 \%$ & 56 & $0,47 \%$ & 1105 & $9,36 \%$ \\
\hline Simões Filho & 45960 & 1189 & $2,59 \%$ & 2359 & $5,13 \%$ & 2716 & $5,91 \%$ & 3072 & $6,68 \%$ & 9602 & $20,89 \%$ & 913 & $1,99 \%$ & 6907 & $15,03 \%$ & 5022 & $10,93 \%$ & 9532 & $20,74 \%$ & 394 & $0,86 \%$ & 4255 & $9,26 \%$ \\
\hline Vera Cruz & 14395 & 400 & $2,78 \%$ & 1008 & $7,00 \%$ & 599 & $4,16 \%$ & 522 & $3,62 \%$ & 2833 & $19,68 \%$ & 1849 & $12,85 \%$ & 1707 & $11,86 \%$ & & $6,14 \%$ & 3690 & $25,63 \%$ & 33 & & 870 & \\
\hline
\end{tabular}

\section{LEGENDA}

$\begin{array}{lll}01 \text { Diretores e gerentes } & 02 \text { Profissionais das ciências e intelectuais } & \begin{array}{l}\text { 03 Técnicos e profissionais de nível médio } \\ 07 \text { Trabalhadores qualificados, operários e }\end{array} \\ \begin{array}{ll}05 \text { Trabalhadores dos serviços, vendedores } \\ \text { dos comércios e mercados }\end{array} & \begin{array}{l}06 \text { Trabalhadores qualificados da } \\ \text { agropecuária, florestais, da caça e da pesca }\end{array} & \begin{array}{l}\text { artesãos da construção, das artes mecânicas e } \\ \text { outros ofícios }\end{array} \\ 09 \text { Ocupações elementares } & \begin{array}{l}10 \text { Membros das forças armadas, policiais e } \\ \text { bombeiros militares }\end{array} & \text { 11 Ocupações mal definidas instalações e máquinas e }\end{array}$

Fonte: Elaboração própria (2016) a partir de tabela base do Censo Demográfico 2010 - Resultados Gerais da Amostra por áreas de ponderação (IBGE, 2013). 
Tabela 13: Pessoas de 10 anos ou mais de idade, ocupadas na semana de referência, por grandes grupos de ocupação no trabalho principal, para 0 grupo de controle 02 - RM de Fortaleza - 2010

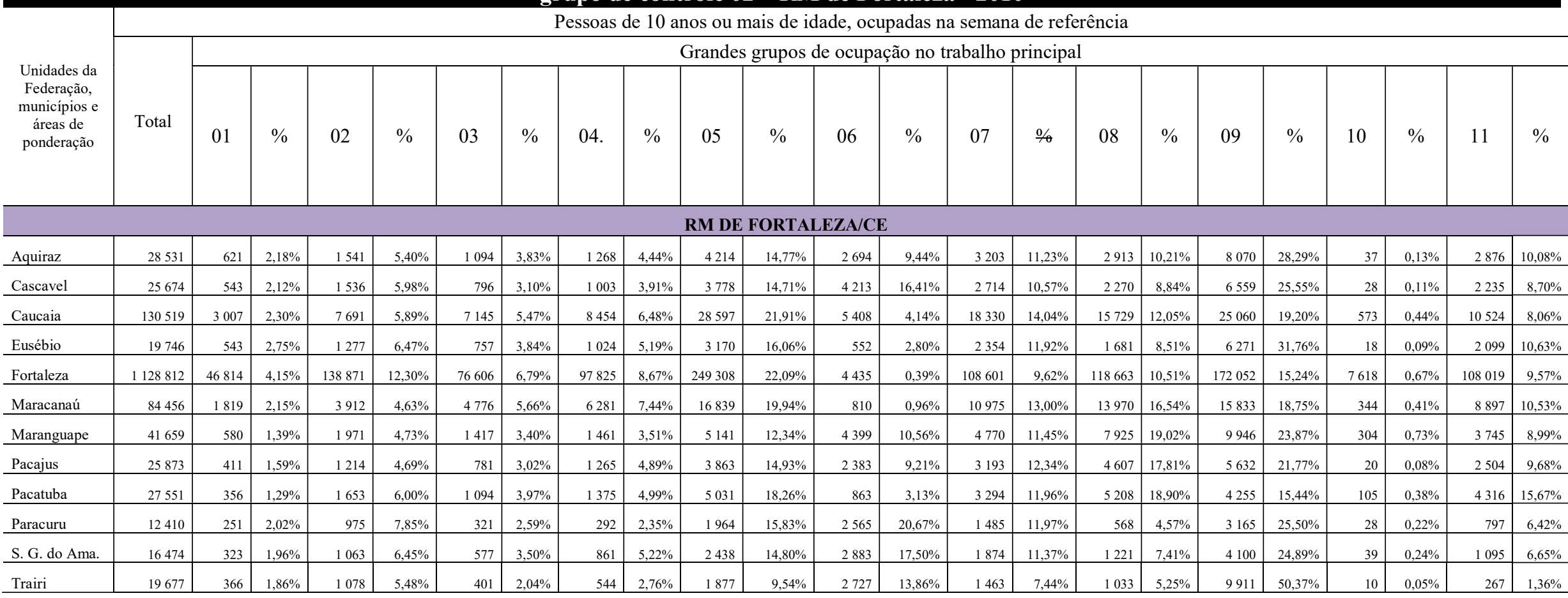

\begin{tabular}{|c|c|c|c|}
\hline \multicolumn{4}{|c|}{ LEGENDA } \\
\hline 01 Diretores e gerentes & 02 Profissionais das ciências e intelectuais & 03 Técnicos e profissionais de nível médio & 04 Trabalhadores de apoio administrativo \\
\hline $\begin{array}{l}05 \text { Trabalhadores dos serviços, vendedores } \\
\text { dos comércios e mercados }\end{array}$ & $\begin{array}{l}06 \text { Trabalhadores qualificados da } \\
\text { agropecuária, florestais, da caça e da pesca }\end{array}$ & $\begin{array}{l}07 \text { Trabalhadores qualificados, operários e } \\
\text { artesãos da construção, das artes mecânicas e } \\
\text { outros ofícios }\end{array}$ & $\begin{array}{l}08 \text { Operadores de instalações e máquinas e } \\
\text { montadores }\end{array}$ \\
\hline 09 Ocupações elementares & $\begin{array}{l}10 \text { Membros das forças armadas, policiais e } \\
\text { bombeiros militares }\end{array}$ & 11 Ocupações mal definidas & \\
\hline
\end{tabular}

Fonte: Elaboração própria (2016) a partir de tabela base do Censo Demográfico 2010 - Resultados Gerais da Amostra por áreas de ponderação (IBGE, 2013). 
Tabela 14: Pessoas de 10 anos ou mais de idade, ocupadas na semana de referência, por grandes grupos de ocupação no trabalho principal, para 0 grupo de controle 02 - RM de Recife - 2010

\begin{tabular}{|c|c|c|c|c|c|c|c|c|c|c|c|c|c|c|c|c|c|c|c|c|c|c|c|}
\hline \multirow{3}{*}{$\begin{array}{l}\text { Unidades da } \\
\text { Federação, } \\
\text { municípios e } \\
\text { áreas de } \\
\text { ponderação }\end{array}$} & \multicolumn{23}{|c|}{ Pessoas de 10 anos ou mais de idade, ocupadas na semana de referência } \\
\hline & \multirow[b]{2}{*}{ Total } & \multicolumn{22}{|c|}{ Grandes grupos de ocupação no trabalho principal } \\
\hline & & 01 & $\%$ & 02 & $\%$ & 03 & $\%$ & 04. & $\%$ & 05 & $\%$ & 06 & $\%$ & 07 & $\%$ & 08 & $\%$ & 09 & $\%$ & 10 & $\%$ & 11 & $\%$ \\
\hline \multicolumn{24}{|c|}{ RM DE RECIFE/PE } \\
\hline Abreu e Lima & 34991 & 999 & $2,86 \%$ & 2282 & $6,52 \%$ & 2436 & $6,96 \%$ & 2908 & $8,31 \%$ & 7042 & $20,13 \%$ & 1306 & $3,73 \%$ & 4539 & $12,97 \%$ & 4466 & $12,76 \%$ & 6330 & $18,09 \%$ & 578 & $1,65 \%$ & 2104 & $6,01 \%$ \\
\hline C.deS. Agostinho & 67594 & 2179 & $3,22 \%$ & 4340 & $6,42 \%$ & 4046 & $5,99 \%$ & 4573 & $6,77 \%$ & 10738 & $15,89 \%$ & 2057 & $3,04 \%$ & 12115 & $17,92 \%$ & 6696 & $9,91 \%$ & 13709 & $20,28 \%$ & 174 & $0,26 \%$ & 6969 & $10,31 \%$ \\
\hline Igarassu & 36088 & 1237 & $3,43 \%$ & 2431 & $6,74 \%$ & 2031 & $5,63 \%$ & 2503 & $6,94 \%$ & 5651 & $15,66 \%$ & 1321 & $3,66 \%$ & 5171 & $14,33 \%$ & 4418 & $12,24 \%$ & 8613 & $23,87 \%$ & 136 & $0,38 \%$ & 2573 & $7,13 \%$ \\
\hline Ipojuca & 28128 & 928 & $3,30 \%$ & 1472 & $5,23 \%$ & 1092 & $3,88 \%$ & 1503 & $5,34 \%$ & 5745 & $20,42 \%$ & 1919 & $6,82 \%$ & 3964 & $14,09 \%$ & 2458 & $8,74 \%$ & 6796 & $24,16 \%$ & 21 & $0,07 \%$ & 2232 & $7,94 \%$ \\
\hline Jaboatão dos G. & 256042 & 13498 & $5,27 \%$ & 22223 & $8,68 \%$ & 20591 & $8,04 \%$ & 22491 & $8,78 \%$ & 55337 & $21,61 \%$ & 2025 & $0,79 \%$ & 28349 & $11,07 \%$ & 19641 & $7,67 \%$ & 49456 & $19,32 \%$ & 2621 & $1,02 \%$ & 19810 & $7,74 \%$ \\
\hline Moreno & 18142 & 666 & $3,67 \%$ & 1286 & $7,09 \%$ & 835 & $4,60 \%$ & 1073 & $5,92 \%$ & 3225 & $17,78 \%$ & 1208 & $6,66 \%$ & 2079 & $11,46 \%$ & 2163 & $11,92 \%$ & 4478 & $24,68 \%$ & 87 & $0,48 \%$ & 1041 & $5,74 \%$ \\
\hline Olinda & 151404 & 7505 & $4,96 \%$ & 18173 & $12,00 \%$ & 15026 & $\begin{array}{l}9,92 \% \\
\end{array}$ & 16049 & $10,60 \%$ & 31961 & $21,11 \%$ & 660 & $0,44 \%$ & 15111 & $9,98 \%$ & 8568 & $5,66 \%$ & 25940 & $17,13 \%$ & 1538 & $1,02 \%$ & 10871 & $7,18 \%$ \\
\hline Paulista & 120875 & 4894 & $4,05 \%$ & 11536 & $9,54 \%$ & 11679 & $9,66 \%$ & 14152 & $11,71 \%$ & 26983 & $22,32 \%$ & 766 & $0,63 \%$ & 12118 & $10,03 \%$ & 9769 & $8,08 \%$ & 18645 & $15,43 \%$ & 1616 & $1,34 \%$ & 8716 & $7,21 \%$ \\
\hline Recife & 661052 & 44486 & $6,73 \%$ & 103028 & $15,59 \%$ & 60988 & $9,23 \%$ & 58712 & $8,88 \%$ & 133311 & $20,17 \%$ & 2815 & $0,43 \%$ & 53899 & $8,15 \%$ & 33368 & $5,05 \%$ & 113239 & $17,13 \%$ & 8502 & $1,29 \%$ & 48704 & $7,37 \%$ \\
\hline L. da Mata & 35196 & 1046 & $2,97 \%$ & 2543 & $7,23 \%$ & 1974 & $5,61 \%$ & 2094 & $5,95 \%$ & 7444 & $21,15 \%$ & 1448 & $4,11 \%$ & 4774 & $56 \%$ & 2696 & $7,66 \%$ & 8869 & $5,20 \%$ & 448 & $1,27 \%$ & 1859 &,, 2 \\
\hline
\end{tabular}

\section{LEGENDA}

\section{Diretores e gerente}

05 Trabalhadores dos serviços, vendedores dos comércios e mercados

09 Ocupações elementares

02 Profissionais das ciências e intelectuais

06 Trabalhadores qualificados da

agropecuária, florestais, da caça e da pesca

10 Membros das forças armadas, policiais

bombeiros militares
03 Técnicos e profissionais de nível médio

07 Trabalhadores qualificados, operários e

artesãos da construção, das artes mecânicas e

outros ofícios

11 Ocupações mal definidas

Fonte: Elaboração própria (2016) a partir de tabela base do Censo Demográfico 2010 - Resultados Gerais da Amostra por áreas de ponderação (IBGE, 2013). 
Por fim, cabe avaliar a categoria 09: Ocupações elementares, que representam diversas profissões de baixa especialização ou nível de instrução, por exemplo trabalhadores dos serviços domésticos em geral, trabalhadores elementares da agropecuária, da pesca, da mineração, da construção, vendedores ambulantes, dentre outros (ver Anexo 01: classificação de ocupações para pesquisas domiciliares - COD). Nas cidades avaliadas essa categoria apresentou um percentual populacional que varia entre 15\% (em Caruaru/PE e Salvador/BA) e $27 \%$ do total (em Sobral/CE).

\subsection{Tempo de deslocamento entre a residência e o trabalho}

Ainda a partir dos dados do IBGE por áreas de ponderação, será avaliada a variável de tempo de deslocamento casa-trabalho. Esta variável está associada às questões de mobilidade e bem-estar da população, mas também pode ser entendida como uma decorrência das formas de organização social e econômica sobre espaço urbano (ALONSO, 1964). Ou seja, as localizações urbanas - especialmente descritas na dicotomia residência e áreas de trabalho, expressas aqui como mais próximas ou mais distantes - carregam um valor agregado que dá suporte aos processos de especulação imobiliária (GORDON, RICHARDSON \& JUN, 1991; LEVINSON \& KUMAR, 1997), além de ser apontado como indicador relevante para análises de desigualdade de renda ou gênero (HANSON \& JOHNSTON, 1985; CRANE, 2007). Traçando um panorama de diversos estudos sobre esta temática realizados para países desenvolvidos, Pereira \& Schwanen (2013) apontam que:

[...] como as diferenças entre durações de viagem casa-trabalho em um mesmo momento do tempo são relacionadas às diferenças de estrutura espacial das cidades, características de emprego, status socioeconômico dos trabalhadores e suas características sociodemográficas como sexo, idade e situação do domicílio [...] Entre as características da estrutura urbana, densidade demográfica, nível de concentração de empregos no centro da cidade (CBD) e dimensão territorial da região metropolitana são fatores importantes relacionados ao tempo que os trabalhadores gastam no deslocamento para o trabalho. (PEREIRA; SCHWANEN, 2013, p. 09).

Avaliando os dados para as RMINE'S, apresentados na Tabela 15 e no Gráfico 7, percebe-se a preponderância da população (cerca de 65\%) que se enquadra na categoria "De 6 minutos até meia hora", pois a sua mobilidade se restringe a deslocamentos dentro do próprio município. Também há cerca de $18 \%$ da população que trabalhava fora do domicílio e que gasta entre meia e uma hora em seus deslocamentos. Em geral, há poucos moradores que gastam mais de uma hora para chegar aos seus locais de trabalho. 


\begin{tabular}{|c|c|c|c|c|c|c|c|c|c|c|c|}
\hline \multicolumn{12}{|c|}{$\begin{array}{l}\text { Tabela 15: Pesso } \\
\text { retornavam par: } \\
\text { trabalho - } 2010\end{array}$} \\
\hline \multirow[b]{3}{*}{$\begin{array}{l}\text { Universo de estudo } \\
\text { por RM's e/ou } \\
\text { municípios }\end{array}$} & \multicolumn{11}{|c|}{$\begin{array}{l}\text { Pessoas ocupadas na semana de referência, que trabalhavam fora do domicílio e retornavam para seu } \\
\text { domicílio diariamente }\end{array}$} \\
\hline & \multicolumn{11}{|c|}{ Tempo habitual de deslocamento para o trabalho } \\
\hline & Total & $\begin{array}{c}\text { Até } 5 \\
\text { minutos }\end{array}$ & $\%$ & $\begin{array}{l}\text { De } 6 \\
\text { minutos } \\
\text { até meia } \\
\text { hora }\end{array}$ & $\%$ & $\begin{array}{l}\text { Mais de } \\
\text { meia hora } \\
\text { até uma } \\
\text { hora }\end{array}$ & $\%$ & $\begin{array}{c}\text { Mais } \\
\text { de uma } \\
\text { hora } \\
\text { até } \\
\text { duas } \\
\text { horas } \\
\end{array}$ & $\%$ & $\begin{array}{c}\text { Mais de } \\
\text { duas } \\
\text { horas }\end{array}$ & $\%$ \\
\hline \multicolumn{12}{|c|}{ RM FEIRA DE SANTANA/BA } \\
\hline Feira de Santana & 173862 & 16921 & $9,73 \%$ & 103289 & $59,41 \%$ & 40205 & $23,12 \%$ & 11814 & $6,79 \%$ & 1633 & $0,94 \%$ \\
\hline São G. dos Campos & 9101 & 1098 & $12,06 \%$ & 5889 & $64,71 \%$ & 1776 & $19,51 \%$ & 235 & $2,59 \%$ & 103 & $1,13 \%$ \\
\hline \multicolumn{12}{|c|}{ RM DO CARIRI/CE } \\
\hline Barbalha & 16624 & 2532 & $15,23 \%$ & 10863 & $65,34 \%$ & 2664 & $16,03 \%$ & 489 & $2,94 \%$ & 76 & $0,46 \%$ \\
\hline Crato & 38066 & 5021 & $13,19 \%$ & 26065 & $68,47 \%$ & 5864 & $15,41 \%$ & 973 & $2,56 \%$ & 143 & $0,38 \%$ \\
\hline Juazeiro do Norte & 74012 & 10099 & $13,64 \%$ & 50746 & $68,56 \%$ & 10748 & $14,52 \%$ & 1741 & $2,35 \%$ & 679 & $0,92 \%$ \\
\hline Missão Velha & 8756 & 1756 & $20,05 \%$ & 5430 & $62,01 \%$ & 1196 & $13,66 \%$ & 302 & $3,45 \%$ & 73 & $0,83 \%$ \\
\hline \multicolumn{12}{|c|}{ RM DO SUDOESTE MARANHENSE } \\
\hline Imperatriz & 79991 & 11645 & $14,56 \%$ & 59672 & $74,60 \%$ & 6930 & $8,66 \%$ & 1194 & $1,49 \%$ & 550 & $0,69 \%$ \\
\hline \multicolumn{12}{|c|}{ RM DE CAMPINA GRANDE/PB } \\
\hline Campina Grande & 119760 & 13252 & $11,07 \%$ & 81447 & $68,01 \%$ & 21138 & $17,65 \%$ & 3156 & $2,64 \%$ & 768 & $0,64 \%$ \\
\hline \multicolumn{12}{|c|}{ RAID PETROLINA - JUAZEIRO } \\
\hline Petrolina & 91243 & 9574 & $10,49 \%$ & 57721 & $63,26 \%$ & 19475 & $21,34 \%$ & 3836 & $4,20 \%$ & 637 & $0,70 \%$ \\
\hline Santa $M^{\text {a }}$ da B.Vista & 13423 & 2357 & $17,56 \%$ & 9189 & $68,46 \%$ & 1467 & $10,93 \%$ & 373 & $2,78 \%$ & 37 & $0,28 \%$ \\
\hline Casa Nova & 15385 & 2606 & $16,94 \%$ & 9347 & $60,76 \%$ & 2584 & $16,79 \%$ & 624 & $4,05 \%$ & 225 & $1,46 \%$ \\
\hline Juazeiro & 60218 & 8029 & $13,33 \%$ & 38454 & $63,86 \%$ & 10882 & $18,07 \%$ & 2447 & $4,06 \%$ & 406 & 0,6 \\
\hline
\end{tabular}

Fonte: Elaboração própria (2016) a partir de tabela base do Censo Demográfíco 2010 - Resultados Gerais da Amostra por áreas de ponderação (IBGE, 2013).

\begin{tabular}{|c|c|c|c|c|c|}
\hline \multicolumn{1}{|c|}{ Gráfico 7: Distribuição do tempo habitual de deslocamento para o trabalho nas RMINE's } \\
selecionadas -2010
\end{tabular}


Para o Grupo de Controle 01 (Tabela 16 e Gráfico 8), os resultados são próximos aos anteriores, onde cerca de $70 \%$ dos trabalhadores tem deslocamentos curtos, de até meia hora, e se reduz o percentual dos que gastam entre meia hora e uma hora para uma média de $12 \%$ da população economicamente ativa.

\begin{tabular}{|c|c|c|c|c|c|c|c|c|c|c|c|}
\hline \multirow[b]{3}{*}{$\begin{array}{l}\text { Universo de estudo } \\
\text { por RM's e/ou } \\
\text { municípios }\end{array}$} & \multicolumn{11}{|c|}{$\begin{array}{l}\text { Pessoas ocupadas na semana de referência, que trabalhavam fora do domicílio e retornavam para seu } \\
\text { domicílio diariamente }\end{array}$} \\
\hline & \multicolumn{11}{|c|}{ Tempo habitual de deslocamento para o trabalho } \\
\hline & Total & $\begin{array}{c}\text { Até } 5 \\
\text { minutos }\end{array}$ & $\%$ & $\begin{array}{l}\text { De } 6 \\
\text { minutos } \\
\text { até meia } \\
\text { hora }\end{array}$ & $\%$ & $\begin{array}{l}\text { Mais de } \\
\text { meia hora } \\
\text { até uma } \\
\text { hora }\end{array}$ & $\%$ & $\begin{array}{c}\text { Mais } \\
\text { de uma } \\
\text { hora } \\
\text { até } \\
\text { duas } \\
\text { horas } \\
\end{array}$ & $\%$ & $\begin{array}{c}\text { Mais de } \\
\text { duas } \\
\text { horas }\end{array}$ & $\%$ \\
\hline \multicolumn{12}{|c|}{ RM DO AGRESTE/AL } \\
\hline Arapiraca & 63603 & 8560 & $13,46 \%$ & 43882 & $68,99 \%$ & 9152 & $14,39 \%$ & 1786 & $2,81 \%$ & 223 & $0,35 \%$ \\
\hline Girau do Ponciano & 10061 & 2612 & $25,97 \%$ & 5650 & $56,16 \%$ & 1290 & $12,82 \%$ & 443 & $4,40 \%$ & 65 & $0,65 \%$ \\
\hline \multicolumn{12}{|c|}{ VITÓRIA DA CONQUISTA/BA } \\
\hline V. da Conquista & 95387 & 10103 & $10,59 \%$ & 61750 & $64,74 \%$ & 19516 & $20,46 \%$ & 3380 & $3,54 \%$ & 638 & $0,67 \%$ \\
\hline \multicolumn{12}{|c|}{ SOBRAL/CE } \\
\hline Sobral & 59478 & 9379 & $15,77 \%$ & 44071 & $74,10 \%$ & 5002 & $8,41 \%$ & 795 & $1,34 \%$ & 231 & $0,39 \%$ \\
\hline \multicolumn{12}{|c|}{ MOSSORÓ/RN } \\
\hline Mossoró & 78390 & 10297 & $13,14 \%$ & 58636 & $74,80 \%$ & 7560 & $9,64 \%$ & 1453 & $1,85 \%$ & 444 & $0,57 \%$ \\
\hline \multicolumn{12}{|c|}{ CARUARU/PE } \\
\hline Caruaru & 94068 & 12772 & $13,58 \%$ & 63834 & $67,86 \%$ & 14916 & $15,86 \%$ & 2262 & $2,40 \%$ & 284 & $0,30 \%$ \\
\hline
\end{tabular}

Fonte: Elaboração própria (2016) a partir de tabela base do Censo Demográfíco 2010 - Resultados Gerais da Amostra por áreas de ponderação (IBGE, 2013).

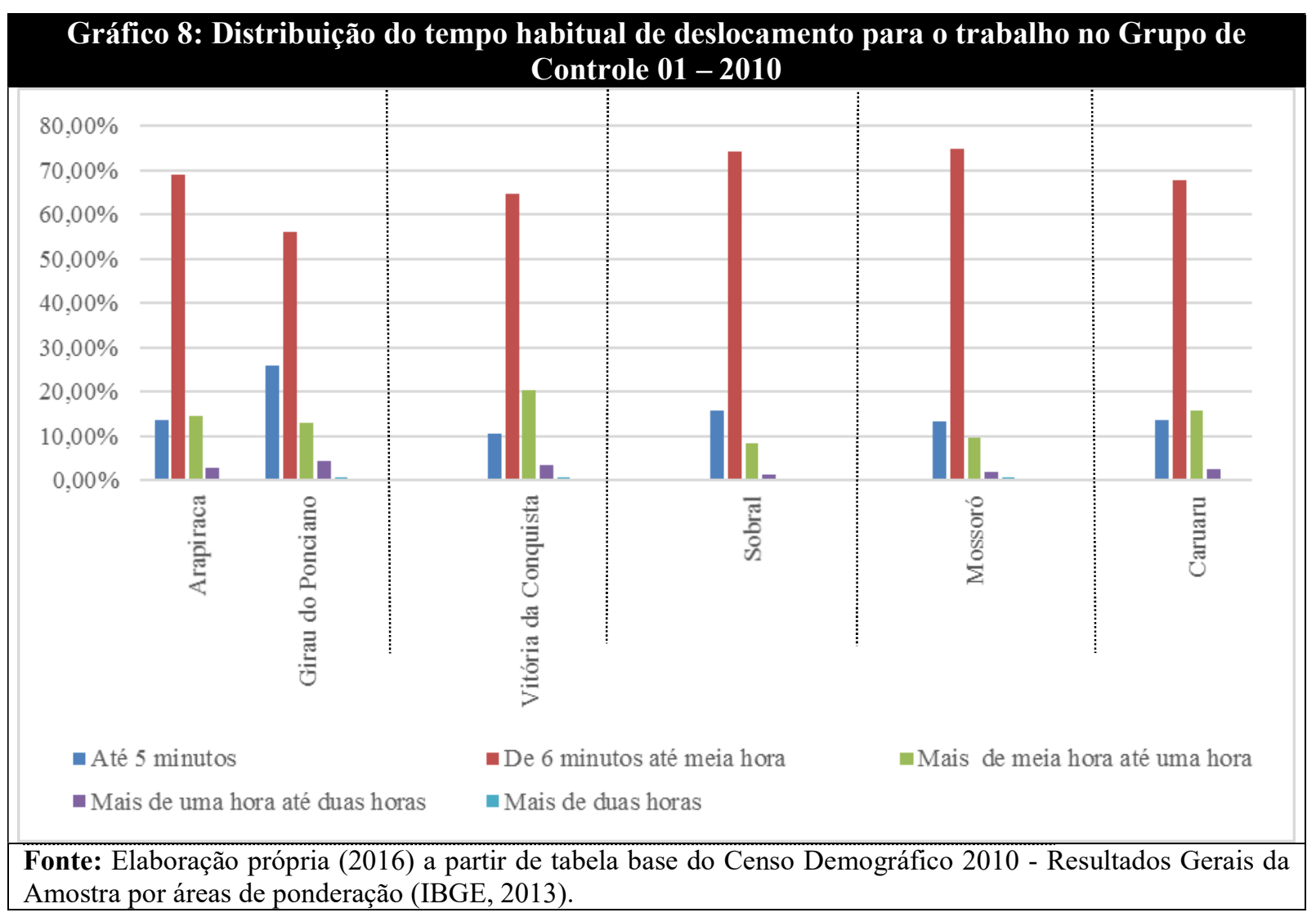


Isso implica novamente que as cidades-sede das RMINE'S, bem como os demais municípios do Grupo 01, concentrem a maioria dos empregos e demais serviços, ensino, saúde, equipamentos urbanos e de lazer. Por fim, analisando os dados organizados na Tabela 17 e no Gráfico 9, percebe-se que a proporção de população que gasta acima de 2 horas em seus deslocamentos aumenta consideravelmente chegando a índices de 2,5\% em Salvador/BA, 3,9\% em Vera Cruz/BA, 4\% em Abreu e Lima/PE, 4,7\% em São Lourenço da Mata/PE 5,2\% em Moreno/PE (pior desempenho). Traçando um comparativo, o valor está acima da média nacional $(1,78 \%)$ e de Brasília, com média de 1,09\% (MEDEIROS \& BARROS, 2015).

Esses dados demonstram um grande movimento pendular relacionado com a concentração dos polos de emprego nas cidades-sede, mais uma expressão da dependência entre os arranjos metropolitanos analisados. O caso mais emblemático é Salvador, único município-sede da RM com índices acima de 2\% (Fortaleza e Recife apresentaram apenas cerca de $1 \%$ dos trabalhadores que gastam mais de 2 horas em seus deslocamentos), o que acredito que se relacione com sua configuração urbana labiríntica em uma topografia acidentada. Esses resultados sugerem uma forte demanda por um sistema de transporte público eficiente que possa amenizar os problemas de mobilidade, recorrentes nas cidades brasileiras e agravados nas RM's.

Analisando esses dados numa evolução temporal, Pereira \& Schwanen (2013) revelam que as regiões metropolitanas de Salvador, Recife, Fortaleza e Belém também apresentaram, entre 1992 e 2009 um aumento de mais de uma hora na duração do trajeto casatrabalho. Os autores afirmam que essa tendência é preocupante, pois estas RM's vivenciam também um aumento na taxa de motorização (mais de 35\% em Recife e Fortaleza; Salvador registrou aumento acima de 45\%), cuja tendência é continuar a elevar-se ainda mais nos próximos anos. Soma-se a este quadro o fato que estas áreas metropolitanas não possuem sistemas de transporte de público que supra as demandas.

Vale ressaltar que a tendência observada por Pereira \& Schwanen (2013) para as principais RM's do país ${ }^{56}$ é o aumento gradual da sua proporção de longas viagens casatrabalho (com duração acima de uma hora). Cada RM possui suas especificidades advindas

\footnotetext{
${ }^{56} \mathrm{O}$ trabalho avaliou as nove maiores regiões metropolitanas do país (Belém, Fortaleza, Recife, Salvador, Belo Horizonte, Rio de Janeiro, São Paulo, Curitiba e Porto Alegre) mais o Distrito Federal. As exceções a essa tendência são as RM's de Porto Alegre e Curitiba, que segundo os autores "têm apresentado uma tendência praticamente estável ao longo de todo o período. Possivelmente, esta estabilidade seja decorrente de um controle mais bem-sucedido da expansão urbana e de sistemas de transporte público mais eficientes nestas áreas" (PEREIRA \& SCHWANEN, 2013, p.18).
} 
das "diferentes combinações de diversos fatores que afetam os padrões de viagem, tais como o crescimento da população urbana, o aumento das taxas de motorização, os investimentos em sistemas de transporte de massa, as mudanças de uso do solo e a expansão urbana" (PEREIRA \& SCHWANEN, 2013, p.18). Tabela 17: Pessoas ocupadas na semana de referência, que trabalhavam fora do domicílio e
retornavam para seu domicílio diariamente, por tempo habitual de deslocamento para o
trabalho-2010

\begin{tabular}{|c|c|c|c|c|c|c|c|c|c|c|c|}
\hline \multirow[b]{3}{*}{$\begin{array}{l}\text { Universo de estudo } \\
\text { por RM's e/ou } \\
\text { municípios }\end{array}$} & \multicolumn{11}{|c|}{$\begin{array}{l}\text { Pessoas ocupadas na semana de referência, que trabalhavam fora do domicílio e retornavam para seu } \\
\text { domicílio diariamente }\end{array}$} \\
\hline & \multirow[b]{2}{*}{ Total } & \multicolumn{10}{|c|}{ Tempo habitual de deslocamento para o trabalho } \\
\hline & & $\begin{array}{l}\text { Até } 5 \\
\text { minuto } \\
\mathrm{s}\end{array}$ & $\%$ & $\begin{array}{l}\text { De } 6 \\
\text { minutos } \\
\text { até meia } \\
\text { hora }\end{array}$ & $\%$ & $\begin{array}{l}\text { Mais de } \\
\text { meia } \\
\text { hora até } \\
\text { uma } \\
\text { hora }\end{array}$ & $\%$ & $\begin{array}{l}\text { Mais de } \\
\text { uma } \\
\text { hora até } \\
\text { duas } \\
\text { horas }\end{array}$ & $\%$ & $\begin{array}{c}\text { Mais } \\
\text { de duas } \\
\text { horas }\end{array}$ & $\%$ \\
\hline \multicolumn{12}{|c|}{ RM DE SALVADOR/BA } \\
\hline Camaçari & 75463 & 6391 & $8,47 \%$ & 43428 & $57,55 \%$ & 18682 & $24,76 \%$ & 5982 & $7,93 \%$ & 980 & $1,30 \%$ \\
\hline Candeias & 24102 & 2393 & $9,93 \%$ & 14188 & $58,87 \%$ & 6278 & $26,05 \%$ & 1116 & $4,63 \%$ & 127 & $0,53 \%$ \\
\hline Dias d'Ávila & 18525 & 2000 & $10,79 \%$ & 10264 & $55,41 \%$ & 4499 & $24,29 \%$ & 1587 & $8,57 \%$ & 175 & $0,95 \%$ \\
\hline Lauro de Freitas & 62962 & 3936 & $6,25 \%$ & 28448 & $45,18 \%$ & 20347 & $32,32 \%$ & 9611 & $15,26 \%$ & 620 & $0,98 \%$ \\
\hline Mata de São João & 10508 & 1185 & $11,28 \%$ & 4933 & $46,94 \%$ & 3105 & $29,55 \%$ & 1130 & $10,75 \%$ & 155 & $1,48 \%$ \\
\hline Salvador & 904959 & 52999 & $5,86 \%$ & 302992 & $33,48 \%$ & 349662 & $38,64 \%$ & 176067 & $19,46 \%$ & 23239 & $2,57 \%$ \\
\hline São F. do Conde & 9145 & 1579 & $17,26 \%$ & 5424 & $59,31 \%$ & 1487 & $16,26 \%$ & 565 & $6,18 \%$ & 90 & $0,99 \%$ \\
\hline Simões Filho & 34870 & 2800 & $8,03 \%$ & 16466 & $47,22 \%$ & 10168 & $29,16 \%$ & 5122 & $14,69 \%$ & 314 & $0,90 \%$ \\
\hline Vera Cruz & 10955 & 2046 & $18,68 \%$ & 5781 & $52,77 \%$ & 1817 & $16,59 \%$ & 881 & $8,04 \%$ & 430 & $3,92 \%$ \\
\hline \multicolumn{12}{|c|}{ RM DE FORTALEZA/CE } \\
\hline Aquiraz & 19647 & 3582 & $18,23 \%$ & 11648 & $59,29 \%$ & 3617 & $18,41 \%$ & 728 & $3,71 \%$ & 71 & $0,36 \%$ \\
\hline Cascavel & 17717 & 3245 & $18,32 \%$ & 11238 & $63,43 \%$ & 2343 & $13,22 \%$ & 791 & $4,46 \%$ & 100 & $0,57 \%$ \\
\hline Caucaia & 96403 & 9669 & $10,03 \%$ & 41677 & $43,23 \%$ & 30642 & $31,79 \%$ & 13155 & $13,65 \%$ & 1260 & $1,31 \%$ \\
\hline Eusébio & 15140 & 2546 & $16,82 \%$ & 8593 & $56,75 \%$ & 3210 & $21,20 \%$ & 692 & $4,57 \%$ & 99 & $0,65 \%$ \\
\hline Fortaleza & 791113 & 68874 & $8,71 \%$ & 356158 & $45,02 \%$ & 265644 & $33,58 \%$ & 92052 & $11,64 \%$ & 8385 & $1,06 \%$ \\
\hline Maracanaú & 66507 & 5728 & $8,61 \%$ & 34781 & $52,30 \%$ & 17709 & $26,63 \%$ & 7868 & $11,83 \%$ & 422 & $0,63 \%$ \\
\hline Maranguape & 27864 & 3400 & $12,20 \%$ & 16049 & $57,60 \%$ & 6182 & $22,18 \%$ & 1923 & $6,90 \%$ & 310 & $1,11 \%$ \\
\hline Pacajus & 20308 & 2767 & $13,63 \%$ & 14706 & $72,42 \%$ & 2235 & $11,01 \%$ & 534 & $2,63 \%$ & 65 & $0,32 \%$ \\
\hline Pacatuba & 18154 & 1551 & $8,54 \%$ & 9122 & $50,25 \%$ & 5020 & $27,65 \%$ & 2234 & $12,31 \%$ & 227 & $1,25 \%$ \\
\hline Paracuru & 8631 & 1225 & $14,19 \%$ & 6017 & $69,71 \%$ & 1025 & $11,87 \%$ & 211 & $2,45 \%$ & 154 & $1,78 \%$ \\
\hline São G. do Amarante & 11053 & 1870 & $16,92 \%$ & 6908 & $62,50 \%$ & 1815 & $16,42 \%$ & 422 & $3,82 \%$ & 37 & $0,34 \%$ \\
\hline Trairi & 13602 & 4008 & $29,46 \%$ & 7868 & $57,84 \%$ & 1287 & $9,46 \%$ & 347 & $2,55 \%$ & 93 & $0,68 \%$ \\
\hline \multicolumn{12}{|c|}{ RM DE RECIFE/PE } \\
\hline Abreu e Lima & 27566 & 2257 & $8,19 \%$ & 10529 & $38,19 \%$ & 7375 & $26,75 \%$ & 6305 & $22,87 \%$ & 1101 & $4,00 \%$ \\
\hline Cabo de S. Agost. & 53350 & 3695 & $6,93 \%$ & 24980 & $46,82 \%$ & 18862 & $35,35 \%$ & 5153 & $9,66 \%$ & 661 & $1,24 \%$ \\
\hline Camaragibe & 45230 & 2403 & $5,31 \%$ & 14283 & $31,58 \%$ & 17132 & $37,88 \%$ & 10557 & $23,34 \%$ & 856 & $1,89 \%$ \\
\hline Igarassu & 26754 & 1951 & $7,29 \%$ & 12673 & $47,37 \%$ & 6905 & $25,81 \%$ & 4615 & $17,25 \%$ & 609 & $2,28 \%$ \\
\hline Ipojuca & 22439 & 2320 & $10,34 \%$ & 13202 & $58,84 \%$ & 5392 & $24,03 \%$ & 1243 & $5,54 \%$ & 282 & $1,26 \%$ \\
\hline Jaboatão dos G. & 199120 & 13125 & $6,59 \%$ & 69205 & $34,76 \%$ & 74788 & $37,56 \%$ & 38300 & $19,23 \%$ & 3702 & $1,86 \%$ \\
\hline Moreno & 13374 & 1053 & $7,87 \%$ & 5331 & $39,86 \%$ & 2841 & $21,24 \%$ & 3441 & $25,73 \%$ & 708 & $5,29 \%$ \\
\hline Olinda & 119567 & 6503 & $5,44 \%$ & 46079 & $38,54 \%$ & 48439 & $40,51 \%$ & 16801 & $14,05 \%$ & 1744 & $1,46 \%$ \\
\hline Paulista & 96622 & 5587 & $5,78 \%$ & 32452 & $33,59 \%$ & 33436 & $34,60 \%$ & 22417 & $23,20 \%$ & 2731 & $2,83 \%$ \\
\hline Recife & 487354 & 33822 & $6,94 \%$ & 229045 & $47,00 \%$ & 169802 & $34,84 \%$ & 49552 & $10,17 \%$ & 5134 & $1,05 \%$ \\
\hline S. Lourenço da M. & 26537 & 2041 & $7,69 \%$ & 8162 & $30,76 \%$ & 6053 & $22,81 \%$ & 9031 & $34,03 \%$ & 1251 & $4,71 \%$ \\
\hline
\end{tabular}

Fonte: Elaboração própria (2016) a partir de tabela base do Censo Demográfico 2010 - Resultados Gerais da Amostra por áreas de ponderação (IBGE, 2013). 


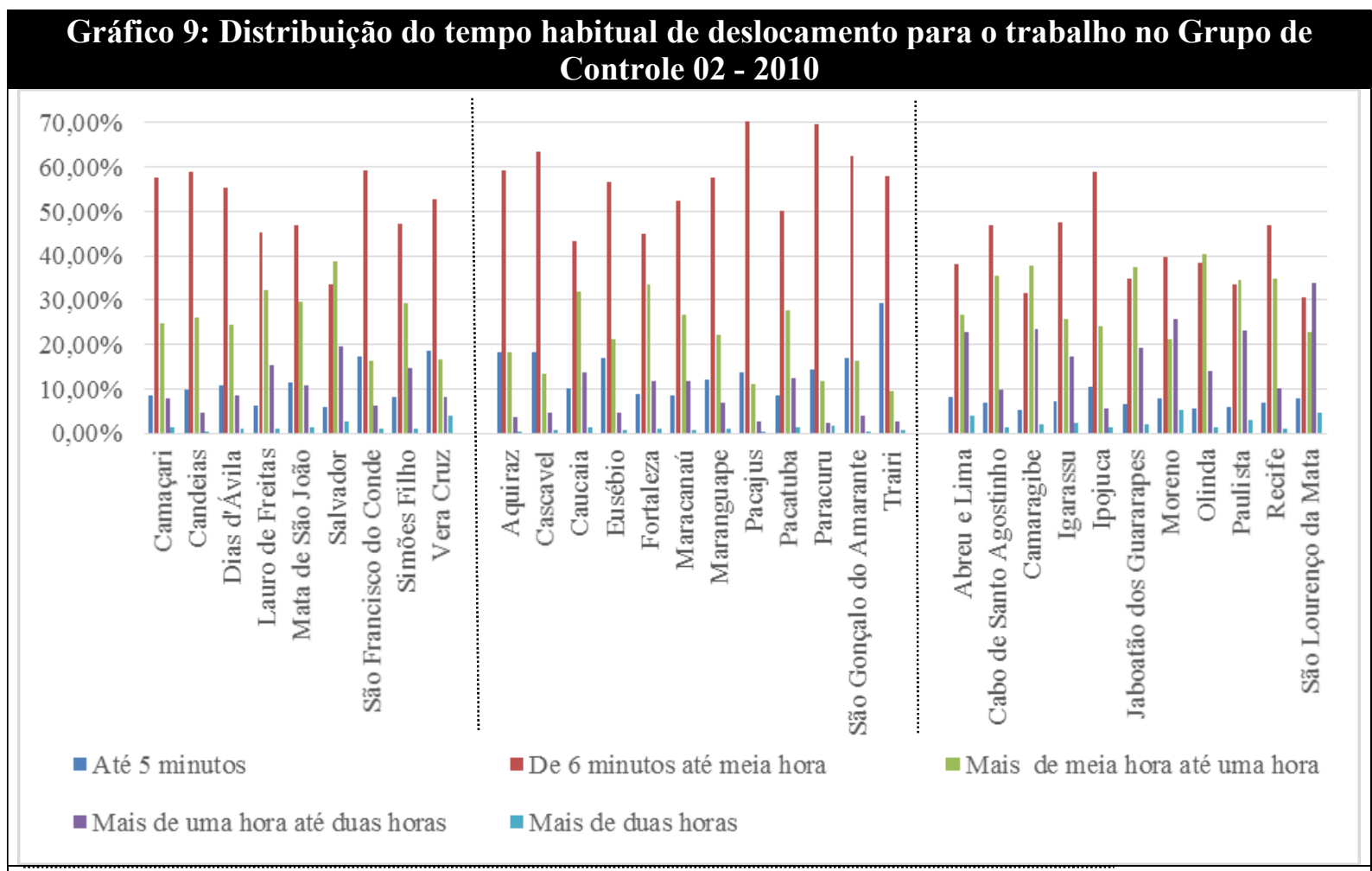

Fonte: Elaboração própria (2016) a partir de tabela base do Censo Demográfíco 2010 - Resultados Gerais da Amostra por áreas de ponderação (IBGE, 2013).

\subsection{Conclusões parciais}

Apesar da limitação em espacializar os dados apresentados, foi possível analisar que certas dinâmicas socioespaciais são recorrentes nas cidades analisadas e quiçá no Brasil como um todo. Destaco a segregação entre as faixas de renda, processo que não é exclusivo da realidade nordestina aqui descrita, mas que se relaciona com a própria estruturação capitalista que (re)cria as desigualdades sociais. Há diversos mecanismos que perpetuam esse sistema: gestão pública, acesso a bens e serviços (CARMO JÚNIOR, 2014).

Mas a própria forma urbana atua como variável independente no processo (HOLANDA, 2007). Em outras palavras, a própria morfologia da cidade oferece padrões desiguais de localização e as classes dominantes se apropriam dos lugares que oferecem melhores "vantagens" sendo a "[...] mais decisiva é a otimização dos gastos de tempo despendido nos deslocamentos dos seres humanos, ou seja, a acessibilidade às diversas localizações urbanas, especialmente ao centro urbano" (VILLAÇA, 2001, p. 328). Este processo, portanto, deverá se correlacionar com a produção habitacional (regular ou irregular), bem como com as densidades de ocupação do espaço urbano que tratarei no próximo capítulo. 
Estas desigualdades também aparecem na escala regional, onde as cidades-sede das RM's ou as capitais regionais B ou C (segundo o REGIC, 2007) congregam os melhores índices de escolaridade, os empregados de maior escalão e, consequentemente, as maiores rendas. Essa polarização se dá pela localização dos empregos, especialmente os qualificados, que estimula também os movimentos de deslocamento entre casa-trabalho cada vez de maior duração, seja pela expansão do tecido urbano ou pela atração dos habitantes dos municípios de entorno. Entretanto, possuir os melhores indicadores nos quesitos analisados não é sinônimo de falta de problemas urbanos. Vale retomar que o aumento do tempo de deslocamentos entre a residência e o local de trabalho pode agravar os problemas de mobilidade caso estas áreas continuem a priorizar o transporte individual em detrimento do coletivo, calcado no escuso planejamento do poder público.

As desigualdades sociais são intrínsecas à formação metropolitana no Brasil: a população migrante do campo, ao fixar-se nos centros urbanos não os integrava econômica e territorialmente. Isso se agrava com as exigências por maiores qualificações profissionais, associadas a um nível de escolaridade maior. Por não possuir as habilitações requeridas, uma grande parcela da mão de obra brasileira passa a formar um mercado de trabalho informal e a ocupar áreas da cidade através da autoconstrução que irão subsidiar os processos de favelização e periferização (RIBEIRO, 2012). Embora timidamente, assistimos nos últimos anos a redução da desigualdade de renda no Brasil decorrente das políticas de transferência de renda e do aumento contínuo do salário mínimo, apesar do país ainda permanecer como um dos mais desiguais do mundo. E os espaços metropolitanos, sejam eles de grande ou médio porte, expõem claramente estas desigualdades. 


\section{A CIDADE E}

AS PESSOAS:

ANÂLISE DAS VARIÁVEIS DE

ORDEM

CONFIGURACIONAL E DO

SISTEMA DE ENCONTROS E

ESQUIVANÇAS 


\section{A Cidade E AS PeSsoas: análise das Variáveis de}

Neste capítulo congrego as análises que têm como enfoque principal objeto a "cidade". Foram organizadas em dois grupos de variáveis de pesquisa: (1) de ordem configuracional e (2) do sistema de encontros e esquivanças. O primeiro grupo diz respeito a aspectos do espaço em si, analisado sobre a ótica da SE. A configuração da cidade, enquanto um sistema de permeabilidades ou barreiras, foi representada neste trabalho por linhas axiais ou segmentos. Como descrito no item de técnicas, a partir daí foi possível calcular uma hierarquização de acessibilidade topológica, ou seja, que não é medida em distância métrica: "refere-se ao número mínimo de linhas interpostas entre uma dada linha, ou conjunto de linhas, e o resto do sistema" (MEDEIROS \& HOLANDA, 2009). Essa acessibilidade correlaciona-se com a distribuição de funcionalidades, que, consequentemente, vai estabelecer a concentração e dispersão de pessoas nos espaços da cidade. São, portanto, estas propriedades que se denominam como o sistema de encontros e esquivanças.

\subsection{Análise das variáveis de ordem configuracional: Centralidade morfológica e funcional}

Para avaliar a centralidade optou-se por avaliar a medida de integração, definida pela $\mathrm{SE}$, calculada a partir dos mapas axiais calculados para a medida de integração $\mathrm{HH}^{57}$ global (Rn). Ou seja, é levada em consideração a acessibilidade topológica calibrada para o sistema inteiro, onde $\mathrm{R}$ representa o raio (quantos eixos se deseja ponderar a partir de um outro qualquer) por um número "n", ilimitado, de conexões (MEDEIROS, 2006, p. 505). Os mapas axiais foram calculados também para a medida de escolha (choice), pois na literatura essa representação tende a dar destaque ao sistema viário principal, indicando os eixos de integração intermunicipal. Para trazer mais refinamento à análise, apresento também os resultados para a representação de segmentos calculada em análise angular para integração e escolha. A centralidade morfológica pode ser correlacionada à distribuição de usos e dá

${ }^{57} \mathrm{O}$ HH faz referência a Hillier e Hanson, os "pais" o cálculo. 
indícios dos processos de transformações de centralidades e formação de subcentros, além de outros processos de expansão urbana.

\subsubsection{RMINE'S selecionadas}

Os primeiros habitantes da área em que hoje se localiza o município de Feira de Santana foram os índios da tribo Paiaiá. A colonização da região se deu por meio dos engenhos de açúcar, além da cultura de exportação de fumo e do tráfico de escravos. Em meados do século XVIII, os donos da Fazenda Sant'Anna dos Olhos D'Água, construíram uma Capela dedicada a Nossa Senhora Sant'Anna, que por sua localização privilegiada, passou a ser entreposto comercial - uma feira - para aqueles que trafegavam na região. Com o passar dos anos, a feira - especialmente de gado, mas também uma feira livre que tomava toda a área central até ser transferida, em 1977, para o Centro de Abastecimento pelo prefeito José Falcão da Silva - foi o atrativo para a fixação de população naquele lugar (SANTO, 2003). Em 1832, foram criados o município e a vila, com o território desmembrado de Cachoeira (IBGE, 2016). A "Princesa do Sertão", como foi apelidada por Ruy Barbosa, em 1919, traz, então, desde suas raízes, atributos que ainda hoje fazem parte de seu dia a dia: a localização em um entroncamento de autoestradas e as intensas atividades econômicas.

Figura 32: Av. Getúlio Vargas, que possui alto valor de integração em Feira de Santana/BA.

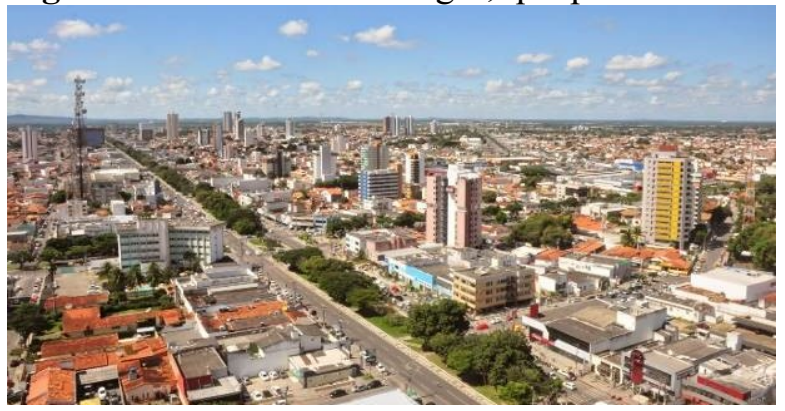

Fonte: Foto de Sivaldo Souza (2014). Disponível em: $<$ http:// oliveiradimas.blogspot.com.br $>$. Acesso em 14 de ago. 2016.

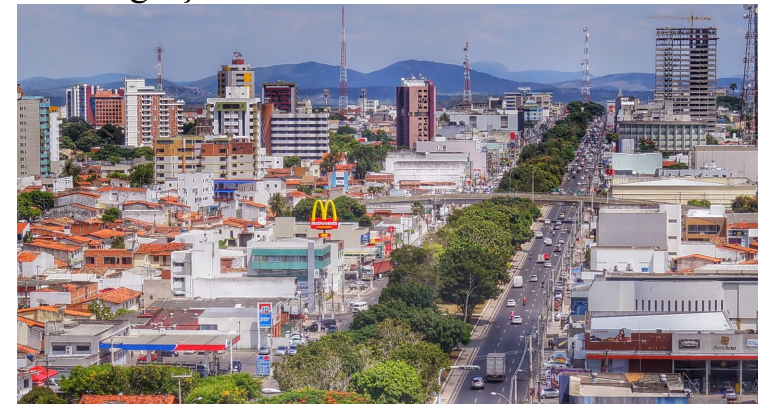

Fonte: Foto de Jóstenis Costa (2014). Disponível em: $<$ http://cidadeprincesa.blogspot.com.br>. Acesso em 14 de ago. 2016.

Figura 33: À esquerda, a Av. João Durval Carneiro e, à esquerda, a Av. Presidente Dutra.

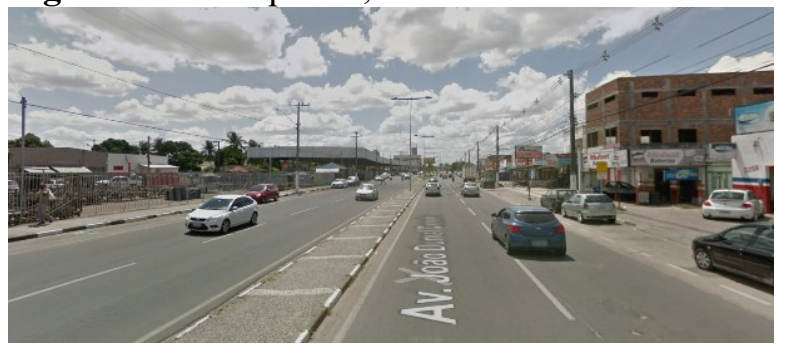

Fonte: Foto de Google Street View (2016). Disponível em: <https://www.google.com.br/maps>. Acesso em 14 de ago. 2016.

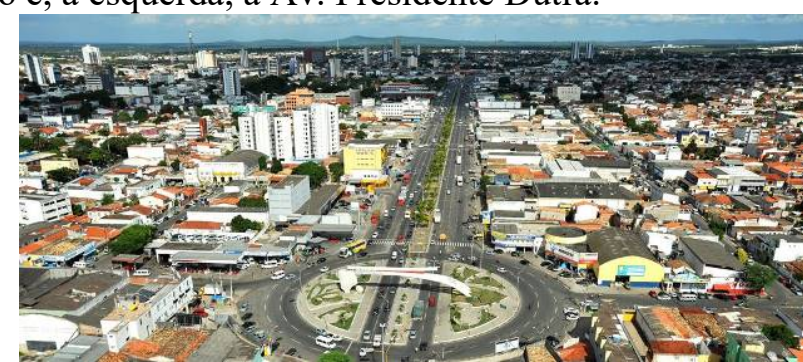

Fonte: Foto de autor não identificado (2010). Disponível em: <https://www.google.com.br/maps $>$. Acesso em 14 de ago. 2016. 
Para a RM de Feira de Santana/BA, o mapa axial apresentado na Figura 35 foi desenhado abarcando também Conceição do Jacuípe e a expansão da malha urbana de Feira de Santana sobre o território do município de São Gonçalo dos Campos (ver mapa-chave), configurando um processo de conurbação física nessa RM em estágio inicial. Esses municípios de entorno têm do ponto de vista socioeconômico, conforme discutido no capítulo anterior, uma forte dependência em relação à Feira. Percebe-se que a maioria dos eixos mais integrados (cores quentes) localizam-se na área central e extremamente densa de Feira de Santana/BA. O núcleo de integração encontra-se no Bairro Centro, espraiando-se a leste ao longo da Av. Getúlio Vargas, a nordeste ao longo do eixo da Av. João Durval Carneiro e a sudeste pela Av. Presidente Dutra. Observando as fotos apresentadas na Figura 32 e na Figura 33, percebe-se que são vias com várias faixas de veículos devido ao seu alto fluxo e onde se encontram diversos estabelecimentos comerciais e de serviço.

Embora esse centro se mostre dinâmico, as novas lógicas comerciais são visualizadas na cidade por meio da instalação de centro comerciais fechados como o Boulevard Feira (antes denominado Shopping Iguatemi) inaugurado em 1999 (Figura 36). Na leitura de Pinho (et al, 2011, s/p.), a “[..] implantação do Boulevard Shopping na cidade de Feira de Santana vai confortar o desejo da elite feirense. A cidade se submete a novos redesenhos, consequências [sic] ao desenvolvimento da cidade e o shopping corresponderá ao sonho da imagem moderna". Soma-se a isso a reprodução do solo urbano por meio da verticalização que ocorre paulatinamente, principalmente nos bairros próximos ao centro da cidade (Figura 34). A cidade cresce de forma diversificada e com alta intensidade, impulsionada pela expansão da atividade comercial e pelo crescimento populacional, a exemplo do verificado nos bairros Cidade Nova ou CASEB, na região do Shopping Boulevard.

Figura 34: Verticalização em Feira de Santana/BA, skyline a partir da Avenida Noide Cerqueira.

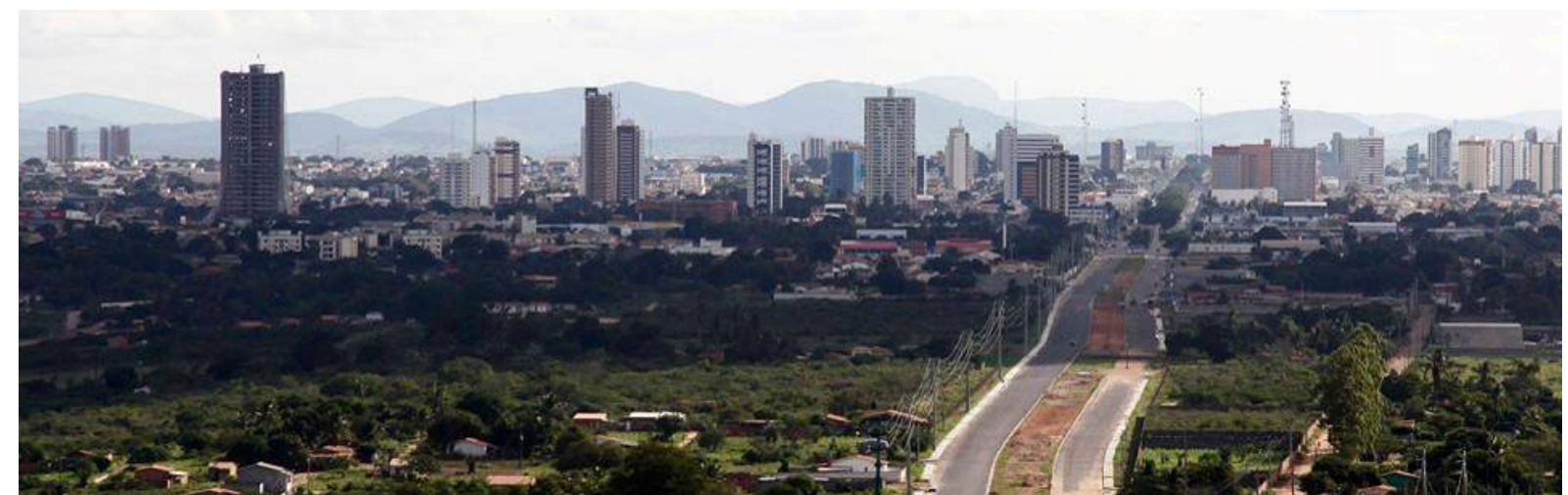

Fonte: Foto de Carlos Augusto (2013). Disponível em: <www.skyscrapercity.com/>. Acesso em 14 de ago. 2016. 
Figura 35: Mapa axial da RM de Feira de Santana/BA calculado por Integração HH global (Rn).

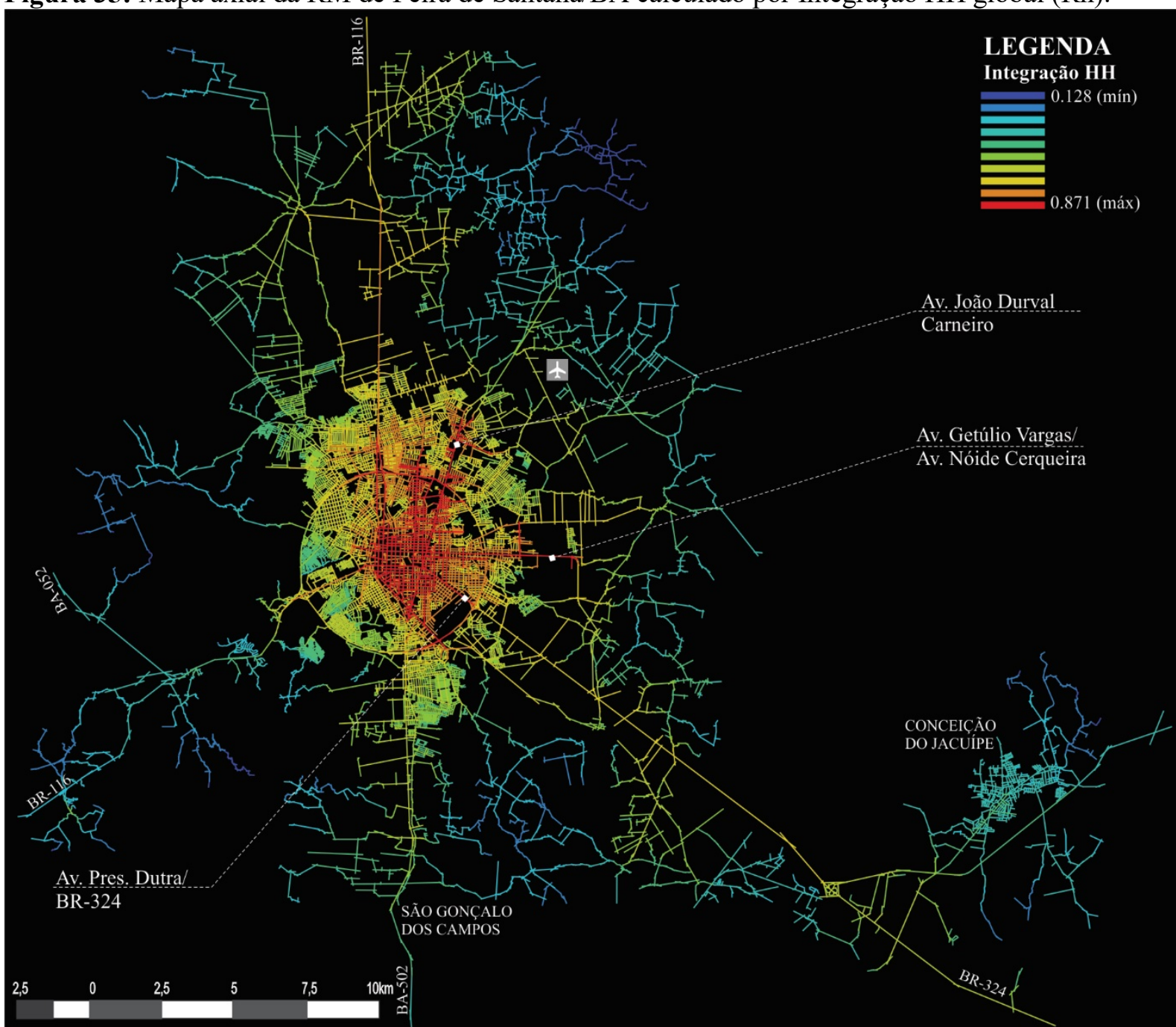

REPRESENTAÇÃO AXIAL - RM FEIRA DE SANTANA/BA INTEGRAÇÃO HH GLOBAL (RN)

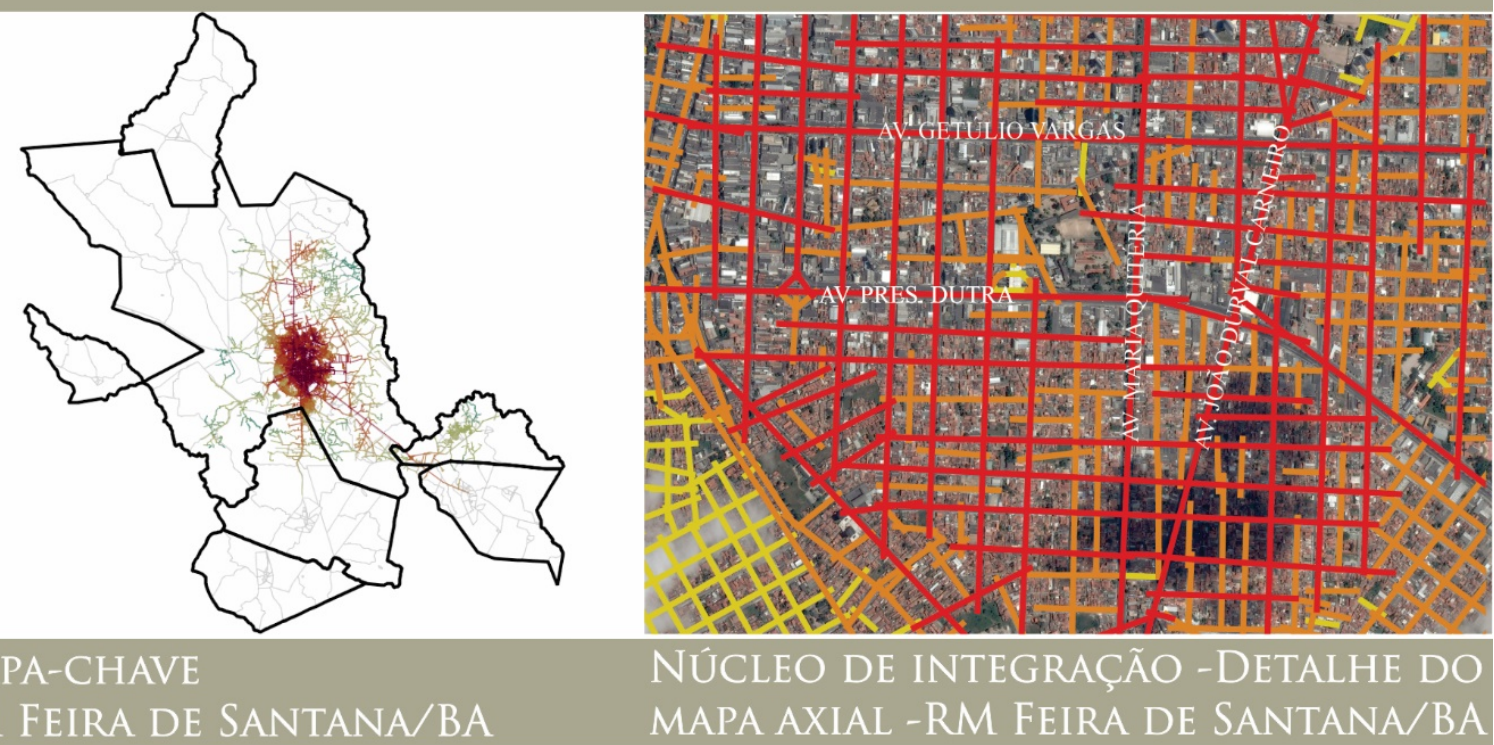

Fonte: Desenho de Amanda Brasil e revisão da autora (2016) a partir da Base Cartográfica do OpenStreetMap (2016) e imagens de satélite do Google Earth (2016). 
Figura 36: Vista geral de Feira de Santana/BA. Em primeiro plano, o Boulevard Shopping.

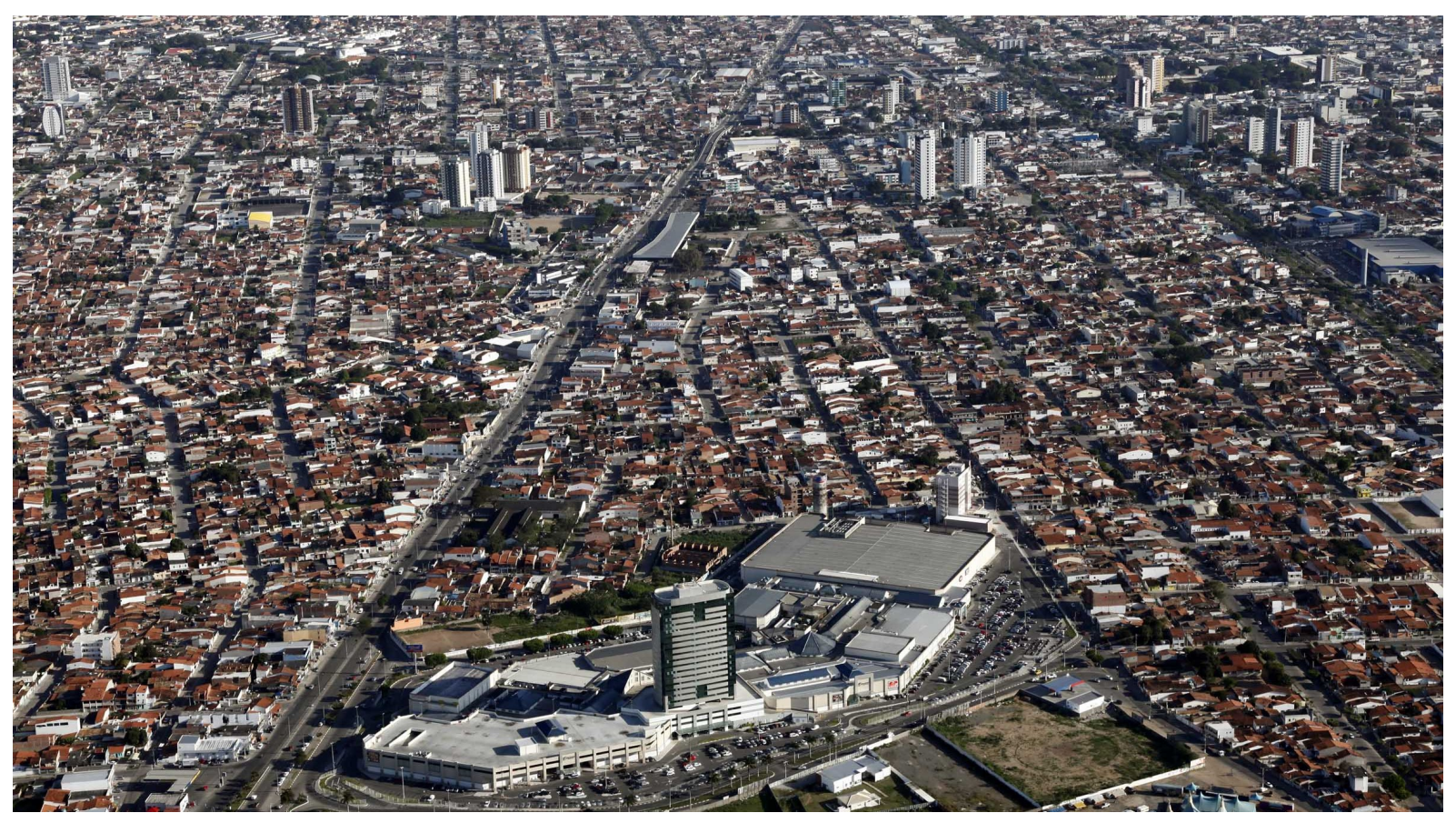

Fonte: Foto de Carlos Augusto (2013). Disponível em: <http://www.skyscrapercity.com/>. Acesso em 14 de ago. 2016.

Dentro do anel viário (estrutura circular bem marcada nos mapas ${ }^{58}$ ) os eixos possuem altas integrações (linhas vermelhas, laranjas ou amarelas), com exceção das porções esverdeadas ao oeste, no bairro Calumbi (Figura 37), e ao sudoeste, no bairro Muchila (Figura 38). Embora estejam dentro do anel de contorno e próximos ao centro, sua infraestrutura é muito precária, acarretando para população "graves problemas sociais e econômicos, posto que lhes são negados diversos direitos referentes à cidadania, tais como o direito a educação de qualidade, a saúde, a segurança e o direito de consumir os espaços da própria cidade, em fím a uma melhor qualidade de vida" (PAIXÃO et al, 2009, s/p.). Essa segregação social possui, portanto, um reflexo na sua estruturação espacial percebido na posição mediana de integração, apenas à frente das ocupações esparsas periurbanas. Segundo Santos \& Santos (2011), até os anos 2000, os condomínios eram localizados, em sua maioria, dentro dos limites do anel de contorno, embora hoje já extrapolem esses limites.

A representação em segmentos, calculada em análise angular para integração (Figura 40), reforça os resultados comentados, porém, dando destaque ao anel viário (Avenida do Contorno) que envolve - praticamente em um círculo perfeito - a área central de Feira, possibilitando o trânsito de veículos e cargas entre as rodovias federais (BR's 116 e 324) sem

\footnotetext{
58 Também denominado de Avenida do Contorno, anteriormente chamada de Avenida Eduardo Fróes da Mota, antes de ser fechada como uma circunferência completa.
} 
impactos maiores na circulação interna. Isso se dá por uma característica intrínseca à própria representação: para representar o círculo são necessárias muitas linhas axiais, o que prejudica sua conectividade e, como os segmentos promovem exatamente essa quebra, é possível captar melhor tal nuance.

Figura 37: Bairro Calumbi, em imagem de satélite (à esquerda) e vista de uma de suas vielas (à direita), em Feira de Santana/BA.

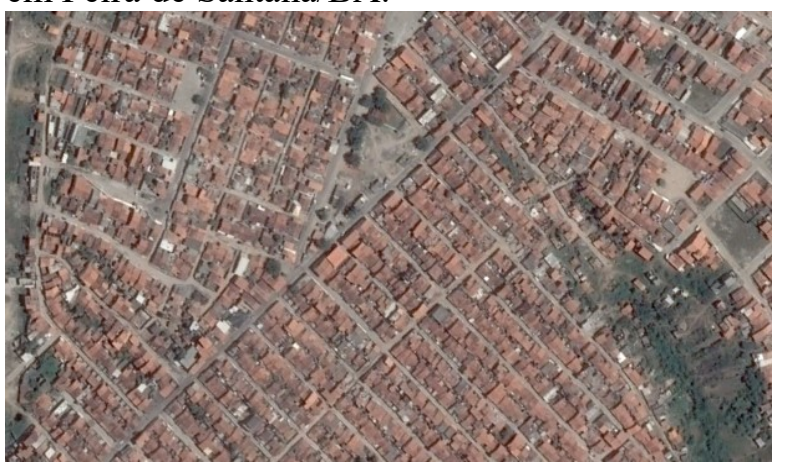

Fonte: Foto de satélite do Google Earth (2016). Acesso em 14 de ago. 2016.

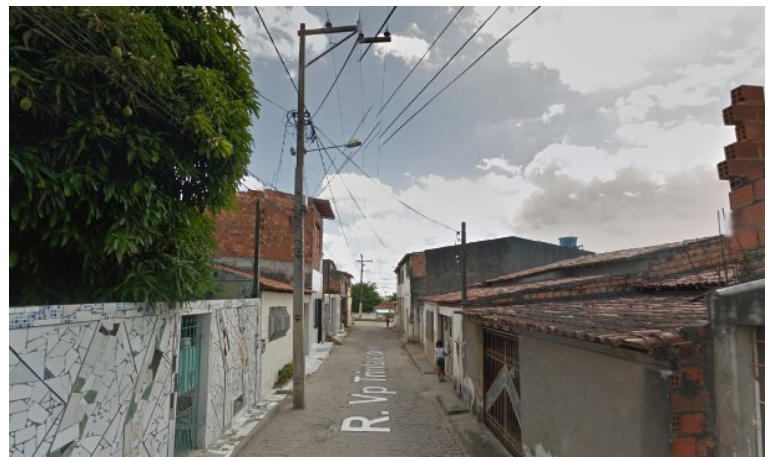

Fonte: Foto de Google Street View (2012). Disponível em: <https://www.google.com.br/maps $>$. Acesso em 14 de ago. 2016.

Figura 38: Bairro Muchila, em imagem de satélite (à esquerda) e vista de uma de suas vielas (à direita), em Feira de Santana/BA.

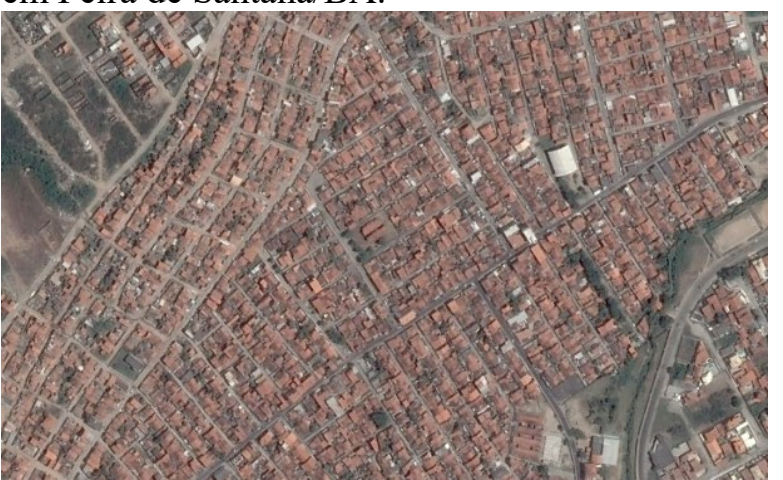

Fonte: Foto de satélite do Google Earth (2016). Acesso em 14 de ago. 2016.

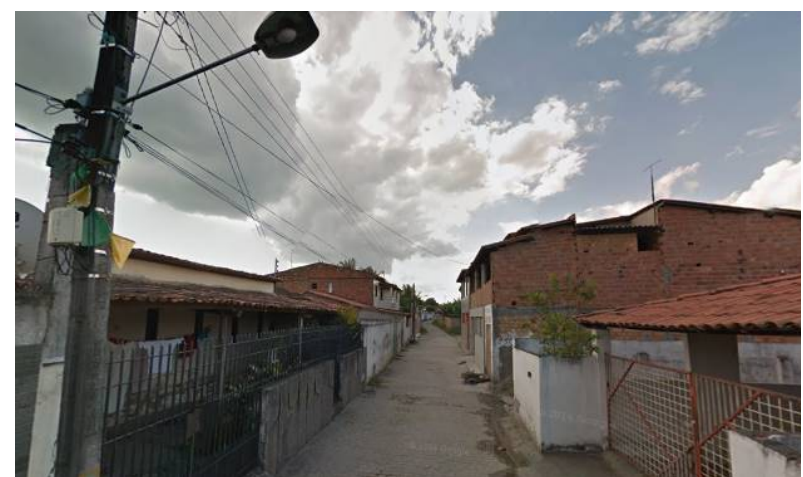

Fonte: Foto de Google Street View (2011). Disponível em: <https://www.google.com.br/maps>. Acesso em 14 de ago. 2016.

Figura 39: Intensidade de Concentração de Condomínios Fechados em Feira de Santana (BA) - 1995 a 2010 .

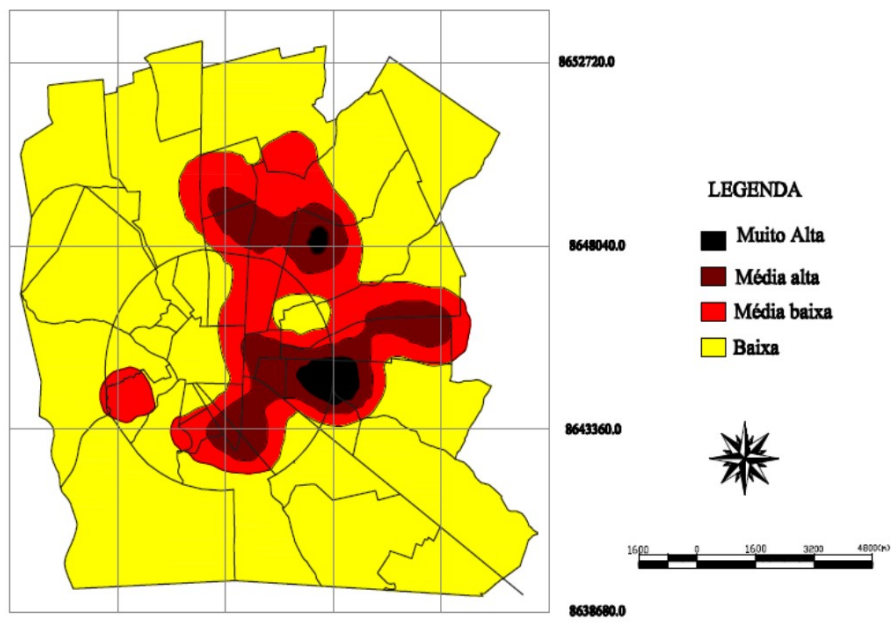

Fonte: Santos \& Santos, 2011, p. 11 
Figura 40: Mapa de segmentos da RM de Feira de Santana/BA calculado por Integração.

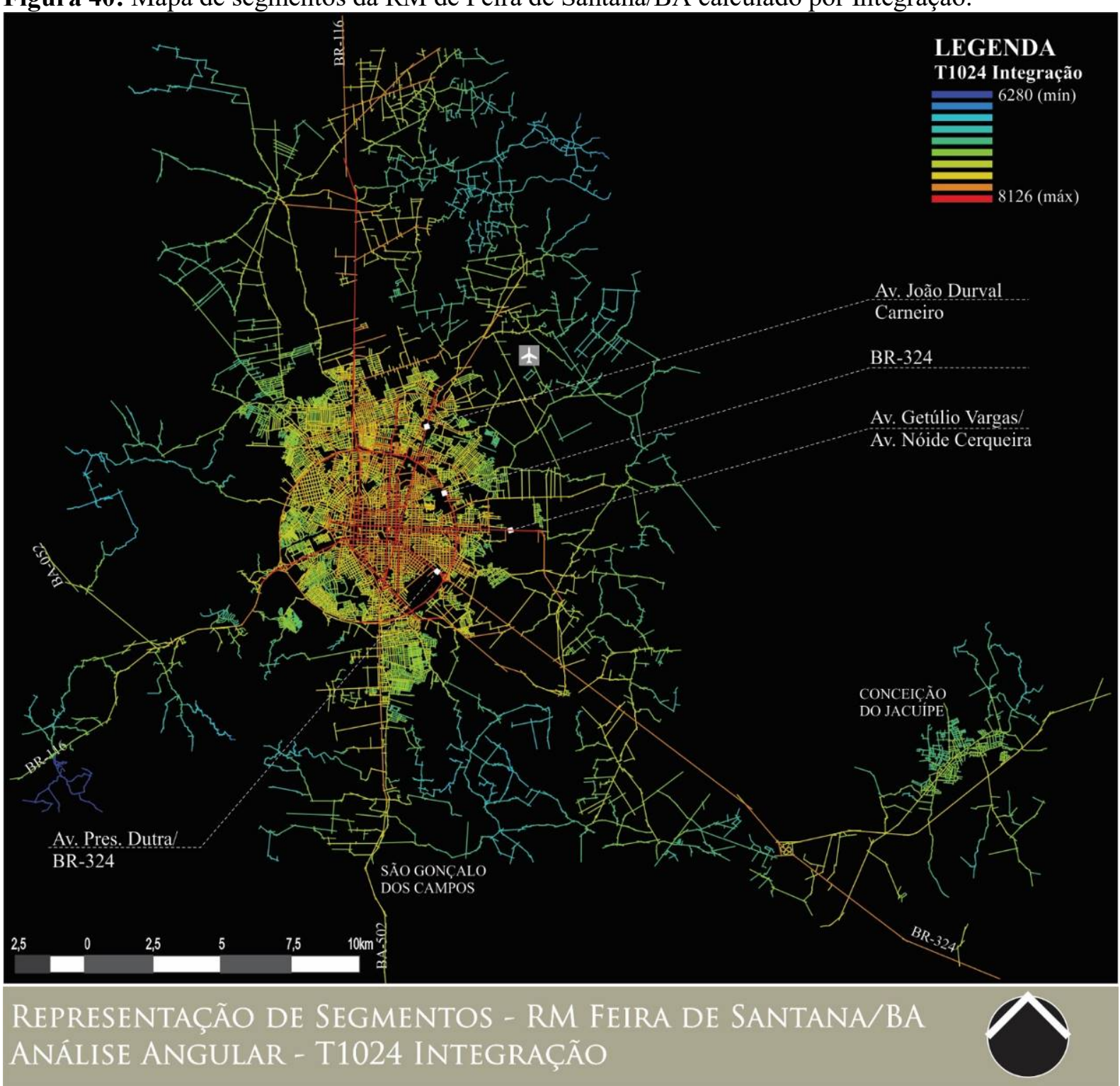

Fonte: Desenho de Amanda Brasil e revisão da autora (2016) a partir da Base Cartográfica do OpenStreetMap (2016) e imagens de satélite do Google Earth (2016).

A análise de escolha (ou choice) reflete as vias de maior probabilidade de utilização em um sistema como um todo, ou seja, vias com valores mais altos (cores quentes) nesta representação coincidem com aquelas que possuem maior calha e melhor capeamento (ou que são priorizadas em obras dessa natureza), como também tendem a ser privilegiadas como rotas do transporte público. Para a RM de Feira (Figura 43 e Figura 44) têm destaque, além das avenidas citadas anteriormente, a Av. Maria Quitéria, a rua Senador Quintino (essas duas também possuem grande potencial de integração - Figura 41) e a BR-116. Vale destacar que a cidade é um dos entroncamentos rodoviários mais importantes do país: é cortada por três rodovias federais: BR 101, 116 e 324 e quatro rodovias estaduais: BA 052, 502, 503 e 504 . Esta característica "favorece uma corrente concentração de fluxo de população, mercadorias e 
dinheiro, num entreposto que liga o Nordeste ao Centro-Sul do Brasil, na fronteira da capital Salvador com o Sertão, do Recôncavo aos Tabuleiros do semi-árido [sic] da Bahia" (MILTÃO, et.al., 2008, p. 327). Na representação de segmentos, pode-se observar a gradação dos eixos, cuja escolha é maior na proximidade do anel rodoviário (interna e externamente), demonstrando mais uma vez a "força" que a área central da cidade exerce.

Figura 41: Vistas da Av. Maria Quitéria em Feira de Santana/BA.

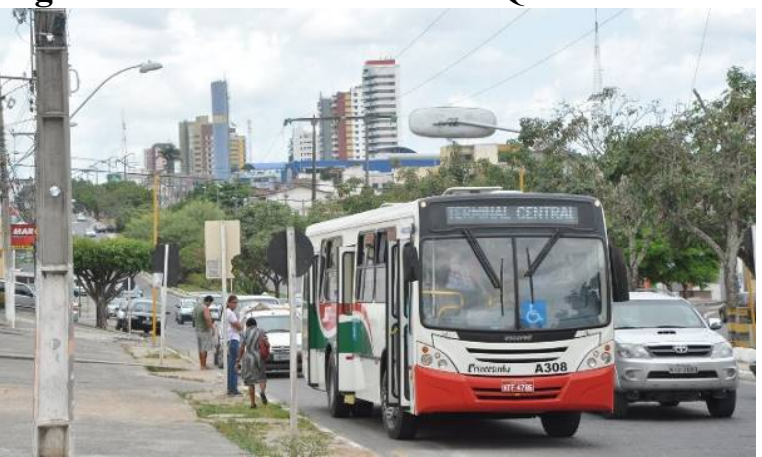

Fonte: Foto de autor desconhecido (2011). Disponível em: $\quad<$ http://fotosfeiradesantana.blogspot.com.br>. Acesso em 14 de ago. 2016.

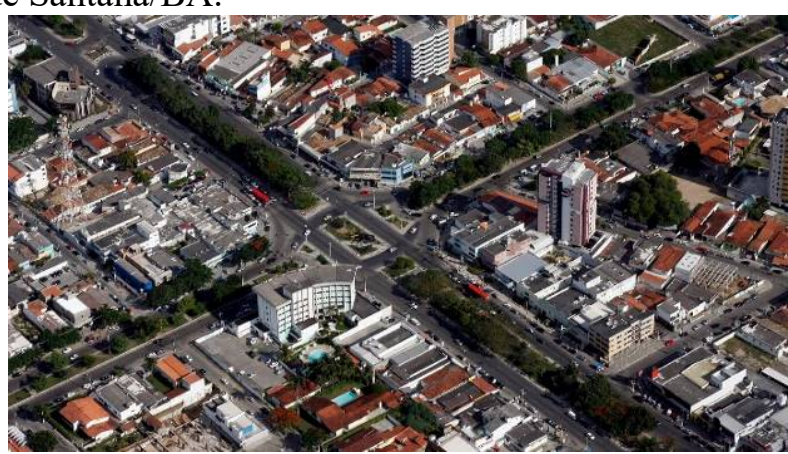

Fonte: Foto de Carlos Augusto (2015). Disponível em: $<$ www.jornalgrandebahia.com.br $>$. Acesso em $14 \mathrm{de}$ ago. 2016.

Figura 42: Vista da Rua Senador Quintino (à esquerda) e vista aérea do Condomínio Alphaville Feira de Santana I, situado às margens da BR-116 (à direita), em Feira de Santana/BA.

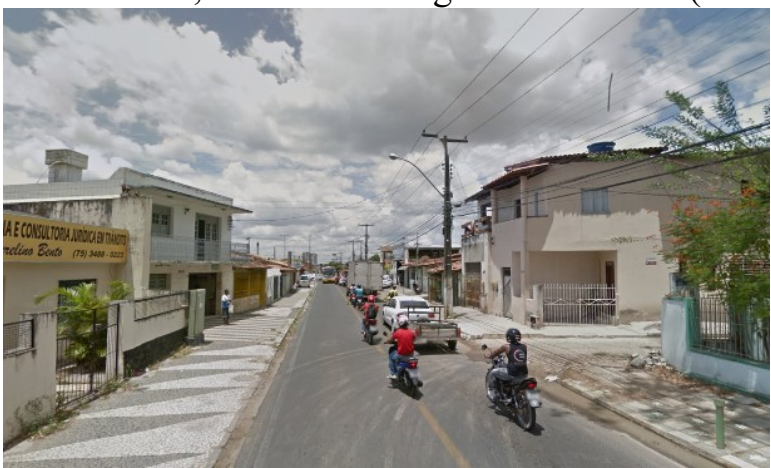

Fonte: Foto de Google Street View (2015). Disponível em: <https://www.google.com.br/maps>. Acesso em 14 de ago. 2016.

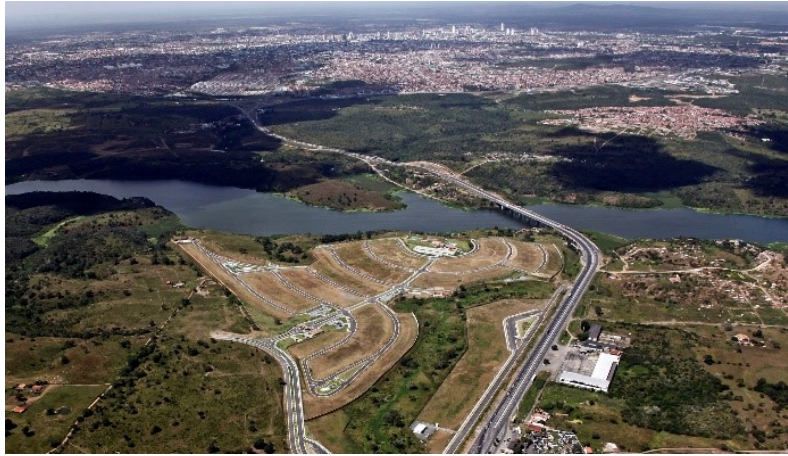

Fonte: Foto de Carlos Augusto (2016). Disponível em: $<w w w . j o r n a l g r a n d e b a h i a . c o m . b r>$. Acesso em 14 de ago. 2016.

Às margens da BR-116 (ao sudoeste da cidade, a cerca de sete quilômetros do centro) encontramos o condomínio residencial fechado Alphaville, uma das maiores marcas imobiliárias do país, inaugurado em meados de 2011. Como é comum aos empreendimentos desse tipo, esta localização é periférica, porém ligada a grandes eixos de circulação. Isso se dá porque é nas franjas urbanas que a empresa encontra grandes e baratas glebas que possibilitam a maximização dos lucros, ampliando a dispersão urbana (PESCATORI \& ABREU, 2016). 
Figura 43: Mapa axial da RM de Feira de Santana/BA calculado por Escolha (choice).

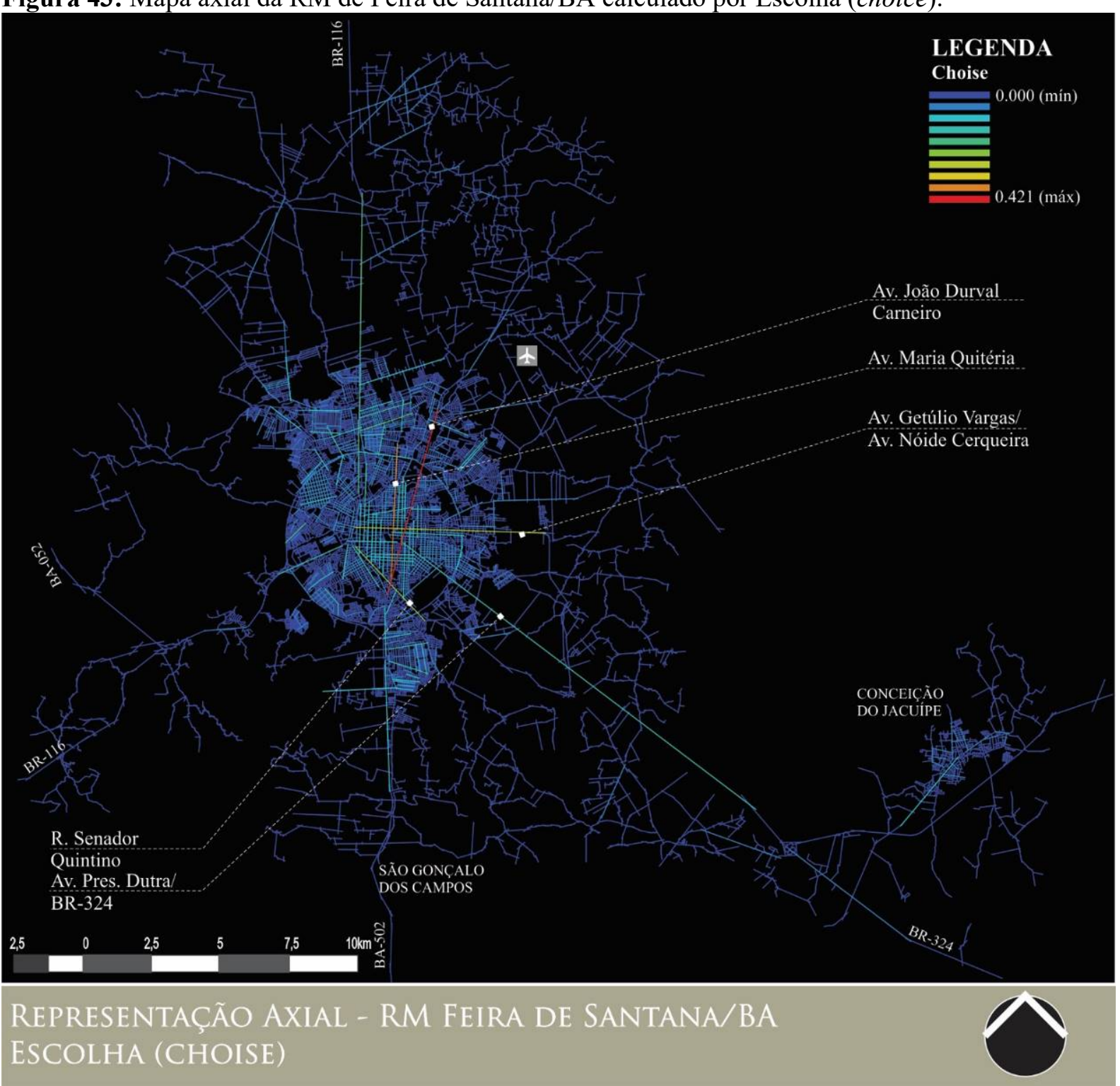

Fonte: Desenho de Amanda Brasil e revisão da autora (2016) a partir da Base Cartográfica do OpenStreetMap (2016) e imagens de satélite do Google Earth (2016).

Vale, portanto, um ressalto: a segregação espacial - entendida aqui no sentido de uma acessibilidade deficitária ao centro - não é atributo exclusivo das faixas de renda menores (há também na cidade diversas expansões residências de baixo e médio padrão, muitas das quais subsidiadas por programas nacionais de financiamento residencial - Figura 45), mas também se aplica àqueles com maior poder aquisitivo que se colocam num processo de segregação voluntária (VILLAÇA, 2001). Esse processo, com o passar dos anos, pode indicar um novo eixo de expansão urbana à medida em que carreiam os investimentos públicos em sua direção, especificamente relacionados ao sistema de mobilidade (focado no individual e não no transporte coletivo). 
Figura 44: Mapa de segmentos da RM de Feira de Santana/BA calculado por Escolha (choice).

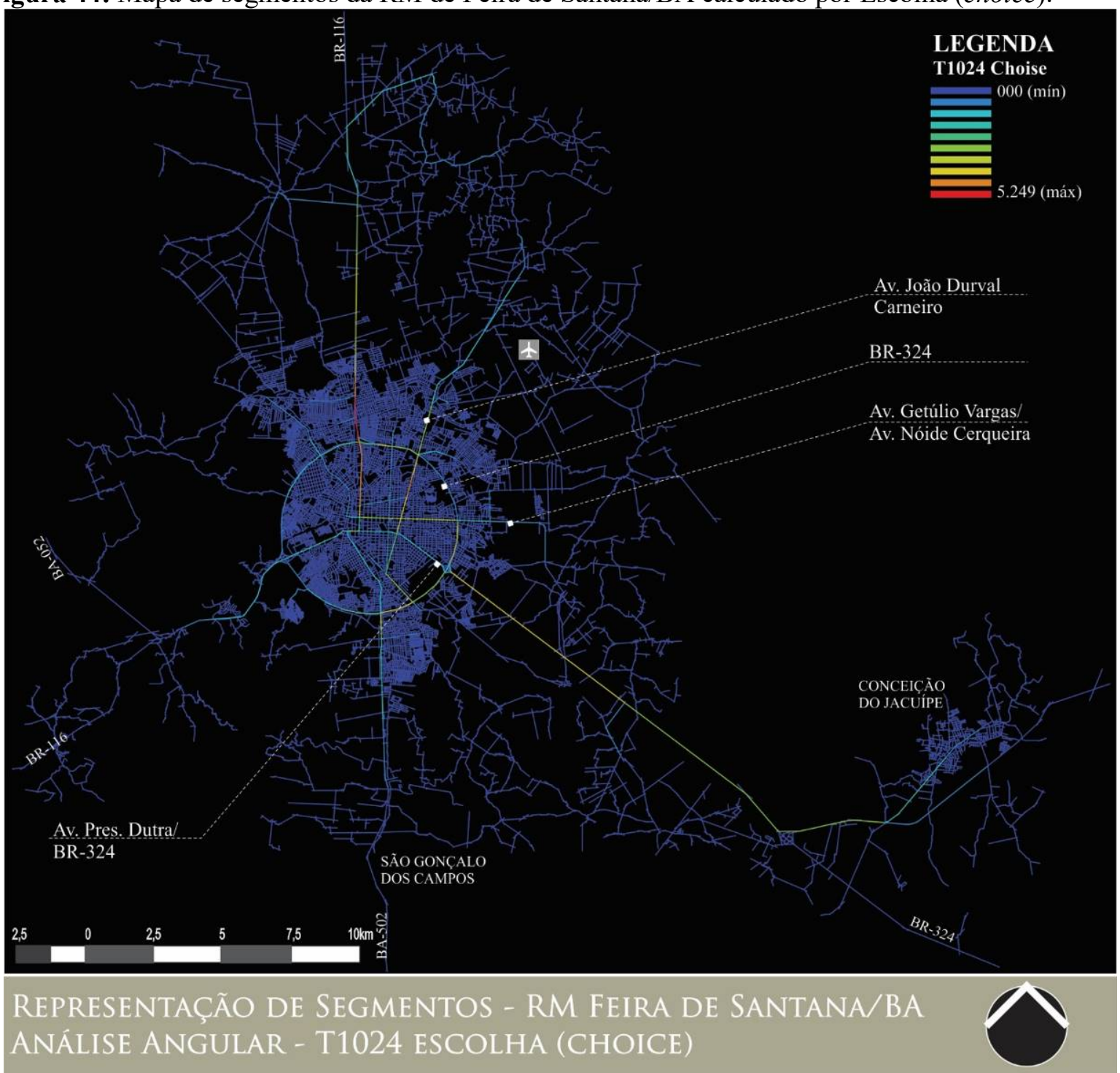

Fonte: Desenho de Amanda Brasil e revisão da autora (2016) a partir da Base Cartográfica do OpenStreetMap (2016) e imagens de satélite do Google Earth (2016).

Figura 45: Tipos de empreendimentos "Minha casa, Minha Vida" em Feira de Santana/BA.

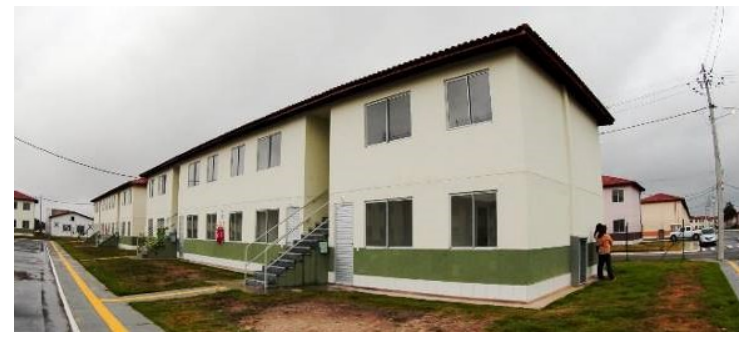

Fonte: Foto de Manu Dias/GOVBA (2014). Disponível em: <http://www.secom.ba.gov.br/>. Acesso em $15 \mathrm{de}$ ago. 2016.

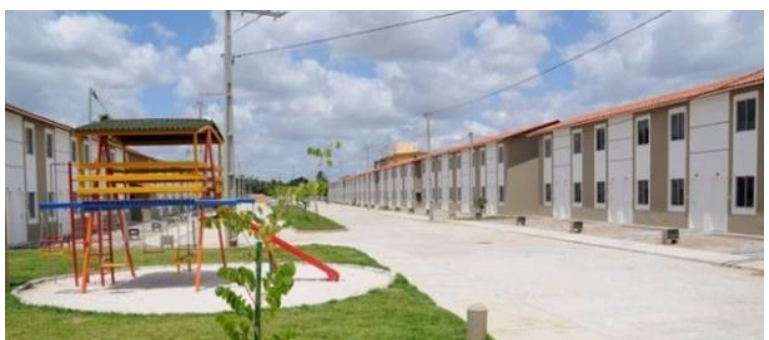

Fonte: autor desconhecido (s/d). Disponível em: $<$ http://www.acordacidade $>$. Acesso em 15 de ago. 2016. 
Historicamente, a cidade do Crato foi uma das primeiras povoações fundadas no Ceará, quando ainda no século XVII foram catequizados os índios que habitavam no vale de terras férteis, onde hoje está sediada a cidade. Sua ocupação e crescimento urbano se deram principalmente por sua atratividade climática-ambiental em meio aos sertões do Nordeste, atraindo muitos retirantes das secas (GURGEL, 2012). A implantação de diversos equipamentos educacionais, tendo como marco inicial o Seminário São José na década de 1870, contribuiu para a consolidação da cidade como polo educacional da região. Em paralelo, o povoado Tabuleiro Grande era apenas um lugarejo com algumas poucas casas e uma rústica capela, até meados de 1872 quando ali chegou o Padre Cícero Romão Batista. A ascensão do padre como santo venerado, figura instalada no imaginário popular até hoje, aliada ao seu papel político acarretou para Juazeiro do Norte um ímpeto de transformação, vislumbrado no crescimento da aglomeração urbana que, em 1911, é elevada à categoria de cidade, desmembrando-se política e territorialmente do Crato. A "Meca do Cariri" é diariamente procurada por fiéis vindos de diversos lugares (recebendo aproximadamente 2,5 milhões de visitantes anuais, segundos dados da Prefeitura). Um pouco à margem desse panorama, a cidade de Barbalha nasceu nos arredores da capela construída no início do século XVIII. Ali surgiram as primeiras casas, formando a pequena aglomeração que posteriormente foi desmembrada do Crato, em 1876. Sob a influência dos senhores de engenho, Barbalha adquiriu uma formação política oligárquica e sociedade aristocrática que, a exemplo de outras cidades no Brasil, contribuíram para trazer para a cidade um patrimônio arquitetônico relevante, ainda hoje, em parte, preservado.

A modelagem axial do Cariri abarca as áreas urbanas dos municípios Crato, Juazeiro do Norte e Barbalha, cuja conurbação é denominada Crajubar. O núcleo de integração do Crajubar (Figura 49 e Figura 50) - percentual das linhas mais integradas - está em sua maior porção sobre a cidade de Juazeiro do Norte/CE. Trata-se de um centro topológico de três "pernas": (1) ao longo da Av. Padre Cícero, ligação com Crato; (2) ao longo da Av. Leão Sampaio, ligação com Barbalha; (3) o próprio centro topológico de Juazeiro, ao longo da Av. Castelo Branco. O encontro dessas três vias dá-se no bairro Triângulo em Juazeiro (Figura 46), que recebe esse nome justamente por ser o entroncamento da rodovia CE-060, que liga Barbalha a Caririaçu, passando por Juazeiro do Norte; e da CE-292, que faz a ligação com o Crato. A alta acessibilidade da área contribuiu para a formação de um aglomerado de serviços, comércio e também de habitações. Esse bairro tornou-se o novo centro de negócios (como edifícios verticais de escritórios e residenciais, o hospital público regional, o Cariri 
Shopping, dentre outros) e polariza a concentração de investimentos de maior porte, os quais demandam uma maior parcela de solo e de serviços que extrapolam as demandas de cada cidade. O grande fluxo viário e a configuração do entroncamento vêm causando diversos problemas de congestionamento do tráfego, subsidiando a discussão de um projeto para um viaduto sobre a Praça José Feijó de Sá, como representado na maquete eletrônica da Figura 46.

Figura 46: Núcleo de integração do Crajubar: à esquerda, uma vista geral do Triângulo e, à direita, maquete eletrônica de um projeto para a área.

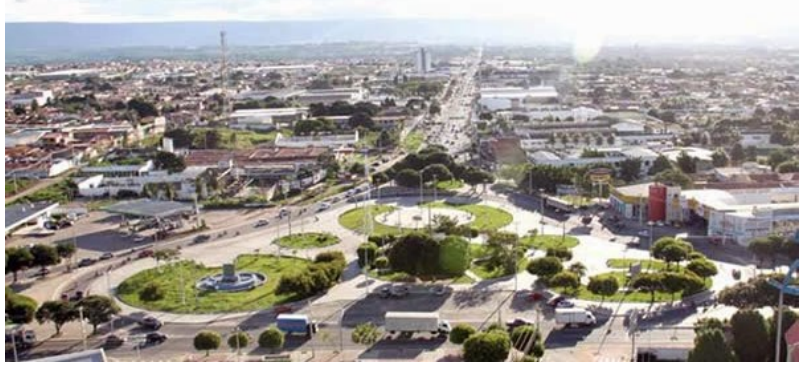

Fonte: Foto de autor desconhecido (2015). Disponível em: <http://madsonvagner.blogspot.com.br $>$. Acesso em 15 de ago. 2016.

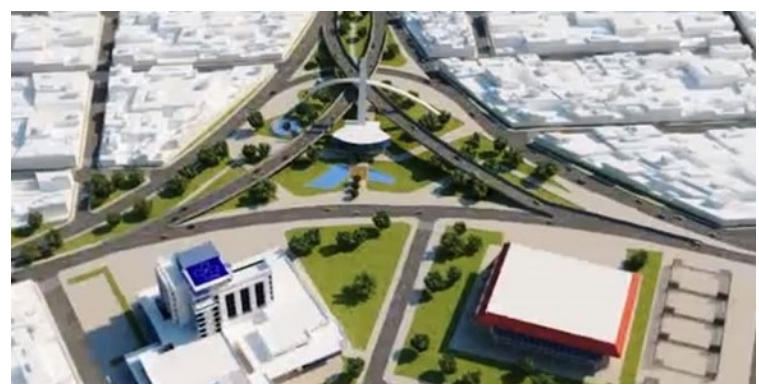

Fonte: Autor desconhecido (2012). Disponível em: $<$ http://noticiasdejua.blogspot.com.br/>. Acesso em 15 de ago. 2016.

Figura 47: Av. Padre Cícero (à esquerda), ligação entre Crato e Juazeiro do Norte, e a Av. Leão Sampaio (à direita).

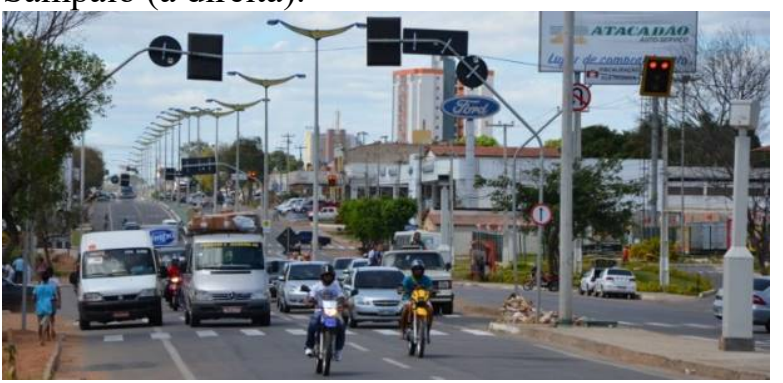

Fonte: Foto de Elizangela Santos (2011). Disponível em: $\quad<$ http://blogs.diariodonordeste.com.br/cariri/>. Acesso em 15 de ago. 2016.

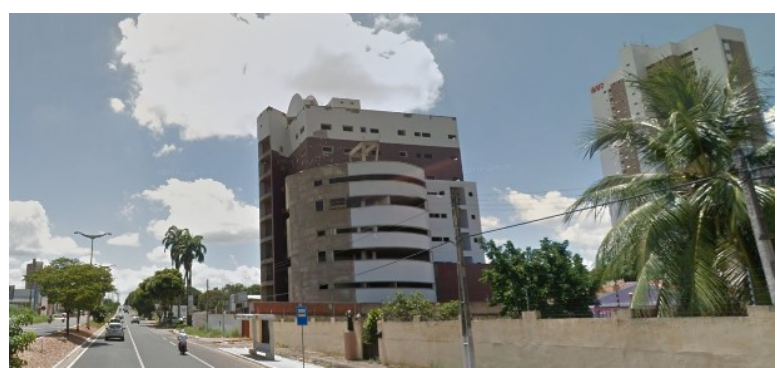

Fonte: Foto de Google Street View (2015). Disponível em: <https://www.google.com.br/maps>. Acesso em 15 de ago. 2016.

Figura 48: Vista geral do bairro Triângulo, onde é possível observar o entroncamento viário e os equipamentos que atendem a uma demanda regional, como o Hospital à direita.

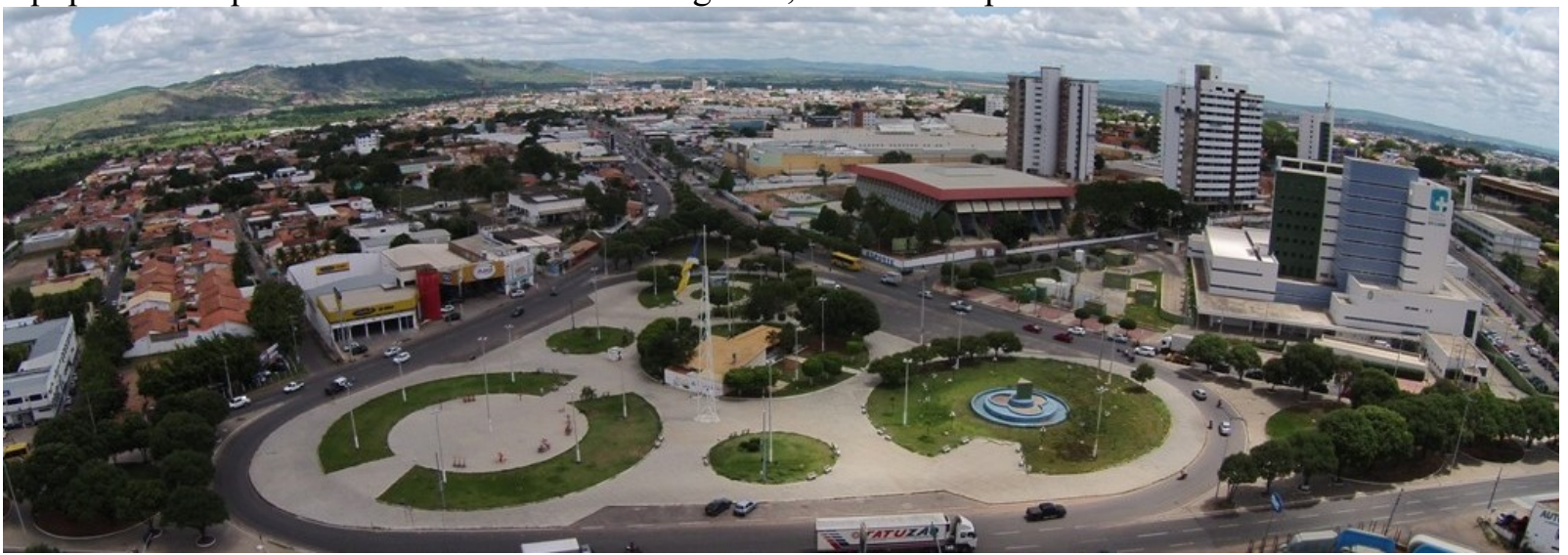

Fonte: Foto de autor desconhecido (2015). Disponível em: <https://s-media-cache-ak0.pinimg.com/>. Acesso em 15 de ago. 2016. 
Figura 49: Mapa axial da RM do Cariri/CE calculado por Integração HH global (Rn).

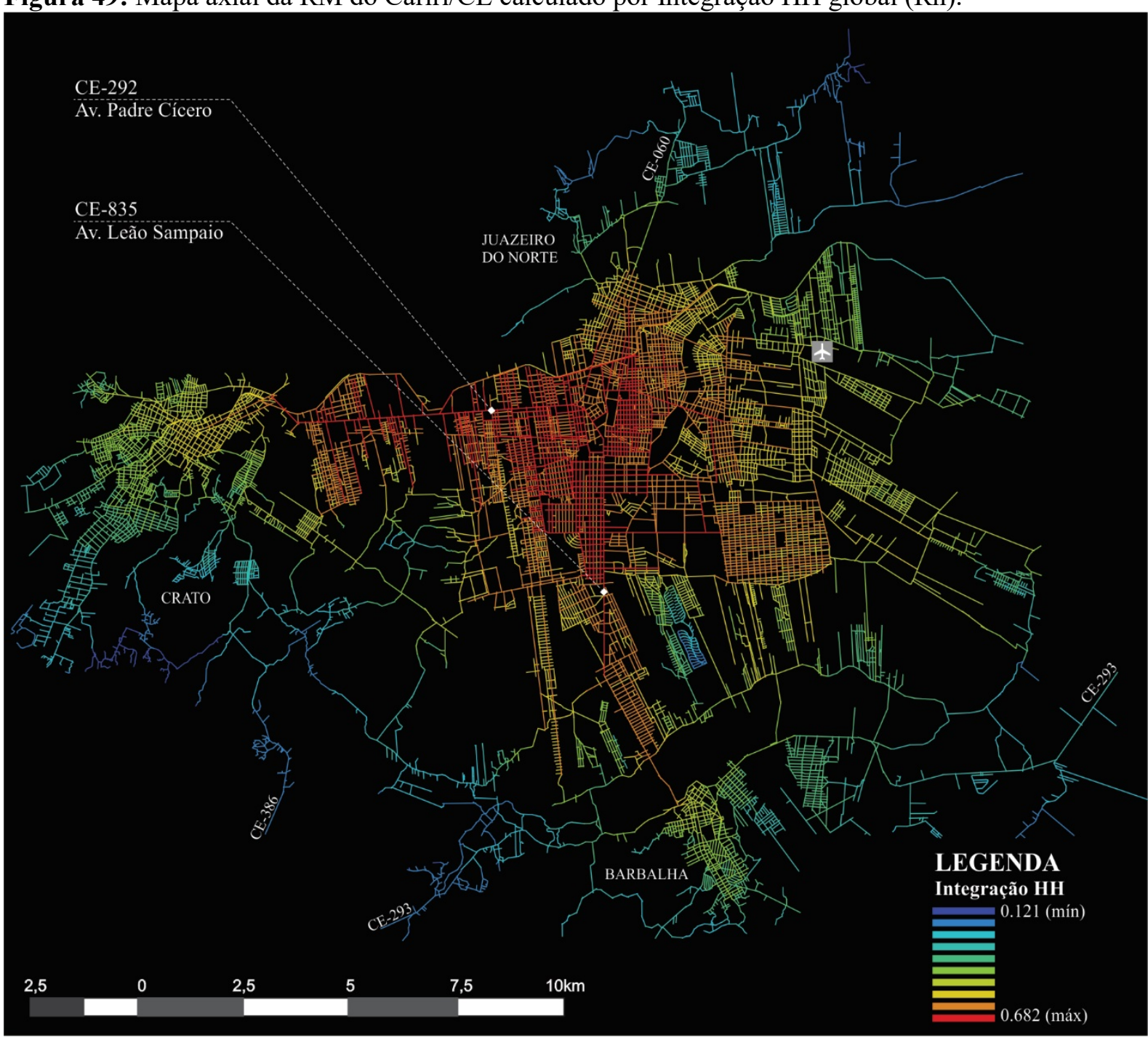

REPRESENTAÇÃO AXIAL - RM CARIRI/CE INTEGRAÇÃO HH GLOBAL (RN)

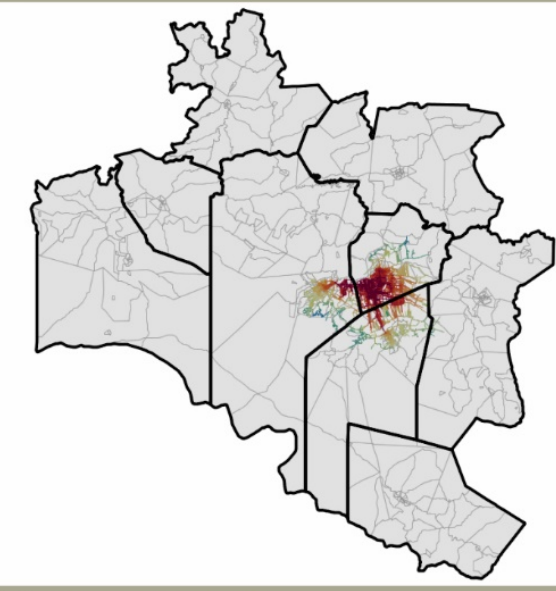

MAPA-CHAVE

RM CARIRI/CE

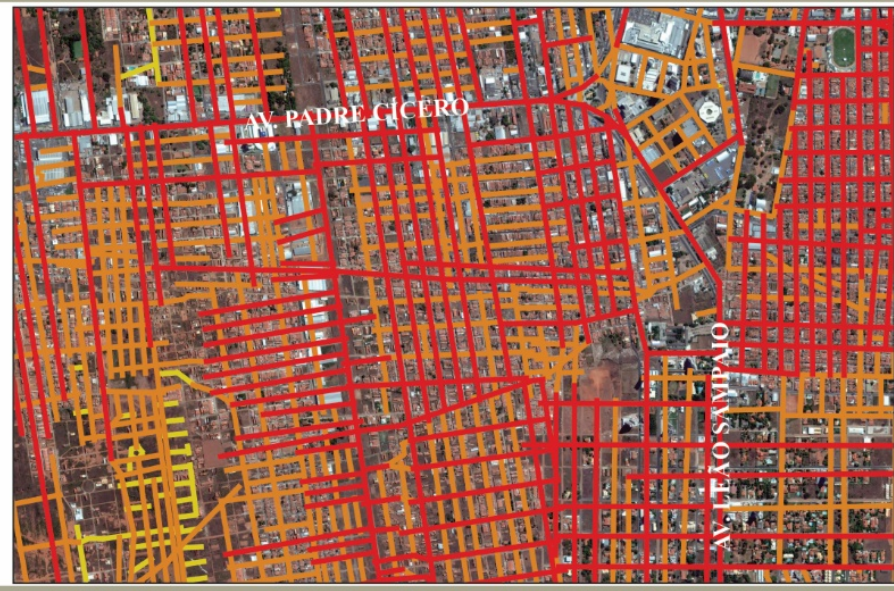

NÚCLEO DE INTEGRAÇÃO -DETALHE DO MAPA AXIAL - RM CARIRI/CE

Fonte: Desenho e revisão da autora (2016) a partir da Base Cartográfica do OpenStreetMap (2016) e imagens de satélite do Google Earth (2016). 
Figura 50: Mapa de segmentos da RM do Cariri/CE calculado por integração.

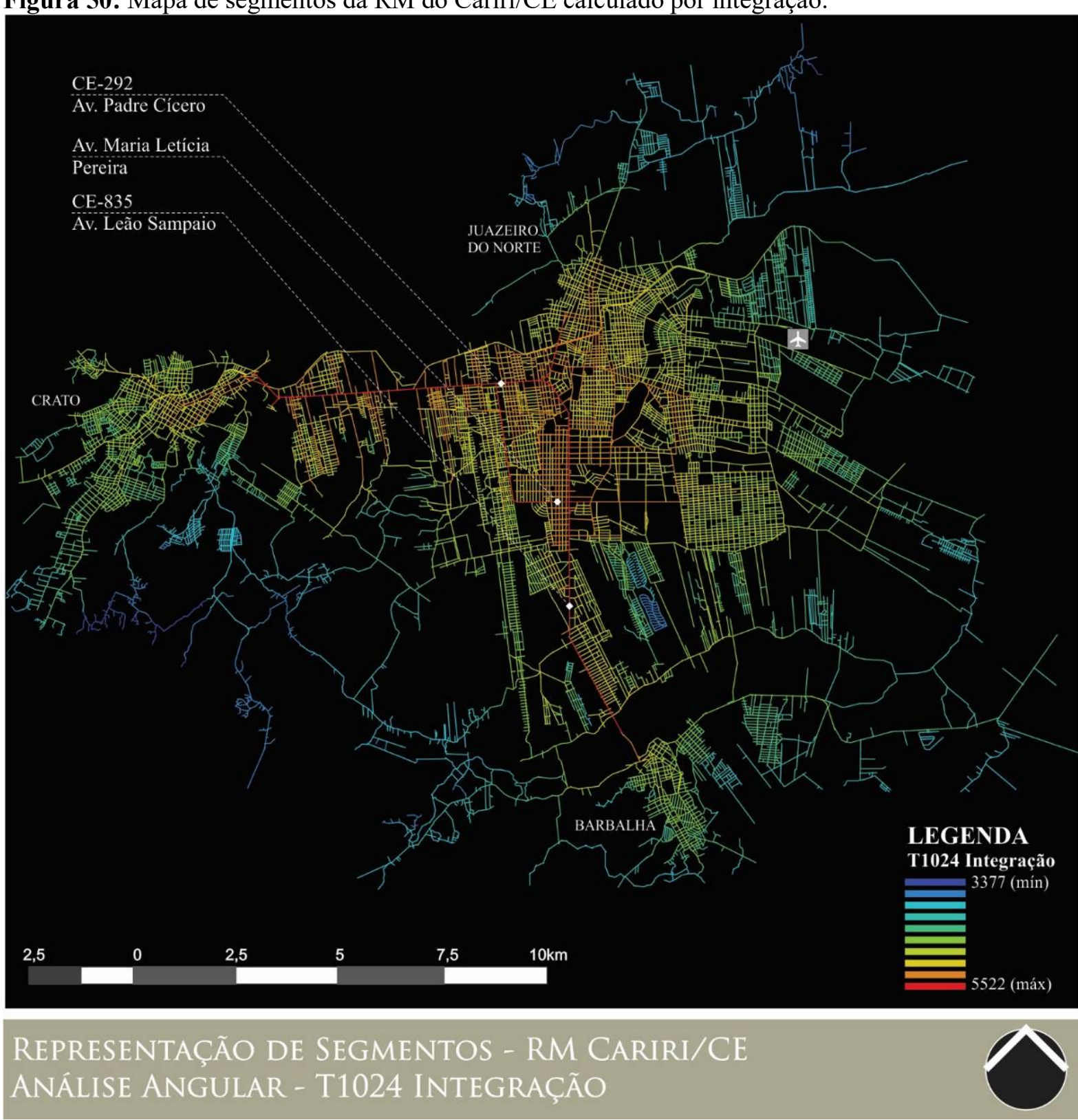

Fonte: Desenho e revisão da autora (2016) a partir da Base Cartográfica do OpenStreetMap (2016) e imagens de satélite do Google Earth (2016).

A representação de segmentos (Figura 50) reafirma o potencial desse núcleo de integração, porém em uma hierarquia cromática que destaca as avenidas de ligação intermunicipal, Padre Cícero e Leão Sampaio, que são as principais locações para equipamentos que atendem a escala regional e que se valem de alta acessibilidade viária: hipermercados, concessionárias, centro de convenções, Ceasa, dentre outros. Vislumbra-se, portanto, o surgimento de uma nova centralidade em escala metropolitana (GURGEL, 2012), independente dos centros tradicionais das três cidades embora a cidade de Juazeiro apresente grande poder polarizador frente ao Crajubar. Essa centralidade regional parece estender-se ao 
longo das avenidas de ligação intermunicipal, Padre Cícero e Leão Sampaio (Figura 47) também em destaque no mapa axial calculado por Escolha (Figura 54) -, o que foi denominado como centralidades lineares: espaços também de acentuadas transformações na ocupação e no uso dos solos, em sua maioria vinculados à escala do automóvel. Fenômenos como esse aqui descrito, de formação de novas centralidades de caráter regional como resposta à transformação de um território em área metropolitana, refletem uma dinâmica urbana comum a muitas cidades brasileiras, nas quais os interesses comerciais e imobiliários unem-se para promover o "[...] desenvolvimento de novas escalas de distribuição de bens e serviços, por meio da instalação de grandes equipamentos na periferia [...], redefinindo seus usos e conteúdos" (SPÓSITO, 1998, p. 30).

O processo de especulação imobiliária no Triângulo contribuiu com o fenômeno de verticalização "[...] iniciado timidamente no início dos anos 2000, porém, dinamizado pela expressiva valorização deste recorte da cidade após a construção do Hospital Regional e o anúncio da expansão do Cariri Shopping ainda em 2010”. (QUEIROZ, 2013, p.180). A expansão imobiliária avança ao longo do eixo da av. Leão Sampaio, onde têm destaque as novas dinâmicas residenciais, sejam elas por meio de verticalização (Figura 47) ou por meio da instalação de condomínios horizontais fechados, desde aqueles de pequeno porte (com até 10 casas) até grandes conjuntos que se apartam e negam o traçado urbano tradicional.

Figura 51: Cenário do bairro Lagoa Seca, área nobre de Juazeiro do Norte/CE que muda com a verticalização de seus imóveis.

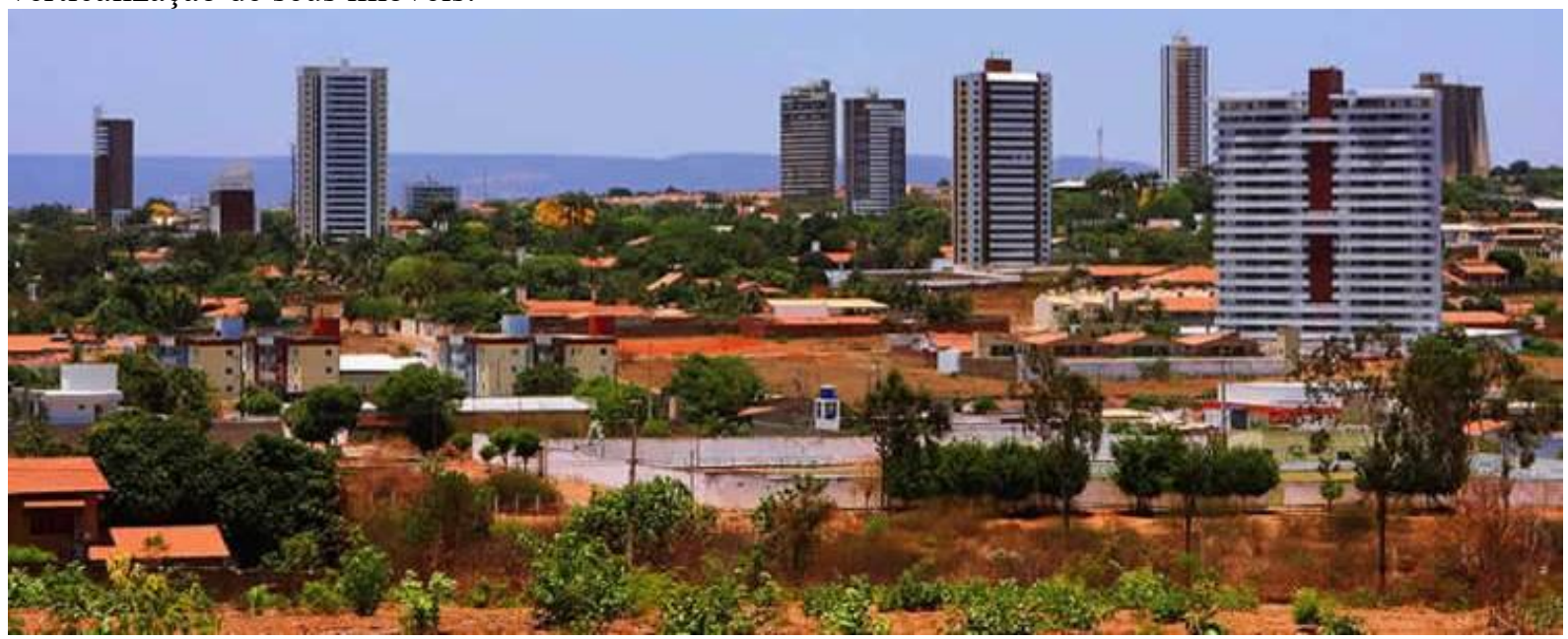

Fonte: Foto de Cícero Valério (2015). Disponível em: <http://www.miseria.com.br/>. Acesso em 17 de ago. 2016.

Estas as novas expansões residenciais para as classes média e alta da região destacam as áreas entre Barbalha e Juazeiro do Norte. No bairro Cidade Universitária (pois abriga o 
campus em Juazeiro da Universidade Federal do Cariri - UFCa) está localizado o Cidade Kariris Residencial Club (em azul no mapa da Figura 49 e Figura 51), um grande empreendimento imobiliário que reproduz a lógica dos condomínios fechados que trazem à tona a discussão de perda da urbanidade. O percentual de espaços cegos, representados pelos muros altos que apartam os condôminos da cidade a sua volta, com uma justificativa de "segurança" sugere uma diminuição da possibilidade de contanto social, refletida também na falta de espaços de lazer comuns (externos ao condomínio) no bairro. A lógica locacional residencial em voga na região tende a se valer dos princípios urbanísticos de caráter monofuncional, por vezes apoiada na própria legislação urbanística municipal que dialoga com a lógica imobiliária. Observa-se uma tendência de crescimento urbano centrífugo por meio da rarefação do tecido urbano, calcado na disseminação do automóvel próprio e onde a tipologia de ocupação pouco atende à escala do pedestre (GURGEL, 2012).

Figura 52: Exemplo dos novos loteamentos no Cariri: à esquerda, imagem de satélite do condomínio fechado "Cidade Kariris Residencial Club" e, à direita, uma imagem promocional do mesmo.

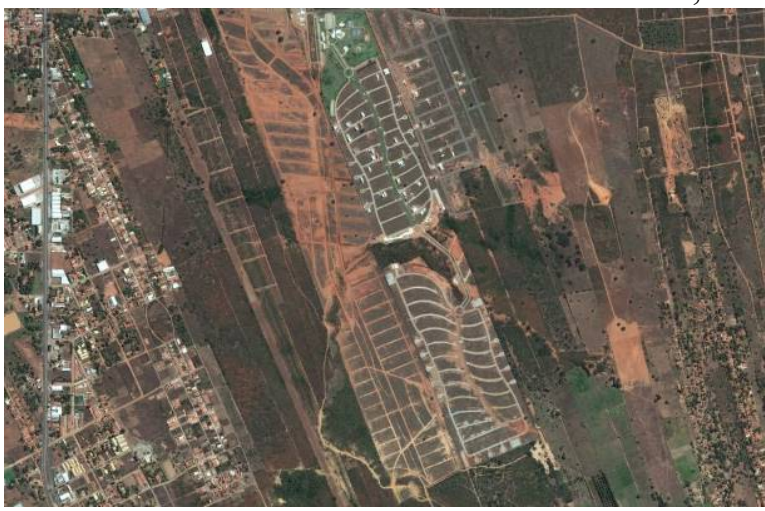

Fonte: Foto de Google Earth (2016). Acesso em 17 de ago. 2016.

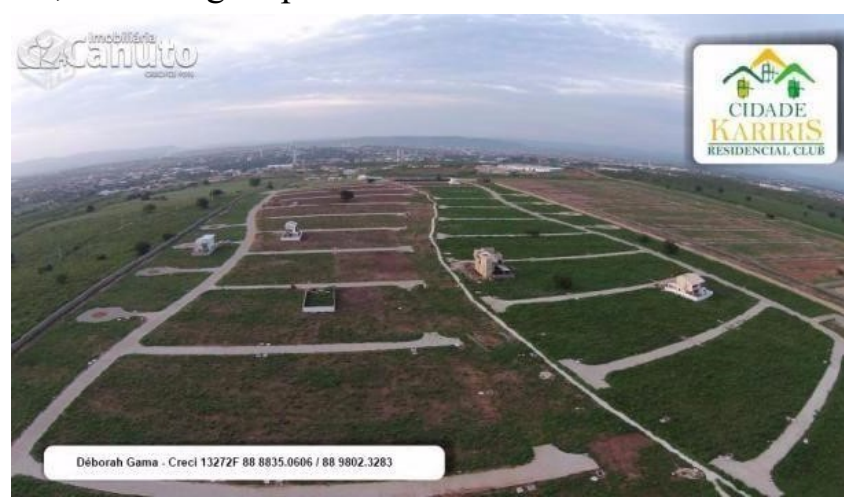

Fonte: Foto de autor desconhecido (s/d). Disponível em: $<$ http://ce.olx.com.br/ >. Acesso em 15 de ago. 2016.

Por outro lado, em ambas as representações percebemos que há poucos eixos na faixa mais baixa de integração. Eles localizam-se principalmente nas extremidades do mapa, o que se atribui ao "efeito borda", ou seja, as linhas próximas aos limites são calculadas e segregadas em função dessa localização (VARGAS, 2003) ${ }^{59}$. Entretanto, cabe ressaltar que a ligação entre Crato e Barbalha se dá em meio a Chapada do Araripe (área de proteção ambiental que divide o Cariri do Pernambuco, numa ocupação de características rurais, realmente segregada do restante da mancha urbana, conforme demonstra a Figura 53.

\footnotetext{
${ }^{59}$ Segundo o mesmo autor: "Esse efeito advém da escolha do recorte, dos limites escolhidos para a representação axial da cidade, se a "janela" escolhida fosse maior ou menor, aquelas linhas seriam mais ou menos integradas. Esse é um resultado natural do trabalho com medidas da profundidade desta linha em relação a este sistema de linhas" (VARGAS, 2003, p. 36).
} 
Figura 53: Ligação entre o Crato e Barbalha, à direita, uma vista do distrito cratense Baixio das Palmeiras e, à esquerda, a CE-293.

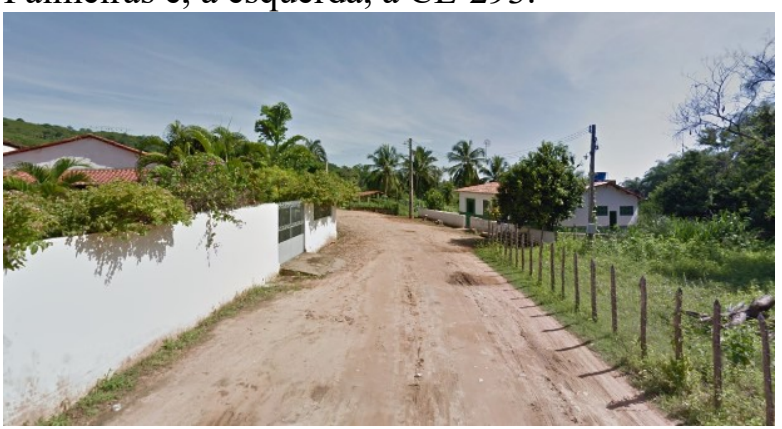

Fonte: Foto de Google Street View (2012). Disponível em: <https://www.google.com.br/maps>. Acesso em 15 de ago. 2016.

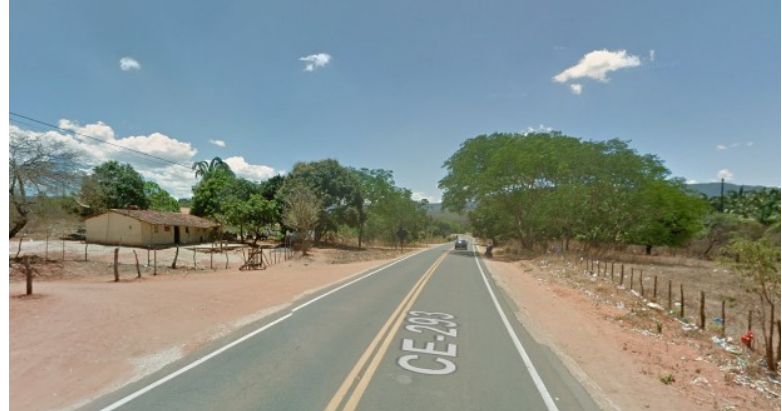

Fonte: Foto de Google Street View (2012). Disponível em: <https://www.google.com.br/maps>. Acesso em 15 de ago. 2016.

Figura 54: Mapa axial da RM do Cariri/CE calculado por Escolha (choice).

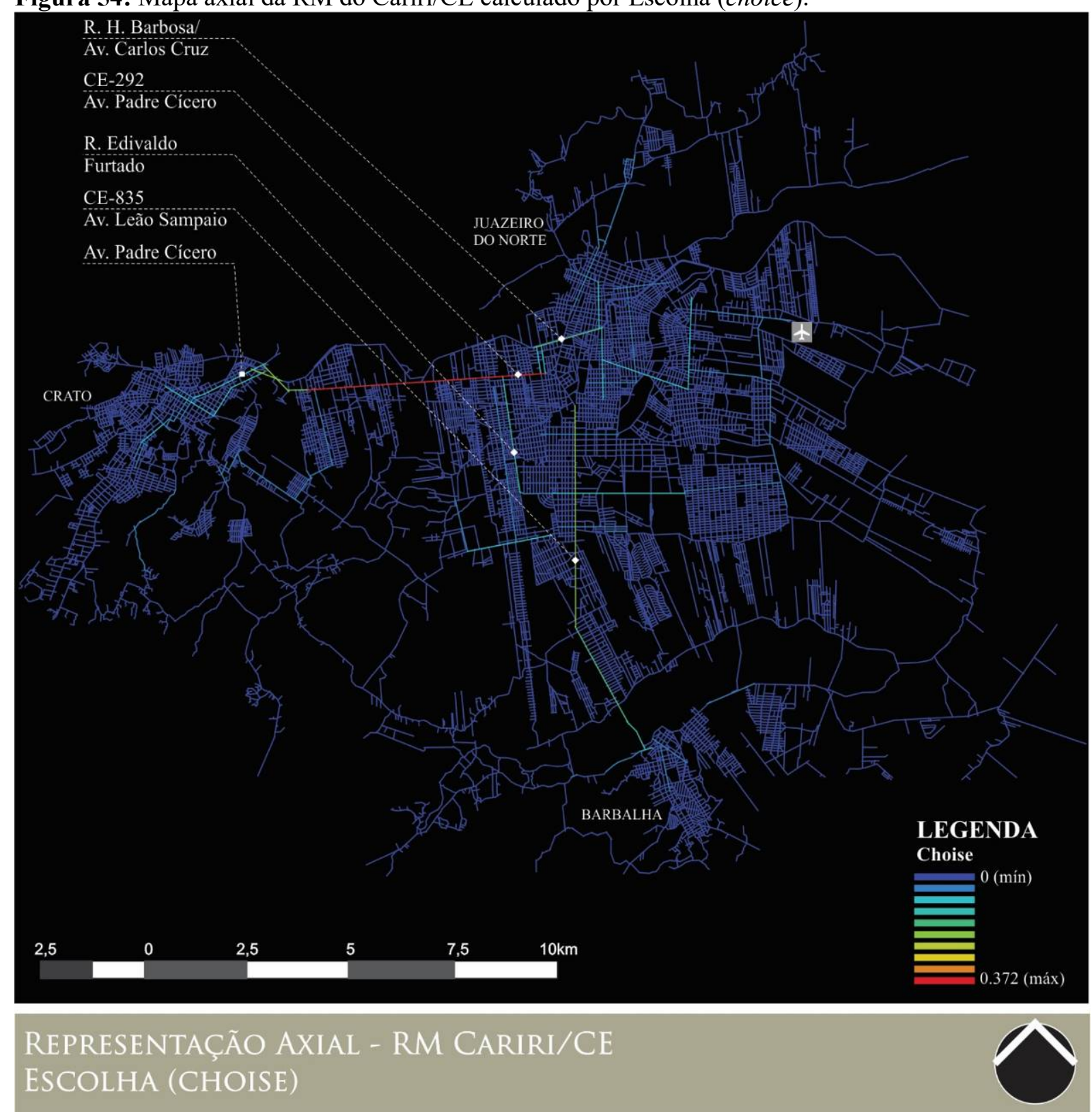

Fonte: Desenho e revisão da autora (2016) a partir da Base Cartográfica do OpenStreetMap (2016) e imagens de satélite do Google Earth (2016). 
$\mathrm{Na}$ representação de segmentos calculada para escolha (Figura 57), percebemos que além do destaque das vias de ligação intermunicipal, há uma evidência a eixos que parecem responder a uma escala local (em comparação com a escala da conurbação). Por exemplo, no Crato, o eixo definido pelas ruas Dom Quintino e Dr. João Pessoa até sua ligação com a Av. Padre Cícero organiza em seu entorno uma centralidade ativa local bem estabelecida, que incide sobre o bairro Centro (Figura 55) e espraia-se sobre os bairros Seminário e Pimenta. Esse é o Centro Tradicional desta cidade, constituído ao longo da ocupação e contando com certa variedade de usos comerciais e serviços, embora com alguns indícios de decadência do ponto de vista da manutenção dos edifícios históricos (GURGEL, 2012).

Figura 55: Centro Tradicional do Crato que tem como principal eixo a R. Dr. João Pessoa.

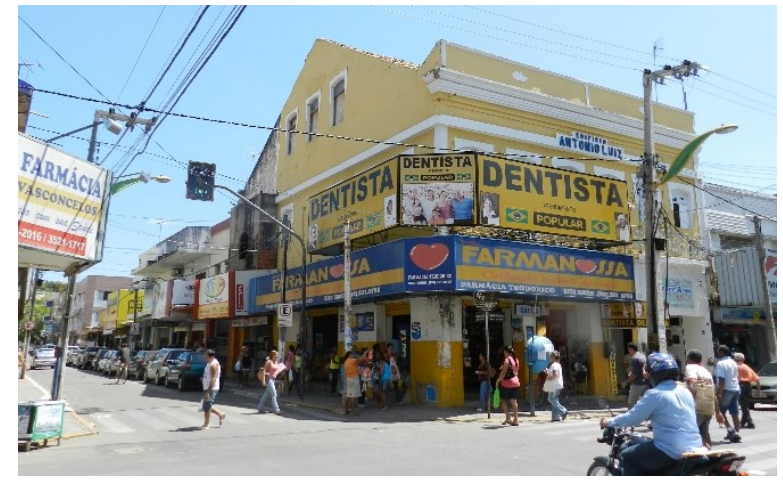

Fonte: Foto da autora (2011). Disponível em GURGEL, 2012.

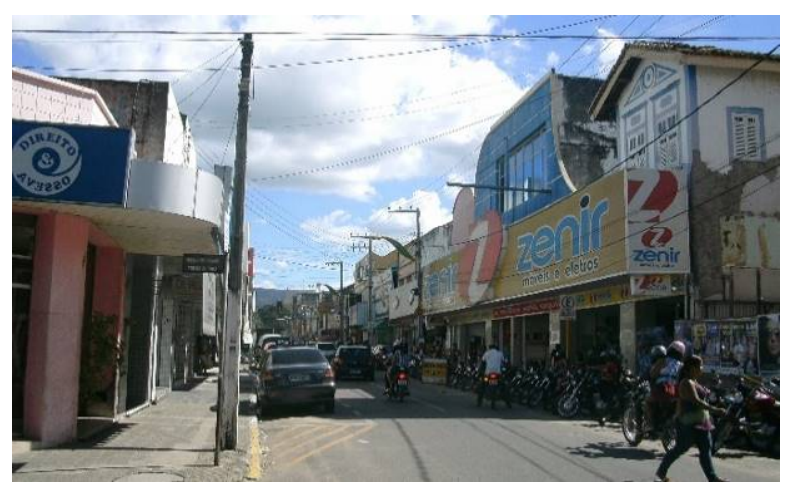

Fonte: Foto da autora (2011). Disponível em: GURGEL, 2012.

Figura 56: Vista geral da área central do Crato. Ao fundo, a Chapada do Araripe e, à direita, a Igreja da Sé (Praça da Sé).

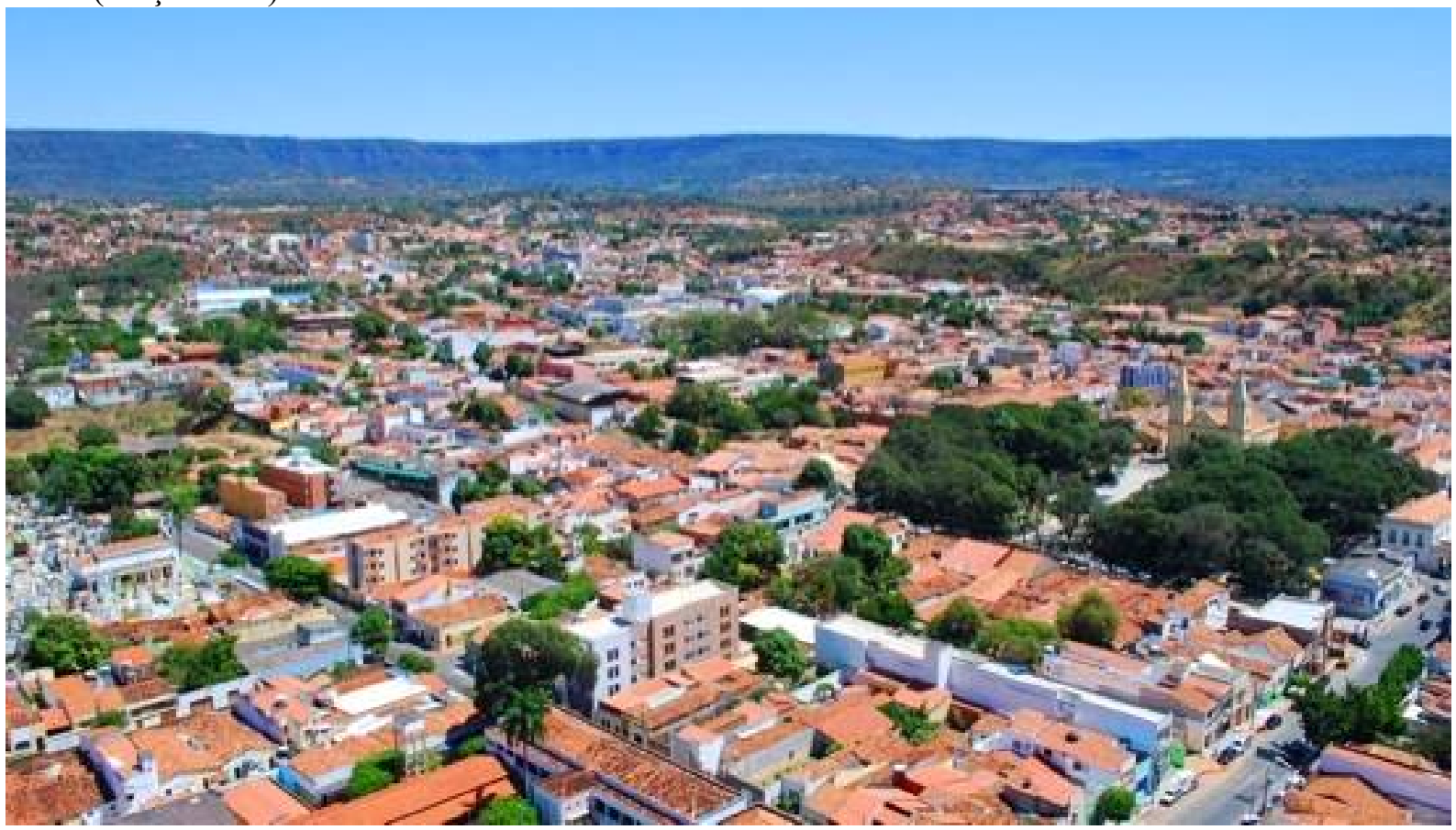

Fonte: Foto de autor desconhecido (s/d). Disponível em: $<$ http://blogs.diariodonordeste.com.br/ $>$. Acesso em 15 ago. 2016. 
Figura 57: Mapa de segmentos da RM do Cariri/CE calculado por Escolha (choice)

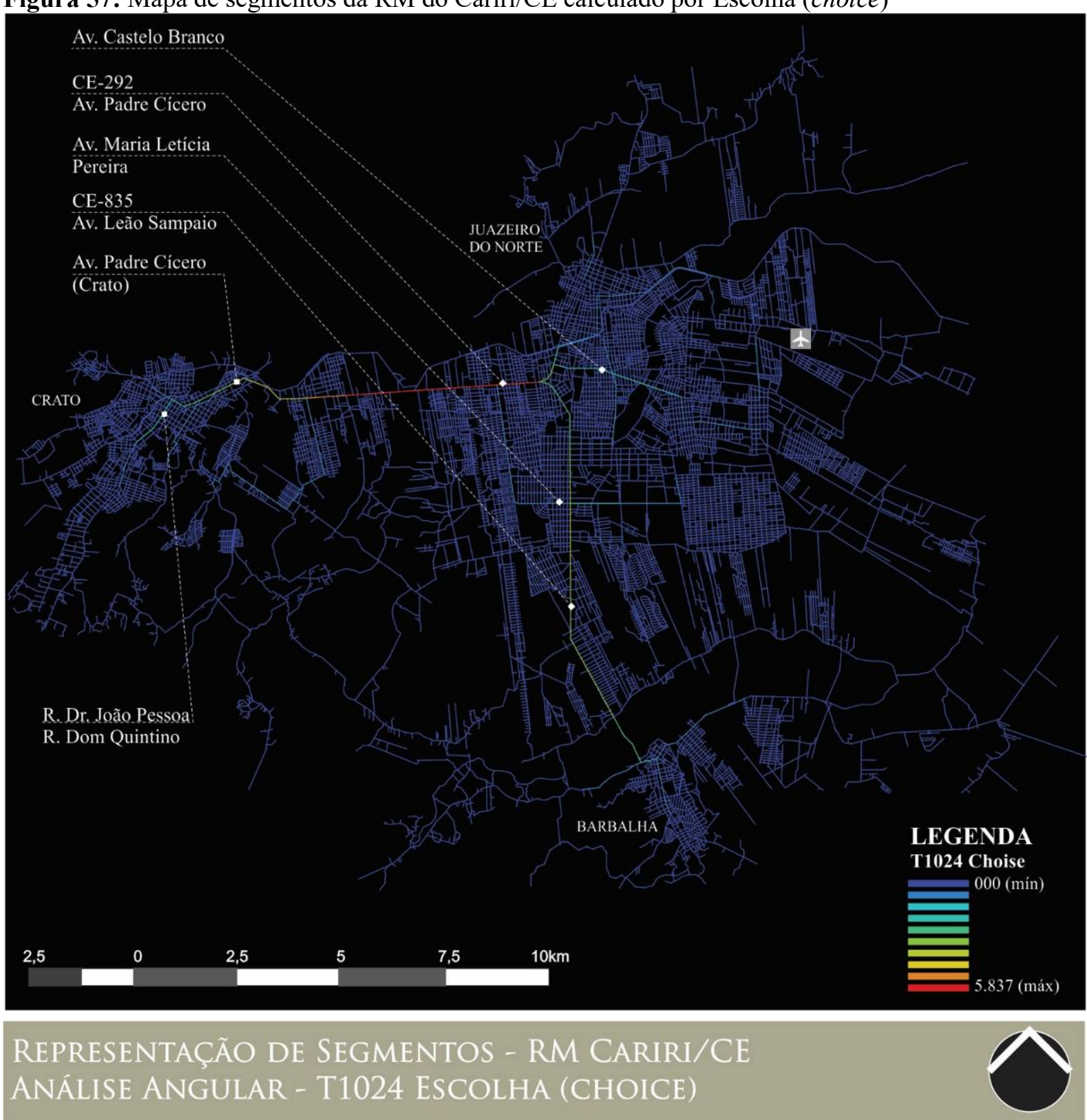

Fonte: Desenho e revisão da autora (2016) a partir da Base Cartográfica do OpenStreetMap (2016) e imagens de satélite do Google Earth (2016).

A ocupação do território que hoje abriga o município de Imperatriz/MA se deu com os bandeirantes de São Paulo a partir de fins do Século XVI e início do século XVII. Das entradas realizadas, tem destaque a de 1658, realizada pelos jesuítas. A fundação de Imperatriz, que recebeu inicialmente o nome oficial de Colônia Militar de Santa Tereza do Tocantins, se deu em 16 de julho de 1852. Após quatro anos, em 27 de agosto de 1856, a lei n. 398 criou a Vila de Imperatriz, nome dado em homenagem à imperatriz Tereza Cristina. Com o tempo, sua denominação foi sendo simplificada pela população, havendo documentos anteriores à Abolição em que a vila é mencionada simplesmente como Imperatriz. Sua 
elevação à categoria de cidade é datada de 22 de abril de 1924 (IBGE, 2016). Até o ano de 1958, quando foi iniciada a construção da rodovia Belém-Brasília, o município de Imperatriz e sua sede permaneceram geográfica e politicamente distantes da capital São Luís, o que resultou em um lento crescimento econômico e populacional. Porém, a partir das décadas 1960-70, a cidade vivenciou um acelerado surto de crescimento. Hoje, por força de seu desempenho nos setores de agricultura, pecuária, extrativismo vegetal, comércio, indústria e serviços, Imperatriz ocupa a posição de segundo maior centro do Estado e o principal da região que aglutina o sudoeste do Maranhão, norte do Tocantins e sul do Pará.

A modelagem axial construída para a RM do Sudoeste maranhense abarca a área urbana de Imperatriz/MA e sua conurbação com o município de João Lisboa. A via mais acessível (em integração, Figura 61, e escolha, Figura 67) é a BR-010, também conhecida como Belém-Brasília. Esta via foi um “corredor" estratégico do desenvolvimento da Amazônia oriental, por meio de diversas políticas públicas que manipularam o ambiente "de modo a torná-lo estratégico ao desenvolvimento do capitalismo na região [...] criando espaços estratégicos no território, com o objetivo de orientar os fluxos migratórios e a mobilidade de força de trabalho" (LIMA, 2005, s/p.). O município de Imperatriz foi o principal núcleo urbano dessa região a partir da década de 1950, com notável crescimento econômico e demográfico, e se mantem como importe polarizador dos investimentos na região até os dias de hoje.

Figura 58: À esquerda, a BR-010 na altura do centro de Imperatriz e, à direita, uma vista da Av. Babaçulândia.

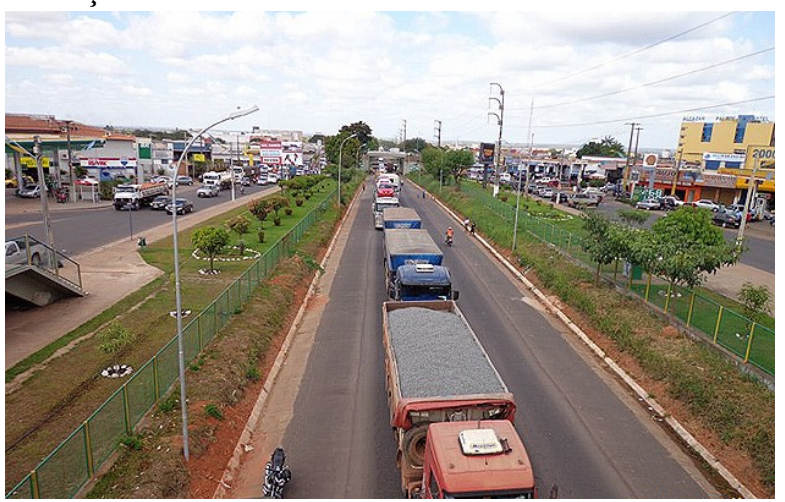

Fonte: Foto de autor desconhecido (2012). Disponível em: <http://jupiter.com.br/>. Acesso em 17 de ago. 2016.

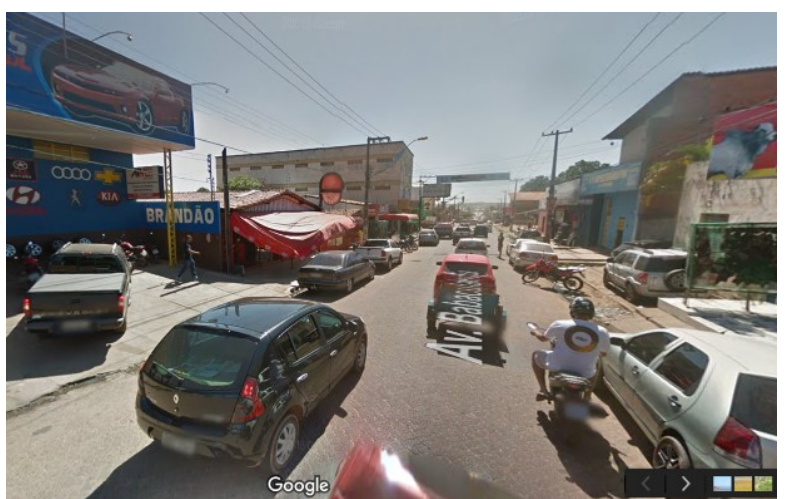

Fonte: Foto de Google Street View (2015). Disponível em: <https://www.google.com.br/maps>. Acesso em 17 de ago. 2016.

A BR-010, apesar de ser um grande eixo de circulação, representa uma barreira urbana, pois seus acessos transversais são poucos e se dão por meio de viadutos e trevos; além disso, há grades que impedem que os pedestres atravessem e as passarelas são insuficientes 
(Figura 58). As vias marginais da rodovia, também com alta integração, são locação para os serviços e comércios relacionados com a manutenção automotiva. Outra via em destaque nos mapas axiais é a Babaçulândia (MA-122 - Figura 58) que é interligada ao município de João Lisboa/MA, onde também são encontrados usos similares ao da BR, embora haja uma maior diversidade conforme o desenho urbano vai tornando mais esparso em direção aos limites do município. Essas vias também estão em evidência na representação de segmentos (Figura 64). Porém, é visível a mudança de distribuição cromática entre as representações axiais e de segmentos. Comparativamente, o bairro Centro "perde" integração quando desenhado como segmentos. Uma explicação é a disposição em grelha ortogonal densa (tabuleiro de xadrez), que possui uma similaridade de conexões que, por sua vez, influencia no cálculo de integração criando um sistema homogêneo. Portanto, visualiza-se um maior destaque para a Rua Pernambuco que não possui usos comerciais expressivos, mas é o eixo mais longo e estabelece a ligação entre a BR-010 e os bairros ao noroeste. Ademais, os segmentos parecem captar com maior refinamento as diferenciações dos eixos que compõem o município João Lisboa/MA, embora a MA-122 permaneça a mais integrada.

Figura 59: Imagem de satélite, apresentando os dois principais centros comerciais de Imperatriz. Em laranja, o Timbira Shopping Center; em verde, o Tocantins Shopping Center e, em vermelho, o Shopping Imperial.

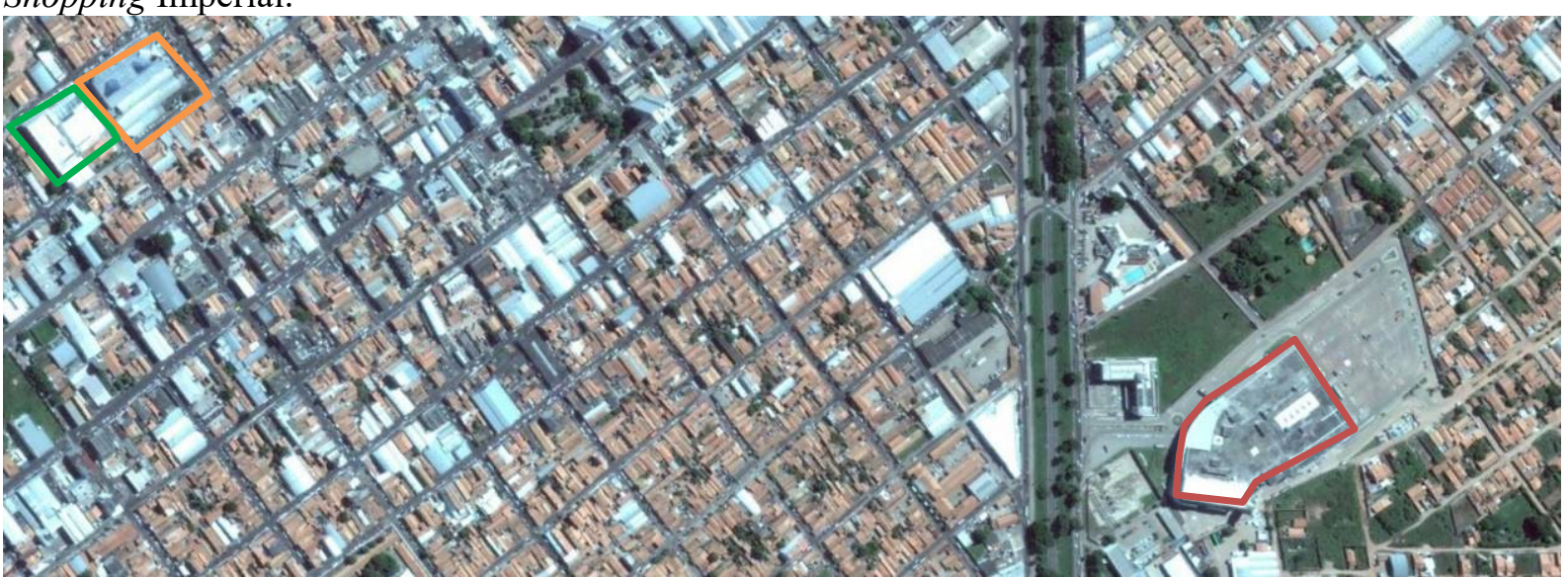

Fonte: Foto de Google Earth (2016) - editado pela autora (2016). Acesso em 17 de ago. 2016.

Figura 60: À esquerda, o Tocantins Shopping Center e, à direita, o Shopping Imperial.

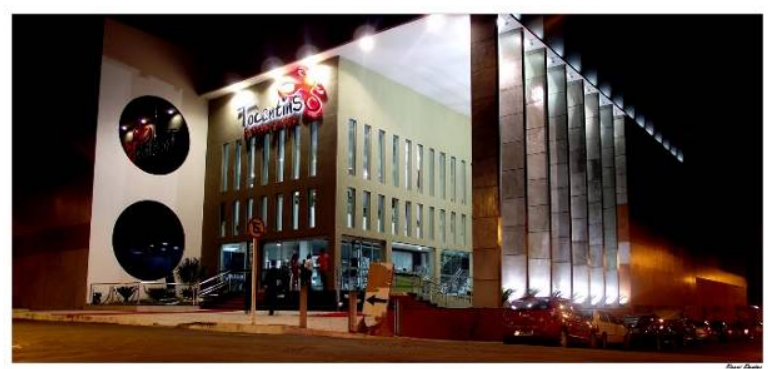

Fonte: Foto de Raoni Dantas (2011). Disponível em: $<$ http://imperatrizimagens.blogspot.com.br $>$. Acesso em 19 de ago. 2016.

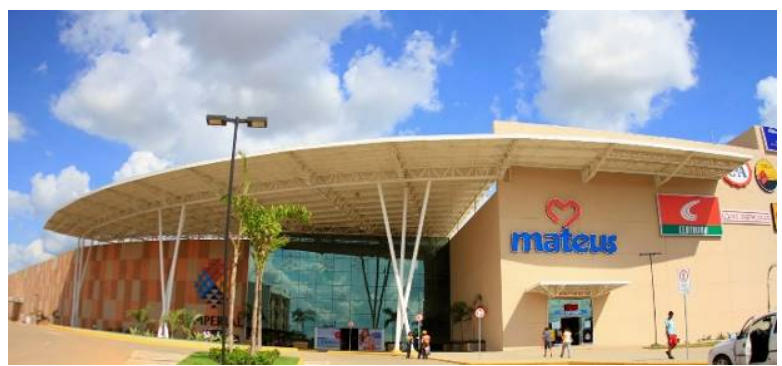

Fonte: Foto de autor desconhecido (2013). Disponível em: <http://josuemoura.blogspot.com.br>. Acesso em 19 de ago. 2016. 
Figura 61: Mapa axial da RM do Sudoeste Maranhense/MA calculado por Integração HH global $(\mathrm{Rn})$.

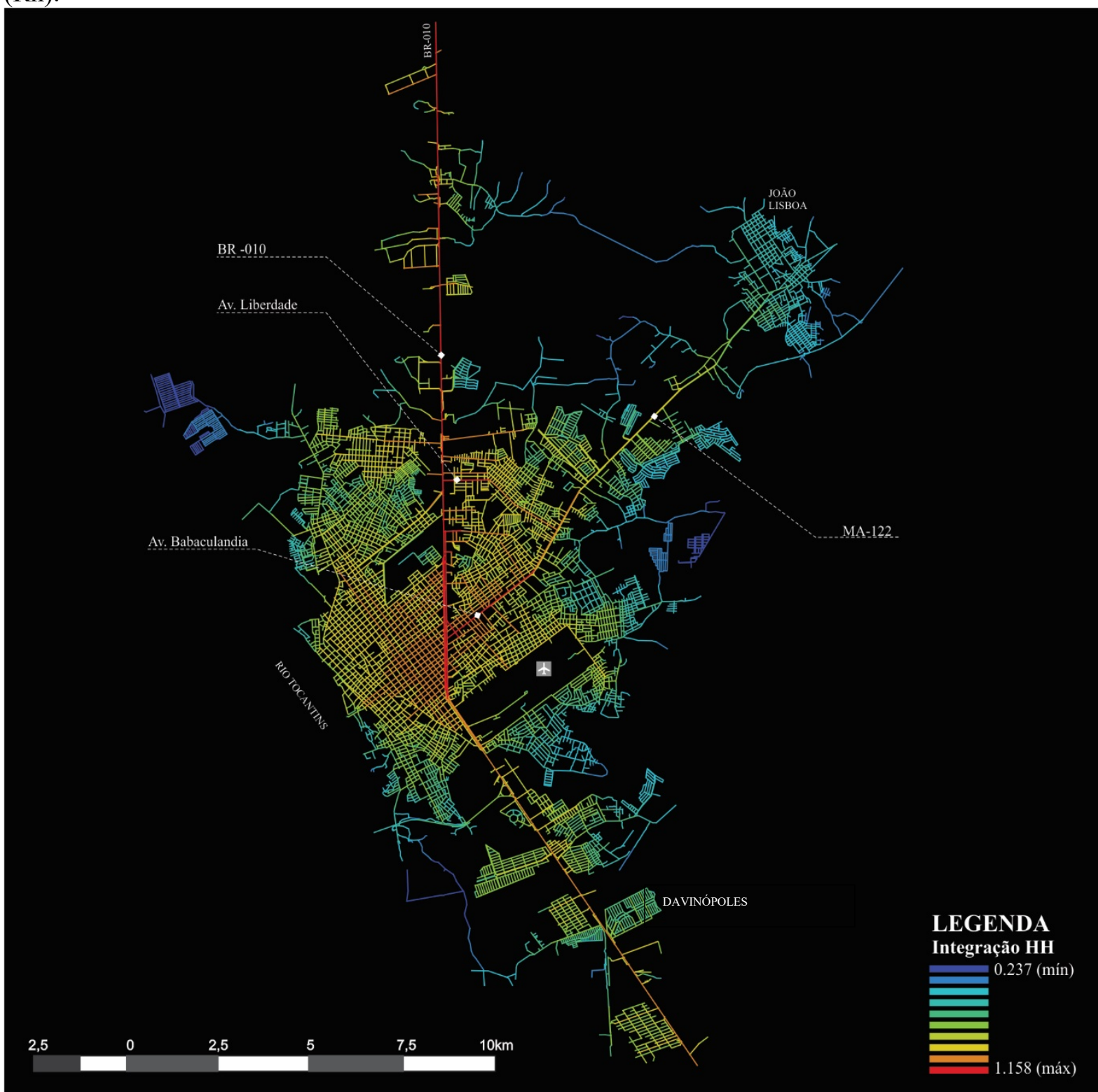

REPRESENTAÇÃO AXIAL - RM SUDOESTE MARANHESE INTEGRAÇÃO HH GLOBAL (RN)
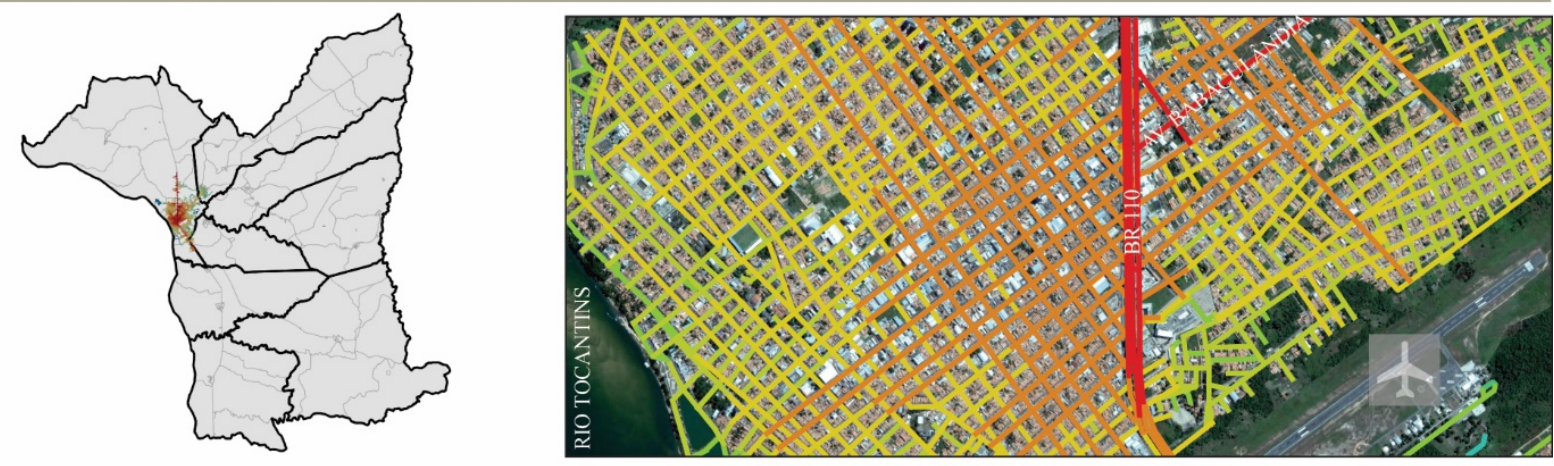

MAPA-CHAVE

NÚCLEO DE INTEGRAÇÃO - DETALHE

RM SUDOESTE MARANHESE DO MAPA AXIAL - RM SUDOESTE MARANHESE Fonte: Desenho gentilmente cedido por Paim (2015), com revisão da autora a partir da Base Cartográfica do OpenStreetMap (2016) e imagens de satélite do Google Earth (2016). 
A alta acessibilidade desse centro, em termos da integração HH calculada para a modelagem axial (Figura 61), é responsável pela locação das novas expressões comerciais nessa porção da cidade, diferentemente de outras RM's estudadas em que os shoppings são independentes dos centros tradicionais (Figura 59 e Figura 60). Inaugurados no início dos anos 2010, esses empreendimentos dinamizam o comércio da cidade oferecendo benefícios que os espaços tradicionais não possuem: segurança, estacionamento, climatização, etc. O shopping é, antes de tudo, um empreendimento imobiliário, e este são elementos vendidos aos consumidores e seus locatórios, pois segundo Villaça (2001, p. 303-304), "é o promotor imobiliário quem define não só a localização, mas uma série de normas ao comerciante [...] ao controlar e impor o mix, também há um domínio do capital imobiliário sobre o mercantil”". Embora não pareça ser o caso aqui e que o processo de declínio dos centros tradicionais seja anterior à disseminação dos shoppings, a instalação desses equipamentos é capaz de atrair a clientela de alta renda que anteriormente frequentava o centro tradicional, contribuindo para seu esvaziamento. Por outro lado, a expansão residencial de médio padrão se localiza ao sul da cidade, também seguindo o eixo da BR-010 e já ultrapassa os limites municipais de Imperatriz. O loteamento "Cidade Nova" (Figura 62), por exemplo, Davinópolis/MA que possui lotes de 200 a 250 metros quadrados. Este tipo de expansão contribui para os processos de dispersão urbana que comentei na RM de Feira de Santana/BA e para a RM do Cariri/CE.

Figura 62: À esquerda, imagem de satélite das expansões residenciais no sul da cidade e, à direita, um folheto de propaganda do Loteamento "Cidade nova" em Davinópolis/MA.

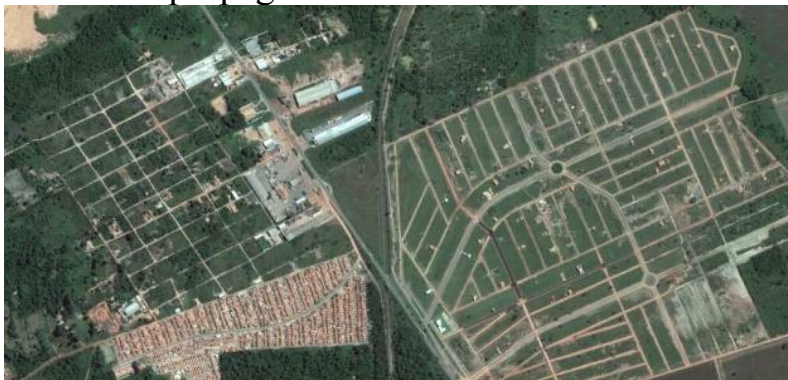

Fonte: Foto de Google Earth (2016). Acesso em 17 de ago. 2016.

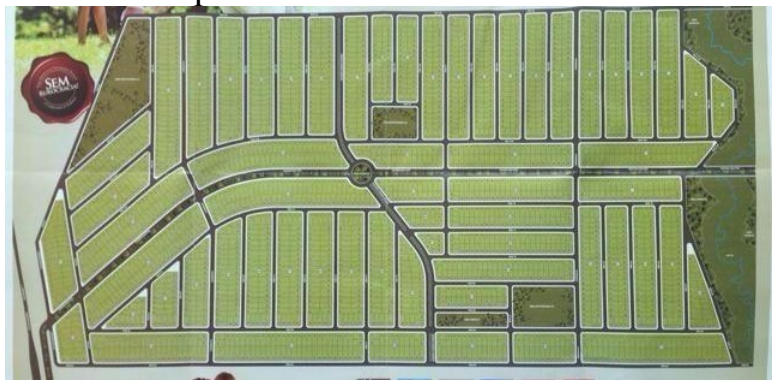

Fonte: Foto de autor desconhecido (s/d). Disponível em: $<\mathrm{http} / / /$ ma.mgfimoveis.com.br/>. Acesso em 17 de ago. 2016.

Figura 63: Imagens de satélite das expansões residenciais ao noroeste da cidade: Parque Independência, à esquerda, e sua inserção "rural". À direita, uma vista das casas dispostas enfileiradas.

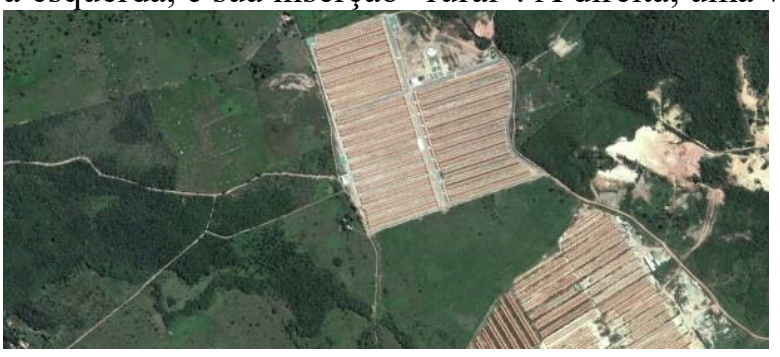

Fonte: Foto de Google Earth (2016). Acesso em 17 de ago. 2016.

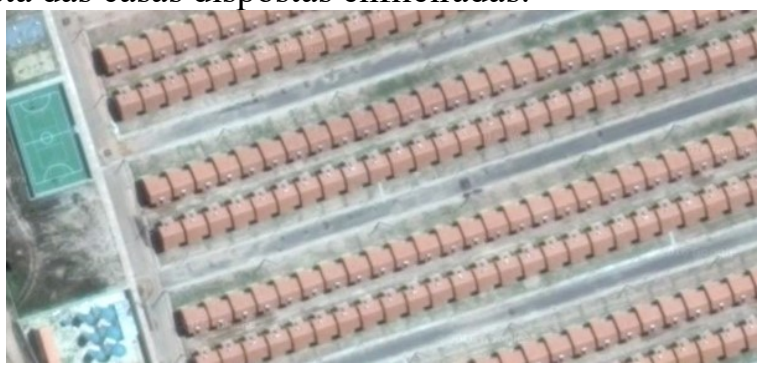

Fonte: Foto de autor desconhecido (s/d). Disponível em: $<$ http://ma.mgfimoveis.com.br/>. Acesso em 17 de ago. 2016. 
Figura 64: Mapa de segmentos da RM do Sudoeste Maranhense/MA calculado por Integração.

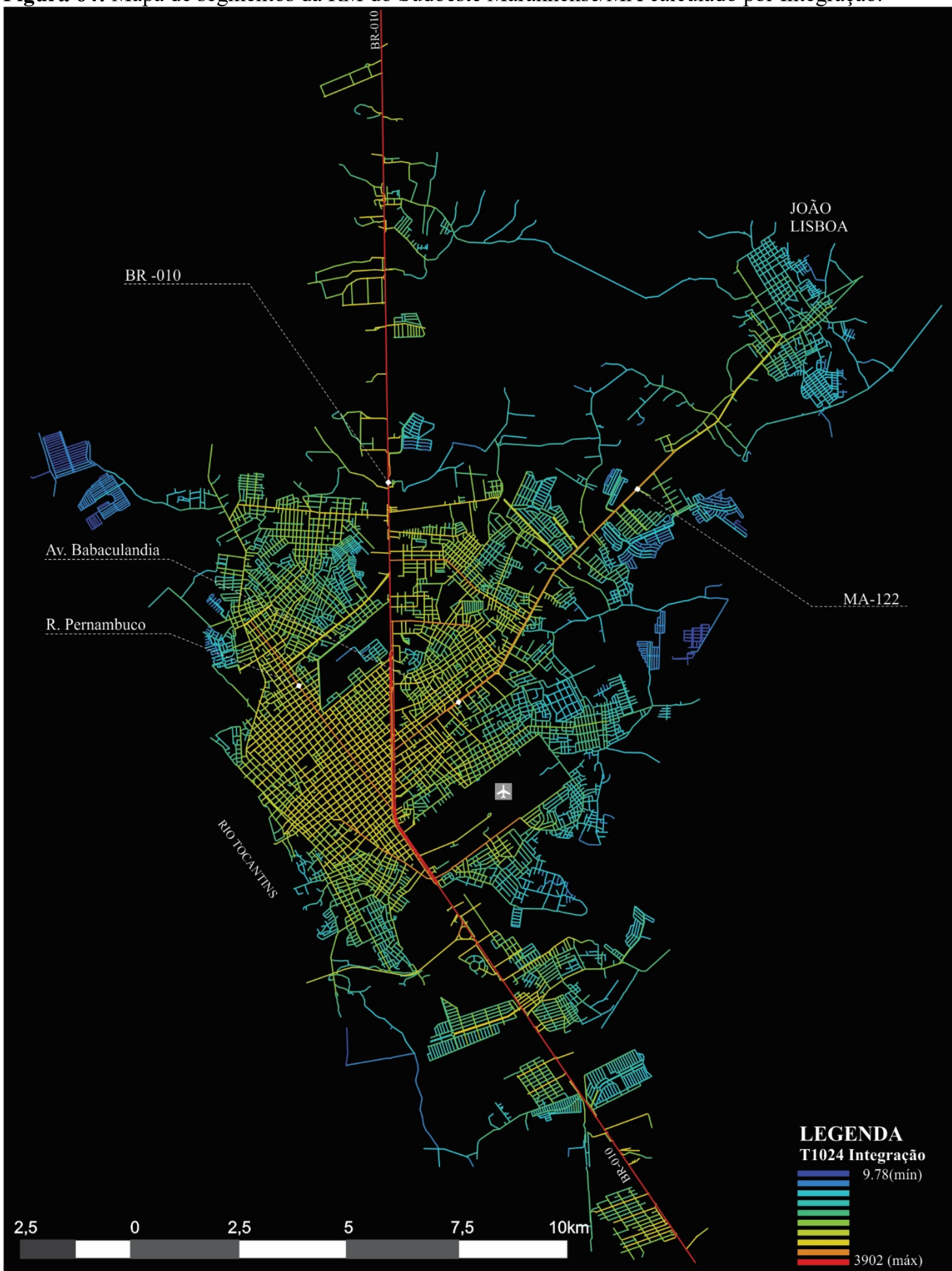

REPRESENTAÇÃO DE SEGMENTOS - RM SUDOESTE MARANHESE ANÁLISE ANGULAR - T1024 INTEGRAÇÃO

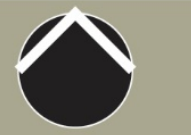

Fonte: Desenho gentilmente cedido por Paim (2015), com revisão da autora a partir da Base Cartográfica do OpenStreetMap (2016) e imagens de satélite do Google Earth (2016). 
Outras ocupações periféricas, como o Parque independência (Figura 63), representam os novos espaços habitacionais para as faixas mais baixas de renda (ocupado sobretudo pelos imigrantes da zona rural e de outros municípios), muitas vezes financiados por programas como o "Minha Casa, Minha Vida". Essa área aparece no levantamento do Censo 2010 como rural e percebe-se que esta expansão não se fez acompanhar dos serviços e equipamentos, em um desenho urbano extremamente monótono, de baixa legibilidade e com pouca diversidade arquitetônica. Essas são críticas recorrentes à produção habitacional deste programa federal, pois:

[...] embora existam exceções - projetos habitacionais de qualidade e inseridos na malha urbana -, a grande maioria dos empreendimentos do PMCMV está localizada na periferia das cidades, distantes dos empregos, desarticulada da malha urbana existente ou de planos de expansão urbana, com projetos de moradias sem qualidade arquitetônica nem identidade com as comunidades locais. (BONDUKI, 2014, p 132).

Reproduzem-se, de certo modo, as lógicas perversas da organização socioespacial, em um processo de segregação involuntária, ou seja, que não é fruto de decisões de seus atores, mas sim, maquinada pelas condições sociais e econômicas. Entretanto, enquanto prevalece na literatura exemplos desse processo, decorrentes da informalidade do mercado imobiliário e favelização das áreas periféricas, posso inferir que o PMCMV (e similares) contribuiu com a "formalização" deste modelo excludente em diversas cidades brasileiras, incluindo as estudadas nesta tese. Este fenômeno foi definido por Lefebvre (1991) como "segregação programada", ou seja, sob ação planejada do Estado.

Figura 65: Aeroporto de Imperatriz - Prefeito Renato Moreira.

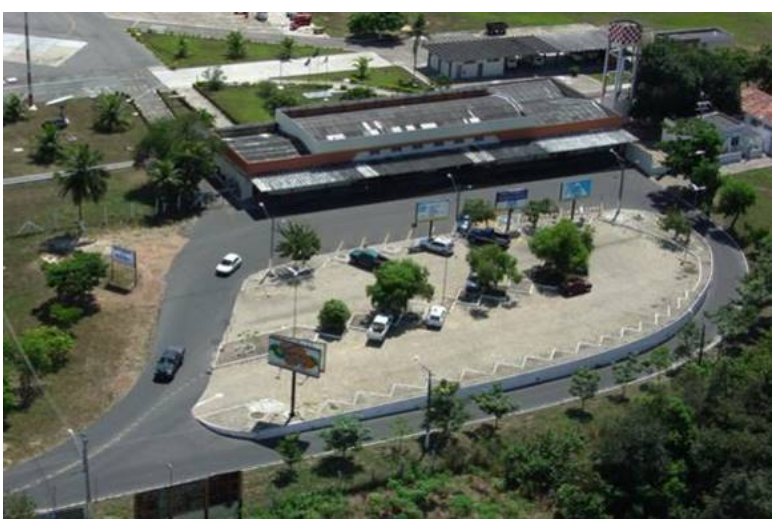

Fonte: Foto de autor desconhecido (s/d). Disponível em: <http://www.dlempreendimento.com.br/>. Acesso em 17 de ago. 2016.

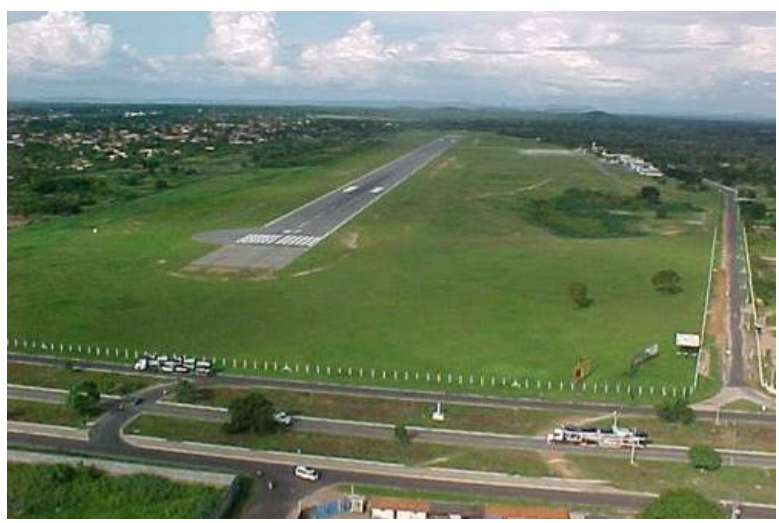

Fonte: Foto de autor desconhecido (2014). Disponível em: <http://www.nortedotocantins.com.br/>. Acesso em 17 de ago. 2016. 
Por fim, traçando um comparativo entre a representação da medida de escolha nas representações axiais e de segmentos (Figura 67 e Figura 68), repete-se, em termos gerais, os mesmos resultados. Porém, os segmentos dão maior refinamento aos resultados pois os cálculos são realizados para eixos menores, o que cria uma hierarquia nas vias de grande extensão, por exemplo a BR-010. Em ambas representações, além da evidência às vias principais de circulação que já foram destacadas no cálculo de integração, há a proeminência das ruas de aceso ao aeroporto Prefeito Renato Moreira, o único a receber aeronaves de porte médio com aviação regular ${ }^{60}$ em uma área de abrangência cobre mais de 40 cidades vizinhas.

O processo de verticalização (Figura 66) da cidade demonstra-se ainda inicial e data da última década. Porém, as novas tipologias residenciais e comerciais em Imperatriz vêm transformando a paisagem urbana da cidade. Diversos projetos de construções verticais foram identificados na mídia imobiliária da região. Segundo dados do IBGE (2010), o Maranhão possui a maior taxa de verticalização da região Nordeste $(48 \%)$ e está acima da média nacional, que é de $43 \%$. Na região, esse número chega a 48\%. O estado possui apenas $3 \%$ do número de apartamentos no Nordeste (conta com 28.636 apartamentos habitados), mas a taxa de crescimento no último censo foi a maior da região. Os dados demonstram ainda que há 1.328 apartamentos em Imperatriz, cujo principal atrativo são os quesitos de segurança.

Figura 66: Vista geral de Imperatriz. À esquerda, o Rio Tocantins e o discreto processo de verticalização desta área.

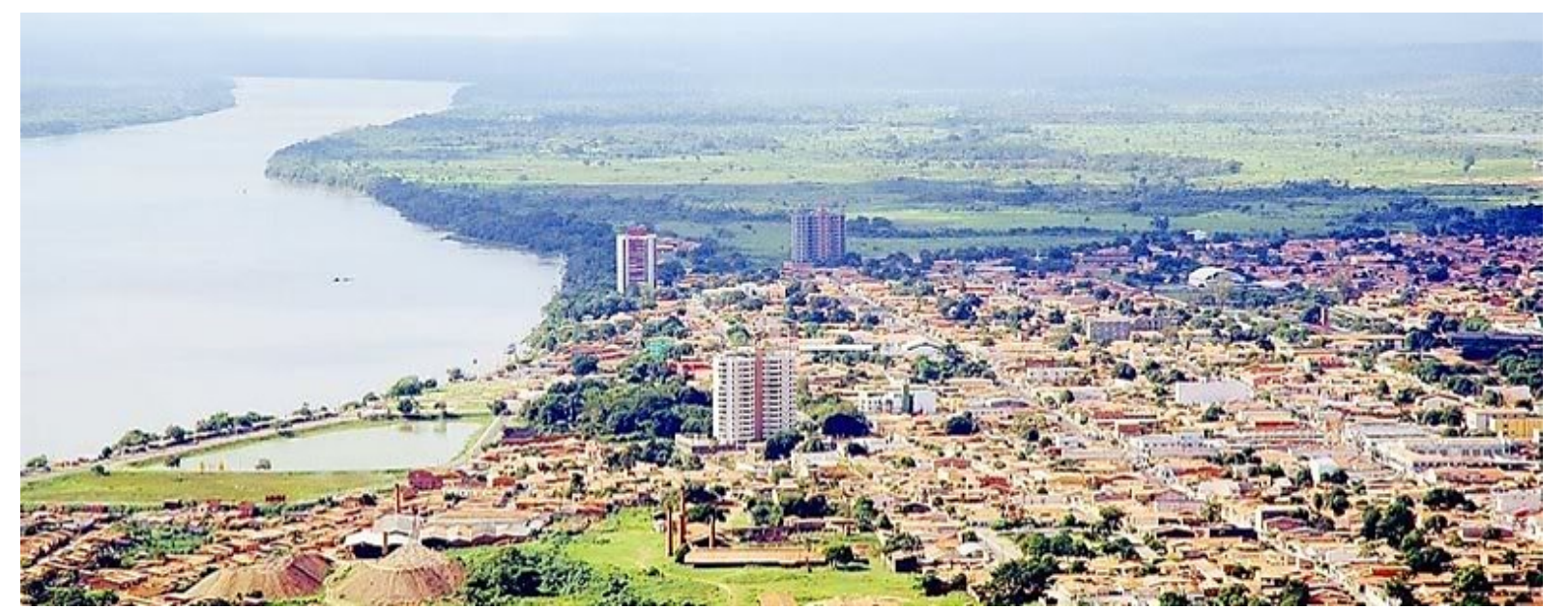

Fonte: Foto de autor desconhecido (s/d). Disponível em: <http://www.encontraimperatriz.com.br/sobreimperatriz/>. Acesso em 17 de ago. 2016.

${ }^{60}$ Segundo dados da INFRAERO, atualmente o aeroporto de Imperatriz conta com voos diários para quatro destinos: Belém (PA), Confins (MG), São Luís (MA) e Brasília (DF). Disponível em: <http:// www.infraero.gov.br/index.php/br/aeroportos/maranhao/aeroporto-de-imperatriz.html>. Acesso em 20 ago.2016. 
Figura 67: Mapa axial da RM do Sudoeste Maranhense/MA calculado por Escolha (choice).

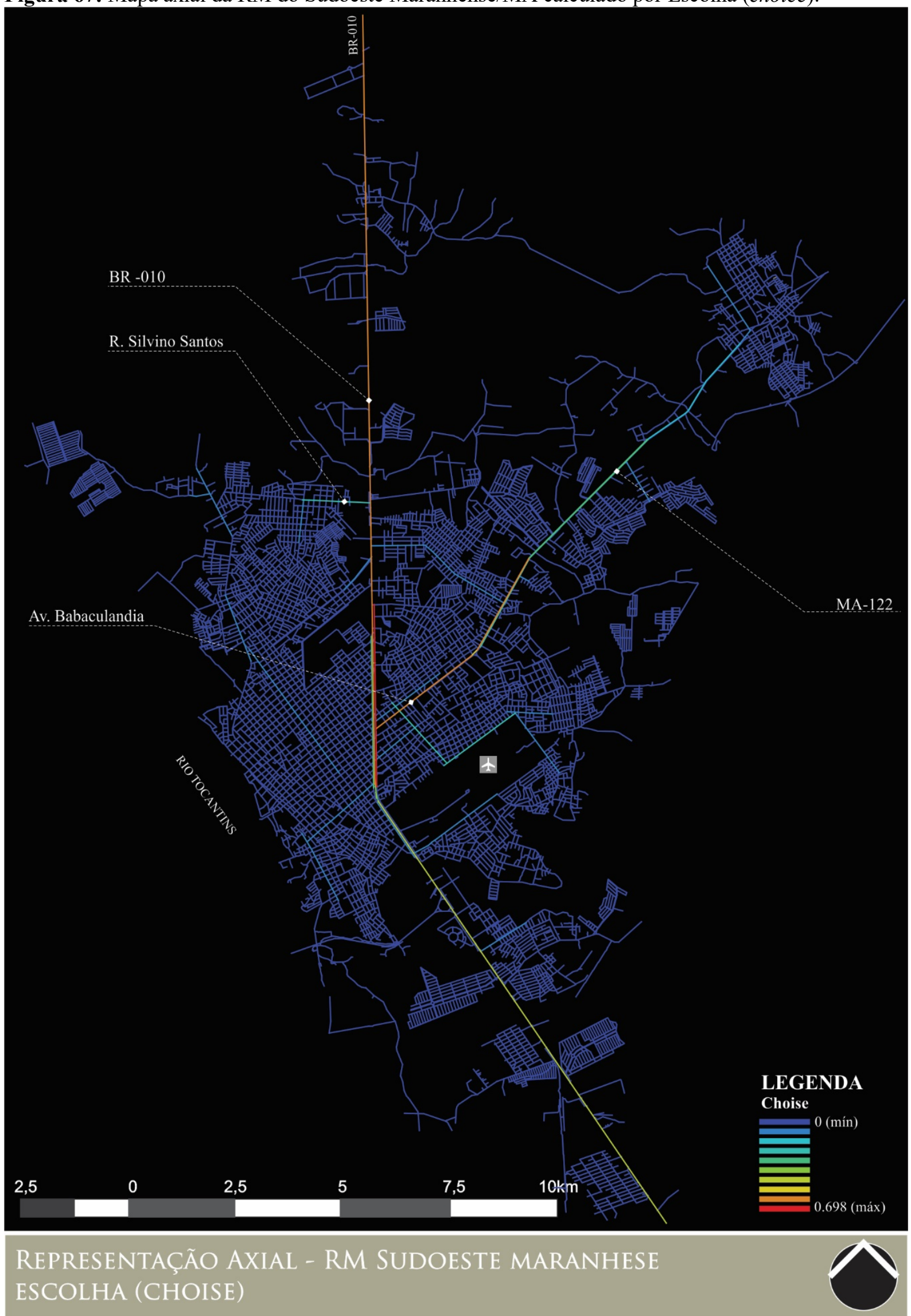

Fonte: Desenho gentilmente cedido por Paim (2015), com revisão da autora a partir da Base Cartográfica do OpenStreetMap (2016) e imagens de satélite do Google Earth (2016). 
Figura 68: Mapa de segmentos da RM do Sudoeste Maranhense/MA calculado por Escolha (choice).

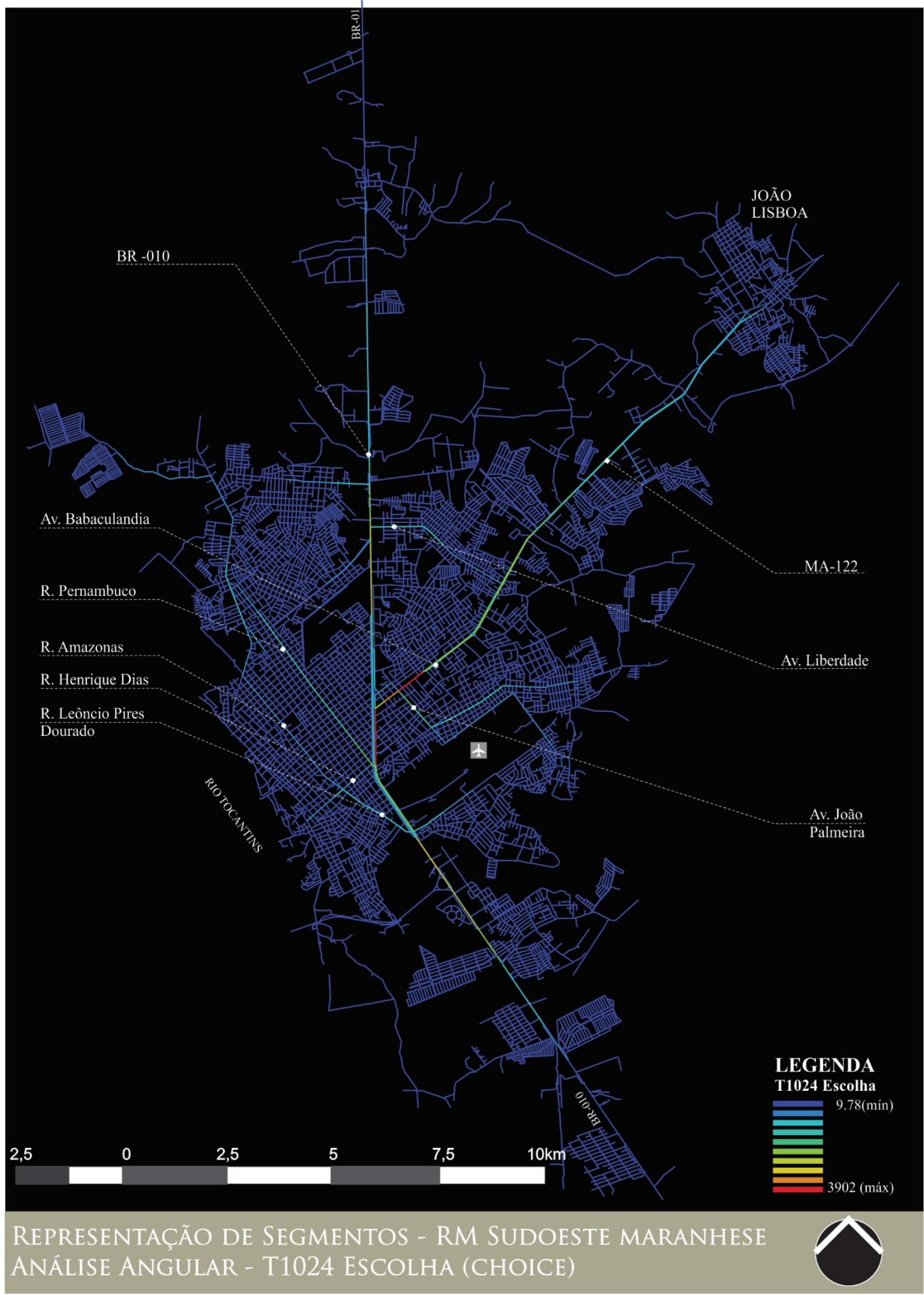

Fonte: Desenho gentilmente cedido por Paim (2015), com revisão da autora a partir da Base Cartográfica do OpenStreetMap (2016) e imagens de satélite do Google Earth (2016). 
Campina Grande foi primitivamente uma aldeia de índios Cariris. Em 1698 iniciou-se a catequese dos indígenas. Com terras propícias à agricultura, situadas entre o sertão e o litoral, o aldeamento rapidamente prosperou e, em 1769, foi elevado à categoria de freguesia, tornando-se vila no ano seguinte sob a denominação de Vila Nova da Rainha (IBGE, 2016). Em 1888, Campina Grande tinha cerca de quatro mil habitantes e era talvez a mais populosa localidade do interior da Paraíba. Passava por ali a principal estrada que ligava os sertões as cidades da Paraíba (hoje João Pessoa) e do Recife. O ramal da Great Western of Brazil Railway Company inaugurado em 1907 acentuou o progresso local (IBGE, 2016).

Na Figura 71 apresento a modelagem axial da RM de Campina Grande/PB calculada para a integração global, a qual apresenta um núcleo de integração que se desloca e se expande em direção à porção oeste da cidade, tendo como principais eixos a Av. Marechal Floriano Peixoto e Av. Dom Pedro II, que conduz ao campus da Universidade Federal de Campina Grande. Dentro deste conjunto das vias de maior integração encontram-se os bairros da Prata e Bela Vista (Figura 69 e 71), que tem passado por processos de especulação e verticalização (com edifícios entre 6 e 17 pavimentos), caracterizando-se como subcentro comercial e de serviços.

Figura 69: À direita, uma imagem da Av. Marechal Floriano Peixoto. À esquerda, vista da verticalização do bairro da Prata e, em segundo plano, a verticalização do bairro da Bela Vista.

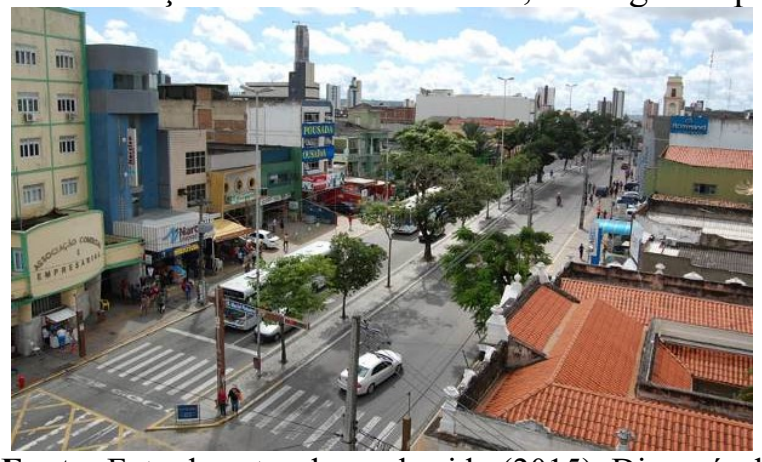

Fonte: Foto de autor desconhecido (2015). Disponível em: <https://www.pbtur.com.br>. Acesso em $15 \mathrm{de}$ ago. 2016.

Figura 70: Vistas do processo de verticalização de Campina Grande nos arredores de Açude Velho.

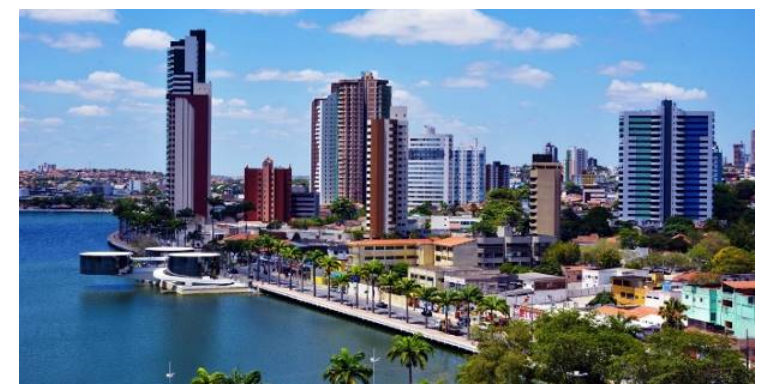

Fonte: Foto de autor desconhecido (2014). Disponível em: <http://www.cagepa.pb.gov.br>. Acesso em 15 de ago. 2016 .

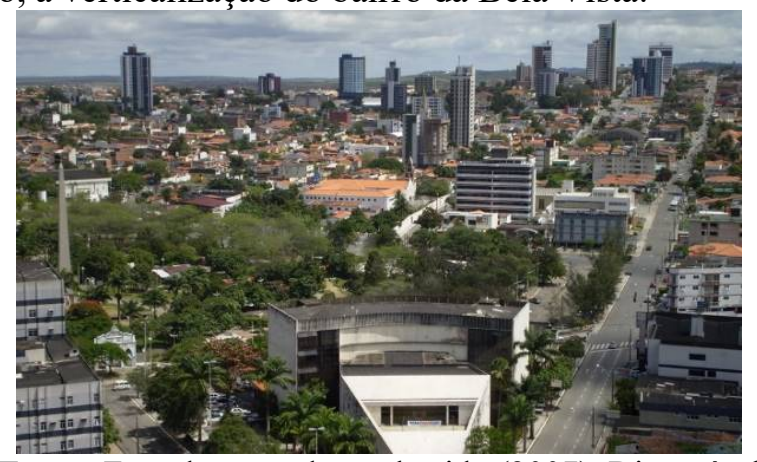

Fonte: Foto de autor desconhecido (2007). Disponível em: $<$ http://www.skyscrapercity.com>. Acesso em 15 de ago. 2016.

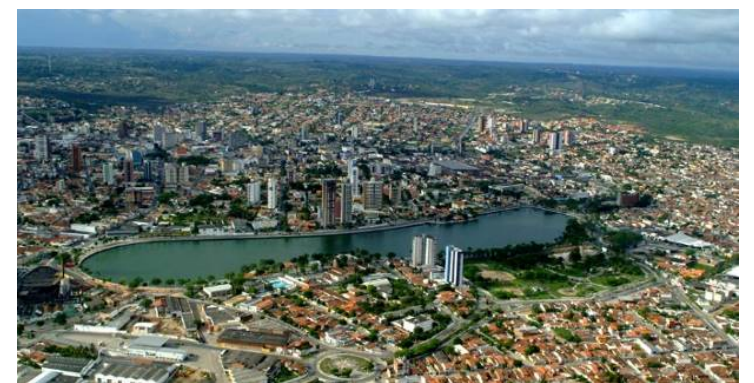

Fonte: Foto de autor desconhecido (s/d). Disponível em: <http://www.onordeste.com/>. Acesso em $15 \mathrm{de}$ ago. 2016. 
Figura 71: Mapa axial da RM de Campina Grande/PB calculado por Integração HH global (Rn).

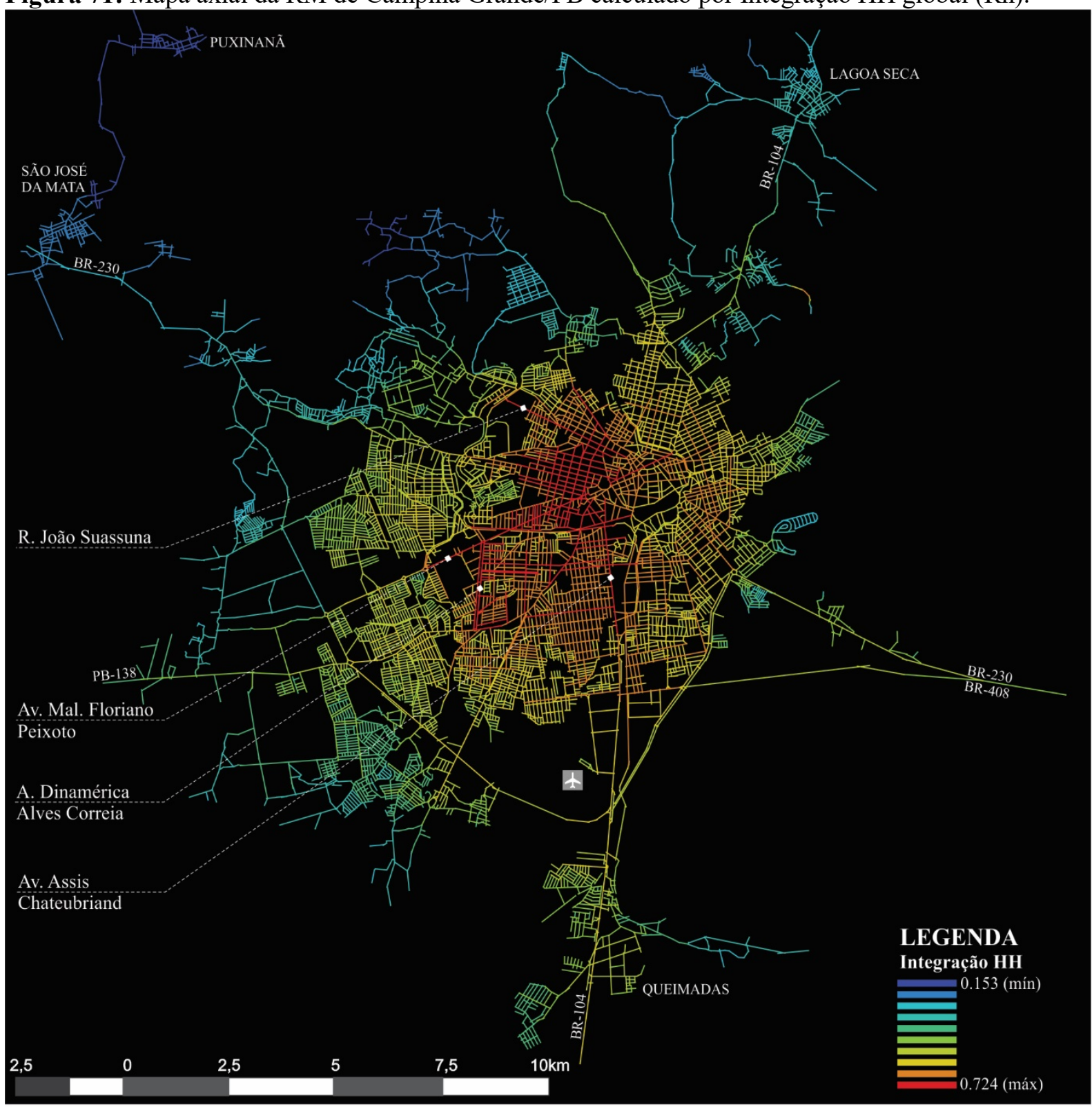

REPRESENTAÇÃO AXIAL - RM CAMPINA GRANDE/PB INTEGRAÇÃO HH GLOBAL (RN)

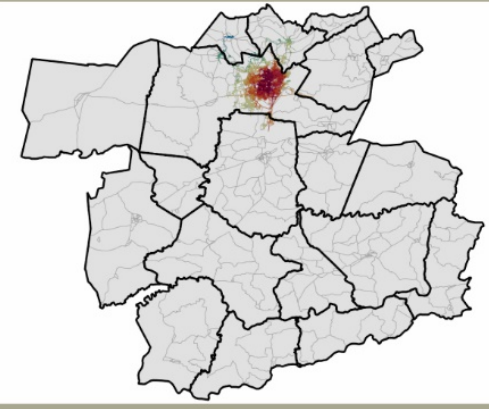

MAPA-CHAVE

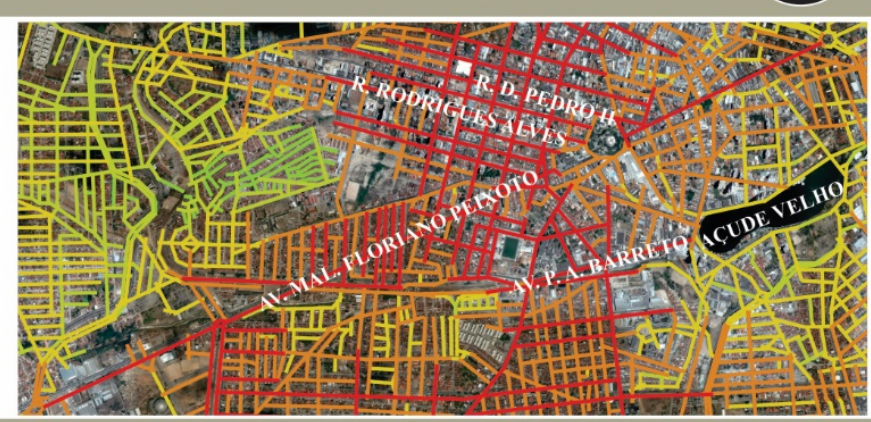

NÚCLEO DE INTEGRAÇÃO -DETALHE DO MAPA AXIAL - RM CAMPINA GRANDE/PB

Fonte: Desenho e revisão da autora (2016) a partir da Base Cartográfica do OpenStreetMap (2016) e imagens de satélite do Google Earth (2016). 
Essas transformações acontecem por meio de uma livre atuação do mercado imobiliário na cidade, uma vez que os instrumentos de gestão urbanística da cidade, como seu Plano Diretor, não são capazes de gerir o processo de adensamento urbano numa tendência a consolidar processos perversos. Os principais pontos de verticalização estão onde se concentram as maiores faixas de renda, portanto, os edifícios simbolizam também a segregação: influenciados pelas ideias de segurança, proximidade com atrativos paisagísticos, mas também por status social, a elite campinense escolhe pagar mais caro para morar cada vez mais alto. Ainda analisando este mapa axial, observa-se que os municípios vizinhos a Campina, que configuram o processo de expansão da mancha urbana da RM, apresentam-se nas faixas mais segregadas da representação, à exceção de Queimadas/PB. Infere-se que o núcleo de integração possui uma tendência de se espraiar em sentido sul, ao longo do eixo formado pelas avenidas Almirante Barroso/Juscelino Kubistchek (Figura 72), sobre os bairros Santa Cruz e Jardim Paulistano, os quais possuem preponderância de usos residenciais de médio padrão.

Figura 72: À direita, uma imagem da Av. Almirante Barroso e, à esquerda, vista da Av Juscelino Kubistchek.

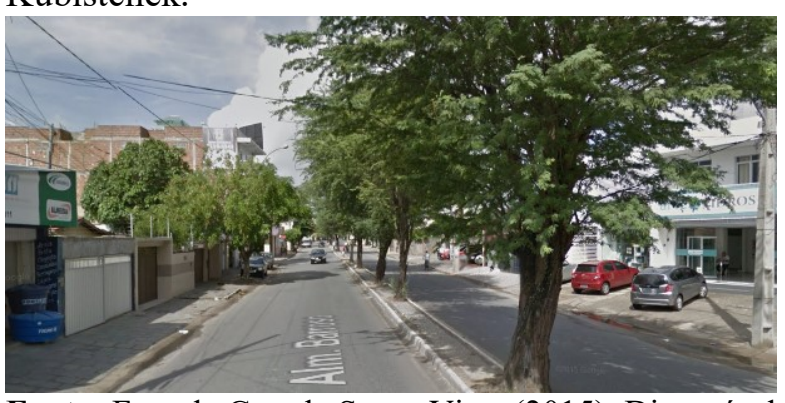

Fonte: Foto de Google Street View (2015). Disponível em: $<$ www.google.com.br/maps>. Acesso em 15 de ago. 2016.

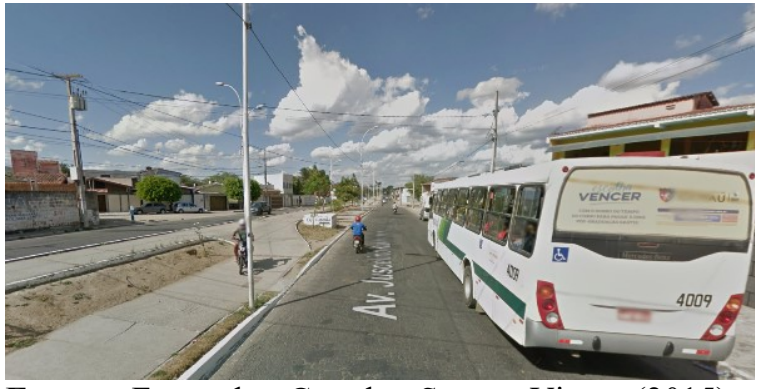

Fonte: Foto de Google Street View (2015). Disponível em: <www.google.com.br/maps>. Acesso em 15 de ago. 2016.

Figura 73: Aspectos do Pedregal: à esquerda, sua ocupação densa em desenho irregular e, à direita, o protesto de uma moradora contra as péssimas condições de habitabilidade do bairro.

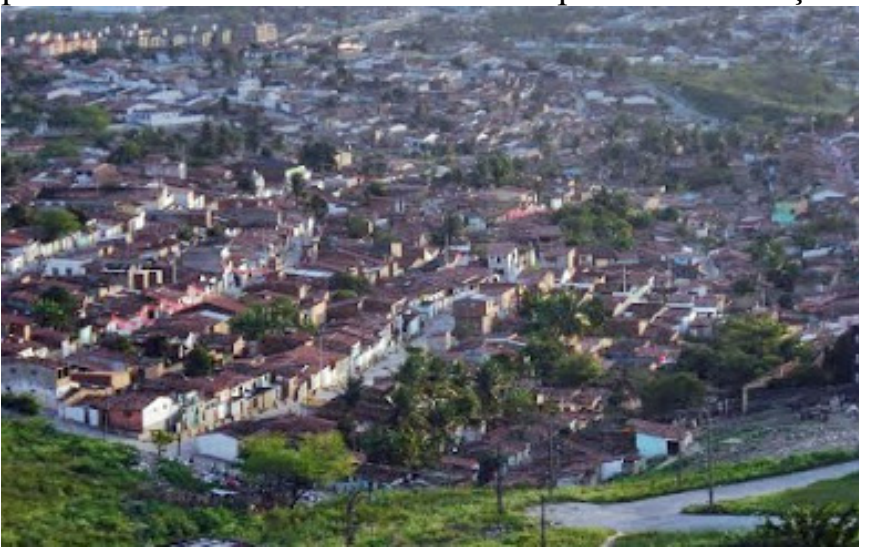

Fonte: Foto de autor desconhecido (s/d). Disponível em: $<\mathrm{http}: / /$ www.renatodiniz.com/>. Acesso em 15 de ago. 2016.

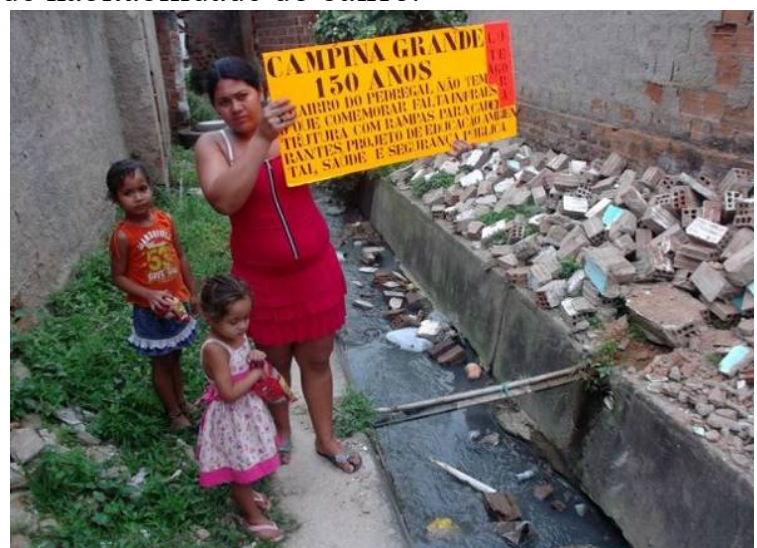

Fonte: Foto de autor desconhecido (2014). Disponível em: <www.portaldolitoralpb.com.br/>. Acesso em 15 de ago. 2016. 
Figura 74: Mapa de segmentos da RM de Campina Grande/PB calculado por Integração.

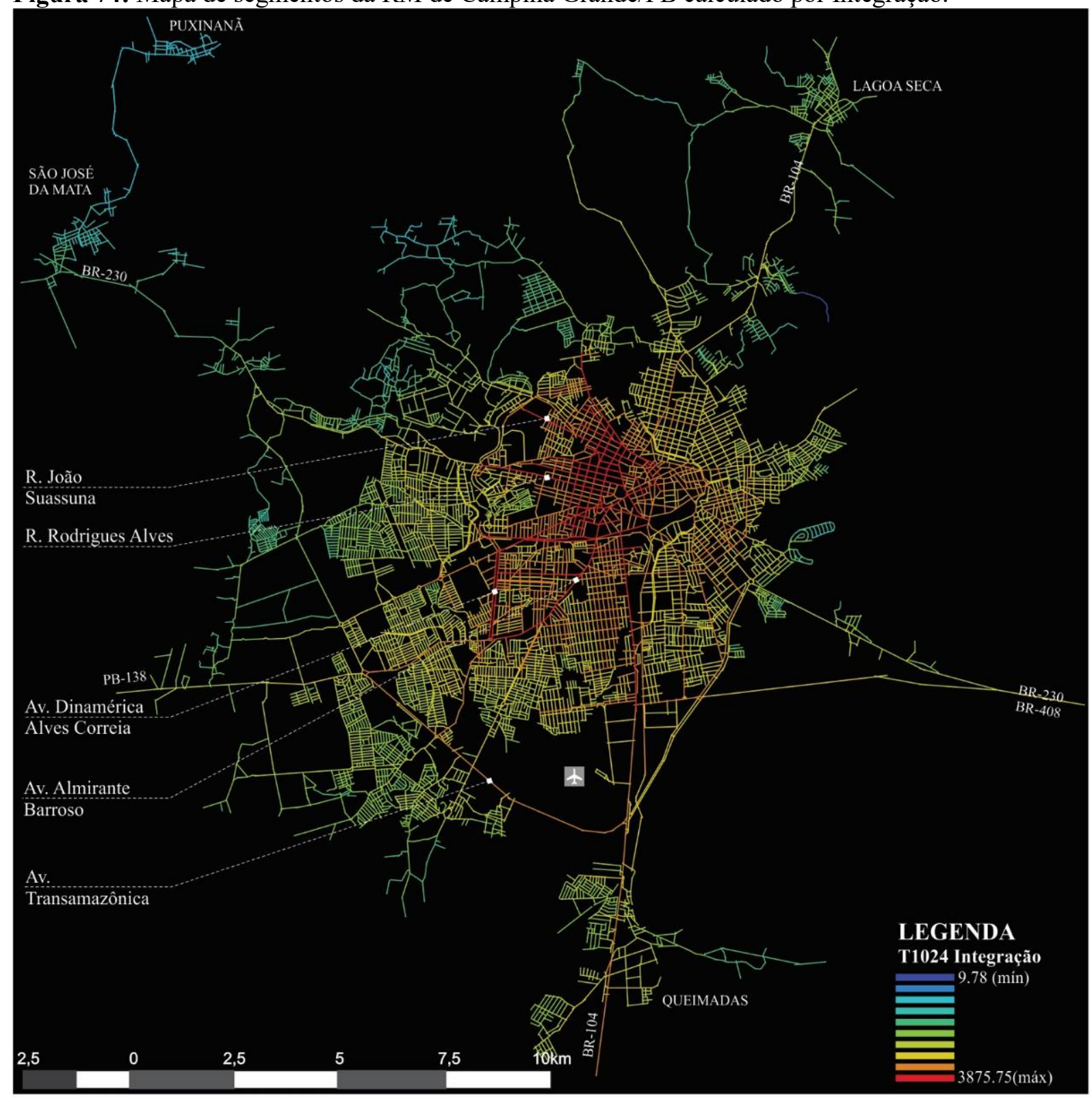

REPRESENTAÇÃO DE SEGMENTOS - RM CAMPINA GRANDE/PB ANÁLISE ANGULAR - T1024 INTEGRAÇÃO

Fonte: Desenho e revisão da autora (2016) a partir da Base Cartográfica do OpenStreetMap (2016) e imagens de satélite do Google Earth (2016).

Muito próxima a essa área de alta integração, podemos observar um conjunto de linhas em tons esverdeados que representa o Pedregal: uma antiga favela que, mesmo havendo recebido algumas melhorias de infraestrutura, ainda permanece como um espaço segregado da cidade (Figura 73). Na leitura de Maia (2010, s/p.):

A referida favela em 1983 apresentava um total de 1.040 habitações, já no ano 2000, segundo o IBGE, o mesmo aglomerado contém 2.158 habitações, o que representa um aumento de $207,5 \%$ no número de 
domicílios particulares permanentes na favela Pedregal. [...]. Atualmente, o Pedregal é delimitado oficialmente como um bairro, porém a sua origem é uma ocupação irregular que se deu ao longo do tempo e de forma individual, caracterizando-se nos termos já mencionados como uma favela. As suas condições em termos de infraestrutura e de edificações não se apresentam de forma homogênea, havendo espaços onde foram instalados grande parte dos equipamentos urbanos e, outros, completamente desprovidos de qualquer um destes. (MAIA, 2010, s/p.).

Quanto às expansões residenciais de médio padrão, destaco o loteamento Alto da Serra (Figura 75), localizado ao norte (bairro Cuités), e o diversos condomínios próximos ao campus da Universidade Federal da Paraíba - UFPB. Incentivados pelos programas nacionais de habitação, esses exemplos replicam o que já comentei sobre Imperatriz/MA: são desvinculados da malha, em um desenho urbano de baixa legibilidade e com pouca heterogeneidade arquitetônica, que no caso do Residencial Dona Lindú (Figura 76), é um condomínio fechado que apresenta a tipologia "bloco H", que vem sendo reproduzida como um carimbo por todo o país desde a atuação do Banco Nacional de Habitação - BNH (BONDUKI, 2014).

Figura 75: Loteamento Alto da Serra. À esquerda, uma imagem de satélite que demonstra a diferenciação entre o tecido urbano novo e o existente. À direita, uma vista das residências construídas na tipologia de sobrados.

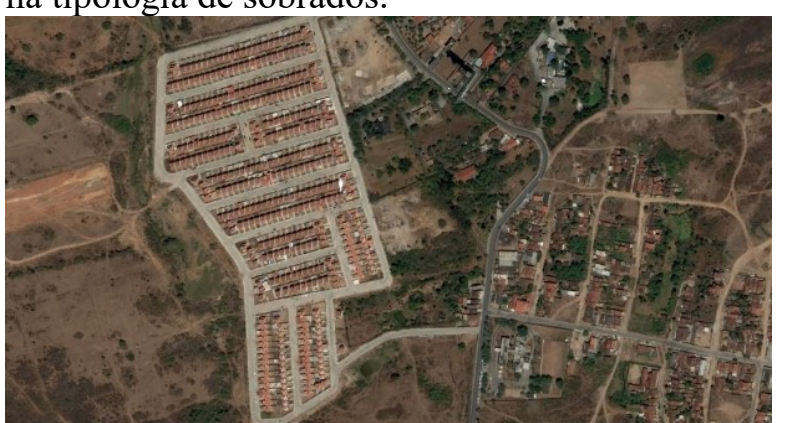

Fonte: Foto de Google Earth (2016). Acesso em 17 de ago. 2016.

Figura 76: Residencial Dona Lindú. À esquerda, uma 2016

Figura 76: Residencial Dona Lindú. À esquerda, uma imagem que demostra a diferenciação entre o tecido novo (fechado) e o existente. À direita, uma vista das tipologia de "bloco H".

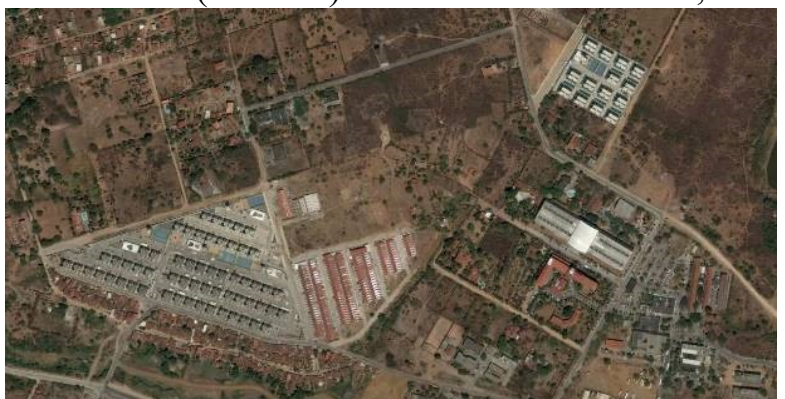

Fonte: Foto de Google Street View (2015). Disponível em: <https://www.google.com.br/maps>. Acesso em 15 de ago. 2016.

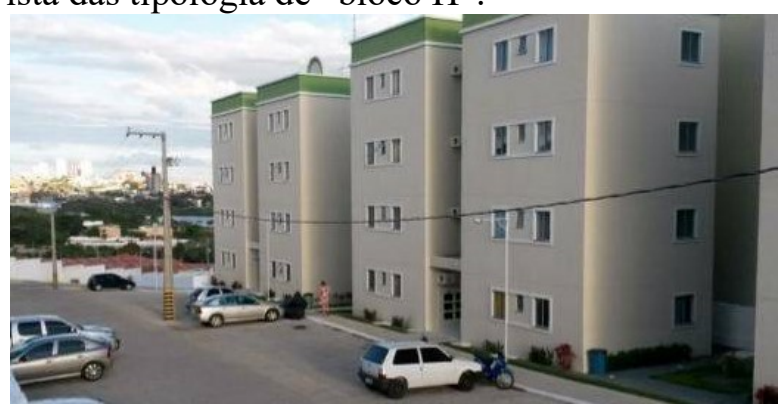

Fonte: Foto de autor desconhecido (s/d). Disponível em: <http://morebempb.com/>. Acesso em 15 de ago. 2016. 
Por fim, na representação axial calculada para escolha (Figura 77) têm destaque as vias de ligação metropolitana: a norte/nordeste, a BR 104 (que conduz ao municio Lagoa Seca) e, ao sul, a av. Assis Chateubriand/BR 104 (em direção a Queimadas). Observo que, apesar das proximidades das manchas urbanas, ainda há um maior percentual de grandes glebas e espaços vazios entre as cidades dessa RM, configurando um estágio inicial de conurbação.

Figura 77: Mapa axial da RM de Campina Grande/PB calculado por Escolha (choice).

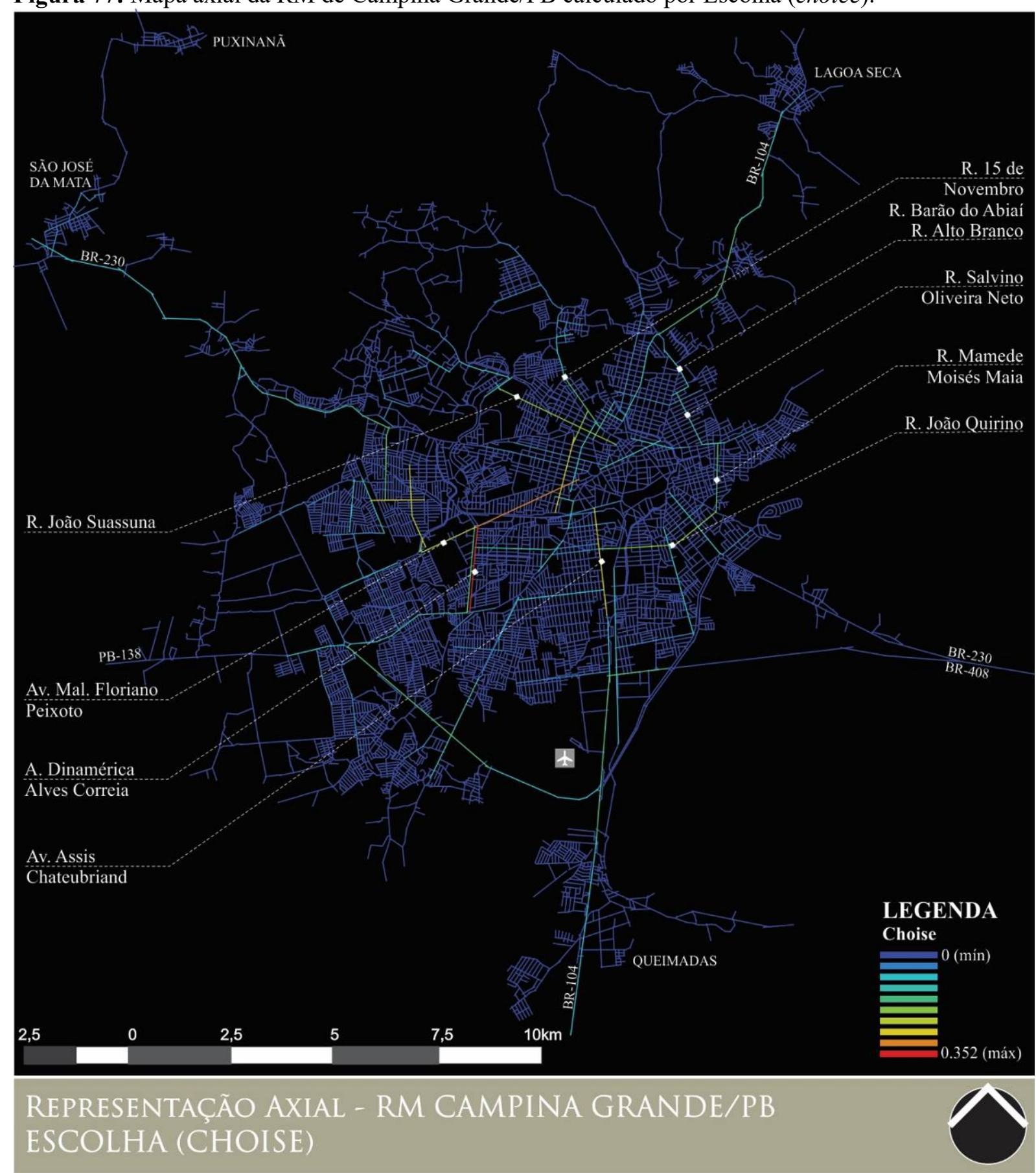

Fonte: Desenho e revisão da autora (2016) a partir da Base Cartográfica do OpenStreetMap (2016) e imagens de satélite do Google Earth (2016). 
Comparativamente, na representação de segmentos calculado por Escolha (Figura 78), embora novamente as vias em destaque sejam as mesmas, a diferenciação é a hierarquia dada a cada trecho. O mapa de segmentos cria esse refinamento de análise que possibilita a visualização de um sistema contínuo, ainda que formado por diversos fragmentos de via. Esse é o sistema viário principal que é, em sua maioria, atendido pelos meios de transporte coletivo.

Figura 78: Mapa de segmentos da RM de Campina Grande/PB calculado por Escolha (choice).

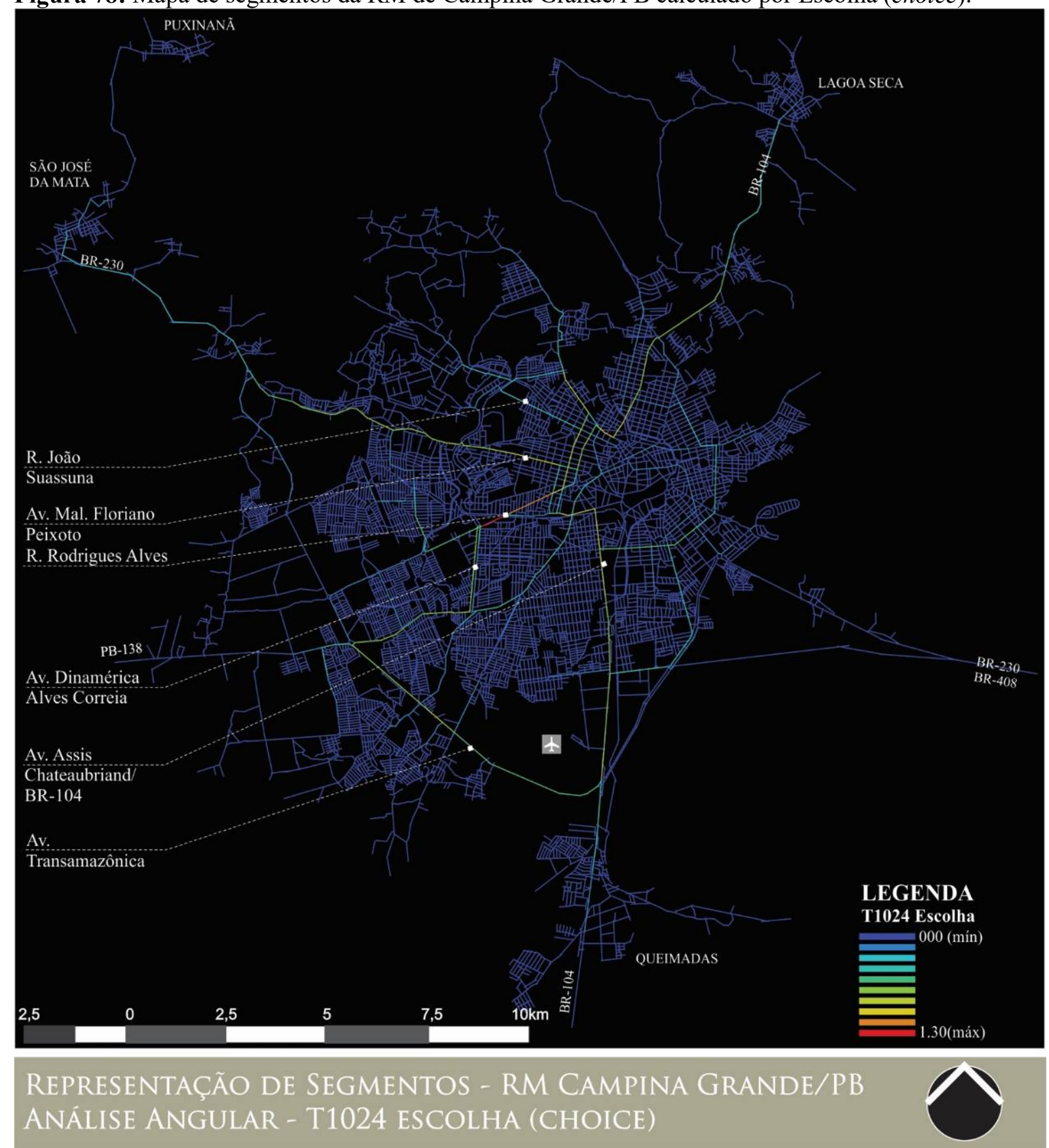

Fonte: Desenho e revisão da autora (2016) a partir da Base Cartográfica do OpenStreetMap (2016) e imagens de satélite do Google Earth (2016). 
O município de Juazeiro foi implantado no cruzamento de duas importantes e estratégicas estradas do interior do Brasil: (1) o Rio São Francisco; (2) um caminho das bandeiras, aberto pelos paulistas, baianos, pernambucanos e pelos nativos. Quando foi elevada à categoria de julgado, sob a jurisdição da Comarca de Jacobina no ano de 1766, já contava com 156 casas. Juazeiro, sucessivamente, foi elevado à categoria de vila e, posteriormente, comarca, transformando-se, pela Lei n. ${ }^{\circ} 1.814$ de 15 de julho de 1878, em cidade (IBGE, 2016). Do outro lado do rio surgiu Petrolina, originariamente denominada "Passagem de Juazeiro", pois era caminho para a cidade vizinha. A localidade servia como ponto de apoio do desenvolvimento da zona sertaneja do Estado, com vias de acesso para os Estados do Piauí, Ceará, Bahia, Minas Gerais, Rio de Janeiro e São Paulo. Foi elevado à categoria de vila, com a denominação de Petrolina, em 1862, e à categoria de cidade em 1895. Com a criação da SUDENE, as autoridades públicas federais voltaram a atenção para as potencialidades agrícolas da microrregião, fazendo com que, gradualmente, a agricultura irrigada se tornasse sua principal atividade.

Na a RAID Petrolina/Juazeiro, o primeiro ponto a ser observado é a relação entre a área total da RM e a pequena área desenhada na técnica da axialidade. Isso se dá pela preponderância agrícola desse aglomerado. Comparativamente, entre as quatro RM's deste primeiro grupo, Feira de Santana/BA é a maior em área "urbanizada". O Cariri/CE encontrase em posição média (uma vez que foi desenhado apenas o Crajubar), enquanto Campina Grande e a RAID possuem as menores manchas em relação à área total. No caso paraibano, isso se dá pela quantidade de municípios constituintes (dezenove) e, na RAID, pelos territórios municipais de grande área (voltarei a comentar sobre essa questão quando tratar de densidade).

Figura 79: À esquerda, uma imagem da Av. 7 de Setembro e, à direita, vista da Av. das Nações.

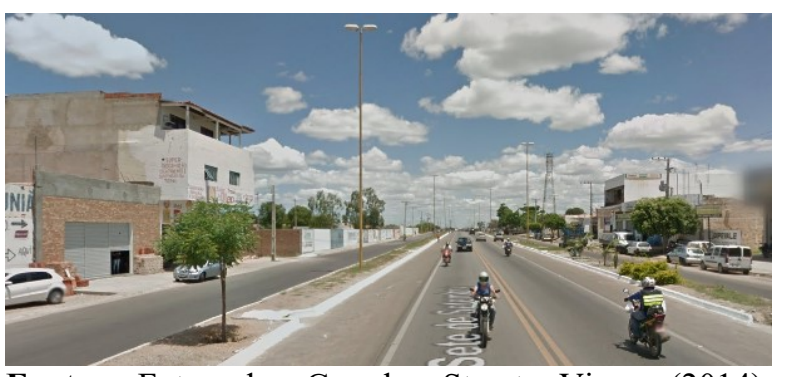

Fonte: Foto de Google Street View (2014). Disponível em: <https://www.google.com.br/maps>. Acesso em 15 de ago. 2016.

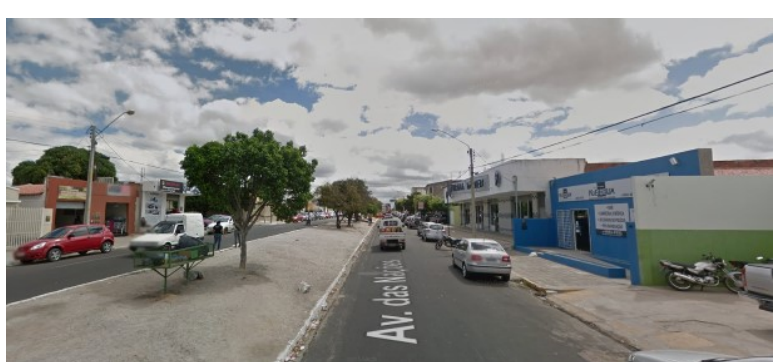

Fonte: Foto de Google Street View (2012). Disponível em: <https://www.google.com.br/maps>. Acesso em 15 de ago. 2016. 
Quanto ao núcleo de integração, sua concentração está nos bairros Centro e Gercino Coelho, em Petrolina, distribuído ao longo das avenidas 7 de Setembro e das Nações (Figura 79). Essa área consolidada é cortada pelos anéis viários das avenidas Integração e 7 de Setembro, é bem provida de infraestrutura básica e constituída pelos bairros mais valorizados. Ali se concentram a maior parte dos estabelecimentos comerciais e de prestação de serviços privados, além de equipamentos de grande porte, como um polo de saúde (de abrangência regional), um polo jurídico/institucional, o Campi da Universidade Federal do Vale do São Francisco - UNIVASF - e do shopping da cidade (Figura 80), o River Shopping (CRUZ, 2013). A barreira do Rio São Francisco e, principalmente, a existência de apenas uma ponte ligando as duas cidades faz com que Juazeiro/BA tenha menor acessibilidade. Entretanto, há uma correlação entre essa média integração (representada em tons amarelos e esverdeados) e a disposição de equipamentos e serviços no município baiano, que usufrui e depende da preponderância comercial de Petrolina. Conforme nos afastamos do rio, mais baixos são os valores de integração das vias que tendem a receber uma população mais pobre. Vale ressaltar que o processo de crescimento demográfico na região é decorrente da migração relacionada a industrialização dos processos agrícolas, que desemprega o homem do campo e, paralelamente, expulsa-o para a cidade (CRUZ, 2013).

Figura 80: À esquerda, uma vista do campus UNIVASF e, à direita, vista do River Shopping.

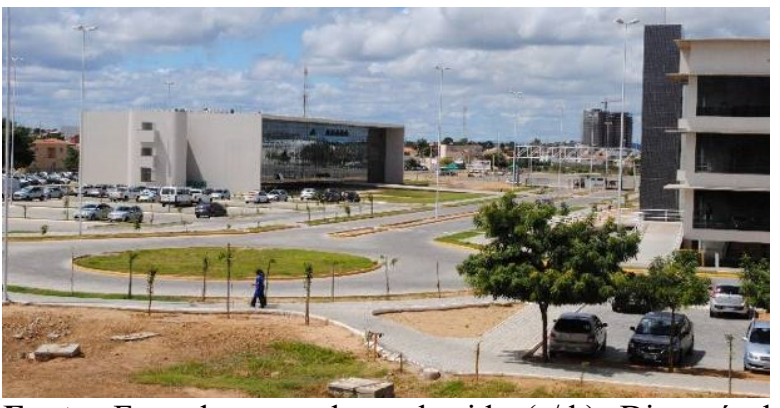

Fonte: Foto de autor desconhecido (s/d.). Disponível em: $\quad<$ www.manualdoestudante.univasf.edu.br/>. Acesso em 15 de ago. 2016.

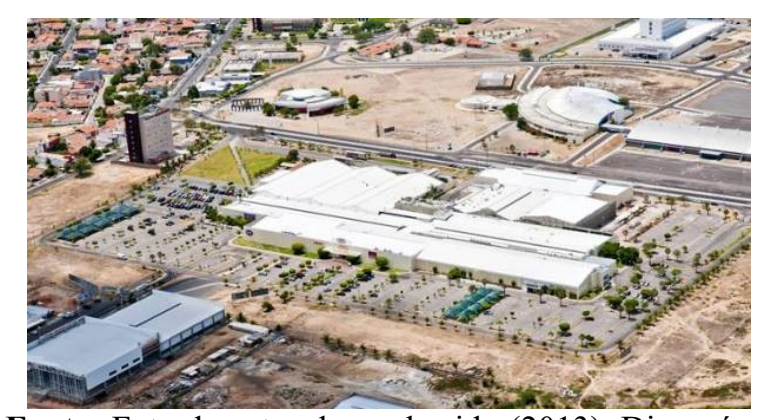

Fonte: Foto de autor desconhecido (2013). Disponível em: $<$ http://wikimapia.org/303081/pt/RiverShopping>. Acesso em 15 de ago. 2016.

Figura 81: À esquerda, uma vista geral de Petrolina, destacando-se a expansão vertical ao longo da margem do Rio S. Francisco e, à direita, áreas carentes em infraestrutura (próximas ao aeroporto).

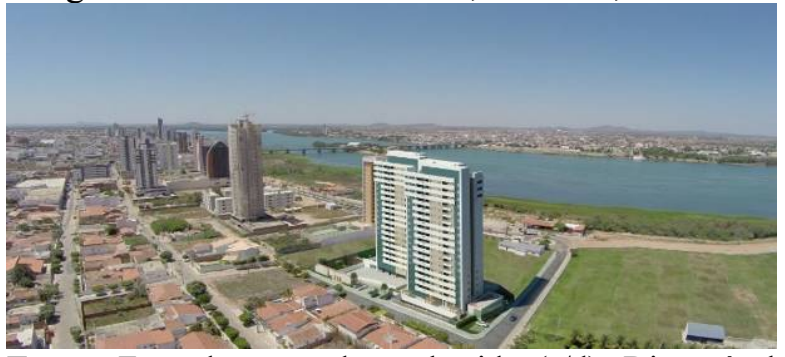

Fonte: Foto de autor desconhecido (s/d). Disponível em: < www.skyscrapercity.com/>. Acesso em 15 de ago. 2016.

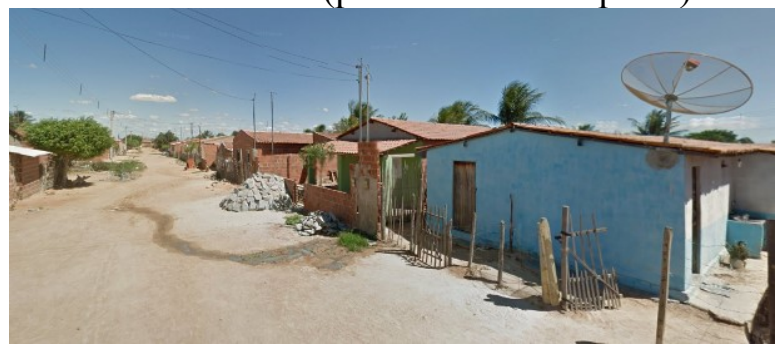

Fonte: Foto de Google Street View (2012). Disponível em: <www.google.com.br/maps>. Acesso em $15 \mathrm{de}$ ago. 2016. 
Figura 82: Mapa axial da RAID Petrolina-Juazeiro calculado por Integração HH global (Rn).

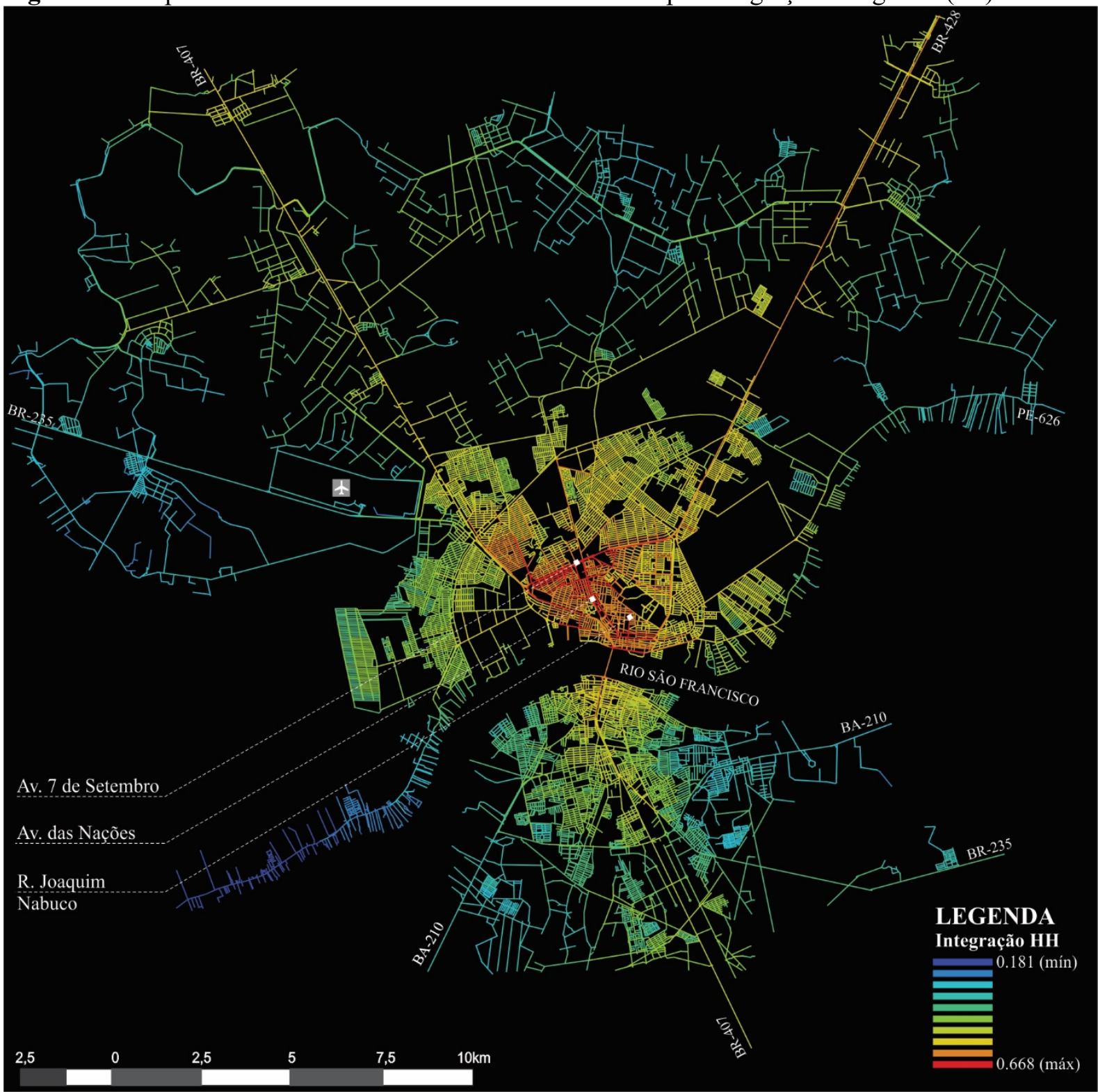

REPRESENTAÇÃO AXIAL - RAID PETROLINAJJUAZEIRO INTEGRAÇÃO HH GLOBAL (RN)

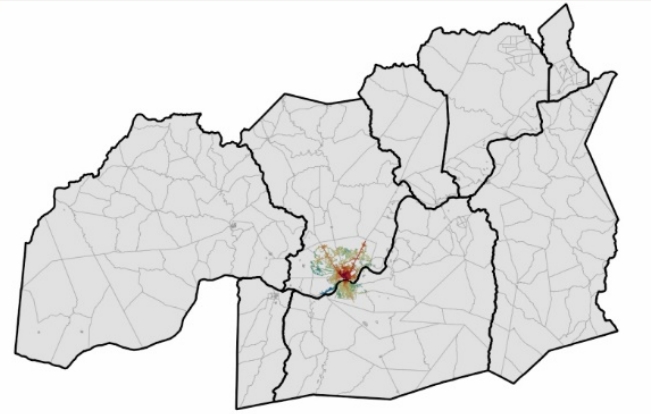

MAPA-CHAVE

RAID PETROLINA/JUAZEIRO

Fonte: Desenho de Petrolina/PE gentilmente cedido por Paim (2015), desenho de Juazeiro/BA pela autora a partir da Base Cartográfica do OpenStreetMap (2016) e imagens de satélite do Google Earth (2016).

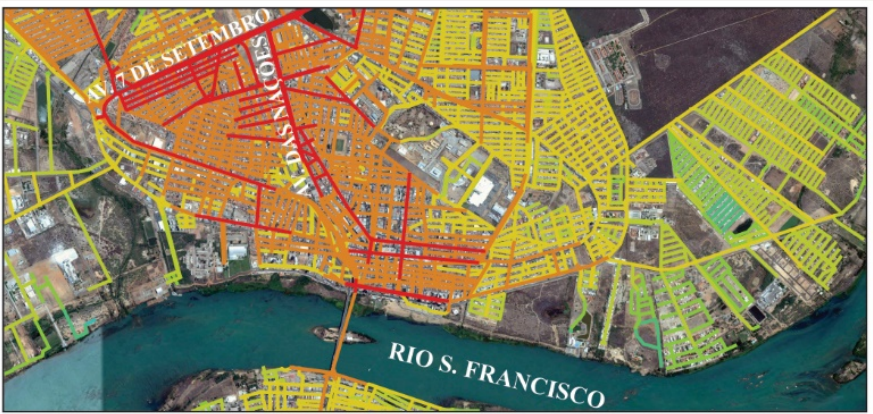

NÚCLEO DE INTEGRAC̨ÃO -DETALHE DO MAPA AXIAL - RAID PETROLINA/JUAZEIRO 
Ali, essa população passa a ocupar áreas onde os investimentos em infraestrutura não acompanham o crescimento. É uma periferia que sofre com problemas de falta de rede de saneamento e habita em residências precárias (Figura 81). A Figura 83 apresenta o cálculo de escolha, onde tem destaque as vias de acesso regional BR-407 (que corta as duas cidades e recebe o nome de Av. Santos Dumont, em Juazeiro) e a BR-428. Nesta representação, a ponte Pres. Dutra - construída nos anos 1950 e que possui um tráfego diário de cerca de 35 mil veículos -, desponta na cor vermelha com alto valor de escolha (Figura 84).

Figura 83: Mapa de segmentos da RAID Petrolina-Juazeiro calculado por Integração.

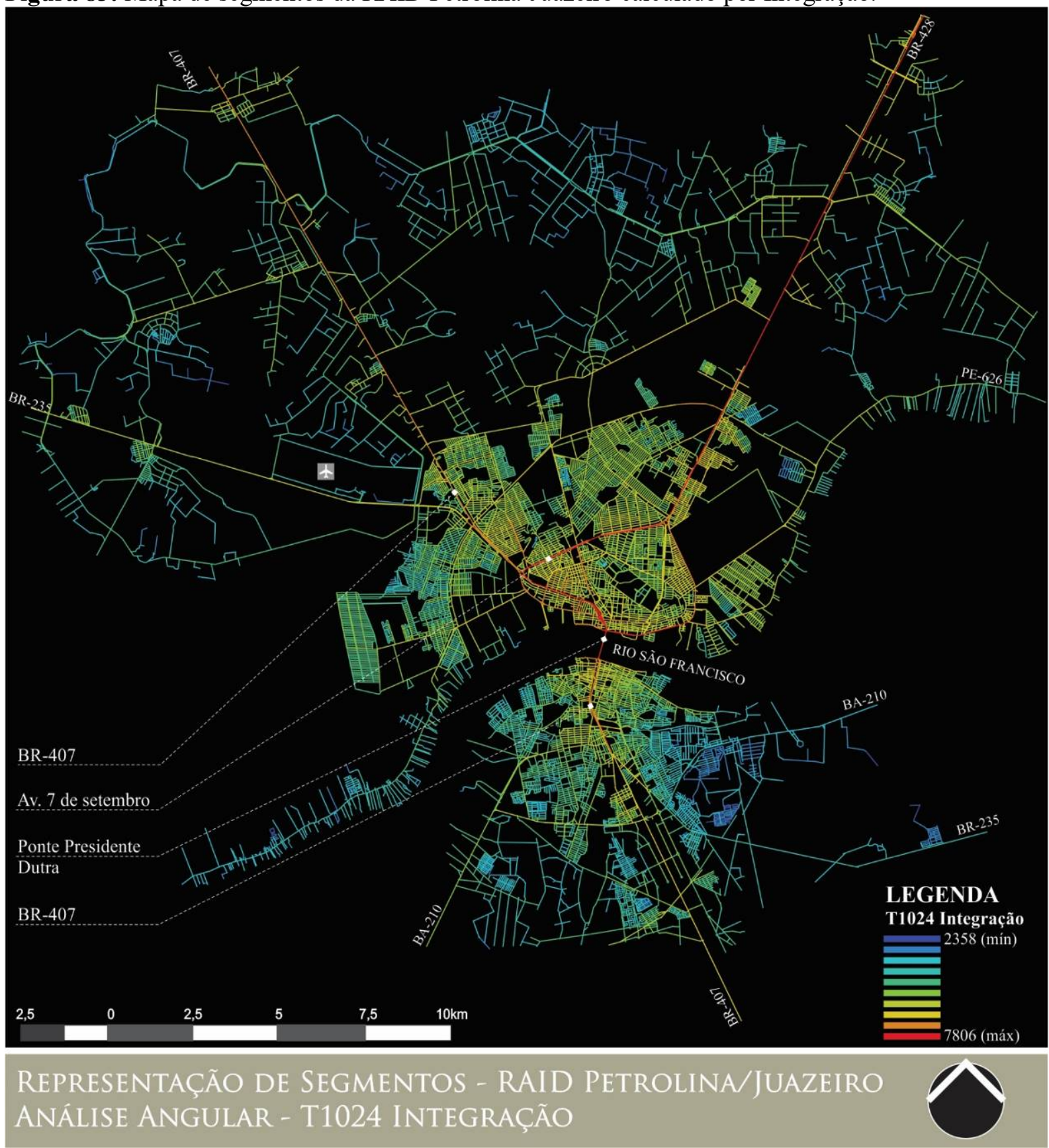

Fonte: Desenho de Petrolina/PE gentilmente cedido por Paim (2015), desenho de Juazeiro/BA pela autora a partir da Base Cartográfica do OpenStreetMap (2016) e imagens de satélite do Google Earth (2016). 
Figura 84: À esquerda, uma vista ponte Presidente Dutra com, ao fundo a cidade de Juazeiro. À direita, a Av. Santos Dumont.

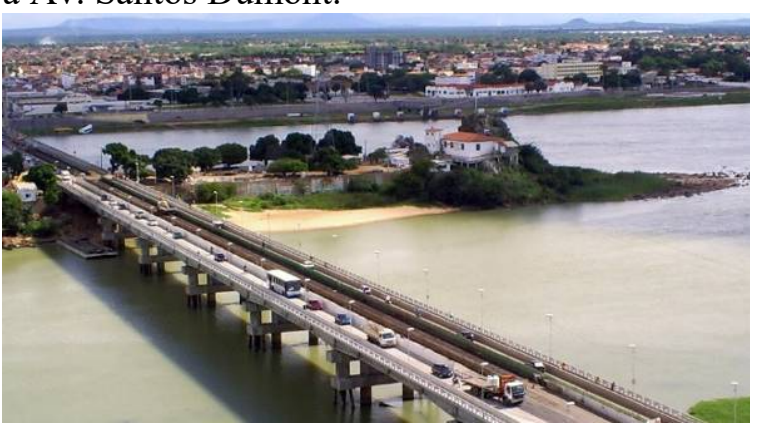

Fonte: Foto de autor desconhecido (s/d). Disponível em: <www.oas.com.br>. Acesso em 15 de ago. 2016.

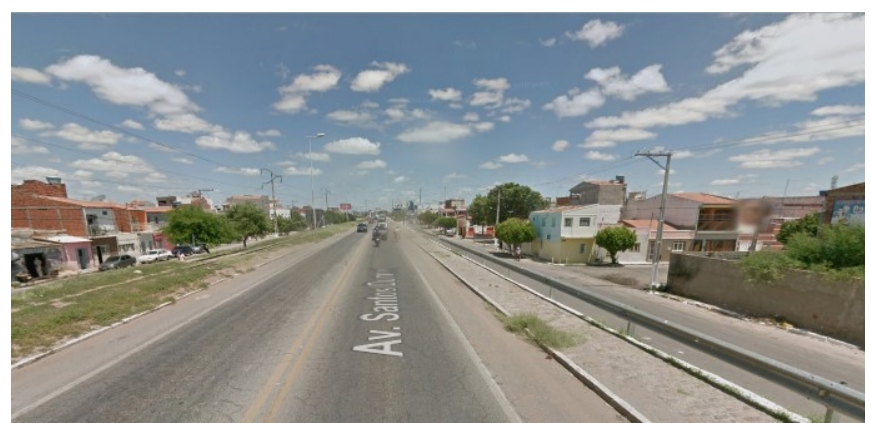

Fonte: Foto de Google Street View (2012). Disponível em: $<$ www.google.com.br/maps>. Acesso em 15 de ago. 2016.

Figura 85: Vista da Igreja Sagrado Coração de Jesus, em Petrolina, e, ao fundo, o processo de verticalização da cidade ao longo da margem do Rio São Francisco.

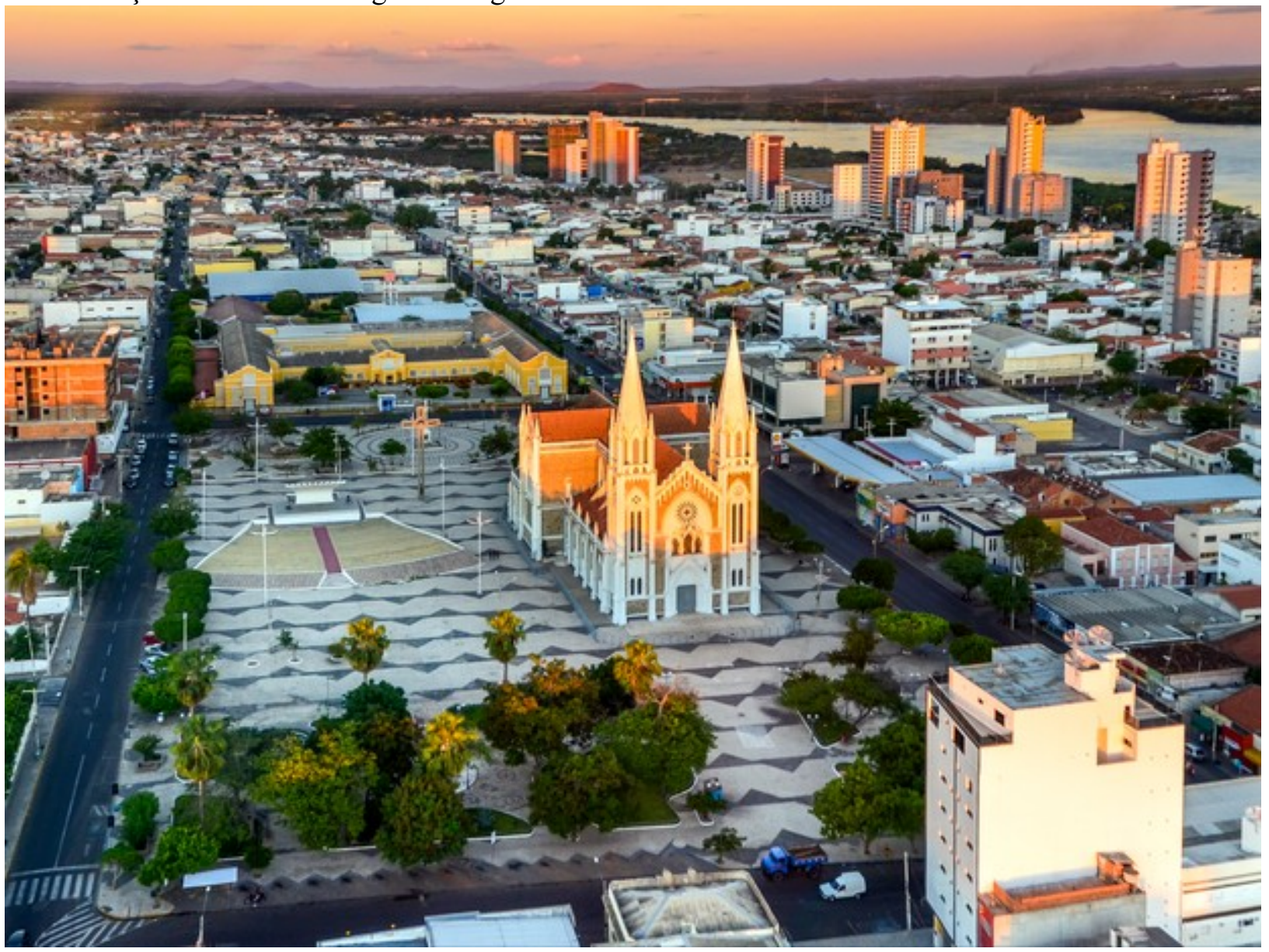

Fonte: Foto de Maurício André Anjos (s/d). Disponível em: <http://g1.globo.com/pe/petrolina-regiao/>. Acesso em 15 de ago. 2016.

Traçando um comparativo entre as ferramentas metodológicas de representação, é recorrente o refinamento do mapa de segmentos, bem como o destaque ao sistema viário principal no cálculo de escolha. Isso ocorre porque essa variável indica o potencial que as linhas segmentadas têm de concentrar o movimento global, realçando linhas com maior 
potencial de ligação com outras partes da cidade (ZAMPERINI, 2012). Em outras palavras, mede-se a probabilidade de uma via ser "escolhida" pelas pessoas/carros para seguirem o seu trajeto, o que se correlaciona com uma infraestrutura que atenda a esta demanda (largura da calha, velocidade permitidas etc.) e com a utilização desses potenciais. Uma característica recorrente nesses eixos é a presença de grande número de outdoors e outros meios de comunicação física de grande escala.

Figura 86: Mapa axial da RAID Petrolina-Juazeiro calculado por Escolha (choice).

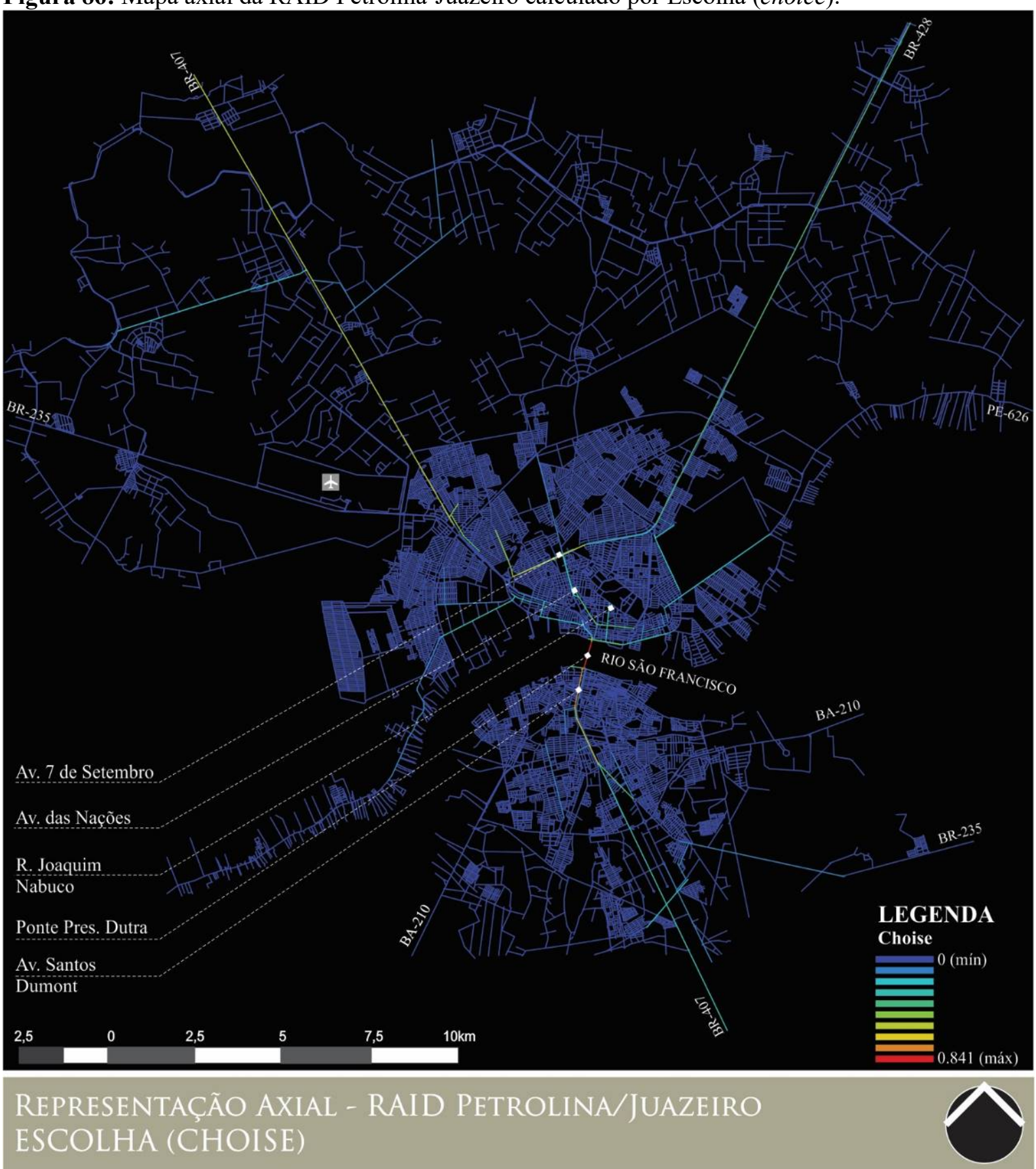

Fonte: Desenho de Petrolina/PE gentilmente cedido por Paim (2015), desenho de Juazeiro/BA pela autora a partir da Base Cartográfica do OpenStreetMap (2016) e imagens de satélite do Google Earth (2016). 
Figura 87: Mapa de segmentos da RAID Petrolina-Juazeiro calculado por Escolha (choice).

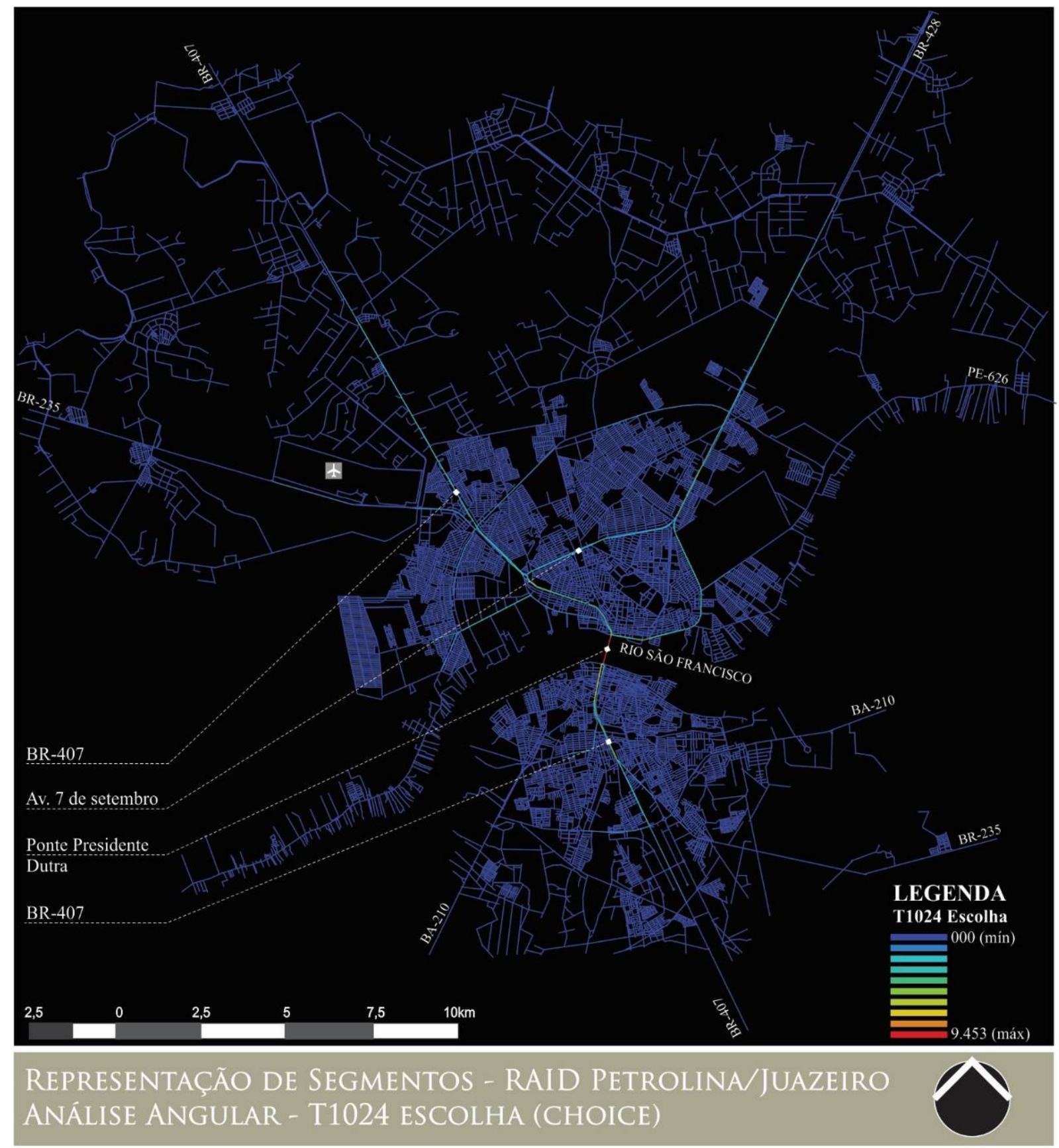

Fonte: Desenho de Petrolina/PE gentilmente cedido por Paim (2015), desenho de Juazeiro/BA pela autora a partir da Base Cartográfica do OpenStreetMap (2016) e imagens de satélite do Google Earth (2016).

Finalizo as análises das RMINE's selecionadas com um comparativo tomado a partir da medida de integração proporcional, apresentada na Tabela 18. Percebe-se que os valores de integração HH máximos apresentados para os miolos das RM's é, em todos os casos, igual ao valor máximo do sistema total, enquanto que os valores mínimos do total e das cercanias estão sempre muito próximos. 
Figura 88: Comparativo entre os mapas por meio da Medida de Integração Proporcional.

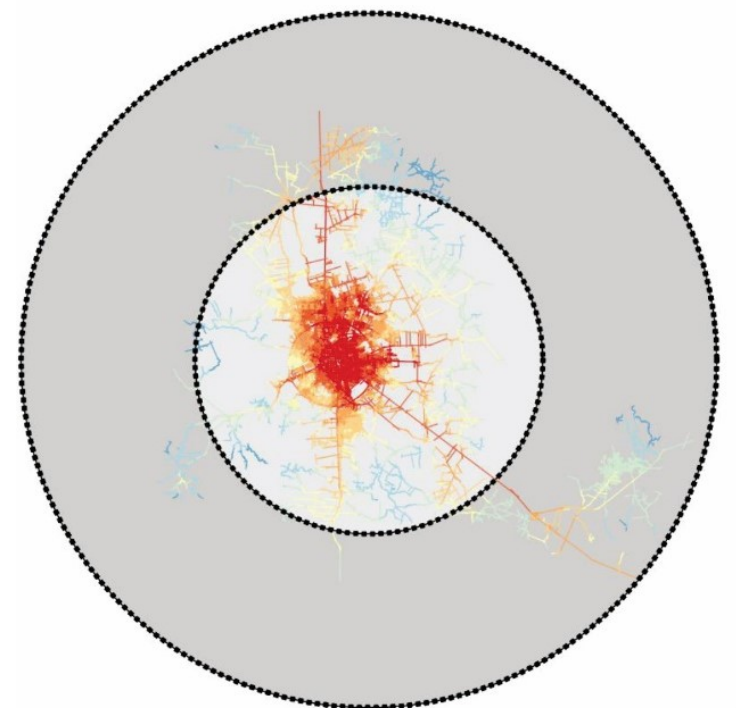

RM FEIRA DE SANTANA/BA

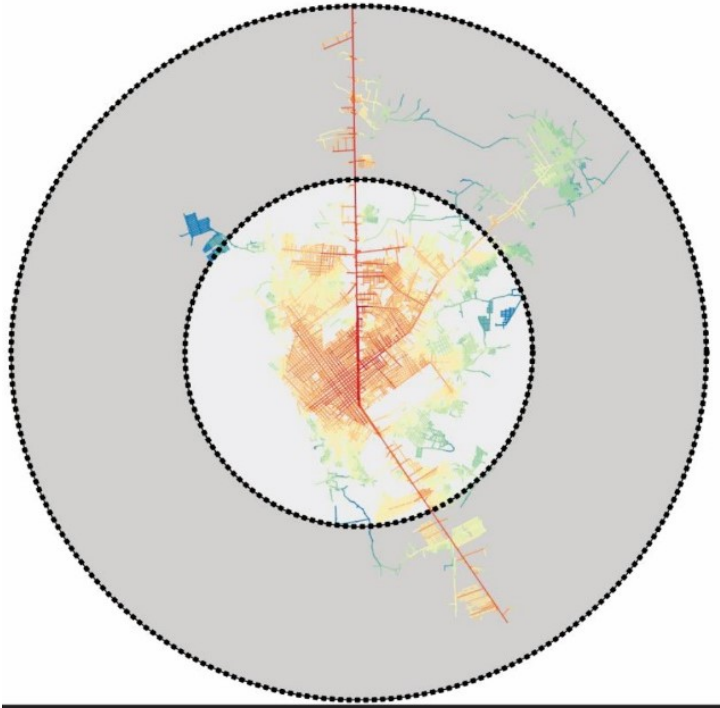

RM SUDOESTE/MA

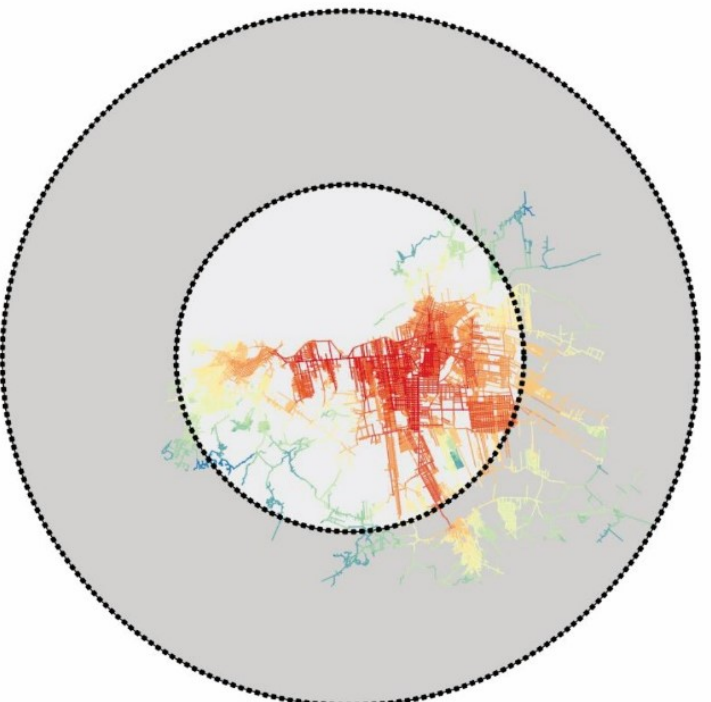

RM CARIRI/CE

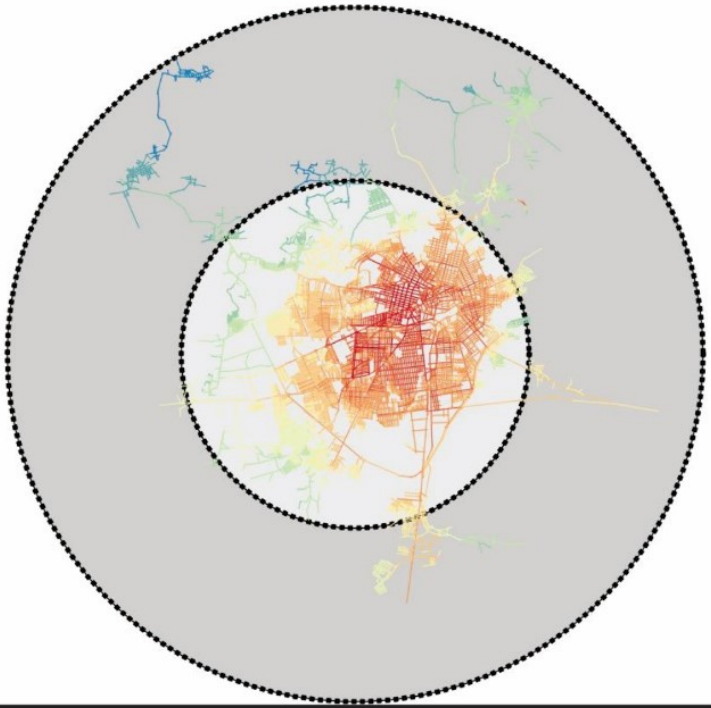

RM CAMPINA GRANDE/PB
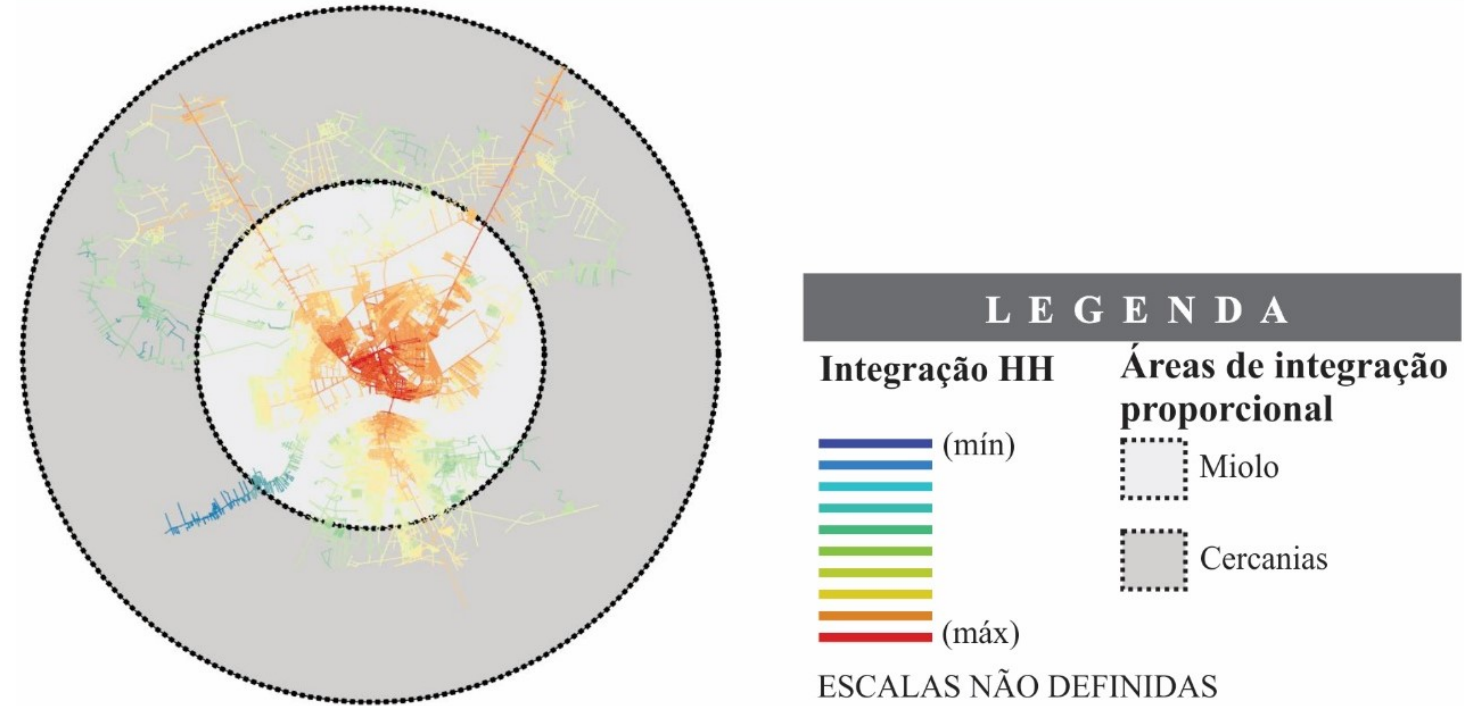

ESCALAS NÃO DEFINIDAS

\section{RAID PETROLINA-JUAZEIRO}

Fonte: Elaboração própria (2016) a partir das bases cartográficas calculadas para integração HH. 
Isso significa que os miolos comportam o núcleo de integração, sendo, portanto, mais integrados (há maior percentual de linhas em cores quentes) do que as cercanias (maior percentual de linhas em cores frias) - Figura 88. Outra observação a ser feita a partir da imagem, é a densidade das ocupações: os miolos, embora correspondam a metade do raio total, concentram a maior parte das linhas axiais, enquanto nas cercanias as ocupações são esparsas.

\begin{tabular}{|c|c|c|c|c|}
\hline RMINE & VALORES & TOTAL & CERCANIAS & MIOLO \\
\hline \multirow{5}{*}{$\begin{array}{c}\text { RM de Feira de } \\
\text { Santana/BA }\end{array}$} & MÍNIMA & 0,129 & 0,129 & 0,129 \\
\hline & MÉDIA & 0,546 & 0,365 & 0,585 \\
\hline & MEDIANA & 0,566 & 0,371 & 0,600 \\
\hline & MÁXIMA & 0,912 & 0,712 & 0,912 \\
\hline & DESVIO PADRÃO & 0,167 & 0,118 & 0,149 \\
\hline \multirow{5}{*}{ RM do Cariri/CE } & MÍNIMA & 0,122 & 0,123 & 0,122 \\
\hline & MÉDIA & 0,444 & 0,345 & 0,476 \\
\hline & MEDIANA & 0,449 & 0,359 & 0,507 \\
\hline & MÁXIMA & 0,705 & 0,617 & 0,705 \\
\hline & DESVIO PADRÃO & 0,138 & 0,097 & 0,134 \\
\hline \multirow{5}{*}{$\begin{array}{l}\text { RM do Sudoeste } \\
\text { maranhense }\end{array}$} & MÍNIMA & 0,238 & 0,271 & 0,238 \\
\hline & MÉDIA & 0,689 & 0,591 & 0,718 \\
\hline & MEDIANA & 0,692 & 0,566 & 0,723 \\
\hline & MÁXIMA & 1,164 & 1,027 & 1,164 \\
\hline & DESVIO PADRÃO & 0,171 & 0,174 & 0,158 \\
\hline \multirow{5}{*}{$\begin{array}{c}\text { RM de Campina } \\
\text { Grande/PB }\end{array}$} & MÍNIMA & 0,154 & 0,154 & 0,232 \\
\hline & MÉDIA & 0,491 & 0,343 & 0,524 \\
\hline & MEDIANA & 0,512 & 0,341 & 0,545 \\
\hline & MÁXIMA & 0,756 & 0,688 & 0,756 \\
\hline & DESVIO PADRÃO & 0,126 & 0,103 & 0,106 \\
\hline \multirow{5}{*}{$\begin{array}{c}\text { RAID Petrolina- } \\
\text { Juazeiro }\end{array}$} & MÍNIMA & 0,181 & 0,181 & 0,231 \\
\hline & MÉDIA & 0,447 & 0,379 & 0,468 \\
\hline & MEDIANA & 0,447 & 0,383 & 0,469 \\
\hline & MÁXIMA & 0,668 & 0,551 & 0,668 \\
\hline & DESVIO PADRÃO & 0,085 & 0,074 & 0,078 \\
\hline
\end{tabular}

Fonte: Elaboração própria (2016) a partir das bases cartográficas calculadas para integração HH.

\subsubsection{Grupo de controle 01}

Tomando de empréstimo o nome de uma árvore comum no Agreste e no Sertão, a cidade de Arapiraca/AL começou a ser povoada na primeira metade do século XIX, desenvolvendo-se em torno da capela de Nossa Senhora do Bom Conselho, construída em 1864, e ao longo da trilha que fazia a ligação com a Vila de Porto da Folha (hoje cidade de 
Traipu), por onde se escoava todos os produtos dos povoados vizinhos. Foi elevada à categoria de município em 1924, constituindo-se de territórios desmembrados de Palmeira dos Índios, Porto Real, São Brás, Traipu e Limoeiro (IBGE, 2016). A partir da década de 1970, por conta da grande área plantada de fumo - que gerou um excesso do produto nas pequenas indústrias de beneficiamento do tabaco que havia na região, e consequentemente, a diminuição de seu preço -, seguiu-se um ciclo de decadência da fumicultura. Desde 1980, verifica-se um crescimento econômico de seu comércio (com destaque para a tradicional Feira Livre) e serviços.

Para a RM do Agreste alagoano, a Figura 91 representa o Mapa axial em Integração do município de Arapiraca. O núcleo de integração tem forma alongada sobre os bairros Brasiliana, Capiatá, Centro e Ouro Preto. Têm destaque a Av. Benjamim Freire de Amorim e as ruas São Francisco e Cláudio A. Lima (Figura 89). A centralidade, sob o ponto de vista dos usos do solo, é contida aos bairros citados, sendo mais densa no Centro. Os bairros ao redor do núcleo de integração possuem uso majoritariamente residencial de gabarito baixo e médio padrão construtivo.

Figura 89: À esquerda, a Av. Benjamim Freire de Amorim (bairro Brasiliana). À direita, a rua São Francisco (bairro Centro).

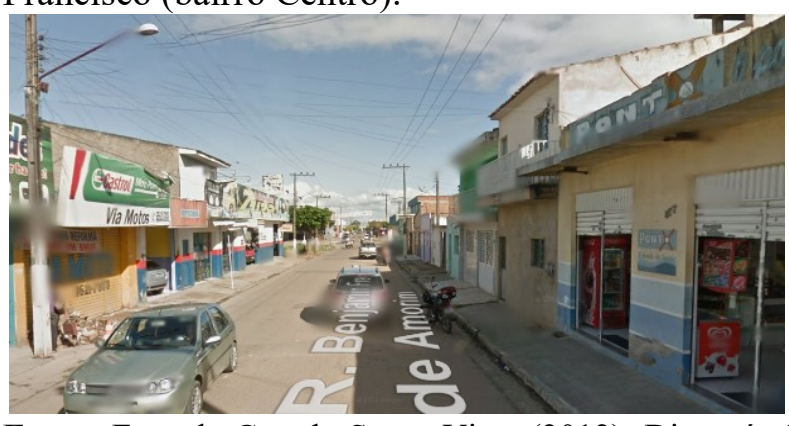

Fonte: Foto de Google Street View (2012). Disponível em: < https://www.google.com.br/maps $>$. Acesso em 15 de ago. 2016.

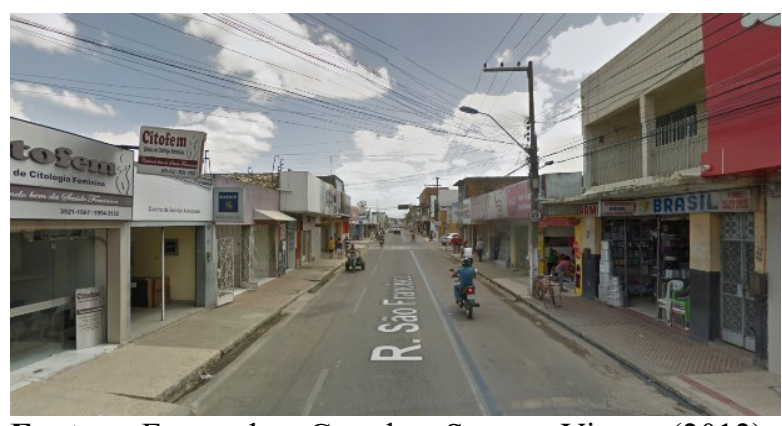

Fonte: Foto de Google Street View (2012). Disponível em: <https://www.google.com.br/maps>. Acesso em 15 de ago. 2016.

Figura 90: A esquerda vista geral de Arapiraca/Al, mostrado sua tímida verticalização, e a direita um exemplo de condomínio fechado horizontal

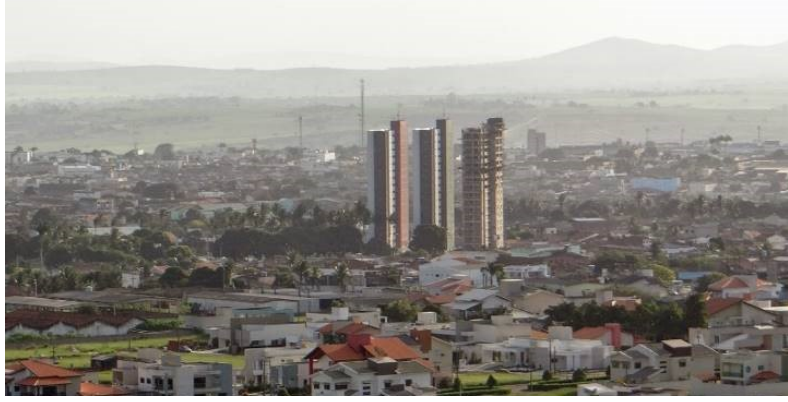

Fonte: Foto de Toni Cavalcante (2014). Disponível em: $<$ http://alagoasbytonicavalcante.blogspot.com.br/>. Acesso em 15 de ago. 2016.

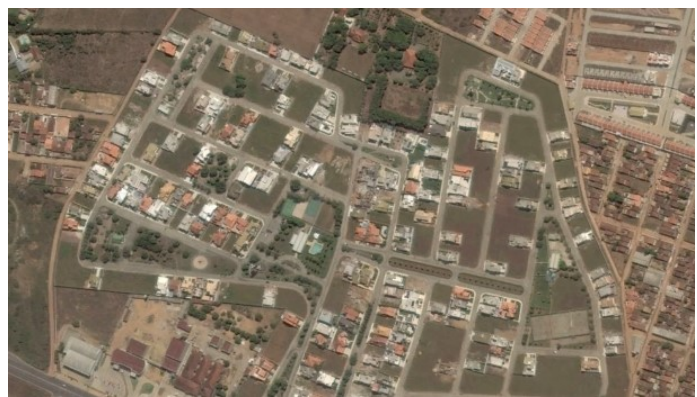

Fonte: Foto de Google Earth (2015). Acesso em 15 de ago. 2016.

Figura 91: Mapa axial da RM do Agreste/AL calculado por Integração HH global (Rn). 


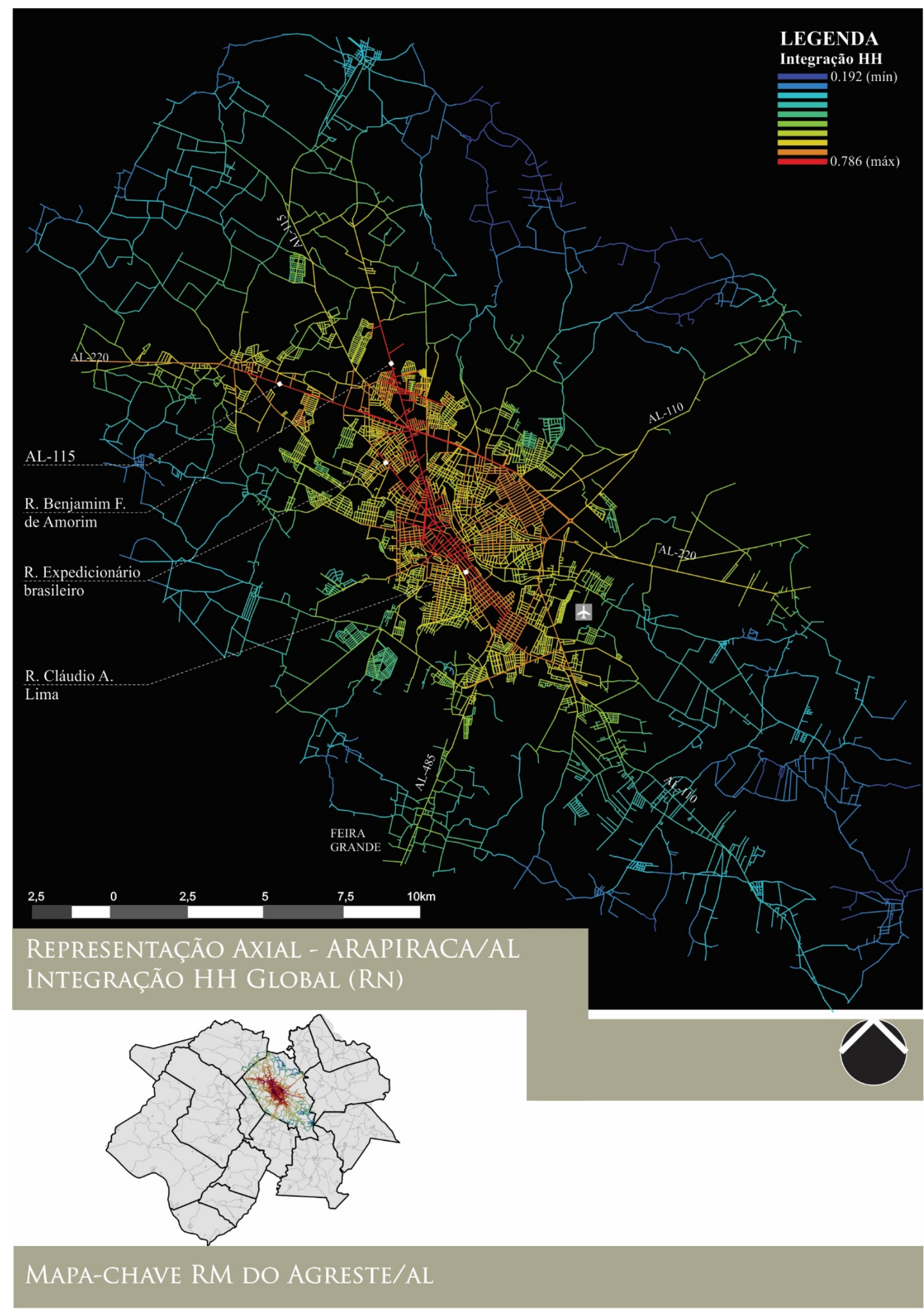

Fonte: Desenho gentilmente cedido por Paim (2015), com revisão feita pela autora a partir da Base Cartográfica do OpenStreetMap (2016) e imagens de satélite do Google Earth (2016). 
O processo de verticalização ainda é bastante tímido, as novas produções do mercado imobiliário de alto e médio padrão são principalmente os condomínios horizontais (Figura 90). Segundo Barros (2015, s/ p.), a ocupação do solo:

[...] tem sido intensa e sem planejamento, diante de uma legislação urbana defasada, contribuindo para gerar problemas e agravar outros já existentes: segregação socioespacial [sic]; fragmentação do tecido urbano; loteamentos irregulares; assentamentos precários (favelas e vilas); infraestrutura urbana deficitária; deterioração do ambiente natural; desvalorização do patrimônio cultural[...] Além de uma mudança no espaço urbano, Arapiraca atravessa uma mudança cultural, novos hábitos, de morar em casas em ruas isoladas, para casas ou apartamentos em condomínios fechados, de realizar compras no intenso comércio do centro da cidade, agora percorre os corredores do shopping center.(BARROS, 2015, s/p.).

Portanto, destaca-se o Arapiraca Garden Shopping (Figura 92), inaugurado em setembro de 2013. Com mais de 36 mil metros quadrados (abarcando 220 lojas e duas mil vagas para estacionamento), o empreendimento atende ao público consumidor da região como um todo. Localizado às margens da rodovia AL-220, no bairro de Santa Edwiges, o centro comercial gera cerca de seis mil empregos diretos e indiretos e é visitado por uma média de 15 mil pessoas por dia, segundo dados da Secretaria Municipal de Cultura e Turismo (2015).

Figura 92: Vista do Arapiraca Garden Shopping, à esquerda, a fachada do empreendimento e, à direita, sua localização (em rosa) às margens da rodovia AL-115, área de expansão da cidade.

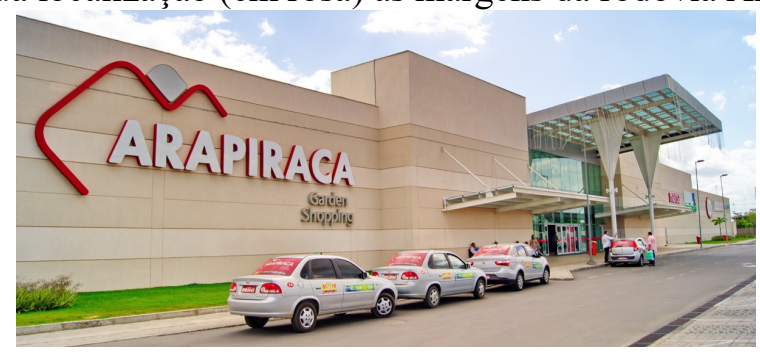

Fonte: Foto de autor desconhecido (2014). Disponível em: <http://estatico.minutoarapiraca.com.br/>. Acesso em 15 de ago. 2016.

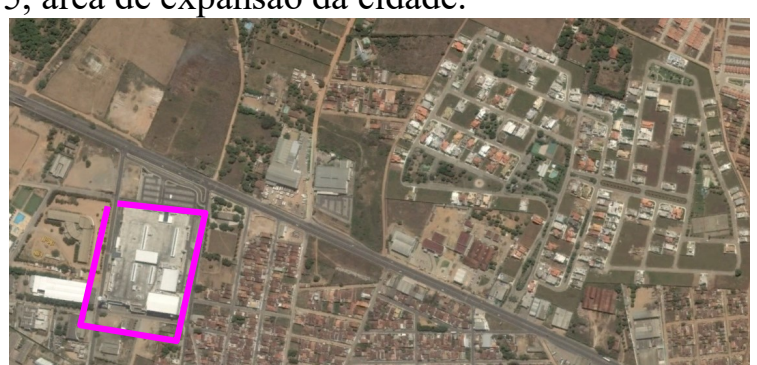

Fonte: Foto de Google Earth (2015). Acesso em 15 de ago. 2016.

Na representação de escolha (Figura 94 e Figura 95) têm destaque as vias de ligação regional: AL-220, que atravessa a cidade pelo norte; ao leste, a AL-110, que cruza a AL-220, ligando a Taquarana e Coité do Nóia; a AL-115, que corta a cidade longitudinalmente ao oeste, interligando com Lagoa da Canoa, Girau do Ponciano e Campo Grande para o sul. Essa confluência da malha rodoviária estadual fez de Arapiraca um polo atrativo de passagem, permitindo fortalecer uma rede de comunicação iniciada a partir dos primitivos caminhos (ROMÃO et al, 2008). 
Figura 93: Mapa de segmentos da RM do Agreste/AL calculado por Integração.

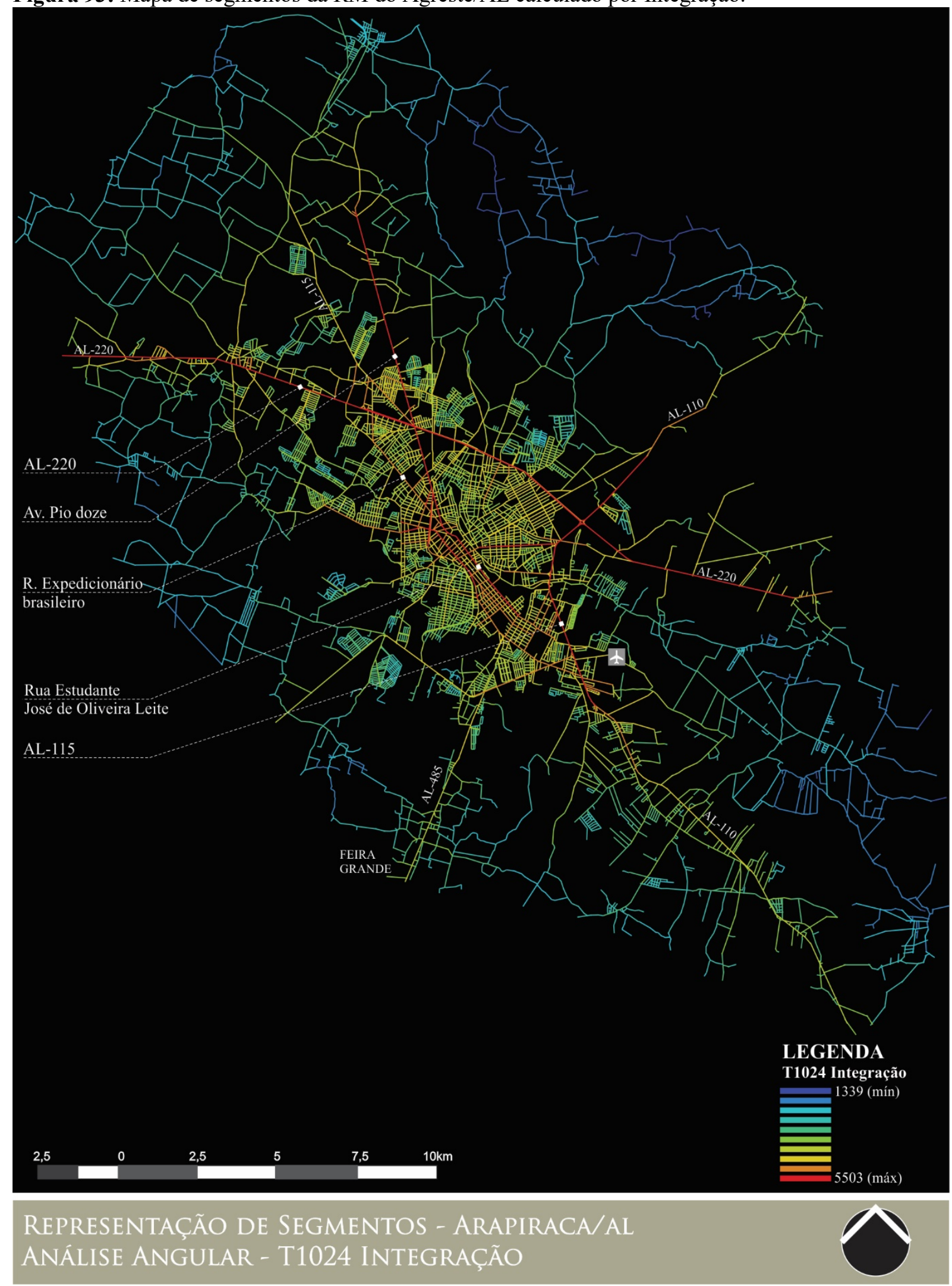

Fonte: Desenho gentilmente cedido por Paim (2015), com revisão feita pela autora a partir da Base Cartográfica do OpenStreetMap (2016) e imagens de satélite do Google Earth (2016). 
Figura 94: Mapa axial da RM do Agreste/AL calculado por Escolha (choice).

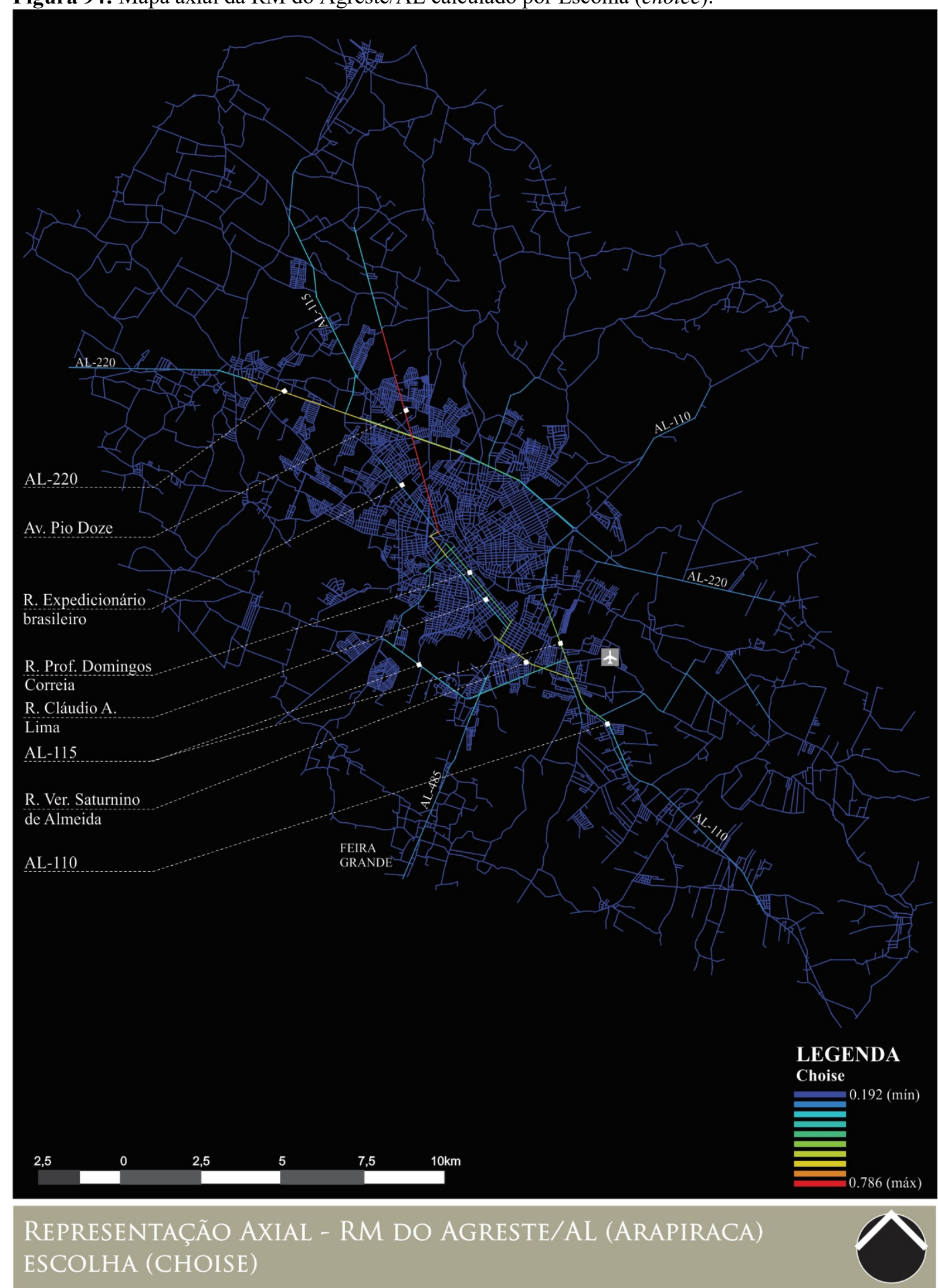

Fonte: Desenho gentilmente cedido por Paim (2015), com revisão feita pela autora a partir da Base Cartográfica do OpenStreetMap (2016) e imagens de satélite do Google Earth (2016). 
Figura 95: Mapa de segmentos da RM do Agreste/AL calculado por Escolha (choice).

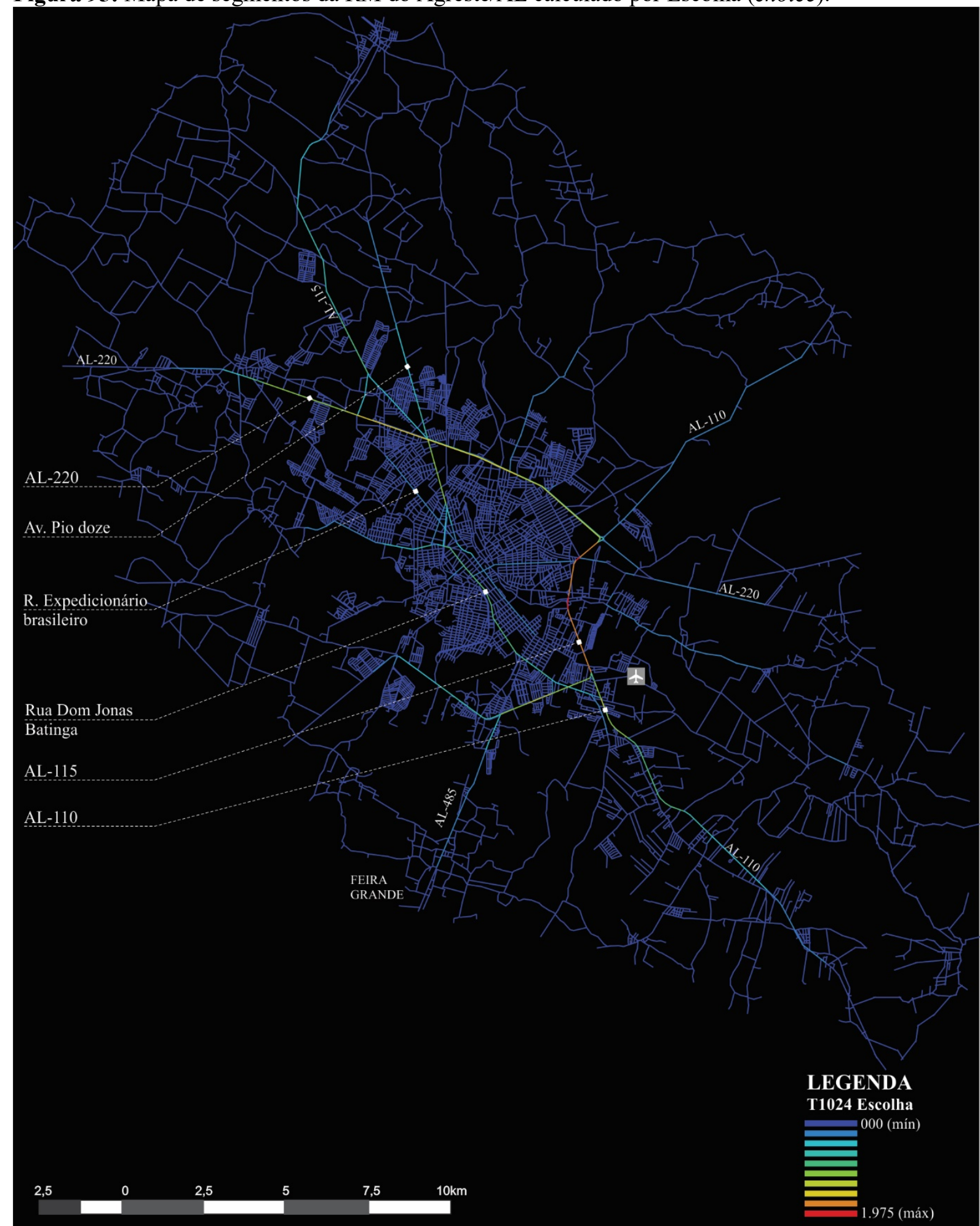

REPRESENTAÇÃO DE SEGMENTOS - ARAPIRACA/AL ANÁLISE ANGULAR - T1024 ESCOLHA (CHOICE)

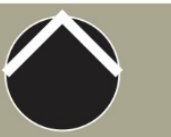

Fonte: Desenho gentilmente cedido por Paim (2015), com revisão feita pela autora a partir da Base Cartográfica do OpenStreetMap (2016) e imagens de satélite do Google Earth (2016). 
Em Arapiraca também se vislumbra a implantação de novas áreas habitacionais ao longo de suas periferias, replicando processos de segregação urbana entre as elites, que escolhem os condomínios fechados (Figura 96), e as mais baixas faixa de renda, que são locadas nos empreendimentos com financiamento federal, como o MCMV (Figura 97).

Figura 96: Vistas dos empreendimentos habitacionais em Arapiraca/AL: Residencial Sierra, condomínio fechado de alto padrão a $3 \mathrm{~km}$ do Arapiraca Garden Shopping e $5 \mathrm{~km}$ do centro.

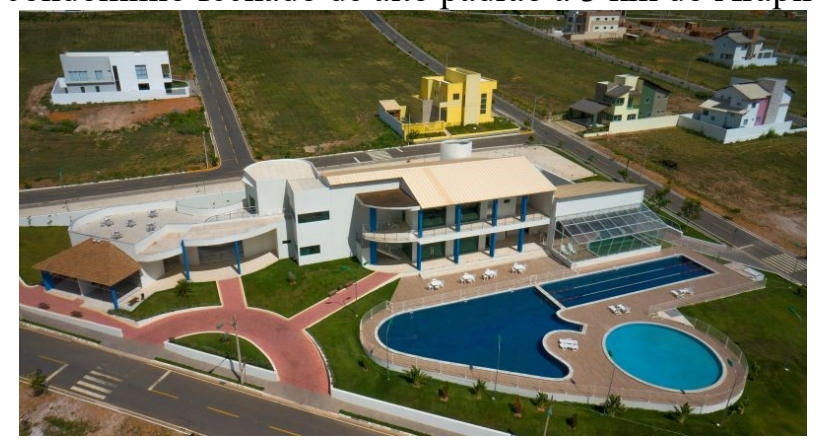

Fonte: Foto de autor desconhecido (s/d.). Disponível em: $<$ http://incorporadoraalamedas.com.br $>$. Acesso em $15 \mathrm{de}$ ago. 2016.

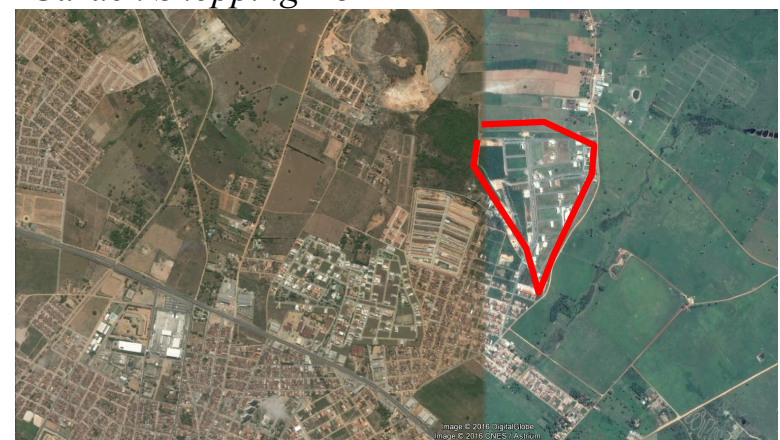

Fonte: Foto de Google Earth (2015). Acesso em 15 de ago. 2016.

Figura 97: Vistas dos empreendimentos habitacionais em Arapiraca/AL: Residencial Brisa do Lago, conjunto habitacional de interesse social implantado na área periférica da cidade.

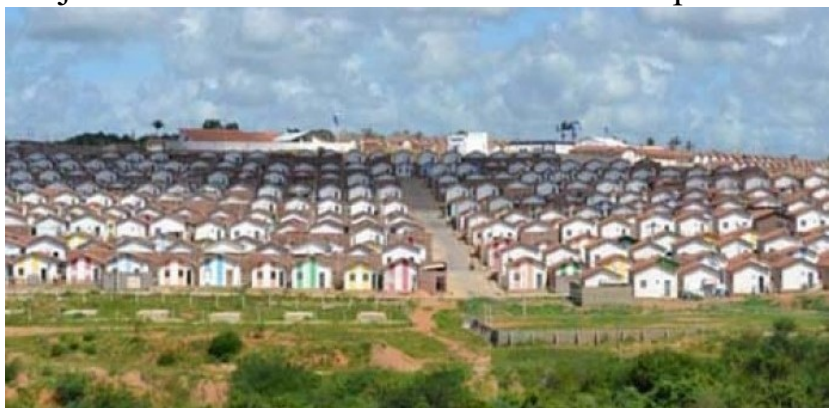

Fonte: Foto de autor desconhecido (s/d). Disponível em: $<$ http://7segundos.ne10.uol.com.br/>. Acesso em $15 \mathrm{de}$ ago. 2016.

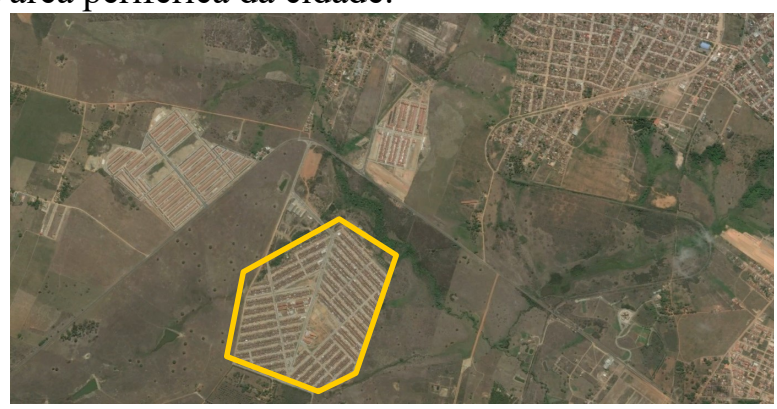

Fonte: Foto de Google Earth (2015). Acesso em 15 de ago. 2016.

O território onde hoje está localizado o município de Vitória da Conquista foi habitado pelos povos indígenas Mongoyó, Ymboré e Pataxó. Os aldeamentos se espalhavam por uma extensa faixa, conhecida como Sertão da Ressaca, que vai das margens do Rio Pardo até o Rio das Contas. A partir de meados de 1720, a vinda dos colonizadores portugueses e mestiços à região esteve ligada à exploração de metais preciosos, principalmente de ouro, e à política de ocupação do território. $\mathrm{O}$ enfrentamento entre os colonos e os indígenas se prolongou até o século XIX e foi marcada por episódios de carnificina. O Arraial era um entreposto para o gado trazido pelos tropeiros de Minas Gerais que iam em direção ao litoral. Em 1840, foi elevado à condição de Vila Imperial da Vitória, distrito da Vila de Caetité. Foi elevado à condição de cidade com a denominação de Conquista em 1891 (IBGE, 2016). Até a 
década de 1940, a base econômica do município se estabelecia na pecuária extensiva, quando passou a ter destaque o comércio e a prestação de serviços. Em função de sua privilegiada localização, com a abertura da estrada Rio-Bahia (atual BR-116) e da estrada Ilhéus-Lapa, o município pôde integrar-se ao estado e ao restante do país e logo passou a polarizar a região centro-sul da Bahia e norte de Minas.

A representação axial de Vitória da Conquista/BA calculada para integração (Figura 100 e Figura 102) apresenta como núcleo de integração os bairros Centro, Brasil e Ibirapuera, tendo como principal eixo a BR 116 (Figura 98) que atravessa a cidade. Esse centro congrega as principais atividades de comércio e serviço da cidade e da região, cujo principal eixo é a Av. Brumado (BA-262). Embora este espaço seja ainda bastante dinâmico (MOTA, 2009, $\mathrm{s} / \mathrm{p}$ ), já se vivenciam na cidade processos de degradação (física e social) decorrentes, dentre outros fatores, da tendência de migração da atividade comercial para os shoppings centers. Nessa cidade, destaco o Shopping Conquista Sul, inaugurado em junho de 2006 e que segundo os dados dos administradores ${ }^{61}$ do empreendimento conta com fluxo mensal de 500 mil pessoas.

Figura 98: À esquerda, a BR-116, que atravessa Vitória da Conquista/BA e, à direita, uma vista da Av. Brumadinho.

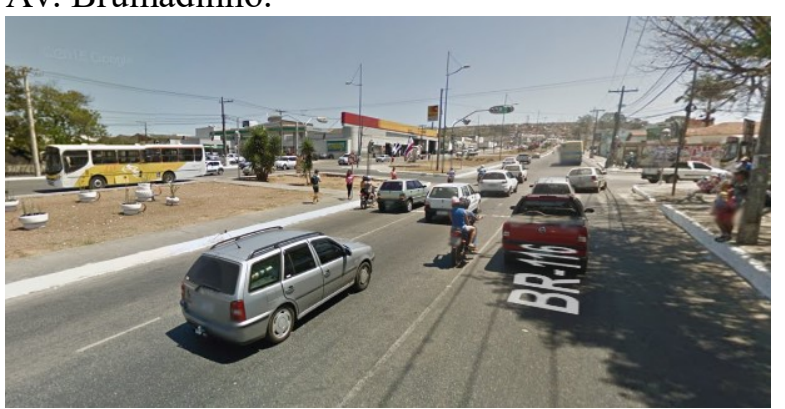

Fonte: Foto de Google Street View (2014). Disponível em: <https://www. google. com. br/ maps $>$. Acesso em 18 de ago. 2016.

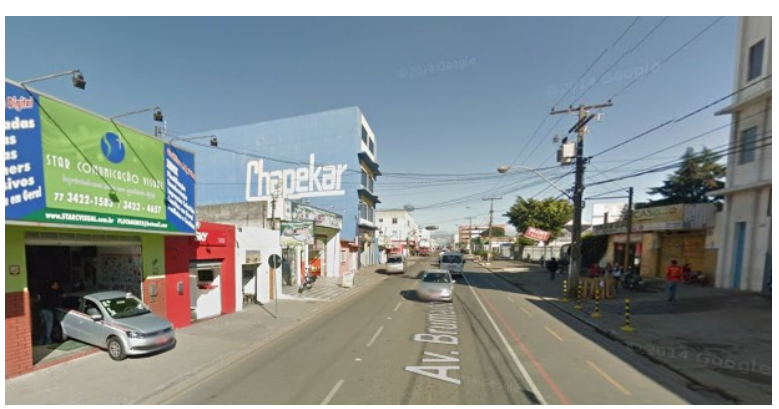

Fonte: Foto de Google Street View (2014). Disponível em: <https://www.google.com.br/maps>. Acesso em 18 de ago. 2016.

Figura 99: À esquerda, uma imagem de satélite da zona sul de Vitória da Conquista/BA, destacado em vermelho o shopping e, em verde, o Condomínio Green Ville. À direita, Shopping Conquista Sul.

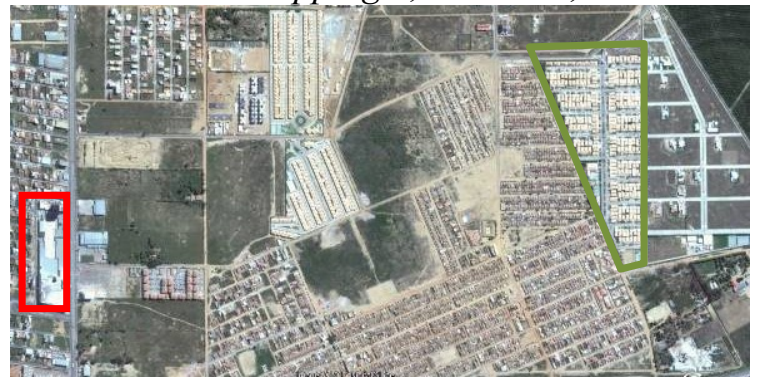

Fonte: Foto de Google Earth (2016) editado pela autora (2016). Acesso em 18 de ago. 2016.

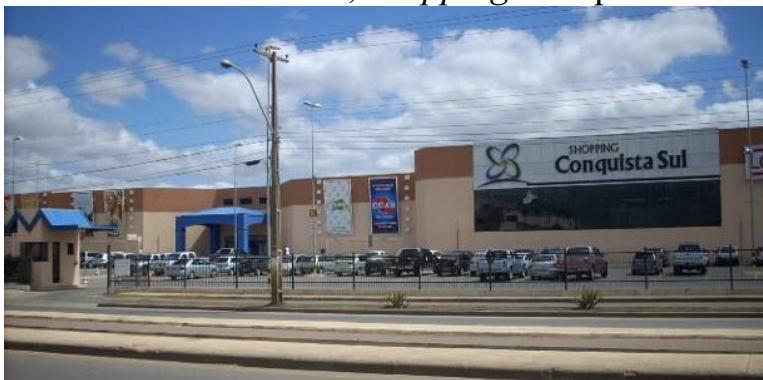

Fonte: Foto de autor desconhecido (2014). Disponível em: <www.blogdaresenhageral.com.br>. Acesso em 18 de ago. 2016.

${ }^{61}$ Dados coletados no sítio: < http://www.shoppingconquistasul.com.br/shopping >. Acesso em 18 ago. 2016. 
Figura 100: Mapa axial de Vitória da Conquista/BA calculado por Integração HH global (Rn).

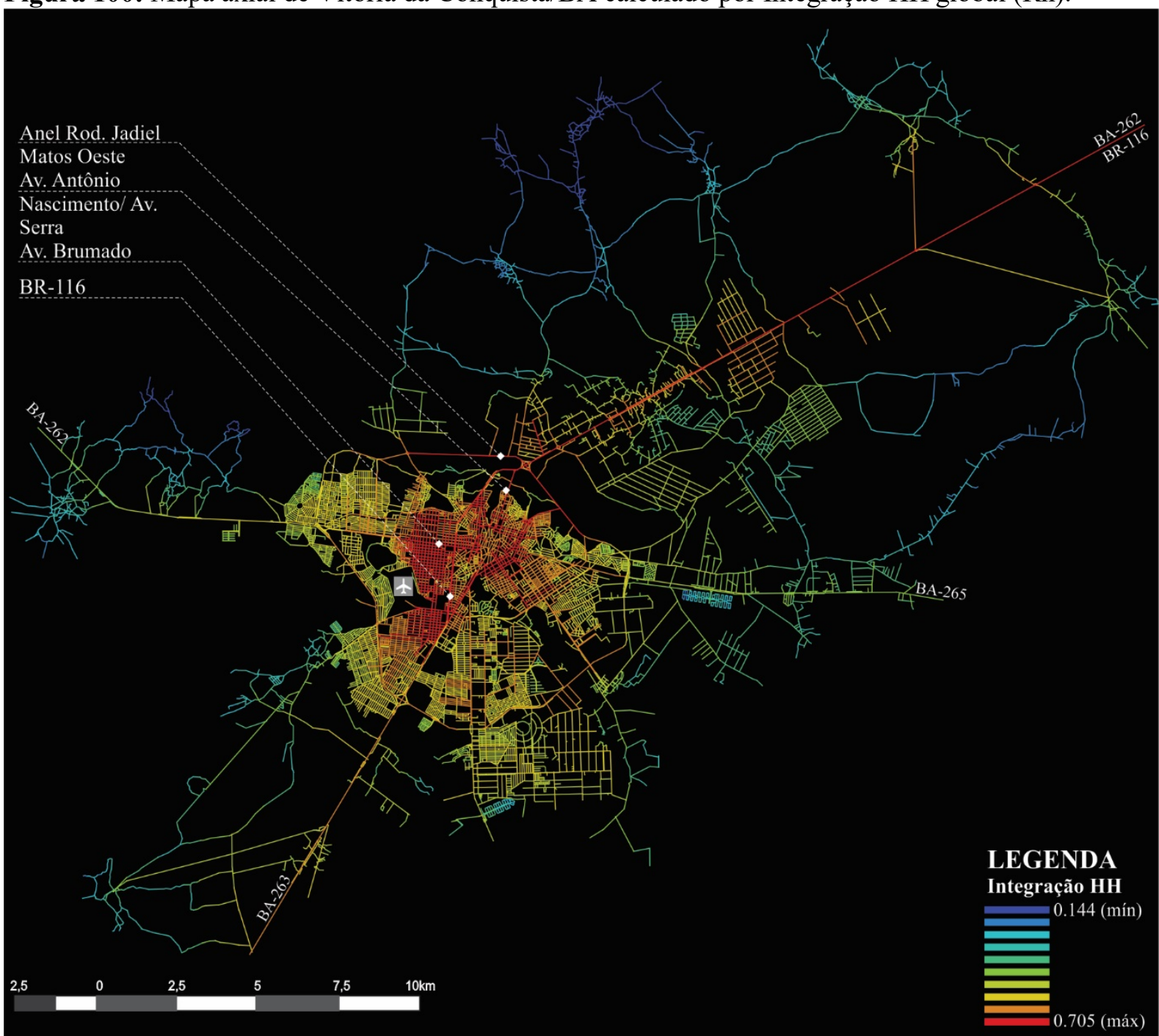

REPRESENTAÇÃO AXIAL - VITÓRIA DA CONQUISTA/BA INTEGRAÇÃO HH GLOBAL (RN)
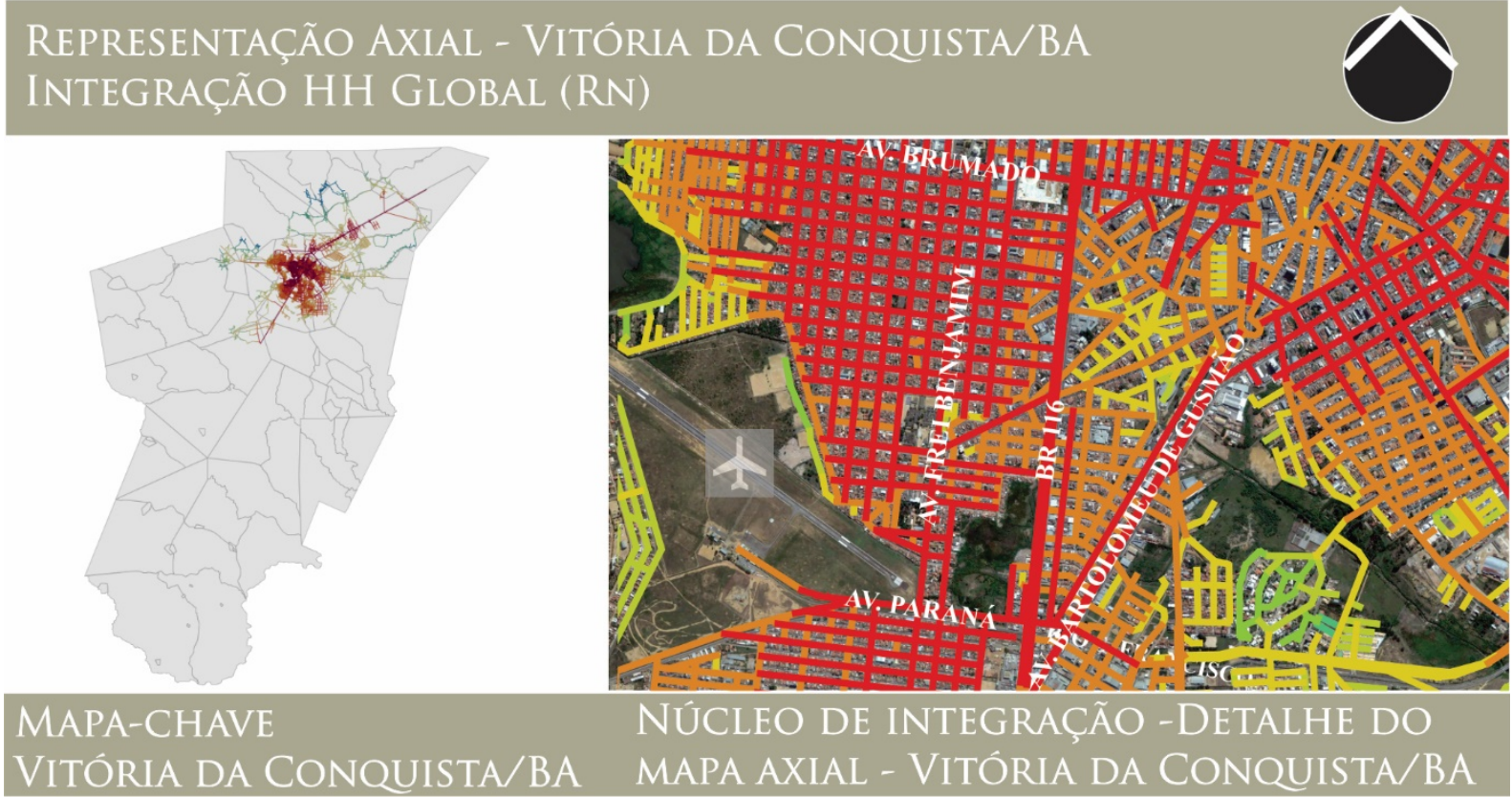

Fonte: Desenho gentilmente cedido por Paim (2015), com revisão feita pela autora a partir da Base Cartográfica do OpenStreetMap (2016) e imagens de satélite do Google Earth (2016). 
O shopping está localizado na zona sul, uma área em acelerado processo de transformação de usos e construção, tendo como eixo a Av. Juracy Magalhães. Ali há a inserção de diversos condomínios fechados, como Condomínio Green Ville (Figura 101), que dispõe de pavimentação, saneamento básico, transporte público, a segurança feita a partir de monitoramento 24 horas e espaços internos de convivência. (ROCHA \& BARROS, 2010, s/p.). Em contraposição, separados apenas por um muro, encontramos o loteamento Vila América (Figura 101). Sua rua não tem pavimentação, não há saneamento básico, o transporte coletivo não atende satisfatoriamente à demanda, as habitações, que foram construídas pelo poder público, apresentam sérios problemas técnicos e a segurança é quase inexistente. (ROCHA \& BARROS, 2010, s/p.).

Figura 101: À esquerda, um exemplo de residência no condomínio Green Ville e, à direita, a vista de seu muro externo onde há outro padrão construtivo e de infraestruturas urbanas.

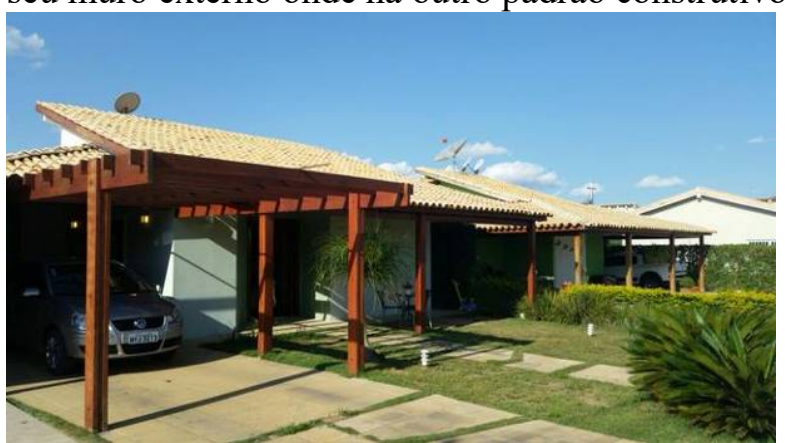

Fonte: Foto de autor desconhecido (s/d). Disponível em: <http://ba.mgfimoveis.com.br/>. Acesso em 18 de ago. 2016.

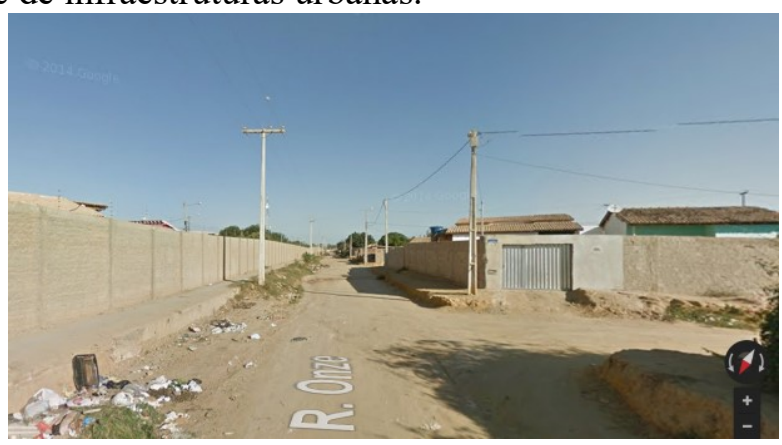

Fonte: Foto de Google Street View (2014). Disponível em: <https://www.google.com.br/maps>. Acesso em 18 de ago. 2016.

Estes processos de segregação socioespacial, exemplificado pelo loteamento Vila América, dizem respeito a posição do município frente à rede urbana, bem como às ações públicas de produção do solo urbano, como explicam Rocha e Barros (2010, s/p.):

Por outro lado, o fato de Vitória da Conquista ter se consolidado como um pólo [sic] regional de desenvolvimento econômico atraiu para o espaço urbano um acréscimo populacional significativo que ocupou durante muitos anos assentamentos irregulares, seja por falta de infra-estrutura [sic] urbana, seja pelas condições ambientais dos lugares. Assim, grandes áreas de ocupação irregular foram estabelecidas em diversas partes da cidade especialmente naquelas mais distantes do centro, e nos espaços de declive acentuado (encostas da Serra do Peri Peri). Neste contexto as políticas habitacionais que aliam esforços e investimentos das três esferas estatais deram origem ao Loteamento Vila América, numa tentativa de reunir legalmente os moradores das diversas ocupações irregulares em um mesmo empreendimento provido pelo governo. 
Figura 102: Mapa de segmentos de Vitória da Conquista/BA calculado por Integração.

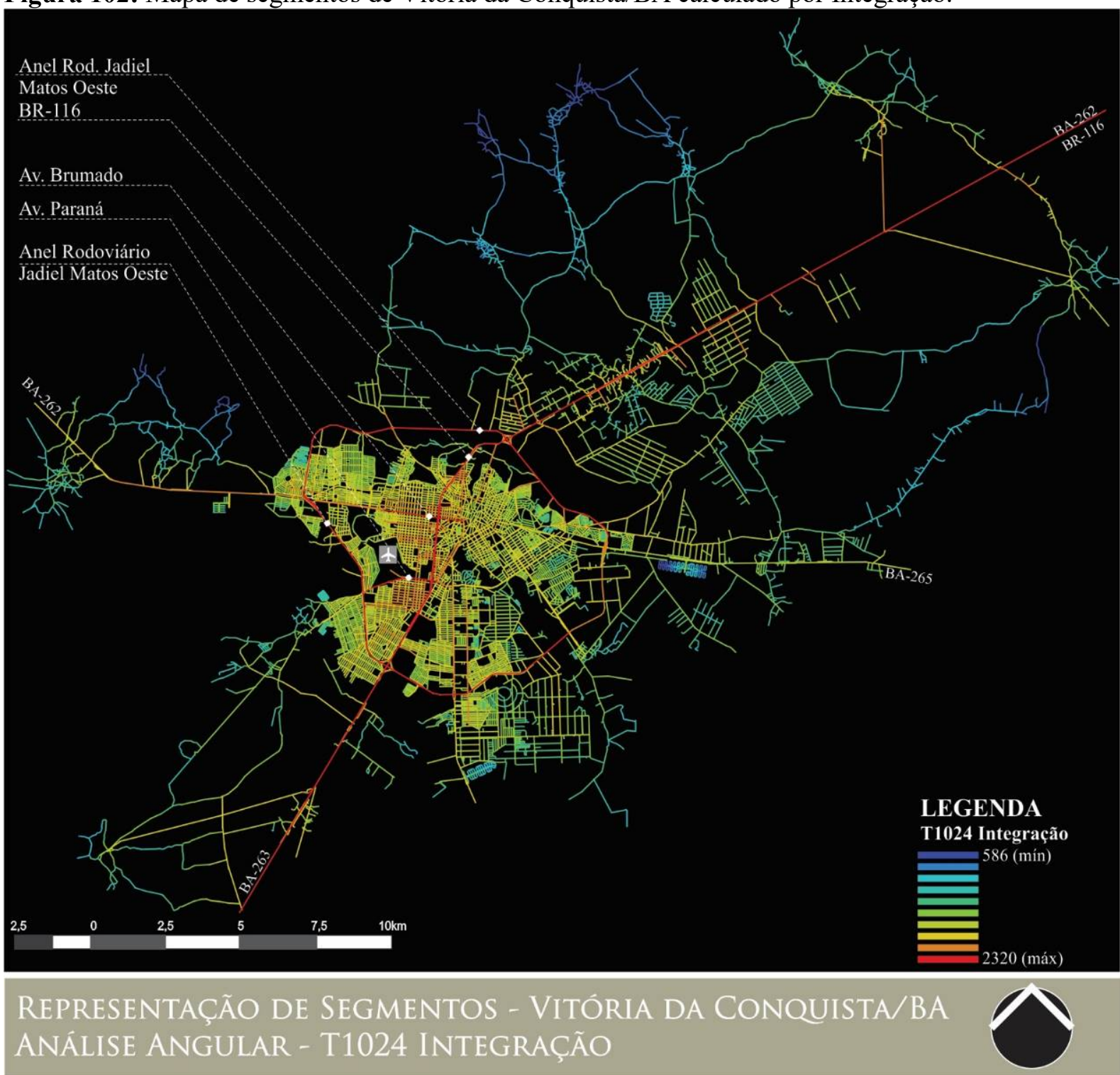

Fonte: Desenho gentilmente cedido por Paim (2015), com revisão feita pela autora a partir da Base Cartográfica do OpenStreetMap (2016) e imagens de satélite do Google Earth (2016).

Trançando um comparativo entre os métodos de representação, na modelagem de segmentos calculada para integração (Figura 102) há um grande destaque ao anel Rodoviário Jadiel Matos, que circunda o núcleo mais denso de ocupação, em detrimento das demais vias identificadas na modelagem axial como núcleo de integração. É interessante destacar que essa solução urbanística já foi vista no outro município baiano em análise, Feira de Santana/BA. Embora justifique-se por oferecer uma "solução" aos problemas de tráfego, tanto de carga quanto de veículos, e de reestruturação da logística de abastecimento da região, esse tipo de intervenção pode ser questionada do ponto de vista da criação de barreiras físicas e sociais. A modelagem apresentada aqui, apoiada na observação empírica, demonstra que essa ideologia 
que favorece os veículos ao invés dos pedestres e que contribui para a perda de urbanidade dos espaços. A perda da "escala humana" nas cidades vem sendo recorrentemente alvo de críticas, a exemplo do que Gehl (2013) define como "síndrome de Brasília”, ou seja:

[...] a cidade é uma catástrofe ao nível dos olhos, a escala que os urbanistas ignoraram. Os espaços são muito grandes e amorfos, as tuas muito largas, e as calcadas e passagens longas e retas. As grandes áreas verdes são atravessadas por caminhos abertos pela passagem das pessoas, mostrando como os habitantes protestaram com os pés, contra o rígido plano formal da cidade. Se você estiver em um avião ou helicóptero ou carro - e a maioria dos moradores de Brasília não está - não há muito que comemorar. (GEHL, 2013, p. 197).

Figura 103: Mapa axial de Vitória da Conquista/BA calculado por Escolha (choice).

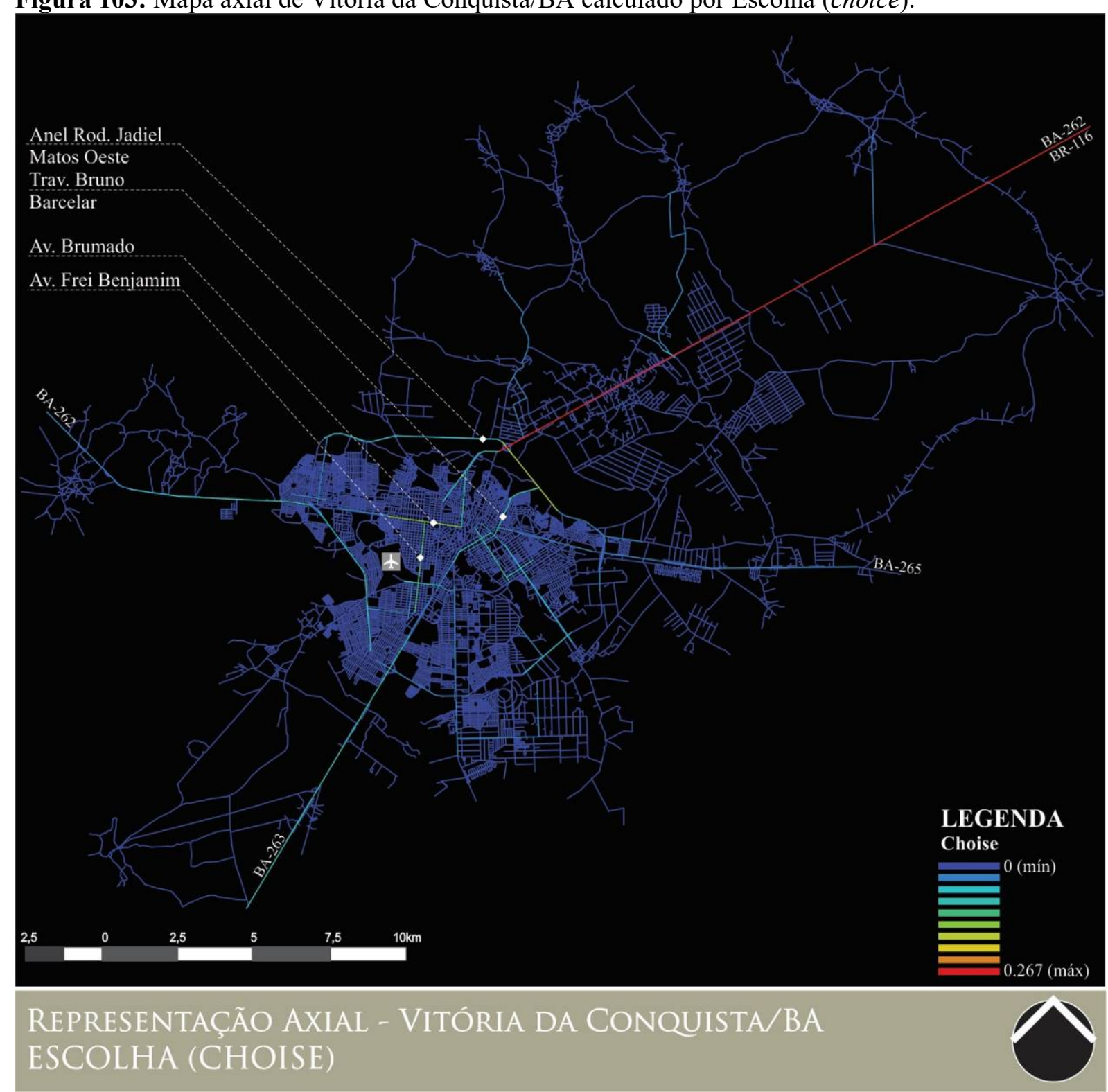

Fonte: Desenho gentilmente cedido por Paim (2015), com revisão feita pela autora a partir da Base Cartográfica do OpenStreetMap (2016) e imagens de satélite do Google Earth (2016). 
Por fim, na representação de escolha (Figura 103 e Figura 104), têm destaque as vias de acesso intermunicipal como a BR-116/BA-262, bem como o anel Rodoviário Jadiel Matos, o que corrobora com a leitura que esta representação tem o poder de representar o sistema viário principal numa escala metropolitana.

Figura 104: Mapa de segmentos de Vitória da Conquista/BA calculado por Escolha (choice).

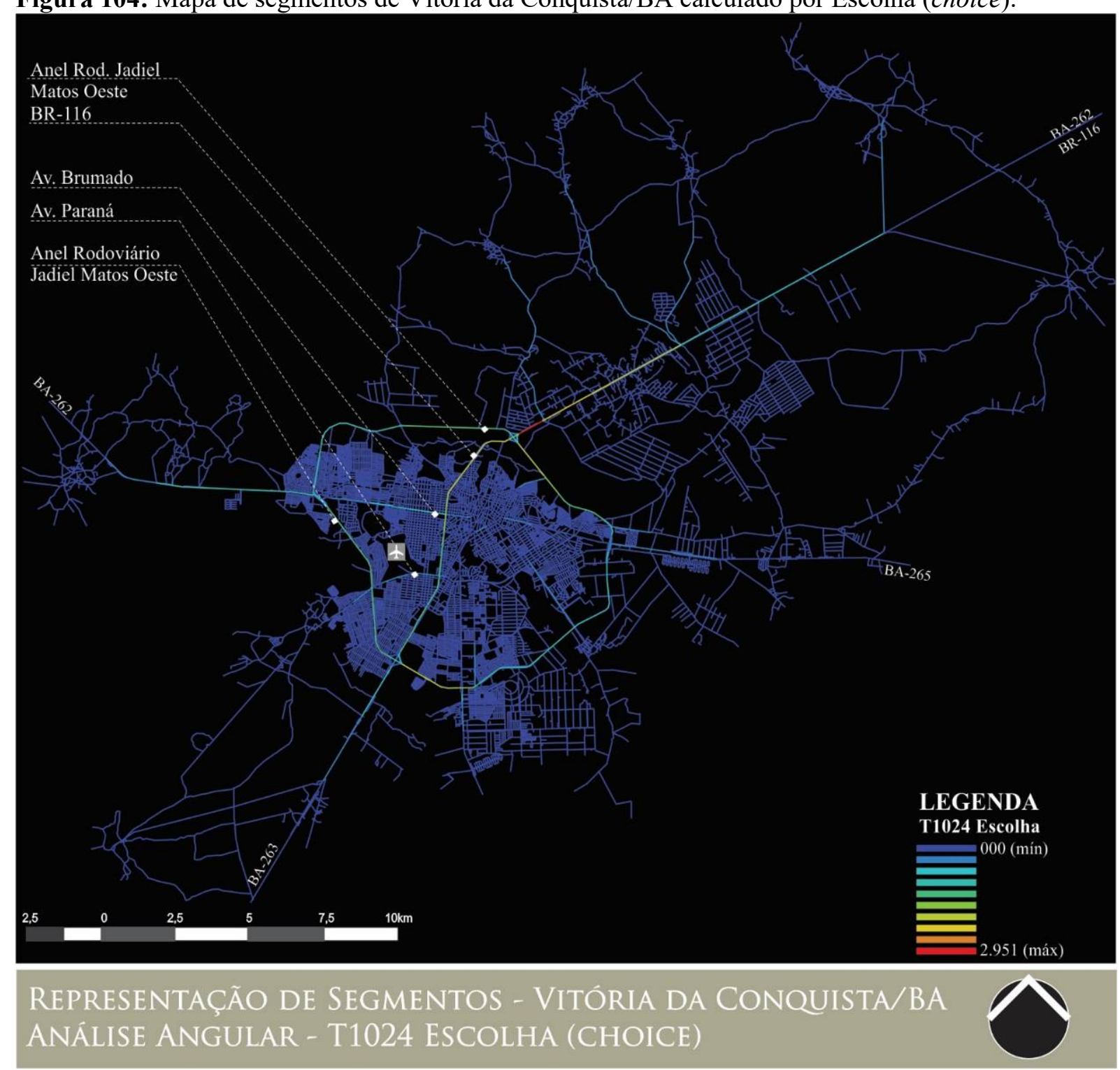

Fonte: Desenho gentilmente cedido por Paim (2015), com revisão feita pela autora a partir da Base Cartográfica do OpenStreetMap (2016) e imagens de satélite do Google Earth (2016).

A origem da cidade de Sobral/CE remonta ao primeiro quartel do século XVIII, quando fugitivos dos invasores estrangeiros do litoral do Nordeste embrenhavam-se pelo interior cearense, instalando-se às margens dos rios Jaguaribe e Acaraú. Por volta de 1728, Antônio Rodrigues Magalhães, procedente do Rio Grande do Norte, instalou a Fazenda Caiçara, considerada berço do município, o qual doou, em 1756, as terras para a instalação da 
Igreja de N. S. da Conceição. Na segunda metade do século XVIII, com o sucesso econômico da Charqueada, o desenvolvimento de Sobral chegou a superar o de Fortaleza - à época, uma das mais importantes cidades do Ceará, junto com as cidades de Icó e Aracati. As excelentes condições de clima e a fertilidade do solo contribuíram para que se desenvolvesse no local um povoado que foi elevado à categoria de vila em 1773, denominando-se Vila Distinta e Real de Sobral. Por lei provincial de 1841, a vila tomou foros de cidade com a denominação de Fidelíssima Cidade Januária de Acaraú, designação que homenageia a Princesa Januária, irmã do Imperador D. Pedro II. A denominação definitiva atual foi dada em 1842 (IBGE, 2016). Com as secas de 1877 e 1879, foi iniciado o projeto da Estrada de Ferro de Sobral, com o intuito de ligar Sobral ao porto de Camocim, criando um escoadouro dos produtos da Serra da Meruoca e da Serra Grande. A estação de trem inaugurada em 1882, consolidou Sobral como centro urbano e comercial, estimulando também o beneficiamento industrial de algodão no início do século XX.

Para Sobral/CE, inicialmente é interessante destacar a proporção entre a mancha urbana (desenhada axialmente - Figura 106) e a área total do município. O grande território municipal é dividido em treze distritos, mas somente a sede tem características urbanas (voltarei a esse quesito quando tratarmos de densidades). A cidade é cortada pelo rio Acaraú, que é transposto por ter pontes. Sobral passou, a partir dos anos 1980, por uma série de investimentos e obras de infraestrutura que vão defini-la como centro de comércio e serviços para atender não só a população urbana que vive na sede do município, mas também, a população de sua área de influência (municípios vizinhos e também do estado do Piauí).

Figura 105: À esquerda, uma visão geral da Grendene em Sobral/CE e, à direita, a Av. Dr José Arimatéia Monte e Silva.

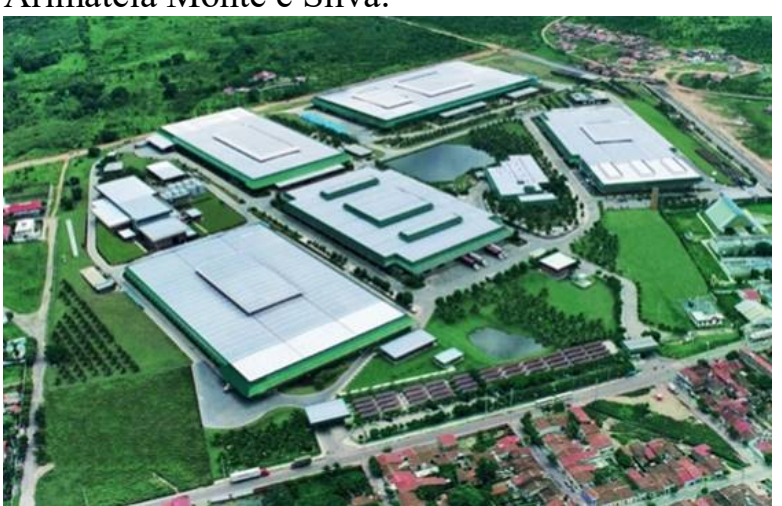

Fonte: Foto de autor desconhecido (s/d). Disponível em: $<$ http://sobralagora.com.br/Acesso em 18 de ago. 2016.

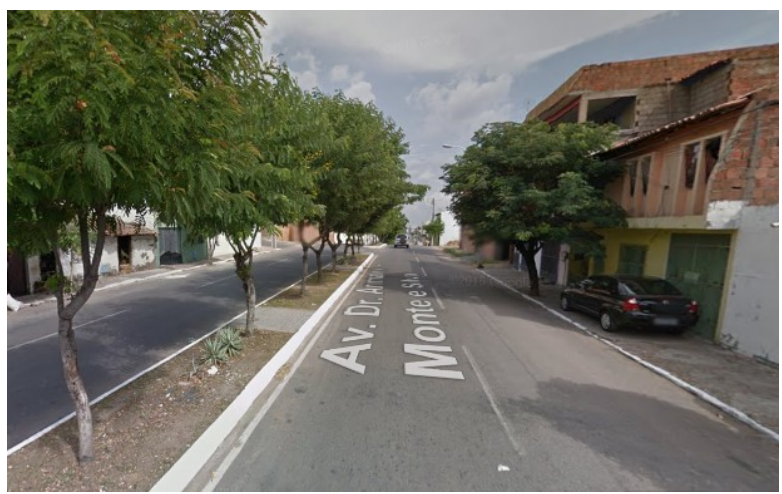

Fonte: Foto de Google Street View (2012). Disponível em: <https://www.google.com.br/maps>. Acesso em 18 de ago. 2016. 
Estas transformações dinamizaram os fluxos da cidade com sua região de influência, especialmente na inserção em sua economia urbana de um polo industrial, exemplificado pela implantação da indústria de calçados Grendene S/A (Figura 105), em 1993, que fez o PIB industrial do município se elevar para 63,00\% (FREIRE, 2011). Na representação axial, o núcleo de integração recai sobre o bairro Centro, tendo como eixo de expansão as avenidas Cleto Ferreira da Ponte (CE-440) e Dr. José Arimatéia Monte e Silva e a rua Jornalista Deolindo (que se destaca também na representação calculada para escolha).

Vale ressaltar que este bairro faz parte da poligonal de tombamento do Instituto do Patrimônio Histórico e Artístico Nacional - IPHAN, definida em 2000. O conjunto arquitetônico e urbanístico de Sobral abrange uma área que se estende da margem do rio Acaraú à Rua Coronel Monte Alverne, onde estão inúmeros imóveis e espaços públicos. A partir de então, a cidade passou a contar com uma série de investimentos do Programa de Aceleração do Crescimento - PAC Cidades Históricas, que promoveram intensas requalificações urbanas que refletem:

[...] uma reorganização política do espaço urbano, podendo nos mostrar um lado da urbe que sofre intervenções de higienização e reconfiguração das relações nos novos espaços construídos, tanto nos seus aspectos físicos quanto nos sociais. A visão publicizada pela administração pública municipal nos veículos de comunicação locais é a de "revitalização" e "modernização" da cidade (FERREIRA, 2009, s/p).

Uma das transformações da paisagem mais marcantes se deu na Margem Esquerda do rio Acaraú (Figura 107), o que Ferreira (2013) vai denominar como "Cid marketing", numa referência irônica ao conceito de city marketing ${ }^{62}$, por ser constantemente apresentada nas propagandas de divulgação do ex-Prefeito de Sobral e ex-governador do Estado do Ceará, Cid Ferreira Gomes. Associado a uma arquitetura contemporânea que requalificou e integrou alguns edifícios abandonados, ao mesmo tempo que contrasta com o conjunto tombado, o projeto criou novas áreas de lazer e equipamentos culturais para a cidade (a citar: a Biblioteca Pública Municipal Lustosa da Costa e a Escola de Cultura, Comunicação, Ofícios e Artes).

\footnotetext{
${ }^{62} \mathrm{O}$ city marketing e os planos estratégicos de cidade aparecem como importantes instrumentos do chamado novo planejamento urbano, que busca recuperar sua legitimidade quanto à intervenção pública, na perspectiva de colocar as cidades no novo mapa do mundo. Neste contexto, a produção de imagens tem um papel cada vez mais relevante na formulação de novas estratégias econômicas e urbanas orientadas, sobretudo, para a internacionalização da cidade, mas, também, para a obtenção de notáveis efeitos internos, particularmente no que se refere à construção de uma ampla adesão social a um determinado modelo de gestão e de administração da cidade. (SANCHÉZ, 2002, p. 25).
} 
Figura 106: Mapa axial de Sobral/CE calculado por Integração HH global (Rn).

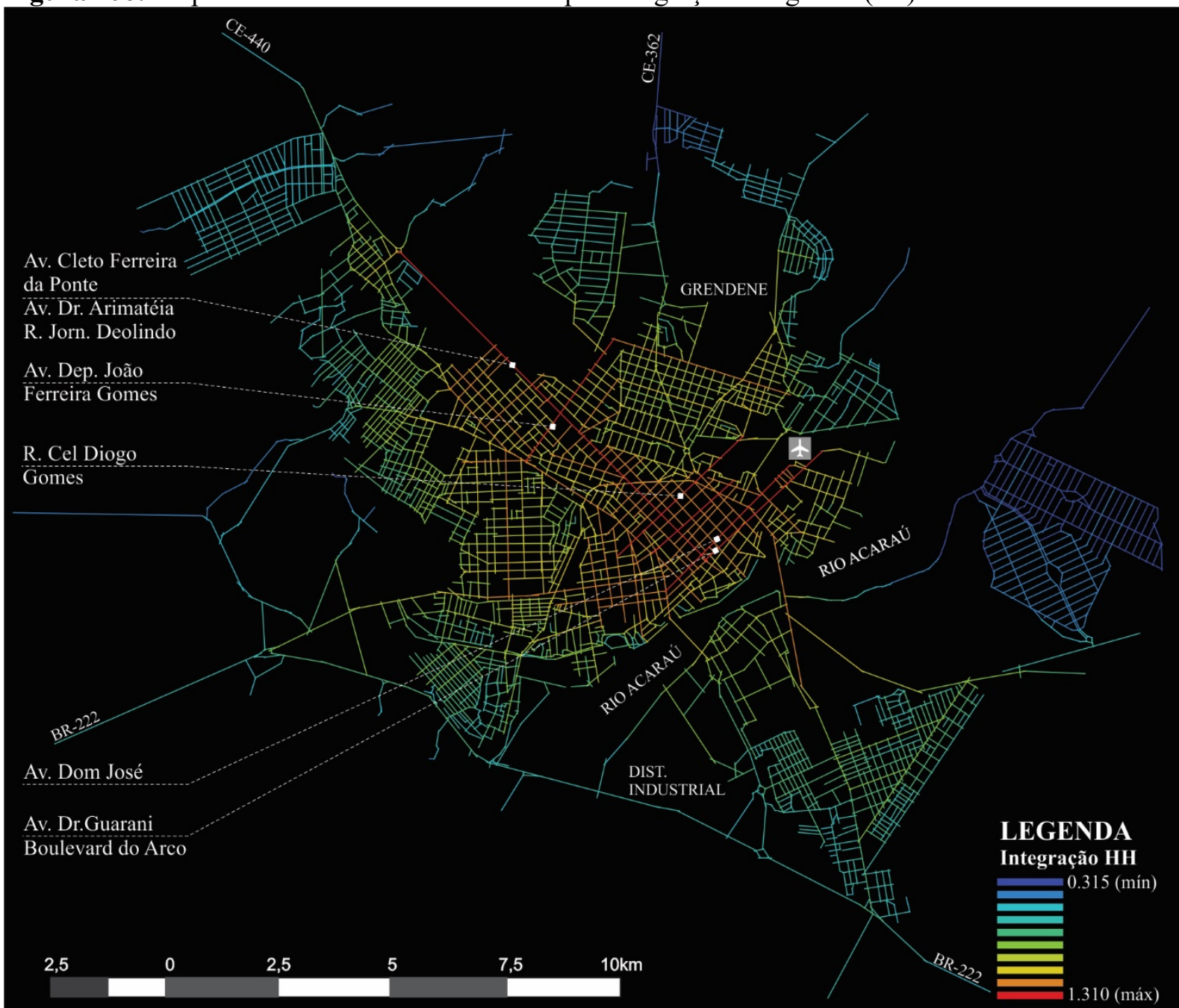

REPRESENTAÇÃO AXIAL - SOBRAL/CE INTEGRAÇÃO HH GLOBAL (RN)
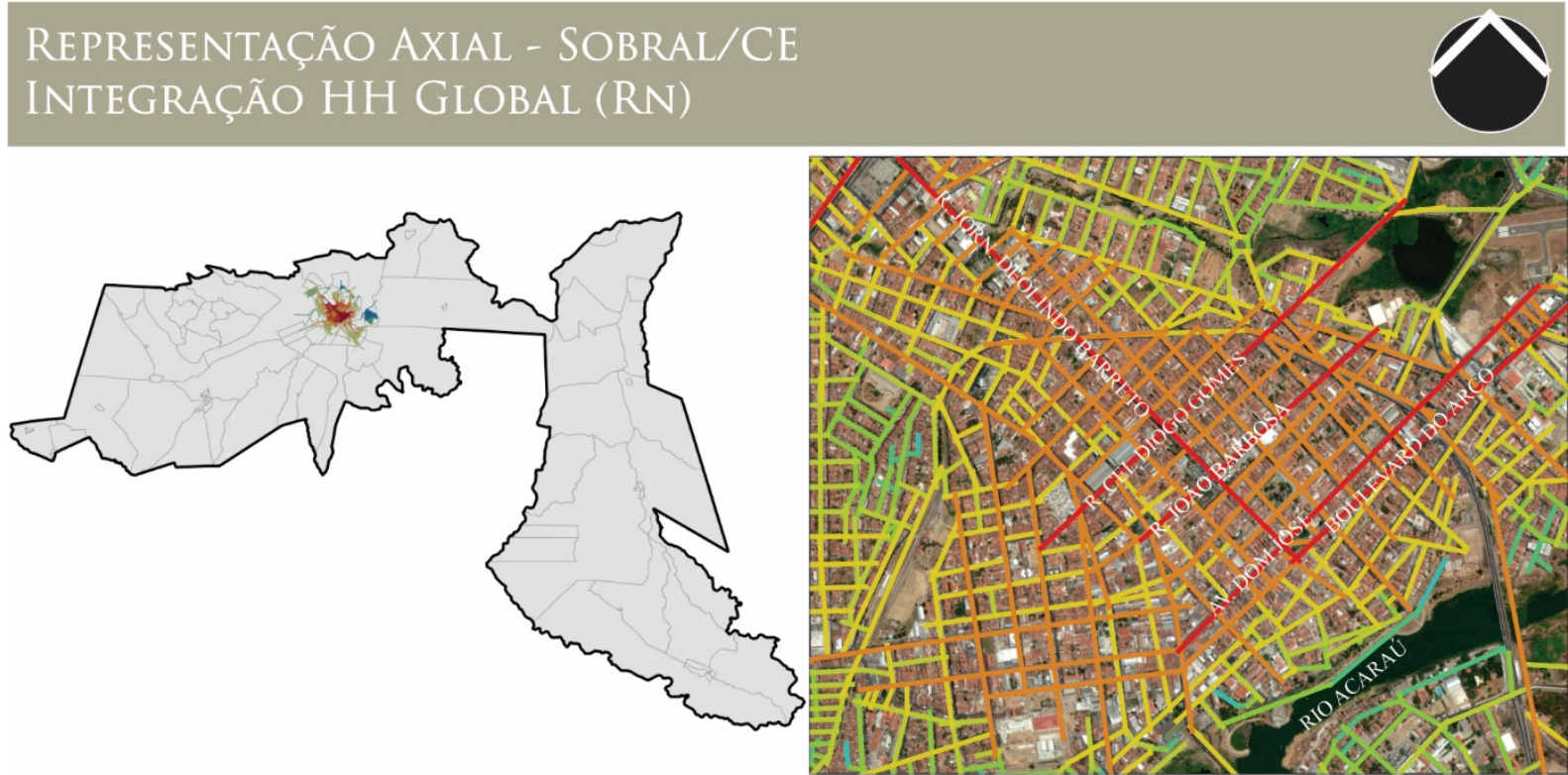

MAPA-CHAVE

NÚCLEO DE INTEGRAÇÃO -DETALHE

SOBRAL/CE

DO MAPA AXIAL - SOBRAL/CE

Fonte: Desenho de Amanda Brasil e revisão da autora (2016) a partir da Base Cartográfica do OpenStreetMap (2016) e imagens de satélite do Google Earth (2016). 
Figura 107: Vistas da intervenção sobre Margem Esquerda do rio Acaraú.

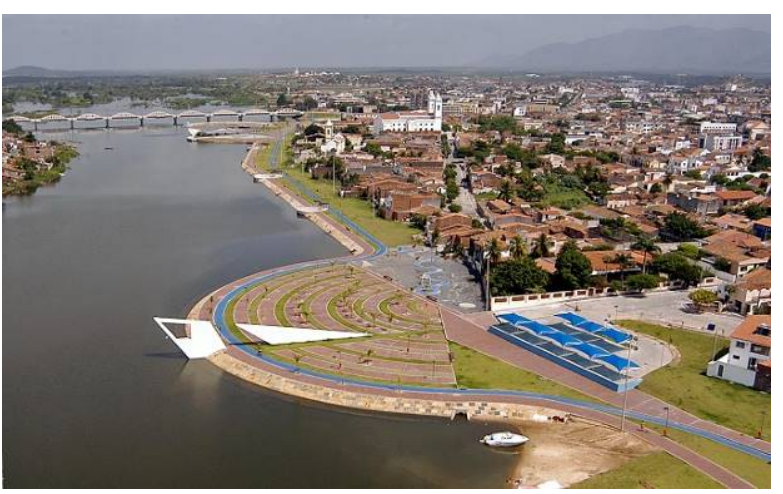

Fonte: Foto de autor desconhecido (s/d). Disponível em: <http://www.skyscrapercity.com/>. Acesso em 18 de ago. 2016.

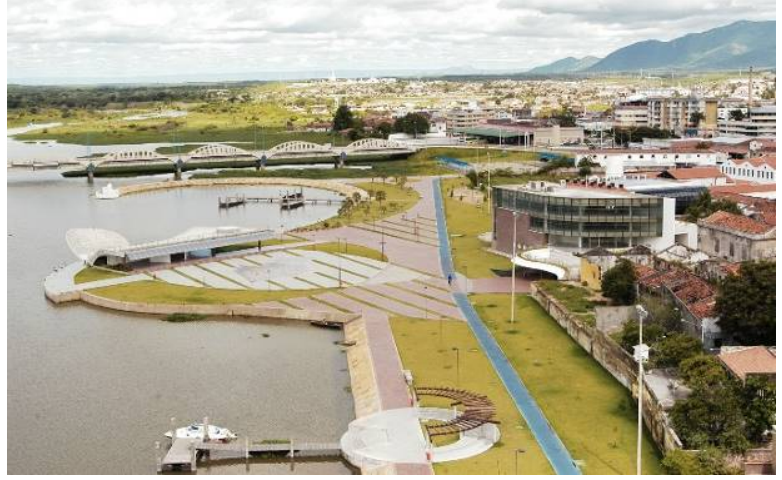

Fonte: Foto de autor desconhecido (s/d). Disponível em: <http://www.skyscrapercity.com/>. Acesso em 18 de ago. 2016.

Frente às novas práticas socioculturais que este espaço fomentou, como "Andar na margem" ou "ir pra [sic] Beira-rio" (FERREIRA, 2009, s/p), a nova imagem da cidade gerou diversos pontos de especulação imobiliária que se extrapolam além dessa área central. As pressões da alta acessibilidade e renovações urbanas sobre áreas patrimoniais são alvo de diversas críticas, pois revelam-se catalizadores para processos de gentifricação e substituição de usos (por vezes não condizentes ou não adaptados para o edifício histórico). $\mathrm{O}$ mapa de integração calculado para a representação de segmentos (Figura 109), reafirma a acessibilidade da área central (em laranja) de Sobral, embora coloque como vias mais integradas novamente as avenidas Cleto Ferreira da Ponte (CE-440) / Dr. José Arimatéia Monte e Silva e a Av. Idelfonso de Holanda Cavalcante (CE- 362), que circundam o centro.

Figura 108: Novos loteamentos em Sobral/CE.

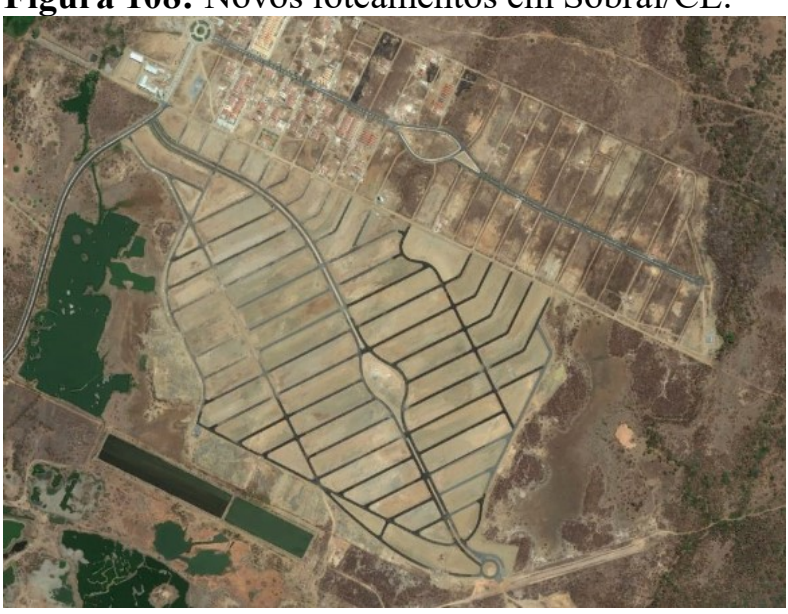

Fonte: Foto de Google Earth (2016). Acesso em 18 de ago. 2016

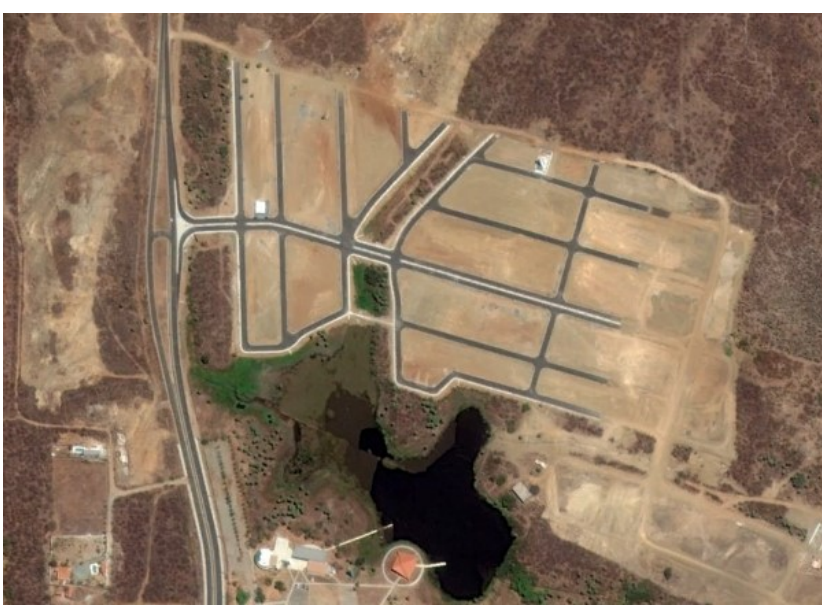

Fonte: Foto de Google Earth (2016). Acesso em 18 de ago. 2016. 
Complementarmente, em relação aos novos espaços residenciais, foi possível localizar na imagem de satélite (datada de março de 2015) uma série de novos loteamentos periféricos, porém ainda sem habitações (Figura 108). Essa expansão urbana é marcada por:

[...] novas formas de habitar na cidade, os condomínios horizontais fechados, alterando a estrutura da cidade, complexificando-a, além de marcar a expansão e descontinuidade do espaço urbano. Os agentes imobiliários junto com o a gestão pública criam diferentes estratégias para permitir uma constante reprodução do capital. Mas identificamos bairros na cidade de Sobral oriundos de ocupações irregulares e precárias, realizadas pela população desprovida de espaço de morar, com destaque para os bairros: Cidade José Euclides Ferreira Gomes, Vila União, Padre Palhano, Alto da Brasília, Vila Recanto (SOBRAL; HOLANDA, 2012, p.49).

Figura 109: Mapa de segmentos de Sobral/CE calculado por Integração.

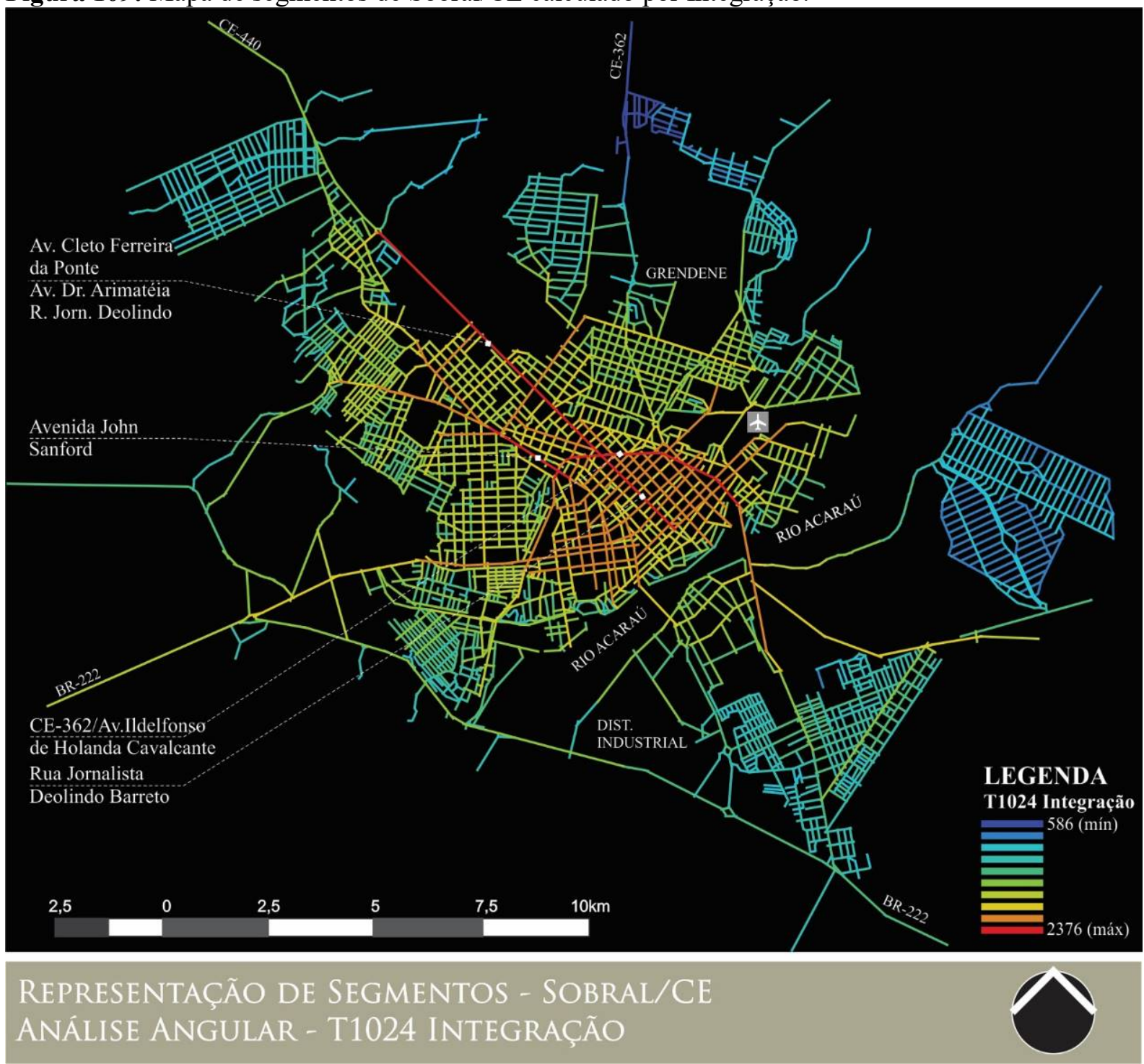

Fonte: Desenho gentilmente cedido por Paim (2015), com revisão feita pela autora a partir da Base Cartográfica do OpenStreetMap (2016) e imagens de satélite do Google Earth (2016). 
Assim, em Sobral, a mercadorização do solo urbano fomenta os processos de segregação urbana. Também é possível vislumbrar nessa cidade novos espaços para consumo, como a instalação de shoppings, como o North Shopping Sobral, locado no bairro Dom Expedito, na margem direita do Acaraú (Figura 110). Localizado nas franjas do núcleo de integração, porém separado dele pelo rio, esse empreendimento define um eixo de expansão ao longo da Av. Monsenhor Aloísio Pinto que passa a abrigar diversas concessionárias (Figura 111).

Figura 110: North Shopping Sobral. À esquerda e em vermelho, sua localização na foto aérea e, à direita, a vista das duas torres que recebem escritórios e um hotel.

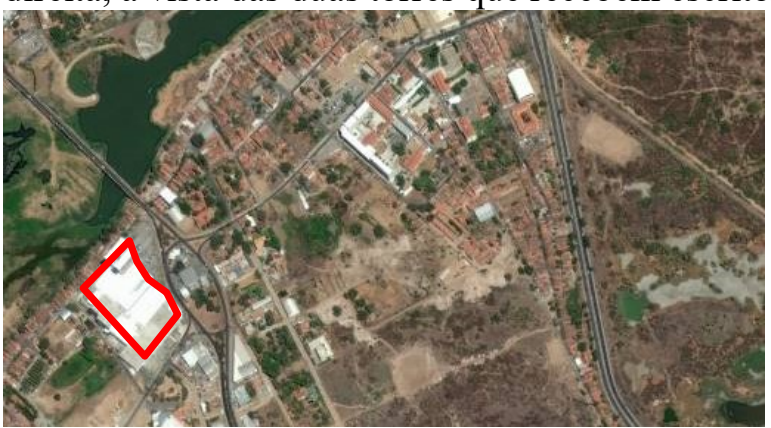

Fonte: Foto de Google Earth (2016). Acesso em 18 de ago. 2016.

Figura 111: À esquerda, Av. Monsenhor Aloísio Pinto e, à direita, uma vista geral dos bairros Centro (em primeiro plano) e Dom Expedito.

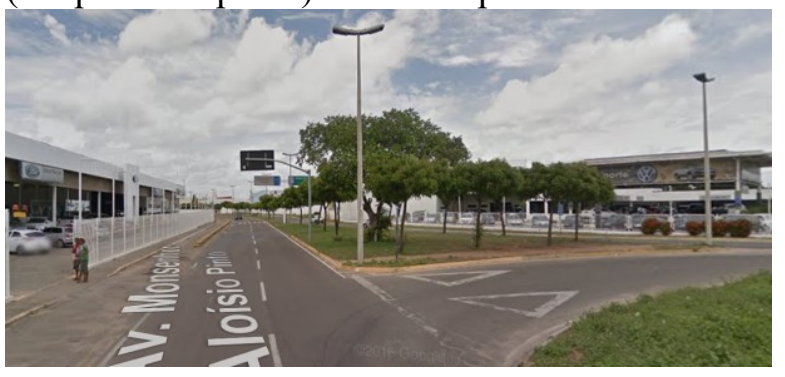

Fonte: Foto de Google Street View (2012). Disponível em: <https://www.google.com.br/maps>. Acesso em 18 de ago. 2016.

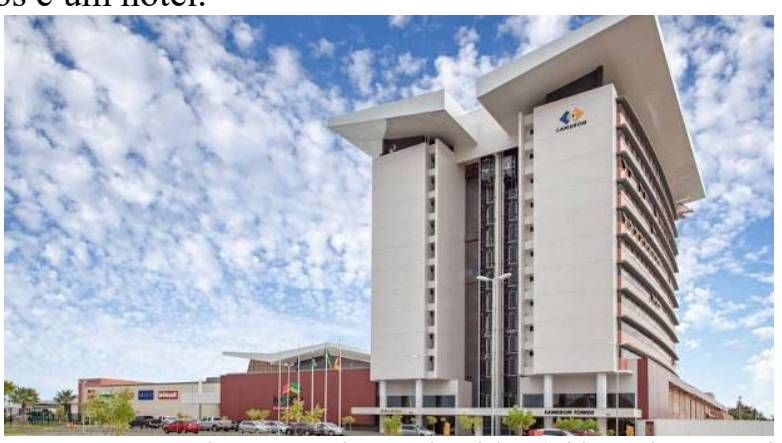

Fonte: Foto de autor desconhecido (s/d). Disponível em: <http://www.ricardomuratori.com.br/>. Acesso em 18 de ago. 2016.

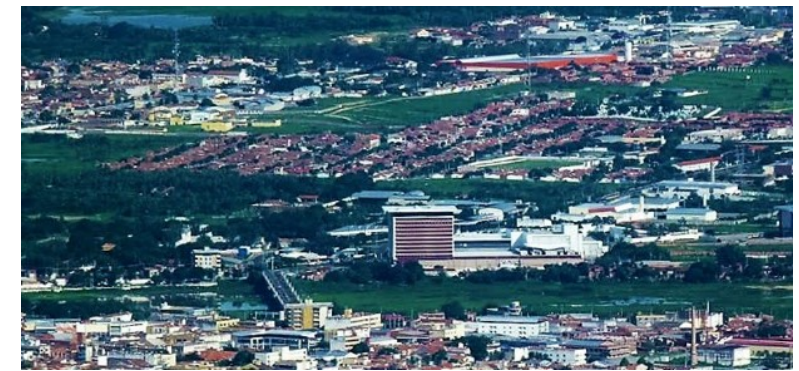

Fonte: Foto de autor desconhecido (s/d). Disponível em: <https://ssl.panoramio.com/> Acesso em $18 \mathrm{de}$ ago. 2016.

Em relação a representação axial calculada para escolha, tem destaque o sistema viário principal da cidade. Vale destacar que estas vias são contempladas no novo sistema de mobilidade implementado em Sobral, o qual combina o tradicional ônibus com o veículo leve sobre trilhos - VLT (Figura 112 e Figura 113). Aproveitando a antiga linha férrea, as obras de implantação do VLT tiveram início em 2011, sob o judice do Governo do estado (na gestão de Cid Gomes). A estimativa da prefeitura é que em 2018, quando o sistema estiver em pleno funcionamento, transportará cerca de 8 mil passageiros por dia. 
Figura 112: Mapa geral do sistema de mobilidade integrado de Sobral/CE.

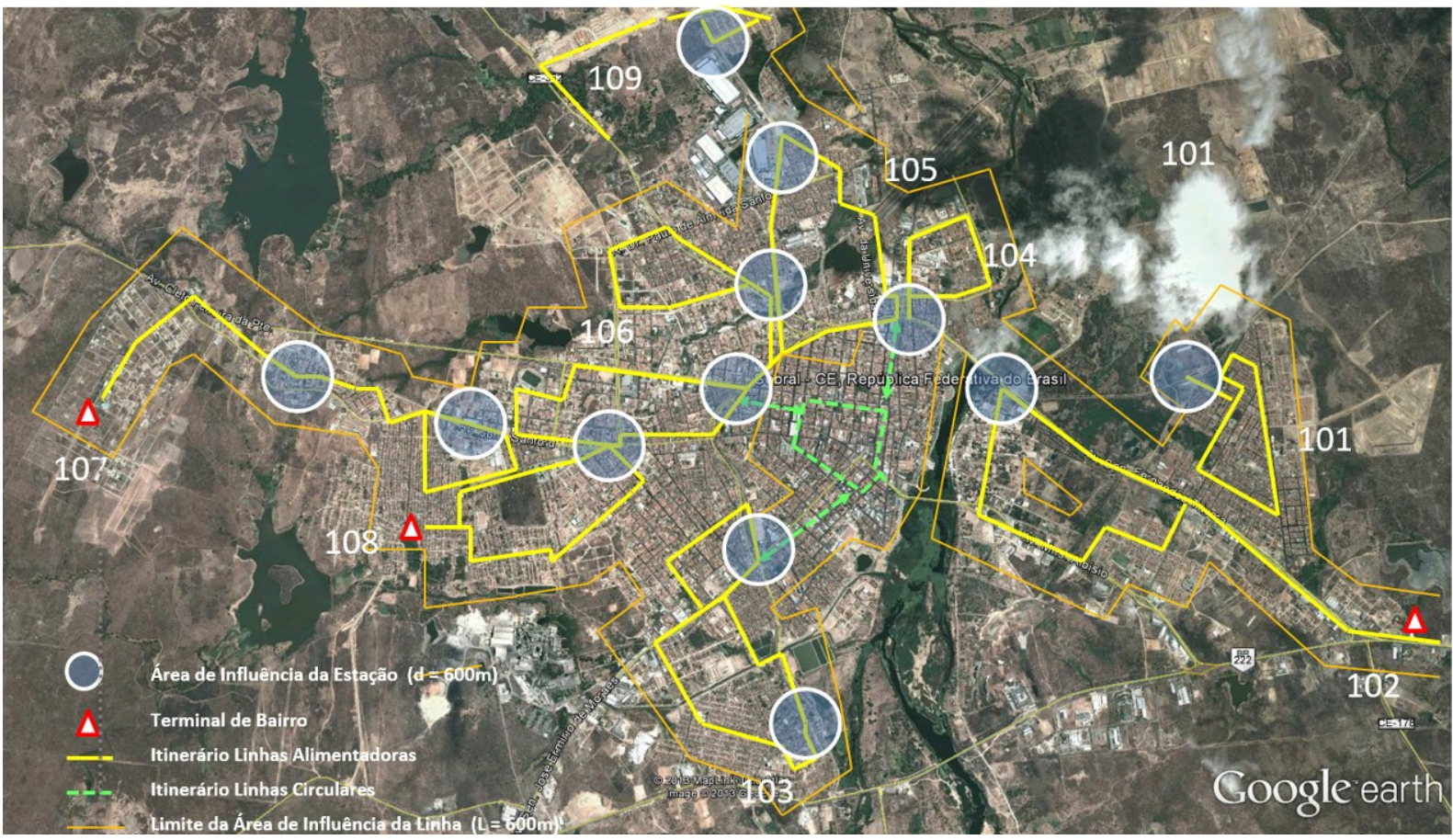

Fonte: Disponibilizado pela Prefeitura de Sobral (s/d).

Figura 113: Vistas do VLT em Sobral/CE.

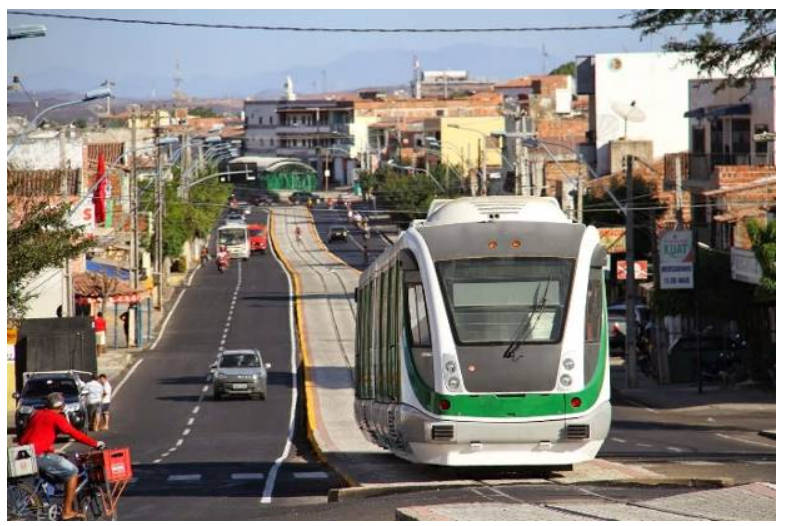

Fonte: Foto de autor desconhecido (s/d). Disponível em: <http://www.cearaagora.com.br/> Acesso em 18 de ago. 2016.

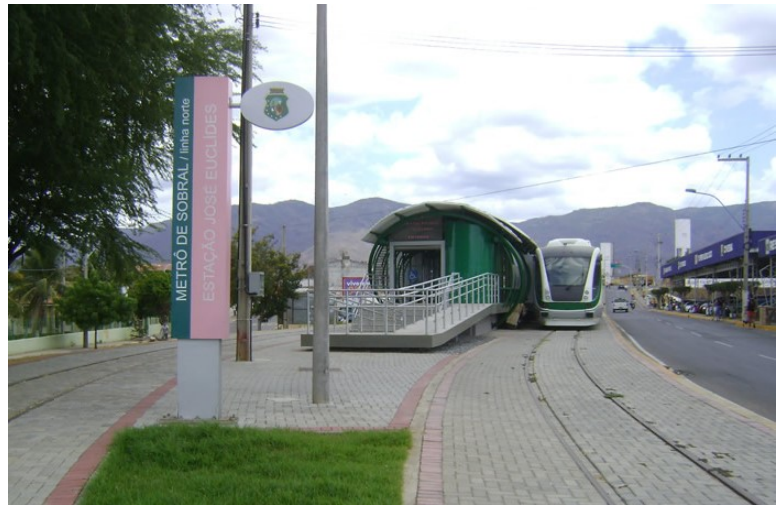

Fonte: Foto de autor desconhecido (s/d). Disponível em: $<$ http://www.skyscrapercity.com/>. Acesso em 18 de ago. 2016.

Para finalizar, traço o comparativo entre as representações calculadas para escolha (Figura 114 e Figura 115) e, em Sobral, repetem-se as mesmas características já comentadas para as cidades anteriores. Além do sistema viário que corta a cidade de noroeste a sudeste, têm ressalto as vias acesso a Grendene, com valores medianos na escala cromática. Como importante polo gerador de empregos e, portanto, de fluxos, o parque industrial atrai também uma série de outras fábricas e serviços para sua circunvizinhança, além de equipamentos (posto de saúdes, escolas, dentre outros) e de um comércio de apoio imediato às residências que caracteriza a área como um subcentro que responde a escala interna da cidade. 
Figura 114: Mapa axial de Sobral/CE calculado por Escolha (choice).

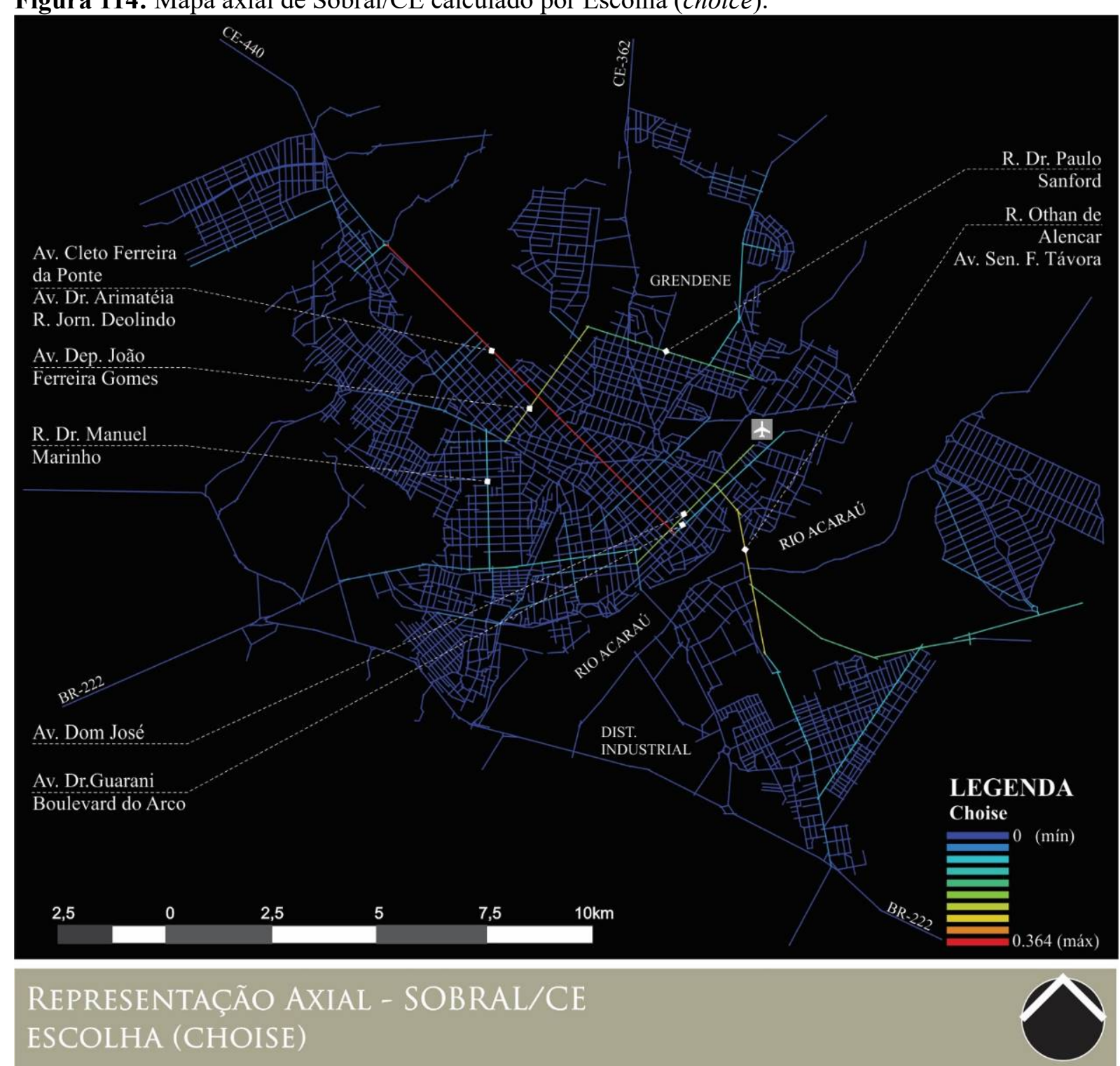

Fonte: Desenho de Amanda Brasil e revisão da autora (2016) a partir da Base Cartográfica do OpenStreetMap (2016) e imagens de satélite do Google Earth (2016).

A origem do município de Mossoró remete aos índios Monxorós. Segundo estudos do pesquisador potiguar Luiz Câmara Cascudo, citado pelo IBGE, as primeiras penetrações na área do que hoje é o município de Mossoró teriam ocorrido por volta de 1600. Cartas e documentos da época falavam sobre o encontro de salinas, que foram exploradas pelos holandeses Gedeon Morris de Jonge e Elbert Smiente até 1644. O distrito de Mossoró foi criado em 1842. Em março de 1852, o distrito foi elevado à categoria de vila, desmembrandose de Assu (na época "Princesa"). Virou cidade em 9 de novembro de 1870, através de lei provincial (IBGE, 2016). 
Figura 115: Mapa de segmentos de Sobral/CE calculado por Escolha (choice).

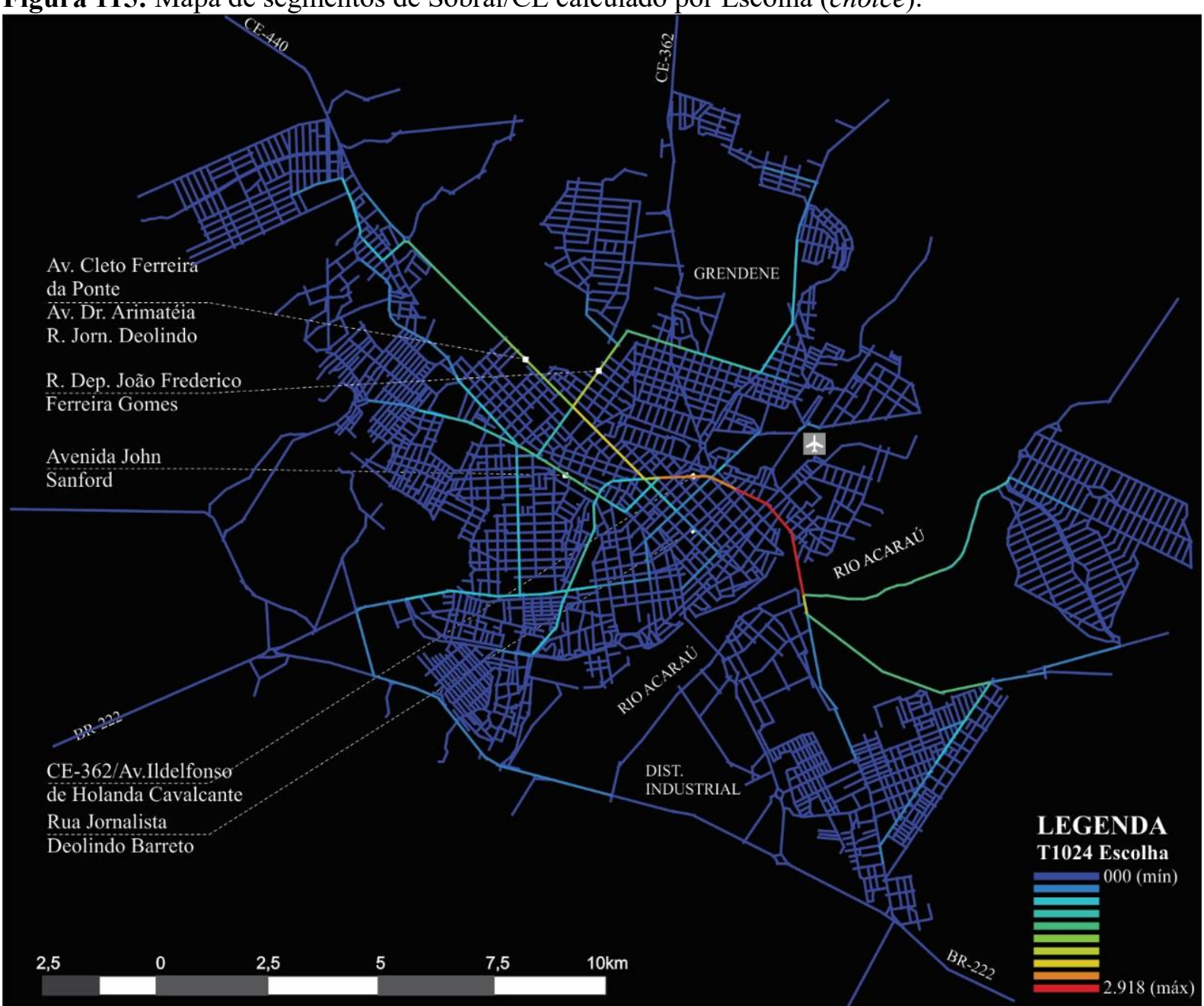

\section{REPRESENTAÇÃO DE SEGMENTOS - SOBRAL/CE ANÁLISE ANGULAR - T1024 ESCOLHA (CHOICE)}

Fonte: Desenho gentimenle cedido por Paim (2015), com revisão feita pela autora a partir da Base Cartográfica do OpenStreetMap (2016) e imagens de satélite do Google Earth (2016).

$\mathrm{Na}$ representação axial de Mossoró/RN apresentada na Figura 116, o núcleo de integração recai sobre os bairros Centro, Doze anos e Nova Betânia, seguindo os eixos definidos pelas ruas Frei Miguelinho e Duodécimo Rosado (Figura 117). Este centro congrega as principais atividades de comércio e prestação de serviço, que atende uma escala regional que, segundo Rocha (2005), gera uma população flutuante de cerca 30 mil pessoas, as quais encontram em Mossoró serviços especializados, tais como: saúde, educação, científicos, tecnológicos e de assistência técnica especializada, além das funções comerciais. Além desse centro tradicional, a cidade possui o Partage Shopping Mossoró (Figura 118), localizado no bairro Nova Betânia, com acesso por meio da BR-304. 
Figura 116: Mapa axial de Mossoró/RN calculado por Integração HH global (Rn).

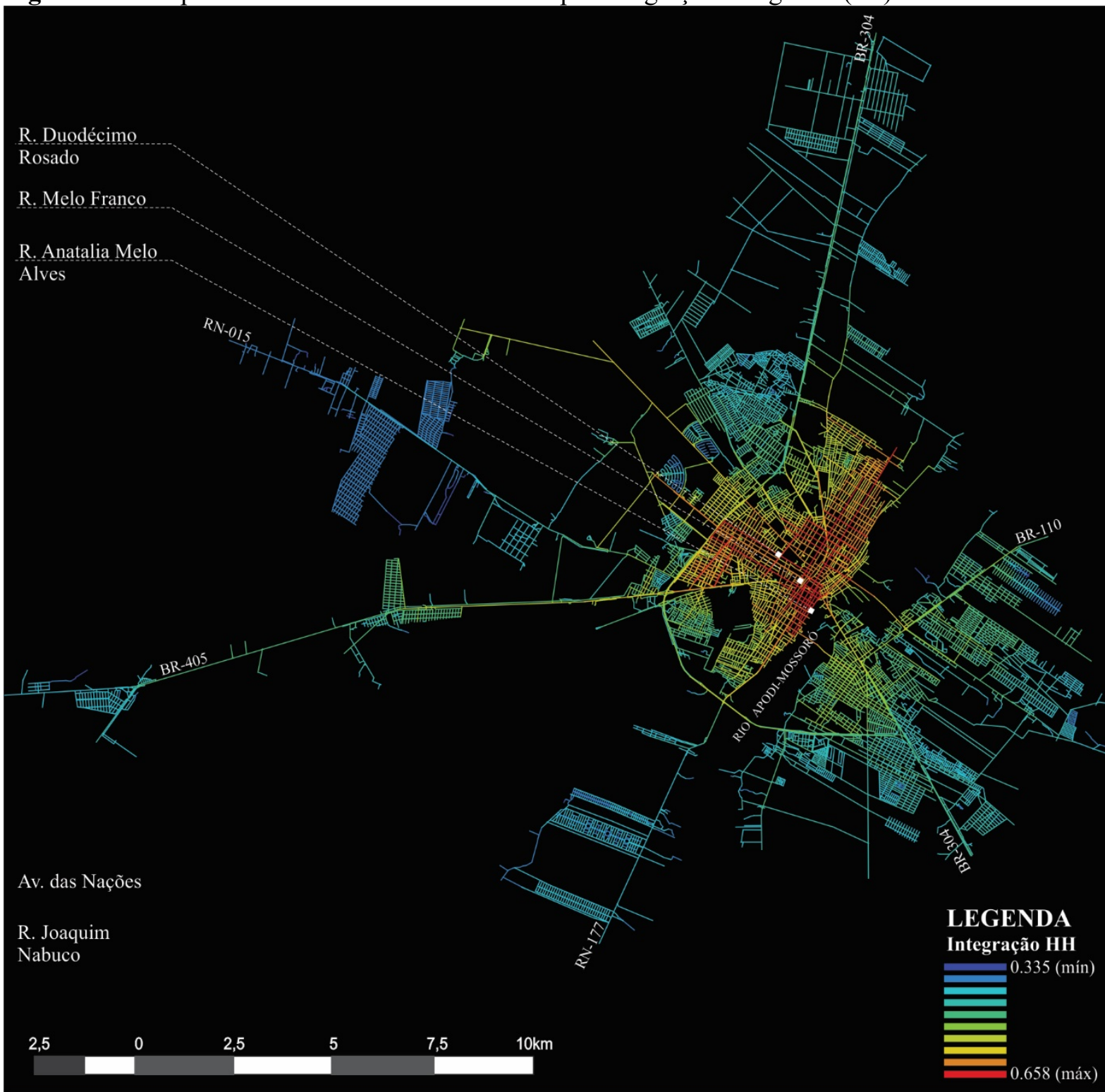

REPRESENTAÇÃO AXIAL - MOSSORÓ/RN

INTEGRAÇÃO HH GLOBAL (RN)
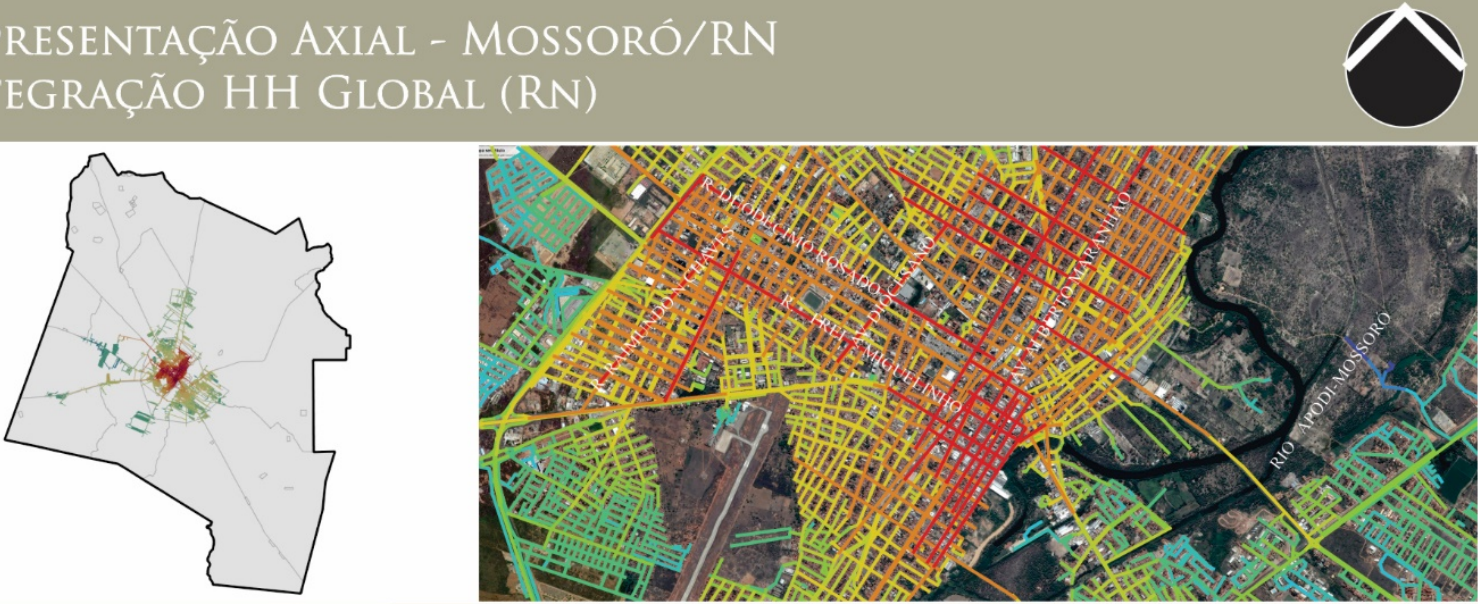

MAPA-CHAVE

NÚCLEO DE INTEGRAÇÃO -DETALHE

MOSSORÓ/RN

DO MAPA AXIAL - MOSSORÓ/RN

Fonte: Desenho gentilmente cedido por Paim (2015), com revisão da autora a partir da Base Cartográfica do OpenStreetMap (2016) e imagens de satélite do Google Earth (2016). 
Figura 117: À esquerda, a R. Frei Miguelinho e, à direita, a R. Duodécimo Rosado.

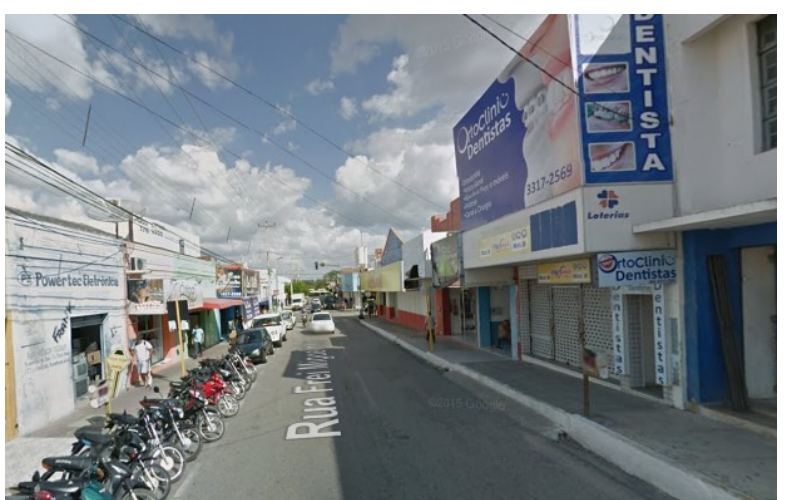

Fonte: Foto de Google Street View (2015). Disponível em: <https://www.google.com.br/maps>. Acesso em 18 de ago. 2016.

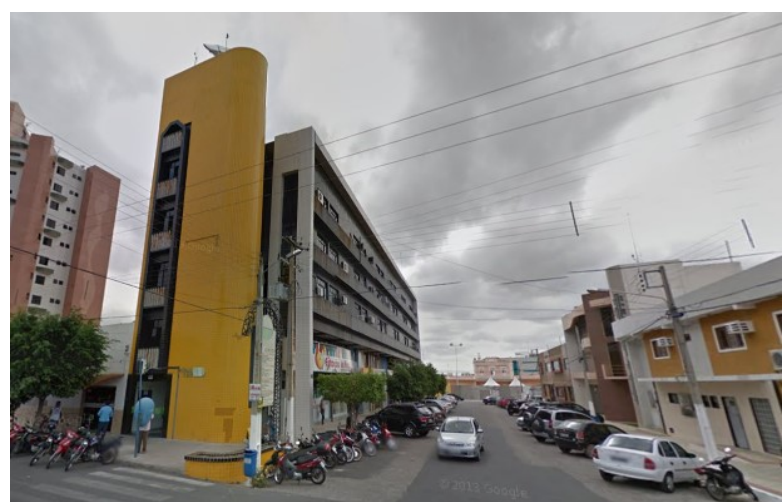

Fonte: Foto de Google Street View (2012). Disponível em: <https://www.google.com.br/maps >. Acesso em 18 de ago. 2016.

Figura 118: À esquerda, o Partage Shopping Mossoró e, à direita, uma imagem de satélite, na qual destaco em azul o condomínio Alphaville, em vermelho, o shopping, em amarelo, a Estrada da Alagoinha e, em laranja, o Hotel Thermas.

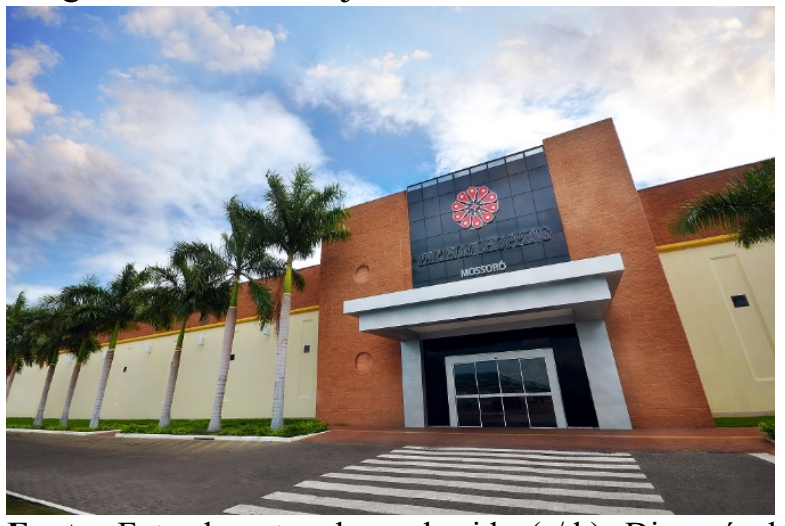

Fonte: Foto de autor desconhecido (s/d.). Disponível em: $<$ http://partageshoppingmossoro.com.br/>. Acesso em 18 de ago. 2016.

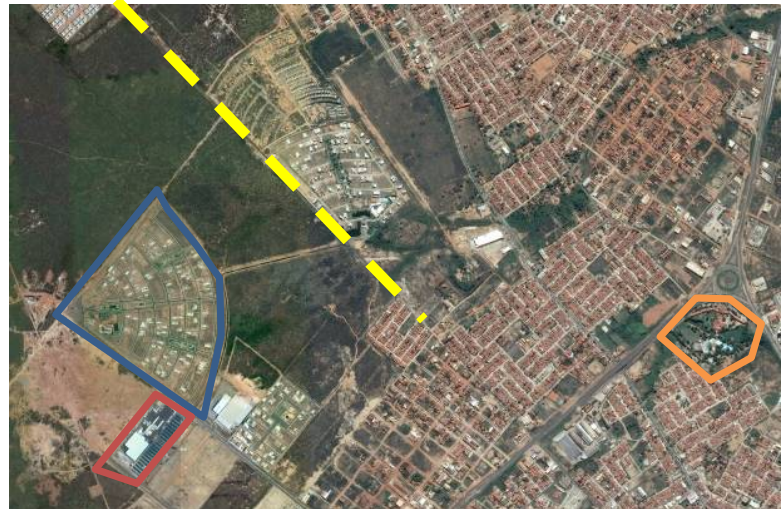

Fonte: Foto de Google Earth (2016) - editado pela autora. Acesso em 18 de ago. 2016.

Quanto as novas expansões residenciais, a área mais valorizada de Mossoró é também o bairro Nova Betânia, onde encontra-se o metro quadrado mais caro do município (ROCHA, 2005). Ali encontramos o Alphaville Mossoró, que reproduz a lógica imobiliária praticada pela empresa. Além desse bairro, cabe destacar outras duas áreas: o bairro Costa e Silva (ao sudeste) e os novos condomínios ao longo da Estada da Alagoinha. No primeiro caso, a proximidade dos campi da Universidade Estadual do Rio Grande Norte - UERN e da Universidade Federal Rural do Semiárido - UFERSA, atua como atrativo para o desenvolvimento de pequenos condomínios fechados de médio e alto padrão. Por outro lado, as áreas de entorno da estrada da Alagoinha (sem pavimentação - Figura 118) configuram uma faixa de expansão urbana sobre terrenos antes rurais, repetindo uma lógica recorrente nesse tipo de empreendimento imobiliário em diversas cidades aqui estudadas (e do Brasil 
como um todo). Complementarmente a esses espaços, assiste-se ainda na cidade a um processo de verticalização (Figura 121), concentrado em proximidade com o centro, área mais cara e valorizada do município para construção de apartamentos (ROCHA, 2005). Por ser uma área consolidada, a maioria dos terrenos disponíveis não são de grandes dimensões, o que pressiona a sua multiplicação em vários pavimentos.

Figura 119: Mapa de segmentos de Mossoró/RN calculado por Integração.

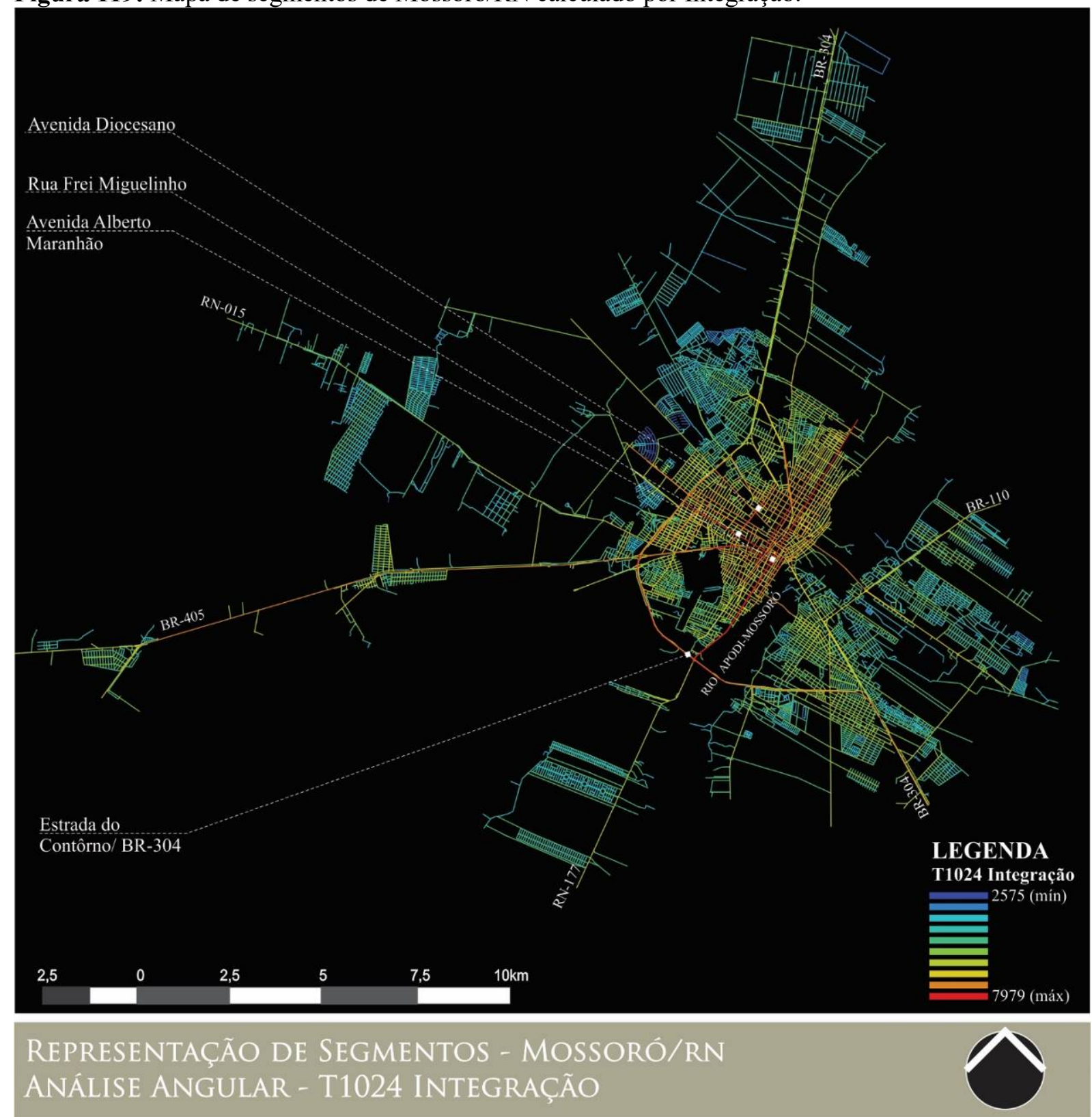

Fonte: Desenho gentilmente cedido por Paim (2015), com revisão da autora a partir da Base Cartográfica do OpenStreetMap (2016) e imagens de satélite do Google Earth (2016).

Em relação aos mapas calculados por Escolha (Figura 120 e Figura 122), além dos eixos já destacadas anteriormente, podemos ver que as vias de ligação intermunicipal, como a 
BR-304 e a RN-177, adquirem grande importância, pois elas interligam a cidade a duas metrópoles regionais: Recife e Fortaleza. A relação entre Mossoró e Fortaleza tem sido intensificada desde os anos 1990, pois há um grande número de poços de extração de petróleo e de fazendas agrícolas no trecho entre as duas cidades, e o escoamento dessa produção se dá majoritariamente pelo porto do Pecém/CE.

Figura 120: Mapa axial de Mossoró/RN calculado por Escolha (choice).

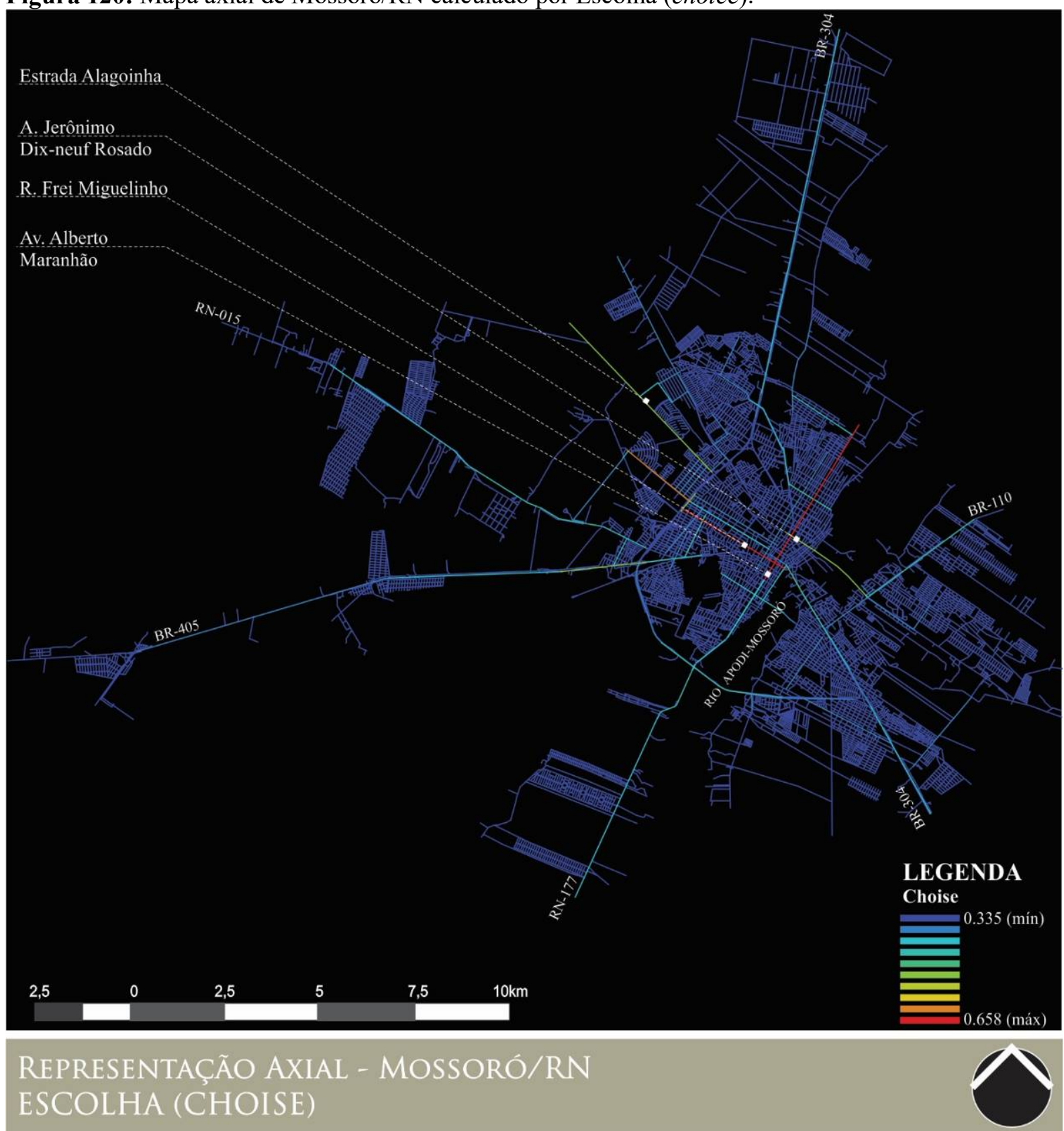

Fonte: Desenho gentilmente cedido por Paim (2 015), com revisão da autora a partir da Base Cartográfica do OpenStreetMap (2016) e imagens de satélite do Google Earth (2016). 
Figura 121: Processo de verticalização em Mossoró/RN.

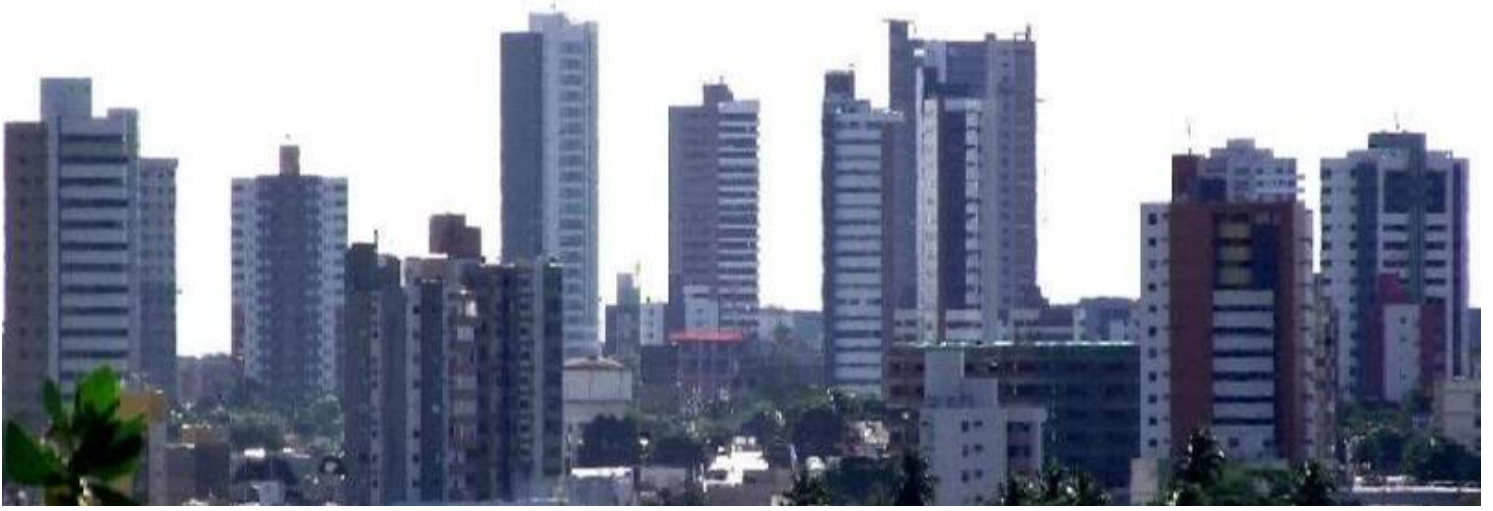

Fonte: Foto de autor desconhecido (2011.). Disponível em: <http://www.skyscrapercity.com/>. Acesso em 18 de ago. 2016.

Figura 122: Mapa de segmentos de Mossoró/RN calculado por Escolha (choice).

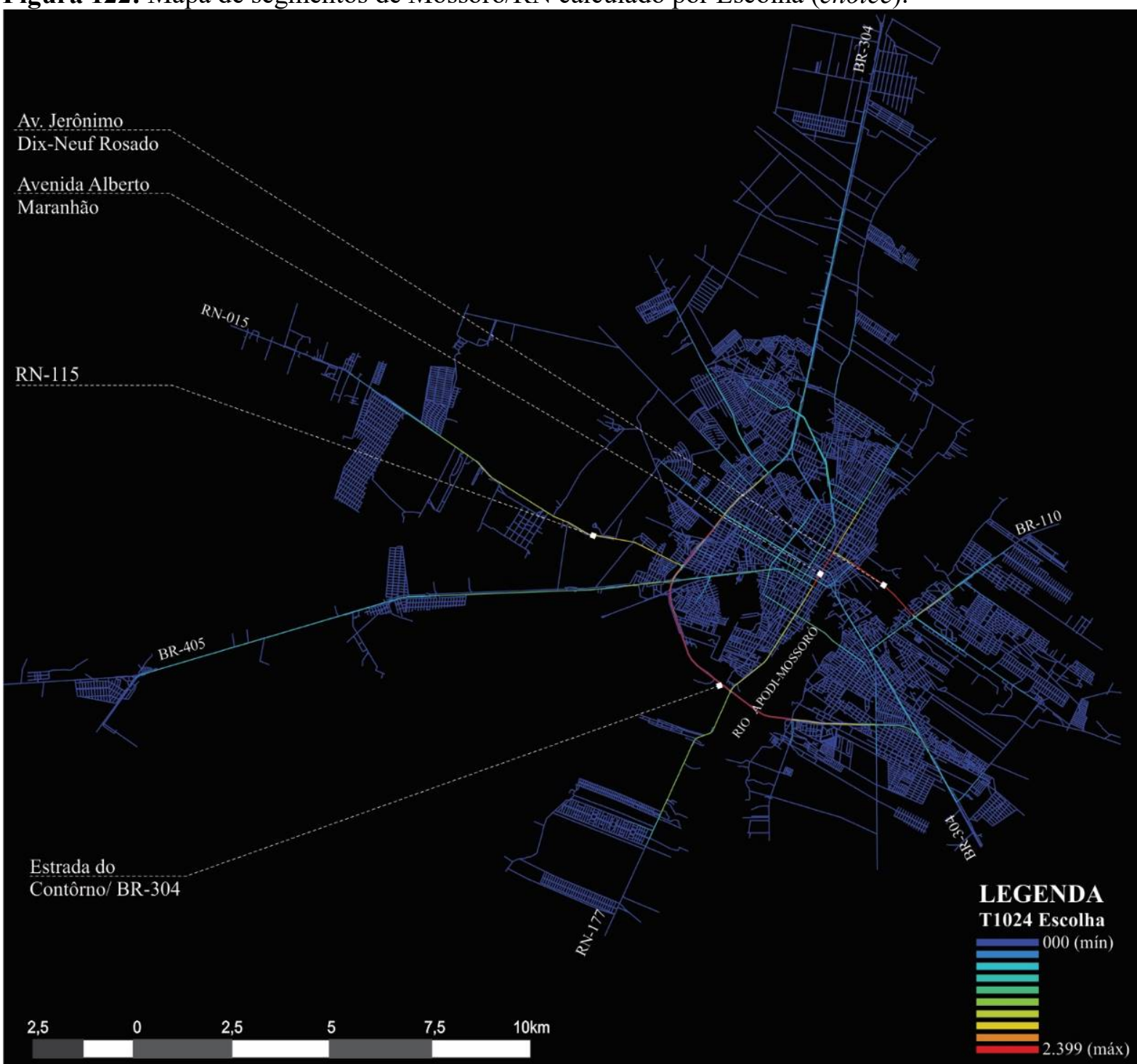

REPRESENTAÇÃO DE SEGMENTOS - MOSSORÓ/RN ANÁLISE ANGULAR - T1024 ESCOLHA (CHOICE)

Fonte: Desenho gentilmente cedido por Paim (2015), com revisão da autora a partir da Base Cartográfica do OpenStreetMap (2016) e imagens de satélite do Google Earth (2016). 
A cidade de Caruaru começou a tomar forma em 1681, quando o governador Aires de Souza de Castro concedeu à família Rodrigues de Sá uma sesmaria com o intuito de desenvolver a agricultura e a criação de gado, denominada Fazenda Caruru. Pouco tempo após a morte do patriarca, a fazenda ganhou uma capela, dedicada à Nossa Senhora da Conceição, que foi acolhendo um pequeno povoado ao seu redor. Devido à sua posição geográfica favorável, no coração do Agreste, passagem obrigatória do transporte de gado do Sertão para o Litoral, logo se estabeleceram diversas propriedades agropastoris. O Distrito criado com a denominação de Caruaru, pela Lei Municipal n. ${ }^{\circ}$ 3, de 2 de dezembro de 1892, era subordinado ao município de Bonito. Foi elevado à categoria de vila em 1848 e, em 1865, à condição de cidade (IBGE, 2016). O desenvolvimento do município teve seu apogeu a partir de 1896, após a construção da Great Western, linha férrea que conecta a cidade à capital pernambucana. Pelos seus trilhos era escoada a produção agrícola, além das mercadorias de sua tradicional feira. Iniciada em 2001 pelo governo pernambucano, a duplicação da principal rodovia que dá acesso ao município, a BR-232, foi crucial para a industrialização da sua economia e para o crescimento do setor de serviços.

Fechando o Grupo de Controle 01, a representação construída para a cidade de Caruaru/PE (Figura 126) demonstra a formação de um núcleo de integração ao longo da BR104, se espalhando ao longo dos bairros lindeiros a esta rodovia. Na modelagem de segmentos há um detalhamento nos resultados e há, também, destaque ao eixo formado pelas ruas Leão dourado/ 13 de Maio/ 15 de Novembro, as quais congregam os principais usos comerciais, além de serem parte do núcleo original do assentamento (Figura 123).

Figura 123: À esquerda, a BR-104. À direita, a R. Leão Dourado.

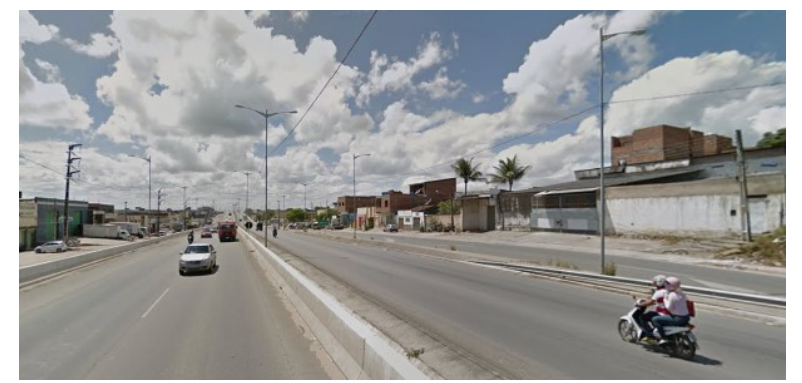

Fonte: Foto de Google Street View (2015). Disponível em: <https://www.google.com.br/maps>. Acesso em 18 de ago. 2016.

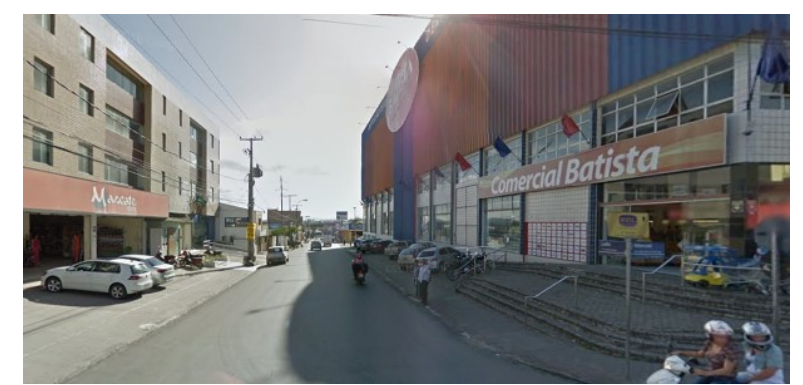

Fonte: Foto de Google Street View (2015). Disponível em: <https://www.google.com.br/maps>. Acesso em 18 de ago. 2016.

A pujança comercial da cidade é exemplificada pela sua feira, eternizada no cancioneiro popular pela música de Onildo Almeida na voz o Luiz Gonzaga. Foi a feira que 
deu origem a cidade e que possibilitou o desenvolvimento de "um comércio formal [que] se estabelece na área central e passa a se beneficiar da atração e do grande fluxo de pessoas que o mercado ao ar livre exercia em toda a região agreste pernambucana, fortalecendo a simbiose do comércio formal com o informal da feira” (MIRANDA, 2009, s/p.). Entretanto, a feira tomou grandes dimensões e passou a causar transtornos de mobilidade e de infraestrutura, até que foi transferida para outro lugar: o Parque 18 de Maio (MIRANDA, 2009).

Figura 124: Feira de Caruaru, à esquerda, quando era locada no centro da cidade (1992) e, à direita, nos dias atuais ocupando seu novo espaço.

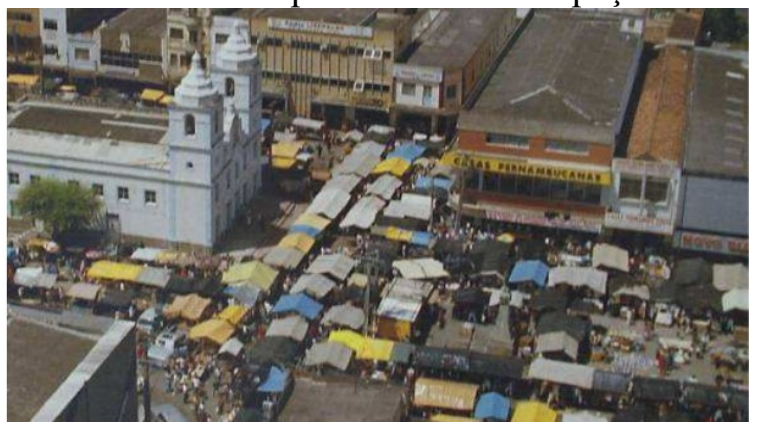

Fonte: Jornal Vanguarda apud Miranda (2009).

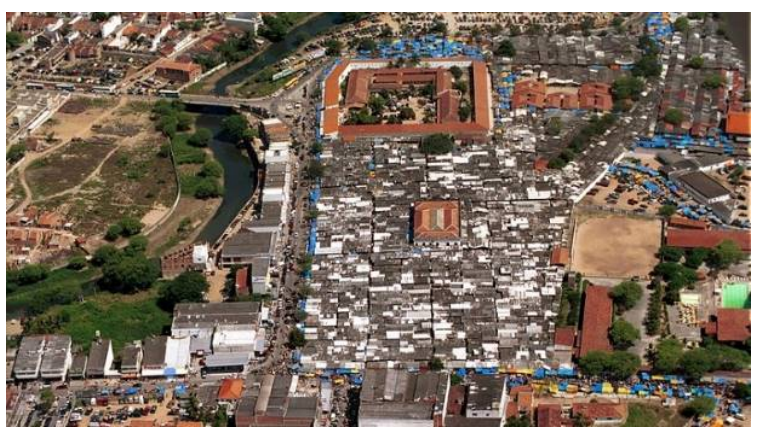

Fonte: Foto de divulgação Prefeitura de Caruaru (s/d). Disponível em: $<$ http://ecopassaporte.com/>. Acesso em 18 de ago. 2016.

À parte esse comércio tradicional, Caruaru já vivencia a instalação de shoppings, a exemplo do Caruaru Shopping (Figura 125), empreendimento inaugurado e que gera um fluxo de visitantes acima de 850 mil pessoas por mês ${ }^{63}$. Quanto a sua localização, o shopping encontra-se na parte sudeste da cidade, cujos acessos principais são a BR-232 e as vias em destaque nos mapas calculados por Escolha (Figura 131 e Figura 133).

Figura 125: Caruaru Shopping, à esquerda, na imagem de satélite (em vermelho) e, à direita, em uma vista aérea.

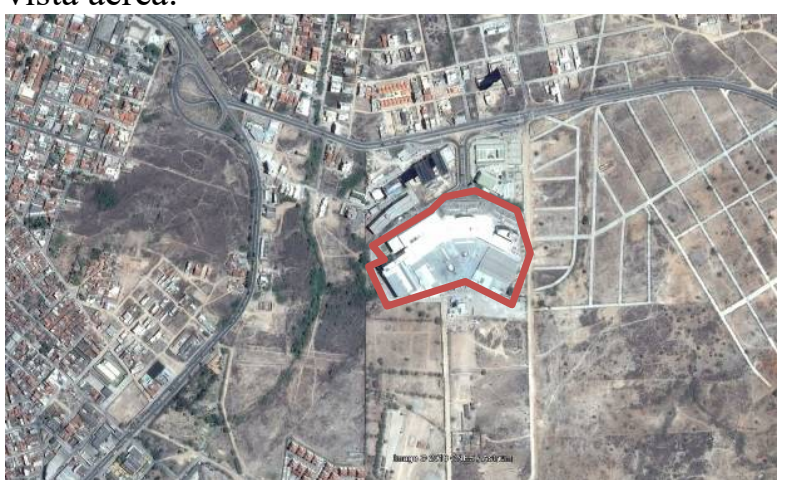

Fonte: Foto de Google Earth (2016) - editado pela autora. Acesso em 18 de ago. 2016.

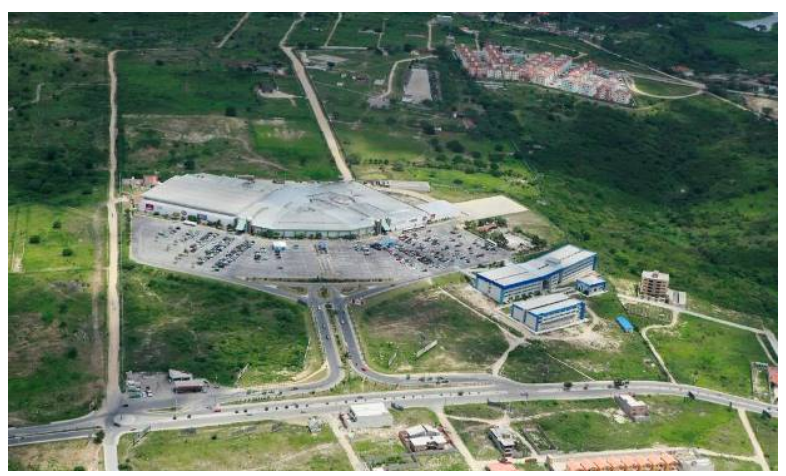

Fonte: Foto de Raniere Lopes (2015). Disponível em: $<$ http://www.skyscrapercity.com/>. Acesso em $18 \mathrm{de}$ ago. 2016.

\footnotetext{
${ }^{63}$ Segundo dados do site oficial <http://www.caruarushopping.com/quem-somos/>. Acesso em 21 ago. 2016.
} 
Figura 126: Mapa axial de Caruaru/PE calculado por Integração HH global (Rn).

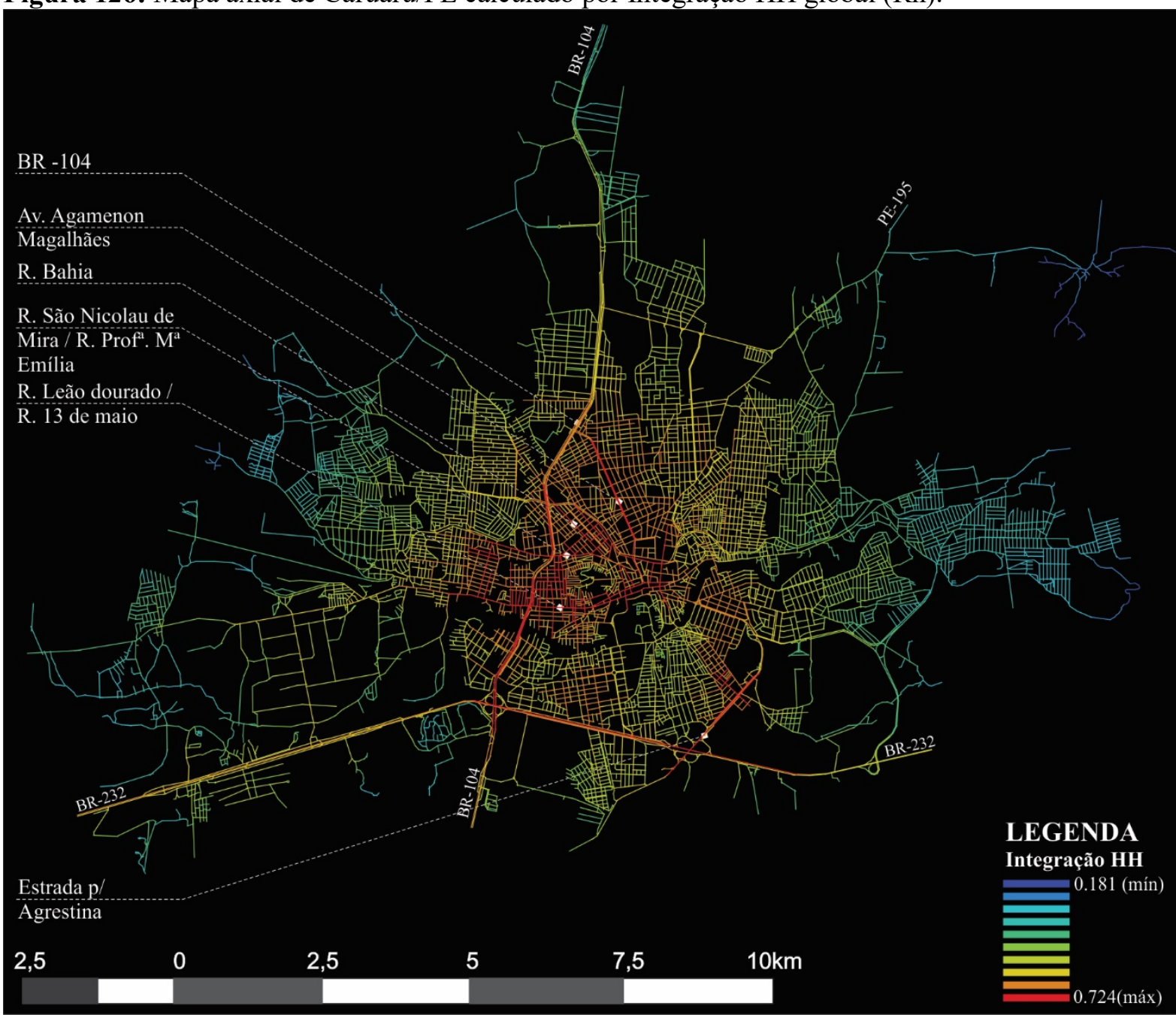

REPRESENTAÇÃO AXIAL - CARUARU/PE INTEGRAÇÃO HH GLOBAL (RN)
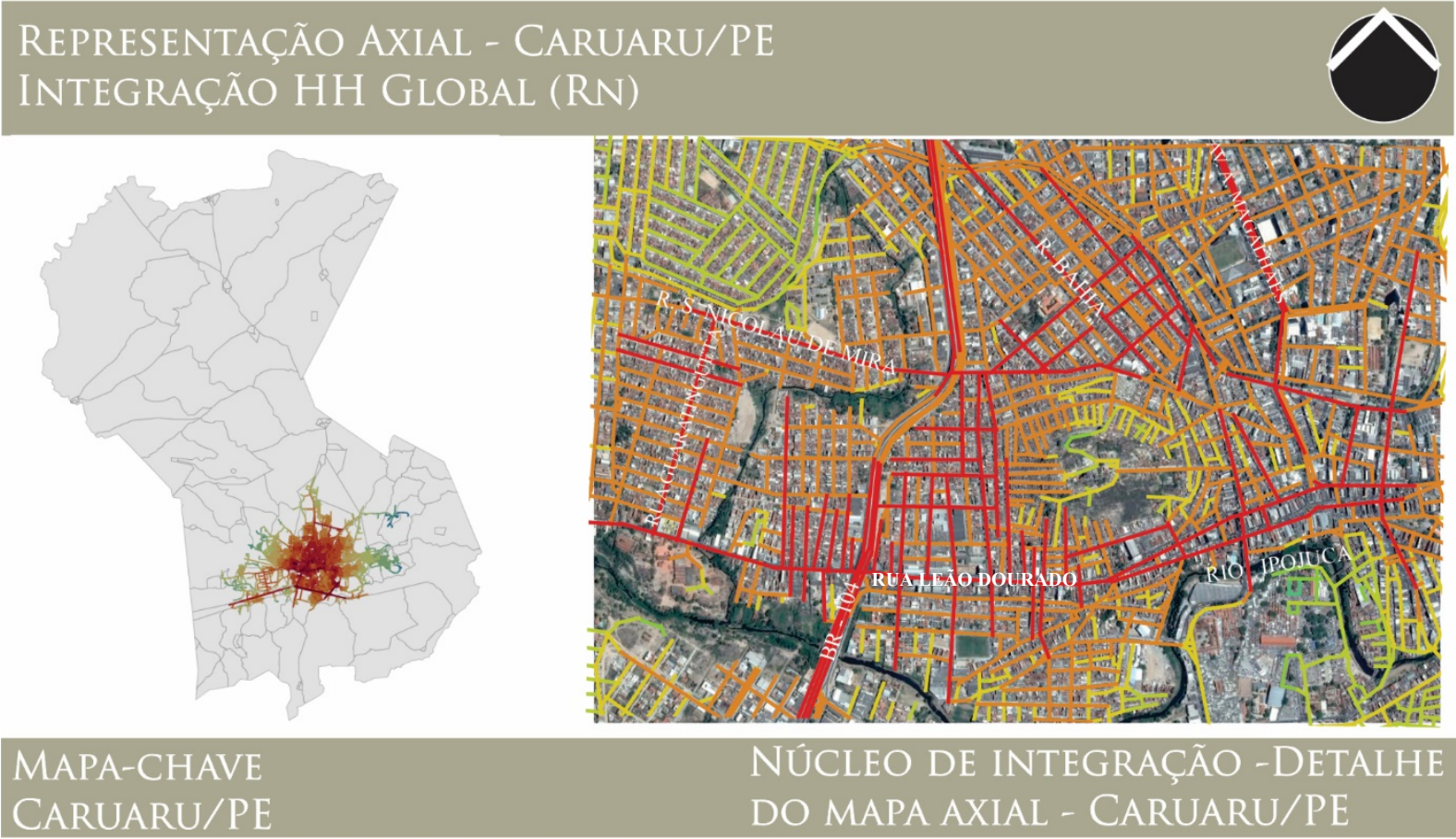

Fonte: Desenho gentilmente cedido por Paim (2015), com revisão da autora a partir da Base Cartográfica do OpenStreetMap (2016) e imagens de satélite do Google Earth (2016). 
A cidade também assiste a um processo inicial de verticalização (Figura 127) concentrado no bairro Maurício de Nassau. Esta porção do espaço urbano possui características que contribuem para a multiplicação do solo: boa localização, do ponto de vista da sua acessibilidade (próximo ao centro), infraestrutura básica e terrenos menores e mais valorizados. Essas novas áreas de habitação para as faixas de renda alta e média parecem causar um deslocamento do setor terciário superior, caracterizado por um comércio e serviços de maior valor agregado, como: clinicas médicas, escritórios, escolas particulares.

Figura 127: Processo de verticalização de Caruaru/PE.

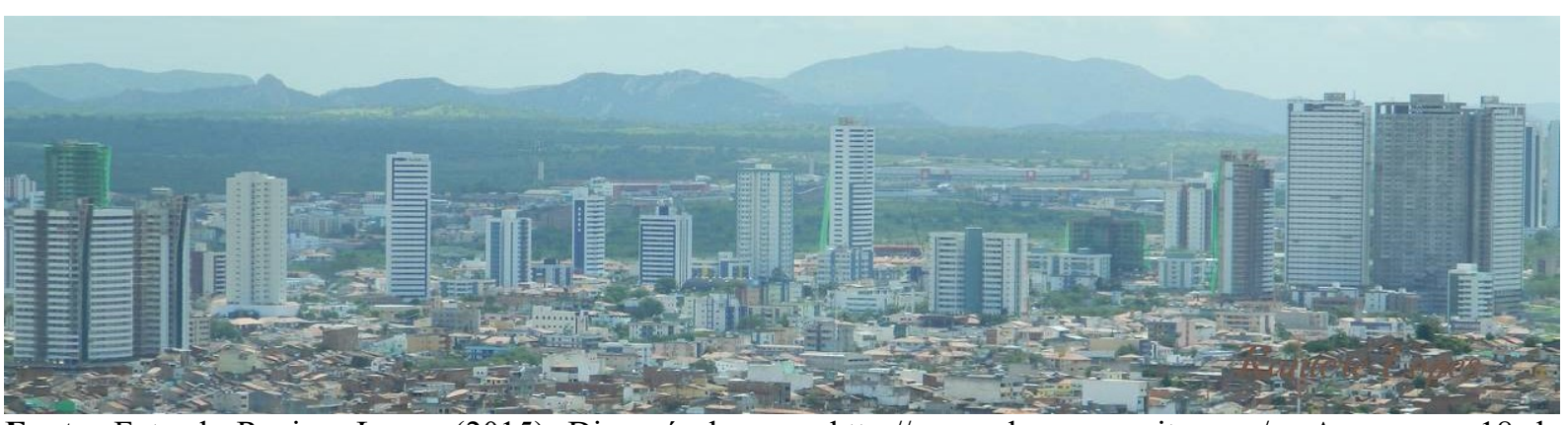

Fonte: Foto de Raniere Lopes (2015). Disponível em: <http://www.skyscrapercity.com/>. Acesso em $18 \mathrm{de}$ ago. 2016.

Soma-se a isso os processos de expansão horizontal, calcados em novos loteamentos e condomínios fechados que definem as novas maneiras de morar, ditadas pelo mercado imobiliário. Um vetor de localização dessas expansões para as altas faixas de renda se dá ao norte, na margem leste da BR-104 e, ao leste, ao longo da PE-195 (Figura 128). Em sentido oposto, no oeste da BR encontramos os empreendimentos voltados para as faixas baixa e médias, exemplificados pelos blocos de apartamento tipo " $\mathrm{H}$ " e as residências padronizadas nos loteamentos abertos, onde predomina a padronização das residências e pouco acesso a equipamentos urbanos (Figura 130).

Figura 128: À esquerda, imagem de satélite do condomínio fechado Quintas da Colina e, à direita, exemplo de uma residência neste empreendimento, cujo valor venal é de $\mathrm{R} \$ 650.000,00$.

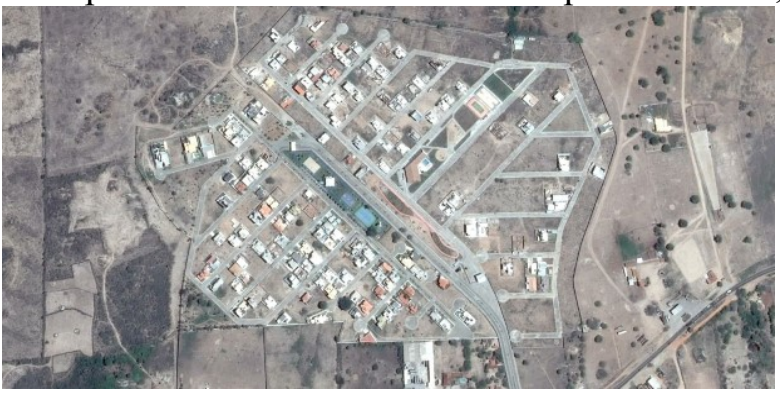

Fonte: Foto de Google Earth (2016) - editado pela autora. Acesso em 18 de ago. 2016.

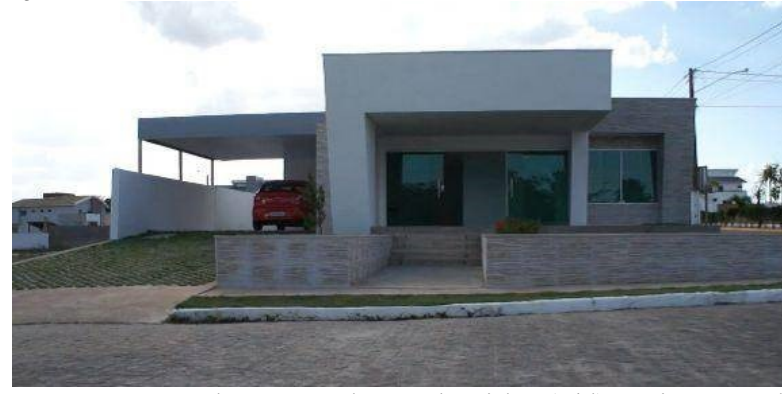

Fonte: Foto de autor desconhecido (s/d). Disponível em: <http://pe.mgfimoveis.com.br/>. Acesso em $18 \mathrm{de}$ ago. 2016. 
Figura 129: Mapa de segmentos de Caruaru/PE calculado por Integração.

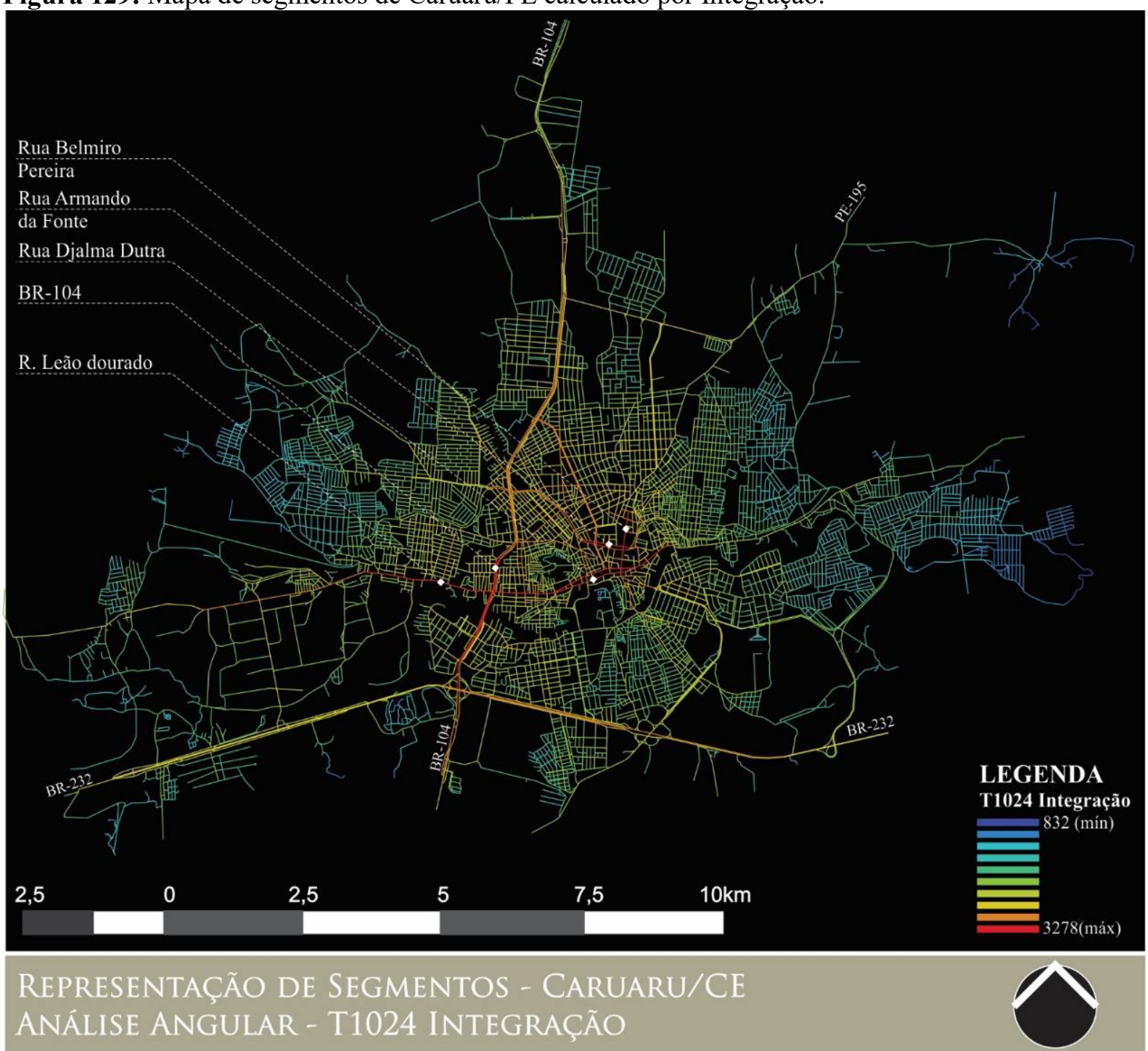

Fonte: Desenho gentilmente cedido por Paim (2015), com revisão da autora a partir da Base Cartográfica do OpenStreetMap (2016) e imagens de satélite do Google Earth (2016).

Figura 130: À esquerda, imagem de satélite do bairro Boa Vista e, à direita, exemplo do conjunto Jardim Ipojuca, que possui apartamentos com média de $50 \mathrm{~m}^{2}$.

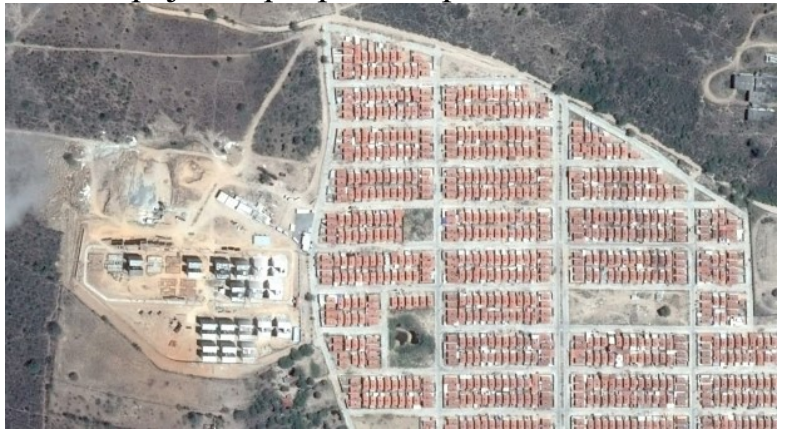

Fonte: Foto de Google Earth (2016) - editado pela autora. Acesso em 18 de ago. 2016.

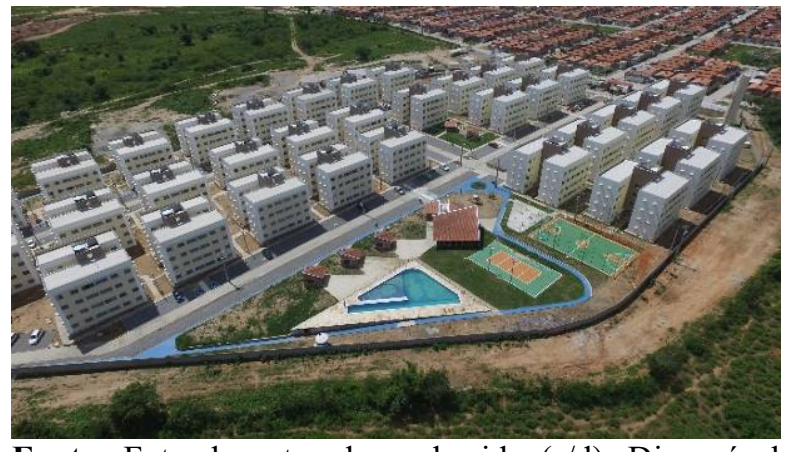

Fonte: Foto de autor desconhecido (s/d). Disponível em: $\quad<$ http://www.multtecnicaengenharia.com.br $>$. Acesso em 18 de ago. 2016. 
Figura 131: Mapa axial de Caruaru/PE calculado por Escolha (choice).

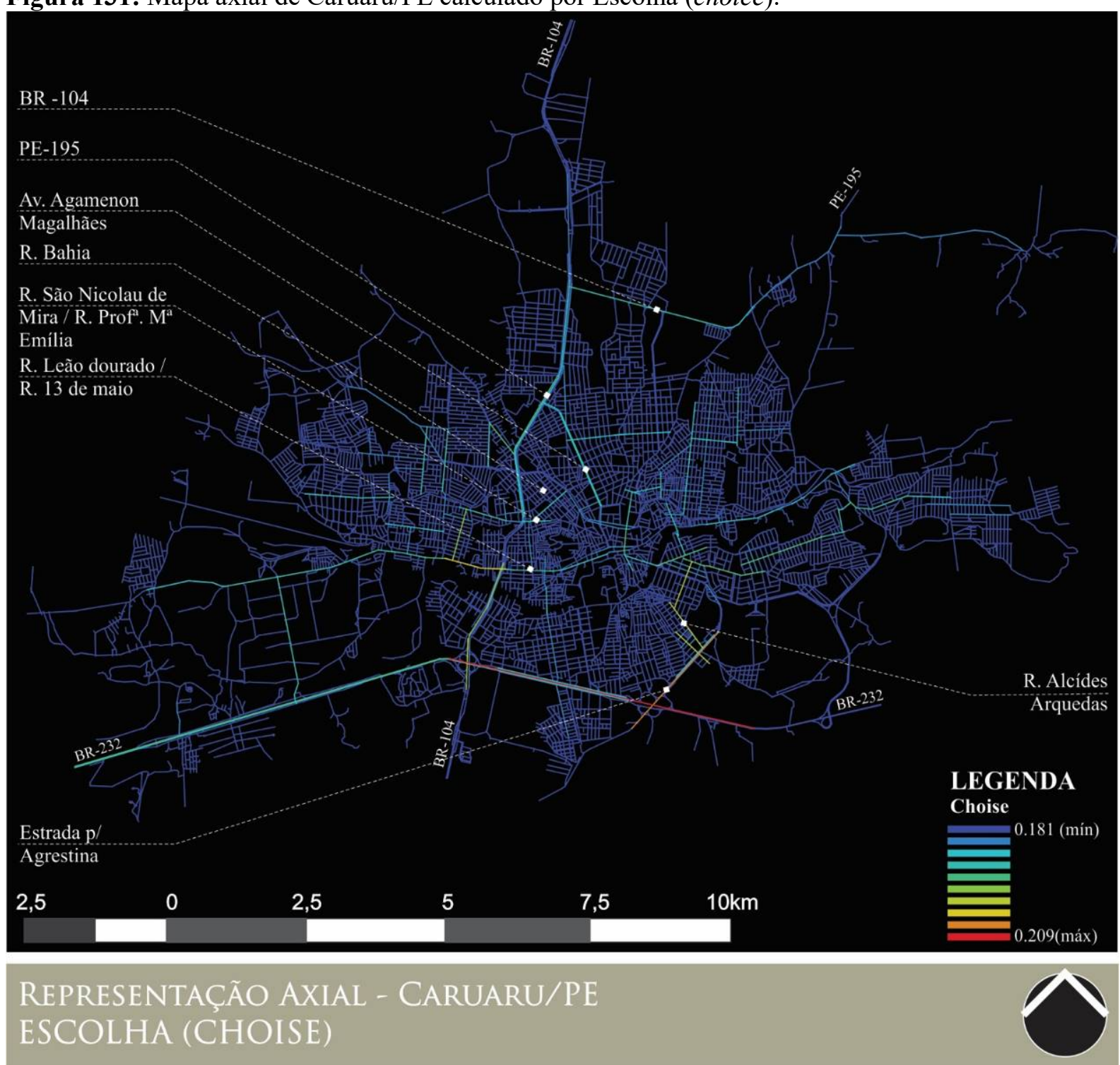

Fonte: Desenho gentilmente cedido por Paim (2015), com revisão da autora a partir da Base Cartográfica do OpenStreetMap (2016) e imagens de satélite do Google Earth (2016).

Figura 132: Vista panorâmica de Caruaru/PE a partir do Monte do Bom Jesus.

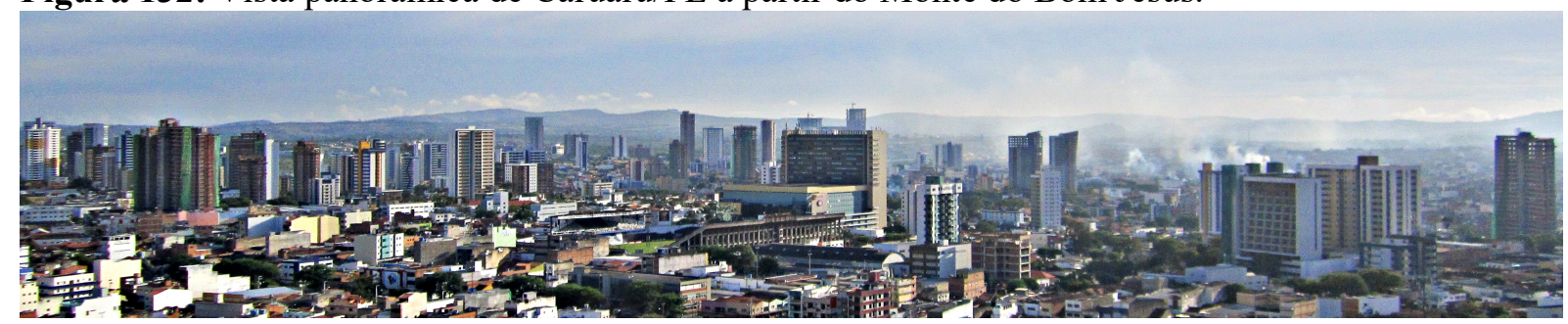

Fonte: Foto de Abdias Jr. (2014). Disponível em: < https://www.flickr.com/photos/>. Acesso em 18 de ago. 2016. 
Figura 133: Mapa de segmentos de Caruaru/PE calculado por Escolha (choice).

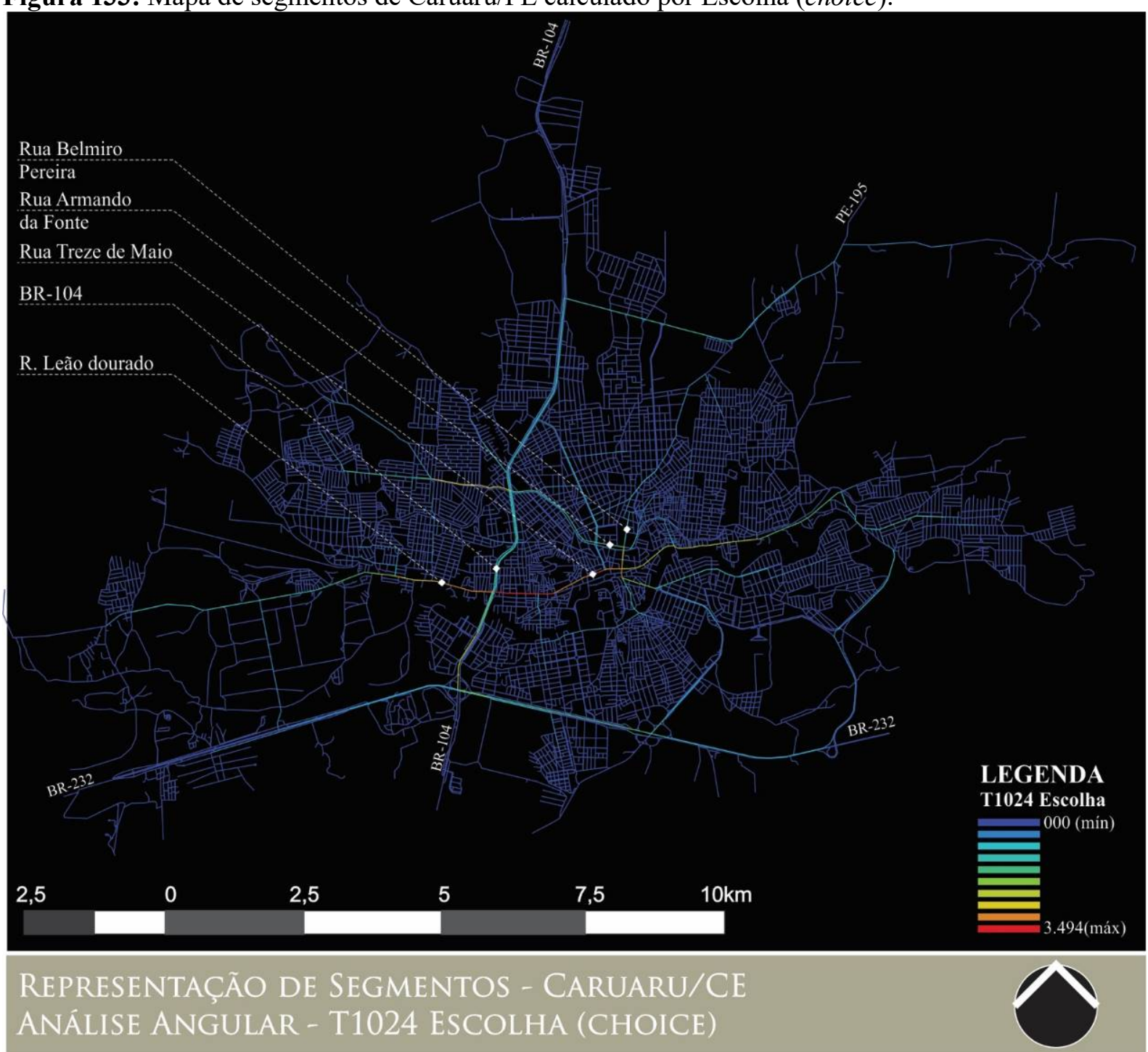

Fonte: Desenho gentilmente cedido por Paim (2015), com revisão da autora a partir da Base Cartográfica do OpenStreetMap (2016) e imagens de satélite do Google Earth (2016).

Finalizo as análises do Grupo de Controle 01 com um comparativo tomado a partir da medida de integração proporcional, apresentada na Tabela 19. Percebe-se que, tal como observado para as RMINE's, os valores de integração HH máximos apresentados para os miolos é igual ao valor máximo do sistema total. Por outro lado, os valores mínimos entre o total e as cercanias estão sempre muito próximos. Embora a forma do núcleo de integração não seja sempre a mesma, ela se assemelha à forma de uma roda de bicicleta, com um centro, raios que partem deste núcleo central em várias direções e um anel periférico, podendo se apresentar mais ou menos deformada, ou mais ou menos completa (HILLIER \& HANSON, 1984; PEPONIS et al, 1989; RIGATTI, 1997). 
Figura 134: Comparativo entre os mapas por meio da Medida de Integração Proporcional.
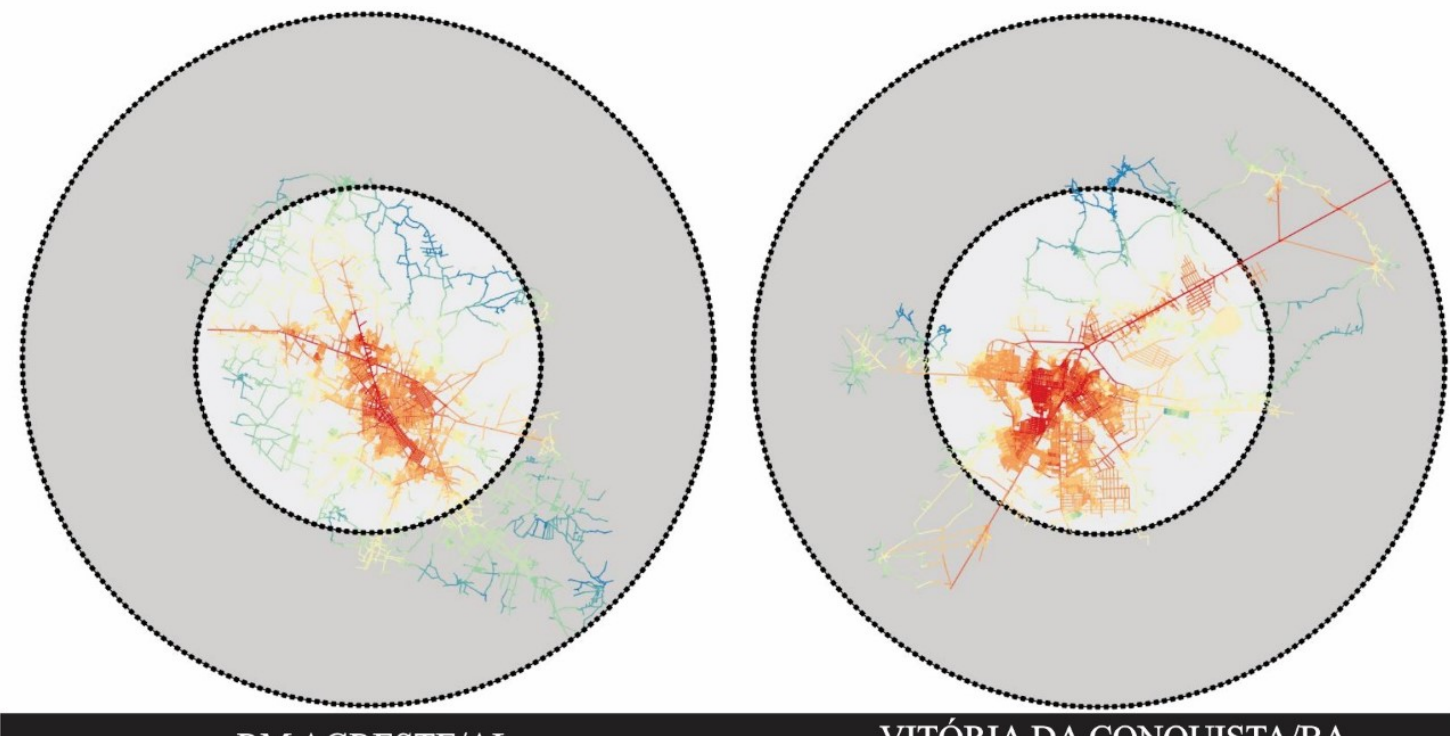

RM AGRESTE/AL

VITÓRIA DA CONQUISTA/BA
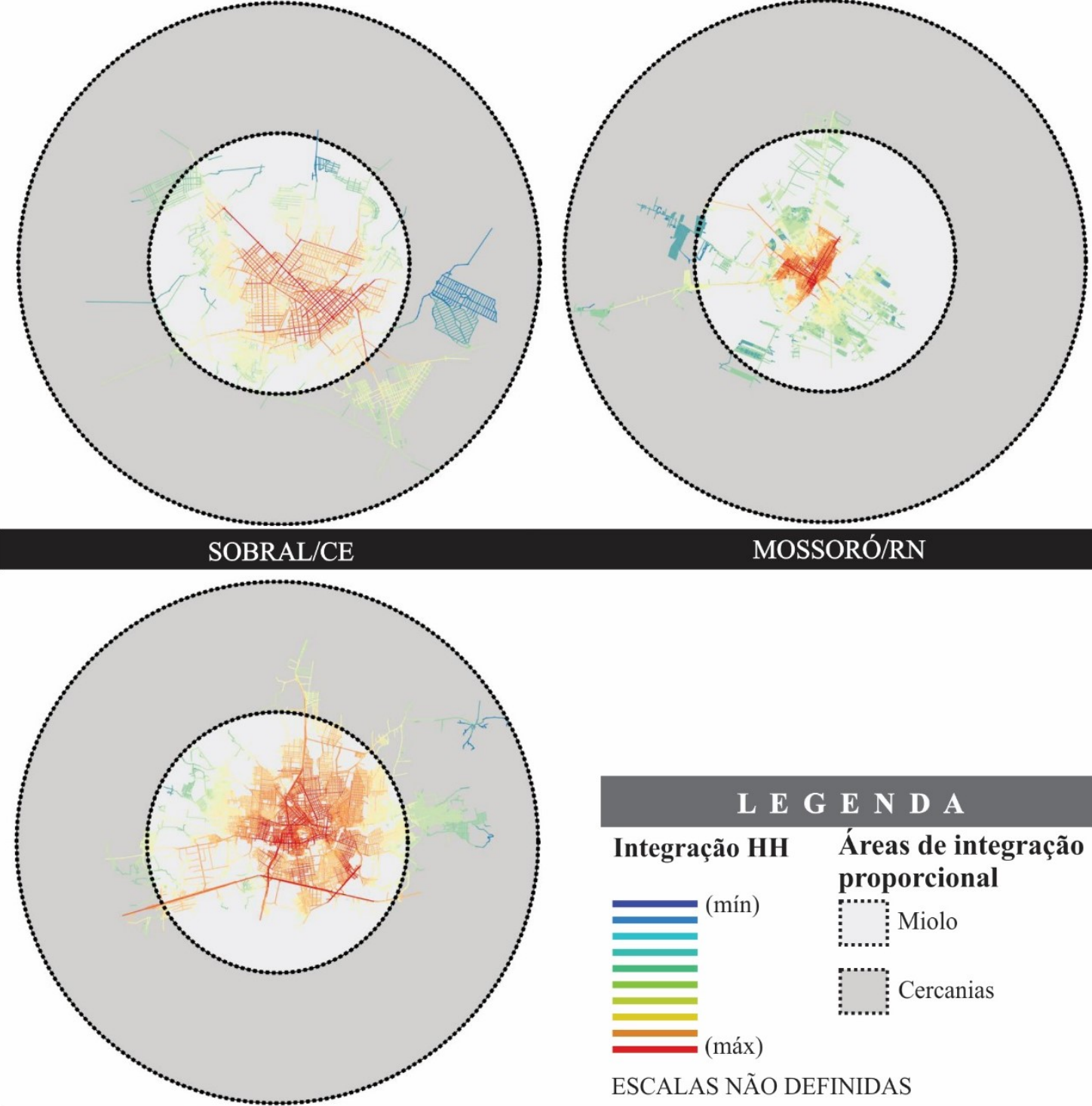

proporcional

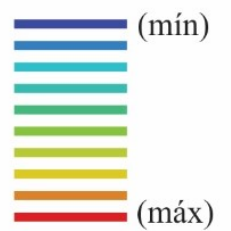

Miolo

\section{CARUARU/PE}

Fonte: Elaboração própria (2016) a partir das bases cartográficas calculadas para integração HH. 
Tabela 19: Medida de integração proporcional do Grupo de Controle 01

\begin{tabular}{|c|c|c|c|c|}
\hline RM OU CIDADE & VALORES & TOTAL & CERCANIAS & MIOLO \\
\hline \multirow{5}{*}{$\begin{array}{c}\text { RM DO } \\
\text { AGRESTE/AL }\end{array}$} & MÍNIMA & 0,193 & 0,230 & 0,193 \\
\hline & MÉDIA & 0,508 & 0,363 & 0,547 \\
\hline & MEDIANA & 0,525 & 0,355 & 0,578 \\
\hline & MÁXIMA & 0,817 & 0,618 & 0,817 \\
\hline & DESVIO PADRÃO & 0,144 & 0,073 & 0,133 \\
\hline \multirow{5}{*}{$\begin{array}{c}\text { VITÓRIA DA } \\
\text { CONQUISTA/BA }\end{array}$} & MÍNIMA & 0,144 & 0,144 & 0,161 \\
\hline & MÉDIA & 0,484 & 0,340 & 0,518 \\
\hline & MEDIANA & 0,519 & 0,335 & 0,547 \\
\hline & MÁXIMA & 0,723 & 0,665 & 0,723 \\
\hline & DESVIO PADRÃO & 0,132 & 0,112 & 0,112 \\
\hline \multirow{5}{*}{ SOBRAL/CE } & MÍNIMA & 0,315 & 0,315 & 0,354 \\
\hline & MÉDIA & 0,780 & 0,590 & 0,838 \\
\hline & MEDIANA & 0,773 & 0,625 & 0,835 \\
\hline & MÁXIMA & 1,320 & 1,018 & 1,320 \\
\hline & DESVIO PADRÃO & 0,200 & 0,150 & 0,177 \\
\hline \multirow{5}{*}{ MOSSORÓ/RN } & MÍNIMA & 0,336 & 0,336 & 0,372 \\
\hline & MÉDIA & 0,659 & 0,518 & 0,672 \\
\hline & MEDIANA & 0,633 & 0,502 & 0,647 \\
\hline & MÁXIMA & 1,105 & 0,770 & 1,105 \\
\hline & DESVIO PADRÃO & 0,144 & 0,090 & 0,142 \\
\hline \multirow{5}{*}{ CARUARU/PE } & MÍNIMA & 0,181 & 0,181 & 0,263 \\
\hline & MÉDIA & 0,526 & 0,383 & 0,555 \\
\hline & MEDIANA & 0,543 & 0,388 & 0,566 \\
\hline & MÁXIMA & 0,756 & 0,625 & 0,756 \\
\hline & DESVIO PADRÃO & 0,107 & 0,076 & 0,087 \\
\hline
\end{tabular}

Fonte: Elaboração própria (2016) a partir das bases cartográficas calculadas para integração HH.

\subsubsection{Grupo de Controle 02}

O local que hoje abriga a cidade de Salvador teve sua colonização iniciada no primeiro quartel do século XVI. Em 1548, Dom João III, rei de Portugal, nomeou Thomé de Souza como Governador do Brasil e o incumbiu de construir a Cidade do Salvador de acordo com o projeto de Luís Dias. Nas décadas seguintes, Salvador tornou-se uma das principais cidades da América Portuguesa, recebendo várias ordens católicas. Em 1624, foi invadida pelos holandeses e reconquistada no ano seguinte. Em 1763, a capital do Estado do Brasil foi transferida para o Rio de Janeiro. Salvador continuou a ser a maior cidade da América Portuguesa até o início do século XIX, quando é ultrapassada pela nova capital (IBGE, 2016). 
Para a RM de Salvador/BA o grande destaque da representação axial (Figura 137) é o núcleo de integração em anel organizado, em sentido anti-horário, pela BR-324 (que liga a capital ao município vizinho Simões Filho e também conduz até Feira de Santana), Av. Luís Viana (mais conhecida como Paralela - também em destaque no mapa axial de somente Salvador - Figura 137) e a BA-526. Essas são vias que estruturam o tráfego da cidade e, portanto, são destaque também no cálculo de escolha (Figura 139). Uma característica morfológica marcante na cidade é a irregularidade dos traçados para vencer os acidentes topográficos, a feição de um labirinto (MEDEIROS, 2006). Esse desenho exacerba os “problemas de setorização, segregação e exclusão espacial” (MEDEIROS, 2006, p. 271)

Figura 135: À esquerda, vista da BR-324 e, à direita, uma vista da Av. Luís Viana (mais conhecida como Paralela) e sua ocupação lindeira marcada pela verticalização.

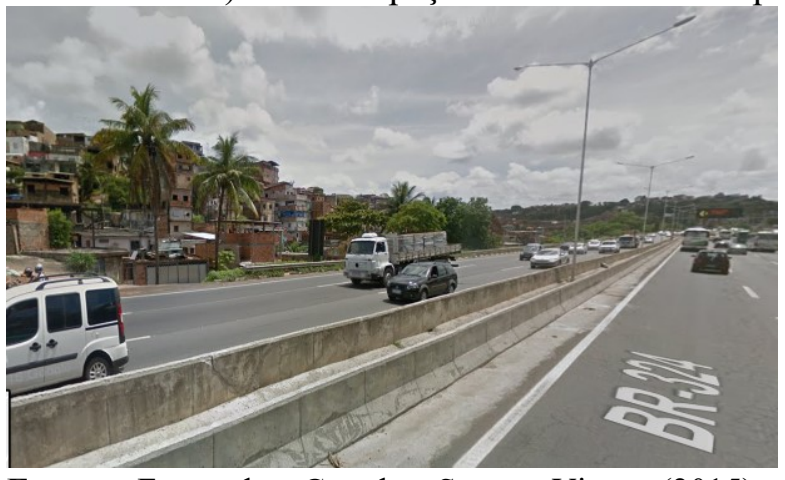

Fonte: Foto de Google Street View (2015). Disponível em: <https://www.google.com.br/maps>. Acesso em 20 de ago. 2016.

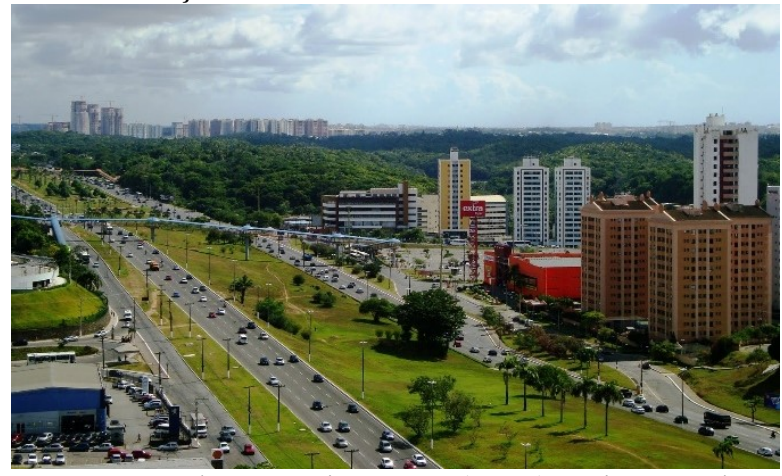

Fonte: Foto de Verônica Vaz (2011). Disponível em: $<$ http://arquiteturaemimagens.blogspot.com.br/2011/01/a v-luiz-viana-filho-paralela.html $>$. Acesso em 20 de ago. 2016.

Esse núcleo de integração carregou consigo as novas centralidades. Na passagem de cidade portuária para terciária foi necessário criar novos eixos de circulação e expansão do tecido urbano. Assim, a construção da Avenida Luís Viana em meados dos anos 1970, cuja concepção era baseada nas propostas das "avenidas de vale"64, favoreceu a construção de diversos conjuntos habitacionais verticais ao longo da avenida. Esse novo polo residencial atraiu para seu entorno vários shoppings e hipermercados, o campus da Universidade Católica do Salvador e outros estabelecimentos de ensino privado, bem como diversos

\footnotetext{
${ }^{64}$ Os estudos desenvolvidos pelo Escritório do Plano de Urbanismo da Cidade de Salvador preconizavam um sistema integrado de redes de avenidas: uma implantada nas cumeadas (com viadutos interligando os espigões) para um tráfego lento de acesso aos bairros, e outra no fundo dos vales onde deveriam ser construídas vias expressas na forma de parkways. "A rede de vales traz uma solução natural; caminhando no meio de jardins, permite uma extrema mobilidade e uma grande segurança já que o fluxo de carros é isolado das habitações e de outros componentes de tráfego que tem uma pista própria. Além disto, os pedestres não usam essa rede, pois as habitações estão situadas nas cumeadas onde chegam também transportes coletivos. Enfim, a conjugação de avenidas de vale com as redes de esgotos, os canais de drenagem e a distribuição de água, facilita a manutenção e implantação dessas infra-estruturas [sic]" (SCHEINOWITZ, 1998, p.12 apud LIMA, 2007, p. 46).
} 
empreendimento público e privado (SCHEINOWITZ, 1998 apud LIMA, 2007). Essa acessibilidade também atraiu outras aglomerações habitacionais resultantes do processo de "invasão", algumas mais consolidadas, como é o caso do Alto da Ventosa em Pernambués, ao lado da Avenida Luiz Eduardo Magalhães.

Vale destacar o avançado processo de conurbação com Lauro de Freitas, concentrando atividades de comércio e serviços dinâmicos e grande quantidade de condomínios, tendo como principal eixo a Av. Paralela e a Estrada do Coco (BA-099 - Figura 136). Nesta última (destacada no mapa axial calculado por Escolha em azul claro - Figura 139), desenvolve-se intensa atividade imobiliária e turística (Figura 141) ao longo da orla de Camaçari e Mata de São João.

Figura 136: Duas vistas da Estrada do Coco (BA-099) - à esquerda, na altura do município de Lauro de Freitas e, à direita, na Praia de Arembepe (localizada no município de Camaçari). Abaixo um mapa esquemático da via.

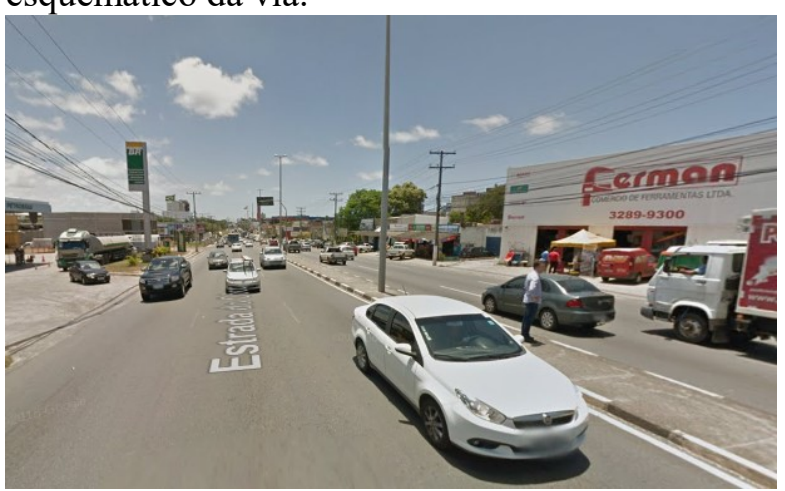

Fonte: Foto de Google Street View (2015). Disponível em: <https://www.google.com.br/maps>. Acesso em 20 de ago. 2016.

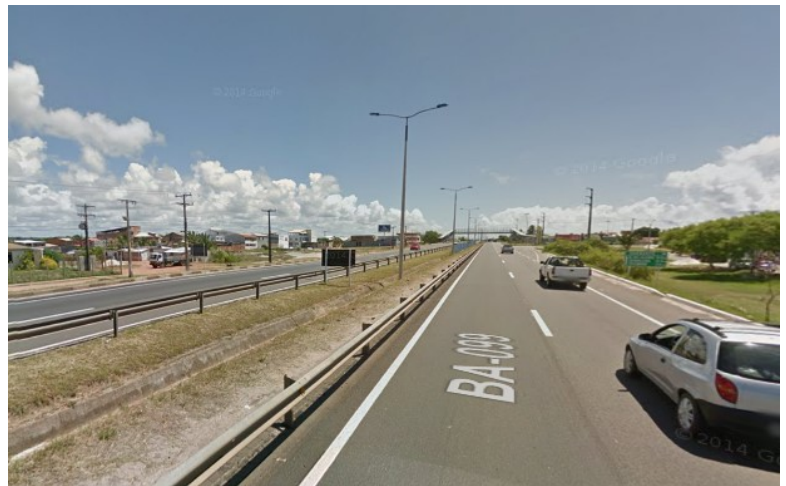

Fonte: Foto de Google Street View (2014). Disponível em: <https://www.google.com.br/maps>. Acesso em 20 de ago. 2016.

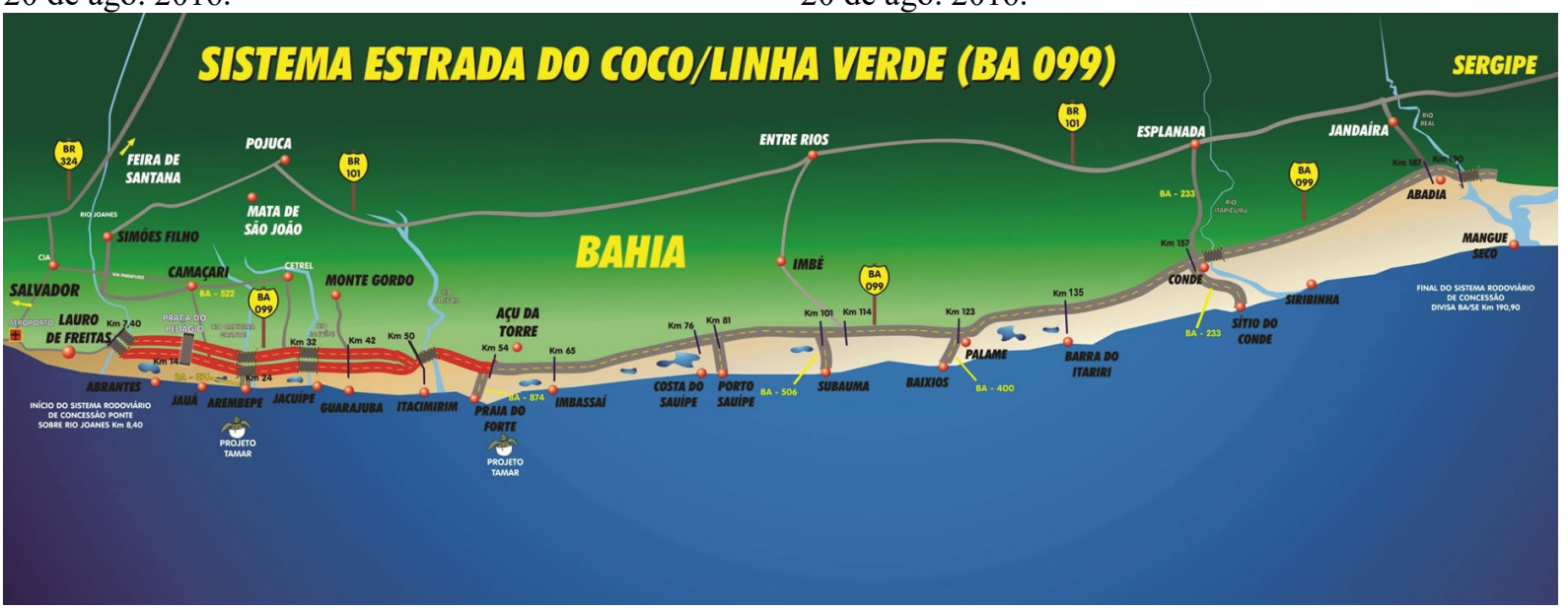

Fonte: Autor desconhecido (s/d). Disponível em: < http://estradas.com.br/>. Acesso em 20 de ago. 2016. 
Figura 137: Mapa axial de Salvador/BA calculado por Integração HH global (Rn) e Escolha.

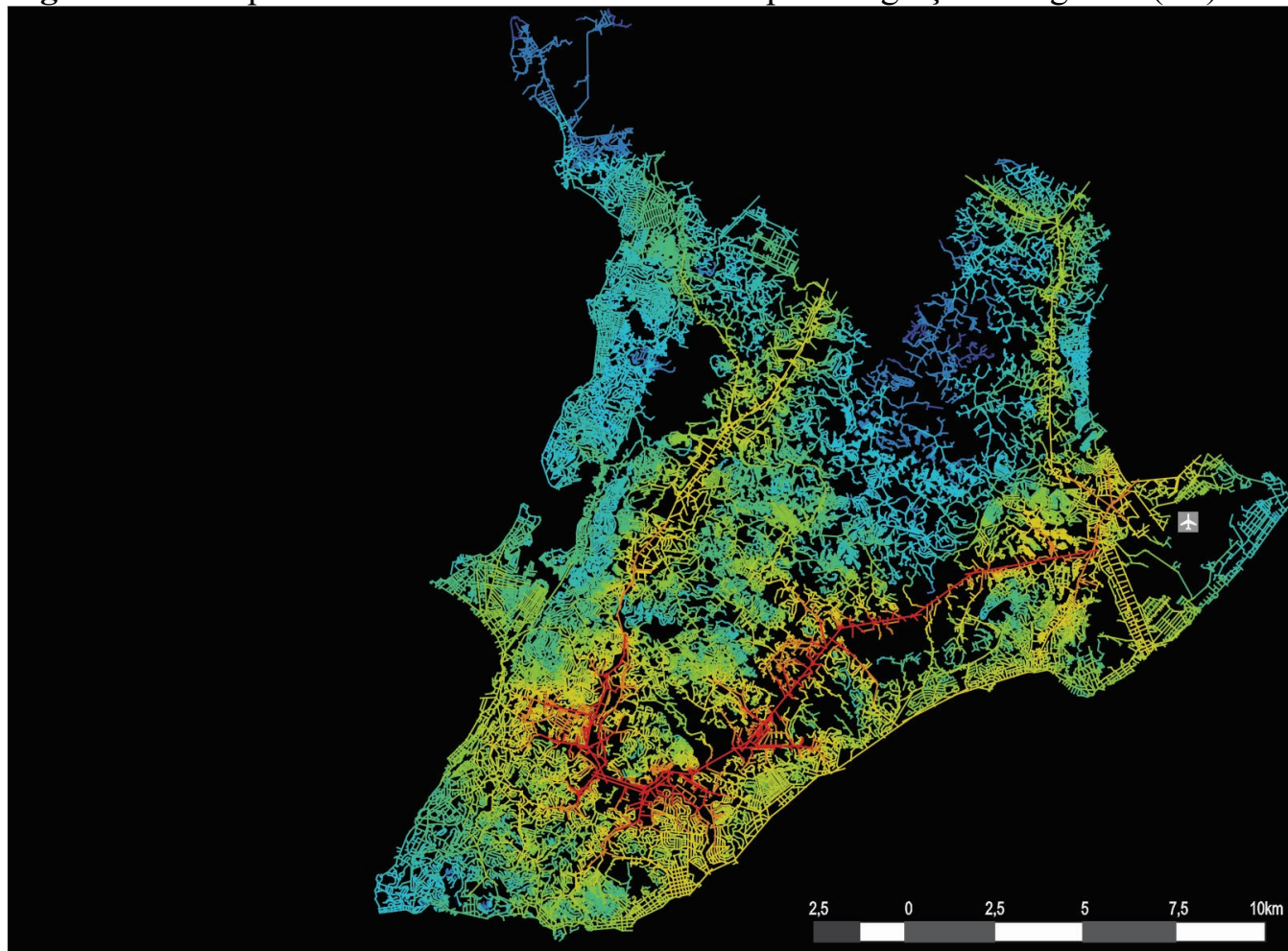

LEGENDA

Integração HH

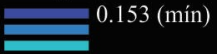

REPRESENTAÇÃO AXIAL - SALVADOR/BA INTEGRAÇÃO HH GLOBAL (RN)

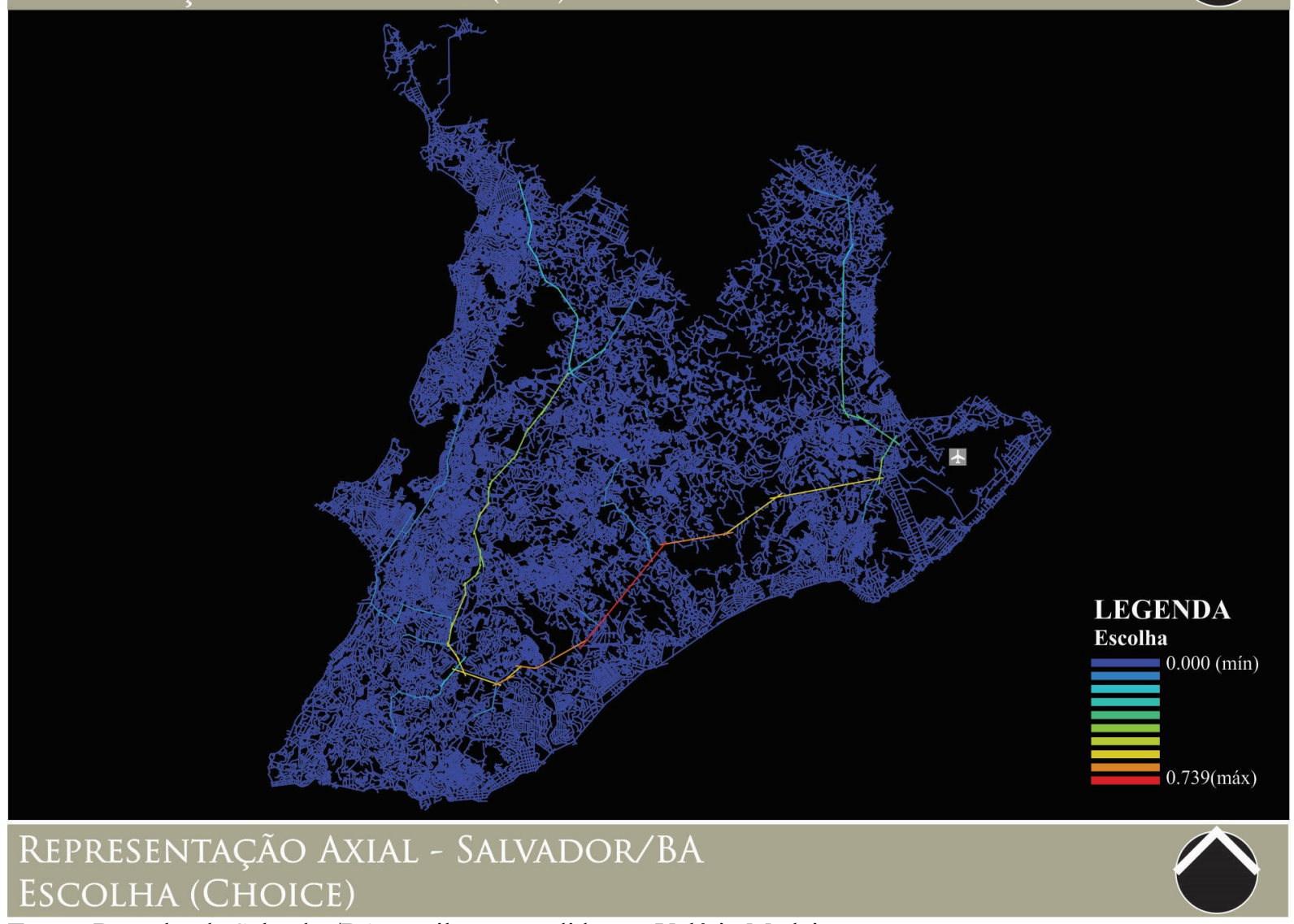

Fonte: Desenho de Salvador/BA gentilmente cedido por Valério Medeiros. 
Figura 138: Mapa axial da RM de Salvador/BA calculado por Integração HH global (Rn).

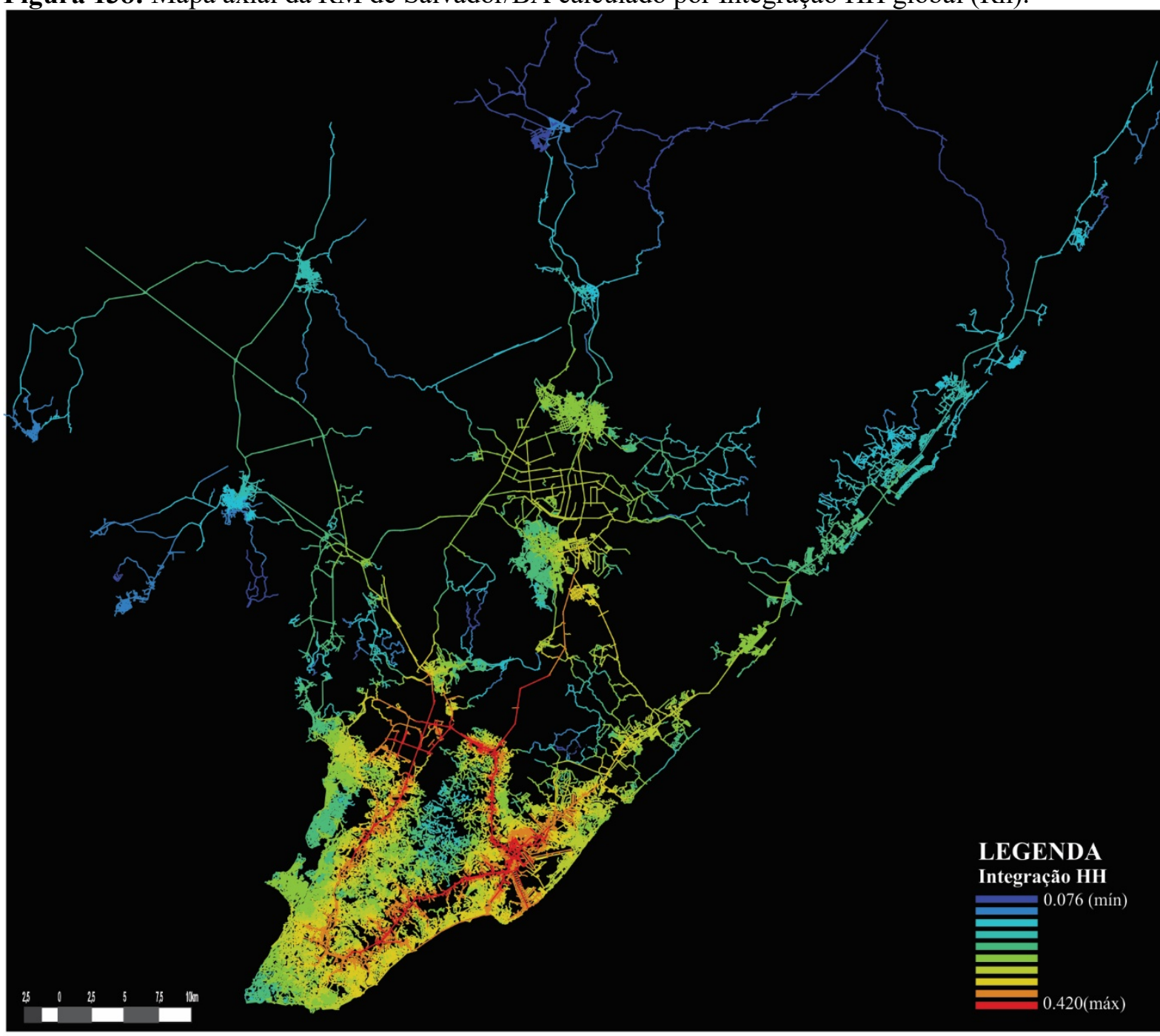

REPRESENTAÇÃO AXIAL - RM SALVADOR/BA

INTEGRAÇÃO HH GLOBAL (RN)

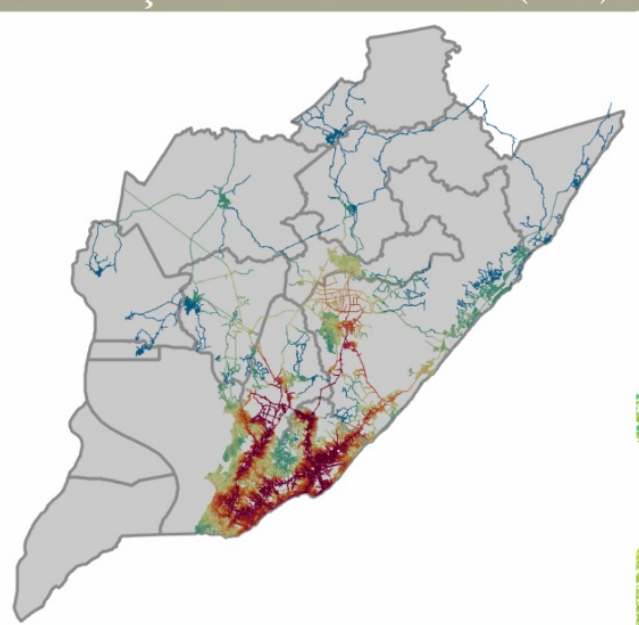

MAPA-CHAVE

NÚCLEO DE INTEGRAÇÃO -DETALHE

RM SALVADOR/BA

DO MAPA AXIAL - SALVADOR/BA

Fonte: Desenho de Salvador gentilmente cedido por Valério Medeiros, restante da RM atualizado por Amanda Brasil (2016) com revisão da autora a partir da Base Cartográfica do OpenStreetMap (2016) e imagens de satélite do Google Earth (2016). 
Figura 139: Mapa axial da RM de Salvador/BA calculado por Escolha (choice).

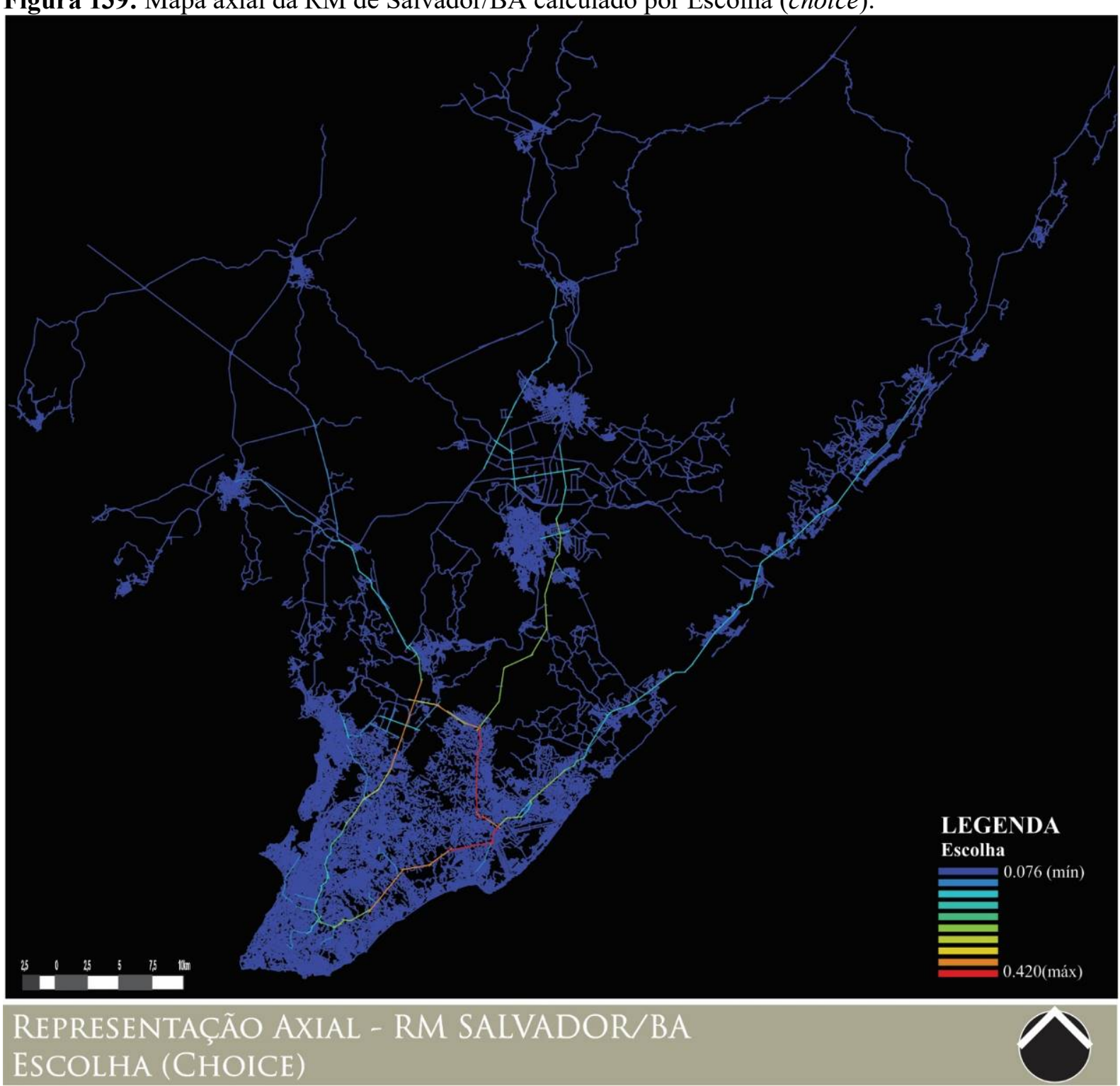

Fonte: Desenho gentilmente cedido por Valério Medeiros, atualizado por Amanda Brasil (2016) com revisão da autora a partir da Base Cartográfica do OpenStreetMap (2016) e imagens de satélite do Google Earth (2016).

Figura 140: Vista da Baía de Todos os Santos, demonstrando o denso processo de verticalização de Salvador/BA.

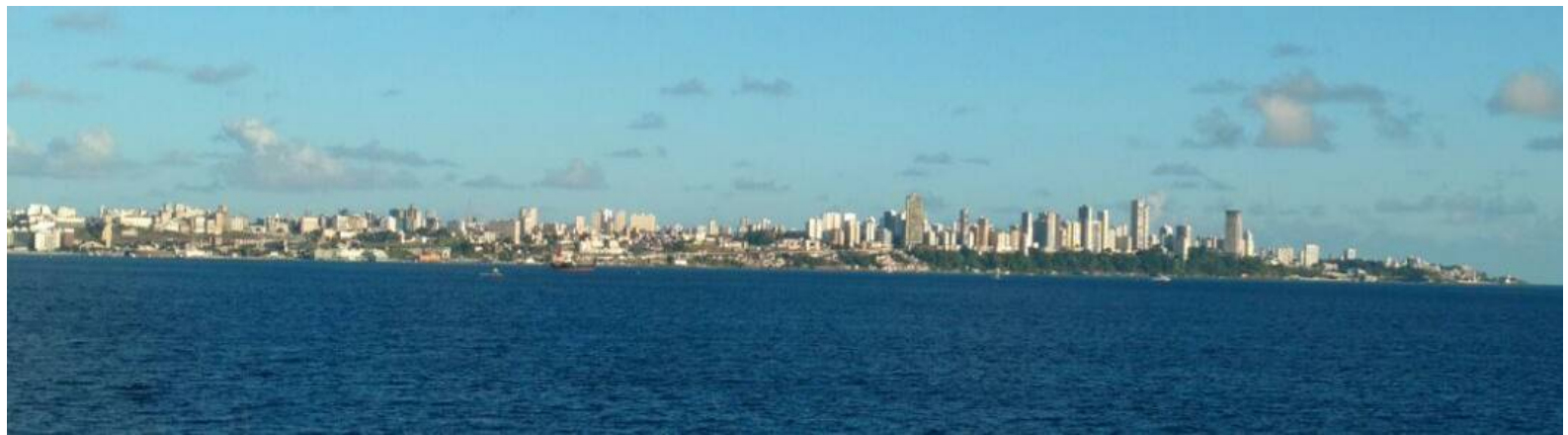

Fonte: Foto de Nicola Maniglia (2016), gentilmente cedida. 
Figura 141: Vista da Praia de Guarajuba, Camaçari - à esquerda, imagem de satélite onde destacamse os condomínios fechados entre a Estrada do Coco e o Oceano Atlântico e, à direita, exemplo de uma residência de luxo nestes condomínios.

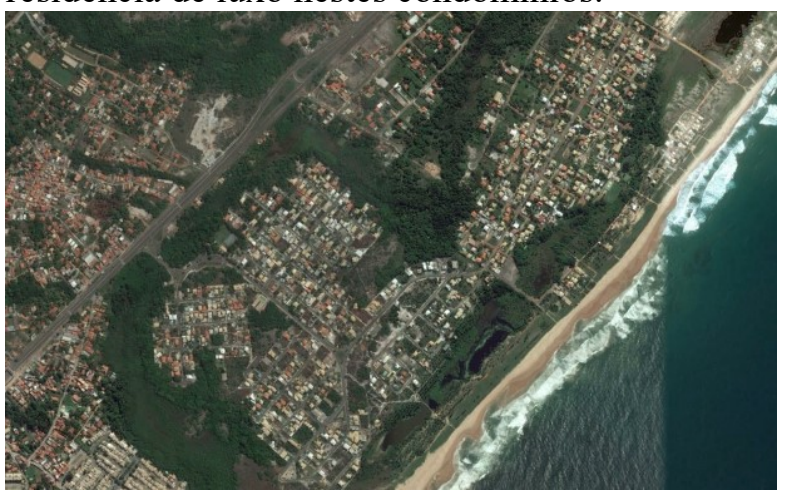

Fonte: Foto de Google Earth (2016) - editado pela autora. Acesso em 18 de ago. 2016.

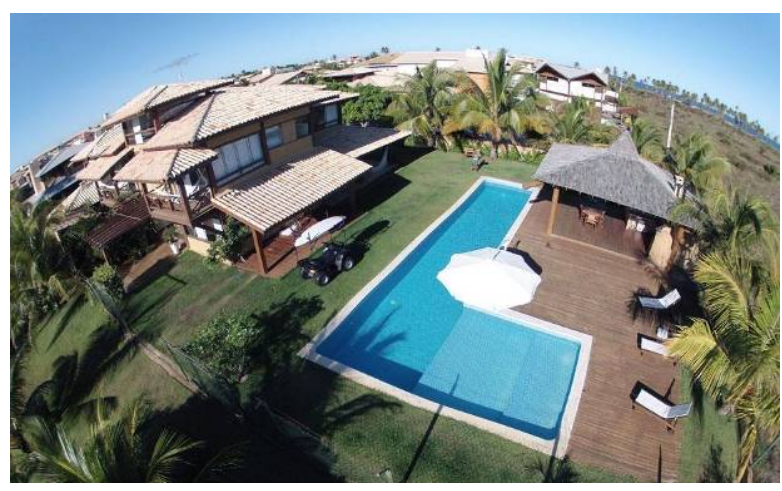

Fonte: Foto de autor desconhecido (s/d). Disponível em: <http://www.guarajubaimoveis.com.br/>. Acesso em 20 de ago. 2016

Salvador possui um processo de verticalização denso e espalhado por diversas partes da cidade $\mathrm{Na}$ topografia acidentada da região central da cidade, os edifícios construídos nos bairros Graça, Federação, Brotas, Campo Grande a cota chegam a 65 metros de altura, em relação ao nível do mar. Outros bairros da cidade passam pelo processo de substituição das residências de até três pavimentos por edifícios de até 32 pavimento-tipo (RAHY, 2012).

Figura 142: Vistas do Centro Histórico de Salvador/BA: à esquerda, o Pelourinho e, à direita, uma moradora da Ladeira da Preguiça, que passou por demolições em decorrência das fortes chuvas de 2015.

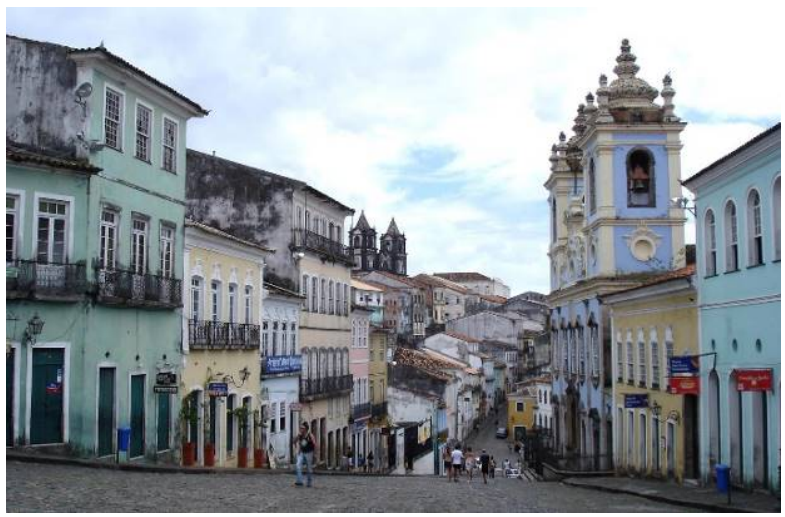

Fonte: Foto de Fernando_Dallacqua (2004). Disponível em: < https://pt.wikipedia.org/wiki/>. Acesso em 20 de ago. 2016

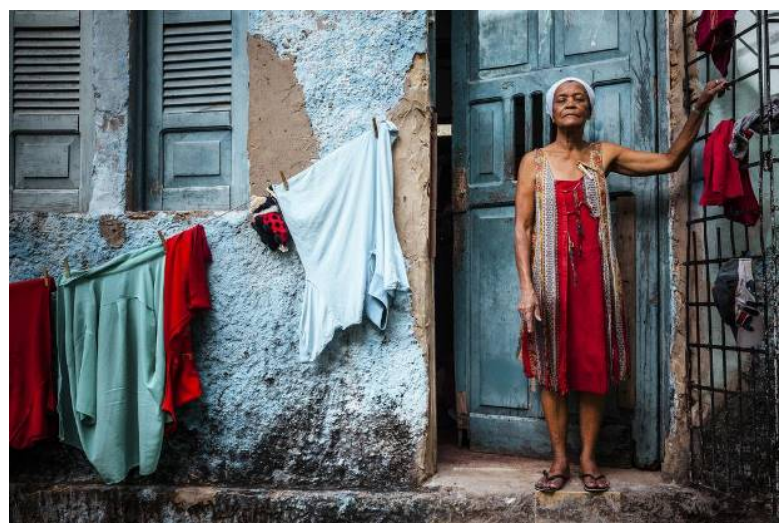

Fonte: Foto de Antonello Veneri. (2015). Disponível em: <http://www.hackcities.com.br//>. Acesso em 20 de ago. 2016

Um breve comentário acerca da preservação patrimonial precisa ser feito sobre Salvador, tendo em vista seu importante acervo urbano-arquitetônico. O Centro Histórico passou (e continua passando) por diversos programas públicos de intervenção tanto no nível da requalificação dos espaços e infraestruturas quanto em ações culturais e sociais. Entretanto, 
ainda há inúmeros problemas: a cara manutenção dos imóveis patrimoniais, trânsito e acessibilidade, ausência de estacionamento, limpeza urbana, poluição sonora e ambiental, bolsões de miséria, tráfico de drogas, prostituição, dentre outros (SCEBA, 2011). Sob a ótica da SE, o Centro Histórico possui integrações medianas (tons verdes-amarelados) o que significa a perda de vantagens locacionais para as áreas mais integradas, condizente com o grande número de edifícios abandonados, ou que passam a abrigar usos que se beneficiam com os baixos alugueis, e, principalmente, com o processo de degradação socioeconômica da área.

O processo de redefinições de centralidades iniciou-se em meados do século XIX. Com a expansão da cidade, a elite econômica e social passou a fixar residência nas áreas de expansão ao sul (Graça, Barra, Garcia), deixando o bairro Centro com uma função predominantemente comercial, rodeada por residências de classes mais baixas, que ocuparam as lacunas deixadas pelos que saíram. Esse processo foi acentuado em meados do século XX, quando as funções públicas do Governo Estadual saíram do centro tradicional para se instalar no Centro Administrativo da Bahia - CAB, implantado nos anos 1970, distante cerca de $15 \mathrm{~km}$ do centro e localizado aproximadamente no meio da recém-inaugurada Avenida Luís Vianna, conhecida como "Paralela" (OLIVEIRA, 2012).

Figura 143: Vista do Centro Histórico de Salvador/BA. Em primeiro plano, o Terreiro de Jesus e, ao fundo, as expansões verticais.

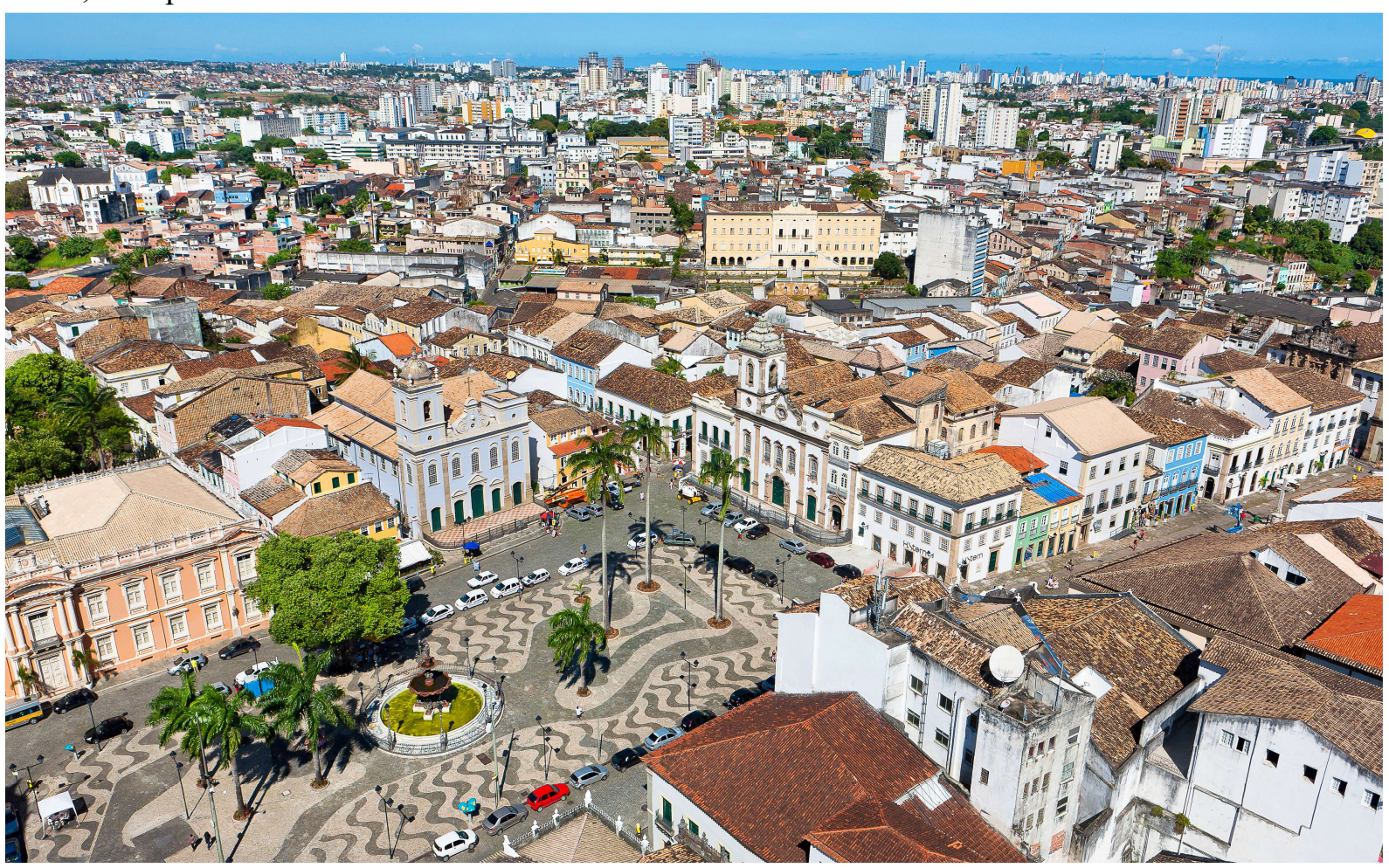

Fonte: Foto do acervo IPAC/BA (2011), gentilmente cedida por Felipe Musse (2016). 
Nesse mesmo período, grandes equipamentos foram deslocados ou criados na região da nova região comercial Iguatemi-Tancredo Neves (no começo da Av. Paralela) para incentivar a expansão e ocupação no sentido da Avenida, entre eles podemos destacar o Shopping Iguatemi (atual Shopping da Bahia), inaugurado em 1975 (o segundo empreendimento do tipo do país), e o terminal rodoviário, inaugurado em 1974. Essa mudança, que acelerou o processo de abandono e degradação do centro antigo da cidade e a expansão dos limites urbanos em direção aos municípios vizinhos, pode ser entendida como motivadora dos atuais processos de expansão, transformação e conurbação urbana vivenciadas na RM de Salvador. Com as atuais demandas decorrentes do espraiamento da cidade, novas demandas de serviços e soluções de mobilidade fazem-se necessárias. Existem propostas de mudança do terminal rodoviário para o bairro de Águas Claras, às margens da BR-324, próxima ao limite noroeste do município, integrando-se a recém-inaugurada linha 01 do metrô de Salvador, que ligará o terminal ao centro antigo da cidade. Ao mesmo tempo está em execução a linha 02 do metrô que sairá do Centro Antigo e acompanhará toda a extensão da Avenida Paralela até o Aeroporto Internacional, localizado no município vizinho de Lauro de Freitas.

Figura 144: Duas vistas da via mais integrada da RM de Salvador, a BA-526, na área em que se localiza o Aeroporto, e o Salvador Norte Shopping (à direita).

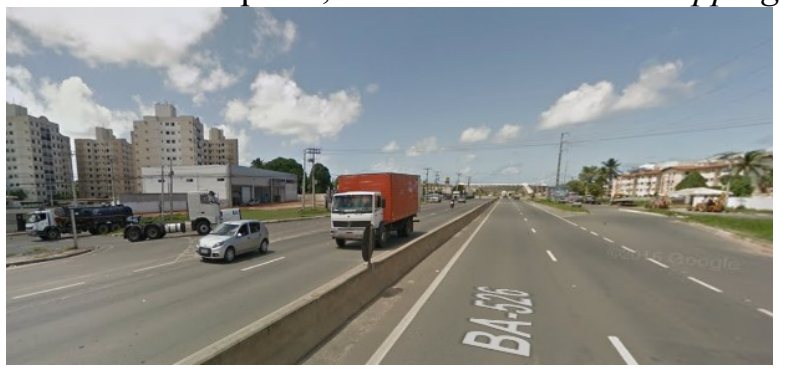

Fonte: Foto de Google Street View (2015). Disponível em: <https://www.google.com.br/maps>. Acesso em 20 de ago. 2016.

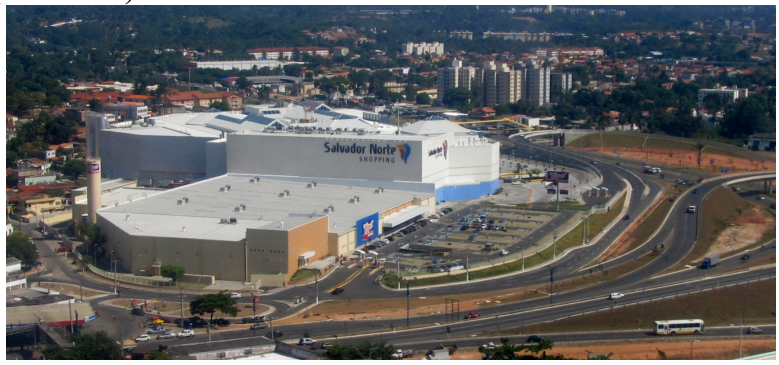

Fonte: Foto de Enio Prado (s/ d). Disponível em: $<$ http://mapio.net/o/2880529/>. Acesso em 20 de ago. 2016.

Acredito que esse eixo de crescimento será o que impactará mais profundamente as transformações futuras da cidade e o surgimento de uma nova centralidade por proporcionar uma melhor mobilidade e consequente ligação entre os centros comercial, administrativo e cívico e os trechos onde tem se acentuado o surgimento de condomínios fechados e empreendimentos voltados à classe média soteropolitana, como um novo shopping (Figura 144) e centros de serviços. Ademais, esse eixo de crescimento facilitará a ligação com o litoral norte da região metropolitana, as praias localizadas ao longo da Linha Verde, principais locais de veraneio e lazer da classe média soteropolitana. 
O início da ocupação do território que viria a ser hoje a cidade de Fortaleza se deu entre os anos de 1597 e 1598. Depois de fracassadas tentativas de colonização, foi somente no início do século XVII, quando é erguido em 1612 (e reconstruído em 1621) o fortim de São Sebastião, na barra do rio Ceará, que a ocupação começa a prosperar. Feito de madeira e estacas de carnaúba, por diversas vezes teve de sofrer reformas, até desmoronar. No local do forte arruinado, foram lançados os alicerces da Fortaleza de Nossa Senhora da Assunção em 12 de outubro de 1812. Em 1726, o povoado do forte foi elevado à condição de vila, tornando-se a segunda do estado. À época, Aquiraz, a primeira vila datada de 1713, era considerada o centro econômico do Ceará, e Fortaleza, o centro político. Foi elevada à condição de cidade com a denominação de Fortaleza da Nova Bragança em 1823 (IBGE, 2016). No final do século XIX, Fortaleza já era um dos oito principais centros urbanos do país, fortalecida pela cultura do algodão e de seus processos de industrialização. Como cidade prioritária em investimentos do governo da província e com a migração dos sertanejos fugindo das recorrentes secas do interior, a cidade cresceu rapidamente, dotando-se de crescente infraestrutura.

Para a RM de Fortaleza/CE (Figura 146), o núcleo de integração incide sobre o município-sede, especificamente sobre o bairro Aldeota e seu arredores. Mas é possível visualizar eixos de expansão deste núcleo definidos em três direções: (1) BR-222 (Av. Bezerra de Menezes em Fortaleza) e BR-220, mais a oeste, que faz a ligação com o interior (em direção ao município de Canindé); (2) CE-060 em direção ao município de Pacatuba (ao centro em laranja); (3) BR-116 em direção ao município de Horizonte. Essas vias ficam claras no mapa calculado por Escolha (Figura 150), mas também são destaque na representação isolada de Fortaleza (Figura 146). Essa representação é condizente com o modelo de expansão urbana proposto por Capasso (2007), apresentado na Figura 148.

Figura 145: Eixos de expansão de Fortaleza À esquerda, a Av. Bezerra de Menezes e, à direita, vista aérea da BR-116.

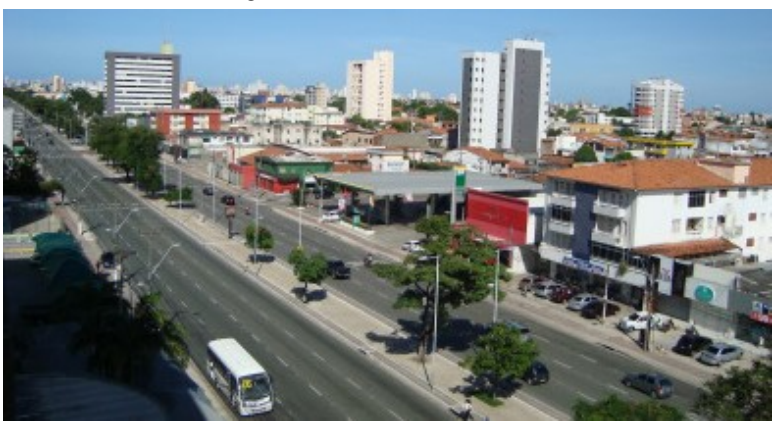

Fonte: Foto de autor desconhecido (s/d). Disponível em: $<$ https://dialogospoliticos.wordpress.com>. Acesso em 20 de ago. 2016.

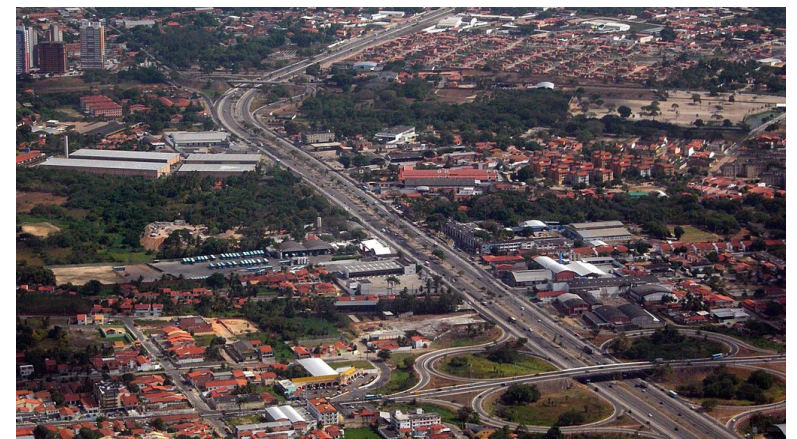

Fonte: Foto de Almeida (2008). Disponível em: $<$ http://www.panoramio.com/>. Acesso em 20 de ago. 2016. 
Figura 146: Mapa axial de Fortaleza/CE calculado por Integração HH global (Rn) e Escolha.



Fonte: Desenho de Fortaleza gentilmente cedido por Lucy Donegan (a base foi elaborada por Valério Medeiros e passou por revisões de Fernanda Linard). 
Figura 147: Mapa axial da RM de Fortaleza/CE calculado por Integração HH global (Rn).

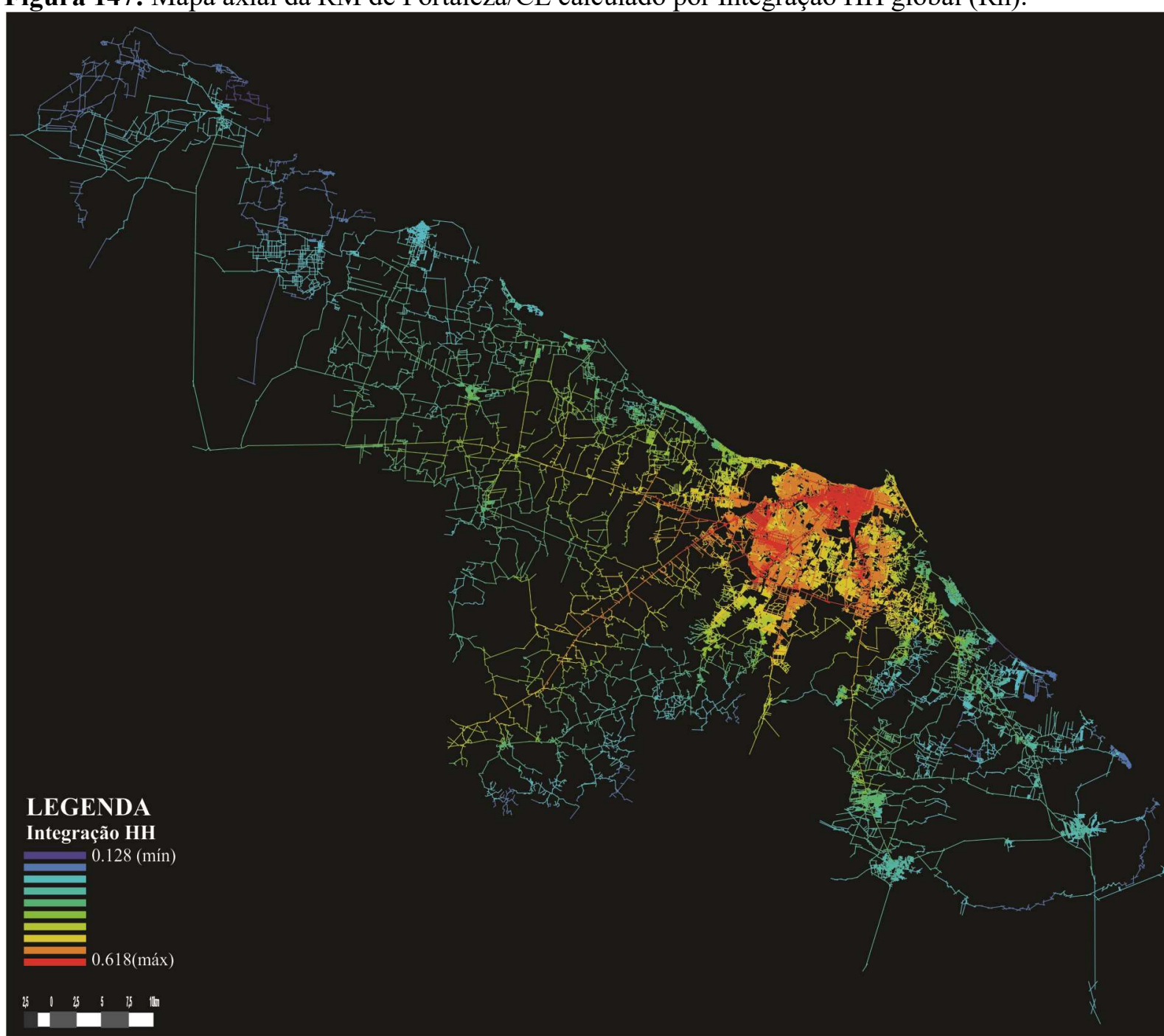

REPRESENTAÇÃO AXIAL - RM DE FORTALEZA/CE INTEGRAÇÃO HH GLOBAL (RN)
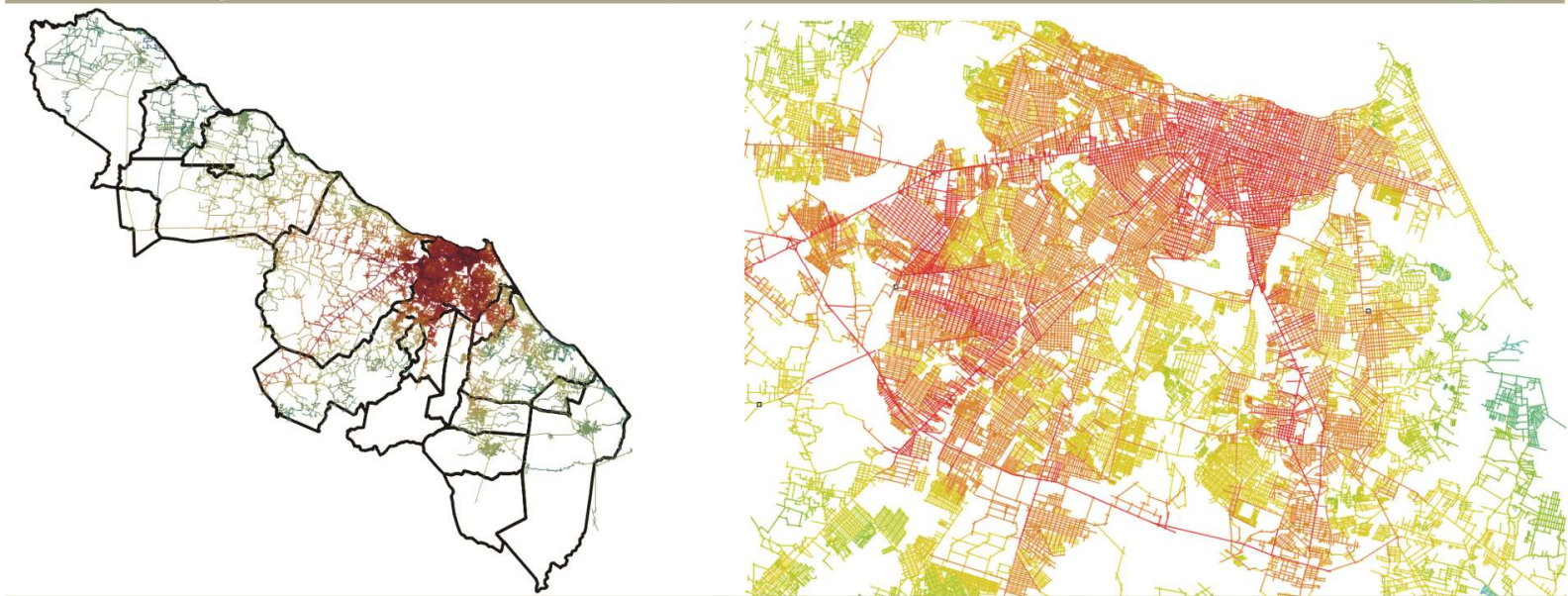

MAPA-CHAVE

NÚCLEO DE INTEGRAÇÃO -DETALHE

RM DE FORTALEZA/CE

DO MAPA AXIAL - FORTALEZA/CE

Fonte: Desenho de Fortaleza gentilmente cedido por Lucy Donegan, com atualizações de Klairton Rodrigues, Plácido Ferreira, Lucas Lima e Pâmela Corrêa (2016), com revisão da autora a partir da Base Cartográfica do OpenStreetMap (2016) e imagens de satélite do Google Earth (2016). 
Figura 148: Esquema de expansão da cidade de Fortaleza/CE desenvolvido por Capasso (2007) baseado no esquema de Hoyt.

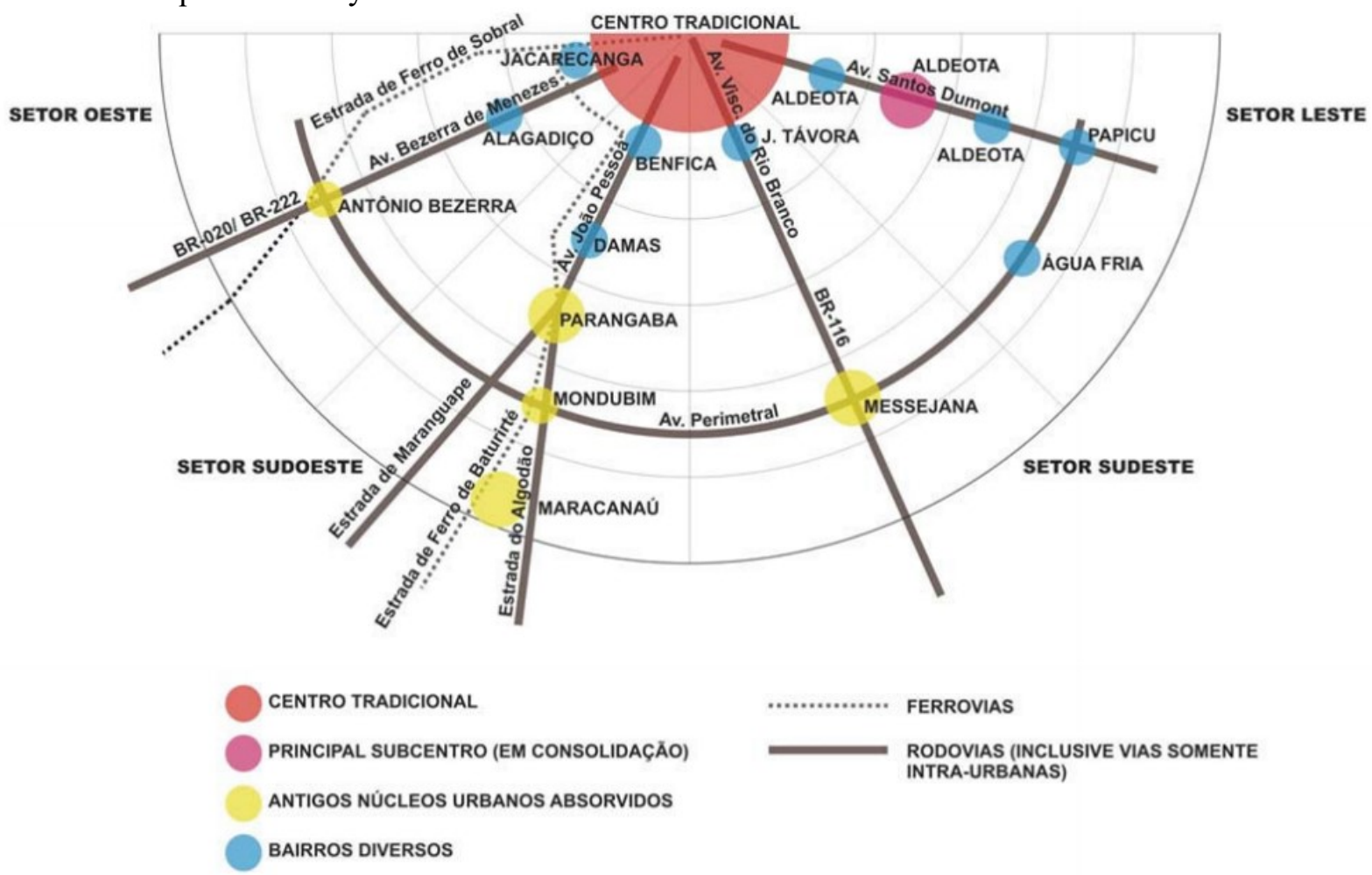

Fonte: CAPASSO, 2007, s/p.

A centralidade definida pela Aldeota e seus bairros vizinhos (por exemplo Meireles), que substituiu o centro tradicional em meados do século XX, concentra hotéis, flats, shopping centers, edifícios de escritórios (e consequentemente a maioria dos empregos formais) e condomínios residenciais de grande porte, habitados pela população de alta renda (CAVALCANTE, 2009). Esta é uma área de acentuada especulação imobiliária e consolidado processo de verticalização (Figura 149).

Figura 149: Vista do bairro Aldeota: à esquerda, a Praça Portugal, espaço simbólico do bairro, e, à direita, uma imagem do Shopping Aldeota localizado na mesma praça.

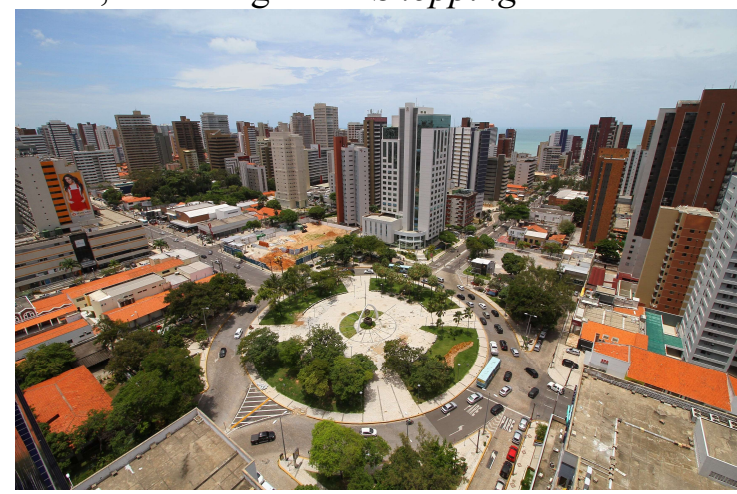

Fonte: Foto do Banco de dados do Jornal O Povo (s/ d). Disponível em: $<$ http://especiais. opovo.com.br/ aldeotaazul $>$. Acesso em 20 de ago. 2016

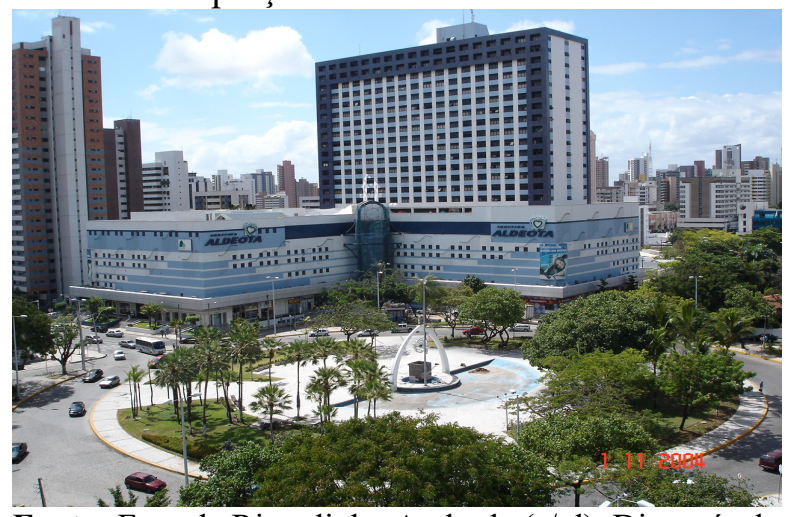

Fonte: Foto de Ricardinho Andrade (s/ d). Disponível em: <http://mapio.net/s/30391595/>. Acesso em 20 de ago. 2016. 
Figura 150: Mapa axial da RM de Fortaleza/CE calculado por Escolha (choice).

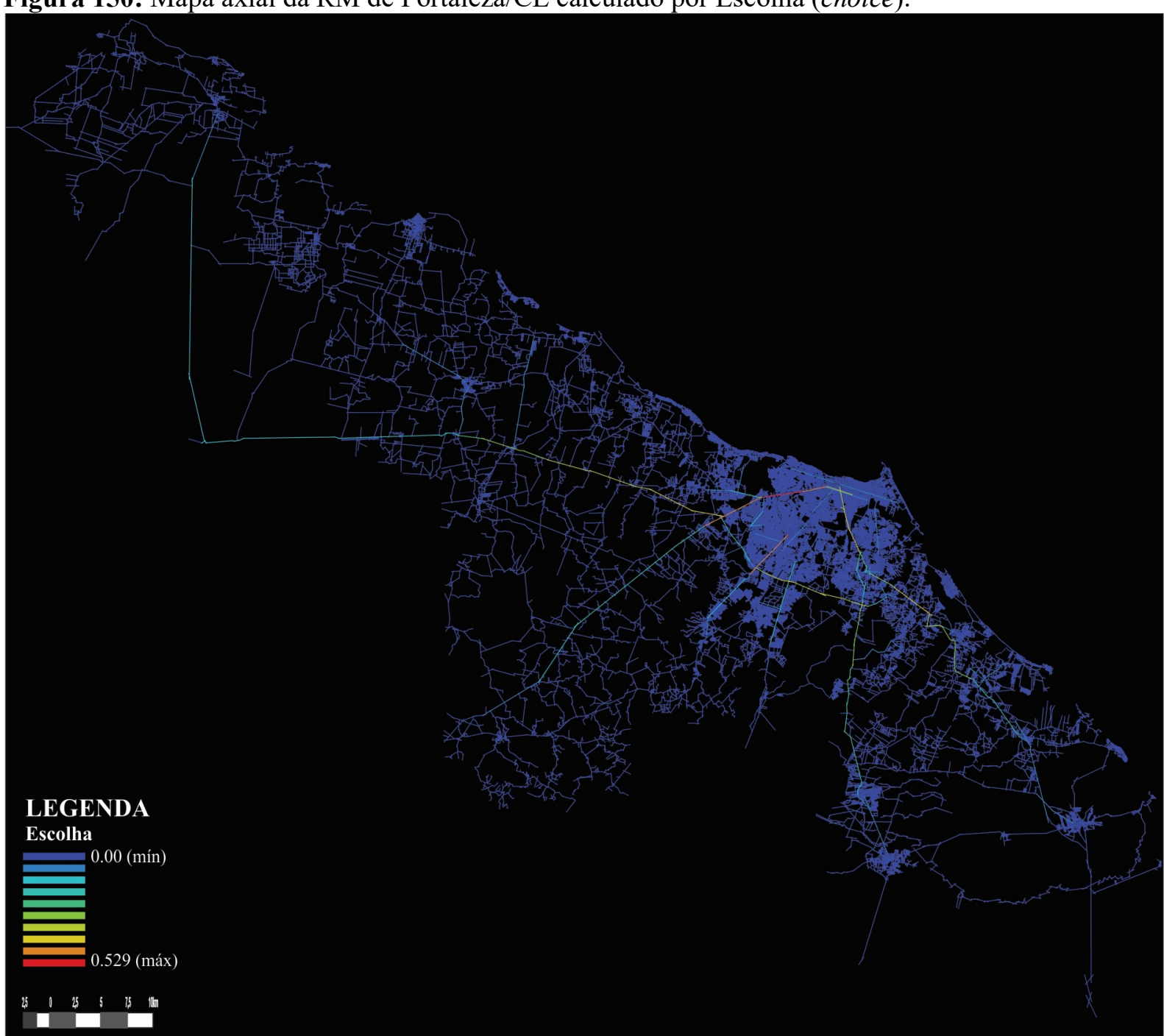

REPRESENTAÇÃO AXIAL - RM DE FORTALEZA/CE ESCOLHA (CHOICE)

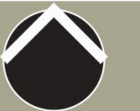

Fonte: Desenho de Fortaleza gentilmente cedido por Lucy Donegan, com atualizações de Klairton Rodrigues, Plácido Ferreira, Lucas Lima e Pâmela Corrêa (2016), com revisão da autora a partir da Base Cartográfica do OpenStreetMap (2016) e imagens de satélite do Google Earth (2016).

Avaliando na escala metropolitana, pode-se sistematizar dois tipos de estágios de conurbação: (1) a zona fortemente adensada composta por Fortaleza, Caucaia, Maracanaú, Pacatuba, Itaitinga, Eusébio e Aquiraz, cujas ocupações tradicionais foram integradas à malha expandida da cidade-sede; (2) uma área de ocupação esparsa, cuja maior parcela é de caracteres rurais, que se alonga ao longo do litoral oeste e leste. Essa segunda porção da RM reforça a crítica aos frouxos critérios de escolha dos municípios constituintes das áreas metropolitanas que exacerbam as desigualdades e a forte polarização de Fortaleza frente à região. 
Como um sintoma das disparidades socioespaciais, a RM de Fortaleza apresenta diversos condomínios e loteamentos fechados, verdadeiros enclaves fortificados que se expandem (em quantidade e em área ocupada), porém sem conseguir, por vezes, um real afastamento da pobreza, que tanto assombra a burguesia. Em Fortaleza eles são verificados em bairros como: Edson Queiroz, Messejana, Sapiranga/Coité e Passaré (Figura 151), áreas de expansão recente da malha urbana que intercala pobreza e riqueza (SANTOS, 2015).

Figura 151: Tipologias habitacionais no bairro Passaré, em Fortaleza/CE.
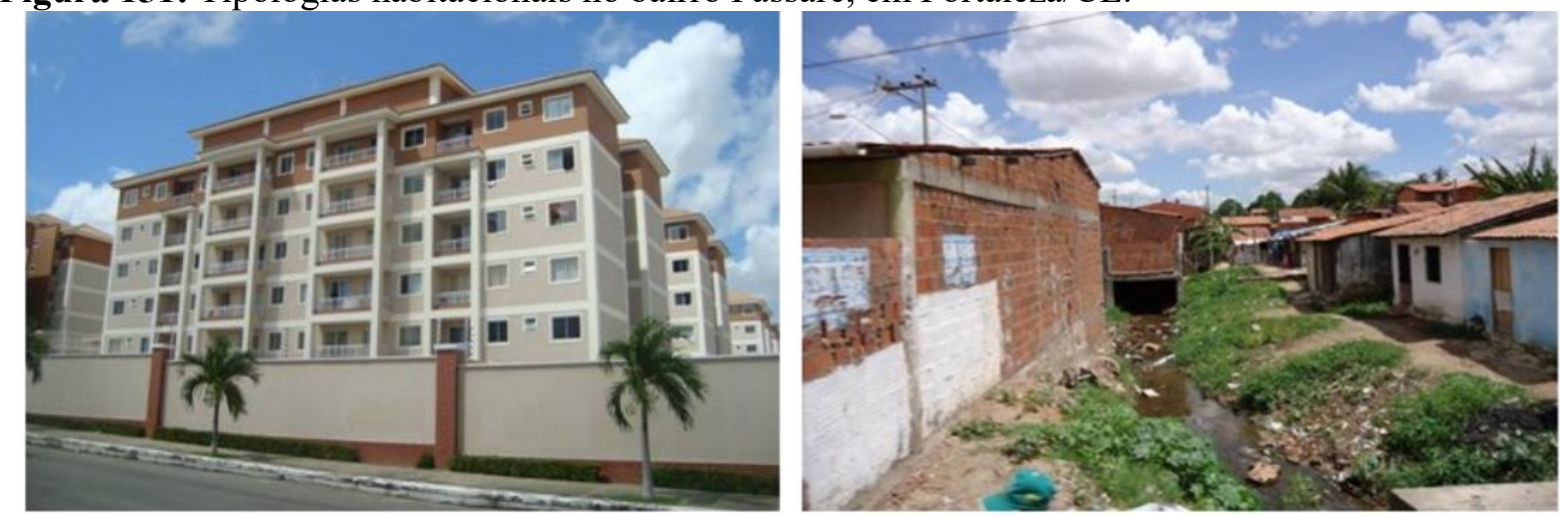

Fonte: SANTOS, 2015, p. 126.

A RM de Fortaleza é também um grande polo atrativo turístico do Brasil, contando com uma série de empreendimentos de alto padrão dispostos ao longo do litoral que redefinem as centralidades funcionais da região. Segundo Diógenes (2012, p. 6), “este setor pode ser caracterizado, no âmbito da Metrópole, como o mais representativo das novas formas de urbanização, indicando rupturas com o modelo tradicional de assentamento urbano". Embora a prática de veraneio no litoral leste tenha se iniciado ainda nas décadas de 1970/80, as classes economicamente privilegiadas inseriram novas formas de uso no espaço, carreando, junto ao Poder Público, obras de infraestrutura urbana (DIÓGENES, 2012).

Figura 152: Loteamento Porto das Dunas, exemplo de condomínio residencial de alto padrão, relacionado com a atividade turística.

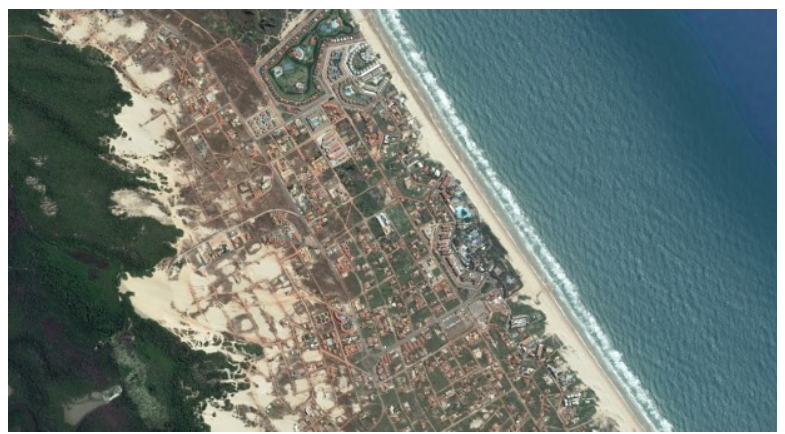

Fonte: Foto de Google Earth (2016) - editado pela autora. Acesso em 28 de ago. 2016.

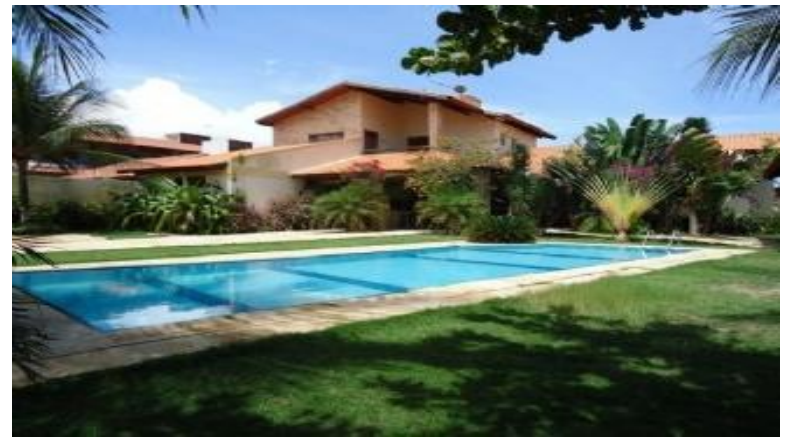

Fonte: Foto de autor desconhecido (s/ d). Disponível em: $<$ http://imoveis.mitula.com.br $>$. Acesso em 28 de ago. 2016. 
A origem do Recife data da terceira década do século XVI. Devido as suas características físicas favoráveis - uma estreita faixa de areia protegida por uma linha de arrecifes que formava um ancoradouro - o local passou a abrigar um porto que servia a Vila de Olinda. O assentamento ocupava a península correspondente ao que hoje é o Bairro do Recife. Nessa região portuária, a atividade comercial desenvolveu-se rapidamente, impulsionando o crescimento do povoado. E em 1537, a constituição da Vila do Recife é registrada (IBGE, 2016). A atividade açucareira também cresceu no interior e as margens dos cursos d'água passaram a ser ocupadas por engenhos e casebres, enquanto os rios tornaram-se caminhos navegáveis para transporte de produtos. Em 1630, Olinda, então centro da capitania, é invadida e incendiada por holandeses. Contudo, os invasores se estabeleceram nas terras baixas da Vila do Recife. A partir do século XVIII, o desenvolvimento da cidade se apoia no comércio externo e a urbanização portuguesa incide predominantemente sobre o antigo território holandês, de forma espontânea, caracterizada por ruas estreitas, que se abrem em pátios e onde se destaca a construção religiosa. No século XIX, a cidade já apresenta um tecido densamente urbanizado que corresponde ao atual centro histórico surgido dos aterros das áreas alagadas e mangues, a partir da ocupação holandesa. No início do século XX, o Recife já era uma cidade muito influente: só perdia em importância político-econômica para o Rio de Janeiro.

Para a RM de Recife/PE (Figura 155), o núcleo de integração recai majoritariamente sobre o município-sede, espraiando-se ao norte, em Olinda (tendo como principal eixo a PE015, também denominada Av. Pan Nordestina), e, ao sul, em Jaboatão dos Guararapes (cujo principal eixo é a PE-008 - Av. Mal. Mascarenhas de Morais) - vias também em destaque no cálculo de escolha (Figura 159). A conurbação entre os três municípios remonta a meados do século passado, embora a relação de interdependência entre Recife-Olinda, como comentado, remonte ao período Colonial. A faixa litorânea, com cerca de $50 \mathrm{~km}$ de extensão (que abarca os três municípios citados e Paulista), configura uma área com os melhores sistemas de infraestrutura e serviços urbanos: transporte coletivo, pavimentação, abastecimento de água, energia elétrica, iluminação, telefonia e limpeza urbana (SOUZA, 2006). Vale destacar também a conurbação com o município de Camaragibe, citado anteriormente em relação a variável de distribuição de renda, que, juntamente com Abreu e Lima, possui um nível de integração física, econômica e social alta, com áreas conurbadas que indicam uma expansão para a periferia oeste do núcleo metropolitano (SOUZA, 2006). 
Figura 153: Eixos de expansão do núcleo de integração da RM de Recife/PE. À direita, a PE-015, em Olinda, e, à esquerda, a PE-008.

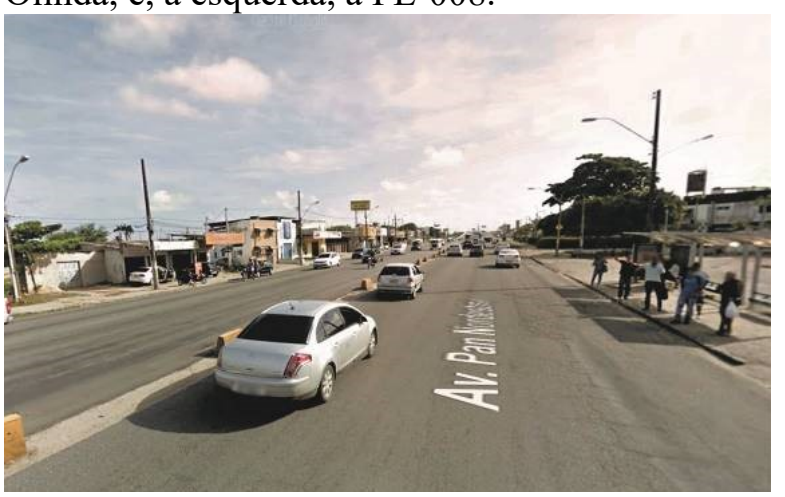

Fonte: Foto de Google Street View (2015). Disponível em: $<$ https://www.google.com.br/maps $>$. Acesso em 27 de ago. 2016.

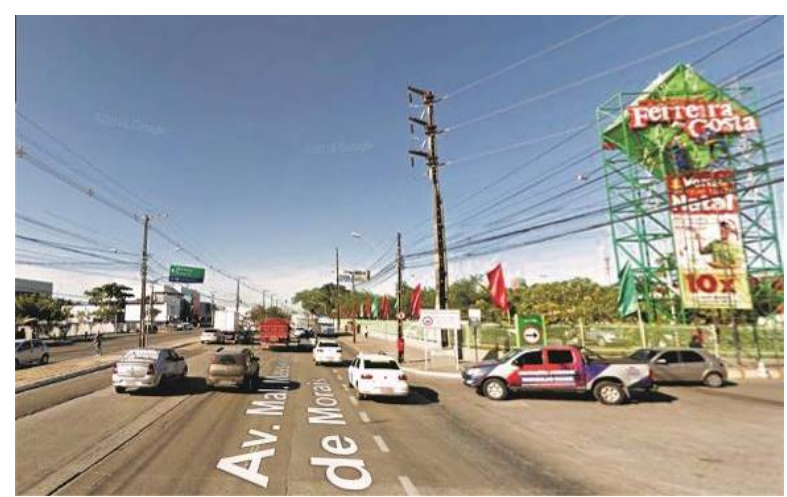

Fonte: Foto de Google Street View (2015). Disponível em: $<$ https://www.google.com.br/maps $>$. Acesso em 27 de ago. $2016 .$.

Figura 154: Panorama do bairro de Santo Antônio, em Recife/PE.

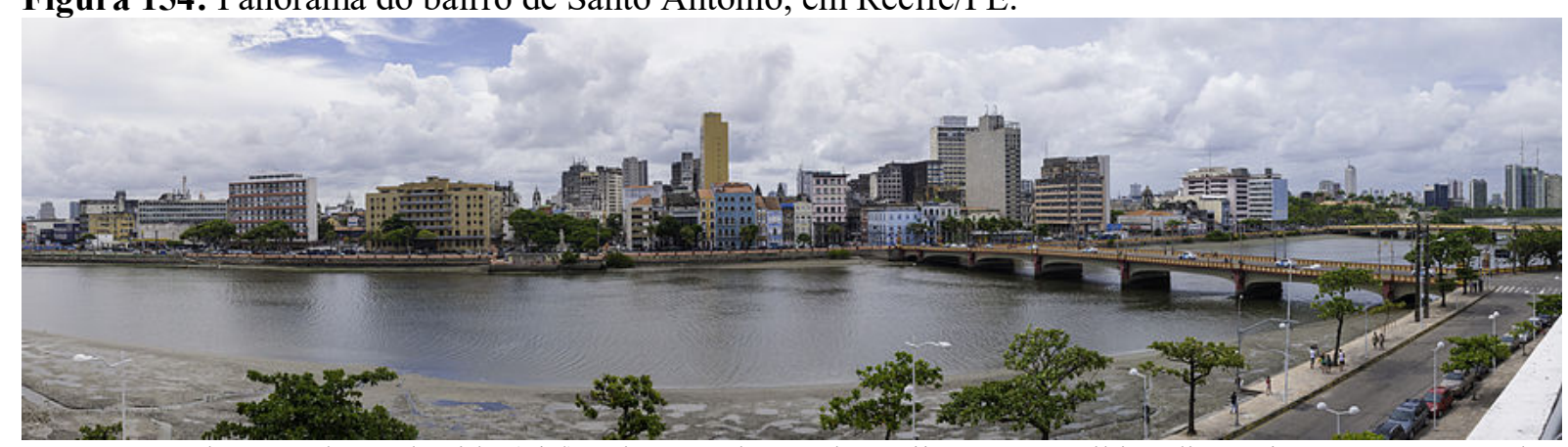

Fonte: Foto de autor desconhecido (s/ d). Disponível em: <https://commons. wikimedia.org/>. Acesso em 28 de ago. 2016.

Até meados dos anos 1970, a RM de Recife configurava-se por uma excessiva oposição entre centro-periferia, onde o primeiro concentrava as principais atividades econômicas, as infraestruturas e serviços urbanos e as áreas residenciais de mais alto nível de renda; e o segundo congregava a grande maioria da população de baixa renda (FARIAS, 2006). A partir da década de 1980, áreas de baixa densidade e alta qualidade ambiental iniciaram o processo de verticalização (Figura 156). Influenciado pela questão simbólica de status e alimentado pela especulação imobiliária, esta ação gerou novas centralidades demográficas e funcionais (LACERDA et al., 2000, s/p). Segundo Farias (2006, p. 55), as localizações dessas expansões verticais se deram "[...]inicialmente, em duas direções: primeiro, no Espinheiro; depois, em Boa Viagem. Assim, o setor terciário "nobre", antes concentrado no centro da cidade, acompanhou esse movimento, seguindo a sua clientela. $\mathrm{O}$ centro tradicional, histórico, entrou em declínio." 
Figura 155: Mapa axial da aglomeração Olinda-Recife-Jaboatão dos Guararapes/PE calculado por Integração HH global (Rn).

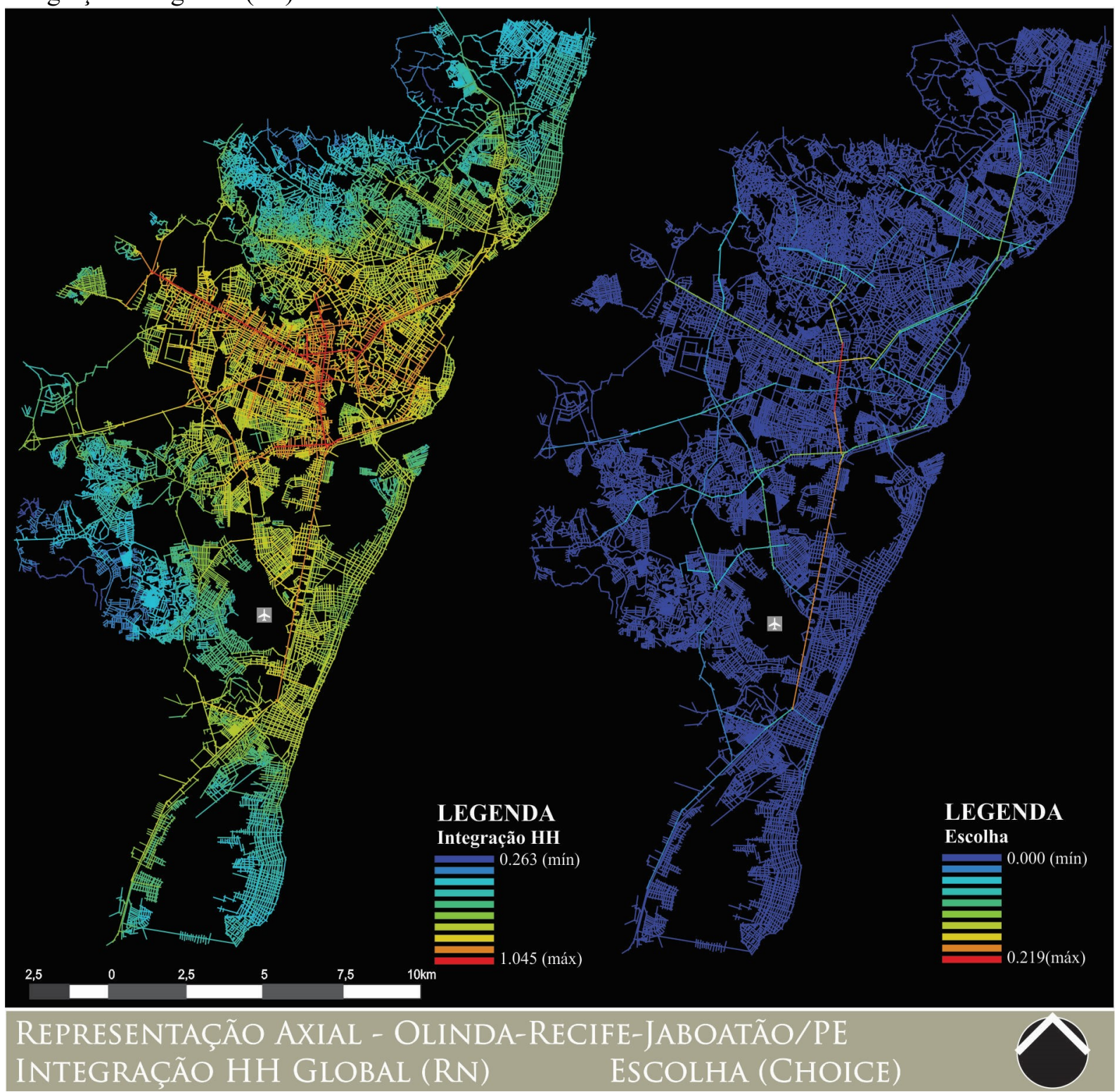

Fonte: Desenho de Olinda/Recife/Jaboatão gentilmente cedido por Valério Medeiros.

Figura 156: Processo de verticalização em Recife/PE. À esquerda, o grande adensamento e, à direita, esse processo na Praia de Boa Viagem, Zona Sul da cidade.

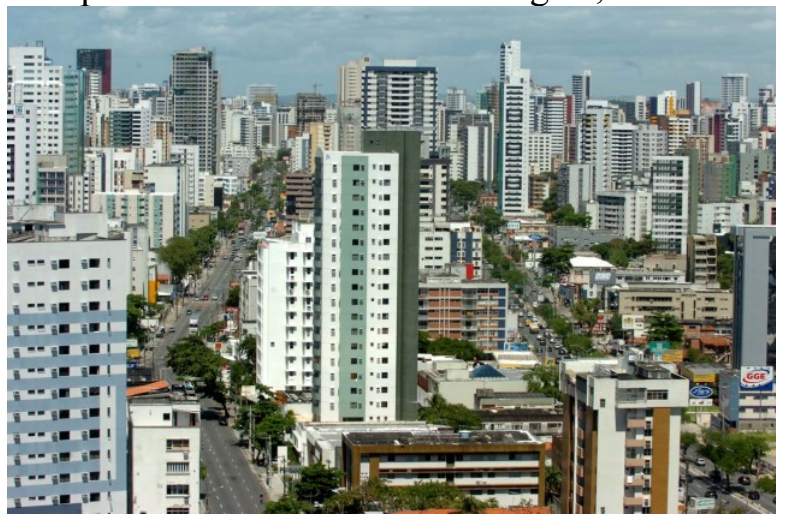

Fonte: Foto de Leo Caldas (s/d). Disponível em: $<$ www.observatoriodorecife.org.br>. Acesso em 27 de ago. 2016.

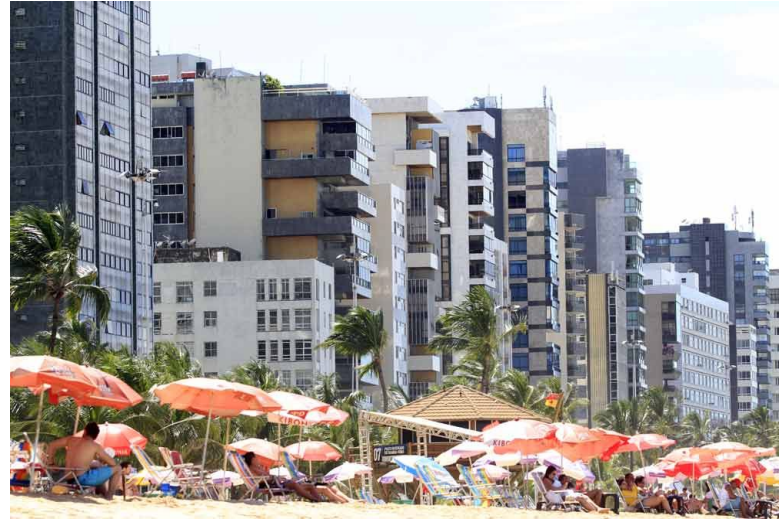

Fonte: Foto de autor desconhecido (2015). Disponível em: <http://jconline.ne10.uol.com.br/>. Acesso em 27 de ago. 2016 . 
Figura 157: Mapa axial da RM de Recife/PE calculado por Integração HH global (Rn).

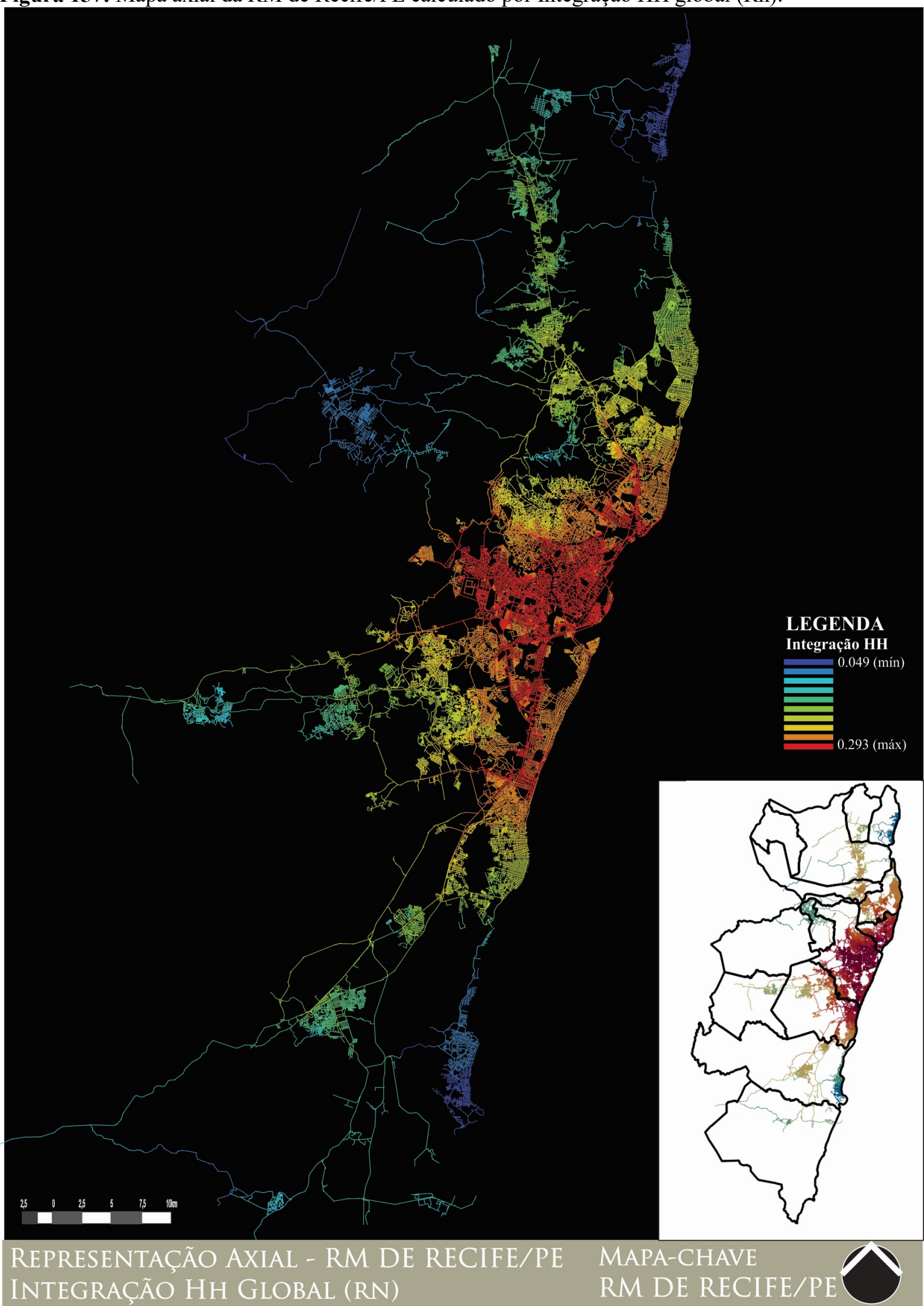

Fonte: Desenho de Olinda/Recife/Jaboatão gentilmente cedido por Valério Medeiros, com atualizações de Pâmela Corrêa e Iasmim de Oliveira (2016), com revisão da autora a partir da Base Cartográfica do OpenStreetMap (2016) e imagens de satélite do Google Earth (2016). 
Essas novas centralidades são marcadas por novos equipamentos comerciais de grande porte e pelos shoppings. O Shopping Center Recife foi o primeiro equipamento do tipo em grande porte, inaugurado na RM em 1980, atuando como atrator para a consolidação de uma nova centralidade: os corredores formados pelas avenidas Engenheiro Domingos Ferreira e Conselheiro Aguiar (FARIAS, 2006). Processo análogo ocorreu no Shopping Guararapes, inaugurado em 1993 em uma área nobre, que também foi um elemento impulsionador da centralidade hoje consolidada, ocasionando um processo de adensamento construtivo e populacional em seu entorno (Figura 158). Essas novas centralidades redefinem funcionalmente os centros tradicionais das cidades, na medida em que oferecem vantagens (localização, acesso, estacionamento, segurança) que o "comércio de rua" não é capaz de oferecer e, por isso, entram em decadência.

Figura 158: Shoppings em Recife. No alto, à esquerda, o Shopping Center Recife, visto em foto de satélite (em rosa) e seu entorno, à direita. Embaixo, à esquerda, o Shopping Guararapes, visto em foto de satélite (em amarelo) e, seu entorno, à direita.

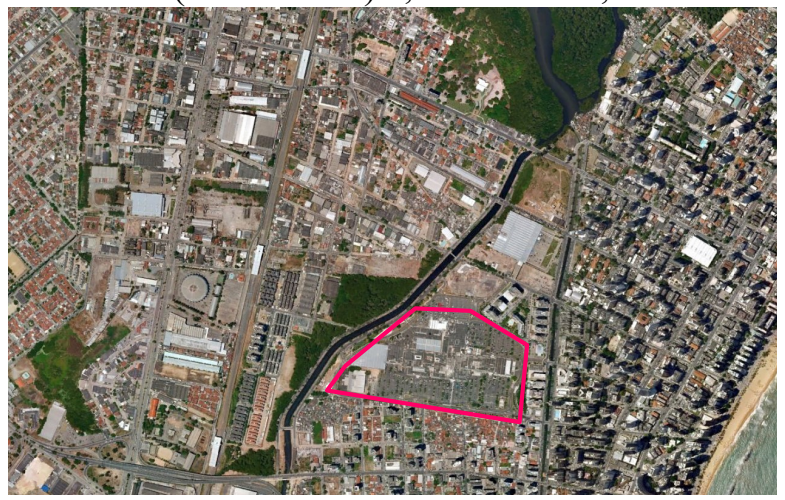

Fonte: Foto de Google Earth (2016) - editado pela autora. Acesso em 28 de ago. 2016.

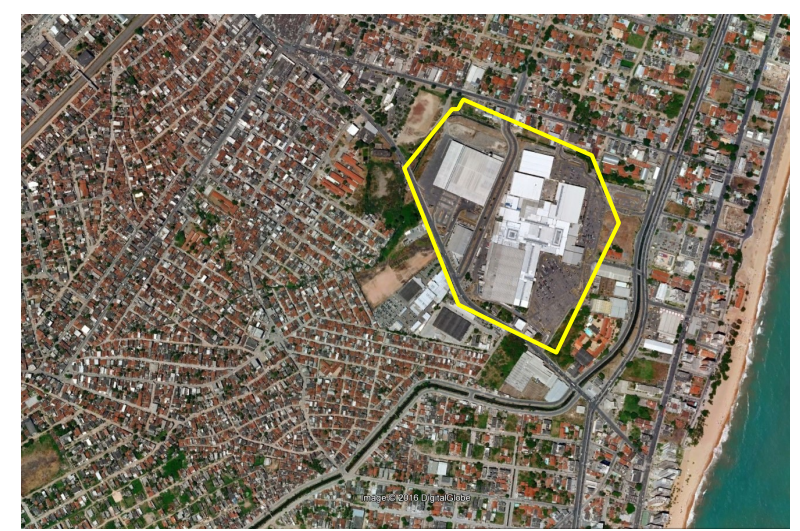

Fonte: Foto de Google Earth (2016) - editado pela autora. Acesso em 28 de ago. 2016.

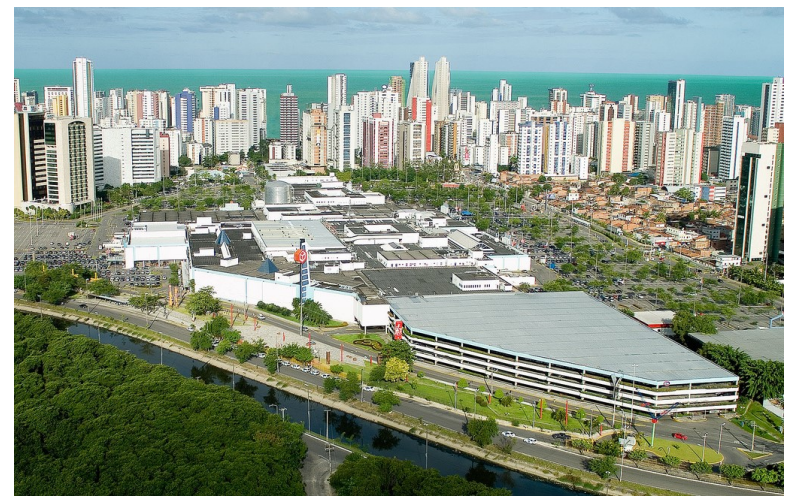

Fonte: Foto de autor desconhecido (s/d). Disponível em: $<$ http://transportenarmr.blogspot.com.br $>$. Acesso em 28 de ago. 2016.

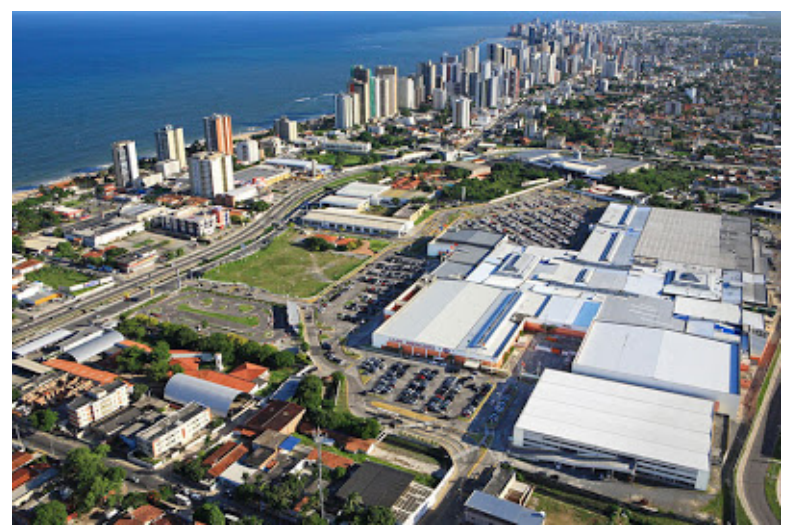

Fonte: Foto de autor desconhecido (s/d). Disponível em: $<$ http://minutoeco.blogspot.com.br/>. Acesso em 28 de ago. 2016. 
Figura 159: Mapa axial da RM de Recife/PE calculado por Escolha (choice).

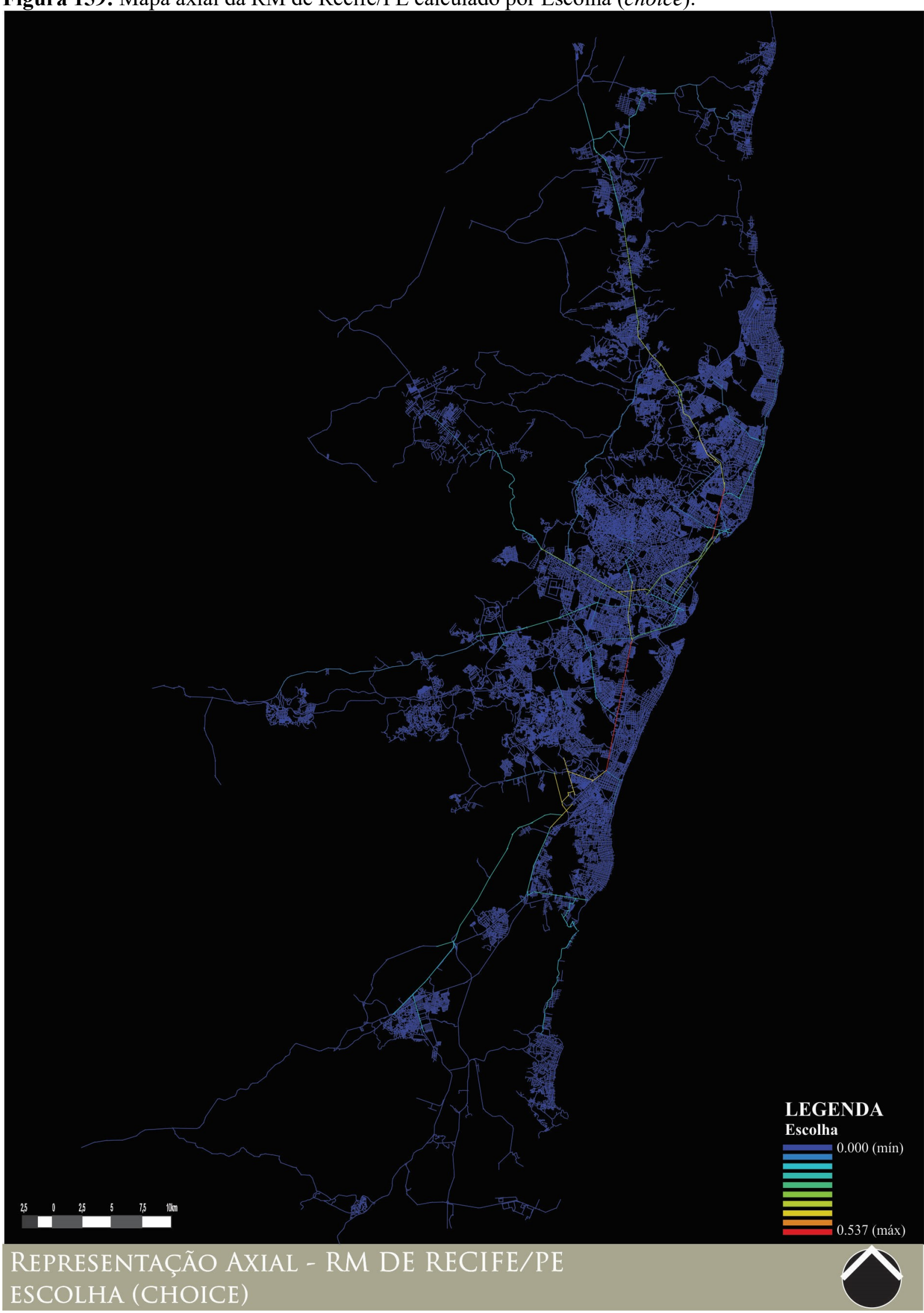

Fonte: Desenho de Olinda/Recife/Jaboatão gentilmente cedido por Valério Medeiros, com atualizações de Pâmela Corrêa e Iasmim de Oliveira (2016), com revisão da autora a partir da Base Cartográfica do OpenStreetMap (2016) e imagens de satélite do Google Earth (2016). 
Essa redefinição de centralidades reacende o debate acerca da preservação patrimonial. Na RM de Recife, destacam-se os núcleos históricos de Antigo Bairro do Recife, tombado em 1998, e o conjunto arquitetônico, urbanístico e paisagístico de Olinda (tombado pelo IPHAN em 1968 e declarado Patrimônio Histórico e Cultural da Humanidade pela UNESCO em 1982) como integrantes do núcleo de integração. Isso significa, na maioria dos casos brasileiros, grandes pressões de transformação arquitetural, visto que o edifício histórico requer inúmeras alterações para se adaptar as lógicas comerciais (e residenciais) atuais. Em que pesem as discussões acerca das ações "cenográficas" nos centros históricos, as transformações nessas áreas se dá de modo velado, porém em acelerado processo (Figura 160). Também vale destacar o centro histórico de Igarassu (na porção norte do mapa), cujo conjunto arquitetônico e paisagístico foi tombado pelo Iphan em 1972. Entretanto, apesar da integração média-baixa (que podem ser benéficas para a preservação), a falta de políticas públicas que regulem os usos e reformas também agrava a manutenção estilística do conjunto.

Figura 160: Preservação e transformações patrimoniais em Olinda/PE. À esquerda, uma vista do colorido casario próximo aos "quatro cantos" e, à direta, uma vista das transformações dos edifícios.

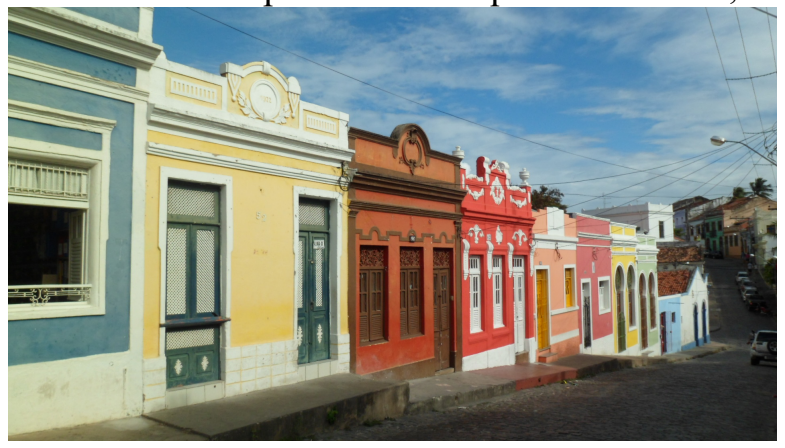

Fonte: Foto de autor desconhecido (s/d). Disponível em: $<$ http://www.mochileirodasmaravilhas.com.br/>. Acesso em 28 de ago. 2016.

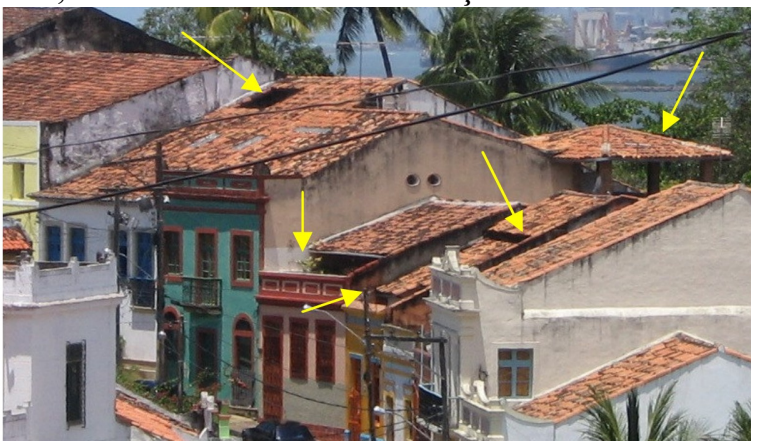

Fonte: Foto de autor desconhecido (s/d). Disponível em: <http://www.tce.pe.gov.br/Acesso em 28 de ago. 2016.

Figura 161: Vista do centro histórico de Igarassu/PE.

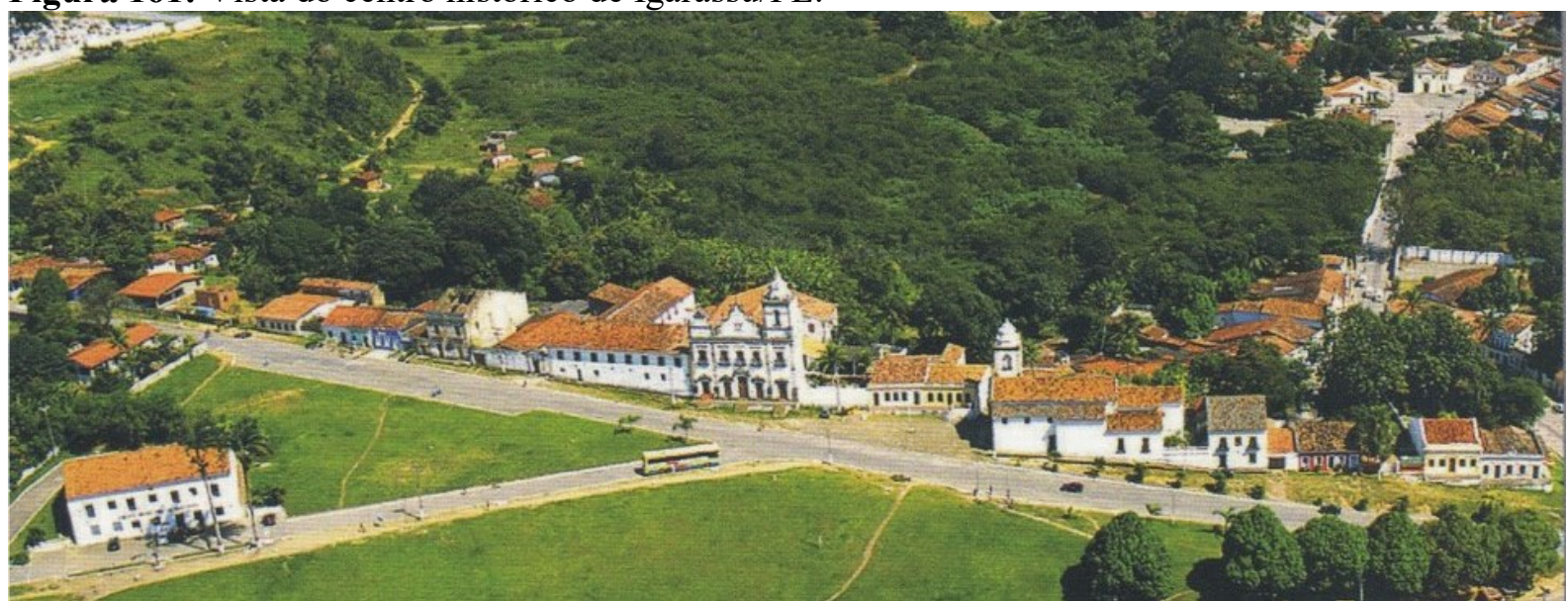

Fonte: Foto de autor desconhecido (s/d). Disponível em: < http://igarassunoticias.blogspot.com.br/>. 
Por fim, traço um comparativo entre as representações axiais a partir da medida de integração proporcional, apresentada na Tabela 20. Percebe-se que os valores de integração HH máximos apresentados para os miolos das RM's é, em todos os casos, igual ao valor máximo do sistema total, enquanto os valores mínimos entre o total e as cercanias estão sempre muito próximos, da mesma maneira que foi verificado nas demais cidades e aglomerações em estudo.

\begin{tabular}{|c|c|c|c|c|}
\hline RMINE & VALORES & TOTAL & CERCANIAS & MIOLO \\
\hline \multirow{5}{*}{$\begin{array}{c}\text { RM DE } \\
\text { SALVADOR/BA }\end{array}$} & MÍNIMA & 0,076 & 0,076 & 0,076 \\
\hline & MÉDIA & 0,267 & 0,158 & 0,275 \\
\hline & MEDIANA & 0,272 & 0,162 & 0,276 \\
\hline & MÁXIMA & 0,422 & 0,236 & 0,422 \\
\hline & DESVIO PADRÃO & 0,062 & 0,034 & 0,056 \\
\hline \multirow{5}{*}{$\begin{array}{c}\text { RM DE } \\
\text { FORTALEZA/CE }\end{array}$} & MÍNIMA & 0,129 & 0,136 & 0,129 \\
\hline & MÉDIA & 0,418 & 0,244 & 0,429 \\
\hline & MEDIANA & 0,441 & 0,244 & 0,456 \\
\hline & MÁXIMA & 0,633 & 0,395 & 0,633 \\
\hline & DESVIO PADRÃO & 0,116 & 0,038 & 0,110 \\
\hline \multirow{5}{*}{$\begin{array}{c}\text { RM DE } \\
\text { RECIFE/PE }\end{array}$} & MÍNIMA & 0,050 & 0,050 & 0,051 \\
\hline & MÉDIA & 0,197 & 0,116 & 0,216 \\
\hline & MEDIANA & 0,210 & 0,116 & 0,226 \\
\hline & MÁXIMA & 0,298 & 0,210 & 0,298 \\
\hline & DESVIO PADRÃO & 0,064 & 0,043 & 0,053 \\
\hline
\end{tabular}

Fonte: Elaboração própria (2016) a partir das bases cartográficas calculadas para integração HH.

Observando os mapas apresentados na Figura 162, os núcleos de integração estão nos círculos de miolo e a maior parte das linhas segregadas (em azul) estão nas cercanias. Entretanto, a RM de Salvador possui uma expansão em apenas uma direção (norte) devido à barreira da Baia de Todos os Santos (ao sul), enquanto as RM de Fortaleza e Recife se expandem em duas direções ao longo do litoral, porém, com a existência de expansões de menor "força" em direção ao interior dos estados. A grande extensão territorial dessas RM's em contraponto a área densamente ocupada e conurbada equivale a menos de $50 \%$ do território, fato que retoma a questão dos critérios de seleção dos municípios metropolitanos. Embora isso não tenha ficado tão evidente nas análises anteriores, principalmente porque se desenhou para as RMINE's e Grupo de Controle 01 as áreas mais urbanizadas, enquanto no Grupo de Controle 02 há um esforço em desenhar o máximo das áreas urbanizadas de todos os municípios constituintes. 
Figura 162: Comparativo entre os mapas por meio da Medida de Integração Proporcional.

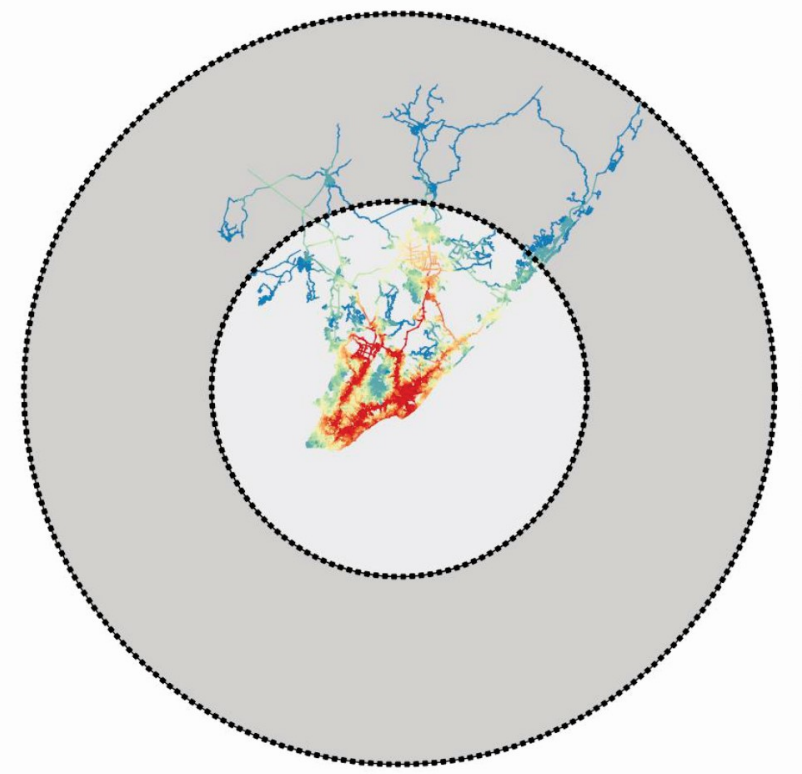

RM DE SALVADOR/BA

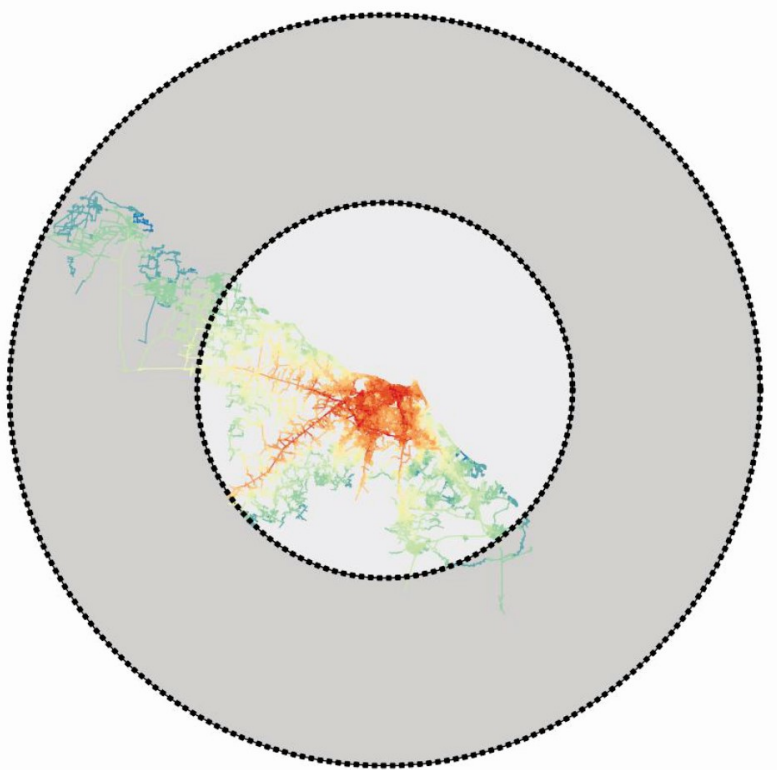

RM DE FORTALEZA/CE

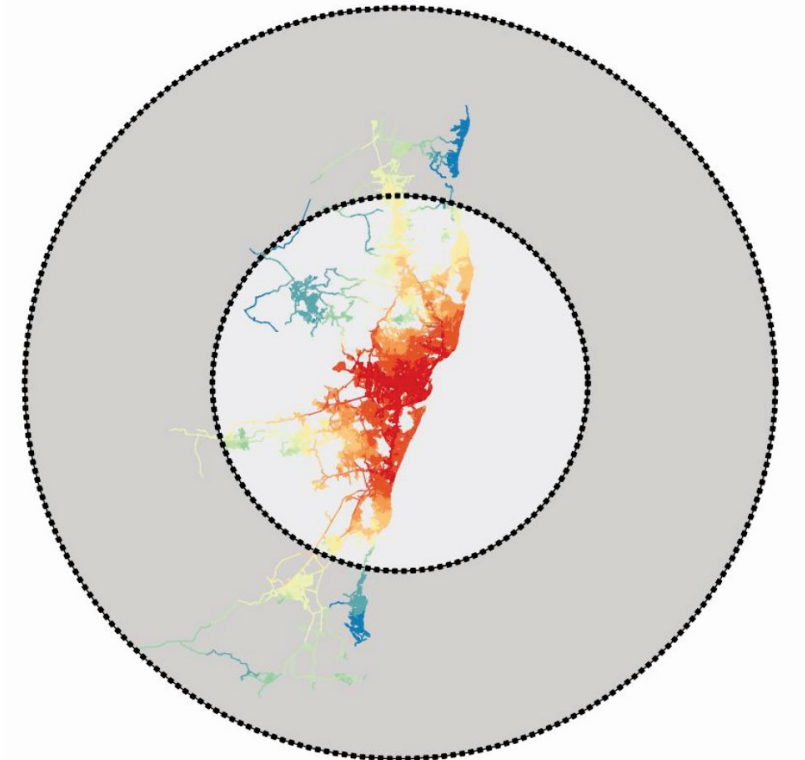

RM DE RECIFE/PE

L E G E N D A

Integração HH
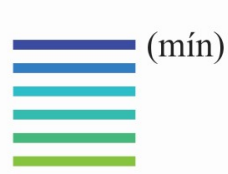

2

(máx)

ESCALAS NÃO DEFINIDAS Áreas de integração proporcional Miolo Cercanias

Fonte: Elaboração própria (2016) a partir das bases cartográficas calculadas para integração HH.

\subsection{Análise das variáveis do sistema de encontros e esquivanças: Densidade populacional}

Nesta variável serão apresentados os dados gerais de estimativa de população 2015 (IBGE) para os municípios constituintes das RM's e demais municípios analisados, bem como os dados detalhados de densidade, dados em habitantes por hectare, distribuídos por 
setor censitário elaborados a partir dos dados do censo 2010 com a utilização de ferramentas de SIG.

\subsubsection{RMINE'S selecionadas}

Para a RM de Feira de Santana/BA, podemos observar na Tabela 21 que o município-sede é responsável por cerca de $82 \%$ da população total da RM e, apesar de possuir o maior território (que representa cerca de $58 \%$ da área total da $\mathrm{RM}$ ), também possui a maior densidade populacional. Vale ressaltar que Feira/BA é a segunda cidade mais populosa do interior do estado (atrás apenas da capital Salvador/BA) e a maior cidade do interior das regiões Norte, Nordeste, Centro Oeste e Sul do Brasil. Na Figura 163 vemos a distribuição das densidades e a predominância é clara na área urbana de Feira.

Quando se analisa apenas a área urbana consolidada da RM, as áreas mais densas se encontram ao longo do anel rodoviário, especialmente na porção oeste. Por outro lado, o centro, de usos predominantemente comerciais, possui densidades inferiores a 48 hab/hec. Apesar da expansão da cidade se caracterizar por uma tendência a seguir em direção leste (SOUZA \& SANTOS, 2011), na representação é possível visualizar também os eixos de expansão ao norte (ao longo da BR-116) e ao sul, em direção ao município de São Gonçalo dos Campos, com densidades médias e baixas, denotando o início dessa ocupação.

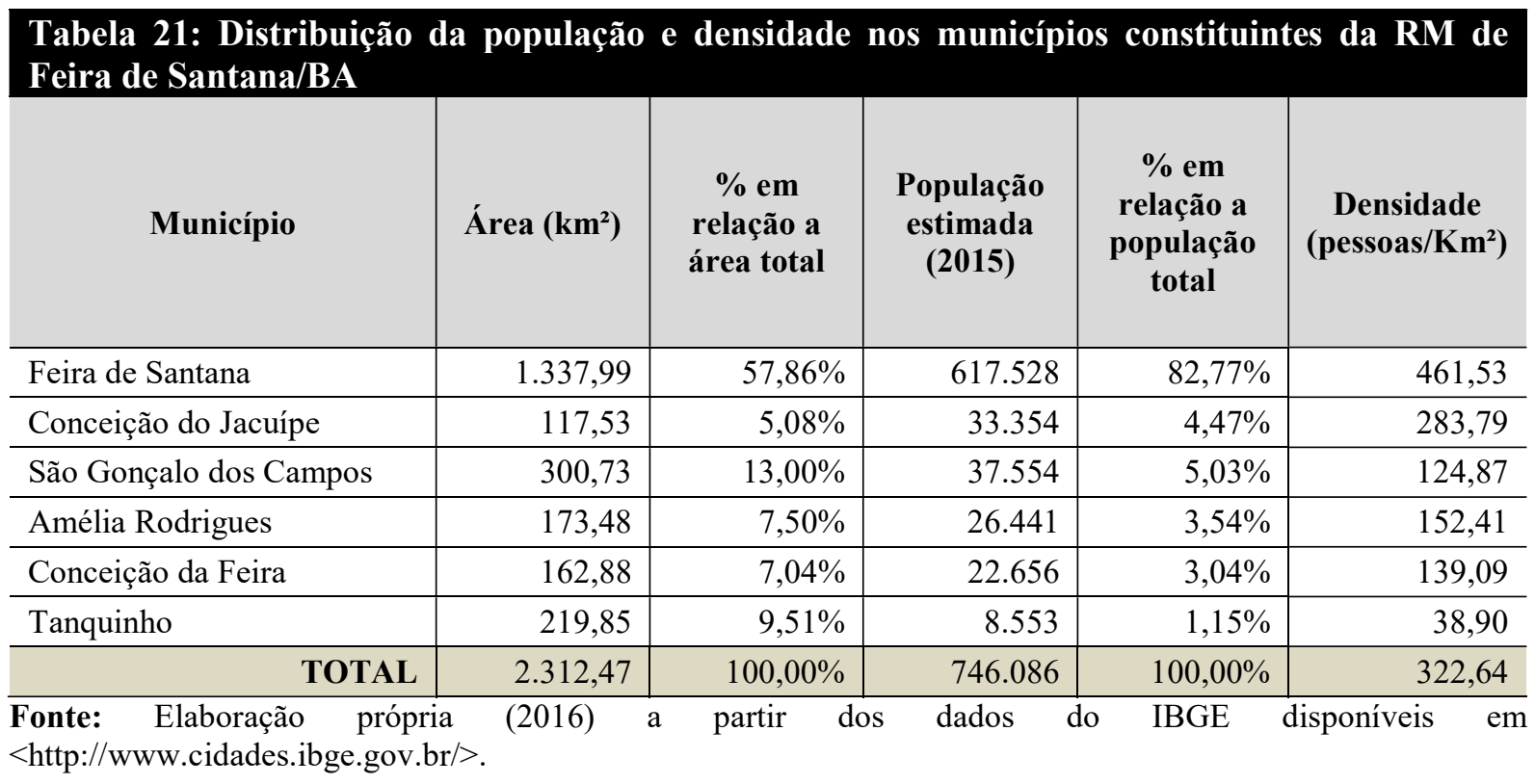


Figura 163: Mapa de Densidade Populacional (em habitantes por hectare) por setor censitário da RM Feira de Santana/BA.

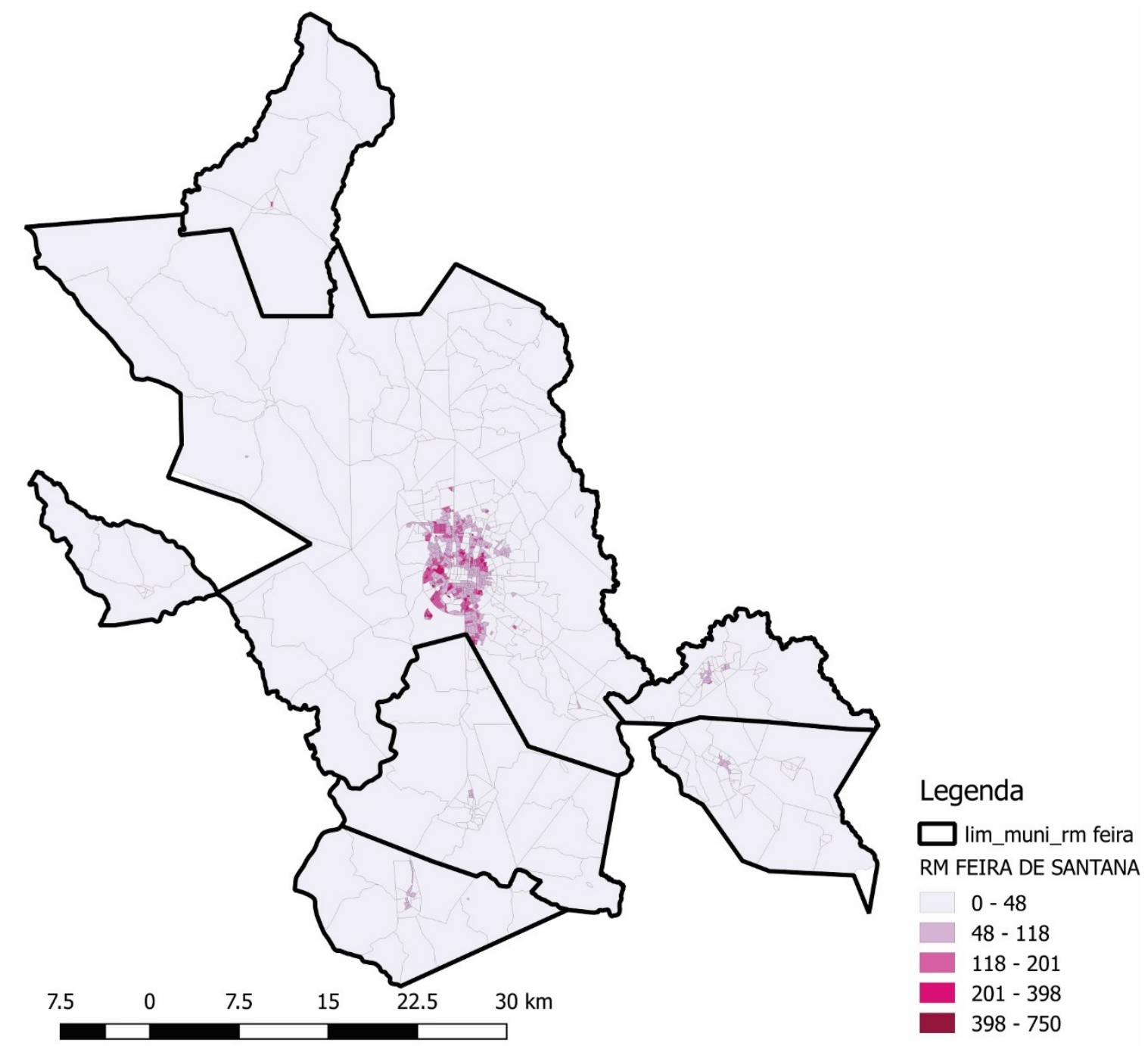

MAPA DE DISTRIBUIÇÃO DE DENSIDADE POPULACIONAL

(HAB/HA) POR SETOR CENSITÁRIO NA RM FEIRA DE SANTANA/BA

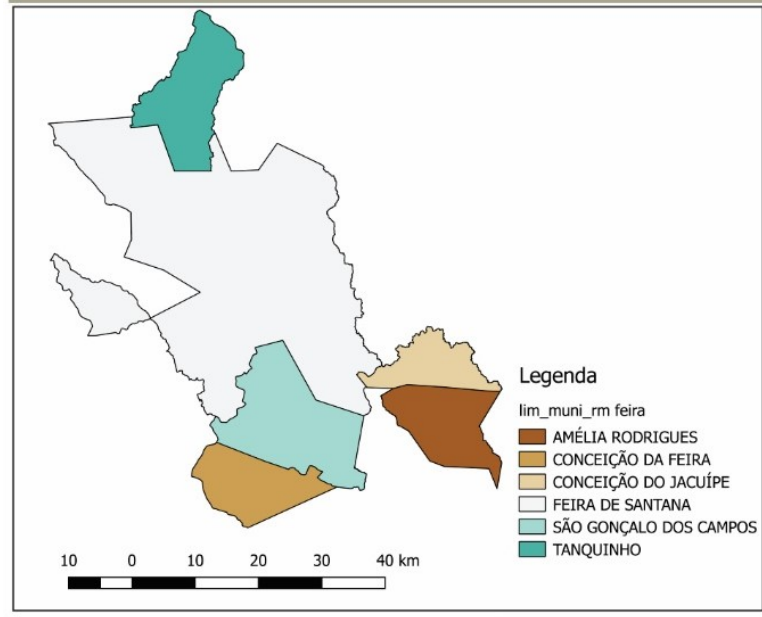

MAPA-CHAVE: MUNICÍPIOS

CONSTITUINTES DA RM FEIRA DE

SANTANA BA

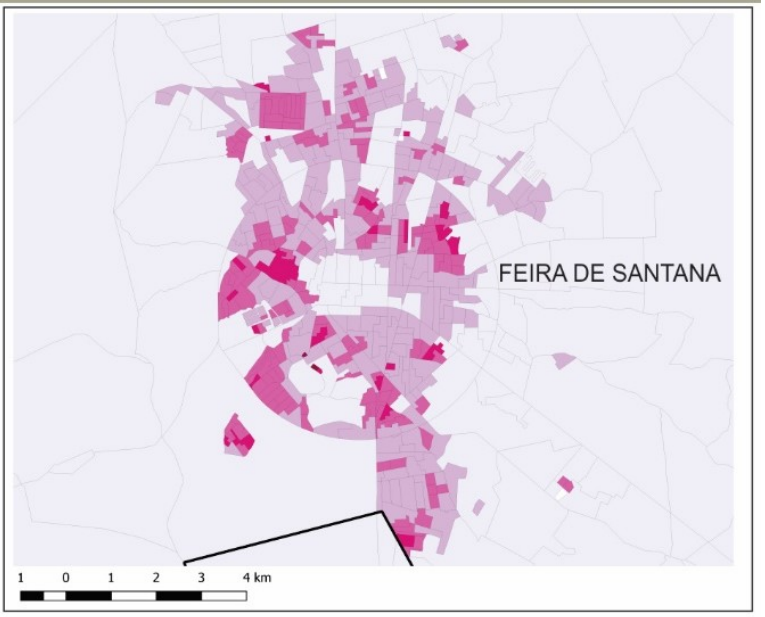

DETALHE DA DISTRIBUIÇÃO DE DENSIDADE POPULACIONAL (HAB/HA) POR SETOR CENSITÁRIO NA RM FEIRA DE SANTANA/BA

Fonte: Elaboração própria (2016) sob a Base Cartográfica do IBGE (2010) e dados do censo de 2010. 
Para o Cariri/CE, na tabela que representa os dados populacionais da região observamos que o Crajubar congrega cerca de $76 \%$ da população da RM. Juazeiro do Norte contribui com cerca de $45 \%$ desse percentual e possui também a maior densidade de todos os municípios-sede de RM, com exceção do Grupo 2. Isso se dá pelo seu pequeno território (o menor da região) que possui cerca de $80 \%$ de área urbanizada.

\begin{tabular}{|c|c|c|c|c|c|}
\hline Município & Área $\left(\mathbf{k m}^{2}\right)$ & $\begin{array}{c}\% \text { em } \\
\text { relação a } \\
\text { área total }\end{array}$ & $\begin{array}{c}\text { População } \\
\text { estimada } \\
\text { (2015) }\end{array}$ & $\begin{array}{c}\% \text { em } \\
\text { relação a } \\
\text { população } \\
\text { total }\end{array}$ & $\begin{array}{c}\text { Densidade } \\
\left(\text { pessoas } / \mathbf{K m}^{2}\right)\end{array}$ \\
\hline Juazeiro do Norte & 248,83 & $4,56 \%$ & 266.022 & $44,77 \%$ & $1.069,08$ \\
\hline Crato & $1.176,47$ & $21,55 \%$ & 128.680 & $21,65 \%$ & 109,38 \\
\hline Barbalha & 569,51 & $10,43 \%$ & 58.855 & $9,90 \%$ & 103,34 \\
\hline Missão Velha & 645,70 & $11,83 \%$ & 35.240 & $5,93 \%$ & 54,58 \\
\hline Jardim & 552,42 & $10,12 \%$ & 27.072 & $4,56 \%$ & 49,01 \\
\hline Caririaçu & 623,56 & $11,42 \%$ & 26.858 & $4,52 \%$ & 43,07 \\
\hline Farias Brito & 503,62 & $9,22 \%$ & 18.861 & $3,17 \%$ & 37,45 \\
\hline Santana do Cariri & 855,56 & $15,67 \%$ & 17.468 & $2,94 \%$ & 20,42 \\
\hline Nova Olinda & 284,40 & $5,21 \%$ & 15.181 & $2,55 \%$ & 53,38 \\
\hline TOTAL & $5.460,08$ & $100,00 \%$ & 594.237 & $100,00 \%$ & 108,83 \\
\hline
\end{tabular}

Ao observamos o mapa com a distribuição desses dados por setor censitário (Figura 164) é possível ver que no censo de 2010 ainda não há densidade nas áreas que correspondem a conurbação. Há duas hipóteses: a primeira, devido aos usos comerciais/serviços predominantes nas vias de ligação intermunicipal (conforme comentado no item anterior) e, a segunda porque esse processo ainda é embrionário, ou seja, os condomínios e loteamentos presentes naqueles arredores são recentes e ainda estão parcamente ocupados.

Traçando uma correlação com a distribuição de renda (Figura 19), os setores mais densos são aqueles de ocupação das faixas baixas e médias. As análises empíricas demonstram que as elites do Cariri se isolam em porções do espaço monofuncionais (onde não há sequer um pequeno comércio de apoio imediato às residências), compostas por grandes lotes (anteriormente identificados como chácaras, embora assista-se a gradativa subdivisão para a construção de condomínios residenciais) que possuem as amenidades climáticas proporcionadas pela proximidade com a Chapada do Araripe, que contribui para a valorização dos terrenos e aumenta a especulação imobiliária (GURGEL, 2012). 
Figura 164: Mapa de Densidade Populacional (em habitantes por hectare) por setor censitário da RM do Cariri/CE.

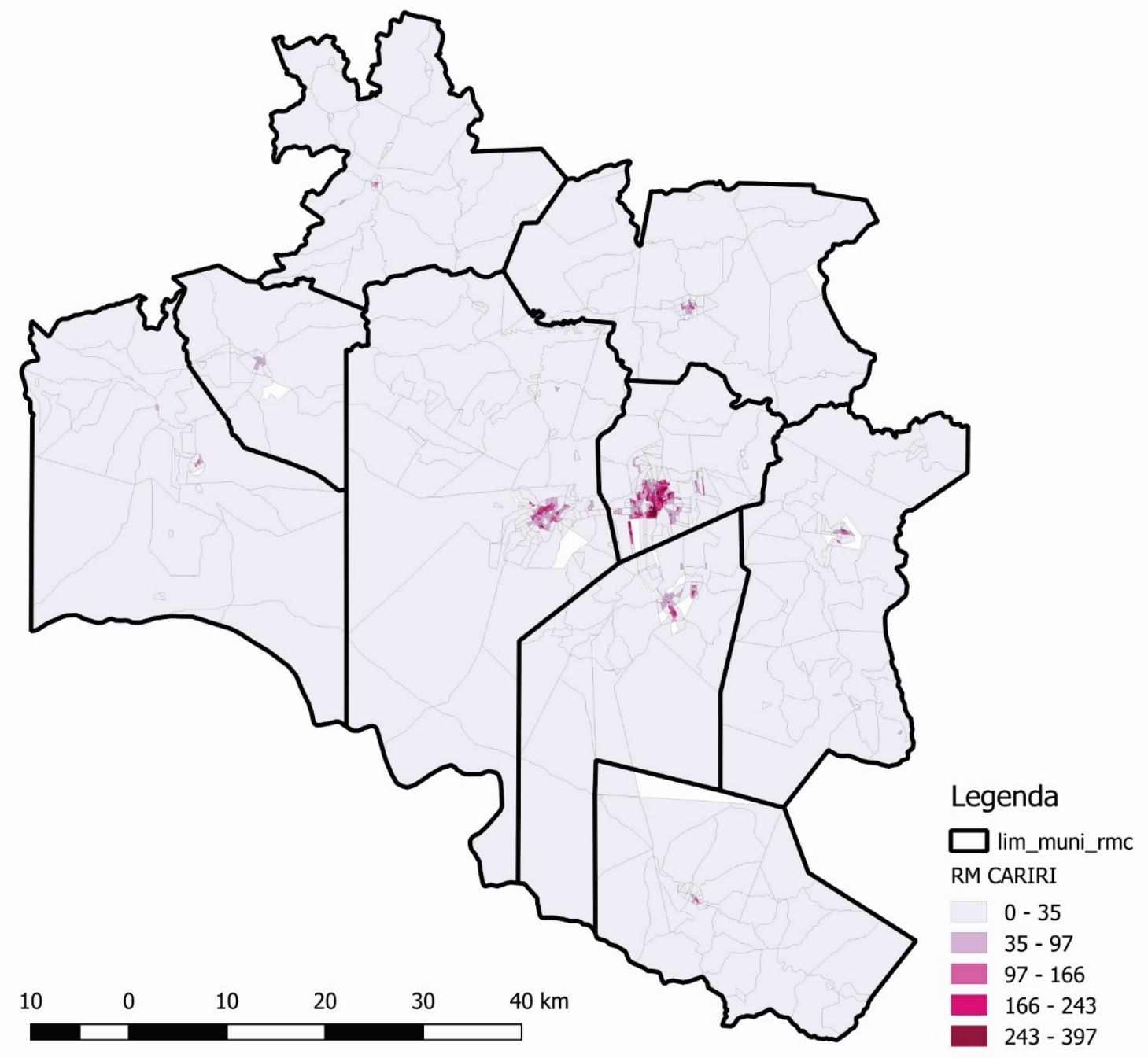

MAPA DE DISTRIBUIÇÃO DE DENSIDADE POPULACIONAL (HAB/HA) POR SETOR CENSITÁRIO NA RM CARIRI/CE

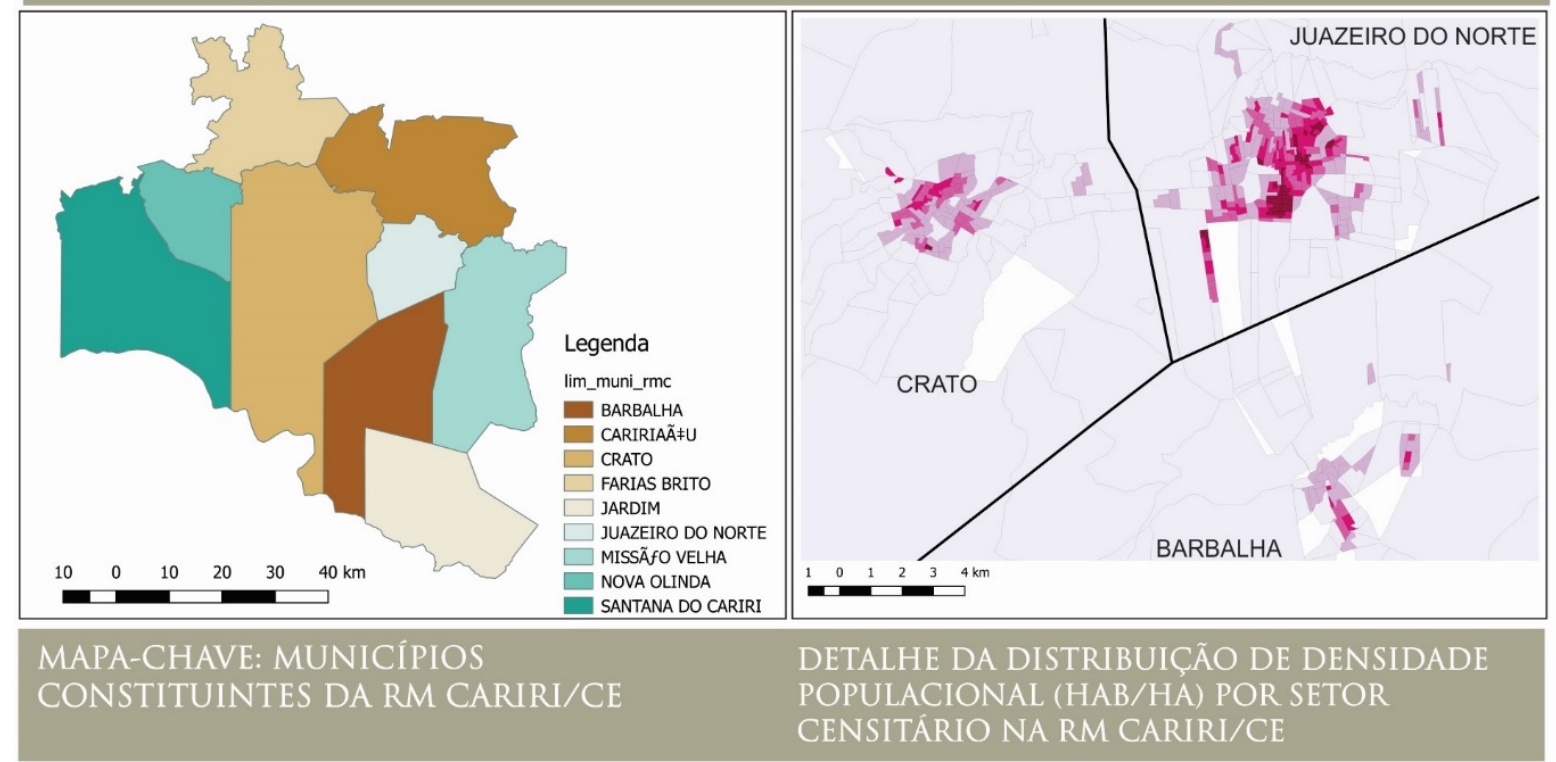

Fonte: Elaboração própria (2016) sob a Base Cartográfica do IBGE (2010) e dados do censo de 2010. 
Analisando os dados coletados para Imperatriz/MA e sua RM (Tabela 20), prevalece, do ponto de vista de densidade populacional, o domínio da cidade sobre seu entorno: o município é responsável por cerca de $72 \%$ da população total da RM. Isso é um dos reflexos do quão desequilibrada é a rede urbana dessa e das RM's analisadas - e quiçá do Brasil - na qual um pequeno número de cidades congrega a maior parcela da população.

Numa escala ampliada, vale destacar que Imperatriz é a cidade-polo da região denominada "Bico do Papagaio", que abrange os estados do Tocantins, Maranhão e Pará. Esta área é a transição entre o Centro-Oeste e a área de expansão agrícola sudoeste nordestina (MENDES, 2009), a que se deve a alcunha de "Portal da Amazônia".

\begin{tabular}{|c|c|c|c|c|c|}
\hline Município & Área $\left(\mathbf{k m}^{2}\right)$ & $\begin{array}{c}\text { \% em } \\
\text { relação a } \\
\text { área total }\end{array}$ & $\begin{array}{c}\text { População } \\
\text { estimada } \\
\text { (2015) }\end{array}$ & $\begin{array}{c}\text { \% em } \\
\text { relação a } \\
\text { população } \\
\text { total }\end{array}$ & $\begin{array}{c}\text { Densidade } \\
\left(\text { pessoas } / \mathrm{Km}^{2}\right)\end{array}$ \\
\hline Imperatriz & $1.368,99$ & $18,88 \%$ & 253.123 & $71,79 \%$ & 184,90 \\
\hline João Lisboa & $1.135,21$ & $15,65 \%$ & 23.232 & $6,59 \%$ & 20,46 \\
\hline Governador Edison Lobão & 615,86 & $8,49 \%$ & 17.747 & $5,03 \%$ & 28,82 \\
\hline Buritirana & 818,42 & $11,29 \%$ & 15.100 & $4,28 \%$ & 18,45 \\
\hline Senador La Rocque & 738,55 & $10,18 \%$ & 14.081 & $3,99 \%$ & 19,07 \\
\hline Davinópolis & 335,77 & $4,63 \%$ & 12.653 & $3,59 \%$ & 37,68 \\
\hline Montes Altos & $1.488,34$ & $20,52 \%$ & 9.026 & $2,56 \%$ & 6,06 \\
\hline Ribamar Fiquene & 750,55 & $10,35 \%$ & 7.609 & $2,16 \%$ & 10,14 \\
\hline TOTAL & $7.251,69$ & $100,00 \%$ & 352.571 & $100,00 \%$ & 48,62 \\
\hline
\end{tabular}

$\mathrm{Na}$ espacialização desses dados por setor censitário (Figura 165), além da já comentada preponderância de Imperatriz, destaco a proximidade das manchas urbanas de densidade média dos municípios limítrofes de João Lisboa e Davinópolis. Essa curta distância pode ser um facilitador para majorar o processo de conurbação ao decorrer dos próximos anos, uma vez que já a modelagem axial sugere que as vias de ligações entre as cidades são importantes vetores de expansão e dinamização. 
Figura 165: Mapa de Densidade Populacional (em habitantes por hectare) por setor censitário da RM do Sudoeste maranhense/MA.

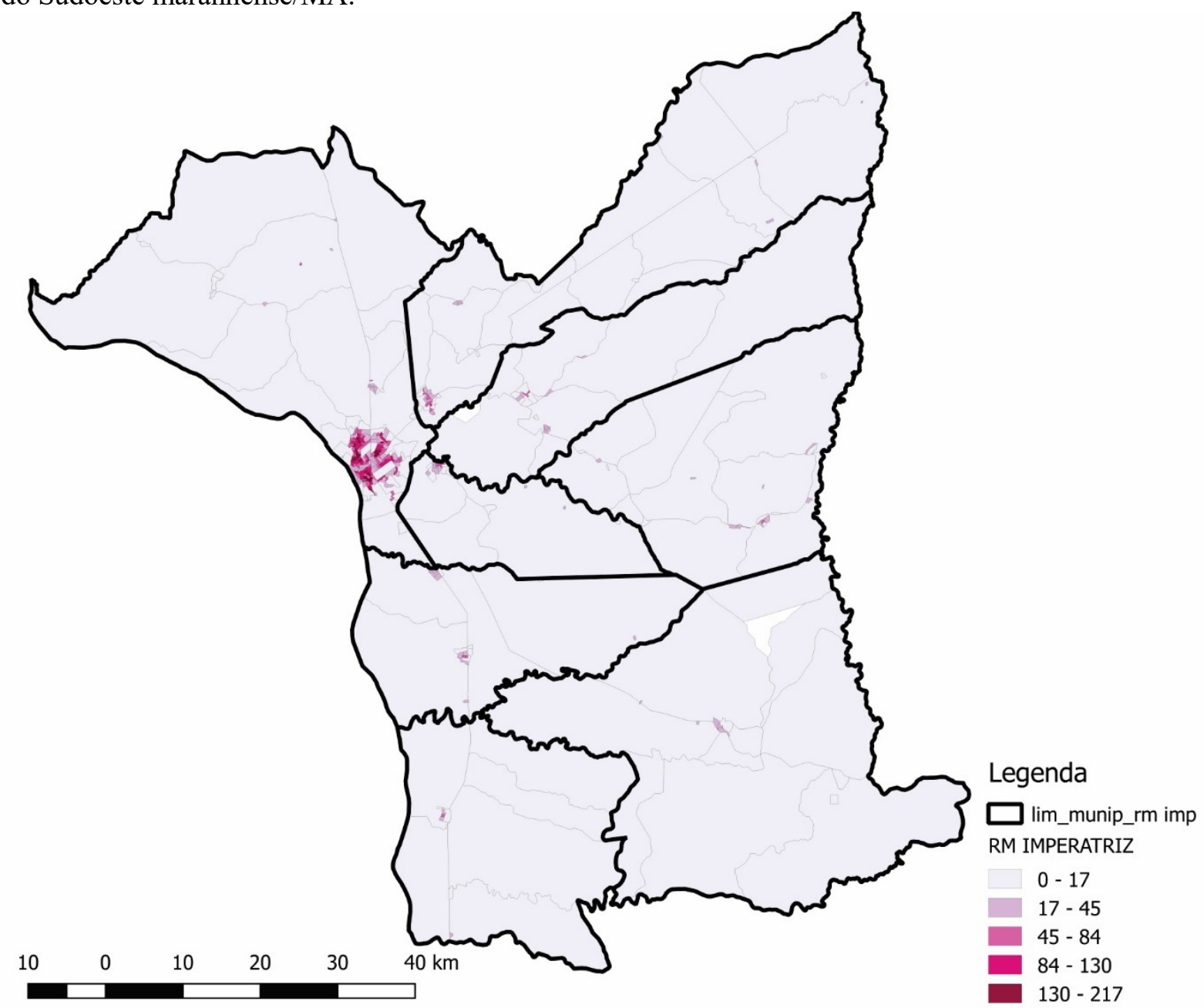

MAPA DE DISTRIBUIÇÃO DE DENSIDADE POPULACIONAL (HAB/HA POR SETOR CENSITÁRIO NA RM SUDOESTE MARANHENSE/MA

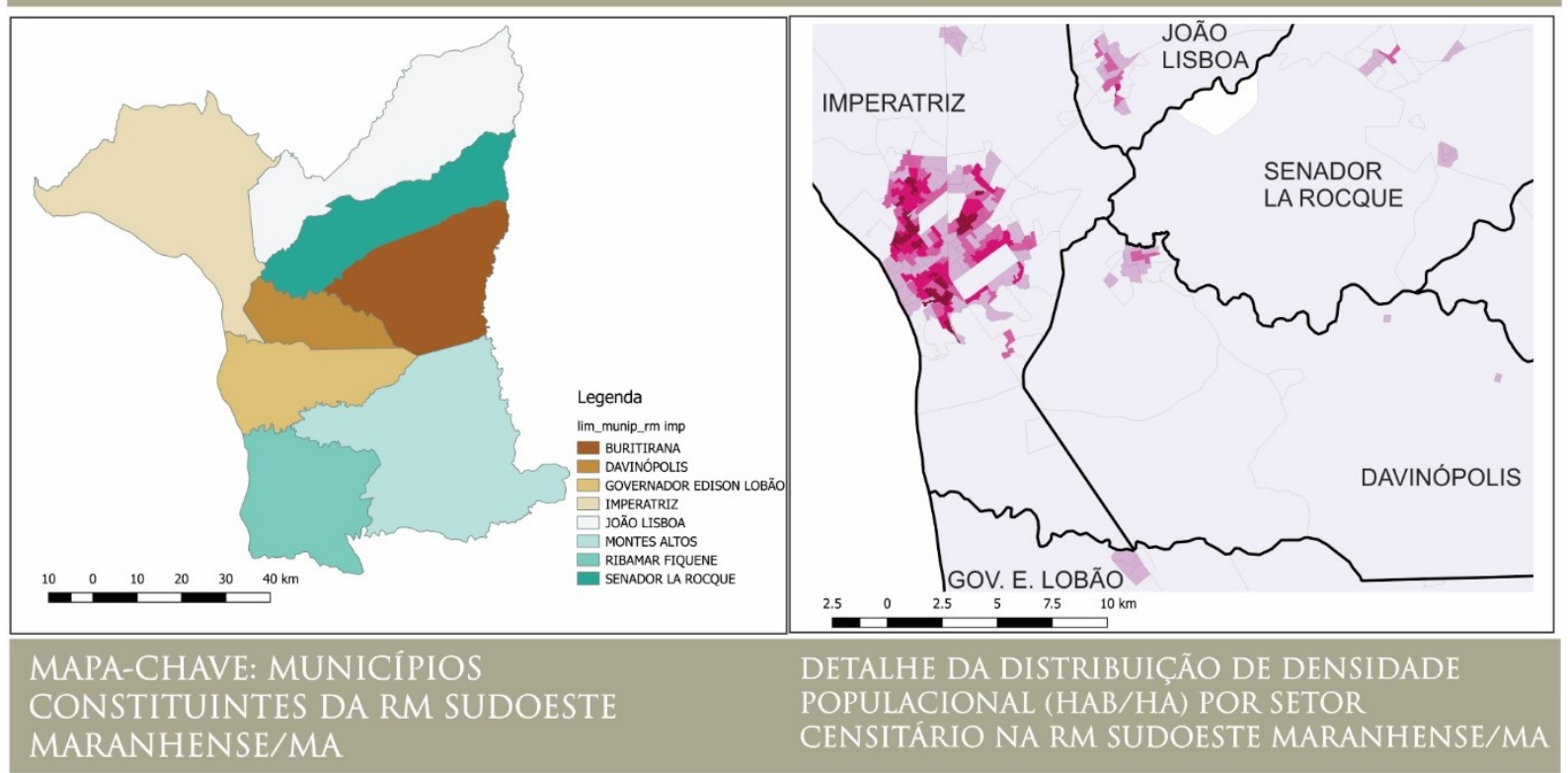

Fonte: Elaboração própria (2016) sob a Base Cartográfica do IBGE (2010) e dados do censo de 2010. 
Para a RM de Campina Grande/PB, após a análise dos dados da Tabela 24, o primeiro destaque a ser feito é a queda do percentual de população da cidade-sede em relação a população total. Enquanto nas demais RMINE's em análise essa percentagem está acima dos 70\%, em Campina Grande corresponde "apenas" a 63\% da população total. Acredito que isso ocorra devido a quantidade de municípios constituintes dessa RM (dezenove no total), sendo que destes, dezesseis têm população inferior a vinte mil habitantes ${ }^{65}$.

\begin{tabular}{|c|c|c|c|c|c|}
\hline Município & Área $\left(\mathbf{k m}^{2}\right)$ & $\begin{array}{c}\text { \% em } \\
\text { relação a } \\
\text { área total }\end{array}$ & $\begin{array}{c}\text { População } \\
\text { estimada } \\
(2015)\end{array}$ & $\begin{array}{c}\% \text { em } \\
\text { relação a } \\
\text { população } \\
\text { total }\end{array}$ & $\begin{array}{c}\text { Densidade } \\
\left(\text { pessoas } / \mathbf{K m}^{2}\right)\end{array}$ \\
\hline Campina Grande & 593,03 & $12,32 \%$ & 405.072 & $63,84 \%$ & 683,06 \\
\hline Queimadas & 402,92 & $8,37 \%$ & 43.667 & $6,88 \%$ & 108,38 \\
\hline Lagoa Seca & 107,60 & $2,23 \%$ & 27.247 & $4,29 \%$ & 253,22 \\
\hline Aroeiras & 374,70 & $7,78 \%$ & 19.204 & $3,03 \%$ & 51,25 \\
\hline Boqueirão & 374,52 & $7,78 \%$ & 17.670 & $2,78 \%$ & 47,18 \\
\hline Massaranduba & 205,96 & $4,28 \%$ & 13.654 & $2,15 \%$ & 66,30 \\
\hline Puxinanã & 72,68 & $1,51 \%$ & 13.557 & $2,14 \%$ & 186,54 \\
\hline Fagundes & 189,03 & $3,93 \%$ & 11.378 & $1,79 \%$ & 60,19 \\
\hline Itatuba & 244,22 & $5,07 \%$ & 10.739 & $1,69 \%$ & 43,97 \\
\hline Natuba & 203,39 & $4,22 \%$ & 10.450 & $1,65 \%$ & 51,38 \\
\hline Umbuzeiro & 186,55 & $3,87 \%$ & 9.889 & $1,56 \%$ & 53,01 \\
\hline Gado Bravo & 192,41 & $4,00 \%$ & 8.450 & $1,33 \%$ & 43,92 \\
\hline Barra de Santana & 374,37 & $7,78 \%$ & 8.249 & $1,30 \%$ & 22,03 \\
\hline Serra Redonda & 55,91 & $1,16 \%$ & 7.053 & $1,11 \%$ & 126,16 \\
\hline Boa Vista & 476,54 & $9,90 \%$ & 6.884 & $1,08 \%$ & 14,45 \\
\hline Santa Cecília & 224,30 & $4,66 \%$ & 6.583 & $1,04 \%$ & 29,35 \\
\hline Alcantil & 305,39 & $6,34 \%$ & 5.451 & $0,86 \%$ & 17,85 \\
\hline Matinhas & 113,34 & $2,35 \%$ & 4.497 & $0,71 \%$ & 39,68 \\
\hline Caturité & 118,08 & $2,45 \%$ & 4.779 & $0,75 \%$ & 40,47 \\
\hline TOTAL & $4.814,94$ & $100,00 \%$ & 634.473 & $100,00 \%$ & 131,77 \\
\hline
\end{tabular}

Municípios de pequeno porte estão presentes em praticamente todas as aglomerações estudadas (capitais e interioranas), com exceção da RM de Salvador/BA, o que traz à tona a discussão acerca dos critérios de delimitação das RM's no país. Não quero dizer com isso que o recorte populacional deve ser determinante ou que deva ser completamente desconsiderado 
(como parece acontecer desde a CF 88), mas que essa definição deve ser pautada sobretudo em indícios socioespaciais de metropolização.

Analisando os dados espacializados (Figura 166) comparativamente com que foi dito sobre Imperatriz, a proximidade das manchas densas dos municípios vizinhos indica uma conurbação física com Campina Grande. Porém, parece-me haver duas tendências distintas: a primeira se dá por uma atração entre o núcleo de Lago Seca (preexistente e consolidado) e a expansão norte de Campina; e a segunda, ao sul, verificada por um "espraiamento" da mancha urbana campinense sobre o território do município de Queimadas, visto que o núcleo desse município se encontra mais a sul.

Para a RAID, os dados da Tabela 25 demonstram características similares às demais RMINE's analisadas: altas concentrações populacionais no(s) município(s)-sede em contraponto a um entorno composto por densidades populacionais menores. A particularidade da RAID é o tamanho dos territórios municipais (somados atingem mais de 33 mil quilômetros quadrados), o maior entre os analisados neste trabalho e um dos maiores do país. Como já comentado no item anterior, uma das explicações é a preponderância agrícola dessa região, mas também remete a discussão sobre a heterogeneidade da divisão municipal brasileira, onde encontramos municípios extremamente pequenos e outros com área superior a 160 mil quilômetros (por exemplo Altamira/PA é maior município brasileiro ${ }^{66}$ ).

\begin{tabular}{|c|c|c|c|c|c|}
\hline Município & Área $\left(\mathbf{k m}^{2}\right)$ & $\begin{array}{c}\text { \% em } \\
\text { relação a } \\
\text { área total }\end{array}$ & $\begin{array}{c}\text { População } \\
\text { estimada } \\
\text { (2015) }\end{array}$ & $\begin{array}{c}\text { \% em } \\
\text { relação a } \\
\text { população } \\
\text { total }\end{array}$ & $\begin{array}{c}\text { Densidade } \\
\left(\text { pessoas } / \mathbf{K m}^{2}\right)\end{array}$ \\
\hline Petrolina $(\mathrm{PE})$ & $4.561,87$ & $13,65 \%$ & 331.951 & $43,58 \%$ & 72,77 \\
\hline Juazeiro (BA) & $6.500,69$ & $19,44 \%$ & 218.324 & $28,66 \%$ & 33,58 \\
\hline Casa Nova (BA) & $9.647,07$ & $28,86 \%$ & 72.172 & $9,47 \%$ & 7,48 \\
\hline S. M ${ }^{a}$ da Boa Vista (PE) & $3.001,18$ & $8,98 \%$ & 41.293 & $5,42 \%$ & 13,76 \\
\hline Curaçá (BA) & $6.079,02$ & $18,18 \%$ & 35.208 & $4,62 \%$ & 5,79 \\
\hline Lagoa Grande (PE) & $1.848,93$ & $5,53 \%$ & 24.757 & $3,25 \%$ & 13,39 \\
\hline Sobradinho (BA) & $1.238,92$ & $3,71 \%$ & 23.583 & $3,10 \%$ & 19,04 \\
\hline Orocó (PE) & 554,76 & $1,66 \%$ & 14.445 & $1,90 \%$ & 26,04 \\
\hline TOTAL & $33.432,44$ & $100,00 \%$ & 761.733 & $100,00 \%$ & 22,78 \\
\hline
\end{tabular}

\footnotetext{
${ }^{66}$ A título de comparação, o Distrito Federal possui $5.779,999 \mathrm{~km}^{2}$ e Sergipe, menor estado da federação, possui $21.910 \mathrm{~km}^{2}$.
} 
Figura 166: Mapa de Densidade Populacional (em habitantes por hectare) por setor censitário da RM Campina Grande/PB.

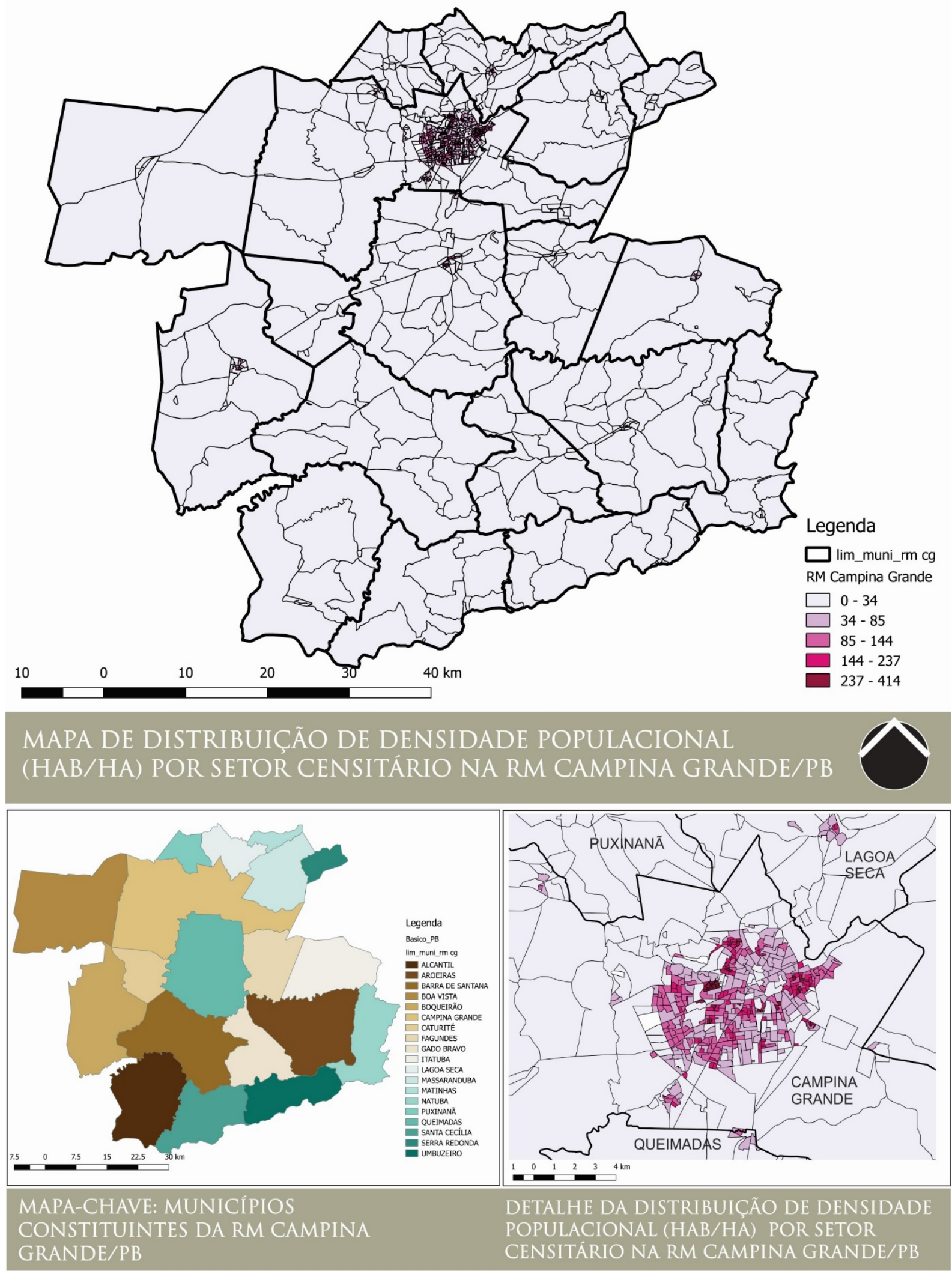

Fonte: Elaboração própria (2016) sob a Base Cartográfica do IBGE (2010) e dados do censo de 2010 
Figura 167: Mapa de Densidade Populacional (em habitantes por hectare) por setor censitário da RAID Petrolina/PE e Juazeiro/BA.

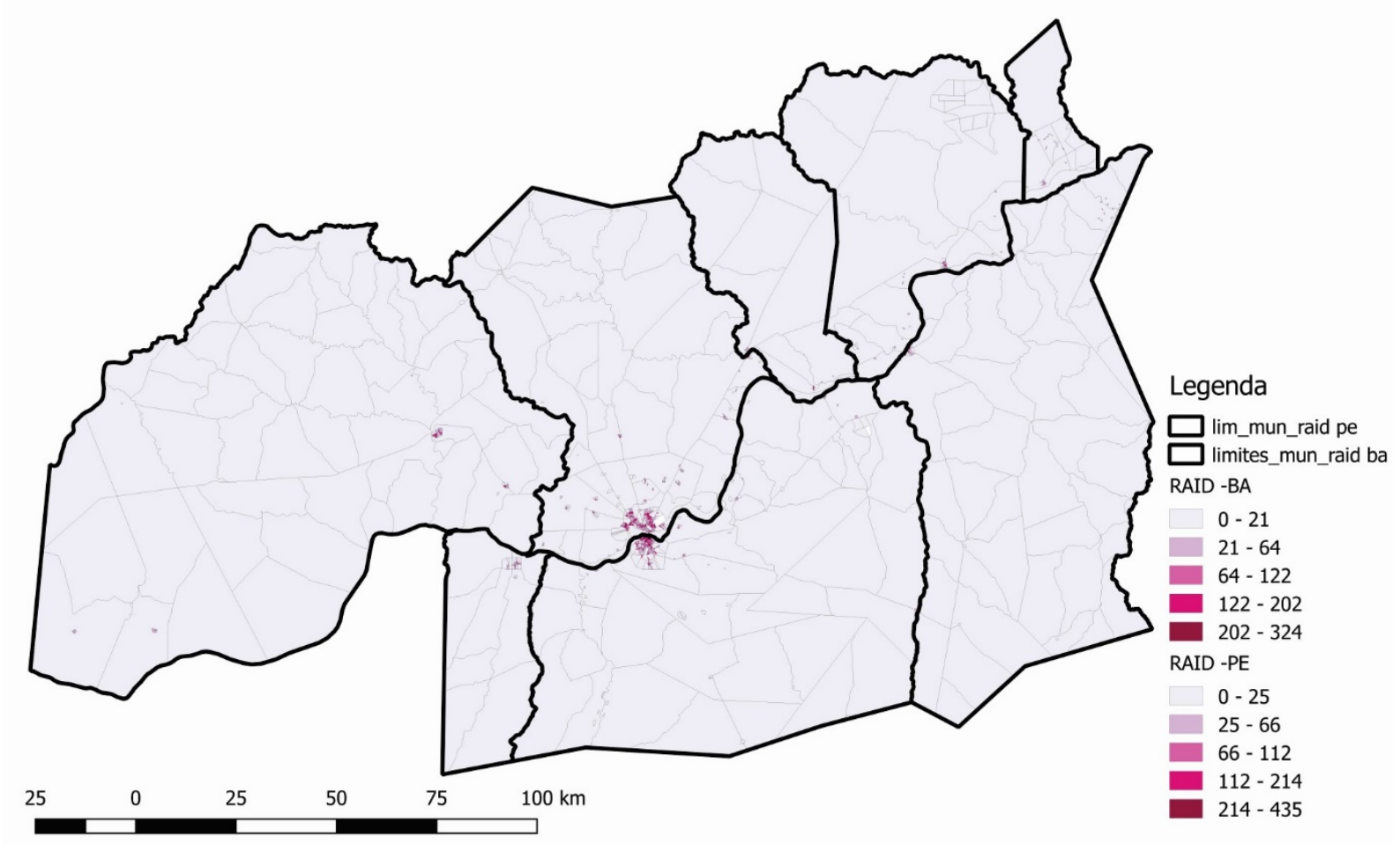

MAPA DE DISTRIBUIÇÃO DE DENSIDADE POPULACIONAL (HAB/HA) POR SETOR CENSITÁRIO NA RAID DE PETROLINA/JUAZEIRO

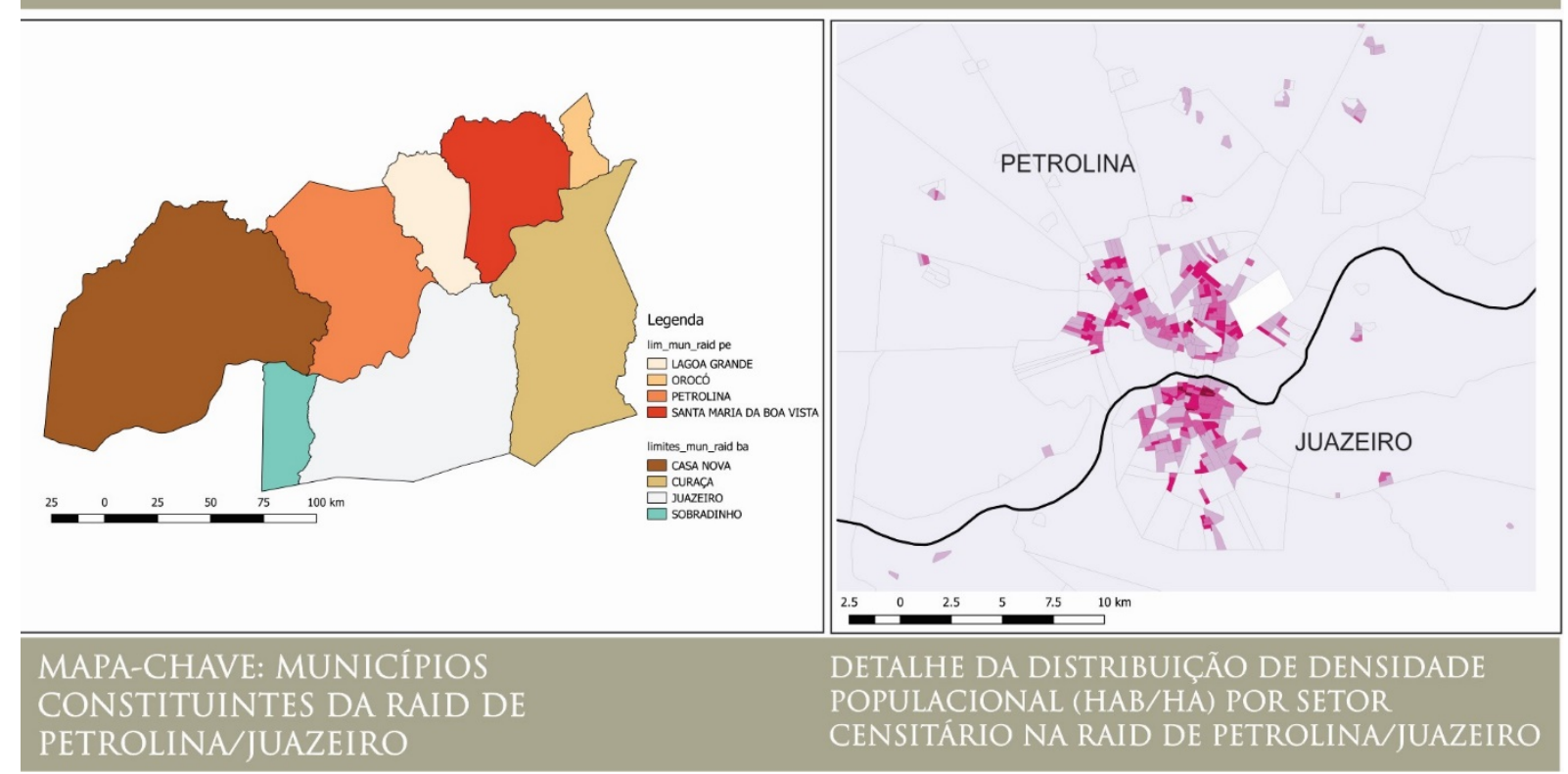

Fonte: Elaboração própria (2016) sob a Base Cartográfica do IBGE (2010) e dados do censo de 2010.

Avaliando a distribuição espacial da densidade (Figura 167), embora haja duas escalas de classificação na legenda (decorrente da limitação técnica de junção dos dados do IBGE para dois estados diferentes), percebe-se claramente a conurbação de Petrolina- 
Juazeiro dominando o grande território. A relação entre as duas cidades sempre foi estreita, porém apartada pela barreira física imposta pelo Rio São Francisco. O processo de conurbação entre as duas cidades não é recente, remontando às suas origens; porém, só a partir da construção da ponte Presidente Dutra que o processo se acelerou.

\subsubsection{Grupo de Controle 01}

A RM do Agreste alagoano, única RMINE do grupo, apresentou uma diferença em relação as RM's avaliadas anteriormente: o município-sede, Arapiraca, corresponde "apenas" a 45\% da população total da RM. Uma hipótese para isso é que, além da grande quantidade de municípios que integram a região (quinze no total), metade destes possuem populações entre 20 e 40 mil habitantes.

\begin{tabular}{|c|c|c|c|c|c|}
\hline Município & Área $\left(\mathbf{k m}^{2}\right)$ & $\begin{array}{c}\% \text { em } \\
\text { relação a } \\
\text { área total }\end{array}$ & $\begin{array}{c}\text { População } \\
\text { estimada } \\
\text { (2015) }\end{array}$ & $\begin{array}{c}\text { \% em } \\
\text { relação a } \\
\text { população } \\
\text { total }\end{array}$ & $\begin{array}{c}\text { Densidade } \\
\left(\text { pessoas } / \mathbf{K m}^{2}\right)\end{array}$ \\
\hline Arapiraca & 345,66 & $9,26 \%$ & 231.053 & $45,23 \%$ & 668,45 \\
\hline Girau do Ponciano & 514,35 & $13,78 \%$ & 40.519 & $7,93 \%$ & 78,78 \\
\hline São Sebastião & 315,17 & $8,45 \%$ & 34.211 & $6,70 \%$ & 108,55 \\
\hline Limoeiro de Anadia & 309,21 & $8,29 \%$ & 28.621 & $5,60 \%$ & 92,56 \\
\hline Traipu & 685,78 & $18,38 \%$ & 27.798 & $5,44 \%$ & 40,53 \\
\hline Junqueiro & 247,72 & $6,64 \%$ & 25.084 & $4,91 \%$ & 101,26 \\
\hline Craíbas & 279,55 & $7,49 \%$ & 24.288 & $4,75 \%$ & 86,88 \\
\hline Feira Grande & 178,06 & $4,77 \%$ & 22.432 & $4,39 \%$ & 125,98 \\
\hline Taquarana & 153,29 & $4,11 \%$ & 19.980 & $3,91 \%$ & 130,34 \\
\hline Lagoa da Canoa & 83,62 & $2,24 \%$ & 18.343 & $3,59 \%$ & 219,36 \\
\hline Coité do Noia & 88,76 & $2,38 \%$ & 10.992 & $2,15 \%$ & 123,84 \\
\hline Campo Grande & 169,99 & $4,56 \%$ & 9.664 & $1,89 \%$ & 56,85 \\
\hline São Brás & 139,95 & $3,75 \%$ & 7.034 & $1,38 \%$ & 50,26 \\
\hline Jaramataia & 103,71 & $2,78 \%$ & 5.695 & $1,11 \%$ & 54,91 \\
\hline Olho d'Água Grande & 117,01 & $3,14 \%$ & 5.178 & $1,01 \%$ & 44,25 \\
\hline TOTAL & $3.731,81$ & $100,00 \%$ & 510.892 & $100,00 \%$ & 136,90 \\
\hline
\end{tabular}

Quanto à distribuição das densidades por setor censitário (Figura 168), a preponderância de Arapiraca se faz notar. $\mathrm{Na}$ análise detalhada dessa cidade, nota-se a distribuição das densidades de maneira centrífuga, referente as características comerciais e de prestação de serviços locadas na área central. 
Figura 168: Mapa de Densidade Populacional (em habitantes por hectare) por setor censitário da RM do Agreste/AL.

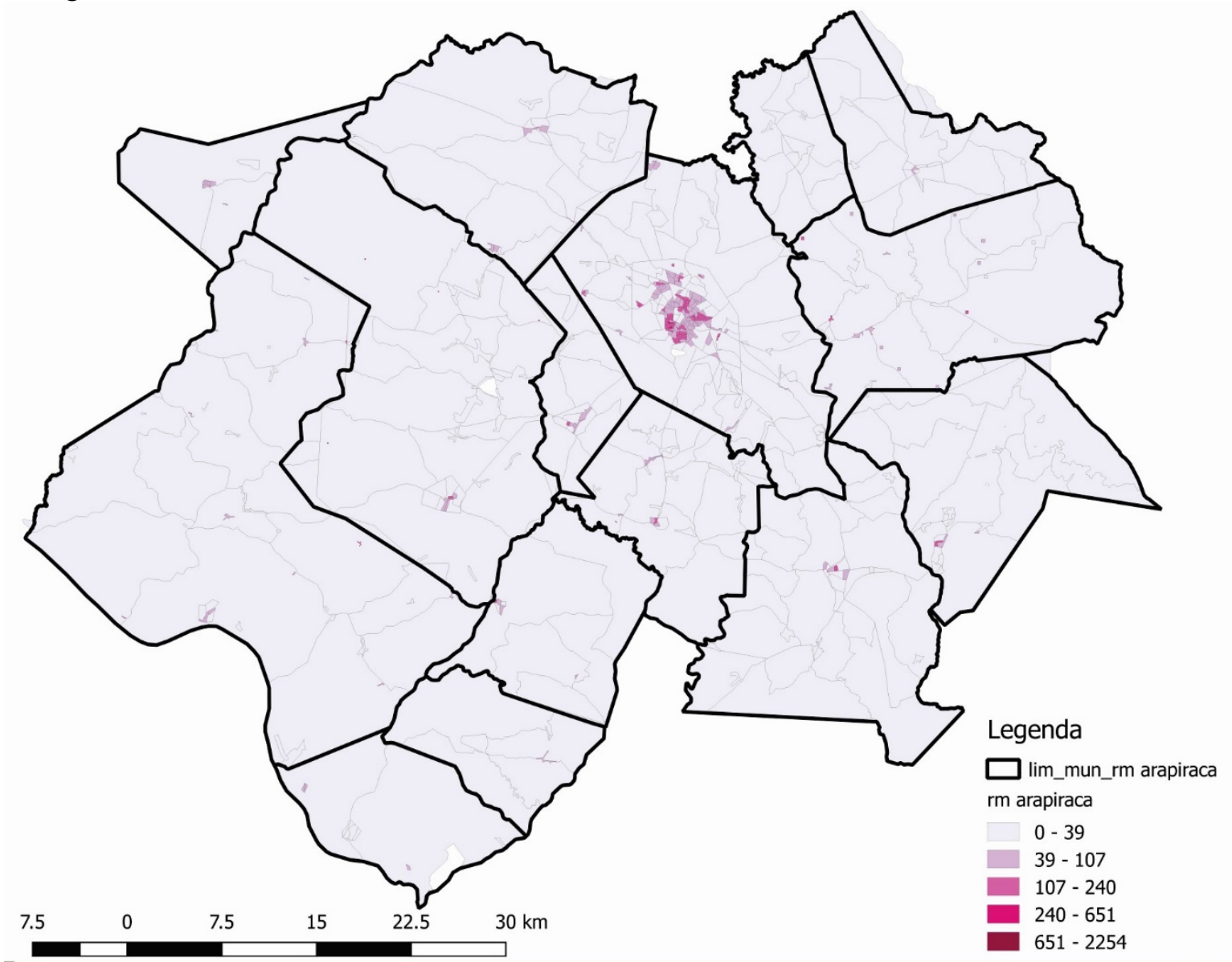

MAPA DE DISTRIBUIÇÃO DE DENSIDADE POPULACIONAL (HAB/HA) POR SETOR CENSITÁRIO NA RM AGRESTE/AL

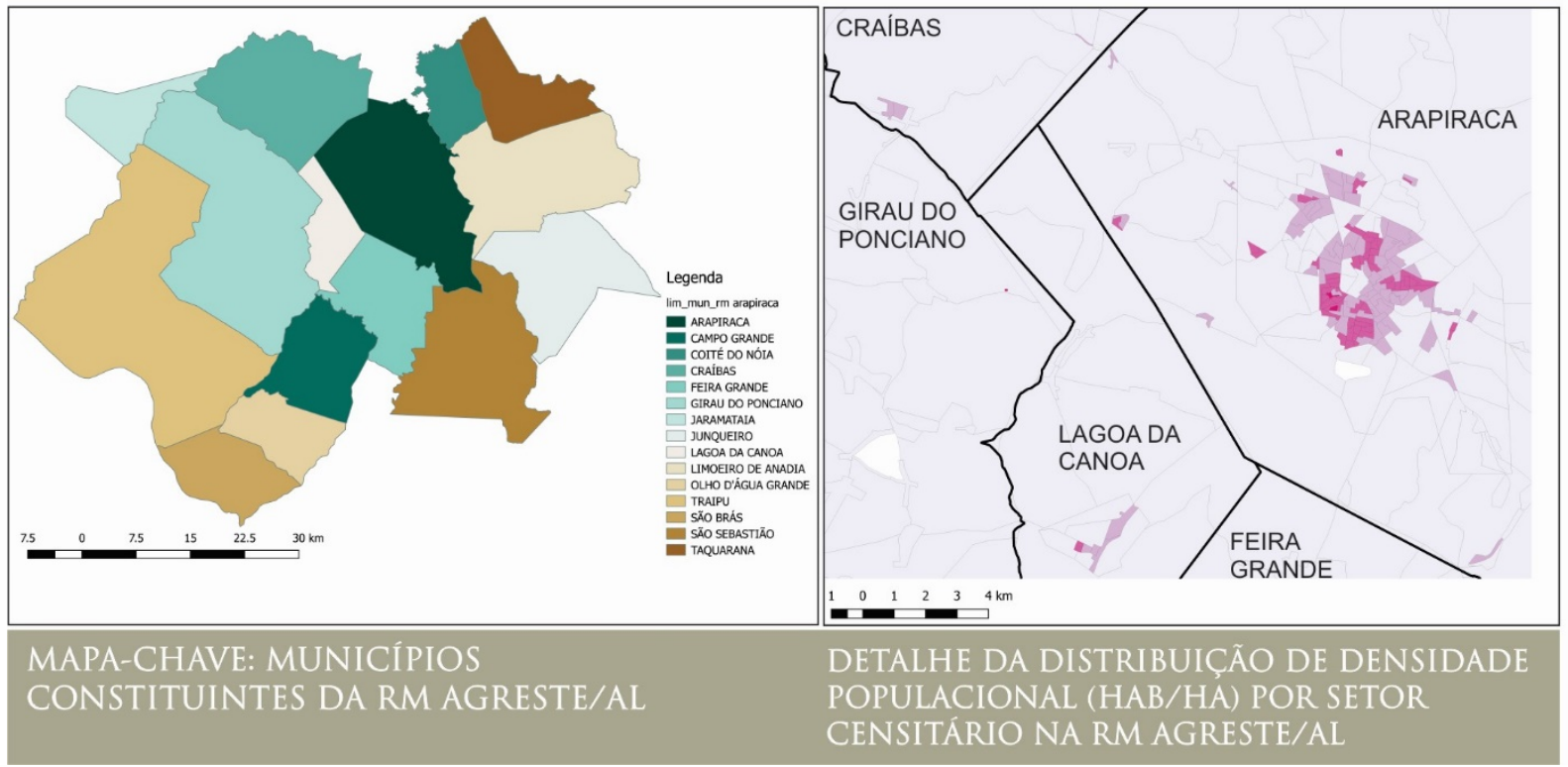

Fonte: Elaboração própria (2016) sob a Base Cartográfica do IBGE (2010) e dados do censo de 2010. 
Para as demais cidades constituintes deste grupo, não foi possível construir tabelas como as apresentadas anteriormente, uma vez que elas não compõem oficialmente RM's. Os dados sistematizados na Tabela 24 apresentam apenas as áreas, populações estimadas e densidade municipais. Entretanto, os resultados são similares aos já comentados até então: estes municípios são mais populosos que o seu entorno imediato, com áreas urbanas densas cercadas por espaços rurais.

\section{Tabela 27: Distribuição da população e densidade nos municípios do Grupo de Controle 01}

\begin{tabular}{|c|c|c|c|}
\hline Município & Área $\left(\mathbf{k m}^{2}\right)$ & $\begin{array}{c}\text { População estimada } \\
\text { (2015) }\end{array}$ & Densidade (pessoas $/ \mathbf{K m}^{2}$ ) \\
\hline Vitória da Conquista & $3.704,02$ & 343.230 & 92,66 \\
\hline Sobral/CE & $2.122,90$ & 201.756 & 95,03 \\
\hline Mossoró/RN & $2.099,33$ & 288.162 & 137,26 \\
\hline Caruaru/PE & 920,61 & 347.088 & 377,01 \\
\hline
\end{tabular}

Quando a análise se dá numa escala mais próxima dos núcleos urbanos, é possível perceber a distribuição entre áreas residenciais (em tons mais escuros) e os espaços de preponderância comercial e de serviços (em tons mais claros). Em Vitória da Conquista/BA os setores mais densos estão a nordeste, nos bairros Alto Maron e Cruzeiro, e a oeste da BA263, áreas de integração alta e média (de acordo com os mapas Figura 100 e Figura 102) e de faixas de renda mais baixas (Figura 24).

Há claramente uma correlação entre renda e densidade: áreas mais densas são mais pobres, enquanto áreas com população de maior poder aquisitivo tendem a apresentar baixas densidades. Esse resultado sugere uma hipótese acerca da dominância das áreas residenciais horizontais, a tradicional "casa no lote" (em condomínios fechados ou não), em detrimento aos apartamentos do processo de verticalização.

Os resultados são similares para as demais cidades desse grupo. Há uma correlação clara entre baixas densidades nas áreas centrais, que correspondem aos núcleos de integração, comentados no item anterior. É possível também perceber vazios demográficos nas cidades, que podem significar barreiras físicas (por exemplo rios) ou áreas em processo de ocupação. Como há um descompasso temporal entre os dados do IBGE (2010) e as bases cartográficas (2016), é possível perceber as nuances das mudanças através da expansão das malhas urbanas comentadas no item anterior. 
Figura 169: Mapa de Densidade Populacional (em habitantes por hectare) por setor censitário de Vitória da Conquista/BA.

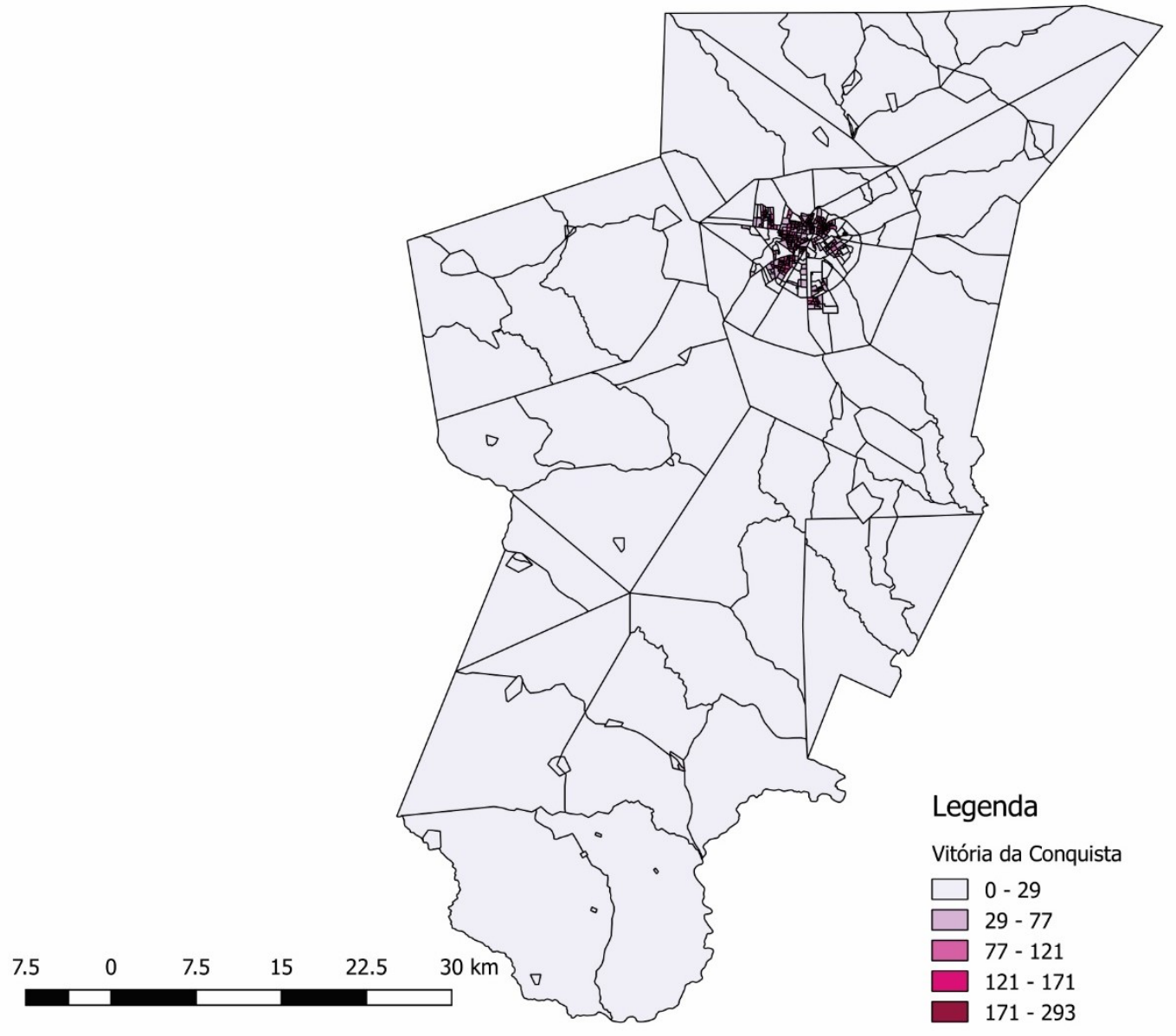

MAPA DE DISTRIBUIÇÃO DE DENSIDADE POPULACIONAL HAB/HA) POR SETOR CENSITÁRIO EM VITÓRIA DA CONQUISTA/BA

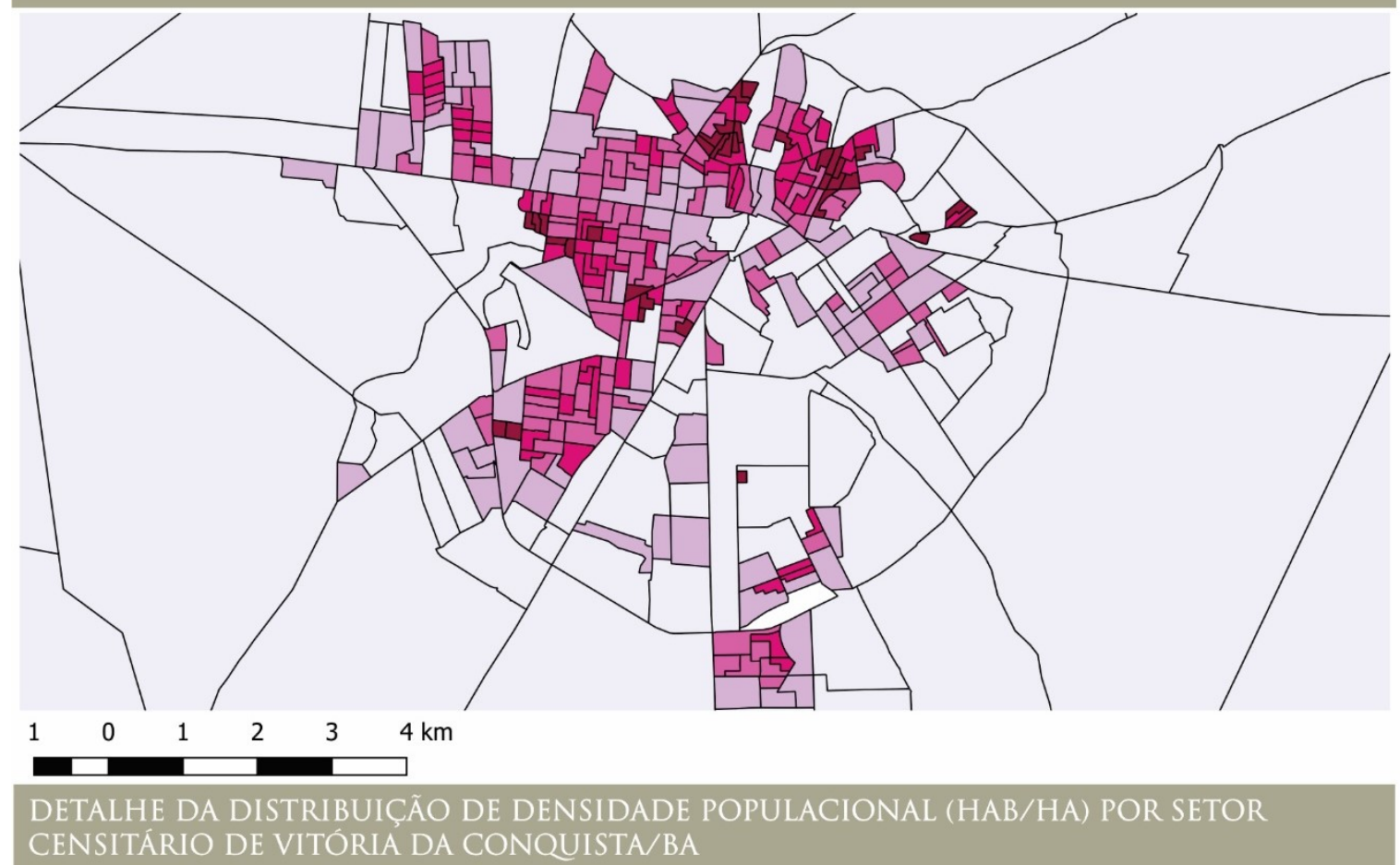

Fonte: Elaboração própria (2016) sob a Base Cartográfica do IBGE (2010) e dados do censo de 2010. 
Figura 170: Mapa de Densidade Populacional (em habitantes por hectare) por setor censitário de Sobral/CE.

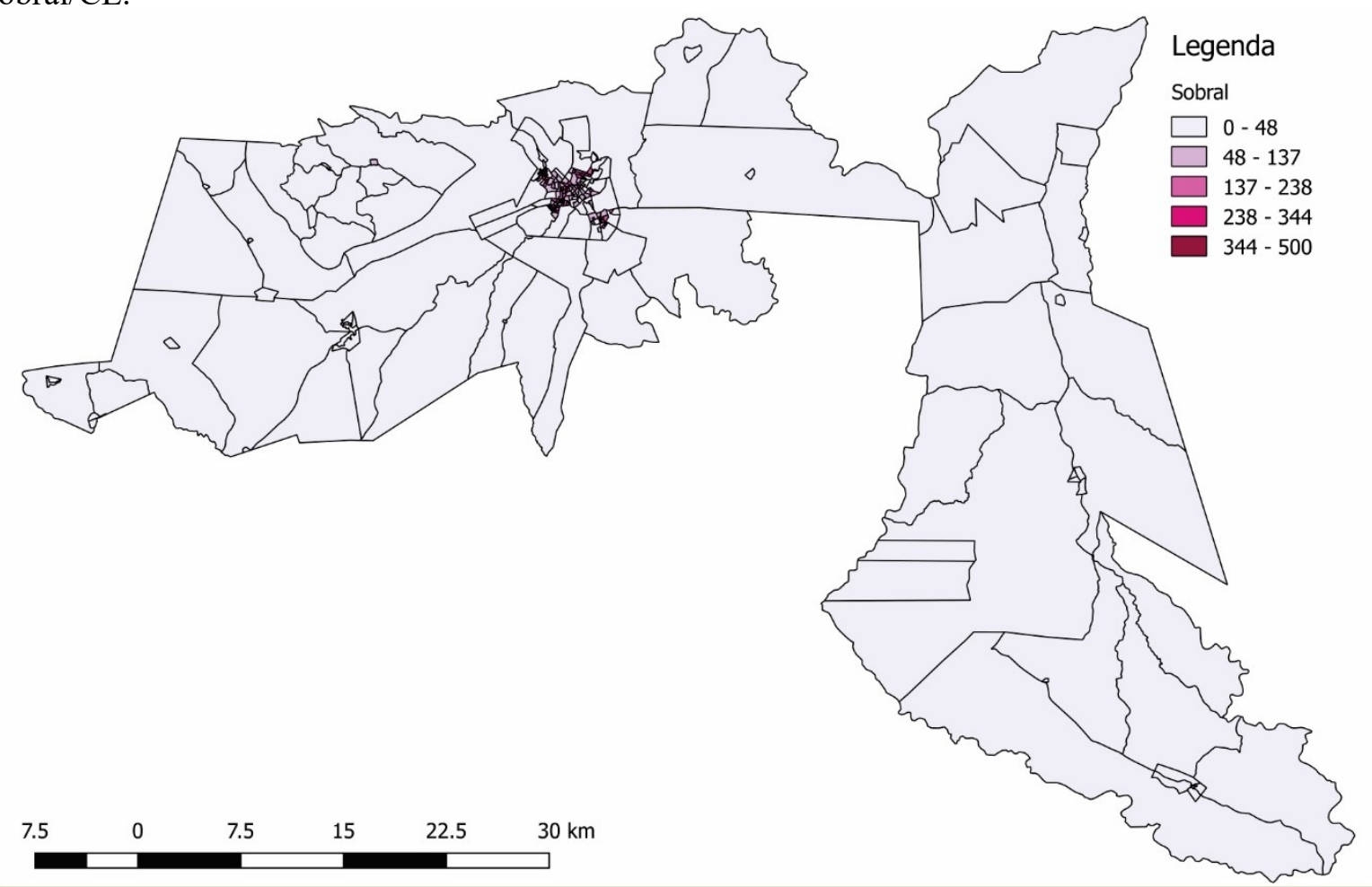

MAPA DE DISTRIBUIÇÃO DE DENSIDADE POPULACIONAL (HAB/HA) POR SETOR CENSITÁRIO EM SOBRAL/CE

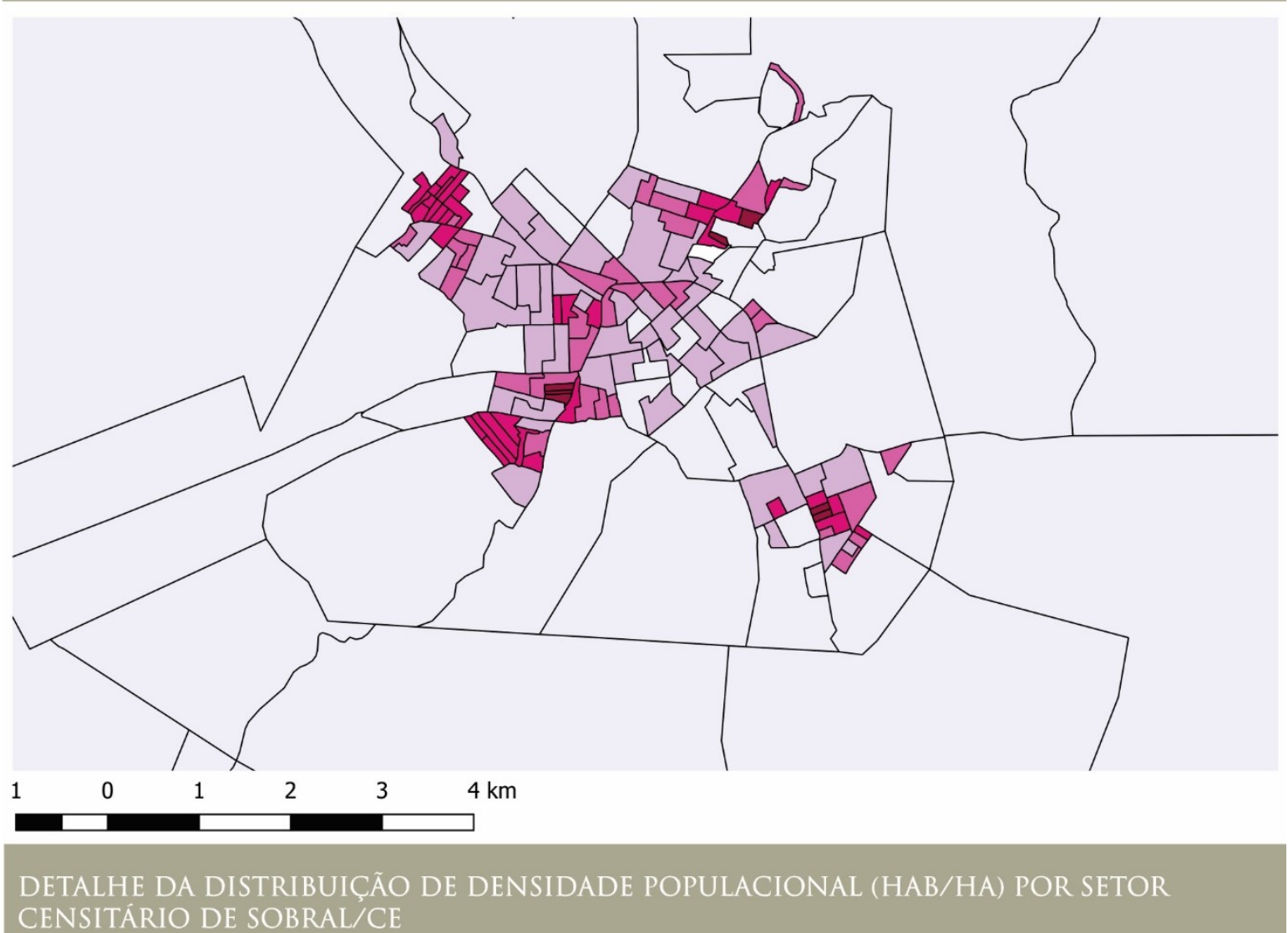

Fonte: Elaboração própria (2016) sob a Base Cartográfica do IBGE (2010) e dados do censo de 2010. 
Figura 171: Mapa de Densidade Populacional (em habitantes por hectare) por setor censitário de Mossoró/RN.

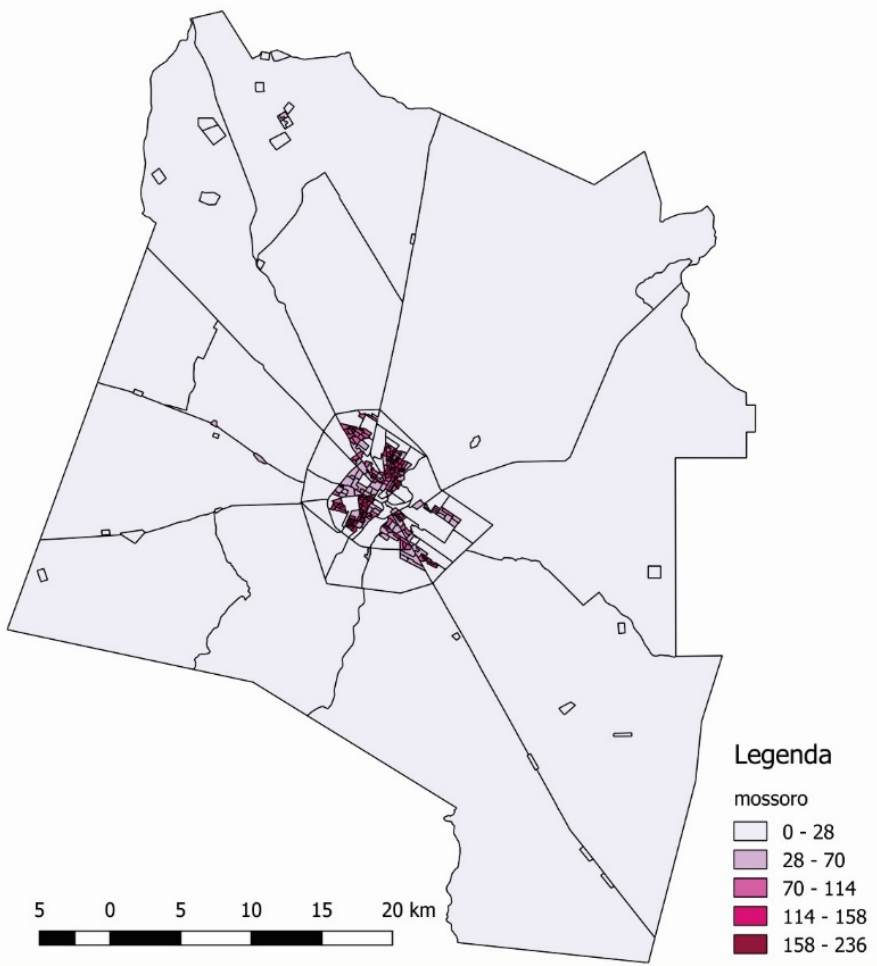

\section{MAPA DE DISTRIBUIÇÃO DE DENSIDADE POPULACIONAL (HAB/HA) POR SETOR CENSITÁRIO EM MOSSORÓ/RN}

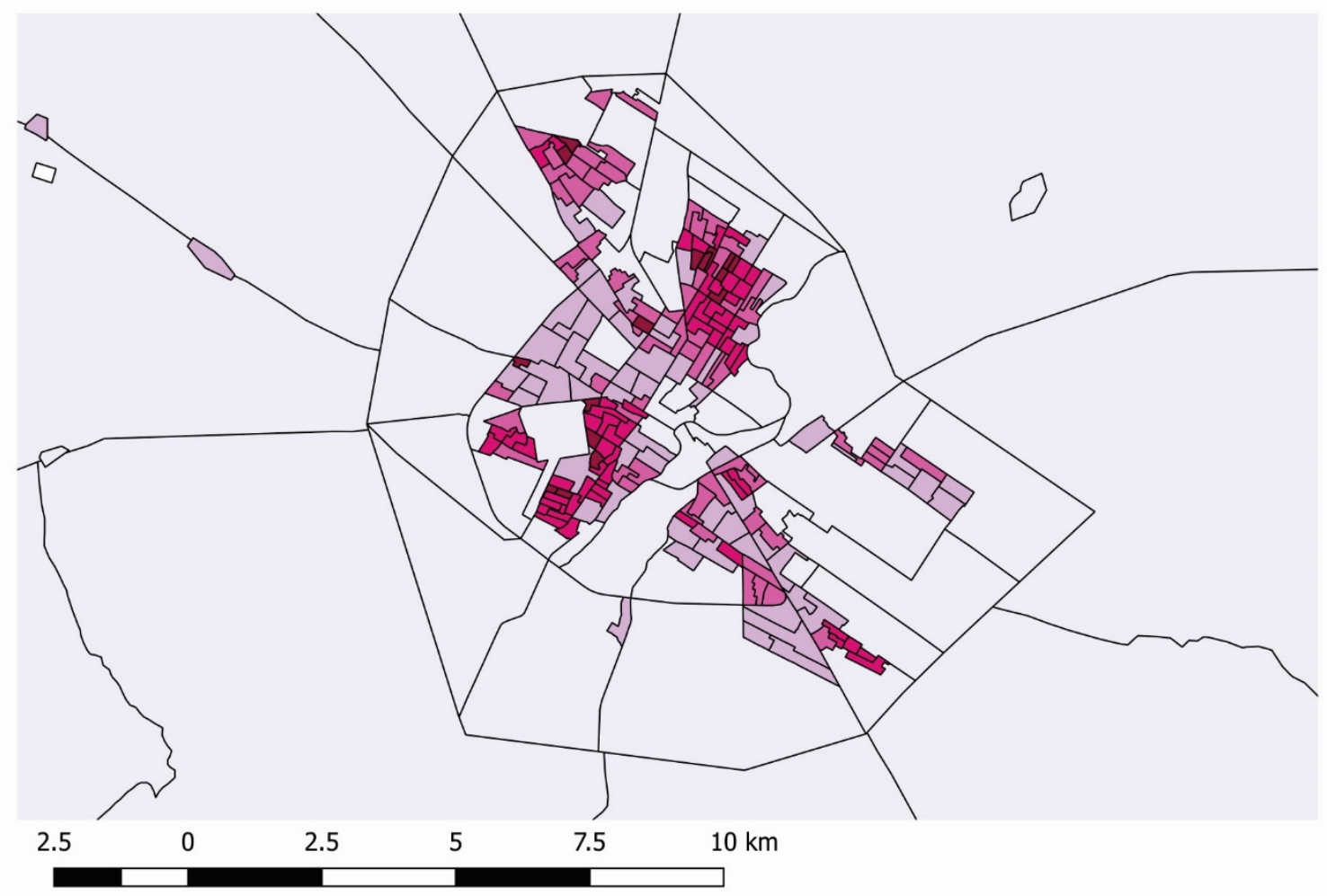

DETALHE DA DISTRIBUIÇÃO DE DENSIDADE POPULACIONAL (HAB/HA) POR SETOR CENSITÁRIO DE MOSSORÓ/RN

Fonte: Elaboração própria (2016) sob a Base Cartográfica do IBGE (2010) e dados do censo de 2010. 
Figura 172: Mapa de Densidade Populacional (em habitantes por hectare) por setor censitário de Caruaru/PE.

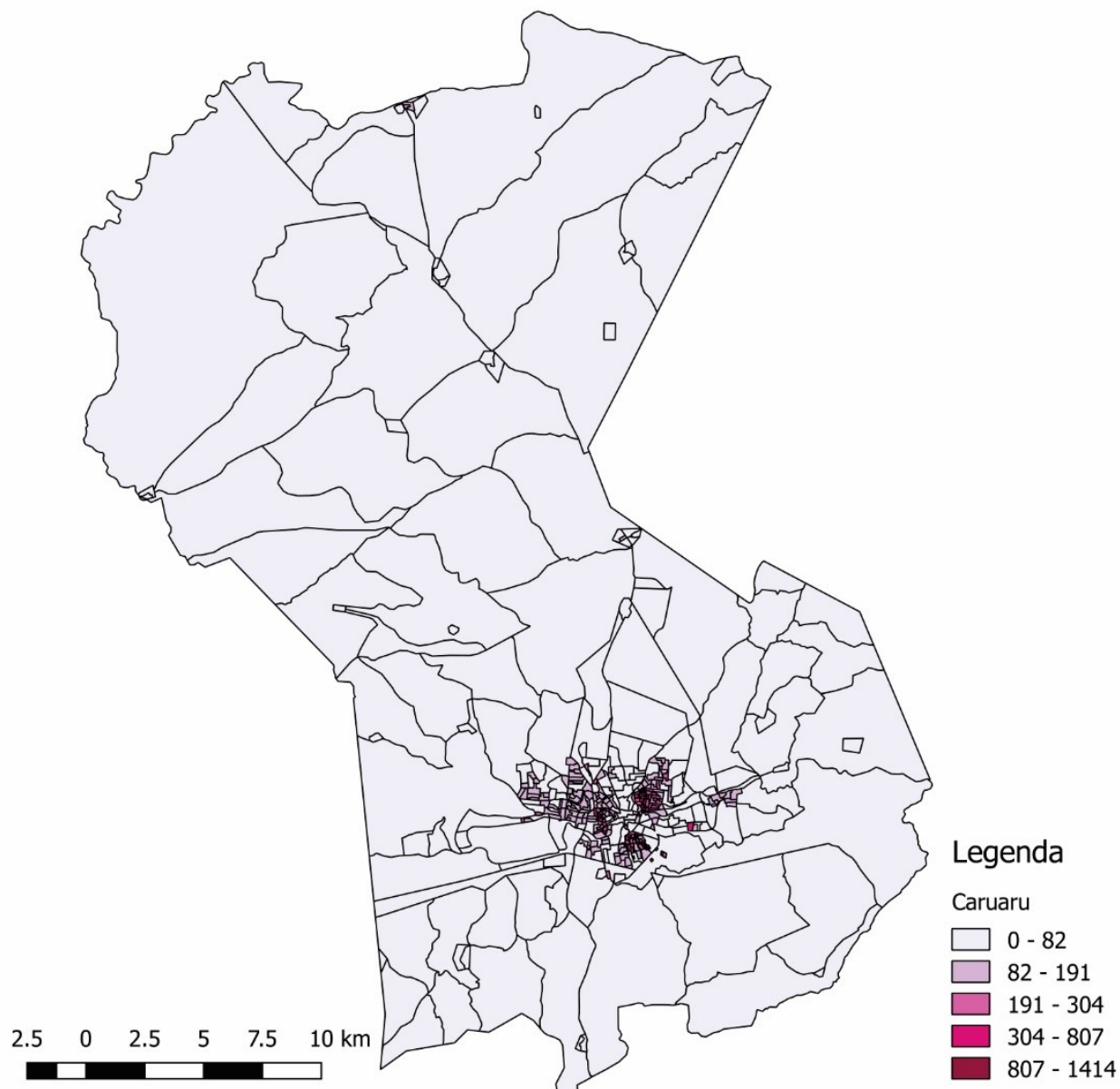

MAPA DE DISTRIBUIÇÃO DE DENSIDADE POPULACIONAL (HAB/HA) POR SETOR CENSITÁRIO EM CARUARU/PE

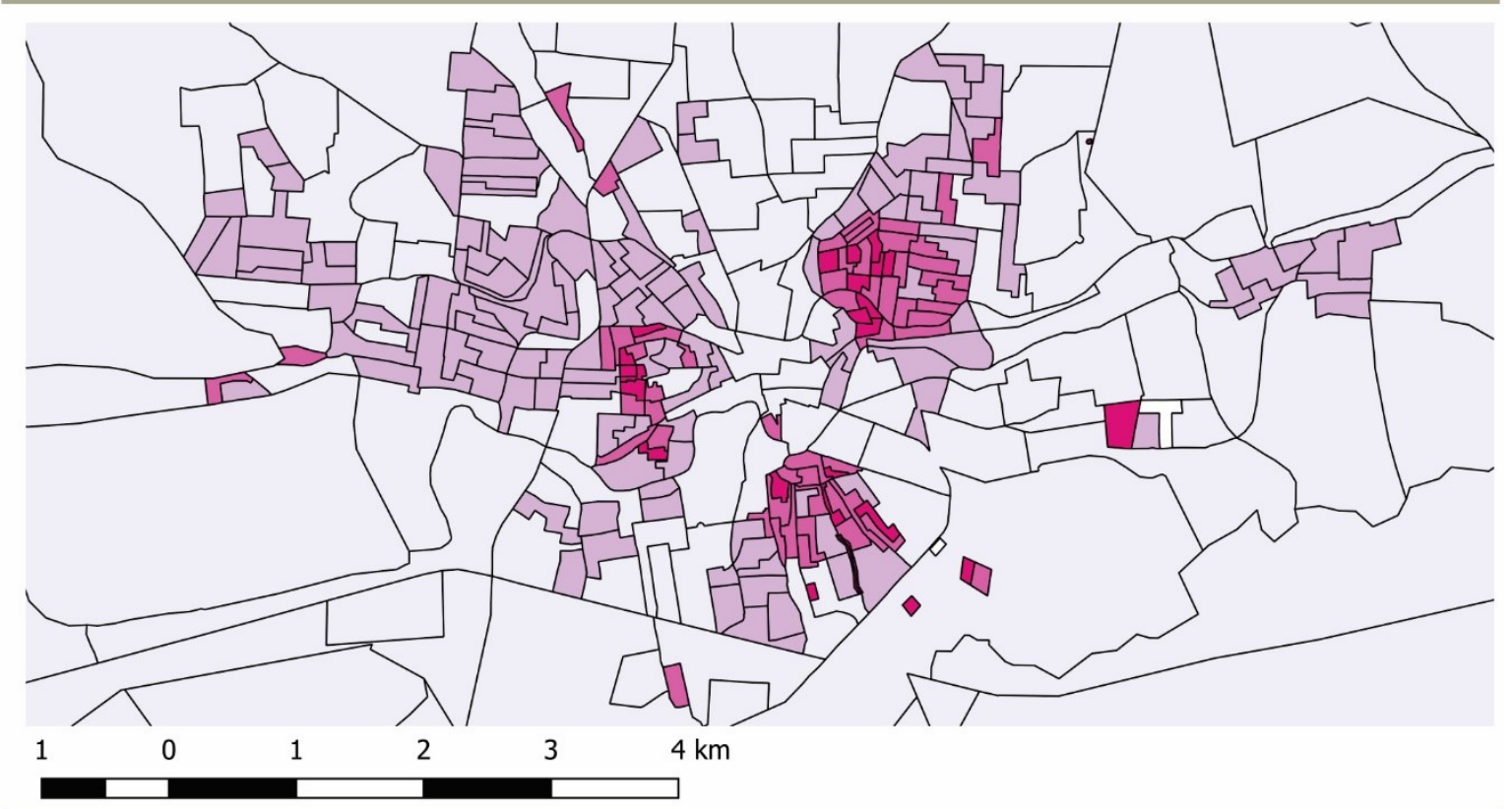

DETALHE DA DISTRIBUIÇÃO DE DENSIDADE POPULACIONAL (HAB/HA) POR SETOR

CENSITÁRIO EM CARUARU/PE

Fonte: Elaboração própria (2016) sob a Base Cartográfica do IBGE (2010) e dados do censo de 2010. 


\subsubsection{Grupo de Controle 02}

Para a RM de Salvador/BA, repete-se o desequilíbrio populacional, já que a cidadesede representa mais de $73 \%$ da população total da região (Tabela 28). Salvador é a terceira maior cidade do país, atrás apenas de São Paulo e Rio de Janeiro. Entretanto, as taxas de crescimento da cidade vêm diminuindo, por exemplo, foram apenas 18.160 novos habitantes entre 2014 e 2015, com uma taxa anual de crescimento de apenas 0,63\% (IBGE, 2016). Num comparativo, Brasília, no mesmo período, teve uma taxa anual de crescimento populacional de $2,19 \%$ e deve nos próximos anos ultrapassar a população soteropolitana ${ }^{67}$. Entretanto, alguns municípios da sua região apresentaram uma dinâmica bem mais significativa. Por exemplo, Lauro de Freitas teve, entre 2014 e 2015, um crescimento médio de 4,6\% ao ano, seguido por Camaçari e Dias d'Ávila, ambas na casa dos 4\% (PEREIRA, 2016; CARVALHO et al., 2014). Essa grande população se comprime em um pequeno território (Salvador tem área maior apenas que Juazeiro do Norte/CE, Campina Grande/PB e Arapiraca/AL), representando a maior densidade populacional até aqui. Esse número é ainda maior quando refaço o cálculo para seu território continental (excluindo a área da Bahia de Todos os Santos): é a maior densidade populacional do país. Traçando um comparativo, São Paulo, maior município brasileiro, possui uma densidade de 7.867,82 habitantes por quilômetro quadrado.

\begin{tabular}{|c|c|c|c|c|c|}
\hline Município & Área $\left(\mathbf{k m}^{2}\right)$ & $\begin{array}{c}\text { \% em } \\
\text { relação a } \\
\text { área total }\end{array}$ & $\begin{array}{c}\text { População } \\
\text { estimada } \\
\text { (2015) }\end{array}$ & $\begin{array}{c}\% \text { em } \\
\text { relação a } \\
\text { população } \\
\text { total }\end{array}$ & $\begin{array}{c}\text { Densidade } \\
(\text { pessoas/Km²) }\end{array}$ \\
\hline \multirow[b]{2}{*}{ Sem área marítima } & 692,82 & \multirow{2}{*}{$15,91 \%$} & \multirow{2}{*}{2.921 .087} & \multirow{2}{*}{$73,89 \%$} & $4.216,23$ \\
\hline & 324,50 & & & & $9.001,80$ \\
\hline Camaçari & 784,66 & $18,02 \%$ & 286.919 & $7,26 \%$ & 365,66 \\
\hline Lauro de Freitas & 57,66 & $1,32 \%$ & 191.436 & $4,84 \%$ & $3.319,97$ \\
\hline Simões Filho & 201,58 & $4,63 \%$ & 133.202 & $3,37 \%$ & 660,80 \\
\hline Candeias & 251,63 & $5,78 \%$ & 88.806 & $2,25 \%$ & 352,93 \\
\hline Dias d'Ávila & 184,23 & $4,23 \%$ & 78.058 & $1,97 \%$ & 423,70 \\
\hline Mata de São João & 633,20 & $14,54 \%$ & 45.813 & $1,16 \%$ & 72,35 \\
\hline São Sebastião do Passé & 538,30 & $12,36 \%$ & 45.482 & $1,15 \%$ & 84,49 \\
\hline Vera Cruz & 299,73 & $6,88 \%$ & 42.650 & $1,08 \%$ & 142,29 \\
\hline São Francisco do Conde & 269,61 & $6,19 \%$ & 39.329 & $0,99 \%$ & 145,87 \\
\hline Pojuca & 290,12 & $6,66 \%$ & 37.543 & $0,95 \%$ & 129,41 \\
\hline Itaparica & 118,04 & $2,71 \%$ & 22.615 & $0,57 \%$ & 191,59 \\
\hline Madre de Deus & 32,20 & $0,74 \%$ & 20.348 & $0,51 \%$ & 631,91 \\
\hline TOTAL & $4.353,77$ & $100,00 \%$ & 3.953 .288 & $100,00 \%$ & 908,01 \\
\hline
\end{tabular}

${ }^{67}$ Segundo a estimativa populacional recém-publicada pelo IBGE para 2016, a população estimada do Distrito Federal atingiu a marca dos 2.977.216 habitantes, enquanto a população de Salvador foi estimada em 2.938.092 habitantes. 
Figura 173: Mapa de Densidade Populacional (em habitantes por hectare) por setor censitário da RM Salvador/BA.

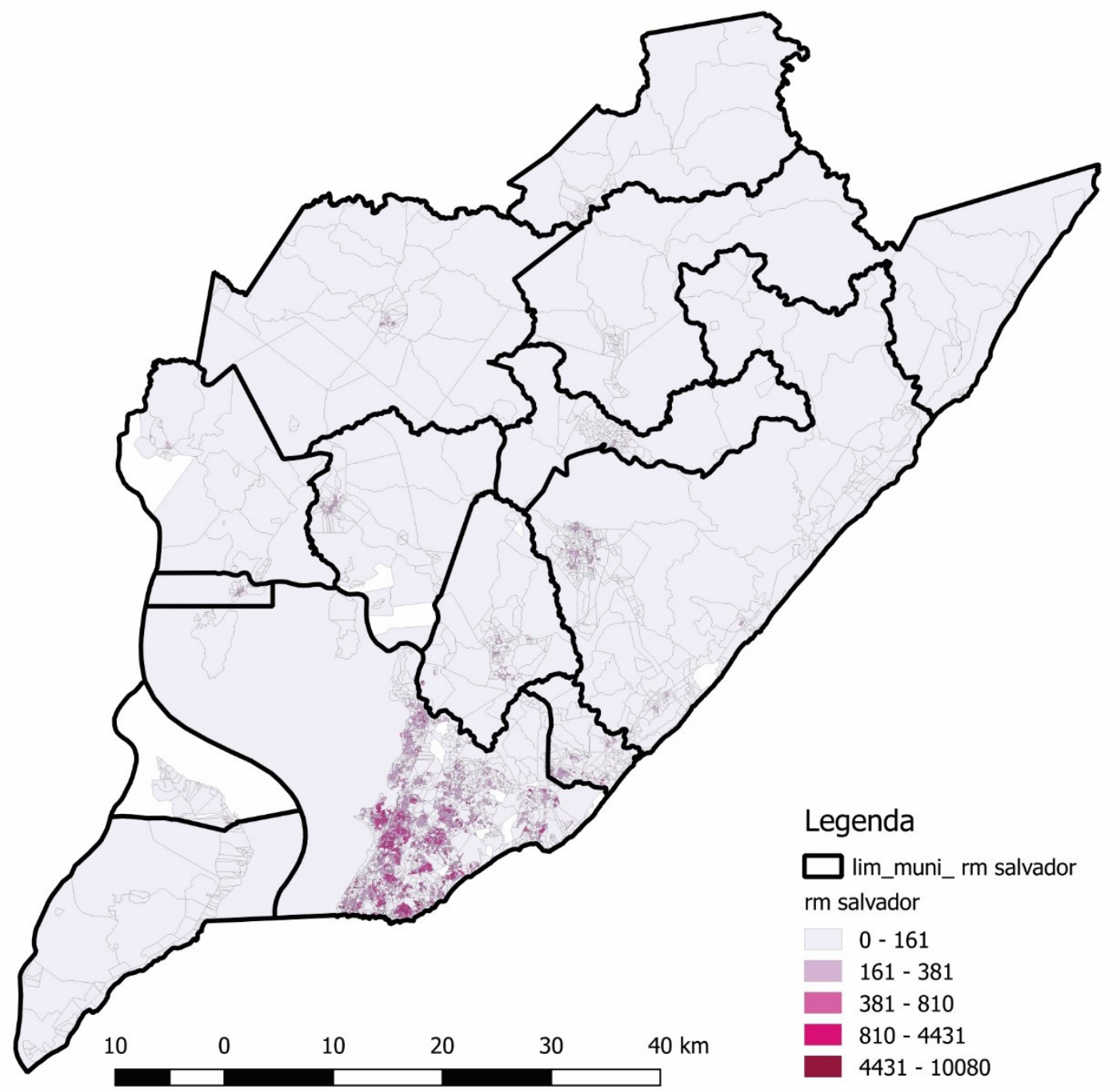

MAPA DE DISTRIBUIÇÃO DE DENSIDADE POPULACIONAL (HAB/HA) POR SETOR CENSITÁRIO NA RM SALVADOR/BA

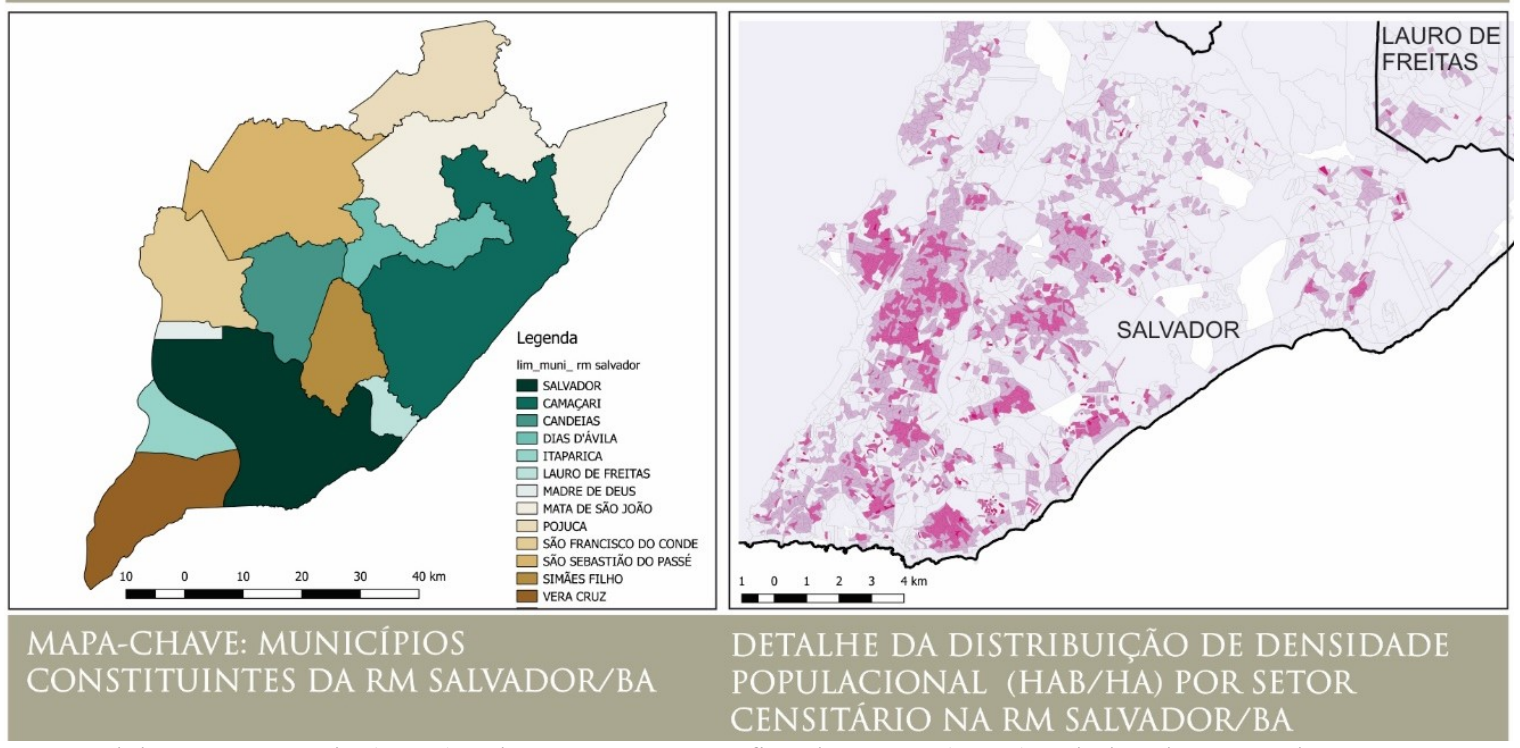

Fonte: Elaboração própria (2016) sob a Base Cartográfica do IBGE (2010) e dados do censo de 2010. 
Analisando o mapa que representa a distribuição por setor censitário (Figura 173), verificam-se diversas áreas que possuem altas densidades, como nos bairros Nordeste de Amaralina e Novos Alagados, que possuem índices de 53 mil e 49 mil habitantes por quilômetro quadrado, respectivamente, quase seis vezes a média da cidade. Por outro lado, regiões como Stella Maris, Itinga, Ceasa, Represa de Ipitanga e Tubarão, localizados nas proximidades limites do município, têm menos de mil habitantes por quilômetro quadrado, uma média acima das demais cidades avaliadas neste trabalho.

A RM de Fortaleza/CE, embora a porcentagem da população caia cerca de $8 \% \mathrm{em}$ relação a Salvador, é o município que mais contribui para a composição da população total da RM, sendo o segundo maior contingente populacional do Nordeste. De 2000 a 2010, a população de Fortaleza cresceu cerca de 1,4\% acima do movimento demográfico de Salvador (crescimento de 0,9\% ao ano) e, principalmente, do Recife (aumento de apenas 0,8\% ao ano). É também responsável pela maior densidade (BUARQUE et al., 2015).

\begin{tabular}{|c|c|c|c|c|c|}
\hline Município & Área $\left(\mathbf{k m}^{2}\right)$ & $\begin{array}{c}\% \text { em } \\
\text { relação a } \\
\text { área total }\end{array}$ & $\begin{array}{c}\text { População } \\
\text { estimada } \\
(2015)\end{array}$ & $\begin{array}{c}\text { \% em } \\
\text { relação a } \\
\text { população } \\
\text { total }\end{array}$ & $\begin{array}{c}\text { Densidade } \\
\left(\text { pessoas } / \mathbf{K m}^{2}\right)\end{array}$ \\
\hline Fortaleza & 314,93 & $4,23 \%$ & 2.591 .188 & $65,02 \%$ & $8.227,82$ \\
\hline Caucaia & $1.228,51$ & $16,51 \%$ & 353.932 & $8,88 \%$ & 288,10 \\
\hline Maracanaú & 106,65 & $1,43 \%$ & 221.504 & $5,56 \%$ & $2.076,96$ \\
\hline Maranguape & 590,87 & $7,94 \%$ & 123.570 & $3,10 \%$ & 209,13 \\
\hline Pacatuba & 131,99 & $1,77 \%$ & 80.378 & $2,02 \%$ & 608,95 \\
\hline Aquiraz & 482,38 & $6,48 \%$ & 77.717 & $1,95 \%$ & 161,11 \\
\hline Cascavel & 835,00 & $11,22 \%$ & 70.047 & $1,76 \%$ & 83,89 \\
\hline Pacajus & 254,64 & $3,42 \%$ & 68.800 & $1,73 \%$ & 270,19 \\
\hline Horizonte & 159,98 & $2,15 \%$ & 63.365 & $1,59 \%$ & 396,08 \\
\hline Trairi & 925,72 & $12,44 \%$ & 54.418 & $1,37 \%$ & 58,78 \\
\hline Eusébio & 79,01 & $1,06 \%$ & 51.127 & $1,28 \%$ & 647,14 \\
\hline São Gonçalo do Amarante & 834,45 & $11,22 \%$ & 47.297 & $1,19 \%$ & 56,68 \\
\hline Itaitinga & 151,63 & $2,04 \%$ & 38.540 & $0,97 \%$ & 254,17 \\
\hline Paracuru & 300,29 & $4,04 \%$ & 33.426 & $0,84 \%$ & 111,31 \\
\hline Paraipaba & 300,92 & $4,04 \%$ & 31.986 & $0,80 \%$ & 106,29 \\
\hline Guaiuba & 267,13 & $3,59 \%$ & 25.841 & $0,65 \%$ & 96,74 \\
\hline Pindoretama & 75,14 & $1,01 \%$ & 20.207 & $0,51 \%$ & 268,92 \\
\hline Chorozinho & 278,41 & $3,74 \%$ & 19.192 & $0,48 \%$ & 68,93 \\
\hline São Luís do Curu & 122,42 & $1,65 \%$ & 12.760 & $0,32 \%$ & 104,23 \\
\hline TOTAL & $7.440,07$ & $100,00 \%$ & 3.985 .295 & $100,00 \%$ & 535,65 \\
\hline
\end{tabular}


Figura 174: Mapa de Densidade Populacional (em habitantes por hectare) por setor censitário da RM Fortaleza/CE.

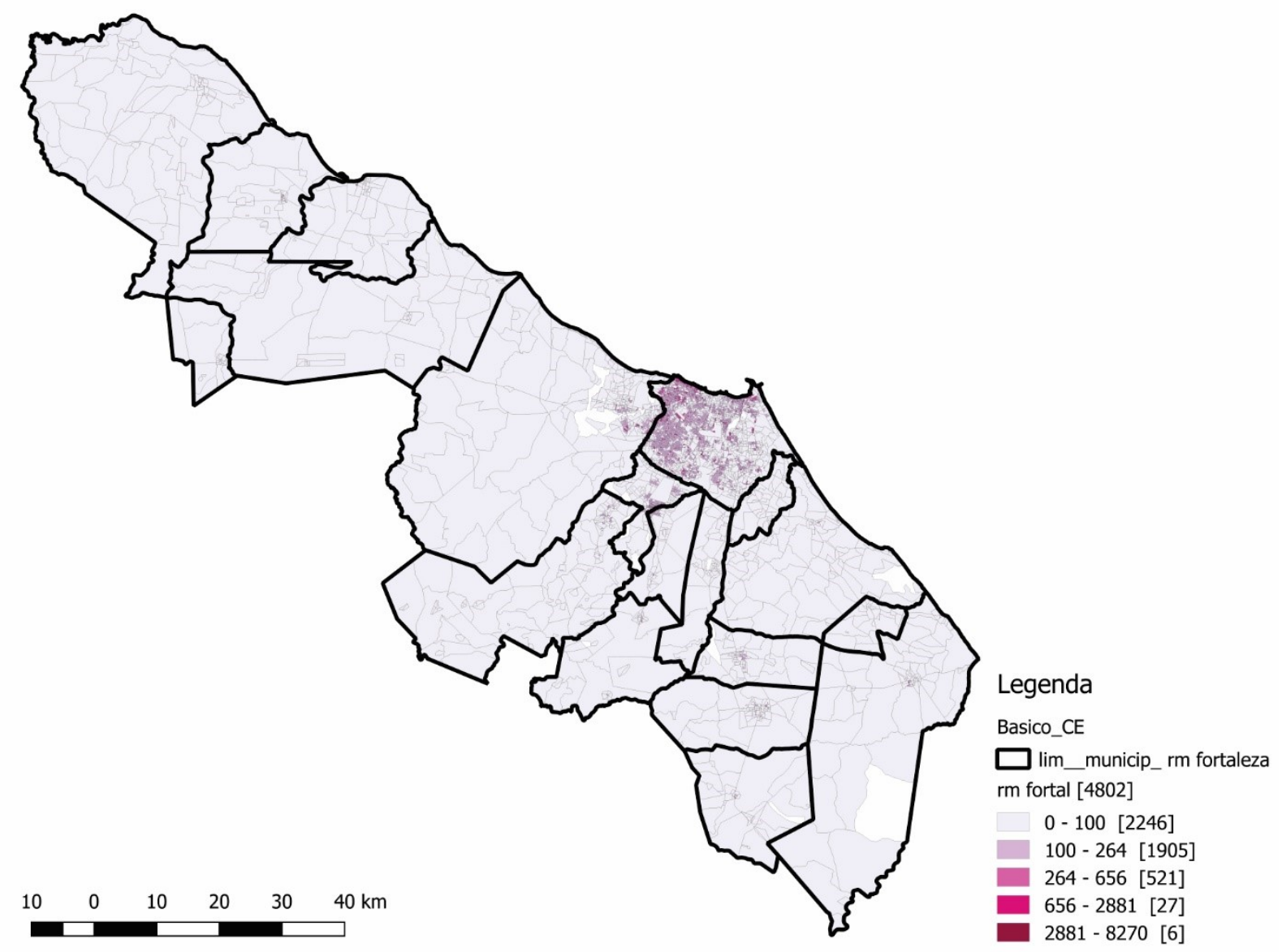

\section{MAPA DE DISTRIBUIÇÃO DE DENSIDADE POPULACIONAL (HAB/HA) POR SETOR CENSITÁRIO NA RM FORTALEZA/CE}

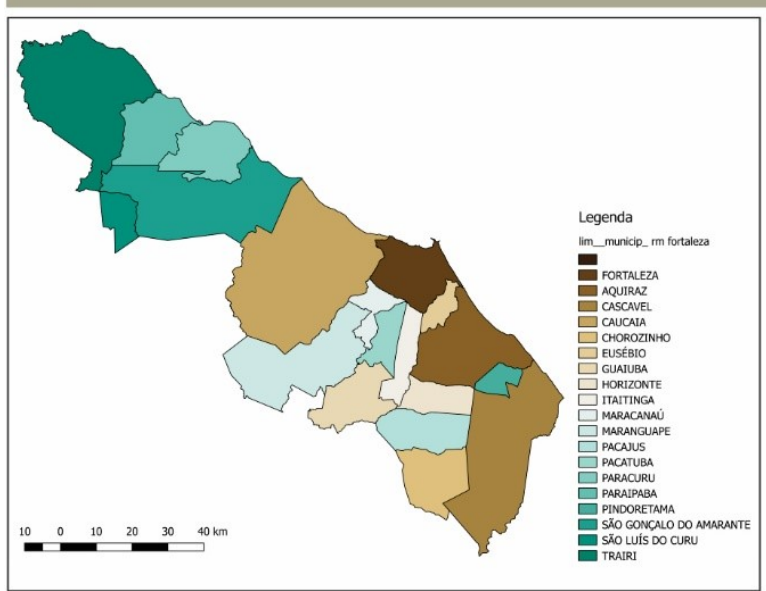

MAPA-CHAVE: MUNICIPIOS CONSTITUINTES DA RM FORTALEZA/CE

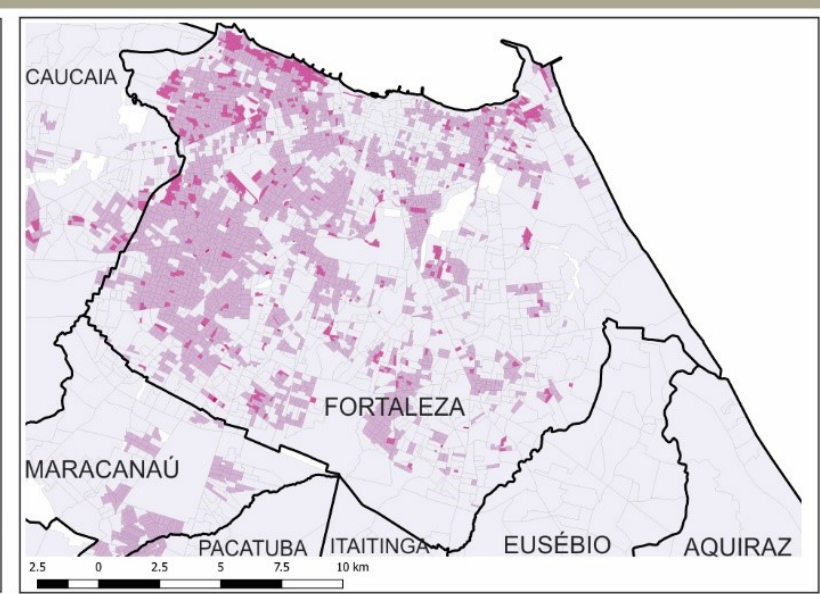

DETALHE DA DISTRIBUIÇÃO DE DENSIDADE POPULACIONAL (HAB/HA) POR SETOR CENSITÁRIO NA RM FORTALEZAVCE

Fonte: Elaboração própria (2016) sob a Base Cartográfica do IBGE (2010) e dados do censo de 2010. 
As áreas mais densas de Fortaleza (Figura 174) estão ao oeste (em direção ao município de Caucaia) e ao sul (em direção ao município de Maracanaú) e são bairros distantes do centro - carentes de infraestrutura básica e com problemas de mobilidade - e de população pobre (Figura 29), parte da qual imigrantes de outros municípios do Estado (BUARQUE et al., 2015).

Os dados da Tabela 27 são referentes à RM de Recife/PE e há uma diferença significativa em relação às RM's anteriores: a população do município-sede corresponde a apenas $41 \%$ do total. Isso se dá, em parte, pelo tamanho de Jaboatão dos Guararapes e de Olinda, que, juntos, possuem mais de um milhão de habitantes.

\begin{tabular}{|c|c|c|c|c|c|}
\hline Município & Área $\left(\mathbf{k m}^{2}\right)$ & $\begin{array}{c}\% \text { em } \\
\text { relação a } \\
\text { área total }\end{array}$ & $\begin{array}{l}\text { População } \\
\text { estimada } \\
\text { (2015) }\end{array}$ & $\begin{array}{c}\% \text { em } \\
\text { relação a } \\
\text { população } \\
\text { total }\end{array}$ & $\begin{array}{c}\text { Densidade } \\
\left(\text { pessoas } / \mathbf{K m}^{2}\right)\end{array}$ \\
\hline Recife & 218,43 & $7,88 \%$ & 1.617 .183 & $41,31 \%$ & $7.403,67$ \\
\hline Jaboatão dos Guararapes & 258,69 & $9,34 \%$ & 686.122 & $17,53 \%$ & $2.652,25$ \\
\hline Olinda & 41,68 & $1,50 \%$ & 389.494 & $9,95 \%$ & $9.344,64$ \\
\hline Paulista & 97,31 & $3,51 \%$ & 322.730 & $8,24 \%$ & $3.316,45$ \\
\hline Cabo de Santo Agostinho & 448,74 & $16,20 \%$ & 200.546 & $5,12 \%$ & 446,91 \\
\hline Camaragibe & 51,26 & $1,85 \%$ & 154.054 & $3,94 \%$ & $3.005,52$ \\
\hline São Lourenço da Mata & 262,11 & $9,46 \%$ & 110.264 & $2,82 \%$ & 420,68 \\
\hline Igarassu & 305,56 & $11,03 \%$ & 112.463 & $2,87 \%$ & 368,06 \\
\hline Abreu e Lima & 126,19 & $4,55 \%$ & 98.602 & $2,52 \%$ & 781,36 \\
\hline Ipojuca & 527,11 & $19,03 \%$ & 91.341 & $2,33 \%$ & 173,29 \\
\hline Moreno & 196,07 & $7,08 \%$ & 61.016 & $1,56 \%$ & 311,19 \\
\hline Itapissuma & 74,24 & $2,68 \%$ & 25.798 & $0,66 \%$ & 347,52 \\
\hline Ilha de Itamaracá & 66,68 & $2,41 \%$ & 24.888 & $0,64 \%$ & 373,22 \\
\hline Araçoiaba & 96,38 & $3,48 \%$ & 19.816 & $0,51 \%$ & 205,60 \\
\hline TOTAL & $2.770,45$ & $100,00 \%$ & 3.914 .317 & $100,00 \%$ & $1.412,88$ \\
\hline
\end{tabular}

Analisando o mapa da distribuição por setor censitário (Figura 175), percebe-se que as maiores densidades são encontradas na conurbação Olinda-Recife-Jaboatão, estendendo-se para os municípios vizinhos de Camaragibe e Paulista. As maiores densidades são os setores que abarcam as áreas de verticalização, onde reside a população de maior renda: orla de Boa Viagem e Setúbal. Também há altas densidades nas áreas ocupadas pela população mais pobre, que ocupa os morros e as áreas de baixios (SOUZA, 2006). 
Figura 175: Mapa de Densidade Populacional (em habitantes por hectare) por setor censitário da RM de Recife/PE.

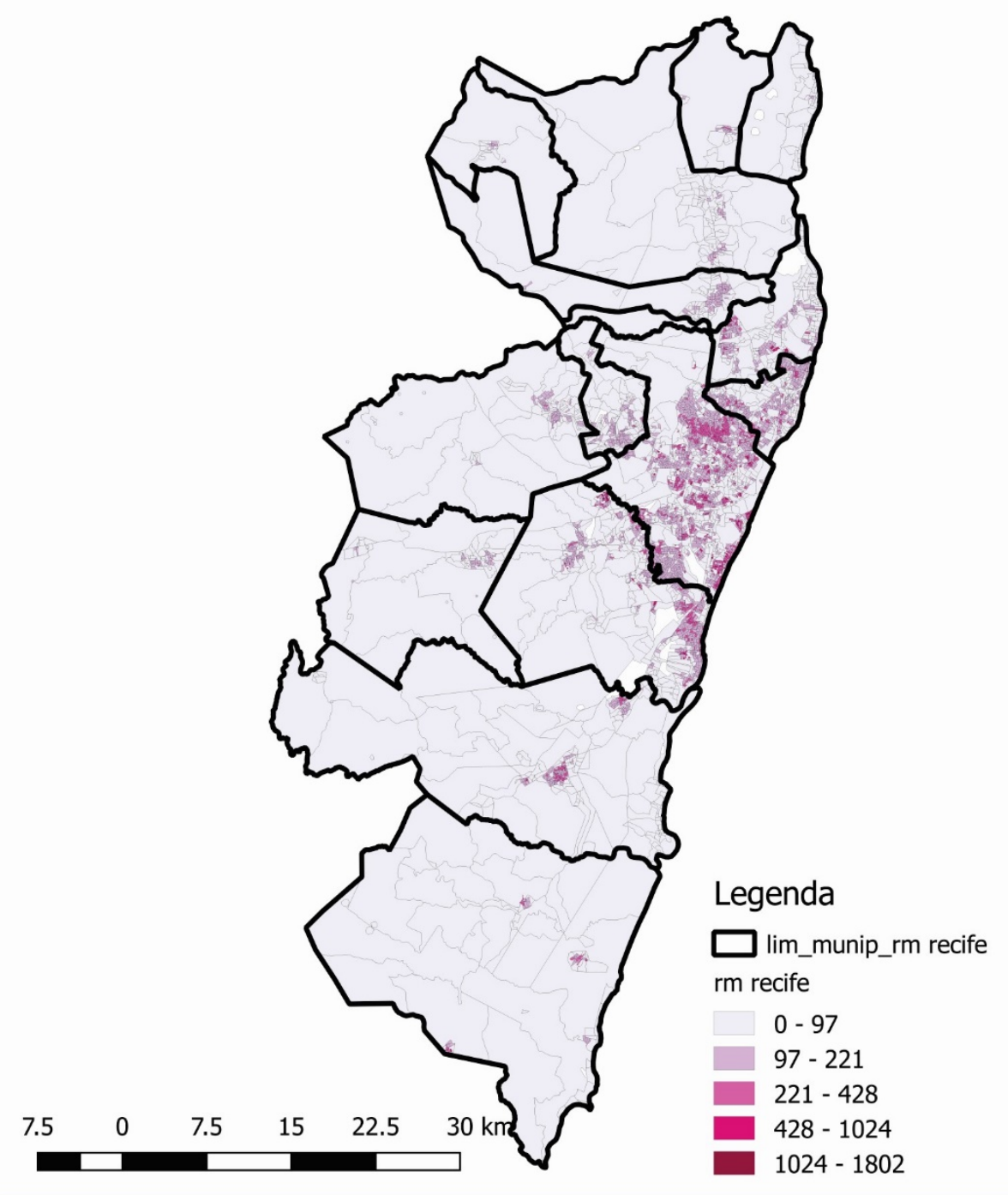

MAPA DE DISTRIBUIÇÃO DE DENSIDADE POPULACIONAL (HAB/HA) POR SETOR CENSITÁRIO NA RM RECIFE/PE

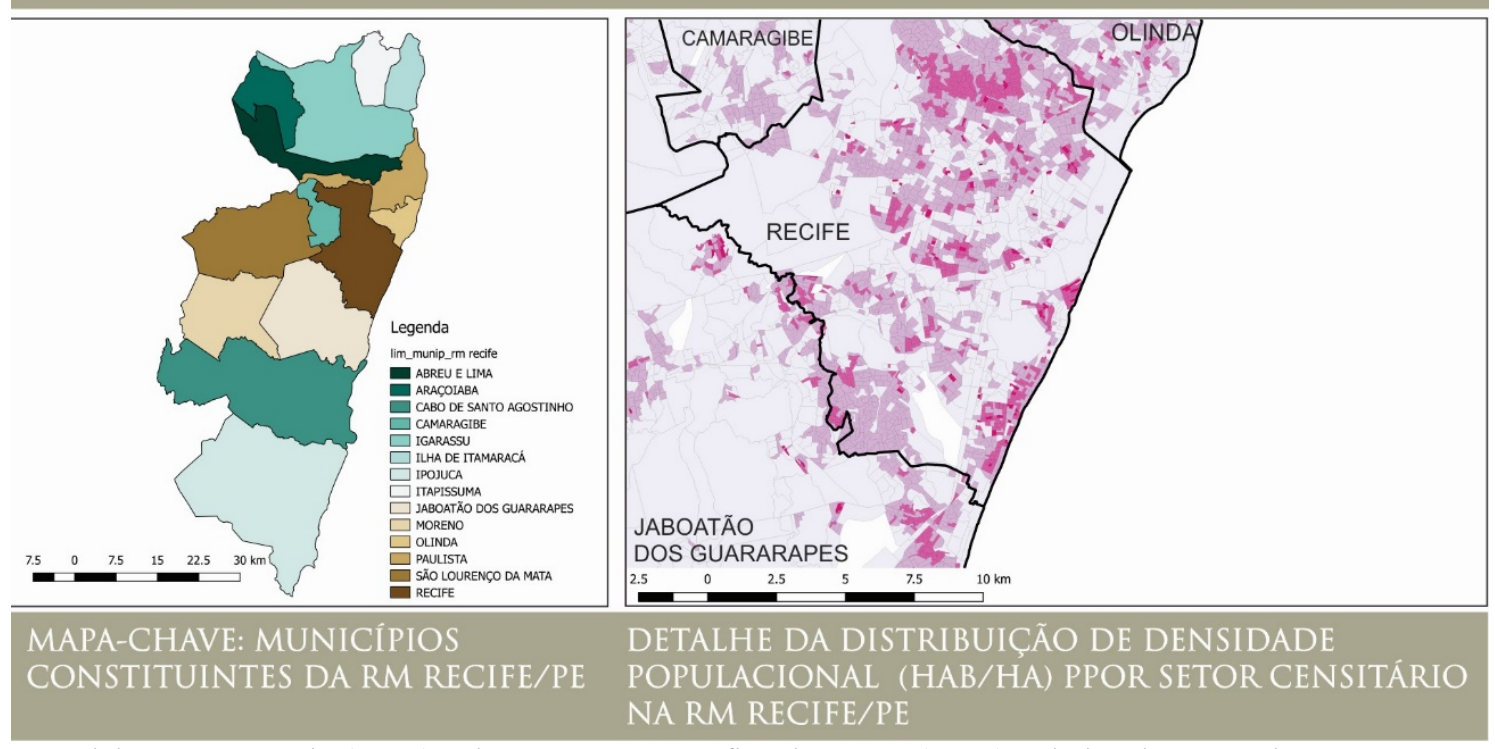

Fonte: Elaboração própria (2016) sob a Base Cartográfica do IBGE (2010) e dados do censo de 2010. 


\subsection{Conclusões parciais}

Para traçar um comparativo entre as regiões e cidades selecionadas, foram sistematizados no Quadro 9: Comparativo entre centralidades, usos e distribuição de e, no Quadro 10: Comparativo entre as tipologias de expansão residencial. Estes quadros são apresentados em escalas cromáticas que quantificam e qualificam os itens em análise.

\begin{tabular}{|c|c|c|c|c|}
\hline \multicolumn{2}{|c|}{ Aglomerações/cidades } & $\begin{array}{c}\text { Centralidade/ } \\
\text { polarização funcional }\end{array}$ & Shoppings & $\begin{array}{c}\text { Distribuição de } \\
\text { densidades e rendas }\end{array}$ \\
\hline \multirow{5}{*}{$\sum_{\underline{a}}^{\text {至 }}$} & $\begin{array}{l}\text { RM de Feira de } \\
\text { Santana/BA }\end{array}$ & $\begin{array}{c}\text { Bem definida } \\
\text { Forte polarização }\end{array}$ & $\begin{array}{c}\text { Consolidados } \\
\text { Inaugurado em } 1999\end{array}$ & $\begin{array}{l}\text { A cidade-sede é dominante } \\
\text { em renda e densidades }\end{array}$ \\
\hline & RM do Cariri/CE & $\begin{array}{c}\text { Bem definida } \\
\text { Forte polarização }\end{array}$ & $\begin{array}{c}\text { Consolidados } \\
\text { Inaugurado em } 1998\end{array}$ & $\begin{array}{l}\text { A conurbação é dominante } \\
\text { em renda e densidades }\end{array}$ \\
\hline & $\begin{array}{l}\text { RM Sudoeste } \\
\text { Maranhense/MA }\end{array}$ & $\begin{array}{c}\text { Bem definida } \\
\text { Média polarização }\end{array}$ & $\begin{array}{c}\text { Recentes } \\
\text { Inaugurado em } 2012 \\
\end{array}$ & $\begin{array}{l}\text { A cidade-sede é dominante } \\
\text { em renda e densidades }\end{array}$ \\
\hline & $\begin{array}{l}\text { RM Campina } \\
\text { Grande/PB }\end{array}$ & $\begin{array}{c}\text { Bem definida } \\
\text { Forte polarização }\end{array}$ & $\begin{array}{c}\text { Consolidados } \\
\text { Inaugurado em } 1999\end{array}$ & $\begin{array}{l}\text { A cidade-sede é dominante } \\
\text { em renda e densidades }\end{array}$ \\
\hline & $\begin{array}{l}\text { RAID de } \\
\text { Petrolina/Juazeiro }\end{array}$ & $\begin{array}{l}\text { Bem definida } \\
\text { Forte polarização }\end{array}$ & $\begin{array}{c}\text { Consolidados } \\
\text { Inaugurado em } 1995 \\
\end{array}$ & $\begin{array}{c}\text { A conurbação é dominante } \\
\text { em renda e densidades }\end{array}$ \\
\hline \multirow{5}{*}{ נ̄ } & RM Agreste/AL & $\begin{array}{l}\text { Bem definida } \\
\text { Média polarização }\end{array}$ & $\begin{array}{c}\text { Recentes } \\
\text { Inaugurado em } 2013\end{array}$ & $\begin{array}{l}\text { A cidade-sede é dominante } \\
\text { em densidades. Rendas } \\
\text { médias distribuídas. }\end{array}$ \\
\hline & $\begin{array}{l}\text { Vitória da } \\
\text { Conquista/BA }\end{array}$ & $\begin{array}{c}\text { Bem definida } \\
\text { Média polarização }\end{array}$ & $\begin{array}{c}\text { Recentes } \\
\text { Inaugurado em } 2006\end{array}$ & $\begin{array}{c}\text { O núcleo urbano é } \\
\text { dominante em renda e } \\
\text { densidades }\end{array}$ \\
\hline & Sobral/CE & $\begin{array}{c}\text { Bem definida } \\
\text { Média polarização }\end{array}$ & $\begin{array}{c}\text { Recentes } \\
\text { Inaugurado em } 2013 .\end{array}$ & $\begin{array}{c}\text { O núcleo urbano é } \\
\text { dominante em renda e } \\
\text { densidades }\end{array}$ \\
\hline & Mossoró/RN & $\begin{array}{c}\text { Bem definida } \\
\text { Média polarização }\end{array}$ & $\begin{array}{c}\text { Recentes } \\
\text { Inaugurado em } 2007\end{array}$ & $\begin{array}{c}\text { O núcleo urbano é } \\
\text { dominante em renda e } \\
\text { densidades }\end{array}$ \\
\hline & Caruaru/PE & $\begin{array}{l}\text { Bem definida } \\
\text { Forte polarização }\end{array}$ & $\begin{array}{c}\text { Consolidados } \\
\text { Inaugurado em } 1997\end{array}$ & $\begin{array}{c}\text { O núcleo urbano é } \\
\text { dominante em renda e } \\
\text { densidades }\end{array}$ \\
\hline \multirow{3}{*}{ Û } & RM Salvador & $\begin{array}{c}\text { Bem definida } \\
\text { Altíssima polarização }\end{array}$ & $\begin{array}{c}\text { Vários - consolidados } \\
1^{\circ} \text { inaugurado em } 1987\end{array}$ & $\begin{array}{l}\text { A conurbação é dominante } \\
\text { em renda e densidades }\end{array}$ \\
\hline & RM Fortaleza & $\begin{array}{c}\text { Bem definida } \\
\text { Altíssima polarização }\end{array}$ & $\begin{array}{c}\text { Vários - consolidados } \\
1^{\circ} \text { inaugurado em } 1982\end{array}$ & $\begin{array}{l}\text { A conurbação é dominante } \\
\text { em renda e densidades }\end{array}$ \\
\hline & RM Recife & $\begin{array}{c}\text { Bem definida } \\
\text { Altíssima polarização }\end{array}$ & $\begin{array}{l}\text { Vários - consolidados } \\
1^{\circ} \text { inaugurado em } 1980\end{array}$ & $\begin{array}{l}\text { A conurbação é dominante } \\
\text { em renda e densidades }\end{array}$ \\
\hline
\end{tabular}

\begin{tabular}{|c|c|c|}
\hline \multicolumn{3}{|c|}{ LEGENDA ESCALAS CROMÁTICAS } \\
\hline \multicolumn{3}{|c|}{ Centralidade/ polarização funcional } \\
\hline $\begin{array}{l}\text { Bem definida } \\
\text { Média polarização }\end{array}$ & $\begin{array}{l}\text { Bem definida } \\
\text { Forte polarização }\end{array}$ & $\begin{array}{l}\text { Bem definida } \\
\text { Altíssima polarização }\end{array}$ \\
\hline \multicolumn{3}{|c|}{ Shoppings } \\
\hline $\begin{array}{l}\text { Recentes } \\
\text { Inauguração a partir dos anos } 2000\end{array}$ & $\begin{array}{l}\text { Consolidados } \\
\text { Inaugurado na década de } \\
1990\end{array}$ & $\begin{array}{l}\text { Vários - consolidados } \\
\text { Inaugurados na década de } 1980\end{array}$ \\
\hline \multicolumn{3}{|c|}{ Distribuição de densidades e rendas } \\
\hline $\begin{array}{l}\text { A cidade-sede é dominante em } \\
\text { densidades. Rendas distribuídas }\end{array}$ & $\begin{array}{l}\text { A conurbação é dominante } \\
\text { em renda e densidades }\end{array}$ & $\begin{array}{l}\text { A cidade-sede é dominante em } \\
\text { renda e densidades }\end{array}$ \\
\hline
\end{tabular}

O núcleo urbano é dominante em renda e densidades

Fonte: Elaboração própria (2016). 
Quanto as centralidades, entendidas sob o ponto de vista da acessibilidade morfológica, há em todos os casos analisados núcleos de integração bem definidos, ou seja, há uma correlação clara entre integração e lugares onde são exercidas atividades que se beneficiam com o movimento natural. Portanto, sob a ótica da funcionalidade, esses centros têm predominâncias de edifícios comerciais e para a prestação de serviços (públicos e privados), além de outras atividades mais qualificadas que estendem sua influência para um entorno mais amplo, por exemplo, capacidades políticas e administrativas. Este alcance, entretanto, tem forças muito diferentes nos casos analisados, os quais classifiquei em: média, forte e altíssima polarização. As RM's das capitais são as localidades que detêm centros com maior poder em virtude da quantidade, concentração e diversidade de serviços oferecidos. As RMINE's e Caruaru/PE (por sua tradição comercial) possuem forte polarização sobre seu entorno imediato. A exceção é a RMINE de Imperatriz/MA que, juntamente com os demais casos do Grupo de Controle 01, apresenta a menor "força" de polarização da comparação, embora valha o destaque que, ainda assim, são os principais centros comerciais e de serviços das suas hinterlândias.

Ainda relacionado a este primeiro item, os shoppings podem ser analisados enquanto novas fórmulas comerciais e de prestação de serviço atreladas ao interesses imobiliários. As expansões residenciais das elites sobre novos espaços atraem esses usos, num processo de depreciação (física e simbólica) dos centros tradicionais. Estes equipamentos são marcantes em todos os casos analisados, porém, em processos de consolidação díspares, especialmente relacionado com o seu tempo de funcionamento. Novamente, o Grupo de Controle 02 destacase por sua força comercial, contando com diversos centros comerciais inaugurados desde os anos $1980^{68}$, de porte e público alvo (e, portanto, localizações urbanas) extremamente diferentes. Quanto aos demais casos, sua inauguração é datada a partir de meados dos anos 1990, embora prevaleçam no grupo 01 empreendimentos mais recentes (segunda metade dos anos 2000 ou da nossa década).

Isso demonstra que esses empreendimentos estão adentrando nas distintas realidades brasileiras e que consolidam consigo os processos de assepsia social que comentamos no capítulo 01. Os shoppings são "ilhas de fantasia” cercados por uma aura de segurança,

\footnotetext{
${ }^{68}$ O primeiro empreendimento do gênero no Brasil, o Shopping Center Iguatemi, em São Paulo, foi inaugurado em novembro de 1966, porém sem grande sucesso inicial foi vendido em 1978. O Conjunto Nacional Brasília foi inaugurado em 1971, mas também só se consolidou em finais da década. Destaco que a primeira experiência de centro comercial de Fortaleza foi o Center Um (inaugurado em 1974), mas que se enquadra na categoria de "Strip Center" coberto, ancorado por um supermercado, com uma faixa de lojas "satélites" em frente aos caixas - o precursor do formato das lojas Carrefour de hoje. (SEMMA, 2016)
} 
limpeza (física e social) e conforto que suplementa a cultura consumista de parcela da população. Sua localização no espaço urbano é, também, reflexo do seu público-alvo: acessados por vias bem integradas/escolhidas dentro do sistema - uma vez que o ingresso se dá majoritariamente por meio de veículos-e em áreas de expansão que proveem grandes lotes para sua construção, por exemplo, na centralidade metropolitana do bairro Triângulo no Crajubar/CE, ou próximo as expansões residenciais de alto padrão em Mossoró/RN. Estabelece-se uma nova relação entre a rua e a loja: enquanto que nos centros tradicionais essa relação é direta, os shoppings negam o espaço a sua volta e se interiorizam. As faixas de renda mais baixas o tem como sonho distante, impossível de abarcar por suas limitações financeiras, mas que subsidia origem de novas tipologias de shoppings: populares e periféricos, para atender também essa população (e evitar seu "indesejável" contato entre as classes sociais). Este processo, embora recorrente nas grandes capitais brasileiras, à exemplo do Grupo de Controle 02, ainda não é aparente nos demais casos analisados. Acredito que os centros tradicionais continuam atendendo as camadas mais pobres e seus processos de degradação física (muitas vezes agregadas a perdas patrimoniais) e social são um reflexo desse processo.

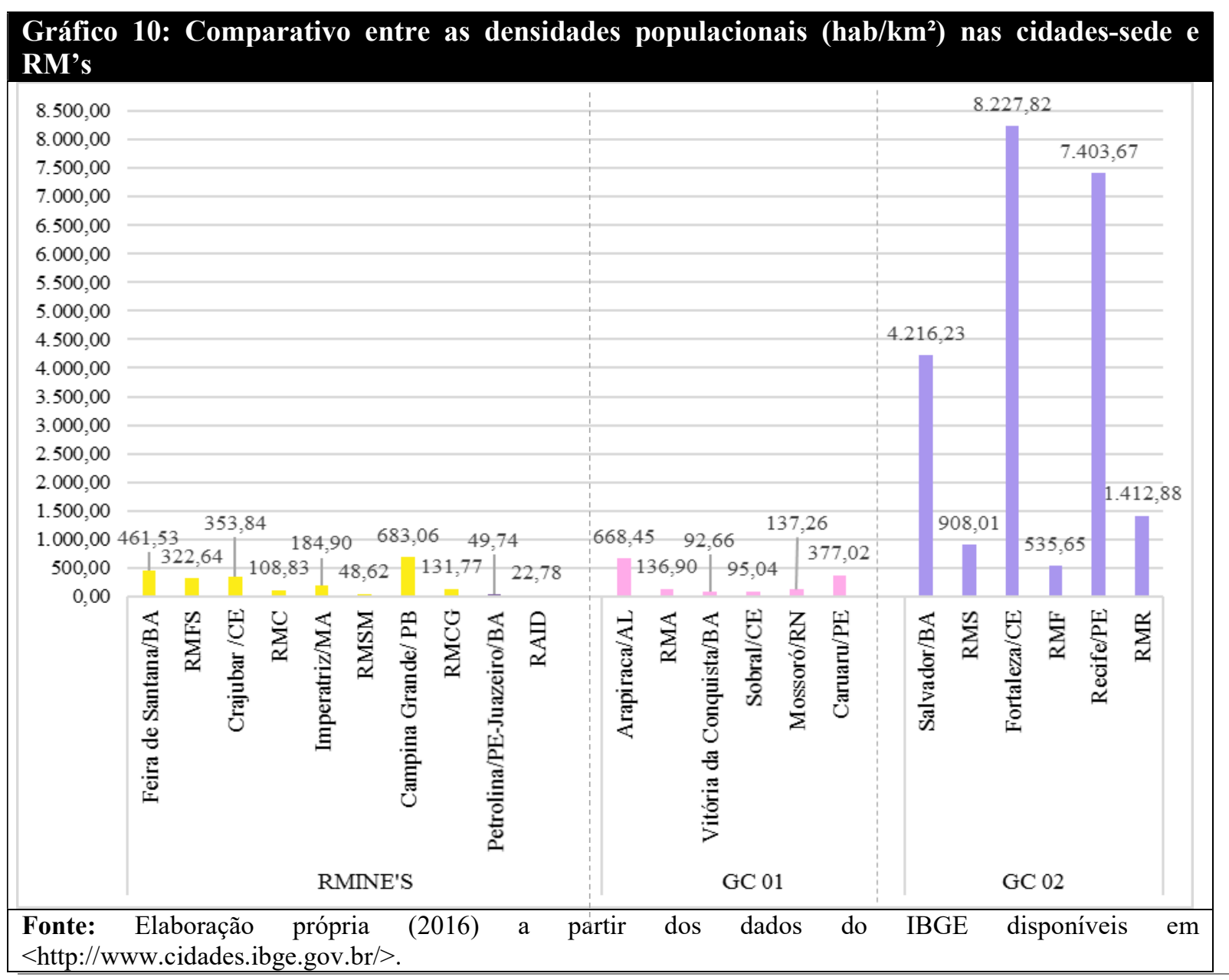


Há entre os casos escolhidos uma grande disparidade de densidades populacionais (Gráfico 10), reflexo da organização da rede urbana brasileira em sua totalidade: dos 5.570 municípios, apenas 41 deles possuem mais de 500 mil habitantes e concentram $29,9 \%$ da população do Brasil (61,2 milhões de pessoas); por outro lado, mais da metade da população (56,0\% ou 114,6 milhões de habitantes) vive em apenas 5,5\% dos municípios com mais de 100 mil moradores (304 no total), enquanto apenas $6,3 \%$ da população (1,4 milhão) reside em 2.451 municípios brasileiros (44\%) com até 10.000 habitantes (IBGE, 2010). Estes desequilíbrios nos padrões de densidade urbana e a concentração de serviços e empregos nas centralidades consolidadas agravam os processos de segregação socioespacial.

Há no Quadro 09 quatro escalas propostas para sistematizar esta análise, a primeira delas é especifica da RM do Agreste/AL, onde Arapiraca é dominante nas densidades, porém as rendas médias são distribuídas por todos os municípios. A hipótese para essa particularidade é a composição rural da RM. As cidades do grupo 01 foram classificadas com o núcleo urbano dominante em renda e densidades, frente ao restante da área municipal normalmente de predominância rural. A ausência dos municípios de entorno (uma vez que não há definição oficial de RM's) foi um dificultador desta análise, pois perco a possibilidade de traçar comparativos regionais. Porém, seu resultado me parece próximo ao das RMINE'S, onde a cidade-sede é dominante em renda e densidades frente ao seu entorno. Embora nos demais casos os processos de conurbação física fazem esse controle de densidades e rendas se diluírem um pouco, ainda prevalece em todos os casos estudados uma grande disparidade de concentrações populacional e de condições sociais de acesso a renda/emprego (como visto no capítulo 04), que se rebatem na utilização excludente e segregada dos espaços da cidade.

Dando continuidade aos comparativos, o quadro 10 representa as variedades de tipologias de expansões do tecido urbano. A primeira delas, a verticalização, é um dos processos mais marcantes da imagem simbólica da metrópole: o aglomerado denso que se eleva aos céus. Como não pensar em São Paulo ou Nova Iorque sem vir à mente a ideia da “selva de pedra"? Nas RM's do grupo 02 já há um estágio consolidado da expansão vertical que se iniciou em meados dos anos 1960 (embora os primeiros estudos acadêmicos datem das décadas de 1980-90 - RAMIRES, 1998), que vai além do uso residencial. Nos demais casos estudados, há três escalas de verticalização: incipiente, inicial (concentrada) e mediana (espalhada por vários bairros). 


\begin{tabular}{|c|c|c|c|c|}
\hline \multicolumn{5}{|c|}{ Quadro 10: Comparativo entre as tipologias de expansão residencial } \\
\hline \multicolumn{2}{|c|}{ Aglomerações/cidades } & Verticalização & Condomínios fechados & $\begin{array}{c}\text { Expansão residencial } \\
\text { de baixo }\end{array}$ \\
\hline \multirow{5}{*}{$\sum_{\underline{Z}}^{\mid-1}$} & $\begin{array}{l}\text { RM de Feira de } \\
\text { Santana/BA }\end{array}$ & $\begin{array}{c}\text { Mediana } \\
\text { Espalhada por diversos } \\
\text { bairros }\end{array}$ & $\begin{array}{l}\text { Poucos -Periféricos } \\
\text { Alto/médio padrão } \\
\text { Auto segregados }\end{array}$ & $\begin{array}{c}\text { Periféricos } \\
\text { Financiamento MCMV } \\
\text { Favelização }\end{array}$ \\
\hline & $R M$ do Cariri/CE & $\begin{array}{c}\text { Inicial } \\
\text { Concentrada em alguns } \\
\text { bairros }\end{array}$ & $\begin{array}{l}\text { Poucos -Periféricos } \\
\text { Médio padrão } \\
\text { Auto segregados }\end{array}$ & $\begin{array}{c}\text { Periféricos } \\
\text { Financiamento MCMV }\end{array}$ \\
\hline & $\begin{array}{l}\text { RM Sudoeste } \\
\text { Maranhense/MA }\end{array}$ & $\begin{array}{c}\text { Inicial } \\
\text { Concentrada em alguns } \\
\text { bairros }\end{array}$ & $\begin{array}{l}\text { Poucos -Periféricos } \\
\text { Médio padrão } \\
\text { Auto segregados } \\
\end{array}$ & $\begin{array}{c}\text { Periféricos } \\
\text { Financiamento MCMV }\end{array}$ \\
\hline & $\begin{array}{l}\text { RM Campina } \\
\text { Grande/PB }\end{array}$ & $\begin{array}{c}\text { Mediana } \\
\text { Espalhada por diversos } \\
\text { bairros }\end{array}$ & $\begin{array}{l}\text { Poucos - Periféricos } \\
\text { Médio padrão } \\
\text { Auto segregados }\end{array}$ & $\begin{array}{c}\text { Periféricos } \\
\text { Financiamento MCMV } \\
\text { Favelização }\end{array}$ \\
\hline & $\begin{array}{l}\text { RAID de } \\
\text { Petrolina/Juazeiro }\end{array}$ & $\begin{array}{c}\text { Inicial } \\
\text { Concentrada em alguns } \\
\text { bairros }\end{array}$ & $\begin{array}{c}\text { Poucos -Periféricos } \\
\text { Médio padrão - Chácaras } \\
\text { Auto segregados }\end{array}$ & $\begin{array}{c}\text { Periféricos } \\
\text { Financiamento MCMV }\end{array}$ \\
\hline \multirow{5}{*}{ ò } & RM Agreste/AL & Incipiente & $\begin{array}{c}\text { Poucos -Periféricos } \\
\text { Médio padrão - Chácaras } \\
\text { Auto segregados }\end{array}$ & $\begin{array}{c}\text { Periféricos } \\
\text { Financiamento MCMV }\end{array}$ \\
\hline & $\begin{array}{l}\text { Vitória da } \\
\text { Conquista/BA }\end{array}$ & Incipiente & $\begin{array}{l}\text { Poucos - Periféricos } \\
\text { Médio padrão } \\
\text { Auto segregados }\end{array}$ & $\begin{array}{c}\text { Periféricos } \\
\text { Financiamento MCMV }\end{array}$ \\
\hline & Sobral/CE & Incipiente & $\begin{array}{l}\text { Poucos - Periféricos } \\
\text { Médio padrão } \\
\text { Auto segregados }\end{array}$ & $\begin{array}{c}\text { Periféricos } \\
\text { Financiamento MCMV }\end{array}$ \\
\hline & Mossoró/RN & $\begin{array}{c}\text { Mediana } \\
\text { Concentrada em alguns } \\
\text { bairros }\end{array}$ & $\begin{array}{l}\text { Poucos -Periféricos } \\
\text { Alto/médio padrão } \\
\text { Auto segregados }\end{array}$ & $\begin{array}{c}\text { Periféricos } \\
\text { Financiamento MCMV }\end{array}$ \\
\hline & Caruaru/PE & $\begin{array}{c}\text { Mediana } \\
\text { Espalhada por diversos } \\
\text { bairros }\end{array}$ & $\begin{array}{l}\text { Poucos -Periféricos } \\
\text { Alto/médio padrão } \\
\text { Auto segregados }\end{array}$ & $\begin{array}{c}\text { Periféricos } \\
\text { Financiamento MCMV }\end{array}$ \\
\hline \multirow{3}{*}{ ป̂ } & RM Salvador & $\begin{array}{c}\text { Alta } \\
\text { Espalhada por diversos } \\
\text { bairros }\end{array}$ & $\begin{array}{l}\text { Diversos -Periféricos } \\
\text { Alto/médio padrão } \\
\text { Auto segregados }\end{array}$ & $\begin{array}{c}\text { Periféricos/incrustados } \\
\text { Financiamento MCMV } \\
\text { Favelização }\end{array}$ \\
\hline & RM Fortaleza & $\begin{array}{c}\text { Alta } \\
\text { Espalhada por diversos } \\
\text { bairros }\end{array}$ & $\begin{array}{l}\text { Diversos - Periféricos } \\
\text { Alto/médio padrão } \\
\text { Auto segregados }\end{array}$ & $\begin{array}{l}\text { Periféricos/incrustados } \\
\text { Financiamento MCMV } \\
\text { Favelização }\end{array}$ \\
\hline & RM Recife & $\begin{array}{c}\text { Alta } \\
\begin{array}{c}\text { Espalhada por diversos } \\
\text { bairros }\end{array}\end{array}$ & $\begin{array}{l}\text { Diversos -Periféricos } \\
\text { Alto/médio padrão } \\
\text { Auto segregados }\end{array}$ & $\begin{array}{l}\text { Periféricos/incrustados } \\
\text { Financiamento MCMV } \\
\text { Favelização }\end{array}$ \\
\hline
\end{tabular}

\begin{tabular}{|c|c|c|}
\hline \multicolumn{3}{|c|}{ LEGENDA ESCALAS CROMÁTICAS } \\
\hline \multicolumn{3}{|c|}{ Verticalização } \\
\hline Incipiente & $\begin{array}{l}\text { Inicial -Concentrada em } \\
\text { alguns bairros }\end{array}$ & $\begin{array}{l}\text { Mediana } \\
\text { Concentrada em alguns bairros }\end{array}$ \\
\hline $\begin{array}{l}\text { Mediana - Espalhada por diversos } \\
\text { bairros }\end{array}$ & $\begin{array}{l}\text { Alta - Espalhada por diversos } \\
\text { bairros }\end{array}$ & \\
\hline \multicolumn{3}{|c|}{ Condomínios fechados } \\
\hline $\begin{array}{l}\text { Poucos -Periféricos - Médio padrão } \\
\text { - Chácaras - Auto segregados }\end{array}$ & $\begin{array}{l}\text { Poucos - Periféricos - Médio } \\
\text { padrão - Auto segregados }\end{array}$ & $\begin{array}{l}\text { Poucos -Periféricos - Alto } \\
\text { /médio padrão Auto segregados }\end{array}$ \\
\hline $\begin{array}{l}\text { Diversos -Periféricos - Alto/médio } \\
\text { padrão - Auto segregados }\end{array}$ & & \\
\hline \multicolumn{3}{|c|}{ Segregação socioespacial } \\
\hline $\begin{array}{l}\text { Periféricos } \\
\text { Financiamento MCMV }\end{array}$ & $\begin{array}{l}\text { Periféricos - Financiamento } \\
\text { MCMV - Favelização }\end{array}$ & $\begin{array}{l}\text { Periféricos/incrustados - } \\
\text { MCMV - Favelização }\end{array}$ \\
\hline
\end{tabular}

Fonte: Elaboração própria (2016). 
Os resultados foram heterogêneos, mas ressalto que as RMINE'S que possuem conurbações consolidadas (Cariri/CE e RAID) apresentam estágios iniciais de verticalização. Minha hipótese é que com a fluidez das malhas entre os municípios, as áreas de expansão horizontal tornam-se vastas, freando, a princípio, a necessidade de multiplicação do solo por meio de edifícios de apartamentos de alto padrão. Outra possível explicação da parca difusão da verticalização no interior diz respeito ao "modo de morar tradicional" das elites nordestinas de tradição rural, que vão preferir as mansões - numa atualização das chácaras do período colonial - preferencialmente em condomínios fechados que lhe agregam itens de segurança e lazer privado. É, portanto, grande o destaque desses empreendimentos nas localidades estudadas. Embora os padrões construtivos variem, todos eles deixam explícitos os processos de auto segregação que as faixas de maior renda impõem, por exemplo, através da utilização de áreas periféricas. O fato das elites se separarem em determinadas áreas das cidades, simbolizando poder, status e distinção, não é novo e não pode ser cominado tão somente aos condomínios fechados. Entretanto, em outros períodos, as vias conservam-se abertas e a possibilidade, por mais remota que fosse, de uma livre circulação de pedestres, existia.

Essas novas áreas trazem à tona a discussão das nova relação entre o público e o privado, uma vez que esses empreendimentos transfiguram o sentido do público em diversas dimensões: criando o solo urbano de maneira privada; impedindo a livre circulação e o convívio democrático entre a população da cidade; transferindo para a esfera privada encargos que são de natureza pública e de acesso universal, como equipamentos sociais; enquanto, paradoxalmente, o poder público arca com o investimento na infraestrutura mais pesada, como vias e perimetrais que facilitam o acesso a essas novas urbanizações. (BARCELLOS \& MAMMARELLA, 2007). Este isolamento provoca cisões também no tecido social, visto que impede a copresença, dificultando as possibilidades de novas relações (SOJA, 2000). É, até certo ponto, portanto, questionável o que Villaça (2001) denomina como segregação voluntária, pois a população que opta por morar nesses condomínios não necessariamente tem plena consciência desses processos e são reféns das escolhas do capital imobiliário que replica o discurso de medo e violência em seu marketing.

De certa maneira, esses condicionantes são replicados também nas áreas de habitação das faixas de renda baixas e medianas através da construção dos conjuntos habitacionais financiados principalmente pelo MCMV. Embora a inserção de programas federais como esse tenha um importante papel em mitigar o déficit habitacional do país, a perda das qualidades espaciais é a crítica recorrente a sua atuação. No nível da edificação, há a homogeneização da 
arquitetura das unidades e, na escala da inserção urbana, sua localização periférica, distante da malha dotada de infraestrutura e mercado de trabalho, agrava problemas urbanos e sociais já insustentáveis em nossas cidades replicando os bolsões de pobreza.

Por fim, retomo a medida de integração proporcional para comparar as integrações $\mathrm{HH}$, embora os tamanhos dos sistemas sejam extremamente diversos (o menor é Sobral/CE com apenas 1.916 linhas e o maior é a RM de Salvador/BA com mais de 68 mil eixos), há uma aproximação entre os resultados: os miolos têm valores de integração iguais ao total, pois, de acordo com o procedimento de elaboração dos círculos, o centro é definido pelo ponto médio da linha mais integrada, que nunca se apresentou, nos casos estudados, mais longa do que o raio do miolo. Em geral, o núcleo de integração e as faixas de média integração (linhas amarelas e verdes) estão contidos neste menor círculo, de modo que se encontram nas cercanias os eixos mais segregados (em tons de azul).

Há, entretanto, uma série de limitações nesta medida proposta. Primeiro, para facilitar a comparação estes dados deveriam ser normalizados, ou seja, passar um procedimento que permita comparar dados de sistemas tão diferentes numa mesma escala. Isso permitiria também a comparação dos dados obtidos nesse trabalho com outras cidades e aglomerações do Brasil e do mundo já estudadas pelas SE (por exemplo, com aquelas estudadas por MEDEIROS, 2006). Por limitações diversas não foi realizado este procedimento, mas este é um possível desdobramento desta tese. Em segundo, sugere-se a delimitação de um terceiro círculo concêntrico com metade do raio do miolo (ou $1 / 4$ do raio total das cercanias). Acreditase que essa medida poderá refinar a leitura do núcleo de integração, ao excluir as faixas de medianas integrações.

Por fim, acredito que medida de integração proporcional pode correlacionar-se com o Índice de Dispersão Urbana, proposto por Bertaud e Malpezzi (1999) ${ }^{69}$, que é "um índice de base demográfica para a análise urbana e tem por intuito relacionar, em função da população total, o número de habitantes por setor urbano à distância daqueles setores ao CCS [Centro de Comércio e Serviços]" (RIBEIRO, et al., 2012, p.236). A base desse método de cálculo advém dos estudos realizados pelo geógrafo Colin Clark que observou que a densidade populacional decai exponencialmente a medida em que se afasta do centro (GONÇALVES,

\footnotetext{
${ }^{69}$ Bertaud e Malpezzi medem a distribuição espacial da população em 50 cidades no mundo, incluindo três cidades brasileiras. Utilizam um reduzido número de indicadores, mas que abarcam importantes dimensões da dispersão urbana: superfície da área construída, a forma dessa área e o modo como a população se distribui. Ribeiro e Holanda (2006) complementam o estudo, atualizando os dados para as cidades brasileiras e incluindo mais sete cidades do País, além de normalizarem os resultados dentro de uma escala padronizada, o que facilita a comparação entre os diferentes centros urbanos. (GONÇALVES, 2011).
} 
2011). A forma urbana é comparada a uma cidade hipotética cilíndrica, de área e população equivalente que indica a compacidade do sistema. A maior parte das cidades brasileiras estudadas por Ribeiro e Holanda (2006) localiza-se numa faixa intermediária da normalização, mas com tendência para maior compacidade. Sugere-se, portanto, investigar futuramente qual a tendência das cidades e aglomerações urbanas desta tese.

\section{Gráfico 11: Comparação das integrações HH máxima, média e mínima para os totais, cercanias e} miolos das RM's e cidades em estudo

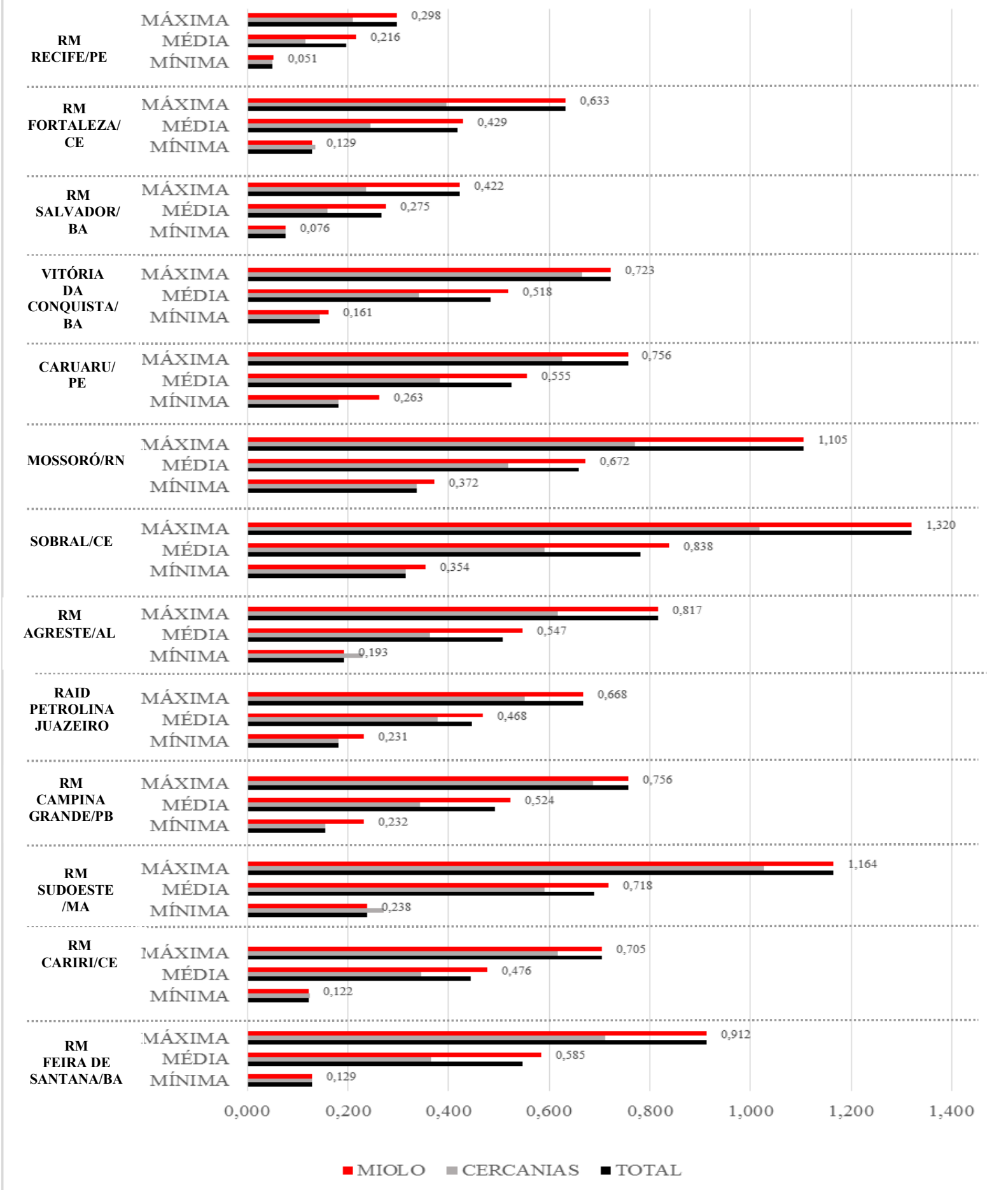

Fonte: Elaboração própria (2016) a partir das bases cartográficas calculadas para integração HH. 


\section{CONCLUSÕES}


Esta tese debruçou-se sobre um amplo referencial empírico e analítico em busca da definição de um tipo metropolitano em termos demográficos e socioespaciais. Escalas ou tipificações de cidades são comuns nos estudos acerca da rede urbana, dos quais destaco Santos (1967), que conceituou como "metrópoles incompletas" aquelas que polarizam a região à sua volta, em oposição à ideia de "metrópoles completas", assim denominadas por congregarem equipamentos e estrutura complexa capazes de organizar o espaço nacional. Entretanto, uma dicotomia tão rígida não parece abarcar toda a realidade urbana brasileira. Não há apenas dois tipos de metrópoles, mas sim uma vasta gama de entretons entre o completo e o incompleto.

Para identificar tais nuanças metropolitanas, proponho um afastamento dos tradicionais critérios de mensuração urbana de densidade populacional e predominância das atividades industriais, como aqueles que subsidiaram a metodologia de formação das RM's nos anos 1970 (GALVÃO et al. 1969 apud BRANCO; PEREIRA; NADALIN, 2013). Embora isso possa soar, em princípio, contraditório, uma vez que a queixa principal ao longo deste trabalho reside na falta de critérios de definição para os arranjos metropolitanos ou, quando há estes aparatos técnicos, pode-se tecer críticas quanto a sua pertinência e qualidade, visto que os resultados obtidos quando aplicados não traduzem a heterogeneidade da metropolização brasileira. Portanto, é preciso ter em mente que no momento em que as primeiras RM's são institucionalizadas, prevalece a ideologia tecnocrática que gerou perfeitas peças técnico-cientificas cujo o destino foi - com algumas raras exceções - o engavetamento (VILLAÇA, 1999). Mesmos com os avanços normativos do Estatuto das Cidades e das Metrópoles, as políticas urbanas e o planejamento no Brasil têm sido marcados por um ideário desenvolvimentista, tecnocrático e com incipiente participação popular. Porquanto a instituição de nossas Regiões Metropolitanas é calcada principalmente em interesses econômicos e políticos que, à primeira vista, desvinculam-se de critérios técnicos. Isso é esperado, visto que tal como um Plano Diretor, a definição de RM's não é um artifício puramente técnico-cientifico, mas é principalmente uma peça política.

Entretanto, é inegável que as RMINE'S estudadas nessa tese apresentam concentrações demográficas e socioeconômicas que lhe dão um papel polarizador frente à 
rede urbana do Nordeste, que lhes confere uma hierarquia intermediária entre o interior e as capitais em estudos como o REGIC (IBGE, 2008). Soma-se a isso a existência de diversos indícios no ambiente edificado, que dão suporte a esta posição mediana na rede urbana. Entender esses padrões é, portanto, de suma importância para deixarmos de nos prender a uma simples nomenclatura de RM's (ou aglomerações urbanas, como proposto no Estatuto da Metrópole) para nos atermos a características socioespaciais como base do planejamento urbano.

Os achados demonstram que há um tipo metropolitano de médio porte no interior do Nordeste que tem tantas caraterísticas: (1) suas sedes são núcleos urbanos (ou conurbações) consolidados e densamente ocupados em relação ao seu entorno, cujas populações totais configuram entre 500 mil e 700 mil habitantes; (2) estes núcleos congregam equipamentos, serviços e empregos que atendem a uma escala regional em uma relação direta com sua centralidade topológica; (3) representam uma dominância socioeconômica e funcional destas cidades-sede sobre suas hinterlândias, exacerbando as desigualdades intraregionais; (4) subsidiando também processos de desigualdades intraurbanas; (5) por meio de segregação socioespacial, entre as faixas de renda e aos acessos a bens e serviços que cada grupo social dispõe; (6) calcado em uma nova produção habitacional - regular ou irregular, vertical e horizontal - que estabelece novas relação entre o público e o privado (Figura 176).

Figura 176: Esquema conceitual do tipo metropolitano do interior do Nordeste.

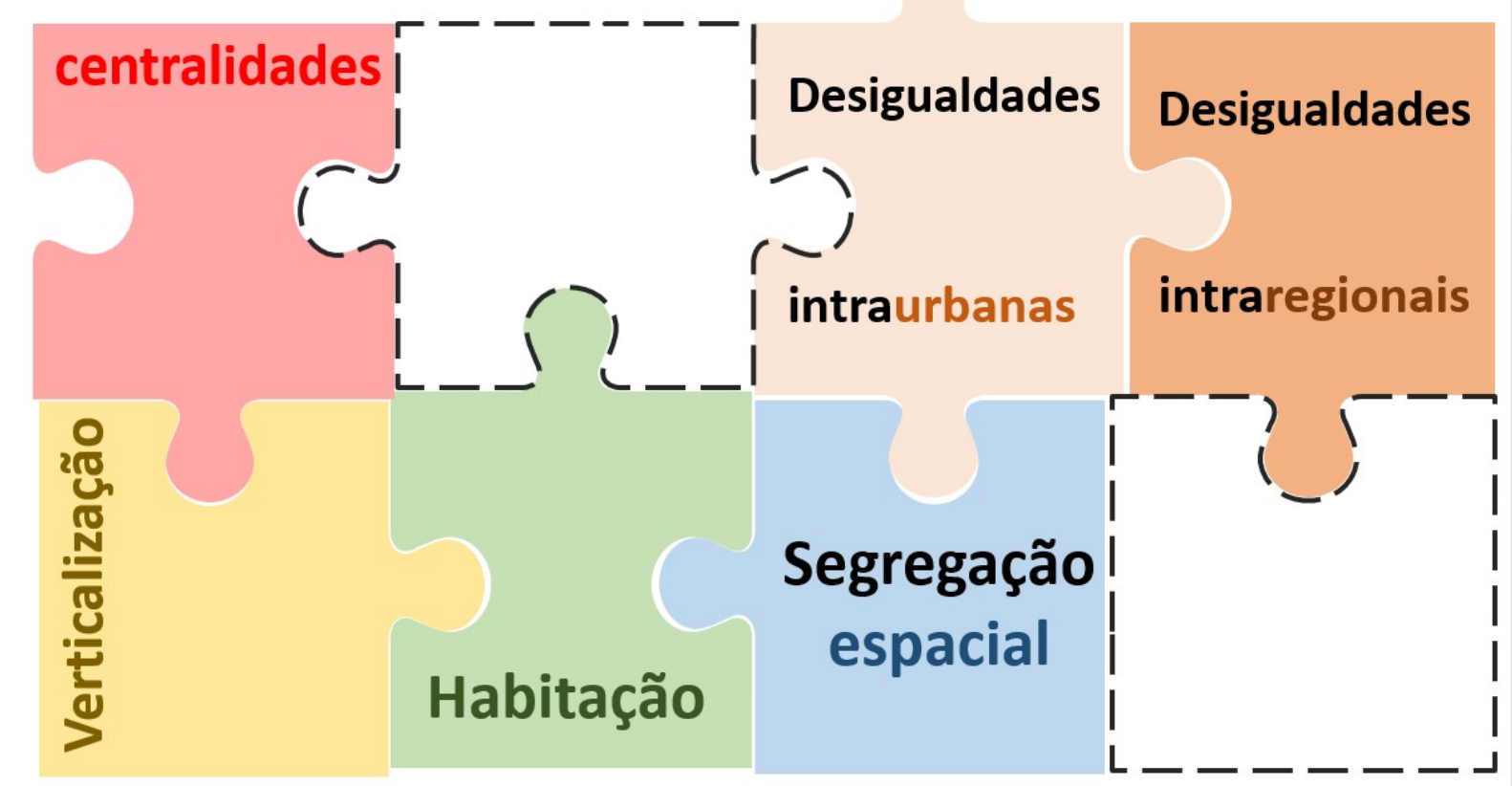

Fonte: Elaboração própria (2016). 
As RMINE'S analisadas apresentam padrões morfológicos em comum que são entendidos como indicativos de metropolização em estágio exordial, visto que esses processos se fazem presentes de modo consolidado nas RM's do Grupo de Controle 02 e apresentam-se ainda em caráter embrionário nos casos do Grupo de Controle 01, estabelecendo, deste modo, uma hierarquia que distingue os casos estudados.

Dentre tais padrões, destaco suas centralidades (expressas configuracionalmente por meio dos núcleos de integração), que congregam acessibilidade e funcionalidades em uma escala regional, que geram fluxos e movimentos pendulares em busca dos empregos que ali se localizam. Nas aglomerações estudadas há uma grande oferta de bens e serviços públicos e privados, representada pelos grandes equipamentos comerciais, no fortalecimento das instituições de educação (especialmente de nível superior) e da rede de saúde. Essa característica de atração funcional exacerba as desigualdades regionais, num processo retroalimentado pela desigual distribuição de rendas e acessos as infraestruturas e serviços urbanos. Esta dinâmica socioeconômica é global, mas produz claros reflexos regionais. $\mathrm{O}$ espaços urbanos precisam ser (re)adequados, em nível local e regional, às formas de organização da produção em escala global. Entretanto, esse processo exacerba as diferenças intraurbanas e intraregionais, que se expressam principalmente na disposição dos novos investimentos na aglomeração regional, ampliando a concentração (de equipamentos, empregos, bens e serviços) e centralização do dinamismo regional nas cidades-sede.

Esse poder de polarização é responsável pela expansão dos tecidos urbanos e pelos processos de conurbação. Dentre as RMINE'S e o Grupo de Controle 01, há diversos tipos e gradações de áreas conurbadas. Os processos mais antigos e consolidados são o Crajubar/CE e Petrolina-Juazeiro. Uma hipótese que explica essa diferenciação é a sua localização: distantes das capitais - Juazeiro do Norte/CE é separado de Fortaleza por cerca de $500 \mathrm{Km}$, Juazeiro/BA também dista cerca de 500km de Salvador e Petrolina está a mais de $700 \mathrm{~km}$ do Recife - e locadas em meio à vasta extensão sertaneja de caracteres rurais. Ao longo da sua formação urbana, estas aglomerações tiveram que responder a funções e serviços que atendiam também as suas circunvizinhanças.

O caso que contradiz essa hipótese é Imperatriz/MA (a cerca de 630km de São Luís ou Palmas/TO e a cerca de $600 \mathrm{~km}$ de Belém/PA). Porém, a ocupação daquele território é mais recente do que o Sertão central ${ }^{70}$. Acredita-se, portanto, que a RM do sudoeste maranhense

\footnotetext{
${ }^{70}$ Por exemplo: o Crato, ocupação mais antiga do Crajubar, é elevado à categoria de vila em 1763; Juazeiro da Bahia foi elevado à categoria de vila entre os anos de 1766 e 1768; enquanto Imperatriz foi elevado à categoria 
tem potencial para desenvolver ao longo das próximas décadas uma conurbação consolidada com os municípios vizinhos e com aqueles do outro lado do rio Tocantins. Caso isso se consolide, deverá passar de RM para uma Região Integrada de Desenvolvimento, por abarcar dois estados da federação e para se adequar as nomenclaturas técnicas utilizadas.

As demais RM's e cidades analisadas estão relativamente próximas das capitais estaduais (por exemplo, Campina Grande/PB é distante de João Pessoa cerca de 130km e está a $190 \mathrm{~km}$ do Recife, enquanto a RM de Feira de Santana e a RM de Salvador tem territórios praticamente contínuos). Nestes casos a força das RM's das capitais, que possuem grande poder polarizador em escala nacional, parece expandir-se e influenciar o crescimento de suas hinterlândias. O ponto que se abre para investigação é: por que motivo o desponte foi Campina Grande ou Caruaru e não uma outra cidade vizinha? Acredito que a resposta a essa pergunta reside nos processos de formação histórica destas cidades, enquanto ocupações mais antigas (e, portanto, mais consolidadas) e nas suas forças políticas que carrearam, ao longo dos anos, recursos e equipamentos que impulsionaram seu desenvolvimento e diferenciação das demais cidades do entorno.

Retomando os processos de expansão urbana, percebe-se nos casos analisados que eles se dão principalmente por novas áreas residenciais que mitigam o déficit habitacional do país por meio do MCMV ou por atender aos novos modos de morar das elites, apartadas da cidade por meio de um arquipélago carcerário (cf. SOJA, 2000) de condomínios e novos espaços de lazer e consumo, ilustrados pelos shoppings. O que se apresenta aqui são os efeitos da globalização e da decorrente massificação cultural, transposta na estrutura urbana como processos de urbanalização (cf. MUÑOZ, 2008). Embora as intensidades sejam discrepantes - obviamente Feira de Santana/BA ou Campina Grande/PB não são capazes de exercer a mesma polarização econômica de uma cidade global como Berlim, por exemplo, e, portanto, não expressam tantos espaços urbanos que respondam a uma escala além da nacional - é possível perceber apropriações locais dos conceitos e ações de gestão e produção urbana no contexto das trocas globais.

Portanto, há metrópoles no interior do Nordeste. Elas não estão consolidadas como os grandes centros do país, mas já evidenciam os mesmos desafios que se impõem à questão metropolitana do Brasil. Estas batalhas são múltiplas e complexas, mas destaco o processo de integração política entre os municípios, extremamente necessário e urgente para o 
enfrentamento de problemas de ordem socioeconômica e de gestão dos serviços compartilhados, pois estes exigem cada vez mais a participação do conjunto metropolitano.

Existem, entretanto, uma série de limitações que, por questões operacionais, incidem na abordagem configuracional adotada. São as peças que faltam ao quebra-cabeças representado na Figura 176. Destaco a dificuldade em construir bases cartográficas atualizadas. Busquei inicialmente os órgãos públicos aos quais compete a gestão e planejamento do território urbano, mas parece prevalecer uma total falta de interesse político em elaborar e atualizar os mapas cadastrais, ou, quando eles existem, há diversas burocracias para sua disponibilização de uso. As imagens de satélite fornecidas pelo Google Earth e Street View foram então a alternativa para o desenho. Entretanto, a construção do mapa axial é uma tarefa subjetiva, ou seja, ela adequa-se aos questionamentos de cada pesquisador e suas interpretações do espaço. Uma carência que admito nesta tese é a falta de vivência em campo de cada uma das realidades urbanas avaliadas em seus mais diversos espaços.

Outra deficiência com relação à cartografia foi a quantificação das RM's do Grupo de Controle 02. Foi realizado um esforço enorme para desenhar o máximo das áreas metropolitanas, visto que os mapas axiais disponibilizados só representavam as cidades-sede ou suas áreas conurbadas. Entretanto, pelos limites de processamento das ferramentas computacionais não foi possível calcular todas as medidas da SE apresentadas para as demais cidade e aglomerações (por exemplo para o cálculo de segmentos da RM de Salvador estimou-se um tempo de 70 horas pois o mesmo possui mais de 256 mil linhas).

Por outro lado, este trabalho se valeu de técnicas de diversas de geoprocessamento que possibilitaram o intercâmbio e a correlação de dados obtidos em diversas fontes (principalmente o IBGE), através da sua espacialização em mapas e tabelas que favorecem a visualização. O uso do SIG se molda aos anseios do pesquisador, possibilitando que este represente a realidade urbana (por exemplo, como nos mapas axiais), bem como as relações entre os elementos que a compõe, de modo que possam ser manipuladas pelas ferramentas computacionais.

Por outro lado, o uso da SE abre diversas potencialidades que, depois, poderão subsidiar por futuras pesquisas. No final do capítulo 05 sugeri a revisão da medida de integração proporcional, ferramenta comparativa proposta pela primeira vez nesta tese, mas que requer calibramentos para facilitar a comparação entre sistemas urbanos tão diversos. Sugere-se também a inserção de outras variáveis de pesquisa, como o índice de dispersão 
(BERTAUD \& MALPEZZI, 1999), comentado anteriormente, onde observa-se que quanto menor a distância média dos locais de moradia em relação ao principal local de concentração de empregos e serviços, melhor o desempenho da forma urbana. Avaliar qual o “comportamento" das RMINE's dentro desse conjunto de dados ajudará a situar nosso universo de estudo, traçando aproximações e diferenciações entre os arranjos metropolitanos.

Outra possibilidade é usar o indicador de continuidade que calcula o grau de fragmentação da forma urbana, considerando os vazios urbanos, através de uma análise do seu perímetro em comparação do polígono convexo ${ }^{71}$ mínimo que o contém (KRAFTA, 2014). Nas cidades estudadas por Paim (2015), encontrou-se uma correlação entre esta medida e a acessibilidade topológica, de modo que quanto menos fragmentado (ou mais compacto) o sistema analisado, maior a sua acessibilidade média, ou seja, o sistema como um todo é mais acessível. A utilização de ferramentas e medidas que possibilitem inserir os casos aqui analisados num comparativo com as demais cidades e aglomerações brasileiras já estudadas, poderá ser de grande valia para estabelecer a escala de nuanças metropolitanas do país.

71 Um polígono convexo possui ângulos internos menores que $180^{\circ}$, impossibilitando-o de apresentar reentrâncias (PAIM, 2015). 


\section{REFERÊNCIAS}




\section{REFERÊNCIAS}

AGUIAR, Douglas Vieira de. Alma espacial. ARQTEXTO, Porto Alegre, v. 3-4, n. 1, p. 8491, 2003. Disponível em: <http://www.ufrgs.br/propar/publicacoes/ARQtextos/PDFs _revista_3-4/09_Douglas \%20 Vieira \%20de\%20Aguiar.pdf $>$. Acesso em: 28 maio 2013.

ALONSO, William. Location and land use: toward a general theory of land rent. Cambridge: Harvard University Press, 1964.

AMORIM FILHO, Osvaldo B. Cidades médias e organização do espaço no Brasil. Revista Geografia e Ensino, Belo Horizonte: v. 2, n. 5, p. 5-35, 1984.

ARAÚJO, Guilherme José Ferreira de; SILVA, Marlene Maria da. Crescimento econômico no semiárido brasileiro: o caso do polo frutícola Petrolina/Juazeiro. Caminhos de Geografia. Uberlândia, v. 14, n. 46 Jun/2013 p. 246-264. Disponível em: <www.seer.ufu.br/index.php/ caminhosdegeografia/article/download/18291/12824>. Acesso em: 28 maio 2016.

ARMSTRONG, W; McGEE, T.G. 1968. Revolutionary change and the third world city: a theory of Urban Involution. Civilisations Vol. 18, No. 3, 1968, p. 353-378. Disponível em: $<$ https://www.jstor.org/stable/41231140?seq=1\#page_scan_tab_contents $>$. Acesso em: $10 \mathrm{jul}$. 2016.

ANDRADE, Manuel Correia de. Formação territorial e econômica do Brasil. Recife: Fundação Joaquim Nabuco/Ed. Massangana, 2003.

ARAÚJO, Tania Barcelar de. A experiência de Planejamento regional no Brasil. In LAVINAS, Lena (org.). Reestruturação do espaço urbano e regional no Brasil. São Paulo: UCITEC, 1993. p. 87-96.

ARONOFF, S. Geographic Information Systems: a management perspective. Ottawa: WDL Publications, 1989.

ASCHER, François. Métapolis ou l'avenir des villes. Paris: Editions Odile Jacob, 1995.

.Novos princípios do urbanismo seguido de Novos compromissos urbanos: um léxico. (Tradução Margarida S. Lobo e Ana Valente) 3ed. Lisboa: Livros horizonte, 2012. $174 \mathrm{p}$.

BAFNA, Sonit. Rethinking genotype: comments on the sources of type in architecture. The Journal of Space Syntax, 2012, Vol. 3 (1), p. 69-80. Disponível em: $<$ https://www.academia.edu/11424925/Rethinking_genotype_Comments_on_the_sources_of_ type_in_architecture $>$. Acesso em 02 de ago. 2016.

BARCELlOS, Tanya M. de; MAMMARELlA, Rosetta. O Significado dos Condomínios Fechados no Processo Segregação Espacial nas Metrópoles. Anais: Encontros Nacionais da ANPUR, 2007, 12. Disponível em: <http://unuhospedagem. com.br/ revista/ rbeur/ index.php/ anais/article/view/3010>. Acesso em: 05 set. 2016.

BARRETO, Maria Claudia Gonçalves. Desigualdades regionais, disparidades de renda e condições sociais: uma análise dos Estados da Região Sudeste. 120f. 2010. Dissertação (mestrado). Universidade Federal de Uberlândia, Programa de Pós-Graduação em Economia. 
Disponível em: $\quad<$ http://www.ppge.ie.ufu.br/sites/ppge.ie.ufu.br/files/Anexos/Bookpage/ Maria\%20Claudia\%20Gon\%C3\%A7alves\%20Barreto.pdf $>$. Acesso em: 29 set. 2015.

BARROS, Alice de Almeida. A Produção da Paisagem Urbana na História Recente de Arapiraca, Alagoas. Portuguese Network of Urban Morphology - PNUM, Brasília, 2015. Disponível em: <http://pnum.fe.up.pt/pt/index.php/download_file/view/262/>. Acesso em: 02 set. 2016.

BAUMAN, Zygmunt. Modernidade Líquida. Rio de Janeiro: Jorge Zahar Editor, 2001.

BENEVOLO, Leonardo. A História da Cidade. 5 ed. Tradução de Silvia Mazza. São Paulo, Perspectiva, 2012.

BERMAN, Marshall. Tudo que é sólido desmancha no ar. (Tradução Carlos F. Moisés e Ana M. L. Ioriatti). São Paulo: Companhia das Letras, 1986.

BERTRAUD, A.; MALPEZZI, S. The Spatial Distribution of Population in 35 World Cities: The Role of Markets, Planning, and Topography. Wisconsin-Madison CULER working papers 01-03. University of Wisconsin Center for Urban Land Economic Research. Disponível em: <https://www.researchgate.net/publication/>. Acesso em: 28 abr. 2015.

BONDUKI, Nabil. Os pioneiros da habitação social. Volume 1: Cem anos de política pública no Brasil. São Paulo: Unesp, Sesc, 2014.

BRAGA, Andrea da C. Morfologia, transformação e copresença em centros urbanos: o caso do centro do Rio de Janeiro/RJ. Dissertação (Mestrado em Arquitetura e Urbanismo) Programa de Pós-Graduação em Planejamento Urbano e Regional, Universidade Federal do Rio Grande do Sul, Porto Alegre, 2003. Disponível em: <http://hdl.handle.net/10183/33051>. Acesso em: 28 abr. 2010.

BRANCO, Maria Luisa G. Castello; PEREIRA, Rafael Henrique Moraes; NADALIN, Vanessa Gapriotti. Rediscutindo a delimitação das Regiões Metropolitanas no Brasil: um exercício a partir dos critérios da década de 1970. In FURTADO, Bernardo Alves; KRAUSE, Cleandro;

BRASIL. Constituição Federal do Brasil. Brasília: Presidência da República, 1937.

Constituição Federal do Brasil. Brasília: Presidência da República, 1967.

Constituição Federal do Brasil (1988). Constituição da República Federativa do

Brasil. Organização de Alexandre de Moraes. 16. ed. São Paulo: Atlas, 2000.

Lei Complementar $n^{0} 14$, de 8 de junho de 1973. Estabelece as regiões metropolitanas de São Paulo, Belo Horizonte, Porto Alegre, Recife, Salvador, Curitiba, Belém e Fortaleza. Brasília: 1973.

Lei Complementar $n^{0}$ 20, de 10 de julho de 1974. Dispõe sobre a criação de estados e territórios. Brasília: 1974.

Lei $\mathrm{n}^{0}$ 10.257, de 10 de julho de 2001. Regulamenta os arts. 182 e 183 da Constituição Federal, estabelece diretrizes gerais da política urbana e dá outras providências. Disponível em: <http://www.planalto.gov.br>. Acesso em: 30 jan. 2015.

Lei $\mathbf{n}^{\mathbf{0}}$ 13.089, de 12 de janeiro de 2015. Institui o Estatuto da Metrópole, altera a Lei no 10.257, de 10 de julho de 2001, e dá outras providências. Disponível em: $<$ http://www.planalto.gov.br>. Acesso em: 30 jan. 2015.

BUARQUE, Sérgio José Calvalcanti; BARBOSA, Rafael Barros; TABOSA, Francisco José Silva. SHIRASU, Maitê Rimekka; FRANÇA, Natália Cécilia. Plano de desenvolvimento 
econômico e social - Fortaleza 2040. Fortaleza: Prefeitura Municipal de Fortaleza, Instituto De Planejamento De Fortaleza - IPLANFOR. Fundação Cearense de Pesquisa e Cultura FCPC, Julho/2015. Disponível em: < http://blog.fortaleza2040.fortaleza.ce.gov.br/>. Acesso em: 30 jun. 2016.

CABRAL, Renan. 1959. Das ideias à ação, a Sudene de Celso Furtado - oportunidade histórica e resistência conservadora. Cadernos do Desenvolvimento. Ano 5, no 8. Rio de Janeiro: Centro Internacional Celso Furtado de Políticas para o Desenvolvimento, 2011. Disponível em: <http://www.centrocelsofurtado.org.br/arquivos/image/201109201209490. CD8_0_018.pdf >. Acesso em: 26 fev. 2016.

CÂMARA DOS DEPUTADOS. Estatuto da Cidade: guia para implementação pelos municípios e cidadãos. 2. ed. - Brasília: Câmara dos Deputados, Coordenação de Publicações, 2002. 273 p. - (Série fontes de referência. Legislação; n. 46). Disponível em: $<$ http://www. agenda21local. com.br/ download/estatuto_cidade_2002.pdf $>$. Acesso em: 13 mar. 2013.

CAMPOS, Roberto de Oliveira. A Experiência Brasileira de Planejamento. In SIMONSEN, Mario Henrique; CAMPOS, Roberto de Oliveira. A Nova Economia Brasileira. Rio de Janeiro: Livraria José Olympio Editora, 1974.

CAPASSO, Marcelo Mota. O Centro Tradicional de Fortaleza - processo de expansão. XII Encontro da Associação Nacional de Pós-Graduação e Pesquisa em Planejamento Urbano e Regional. Belém, 2007. Disponível em: <http://unuhospedagem.com.br/ revista/ rbeur/index.php/anais/article/view/2986/2921>. Acesso em: 22 jun. 2016.

CARDOZO, Anderson. 1960. SUDENE - resistência e desconfiança. Cadernos do Desenvolvimento, vol. 6 (8), maio de 2011. Disponível em: $<$ http://www.centrocelsofurtado.org.br/arquivos/image/201109201210380.CD8_0_036.pdf $>$. Acesso em: 12 jan. 2014.

CARLOS, Ana Fani Alessandri. A (re)produção do espaço urbano. São Paulo: Edusp, 1994, $284 \mathrm{p}$.

A natureza do espaço fragmentado. In: SANTOS, Milton; SOUZA, Maria Adélia Aparecida de; SILVEIRA, Maria Laura (orgs.). Território: globalização fragmentação. São Paulo: Hucitec/ANPUR, 1994.

CARMO JÚNIOR, João Batista. A forma do privilégio: renda, acessibilidade e densidade em Natal-RN. 2014. 306 f. Tese (Doutorado em Conforto no Ambiente Construído; Forma Urbana e Habitação) - Universidade Federal do Rio Grande do Norte, Natal, 2014. Disponível em: <http://repositorio.ufrn.br/jspui/handle/123456789/12324>. Acesso em: 20 jan. 2016.

CARVALHO, Inaiá Maria Moreira de; PEREIRA, Gilberto Corso; RIBEIRO, Luiz Cesar de Queiroz (coord.). Salvador: transformações na ordem urbana: metrópoles: território, coesão social e governança democrática. Rio de Janeiro: Letra Capital: Observatório das Metrópoles, 2014. Disponível: <http://www. redbcm. com.br /arquivos/ bibliografia/ serie_ordemurbana_salvador.pdf $>$. Acesso em: 20 jun. 2016.

CASTELLS, Manuel. A sociedade em rede. 6ed. São Paulo: Paz e Terra, 1999.

A questão urbana. Rio de Janeiro: Paz e Terra, 2000.

CASTRO, Alexandre. Sintaxe Espacial e A Análise Angular de Segmentos, Parte 1: Conceitos e Medidas. Publicado em 24 de maio de 2016. Disponível em: $<$ https://aredeurbana.wordpress.com/2016/05/24/sintaxe-espacial-e-a-analise-angular-desegmentos-parte-1-conceitos-e-medidas/>. Acesso em: 04 jul. 2016. 
CAVAlCANTE, Antonio Paulo de Hollanda. A Arquitetura da Cidade e os Transportes: O Caso dos Congestionamentos em Fortaleza, Ceará. 2009. 347f. Tese (Doutorado em Arquitetura e Urbanismo) - Universidade de Brasília, Brasília, 2009. Disponível em: $<$ http://repositorio.unb.br/handle/10482/3999>. Acesso em: 20 jul. 2016.

CORREAA, Roberto Lobato. Trajetórias geográficas. Rio de Janeiro: Bertrand Brasil, 1997

Reflexões sobre a dinâmica recente da rede urbana brasileira. ENCONTRO NACIONAL DA ANPUR, IX, 2001, Rio de Janeiro. Anais... Rio de Janeiro: ANPUR, vol. 1, 2001 (p.424-430). Disponível em: <http://unuhospedagem.com.br/revista/rbeur/ index.php/anais/article/view/2172>. Acesso em: 04 jan. 2015.

CORTEZ, Bruno Freitas; MONTENEGRO, Flávio Marcelo Tavares; BRITO, José André de Moura Censo Demográfico 2010 - definição das áreas de ponderação para o cálculo das estimativas provenientes do questionário da amostra. XVIII Encontro Nacional de Estudos Populacionais - ABEP, 2012. Disponível em: <http://wiki.dpi.inpe.br/lib/e xe/fetch.php?media=ser457-cst310:aulas_2015:cortez_2012.pdf >. Acesso em: 04 jul. 2016.

COSTA, Marco Aurélio. Quarenta anos de regiões metropolitanas no brasil: um breve balanço exploratório. In COSTA, Marco Aurélio; TSUKUMO, Isadora Tami Lemos. 40 anos de regiões metropolitanas no Brasil. Brasília: Ipea, 2013. 336 p. (Série Rede Ipea. Projeto Governança Metropolitana no Brasil; v. 1). Disponível em: <http://www.ipea.gov.br/redeipea/ images/pdfs/governanca_metropolitana/livro_40_anos_de_regioes_metropolitanas_v1_web.p df>. Acesso em: 26 fev. 2016.

COUTINHO, Evaldo. O espaço da arquitetura. Recife: UFPE, 1970.

CRANE, Randall. Is there a quiet revolution in women's travel? Revisiting the gender gap in commuting. Journal of the American Planning Association, v. 3, n. 7, p. 298-316, 2007 Disponível em: <http://www.tandfonline.com/doi/abs/10.1080/01944360708977979>. Acesso em: 29 ago. 2016.

CRUZ, Isolina; CAMPOS; Vânia Barcellos Gouvêa. Sistemas de informações geográficas aplicados à análise espacial em transportes, meio ambiente e ocupação do solo. Rio de Transportes III, Rio de Janeiro, 2005. Disponível em: <http://aquarius.ime.eb.br/ $\sim$ webde2/ prof/vania/pubs/(15)SIG-AE2.pdf>. Acesso em: 11 jul. 2015.

CRUZ, Patricia Fernanda de Sousa. Reestruturação urbana em Petrolina (PE): um olhar a partir da implantação dos novos produtos imobiliários. 2013. 170f. Dissertação (mestrado) Programa de Pós-Graduação em Planejamento Urbano e Regional, da Faculdade de Arquitetura da Universidade Federal do Rio Grande do Sul. Disponível em: $<$ http://hdl.handle.net/10183/85209>. Acesso em: 15 ago. 2016.

CUNNINGHAM, David. The concept of metropolis: philosophy and urban form. Radical Philosophy, 133. Set/Out, 2005. p. 13-25. Disponível em: <www.radicalphilosophy.com/>. Acesso em: 10 de jun. 2016.

DEÁK, Csaba. À busca das categorias da produção do espaço. Memorial crítico apresentado como condição parcial para inscrição em Concurso de Livre Docência do Departamento de Projeto. Universidade de São Paulo, Faculdade de Arquitetura e Urbanismo, 2001. Disponível em: <http://www. usp.br/fau/docentes/ depprojeto/c_deak/ CD/ 3publ/ 01LDcateg/MC-categ-esp.pdf>. Acesso em: 05 abr. 2013.

DIAS, Patricia Chame; ARAÚJO, Mayara Mychella Sena. Bahia: antigos processos, novas dinâmicas e a consolidação de centros tradicionais. In PEREIRA, Rafael Henrique Moraes; FURTADO, Bernardo Alves (org.). Dinâmica urbano-regional, rede urbana e suas 
interfaces. Brasília: Ipea, 2010. Disponível em: <http://www.ipea. gov.br /portal/ index. php?option $=$ com_content\&view $=$ article\&id=7636> . Acesso em: 05 abr. 2016.

DIÓGENES, Beatriz Helena Nogueira. Dinâmicas urbanas recentes da área metropolitana de Fortaleza. 2012. 360 f. Tese (Doutorado em História e Fundamentos da Arquitetura e do Urbanismo) - Faculdade de Arquitetura e Urbanismo da Universidade de São Paulo, São Paulo, 2012. Disponível em: <www.teses. usp. br/ teses/ disponiveis/ 16/ 16133/.../ tese_beatrizd_original.pdf $>$. Acesso em: 25 ago. 2016.

EGLER, Claudio Antonio G; MENDES, Constantino Cronemberger; FURTADO, Bernardo Alves; Pereira Rafael Henrique Moraes. Bases conceituais da rede urbana brasileira: análise dos estudos de referência. In PEREIRA, Rafael Henrique Moraes; FURTADO, Bernardo Alves (org.). Dinâmica urbano-regional, rede urbana e suas interfaces. Brasília: Ipea, 2010. Disponível em: <http:// www.ipea. gov.br /portal/ index. php?option=com content\&view $=$ article\&id=7636>. Acesso em: 05 abr. 2016.

ELIAS, Denise; PEQUENO, Renato. Espaço urbano no Brasil agrícola moderno e desigualdades socioespaciais. Terra Livre, 2015, ano 21, v. 2, n.25, jul/dez 5015. P.13-33. Disponível em: <http://www.agb.org.br/publicacoes/index.php/terralivre/article/view/395>. Acesso em: 15 ago. 2016.

FARIAS, Silvana Monteiro de. O entorno dos Shopping Centers: do lugar ao espaço de deslocamentos: o caso do Complexo Comercial formado pelo Hiper Casa Forte e Plaza Shopping Casa Forte. 2006. 119 f. Dissertação (Mestrado em Desenvolvimento Urbano) Programa de Pós-Graduação em Desenvolvimento Urbano da Universidade Federal de Pernambuco. Recife: 2006. Disponível em: <http://repositorio.ufpe.br>. Acesso em: 25 ago. 2016.

FERRARA, Lucrécia D’Alessio. Cidade: imagem e imaginário. In SOUZA, Célia Ferraz de \& PESAVENTO, Sandra Jatahy (orgs). Imagens Urbanas: os diversos olhares na formação do imaginário urbano. 2. ed. Porto Alegre: Editora da UFRGS, 2008.

FERRARI, Celson. Dicionário de urbanismo. 1. ed. São Paulo: Disal, 2004.

FERREIRA, Diocleide Lima. Requalificação Urbana em Sobral-Ce: lazer, questões ambientais e desigualdades sociais. XXVII Congresso da Associação Latino Americana De Sociologia-Alas, 2009, VIII Jornadas de Sociología de la Universidad de Buenos Aires. Asociación Latinoamericana de Sociología, Buenos Aires, 2009. Disponível em: $<$ http://www.aacademica.org/000-062/167.pdf > . Acesso em: 18 ago. 2016.

A (re)invenção de uma cidade: Cid marketing e a requalificação urbana em Sobral-CE. 2013. 296f. Tese (Doutorado em Ciências Sociais). Universidade Estadual de Campinas - UNICAMP. Campinas, 2013. Disponível em: <http://www. bibliotecadigital. unicamp.br/ document/?code $=000918645>$. Acesso em: 18 ago. 2016.

FIGUEREDO, Lucas. Linhas de continuidade no sistema axial. 2004. 104f. Dissertação (Mestrado em Desenvolvimento Urbano). Programa de Pós-graduação em Desenvolvimento Urbano da Universidade Federal de Pernambuco, Recife, 2004.

FIRKOWSKI, Olga L. C. de Freitas. Por que as Regiões Metropolitanas no Brasil são Regiões, mas não são Metropolitanas. In Revista Paranaense de Desenvolvimento, Curitiba, n.122, p.19-38, jan. /jun. 2012. Disponível em: <http://www.ipardes.pr.gov.br/ojs/index.php/ revista paranaense/ article/view/465>. Acesso em: 29 jun. 2013. 
FRANCISCONI, Jorge Guilherme; SOUZA, Maria Adélia A. de. Política Nacional de desenvolvimento urbano: estudo e proposição de alternativas. Brasília: IPEA, 1976 (série Estudos para o Planejamento, n 15).

FRANÇA, Karla Chistina Batista de (edit.). Território metropolitano, políticas municipais por soluções conjuntas de problemas urbanos no âmbito metropolitano. IPEA: Brasília, 2013. Disponível em: < http://www.ipea.gov.br/ portal/ index. php? option=com content\&view=article\&id $=19461>$. Acesso em: 25 abr. 2016.

FREIRE, Heronilson Pinto. O uso do território de Sobral, Ceará pelas instituições de ensino superior. Dissertação de Mestrado. Programa de Pós-Graduação em Geografia, Universidade Estadual do Ceará. Fortaleza, 2011.

FULGÊNCIO, Vinícius Albuquerque; SANTOS, Caroline Gonçalves Dos. A dinâmica da rede urbana nordestina: uma análise a partir da hierarquia urbana. Human $\boldsymbol{E}$. Questões controversas do mundo contemporâneo. v. 9. n. 2, Ano, 2015. Disponível em: $<$ http://humanae.esuda.com.br/index.php/humanae/article/view/319>. Acesso em: 10 jun. 2016.

FURTADO, Celso. A fantasia desfeita. Rio de Janeiro: Paz e Terra, 1989.

GALVÃO, Marília Velloso; FAISSOL, Speridião; LIMA, Olga Maria Buarque de; ALMEIDA, Elisa Maria José Mendes de. Áreas de pesquisa para determinação de áreas metropolitanas. Revista Brasileira de Geografia, Rio de Janeiro, ano 31, n. 4, p. 53-127, out.-dez. 1969. Disponível em: <http://biblioteca.ibge.gov.br/ visualizacao/periodicos/ 115/ rbg_1969_v31_n4. pdf>. Acesso em: 20 jun. 2016.

GARSON, Sol; RIBEIRO, Luiz Cesar de Queiroz; RODRIGUES, Juciano Martins. Regiões Metropolitanas do Brasil. Observatório das metrópoles/ IPPUR/ UFRJ/ CNPQ /FAPERJ, 2009. Disponível em: <http://www.observatoriodasmetropoles.net/ download/observatorio _RMs2010.pdf >. Acesso em: 20 jan. 2016.

GEHL, Jan. Cidade para Pessoas. 2.ed. Tradução Anita Di Marco. São Paulo: Perspectiva, 2013.

GONÇALVES, Alice Rauber. Indicadores de dispersão urbana. Dissertação (mestrado em planejamento urbano e regional) - Faculdade de Arquitetura, Universidade Federal do Rio Grande do Sul, Porto Alegre, 2011. Disponível em: <http://www.ufrgs.br/ propur/ teses_dissertacoes/ Alice_Goncalves.pdf $>$. Acesso em: 20 jan. 2016.

GONZAGA, Luiz; DANTAS, Zé. Vozes da seca. Disponível em: <http://www.mpbnet. com.br/musicos/luiz.gonzaga/letras/vozes_da_seca.htm>. Acesso em: 25 jun. 2015

GORDON, Peter; RICHARDSON, Harry W.; JUN, Myung-Jin. The commuting paradox: evidence from the top twenty. Journal of the American Planning Association, v. 57, p. 416420, 1991. Disponível em: <http://www.tandfonline.com/ doi/ abs/ 10.1080/ 01944369108975516>. Acesso em: 29 ago. 2016.

GROSTEIN, Marta Dora. Metrópole e expansão urbana: a persistência de processos "insustentáveis". São Paulo Perspec., São Paulo, v. 15, n. 1, p. 13-19, Jan. 2001 Disponível em: $\quad<$ http://www .scielo.br/scielo. php?script=sci_arttext\&pid= $88392001000100003 \& \operatorname{lng}=$ en\&nrm=iso $>$. Acesso em: 05 abr. $201 \overline{6}$.

GUARDA, Israel Vindeirinho. Análise configuracional dos grandes conjuntos urbanos na região de Lisboa (1945 - 1974): Contributos da Sintaxe Espacial para a história de arte como história da cidade. 2015. 256f. Tese (doutorado em História de Arte Contemporânea). 
Disponível em: <https:// run.unl.pt/ bitstream/ 10362/17026/1/ Doutoramento-Israel_ Vindeirinho_Guarda.pdf $>$. Acesso em: 02 de ago. 2016.

GURGEL, Ana Paula C. Entre serras e sertões: a(s) (trans)formação(ões) de centralidade(s) da Região Metropolitana do Cariri/CE. 2012. 129 f. Dissertação (Mestrado em Conforto no Ambiente Construído; Forma Urbana e Habitação) - Programa de Pós-Graduação em Arquitetura e Urbanismo, Universidade Federal do Rio Grande do Norte, 2012. Disponível em: <http://repositorio.ufrn.br:8080/jspui/handle/123456789/12378> . Acesso em: 25 jun. 2015.

GURGEL, Ana Paula C.; TRIGUEIRO, Edja. Modelando centralidades: um estudo comparativo da Região Metropolitana do Cariri/CE. Anais do XIV Encontro Nacional da ANPUR. Rio de Janeiro, ANPUR, 2011. Disponível em: <http://unuhospedagem. com.br /revista /rbeur/index.php/anais/article/viewFile/3788/3709>. Acesso em: 13 jun. 2014.

HANSON, Susan; JOHNSTON, Ibipo. Gender differences in work-trip length: explanations and implications. Urban geography, v. 6, n. 3, p. 193-219, 1985. Disponível em: $<$ http://www.tandfonline.com/doi/abs/10.2747/0272-3638.6.3.193>. Acesso em: 29 ago. 2016.

HARVEY, David. A Justiça Social e a Cidade. (Trad. Armando Corrêa da Silva) São Paulo: Hucitec, 1980.

Condição pós-moderna. 23ed. São Paulo: Edições Loyola, 2012. 348p.

HILLIER, Bill. Space is the machine. Londres: Cambridge University Press, 1996. Disponível em: < http://eprints.ucl.ac.uk/3881/1/SITM.pdf>. Acesso em: 07 maio 2015.

Centrality as a process: accounting for attraction inequalities in deformed grids. In Urban Design International, 1999, 4(3\&4), p.107-127.

A theory of the city as object, or how the spatial laws mediate the social construction of urban space. In International Space Syntax Symposium, 3., Atlanta, 2001. Anais. Ann Arbor, MI: A. Alfred Taubman College of Architecture and Urban Planning/ University of Michigan, 2001, p. 02.1-02.28.

HILLIER, Bill; HANSON, Julienne. The social logic of space. Londres: Cambridge University Press, 1984.

HILlIER, B., PENN, A., HANSON, J., GRAJEWSKI, T., XU, J. Natural Movement: or, configuration and attraction in urban pedestrian movement. In Environmental and Planning B, volume 20, 1993. p. 29-66. Disponível em: <http://discovery.ucl.ac.uk/1398/1/hillier-etal1993_NaturalMovement.pdf>. Acesso em: 20 maio 2011.

HOLANDA, Frederico de. O espaço da exceção. Brasília: Editora da Universidade de Brasília, 2002. 466 p. (Coleção Arquitetura e Urbanismo)

Arquitetura Sociológica. Revista Brasileira de Estudos Urbanos e Regionais, v.9, n.1, Anpur, 2007.

. Urbanidade e reestruturação das cidades: o que nos ensina Brasília? p. 227-248 In: FELDMAN, Sarah; FERNANDES, Ana (Org.). O urbano e o regional no Brasil contemporâneo: mutações, tensões, desafios. Salvador: EDUFBA, 2007. 396 p.

Brasília: cidade moderna, cidade eterna. Brasília: FAU/UnB, 2010. 152 p. (Coleção Brasília Histórica 50 anos, 3).

Dez mandamentos da arquitetura. Brasília: FRBH, 2013a. 
Tópico 6: introdução à sintaxe espacial. Notas de aula, disciplina Espaço e organização social, Programa de Pós-Graduação em Arquitetura e Urbanismo, Faculdade de Arquitetura e Urbanismo, Universidade de Brasília, 2013b.

IBGE. Contagem da População 2010. Disponível em: <http://www.censo 2010.ibge.gov.br/sinopse>. Acesso em: 10 jun. 2011.

. Regiões de Influência das Cidades 2007. Rio de Janeiro: IBGE, 2008. Disponível em: <http://www.mma. gov.br/estruturas/PZEE/_arquivos/regic_28.pdf >. Acesso em: 13 jan. 2016.

Divisão Urbano Regional. Diretoria de Geociência, Coordenação de Geografia. 2013. Disponível em: <ftp://geoftp.ibge.gov.br/ divisao_urbano_regional/ documentacao /divisao_urbano_regional_apresentacao_do_trabalho.pdf $>$. Ācesso em: 13 jan. 2016.

Censo Demográfico 2010: Resultados Gerais da Amostra por áreas de ponderação. Disponível em: <http://ibge.gov.br /home /estatistica/ populacao/ censo2010/ resultados_gerais_amostra_areas_ponderacao/default.shtm>. Acesso em: 13 jul. 2016.

Disponível

Produto interno bruto dos municípios 2010. Rio de Janeiro: IBGE, 2012.

$<$ http://www.ibge.gov.br/home/estatistica/economia/pibmunicipios/2010/default.shtm.>

Acesso em: 08 ago. 2015.

HOTZ, Eduardo Fontes. A organização metropolitana pós-constituição de 1988. São Paulo em Perspectiva, São Paulo, v. 14, n. 4, p. 91-98, Out. 2000. Disponível em: $<$ http://www.scielo.br/scielo.php?script=sci_arttext\&pid=S0102-88392000000400010 \&lng $=$ en $\&$ nrm=iso $>$. Acesso em:10 Jul. 2016.

INPEA. População das cidades médias cresce mais que no resto do Brasil. Disponível em: $<\mathrm{http}$ ://www.ipea.gov.br>. Acesso em: 25 maio 2013.

IPEA, IBGE, UNICAMP. Caracterização e tendências da rede urbana do Brasil: configurações atuais e tendências da rede urbana. Volume 01. Brasília: IPEA, 2001a. (Série de 6 volumes)

Caracterização e tendências da rede urbana do Brasil: redes urbanas regionais: Norte, Nordeste e Centro-oeste. Brasília: IPEA, 2001b. (Série de 6 volumes)

JALES, Antonio Wagner Lopes. Os impactos urbanos de uma intervenção viária. Avaliação da implantação da Via Expressa em São Luís usando a Sintaxe Espacial. Arquitextos, São Paulo, ano 15, n. 171.02, Vitruvius, ago. 2014. Disponível em: <http://www. vitruvius. com.br/ revistas/ read/arquitextos/15.171/5289>. Acesso em: 12 maio 2016.

KENSKI, Rafael. Sorria: você está sendo filmado. As novas tecnologias estão acabando com a privacidade das pessoas. Superinteressante. Maio de 2001. Disponível em: $<$ http://super.abril.com.br/tecnologia/sorria-voce-esta-sendo-filmado-442143.shtml $>$. Acesso em: 04 fev. 2015.

KOHLSDORF, Maria Elaine. A apreensão da forma da cidade. Brasília: Editora Universidade de Brasília, 1996.

KRAFTA, Romulo. Notas de aula de Morfologia Urbana. Porto Alegre: Editora da UFRGS. 2014.

LACERDA, Norma. Fragmentação e integração: movimentos de (re)estruturação espacial das metrópoles brasileiras. In: RIBEIRO, Ana Clara Torres Ribeiro, LIMONAD, Ester, 
GUSMÃO, Paulo Pereira (Orgs.). Desafios ao planejamento: produção da metrópole e questões ambientais. Rio de Janeiro: Letra Capital/ANPUR, 2012. P.21-42.

LACERDA, Norma; MENDES ZANCHETI, Sílvio; DINIZ, Fernando. Planejamento metropolitano: uma proposta de conservação urbana e territorial. EURE, Santiago, v. 26, n. 79, p. 77-94, dic. 2000 . Disponível em: <http://www.scielo.cl>. Acesso em: 24 ago. 2016.

LAKATOS, Eva Maria; MARCONI, Marina de Andrade. Metodologia científica. São Paulo: Atlas, 1986.

LEFEBVRE, Henri. O direito à cidade. São Paulo: Ed. Moraes, 1991.

A revolução urbana. Belo Horizonte. Editora da UFMG, 2002.

Espaço e política. Belo Horizonte: Editora UFMG, 2008.

LENCIONI, Sandra. Uma Nova Determinação do Urbano: o desenvolvimento do processo de metropolização do espaço. In: CARLOS, Ana Fani Alessandri e LEMOS, Amália Inês Geraiges. (Orgs.). Dilemas Urbanos: Novas Abordagens sobre a Cidade. São Paulo: Contexto, 2003.

. Da Cidade e sua Região à Cidade-região. In: SILVA, José Bozarcchiello; LIMA, Luiz; ELIAS, Denise (orgs.). Panorama da Geografia Brasileira I. São Paulo: Annablume, 2006.

LEVINSON, David M.; KUMAR, Ajay. Density and the journey to work. Growth and change, n. $28, \quad$ v. 3 , p. 147-172, 1997. Disponível em: $<$ http://nexus.umn.edu/papers/density.pdf>. Acesso em: 29 ago. 2016.

LIMA, Claudia Brandão Vieira. Paralela em movimento: um estudo sobre a apropriação do espaço público do canteiro central da Avenida Luís Viana. 2007. 121 f. il. Dissertação (mestrado) - Universidade Federal da Bahia, Instituto de Geociências, 2007. Disponível em: $<$ https://repositorio.ufba.br/ri/handle/ri/19852>. Acesso em: 20 de ago. 2016.

LIMA, Rosirene Martins. Espaços urbanos e rurais na cidade: um estudo sobre os trabalhadores rurais em Imperatriz no estado do Maranhão. Anais do X Encontro de Geógrafos da América Latina, 2005. Disponível em: $<\mathrm{http}$ ://observatoriogeograficoamericalatina. org.mx/egal10/ Geografiasocioeconomica/ Geografiaespacial/16.pdf $>$. Acesso em: 15 de ago. 2016.

LYNCH, Kevin. A imagem da cidade. Tradução Jefferson Luiz Camargo. 3.ed. São Paulo: WMF Martins Fontes, 2011. 227p. (Coleção cidades)

MAIA, Doralice Sátyro. Cidades médias e pequenas do Nordeste: conferência de abertura. In LOPES, Diva Maria Ferlin; HENRIQUE, Wendel (org). Cidades médias e pequenas: teorias, conceitos e estudos de caso. Salvador: SEI, 2010. (Série estudos e pesquisas, 87).

A periferização e a fragmentação da cidade: loteamentos fechados, conjuntos habitacionais populares e loteamentos irregulares na cidade de Campina Grande-PB, Brasil. Scripta Nova, Revista Electrónica de Geografía y Ciências Sociales. Universidad de Barcelona. Vol. XIV, núm. 331 (80), 1 de agosto de 2010. Disponível em: $<$ http://www.ub.edu/geocrit/sn/sn-331/sn-331-80.htm>. Acesso em: 15 de ago. 2016.

MARICATO, Ermínia. A Política Habitacional do Regime Militar. Petrópolis: Vozes, 1997.

. Metrópoles desgovernadas. Estudos Avançados, São Paulo, v. 25, n. 71, p. 7-22, Abr. 2011. Disponível em: <http://www.scielo.br/scielo.php?script=sci_arttext\&pid=S0103$40142011000100002 \& \operatorname{lng}=$ en\&nrm=iso $>$. Acesso em: 02 de set. 2016. 
MONTE-MÓR, Roberto Luís. As teorias urbanas e o planejamento urbano no Brasil. In: DINIZ \& CROCCO (eds.). Economia Regional e Urbana: contribuições teóricas recentes. Belo Horizonte: Editora UFMG, 2006. p. 61-85.

MEDEIROS, Valério Augusto Soares de. Urbis brasiliae ou sobre cidade do Brasil. Inserindo assentamentos urbanos do país em investigações configuracionais comparativas. 2006. Tese (Doutorado em Arquitetura e Urbanismo) Programa de Pesquisa e Pós-Graduação, Universidade de Brasília, Brasília, 2006.

Módulo A - Premissas. Notas de aula, disciplina estudos especiais de desenho urbano I e II. Programa de Pós-Graduação em Arquitetura e Urbanismo, Faculdade de Arquitetura e Urbanismo, Universidade de Brasília, 2013.

MEDEIROS, Valério Augusto Soares de HOLANDA, Frederico Borges Rosa de. A configuração como estratégia para o projeto: experiências e reflexões. IV Seminário Nacional sobre Ensino e Pesquisa em Projeto de Arquitetura - PROJETAR 2009. São Paulo/SP. Disponível em: < http://hdl.handle.net/123456789/1564>. Acesso em: 15 de jun. 2015.

MEDEIROS, Valério Augusto Soares de; HOLANDA, Frederico Borges Rosa de; BARROS, Ana Paula Borba Gonçalves. O labirinto das cidades brasileiras: heranças urbanísticas e configuração espacial. Brasília; IPEA; 2011.72 p. (IPEA - Texto para discussão, 1601). Disponível em: <http://repositorio. ipea. gov. br/ bitstream/ 11058/ 1813/1/td_1601.pdf>. Acesso em: 15 de jun. 2015.

MEDEIROS, Valério Augusto Soares de; BARROS, Ana Paula Borba Gonçalves. Organização social do território e mobilidade urbana. In RIBEIRO, Rômulo José da Costa; TENÓRIO, Gabriela de Souza; HOLANDA, Frederico de; RIBEIRO; Luiz Cesar de Queiroz. (Org.). Brasília transformações na ordem urbana. 1ed. Rio de Janeiro: Letra Capital, 2015, v. 1, p. 252-284.

MENDES, Constantino Cronemberger. Rede urbana, território e desenvolvimento regional. Boletim IPEA/DIRUR, Brasília, DF, n. 3, p. 67-75, dez. 2009. Disponível em: <http:// repositorio. ipea.gov.br/bitstream/11058/5495/1/BRU_n3_rede_urbana.pdf $>$. Acesso em: 15 de jun. 2016.

MILTÃO, Milton Souza Ribeiro; ARAÚJO, Péricles César de; SANTOS, Denilton Salomão S. dos. O papel do município de Feira de Santana frente ao desenvolvimento baiano e possíveis ações da UEFS. Bahia Análise \& Dados, Salvador, v. 18, p. 317-330, jul./set. 2008. Disponível em: <https://www.academia. edu/6779636/ O_papel_do_município_de_Feira_ de_Santana_frente_ao_desenvolvimento_baiano_e_possíveis_ações_da_UEFS $>$. . Acesso em: 14 ago. 2016.

MIRANDA, Gustavo Magalhães Silva. A cidade e a feira no tempo: a relação feira-cidade e os diferentes modos de ocupação do território pela feira de Caruaru. XIII ENANPUR Encontro Nacional da ANPUR, 2009, Florianópolis. Disponível em: $<$ http://unuhospedagem. com.br/revista/rbeur/ index.php/anais/article/view/3244>. Acesso 18 em: ago. 2016.

A feira na cidade: limites e potencialidades de uma interface urbana nas feiras de Caruaru (PE) e de Campina Grande (PB). 189 f. Dissertação (mestrado) - Universidade Federal de Pernambuco. CAC. Desenvolvimento Urbano, 2009. Disponível em: $<$ http://repositorio.ufpe.br/handle/123456789/3220>. Acesso em: 18 ago. 2016. 
MOTA, Cássia de Souza. Um projeto para o centro de Vitória da Conquista. Minha Cidade, São Paulo, ano 10, n. 113.04, Vitruvius, dez. $2009<\mathrm{http}: / /$ www.vitruvius.com.br revistas $/ \mathrm{read} / \mathrm{minhacidade} / 10.113 / 1821>$.

MOUDON, A. V. Thinking about micro and macro urban morphology. Urban Morphology, v. 6, n. 1, 2002, p. 37 - 39.

MOURA, Rosa. Morfologias de concentração no Brasil: o que se configura além da metropolização? In Revista Paranaense de Desenvolvimento, Curitiba, n.107, p.77-92, jul./dez. 2004. Disponível em: <http://www. ipardes.pr. gov.br/ojs/ index.php/ revistaparanaense/ article/view/103>. Acesso em: 30 de jun. 2013.

MOURA, Rosa; FIRKOWSKI, Olga L. C. de. Metrópoles e regiões metropolitanas: o que isso tem em comum? IX Encontro Nacional da ANPUR, 2001, Rio de Janeiro. Anais. Rio de Janeiro: ANPUR, 2001. v. 1, p.105-114.

MOURA, Rosa; FIRKOVSKI, Olga. Estatuto da Metrópole - contribuição ao debate. Boletim Semanal do Observatório das Metrópoles, Rio de Janeiro, p. 1 - 8, 09 abr. 2008. Disponível em $<$ http://observatoriodasmetropoles.net $>$. Acesso em: 20 maio 2014.

MOURA, Rosa; HOSHINO, Thiago de Azevedo Pinheiro. Estatuto da Metrópole: enfim, aprovado! Mas o que oferece à metropolização brasileira? Informativo Observatório das Metrópoles, Rio de Janeiro, p. 1 - 14, 2015. Disponível em <http://www. observatorio dasmetropoles. net/download/estatuto_metropole_artigo_rosa.pdf>. Acesso em: 20 out. 2015.

MUÑOZ, Francesc. Urbanalización: paisajes comunes, lugares globales. Barcelona: Gustavo Gilli, 2008.

NASPOLINI, Vicente. Paradigmas do urbanismo: a contribuição de François Ascher. Dissertação (mestrado) - Universidade Federal de Santa Catarina, Centro Tecnológico, Programa de Pós-graduação em Urbanismo, História e Arquitetura da Cidade, Florianópolis, 2009. Disponível em: <http://repositorio.ufsc.br/xmlui/handle/123456789/92292>. Acesso em: 21 jul. 2016.

NETTO, Vinicius de Moraes. O que a sintaxe espacial não é? Arquitextos, São Paulo, ano 14, n. 161.04, Vitruvius, out. 2013. Disponível em: <http://www.vitruvius. com.br/revistas/ read/ arquitextos/14.161/4916>. Acesso em: 25 jun. 2015.

ONU. Department of Economic and Social Affairs, Population Division World urbanization prospects. The 2014 revision. New York: United Nations, 2015. Disponível em: $<$ http://esa. un.org/unpd/wup/ Publications/Files/WUP2014-Report.pdf>. Acesso em: 11 jan. 2016.

OLIVEIRA, Francisco de. Elegia para uma re(li)gião: SUDENE, nordeste, planejamento e conflitos de classes. Rio de Janeiro: Paz e Terra, 1977.

OLIVEIRA, Felipe Musse de. O outro lado da linha: o bairro da Saúde no entorno do Centro Histórico de Salvador/BA. 2012. 131f. Dissertação (Mestrado em Arquitetura e Urbanismo) - Programa de Pós-Graduação de Arquitetura e Urbanismo da Universidade Federal da Bahia, 2012.

OLIVEIRA, Vítor Manuel Araújo de; MARAT-MENDES, Teresa; PINHO, Paulo (coord.). O estudo da forma urbana em Portugal. Porto: U.Porto Edições, 2015. (Série Para Saber, 43)

OLIVEIRA JÚNIOR, Gilberto Alves de. Novas expressões de centralidade e (re)produção do espaço urbano em cidades médias: o Jequitibá Plaza Shopping em Itabuna-BA. 2008. 449 f. Dissertação (Mestrado em Geografia) - Universidade de Brasília, Brasília, 2008. Disponível em: <http://hdl.handle.net/10482/1185>. Acesso em: 28 abr. 2010. 
PAIM, Daniel Trindade. Comportamento agregado da medida de acessibilidade na descrição da morfologia urbana. 2015. 258 f. Dissertação (Mestrado) - Programa de PósGraduação Faculdade de Arquitetura e Urbanismo da Universidade Federal de Pelotas, 2015. Disponível em: $<$ http://prograu.ufpel.edu.br/uploads/biblioteca/dissertacao_daniel_paim.pdf $>$. Acesso em: 29 mar. 2016.

PAIXÃO, Flávia; SANTANA, Geruza; SÁ, Jeferson Braga de; REIS, Simony; CONCEICAO, Edney. Análise espacial da violência urbana no município de Feira de Santana - Bahia. In XII Encontro de Geógrafos da América Latina, 2009, Montevideo. Caminando en una América latina en transformación. Montevideo: Easy Planners, 2009. v. XII

PEPONIS, John. Espaço, cultura e desenho urbano. Projeto, n. 41, p. 78-83, abr/mai 1992.

PEPONIS, John; HADJINIKOLAOU, E.; LIVIERATOS, C.; FATOUROS, D.A. The spatial core of the urban culture. Ekistiks, n. 334/335, v. 56, p. 43-55, jan./fev./mar./abr., 1989. Disponível em: <https://www.jstor.org/stable/43622102?seq=1\#page_scan_tab_contents $>$. Acesso em: 23 jul. 2015.

PEREIRA, Gilberto Corso (coord.). Salvador no Século XXI: transformações demográficas, sociais, urbanas e metropolitanas - cenários e desafios. Relatório Final 2016. Disponível em: <http://repositorio.ufba.br/ri/handle/ri/18749>. Acesso em: 20 jul. 2016.

PEREIRA, Rafael Henrique Moraes; SCHWANEN, Tim. Tempo de deslocamento casatrabalho no brasil (1992-2009): diferenças entre regiões metropolitanas, níveis de renda e sexo. Texto para discussão / Instituto de Pesquisa Econômica Aplicada. Brasília: Rio de Janeiro: IPEA, 2013. Disponível: <http://www.ipea.gov.br/ portal/ images/ stories/ PDFs/ TDs/td_1813.pdf $>$. Acesso em: 29 jul. 2016.

PESCATORI, Carolina. Cidade compacta e cidade dispersa: ponderações sobre o projeto do Alphaville Brasília. Revista Brasileira de Estudos Urbanos e Regionais, Recife, v. 17, n. 2, p. 40-62, ago. 2015. Disponível em: <http://unuhospedagem. com.br/ revista/ rbeur/ index.php/rbeur/article/viewFile/4995/4689>. Acesso em: 13 ago. 2015.

PESCATORI, Carolina; ABREU, Lucas Batista de. Da construtora Albuquerque e Takaoka à Alphaville Urbanismo S.A.: reestruturação e expansão nacional de um modelo de urbanização. Encontro da Associação Nacional de Pesquisa e Pós-Graduação em Arquitetura e Urbanismo, Porto Alegre, 2016. Disponível em: <http://academia. edu. documents/46838515/ artigo_enanparq_2016.pdf?>. Acesso em: 14 ago. 2016.

PINHO, Maristela dos Santos; CARNEIRO, Nadia Virginia Barbosa; OLIVEIRA, Lysie dos Reis. Cidade-Shopping-Cidade: O olhar sobre o Boulevard Shopping de Feira de Santana, Bahia, como cidade. III Encontro Nacional de Imagens, 2011. Disponível em: $<$ http://www.uel.br/eventos/eneimagem/anais2011/trabalhos/>. Acesso em: 02 ago. 2016.

QUEIROZ, Ivan da Silva. A metrópole do Cariri: institucionalização no âmbito estadual e a dinâmica urbano-regional da aglomeração do Crajubar. 2013. 203 f.: Tese (doutorado em Geografia) - Universidade Federal de Pernambuco, Recife, 2013. Disponível em: $<$ http://repositorio.ufpe.br/bitstream/handle/123456789/11043/Tese\%20Ivan\%20Queiroz.pdf? sequence=1\&isAllowed=y>. Acesso em: 02 mar. 2015.

RAHY, Izarosara Borges. Verticalização e Paisagem Urbana. Anais do III Seminário Internacional Urbicentros. Salvador, 2012. Disponível em: <http:// www. ppgau. ufba.br /urbicentros/2012/ST311.pdf>. Acesso em: 05 ago. 2016.

RAMIRES, Júlio Cesar de Lima. O processo de verticalização das cidades brasileiras. Boletim de Geografia, Maringá: UEM-PGE. V.16, $\mathrm{n}^{\circ}$ 1, p. 97-105, 1998. Disponível em: 
$<$ http://ojs.uem.br/ojs/index.php/BolGeogr/article/download/12156/7320.>. Acesso em: 02 mar. 2016.

RIBEIRO, Marcelo Gomes. Educação, estrutura social e segmentação residencial do território metropolitano: análise das desigualdades de renda do trabalho em regiões metropolitanas do Brasil. $321 \mathrm{f}$. Tese (doutorado) - Universidade Federal do Rio de Janeiro, Instituto de Pesquisa e Planejamento Urbano e Regional, 2012. Disponível em: $<$ http://objdig.ufrj.br/42/teses/789782.pdf>. Acesso em: 25 jun. 2016.

RIBEIRO, Luiz Cesar de Queiroz. (Org.). Metrópoles: entre a coesão e a fragmentação, a cooperação e o conflito. São Paulo: Ed. da Fundação Perseu Abramo; Rio de Janeiro: FASE, 2004.

RIBEIRO, Luiz Cesar de Queiroz; MOURA, Rosa; DELGADO, Paulo; et. al. Níveis de integração dos municípios brasileiros em RMs, RIDEs e AUs à dinâmica da metropolização. Rio de Janeiro, 2012. Disponível em: $<\mathrm{http}: / /$ observatoriodasmetropoles.net/download/ relatorio_integracao.pdf $>$. Acesso em: 25 jun. 2013.

RIBEIRO, Luiz Cesar de Queiroz; SANTOS JÚNIOR, Orlando Alves, RODRIGUES, Juciano Martins. Estatuto da Metrópole: o que esperar? Avanços, limites e desafios. Observatório das Metrópoles, Rio de Janeiro, 2015. Disponível em: <http://www. observatorio das metropoles. net/index.php>. Acesso em: 20 jan. 2016.

RIBEIRO, Rômulo José da Costa; HOLANDA, Frederico. Proposta para análise do Índice de Dispersão Urbana. Cadernos Metrópole, Observatório das Metrópoles, n. 15, 2006, p. 49-70.

RIBEIRO, Rômulo José da Costa; HOLANDA, Frederico; COELHO, Juliana Machado. Índices de qualidade configuracional urbana caso do Distrito Federal, Brasil. EURE, Santiago, v. 38, n. 114, mayo 2012, p. 229-255. Disponível em: <http://www.scielo.cl/>. Acesso em: 20 jan. 2016.

RIBEIRO, Rômulo José da Costa; TENORIO, Gabriela de Souza. Estrutura social e organização social do território. In RIBEIRO, Rômulo José da Costa; TENÓRIO, Gabriela de Souza; HOLANDA, Frederico de; RIBEIRO; Luiz Cesar de Queiroz. (Org.). Brasília transformações na ordem urbana. 1ed. Rio de Janeiro: Letra Capital, 2015, v. 1, p. 176200.

RIGATTI, Décio. Do espaço projetado ao espaço vivido: modelos de morfologia urbana no Conjunto Rubem Berta. 1997. Tese (Doutorado em Arquitetura e Urbanismo) Faculdade de Arquitetura e Urbanismo, Universidade de São Paulo. Disponível em: http://www.lume.ufrgs.br/handle/10183/15861>. Acesso em: 25 jan. 2015.

ROCHA, Aristotelina Pereira Barreto. Expansão urbana de Mossoró: período de 1980 a 2004. 2005. 290 f. Dissertação (Mestrado em Dinâmica e Reestruturação do Território) Universidade Federal do Rio Grande do Norte, Natal, 2005. Disponível em: $<$ https://repositorio.ufrn.br/jspui/handle/123456789/18882> Acesso em: 18 ago. 2016.

ROCHA, Ione Santos; BARROS, Glauber. Codomínio Greenville e loteamento Villa América: Um retrato da segregação sócio-espacial em Vitória da Conquista. La planificación territorial y el urbanismo desde el diálogo y la participación. Actas del XI Coloquio Internacional de Geocrítica, Universidad de Buenos Aires, 2-7 de mayo de 2010. Disponível em: <http://www.filo.uba .ar/contenidos/investigacion /institutos/geo/ geocritica2010/ 526.htm> Acesso em: 16 ago. 2016. 
ROCHEFORT, Michel. Cidades e globalização. (Tradução Eustógio Wanderley Correia Dantas). Mercator: Revista de Geografia da UFC, ano 01, número 02, 2002. Disponível em: <www.mercator.ufc.br/index.php/mercator/article/download/177/143>. Acesso em: 20 mai. 2016.

RODRIGUES, A. M. Desigualdades socioespaciais - a luta pelo direito à cidade. In Cidades, v. 4, n. 6, Presidente Prudente: GEU, 2007, p.73-88. Disponível em $<$ http://revista.fct.unesp.br/index.php/revistacidades/article/viewFile/571/602>. Acesso em: 23 jun. 2016.

RODRIGUES, Antonia Helaine Veras; HOLANDA, Virgínia Célia Cavalcante de. As feições da especulação imobiliária e a produção do espaço da cidade média de Sobral-CE. Revista da Casa de Geografia de Sobral, v. 14, p. 44-55, 2012. Disponível em: <http://www. vanet .br/ rcgs/ index.php/RCGS/article/view/12>. Acesso em: 21 ago. 2016.

ROMÃO, Simone Rachel L; IRMÃO, José Matias; LIRA, Rosa M. Ângelo de Oliveira. A cidade do futuro: agenda 21 Arapiraca. Maceió: IDEARIO, 2008. 171 p. Disponível em: $<$ http://news.arapiraca.al.gov.br/noticias/downloads/downloads/dw141/livroagenda21 arapirac a.pdf $>$. Acesso em: 21 ago. 2016.

SÁNCHEZ, Fernanda. A reinvenção das cidades: para um mercado mundial. Chapecó/SC: ARGOS Editora Universitária, 2003.

SANTO, Sandra Medeiros. O desenvolvimento urbano em Feira de Santana. Sitientibus. Feira de Santana, n.28, p. 9-20, jan./jun., 2003. Disponível em: <http://www2. uefs.br /sitientibus/pdf/28/o_desenvolvimento_urbano.pdf>. Acesso em: 02 set. 2016.

SANTOS, Milton. Crescimento nacional e a nova rede urbana: o exemplo do Brasil. Revista Brasileira de Geografia, v.29, n.4., out./dez. 1967, p.78-92.

A Metrópole corporativa, fragmentada. São Paulo: Studio Nobel, 1989.

Involução Metropolitana e Economia Segmentada. O caso de São Paulo. In:

RIBEIRO, Ana C.T. et al (org.). Seminário Metropolização e Rede Urbana, Perspectivas dos anos 90. Rio de Janeiro: IPPUR/UFRJ, 1993.

Pensando o espaço do homem. 4. ed. São Paulo: Hucitec, 1997.

A natureza do espaço: técnica e tempo, razão e emoção. São Paulo: Edusp, 2004.

EDUSP, 2008.

Técnica, espaço, tempo: globalização e meio técnico-científico-informacional.

SANTOS, Paulo. A formação de cidades no Brasil colonial. $2^{\mathrm{a}}$ ed. Rio de Janeiro: Editora UFRJ/IPHAN, 2002. 182p.

SANTOS, Maria Adriana Martins dos. Os condomínios fechados horizontais e as dinâmicas recentes da produção do espaço urbano: bairro Passaré em Fortaleza-CE. 2015. 187f. Dissertação (Mestrado em Geografia) Programa de Pós-Graduação em Geografia do Centro de Ciências e Tecnologia da Universidade Estadual do Ceará. Disponível em: $<\mathrm{http}: / /$ www.uece.br/mag/dmdocuments/maria_adriana_martins_dossantos.pdf $>$. Acesso em: 20 jul. 2016.

SANTOS, Bethsaide Souza; SANTOS, Rosangela Leal. Análise da expansão urbana de Feira de Santana através de condomínios fechados. Urba11, Salvador: UFBa, 2011. Disponível em: $<$ http://www.ppgau.ufba.br/urba11/>. Acesso em: 28 ago. 2016.

SASSEN, Saskia. As cidades na economia global. (Tradução Carlos E. M. de Moura). São Paulo: Studio Nobel, 1998. (Coleção megalópoles) 
SCEBA. Infocultura: informativo da Secretaria de Cultura do Estado da Bahia. Ano.2, n.2, 2ed. Salvador: Secretaria de Cultura do Estado Bahia, 2011. 24 p. Disponível em: $<$ http://www.cultura.ba.gov.br/arquivos/File/Miolo_Infocultura_n_02_web.pdf $>$. Acesso em: 23 ago. 2016.

SCHEINOWITZ, A. S. O macroplanejamento da aglomeração de Salvador. Salvador: Secretaria da Cultura e Turismo, EGBA, 1998.

SEMMA. História dos Shopping Centers no Brasil: do Nascimento até a Década de 90. Disponível em: $\quad<\mathrm{http}: / / \mathrm{www}$.semma.com.br/historia-dos-shopping-centers-no-brasil/>. Acesso em: 25 jul. 2016.

SERRA, Geraldo. Urbanização e centralismo autoritário. São Paulo: EDUSP/Nobel, 1991.

SPÓSITO, Maria Encarnação Beltrão. A gestão do território e as diferentes escalas da centralidade urbana. In Revista Território, ano III, n. 4, jan./jul. 1998. p. 27-37. Disponível em: $<$ http://www.revistaterritorio.com.br/pdf/04_3_sposito.pdf >. Acesso em: 25 jul. 2010.

Desafios para o estudo das cidades médias In: Seminário Internacional de la Red Iberoamericana De Investigadores Sobre Globalización Y Território, 11, 2010, Mendoza. Anais... Mendoza: UNCUYO - Universidad de Cuyo, 2010. p. 01-18.

A Urbanização da sociedade: reflexões para um debate sobre as novas formas espaciais. In: DAMIANI, A. L. et al. (Orgs.). O espaço no fim de século: a nova raridade. São Paulo: Contexto, p.100-117, 1999

SPÓSITO, Maria Encarnação B. (Org.). Cidades médias: espaços em transição. São Paulo: Expressão Popular, 2007.

SOARES, Beatriz Ribeiro. Repensando as cidades médias brasileiras no contexto da globalização. Palestra proferida junto ao Programa de Pós-graduação em Geografia em 18 jun. 1998. Formação, Presidente Prudente, n. 6, 1999. Disponível em: $<$ http://revista.fct.unesp.br/ index.php/formacao/ article/view/1167/1168>. Acesso em: 28 abr. 2015.

SOUZA, Marcelo Lopes de. A B C do desenvolvimento urbano. Rio de Janeiro: Bertrand Brasil, 2003.

SOUZA, Maria Ângela (coord.). Como anda a Região Metropolitana do Recife. Recife: UFPE, DCG, DAU, FASE, Observatório Pernambuco de Políticas Públicas e Práticas SócioAmbientais, 2006. Disponível em: <http://docplayer.com.br/2636437-Como-anda-a-regiaometropolitna-do-recife.html $>$. Acesso em: 31 de ago. 2016.

SOUZA, Marcus V. M. de. Cidades médias e novas centralidades: análise dos subcentros e eixos comerciais em Uberlândia (MG). 2009. 248f. Dissertação (Mestrado em Planejamento Urbano e Regional) - Programa de Pós-Graduação em Geografia, Instituto de Geografia, Universidade Federal de Uberlândia. Uberlândia, 2009. Disponível em: $<$ http://hdl.handle.net/ 10183/5145>. Acesso em: 28 abr. 2010.

SOUZA, Bethsaide de Souza; SANTOS, Rosângela Leal. Análise da expansão urbana de Feira de Santana através de condomínios fechados. 11 Seminário Urbanismo na Bahia: Direito à Cidade, Cidade do direito, 2011, Salvador. Anais 11 Seminário Urbanismo na Bahia. Salvador: EDUFBA, 2011. v. 1. p. 1-13. Disponível em: $<$ http://www.ppgau.ufba.br/urba11/>. Acesso em: 10 jun. 2016.

SUASSUNA, Ariano. Iniciação à estética. 11ed. Rio de Janeiro: José Olympio, 2011. 396p. 
STEINBERGER, Marília. BRUNA, Gilda Collet. Cidades médias: elos do urbano-regional e do público-privado. In ANDRADE, Thompson A.; SERRA, Rodrigo V.(org). Cidades Médias Brasileiras. Rio de Janeiro: IPEA, 2001. (p. 35-79)

TEIXEIRA, Ana Carolina W. Região metropolitana: instituição e gestão contemporânea dimensão participativa. Belo Horizonte: Fórum, 2005. 205p.

TRIGUEIRO, Edja; MEDEIROS, Valério A. S. de; RUFINO, Iana Alexandra. Investigando consequências de projetos de intervenção na malha viária sobre o patrimônio remanescente no centro histórico de Natal. In: III Seminário Internacional Patrimônio e Cidade Contemporânea, 2002, Salvador. CD Anais - III Seminário Internacional Patrimônio e Cidade Contemporânea. Salvador: FAU-UFBA, 2002.

TURNER, Alasdair. Depthmap 4 - A Researcher's Handbook. Bartlett School of Graduate Studies, UCL, London, 2004. Disponível em: <http://www.vr.ucl.ac.uk/ depthmap/depthmap4. pdf>. Acesso em: 10 jun. 2013.

Getting Serious with Depthmap. Segment Analysis and Scripting. Bartlett School of Graduate Studies, UCL, London, 2008. Disponível em: <http://www.vr.ucl.ac.uk/ depthmap/tutorials/ advanceddepthmap.pdf $>$. Acesso em: 10 jun. 2013.

UFPE - UNIVERSIDADE FEDERAL DE PERNAMBUCO; ESTADO DO RIO GRANDE DO NORTE. Proposta de modelo de gestão da Região Metropolitana de Natal: Plano estratégico de desenvolvimento sustentável para Região Metropolitana de Natal: Natal metrópole 2020: Produto 8. Recife: Fade/UFPE, nov. 2007.

UGALDE, Cláudio; RIGATTI, Décio. Configuração espacial e desenvolvimento urbanoregional. In: XII Encontro Nacional da ANPUR, 2007, Belém. Anais do XII Encontro Nacional da ANPUR. Belém: ANPUR, 2007. v. 1. p. 1-22. Disponível em: $<$ http://www.capitalsocialsul.com.br/capitalsocialsul/desenvolvimentoregional/Grupo $\% 202 / 1$ 7.pdf>. Acesso em: 02 mai. 2011.

VAINER, Carlos B. Fragmentação e projeto nacional: desafios para o planejamento territorial. Anais do XII Encontro da Associação Nacional de Pós-Graduação e Pesquisa em Planejamento Urbano e Regional. Disponível em: $<\mathrm{http}$ :/www.anpur.org.br /revista/rbeur/index.php/anais/article/view/2411/2383>. Acesso em: 20 de fev. 2014.

VASCONCELOS, Ana Maria Nogales; MOURA, L.B.A.; BESSA, L. F.; LUCIO, M.; MAKIUCHI, M. F.; GOMES, Marília Miranda Forte. Os arranjos domiciliares na Área Metropolitana de Brasília. In RIBEIRO, Rômulo José da Costa; TENÓRIO, Gabriela de Souza; HOLANDA, Frederico de; RIBEIRO; Luiz Cesar de Queiroz. (Org.). Brasília transformações na ordem urbana. 1ed. Rio de Janeiro: Letra Capital, 2015, v. 1, p. 176200.

VIANNA, Pedro Jorge Ramos. Um pouco de história: os primórdios do Banco do Nordeste do Brasil S/A. Disponível $<$ http://www.econometrix.com.br/colunistas.php?id=17644>. Acesso em: 20 fev. 2016.

VILLAÇA, Flávio. Espaço intra-urbano no Brasil. 2. ed. São Paulo: Studio Nobel, FAPESP, Lincoln Institute, 2001. 373p.

. Uma contribuição para a história do planejamento urbano no Brasil. In: DEAK,

C; SCHIFFER, S.R.. (Org.). O processo de urbanização no Brasil. São Paulo: FUPAM/EDUSP, 1999, p. 169-244.

ZAMPIERI, F. L. O Fenômeno Social do Movimento de Pedestres em Centros Urbanos. 2012. Tese (Doutorado). 918 p. PROPUR, UFRGS, Porto Alegre, 2012. 
ZEVI, Bruno. Saber ver a arquitetura. (Tradução Maria Isabel Gaspar) Gaëtan Martins de Oliveira. 6ed. São Paulo: WMF Martins Fontes, 2009. 286p. (Coleção Mundo da Arte) 

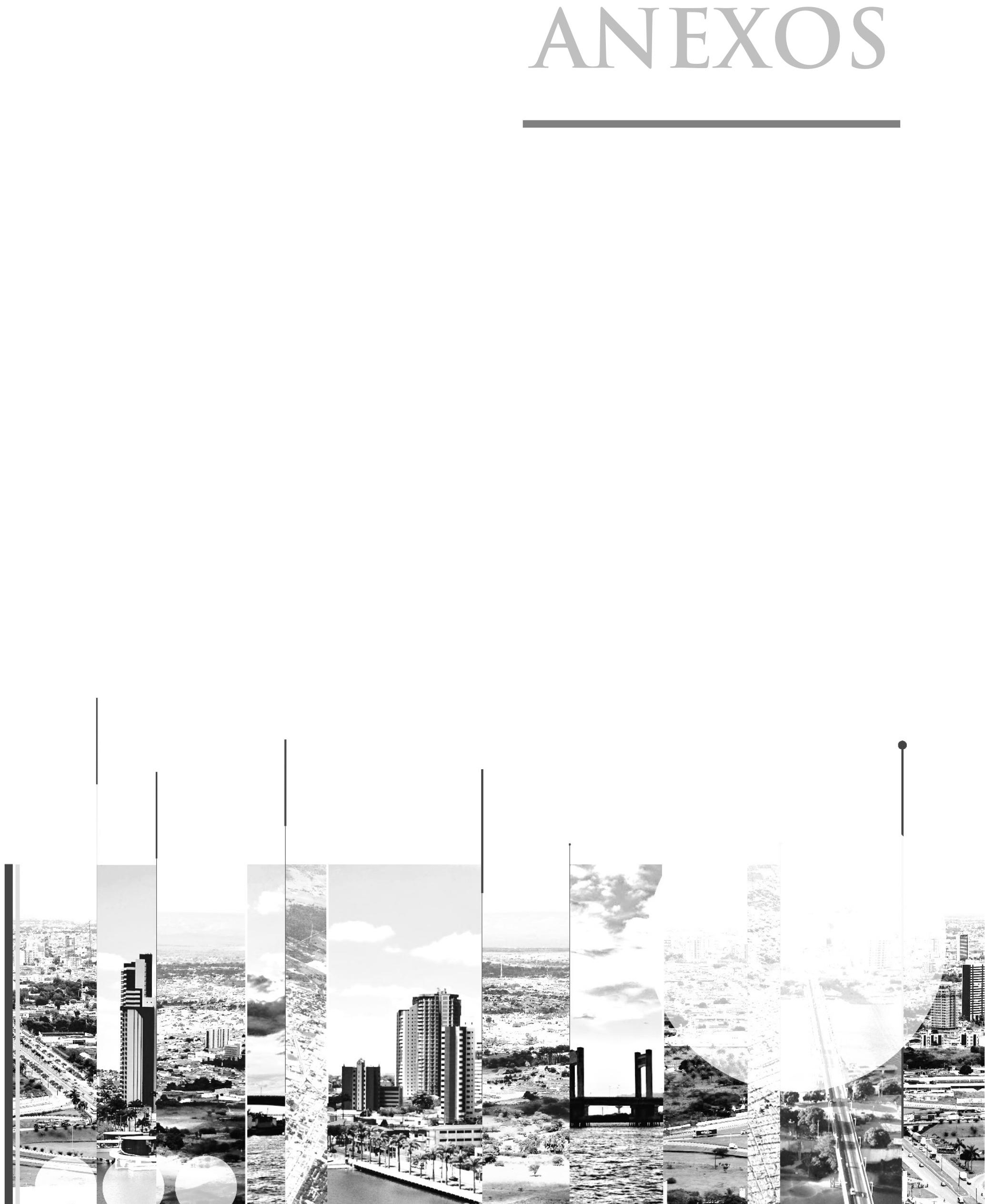


\section{ANEXOS}

Anexo 01 - Classificação de Ocupações para Pesquisas Domiciliares - COD 